\title{
METAPHOR IN EDUCATION
}

$$
\text { by }
$$

\author{
Maureen Kortens \\ A thesis \\ in partial fulfilment of the \\ thesis requirements for the degree of \\ Master of Arts \\ in Education
}

Victoria University of Wellington

1988 


\section{ACKNOWLEDGEMENT}

I wish to record my appreciation for the financial support given to me by the awards of a James Macintosh Postgraduate Scholarship in Education and a Sarah Anne Rhodes Research Fellowship during 1987, my first year of full-time university study at victoria University of Wellington. 
ABSTRACT

THE MAGIC OF METAPHOR

Without aetaphor there vould be no legs on the table, no hands on the clock. These are dead metaphors. Even that expression is a metaphor, for how can something be dead that has never literally been born. It is an expression which eannot be taken literally. In its first use it was 'alive' in the sense of being nev or vitty or apt and menorable.

Without metaphor we are reduced to the bare bones of language, to a kind of Drvellian Nevspeak. One can hardly avoid using metaphors to explain them. Even scientists and mathematicians use metaphors but they usually refer to them ds model 5.

Metaphor is a function of language which enables us to be creative. Not only the person who coins, invents, or thinks of the nev metaphor but also the listener or reader who constructs a personal meaning for him or her self,

We speak of creativity in education, as a human capacity to be encouraged and developed. How creative can humans be? Do they ever really 'create' anything nev apart from reproductions of themselves? Any creative activity such as painting, building or gardening is really re-organising elements already created. So humans enjoy 'creating' their own order, 
foras, or patterns which ve call art.

Language is capable of endless patterns. The basic patterns, usually known as graanar, appear to be innate and in speech and writing we use these 'inbuilt' structures to create ney sentences of our own. At its highest level ve call this literature. It has taken us some time to realise that a vord in itself has no meaning as it is a syabol only.

For those aspects of experience which are difficult to explain we turn to metaphor. Thus religions often use myths and syabols. Anthropology describes many human activities as aetaphoric, for exanple myths or totenism.

Practically every sphere of human activity is iabued with this magical quality of metaphor, for it extends our understanding of the vorld by giving us a kind of 'elastic' way of describing our experiences. It is not the prerogative of vriters or poets but a pover we all possess and one which has been derided and abused at times in our history. Only now is it increasingly being recognized as a human capacity worthy of study.

In this work I delve into some aspects of the use of metaphor to show how we need to be aware of its potent, parvasive power, especially those of us involved in teaching for whom I vill attempt to demonstrate that teaching is itself a aetaphoric activity. 
CONTENTS

page

Acknowledgment.....................

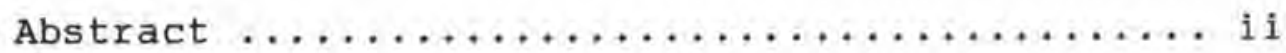

Introduction $\ldots \ldots \ldots \ldots \ldots \ldots \ldots \ldots \ldots \ldots \ldots \ldots \ldots \ldots \ldots$

Chapters:

1. The Nature of Metaphor............... 12

2. Metaphor as Literary Device..............64 64

3. Metaphor in Religion.................... 27

4. Our Perception of Childhood...............197

5. Metaphor in Education.................. 334

6. Educational Administration..............424

7. Metaphor in science................. 532

8. Metaphor in Psychology.................621

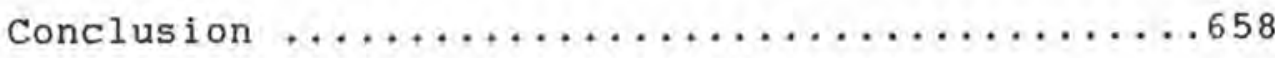




\section{INTRODUCTION}

You'd be a brave human who would say where all the influences

come from, but I think the vord sets the whole thing up.1

This study is partly an enquiry into the nature of aetaphor and its role in education but sore particularly into the implications of that nature for teaching and learning. My special concern is for ay fellow colleagues, teachers of English, those nembers of the teaching profession Who have the nost exciting and daunting of tasks, to develop in their students both an understanding of language and an appreciation of literature. Within this brief there is a vilderness of territory some of which has never been fully explored.

The dichotomy betveen ordinary language and literature is not the chasm some yould have us believe. To extend this basic metaphor; if language acquisition is the kitting of oneself with map, compass and equipment, then beconing faniliar vith literature and learning to enjoy it is the great cliab to a far-reaching peak; an achievement within sight of all but attainable only with determination and skill. The teacher is both guide and fellow dimber.

Several years ago the exaniner's report for the bursary English

1. Keri Hulne, Ie Kaihau The Windeater, Victoria University Press, New lealand, 1986, P.12. 
exaninations in Ney lealand exhorted teachers to be sure their students understood metaphor for without this there could be no understanding of literature. When children first meet the tern aetaphor it is usually vhen they are grappling with the nore condensed language of poetry. They discover that poets particularly have great expertise in conveying ideas and inages by using language inaginatively. This an not be a novelty to students if they have been encouraged in creative uriting and have uritten poetry. Siniles are fairly easily understood because they are simply comparisons and the vords 'like' or 'as' are clear markers but metaphor is a little more difficult to recognise and understand. Here the writer says something or some person Is something or someone else. He or she makes a statement which cannot be taken literally,

Language is confusing even in ordinary everyday situations. He speak of e.g. 'taking a break'. What is a break? Where are we taking it ? We speak of being 'in love', but is it something you fall or cliab into? Every word we use carries a range of neaning which confuses learners especially second language learners. Metaphors are not peculiar to literature alone. Even jokes and riddles have many of the attributes of metaphor. It is strange therefore that ve tend to examine metaphor as a literary phenomenon. Often it is learnt as a literary ter along vith assonance and onomatopoeia, iteas on a checklist to be learned for tests. This is unfortunate, as an exploration of metaphor can become a fascinating multi-disciplinary study, possibly the kind of study which could break down subject barriers and enable students to appreciate learning in school nore holistically.

It is the ability to visualise, to inagine, which makes us human, not merely intelligence or feeling or even language. "The imagination" said Coleridge in his seventh lecture on Nev Systems of Education "is the distinguishing characteristic of man as a progressive being." Language 
aquisition is more than collecting new words--it embraces oeanings which are distinct and unique for each of us. My concept of love or faith or even of a house vill be unique to ay aind and different to yours or that of any other person. This is a private aental vorld of images, ideas, which I aay wish to try to share with you, but to do so I have to create messages which you can interpret even though your i 1 ages and ideas can never be precisely the same as aine. Comanication therefore is sharing and finding links betveen these private worlds of ideas. Sonetimes the coman ground ady be in a aetaphor.

It has been said that "Many traditions treat language as a sacred thing; they are justified in so doing, for it is language that gives order and significance to primal cha05," Prophets and leaders often speak in aetaphoric teras of their visions, dreans, ideals. The Bible for exaaple is full of metaphors as are other holy books. To ny aind one of the nost noving and aysterious expressions is the opening line of St. John's gospel: "In the beginning vas the word: and the word vas with God: and the word vas God."

In seeking for truth and understanding, language is the medium we use. We conaunicate in symbols which can never express our exact meanings. When our own language fails to be precise or descriptive enough we often turn to other languages which sometines seen more expressive or in the case of science or technology we nake up words from existing vords. The vay we organise our words alters the shade of meaning and by use of analogy or aetaphor we can suggest new meanings, for example love poetry is forever trying to find vays to express the vonder of human love or to describe the

1. R.H.Robins, 'The Structure of Language,'in Language in Education, Routledge and Kegan Paul in Association with Open University, London,1972.P.24. 
beloved. The endurance of certain images is illustrated in Greek Anthology 1

by Lord Neaves, for example in the first part of a poen ascribed by some to Rufinus, by others to Dionysius the Sophist:

Oh that I were some gentle air, That when the heats of sumer glow, And lay thy panting boson bare, I might upon that boson blow!

Secondly, in the familiar lines fron Romeo and Juliet:

Oh that I vere a glove upon that hand, That I night touch that cheek!

and finally from Burns:
0 that ay love were yon red rose
That grows upon the castle va', And I wyself a drop of dew, Into her bonny breast to fa'!

Whatever way we twist or shape or turn the language ve challenge the reader or listener to interpret our novel creations. If we share vith that person similar feelings or experience or culture or education then the chances of a mutual understanding are very high even though ve can never know exactly what that understanding is. This is the mysterious aspect of metaphor which aakes it so fascinating to study.

Metaphor is not peculiar to poets either. An earthquake in New lealand in March 1987 was recorded by children in language reflecting their feelings. One tuelve-year old known to his friends as 'Pizza-face' (in Itself a descriptive although unkind metaphor) said that they all "hit the ground." Another boy "went white as a sheet' and one girl used a more original description "if all the school had got any sore nervous ve vould have moved the Lawn with our hands." One has an anthropomorphic view "The earthquake decided it would go to another town 50 it vent to Kaverau.

1. Lord Neaves, The Greek Anthology, ed.W.Lucas Collins, Hilliam Blackwood and Sons, Edinburgh, MDCCCLXXIV, p. 93. 
Kawerau people didn't want it, but it obeyed the aaster's rules." Another said "Our house vas turned upside doun like a giant had picked up our house and then just dropped it."

Other reports from the children included the following: "our desks vere moving fron side to side like boats in a giant stora... ny heart felt like it had been ripped to threads....screans pierced the air... My heart felt as if it had nissed a beat and junped up tovards ay throat., I rushed out in terror that was floating out of my ears... When the earthquake struck it looked like my 5 nail vas break-dancing... it felt like being on vaves that vere about to burst... the courts vere like jelly and the buildings like they had come to life... it felt as if you were very saall, sitting on a blanket being shaken out... The lamp-posts were just like bendy bits of plastic... The concrete vas noving like the sea, but at the same tine it was juaping up and down like the electric bop... The cars looked like they vere playing jump-rope," Metaphors abounded as reporter Richard Rau 1 noted.

The interesting thing about these examples is that they illustrate hov figurative language is used naturally by children to recount their experiences, in this case a frightening and unusual one. Soae use cliches e.g. 'white ds a sheet' fron the common stock of vell known expressions but others are more fanciful and original, some are even in ayth-like form, but all share a conmon factor, to express this experience they have all used siniles and metaphors and most of the references are based on associations with experiences already known and familiar to then e.g. break-dancing, bop, jump-rope, giants from fairy stories etc. That is, they use the known

1. Brian Rudman, 'The Day Our Buildings Came to Li fe,'Listenent, New Zealand, April 11, 1987. 
to describe, explain and presumably accept and understand the nev. Fear, shock and visual effects of sovenent are recorded in figurative language which vividly captures the oonent and the aood. Metaphor has this characteristic of being involved with tension and enotion and vith visual inages. It is noticeable that in a report uritten by slightly older children there vas a more restrained, more literal style of language. It vould be interesting to study the development of this facility in children and to conpare their aetaphors vith those of adults.

Language in some senses seems to have a life of its oun over which ve have minial control. You cannot oun a vord, but you can give life to a new one. Children often do this spontaneously. You cannot keep a vord to yourself, even one's own name is a kind of abstract syabol which you are knovn by. Everything spoken travels on sound waves ad infinitun. Children chant that "Sticks and stones aay break wy bones but names vill never hurt me," yet in fact naees can hurt permanently. Words take on multiple and complex meanings. They experience a kind of birth, they evolve over time, and with use; each has uniqueness but they can also die. We speak of 'dead' metaphors and 'dead' languages such as Latin, though it is not entirely defunct for it is still used but is no longer developing or evolving.

One theory of how language developed says that in its initial stages there vas only a literal use of words which had a bearing on concrete or perceptible things, qualities, occurences etc, but when there came a need

1. Kin Gray, Edgecumbe Teenagers Look back on Quake, Children's Express, Evenging Post, Wellington, New Zealand, May 4,1987.

2. J.J. A. Mooi j, A Study of Metaghor, Nor th Holl and Pub.Co.,1976, P.11. For this theory Mooij refers us to F.M. Muller, Lectures on the science of Ianguage, (2 vols, , London 1861-1864), Ch. B. 
to speak of abstract ideas this vas met by the use of metaphors. If ve find this theory too siaplistic says Hooij the "still less acceptable is the contrary view that the very initial stage of language vould have been completely metaphorical" because as its opponents say "the metaphorical use of language is only possible if a literal use of language is already in existence." Many descriptions of phenomena perceived by the senses do reveal a maphorical origin e.g. 'high pitch' and 'vivid colours', which way indicate that metaphors have al ways played a part in the development of language. Many abstract vords have concrete origins $\varepsilon, g$. 'grasp' meaning to understand, and the vord 'aetaphor' itself eaning to 'bear' or transfer. There is wuch speculation and research in this area of the history of language but as yet no definite conclusions.

Metaphor-aking is an associative process which has been likened to recognition in Rorschach tests. We need aetaphors to explain but ve are surrounded by then also. Even the sports and business pages of the neuspapers are full of metaphors, many of these taken fron the language of var because of their aggressive and competitive nature. Others are frozen as it vere in the art around us. Even the villow-pattern on a dinner plate aight be telling us the sad story of an unrequited love and is a pereanent and daily reminder of another time, another place and strange unknown people but with whom ve can identify emotionally at least. The 'bridge' of this scene could be a metaphor for setaphor itself. Metaphors are more than words. They can capture as they do in art and literature and in science, tian, history, culture, feelings, ideas. They illustrate the tines ve live in too for as Leavis has said "people cannot live vithout a sense of significance."

1. J.J.A.Mooi j, A Study of Metaghhor, Nor th Holland Pub. Co., 1976, p.11.

2. F.R. Leavi5, quoted in IIMES Profile, London, February $17,1975$. 
No-one can deny that metaphors are endenic but to understand them ve really need to know how the human aind works.

Earlier uriters capitalized on this need for inagery by sonetines supplying volumes of instant stock imagery for yriters, seraon makers or orators. They were used in much the same way that a crossword neophyte night use a dictionary or thesaurus. Carol Clark describes these reference books in her Web of Metaghor in vhich she scrutinizes the isagery in Montaigne's Essais. Apparently in his time aany stock images vere in comon u5e. Although noted by critics for his lively and novel inagery he did borrow as others did fros authors of antiquity and this vas expected: "The culling of sentences, examples and sinilitudes fron the vork of one's predecessors was a recognized method of literary composition." The source books were knoun as connonplate books.

Clark says that in the Ratio Colligendi Exempla of Erasnus be gives instructions on the collecting of such samples and how to classify them, and in his Parabolae sive siailtudines published in 1513 is a collection of nearly two thousand siniles, mainly from classical authors especially Plutarch and Seneca. There was, "a whole world of shared inagery...inagery, and the arguments from analogy that it provided formed nothing less than a method of thought, or more accurately a substitute for thought for men of the sixteenth century..." They vere used not merely for flowery adornment but in this pre-scientific age as rhetorical devices to convince listeners or readers in situations where rational argument was not available. One is reminded of Plato resorting to myth in similar situations.

Clark is particularly interested in Montaigne because although he uses stock iaages such as "pedants as birds carrying food to their

1. Carol Clark, The Web of Metaphor, French Forum, Kentucky,1978,p.43. 
young." (11 25)

He does not, indeed as a man of the modern age vould, sioply reject inagery as a eans of investigation--he still thinks images have some pover to reveal relations betveen things, and that these relations have some factual reality. But the patterns thus disclosed are fragaentary and arbitrary, aere gliapses of a universal network of connections which, in its conplexity, is imaeasurably beyond hunan pover to grasp.l

There are several ideas here which I vill extrapolate and discuss in further chapters because they relate to inportant aspects of metaphor; they are: patterns, network, and the description of metaphor as a kind of 'grasping', or 'groping' for meaning. These I believe to be key issues inherent in the study of aetaphor.

Metaphors are of interest in Philosophy, Psychology, Linguistics, Science, Art, Literature, Metaphysics, Semantics, Semiotics, even Religion, and nore recently Computer Technology. Practitioners in each area all have slightly different views on aetaphor but all of then go back to Aristotle some of whose ideas are sumarised in the next chapter.

By giving separate chapters to Art and Science I do not wish to ieply a division betwen then for in fact the evidence shovs that any gap that may have existed betveen them is narrowing quite rapidly. If aetaphor is part of both the process and product of literature it is equally part of the process particularly of science. Writers on the subject of metaphor are legion, as a bibliography by Shibles testifies, but anong the nost influential appear to be Max Black, I.A.Richard5, and Paul Ricoeur.

Every aspect of aetaphor impinges on education both in the vay we view teaching and children and educational institutions and the manner in which we instruct and educate the young. There are metaphors for education itself, for what goes on in educational institutions and for the people who

1. Carol Clark, The Web of Metaphor, French Forum, Kentucky, 1978, p.43. 
administer them and those on the receiving end. Agricultural and horticultural metaphor 5 abound presumably because children are 50 vulnerable, 50 dependent on adults for 50 long. This very vulnerability means that parents and teachers can choose to be protectors or bullies, cultivators or destroyers. Even at our supposedly advanced gvolutionary stage there are still children deliberately aaimed, abandoned, neglected, exploited, tortured, and sold. Legislation has tried to stanp out most inhumane practices, especially the institutionalized ones such as aining, and slavery, but society cannot prevent the abuse and neglect of children merely by lavs. It is interesting to exalaine some of the metaphors concerning attitudes to children as I have done here and to see and how these are reflected in our educational practices, also to examine whether the uriters of a wore scientifce age still revert to the same inagery and aetaphors to explain the educational imponderables. This leads one to vonder just what constitutes knowledge and makes one also avare of the need to more fully understand just what is involved in teaching and learning. Metaphor seems to me to be an integral part of this.

Many metaphors have been used in education, soee of which will be examined here, but I have come to believe that the journey one is still appropriate, with the teacher, parents and community as guides. The pursuit of knovledge and truth is a vell-trodden path which appears to get vider as well as longer and ve seem like so many hunters chasing an elusive quarry thich pereptually slips forever just over another hill in the distance. Elliot hovever considers the guidance metaphor to be somewhat outdated and warns us that "no metaphor can give us insight into the essence of education for it is not a natural species and does not have an essence." Never-

1. R.K.Elliot, Metaphor, Imagination and Conceptions of Education, in Metaghors of Education, ed. K. Taylor, Heinemann, London, 1984, p. 52. 
theless a aetaphor can have inaginative appeal, as he says. I an also inpressed by Sylvia Ashton Warner's netaphor of the teacher as conductor of an orchestra where, each performer and instrument is individually in tune and vell prepared but needing the leader ship of the conduct or to produce 1

their finest perfornance.

2

Breal has said that the topic of netaphor is inexhaustible and $I$

have cone to agree vith him, it is difficult to do justice to this inter-

disciplinary topic which is none the less fascinating, appearing as it does wherever one turns. Shibles has even clained that it ought to be a subject 3

of study at universities. There is no part of a school syllabus where it is not relevant but not all subjects are considered in this study. Mathenatics and Art are two neglected ones that must prove rich sources particularly in the area of learning and teaching. As a researcher one can be encouraged hovever by what I.A.Richards has said in his Philosophy of Rhetoric: "In this subject it is better to make a mistake that can be exposed than do nothing, better to have any account of how metaphor works (or thought goes on) than to have none."

This work, based as it is on a selection of readings relating to the topic, vill add nothing to the theory of aetaphor but ains to raise the consciousness of teachers, particularly as to the nature and importance of metaphor in teaching and learning.

1. Sylvia Ashton Warner, Teacher in Aneriçą, Cassel1, London, 1972, p.186.

2. Warren A.Shibles, Metagehor an Annotated Bibliograghy and History, Whitewater, Wisconsin,1971. P.V11.

3. Willian Taylor ed., Metaghhors of Education, Heinenann, London, $1984,0.7$, 
CHAPTER I

THE NATURE OF METAPHOR

Metaphor has by now been defined in 50 many ways that there is no human expression, whether in language or any other aedium, that vould not be estaphoric in SOMEONE'S definition. 1

2

Aristotle said aetaphor vas a sign of genius, Locke called it an art 3 of fallacy, a cheat, a great fault, wholly to be avoided. Hobbes likevise believed it was a form of playing with words and a vay of deceiving others. According to Cohen it is a vonderful topic which has become acadenically 5

respectable. Questions which he thinks need to be applied concern:

1. The relationship between 'poetic' metaphors and ordinary speech and

prose.

2. How to incorporate setaphor with theories of language and aeaning.

1. Wayne C. Booth,'Metaphor as Rhetoric:The Problen of Evaluation', in Sheldon Sacks, On Metaghor, University of Chicago Press 1978, p.48,

2. Aristotle, 'On Poetics', The Works of Aristotle Vol_II, Encyclopaedia Brittanica publisher William Benton U.S.A. 1952, p, 694

3. J.Locke, quoted in W. Taylor ed. Metaghors of Education, Heinemann, London $1984,0.115$.

4. Thomas Hobbes, Leviathan, Encyclopaedia Brittanica, Hilliam Benton U.S.A.1952, Ch. 4, p. 55 .

5. Ted Cohen, 'Metaphor and the Cultivation of Intinacy', in Sheldon Sacks On Metaghor, University of Chicago Press 1978, p.1. 
Metaphor appears to be something of an eabarrassment to philosophers and causes problems between departaents of schools and universities when defining the bounds of their type of discourse or fields of enquiry. The subject is problematic.

This chapter examines some of the many descriptions of metaphor and something of its history and its problems.

No-one seens to be able to give us a generally accepted or standard definition of metaphor, but as Wayne C. Booth says we can all recognise one : "We seea to have a kind of common-sense agreement about a fairly narrow definition, one that survives even while our theory expands the original concept beyond recognition." Because the subject is 50 controversial and value-laden I vill turn first to a semiotician for a 'general' or supposedly 'scientific' description of metaphor. According to Bela Buky aetaphors are fundamentally based on comparisons: "Whatever the ain is, there is alvays-2 in any eetaphor--a concept related to another one." Each of these can be classified into one of five categories:

1 = concept of a (real or inaginary) object, place, time, action, event or phenomenon, quality or any other abstract notion.

2 = concept of a (real or inaginary) plant

$3=$ concept of a (real or inaginary) aniaal

4 = concept of a (real or ieaginary) hunan being

$5=$ concept of a supernatural being (God, Satan etc.)

Likevise the concepts to be compared fall into the same

1. Wayne C. Booth, 'Metaphor as Rhetoric; The Problen of Evaluation', in Sheldon Sacks, On Mataghor, University of Chicago Press, 1978, p.49.

2. Bela Buky 'The systen of metaphors semiotically considered' in Seniotics Unfolding ed.Tasso Borbe Mouton, 1983, p.783. 
categories. This results in at least twenty-five permutations. Buky also mentions artistic aetaphors such as Iconic signs and Indexic signs but these are wore properly related to art 50 I vill refer here merely to those coesents on spoken or uritten aetaphors. According to Buky :

Metaphors reach their effect through characterization (a type of qualification). There is alvays an abstractness characterized by a concrete quality. (When Siaon is called Peter i.e.a rock, here e.g. Sinon's personality (abstractness) is characterized by the quality of the rock (solidity-concrete quality.) I

Buky says (as Carol Clark does when explaining Montaigne's essais) that metaphors vere used when scientific terminology vas not available to explain phenomena, and clains that the use of metaphors in science is on the decline but that they proliferate in journalism and in literary texts where poetic metaphors prevail. In private conversations any emotive or phatic metaphors can occur, such as endearwents or nicknames.

Buky confirms my earlier coment that people have to decode metaphors in social groups:

If one vants to adapt hinself to the community of a group, he has to learn to use appropriately the allusion-systen and metaphor system current anong the group aenbers.3

Shibles refers to 'universes of discourse' which Urban says are created not by individuals but by groups or speech communities: "The vord does not have the same meaning in each universe of discourse in which it is used." It is obvious that teachers need to be aware of this factor in their

1. Bela Buky 'The system of metaphors semiotically considered ' in Seniotics Unfolding ed. Tasso Borbe Mouton 1983 p.785.

2. Carol Clark, The Heb of Metaphor, Studies in the imagery of Montaigne's Essais, French Forum Publishers, 1978

3. Buky p, 789,

4. Warren A. Shibles, Analysis of Metaghor In The Light of W.M. Urban's Theories, Mouton, The Netherlands, 1971, p.45 
subject areas where specialists tend to use language vithout considering that it may be unfamiliar to children and also in preparing youths for adult life vhere they will aeet any unfaniliar metaphors. As Buky says:

To be able to decode, as quickly as possible, the newest aetaphors, the ones created in the hurry of the spoken language, a high

'elasticity 'of aind is needed. 1

Interesting that the ter 'elasticity' is used here which is one I have used ayself in trying to describe metaphor. Implicit in netaphor there is alvays a concept of stretching, of tension, of straining for new seanings. Literary critics particularly refer to this aspect of metaphor e.g. I.A.Richards speaks of .."a resultant tension between the particular 2 sinilarity employed and more stable habitual classifications..." and Philip Wheeluright stresses the 'energy tension' which characterizes metaphor and believes that similes lack this "degree of intensity...depth of penetration 3

(and) freshness of recombination."

Aspin believes that there are in fact some 'universal aetaphors or key ideas in that they are comaon to all cultures:

...there is a universality about human language and the pover to conceptualize that is a function of certain features that are basic to all human perceptions of ourselves and our environment and, whether ve describe these as being fixed in time, space, quantity, quality, modality and relation; or based on colour, spatial extension, natural dimension and substance, the outcone is the same. It is that there are certain fixed points that are the ground of our appraisal of reality...4

1. Bela Buky, 'The system of metaphors semiotically considered' ${ }^{\prime}$ in Semiotics Unfolding ed.Tasso Borbe, Mouton, 1983 p.789.

2. I.A.Richards, Intergretatition in Ieaching, Routledge and Kegan Paul, London 1949, p.59

3. David Cooper, Metaghor, Blackwell, Oxford, 1986 p.59 and p.186, quoting Philip Wheeluright, The Burning Fountain (Indiana University Press, 1954)p.100

4. David Aspin, 'Metaphor and Meaning in Educational Discourse' in Metaghors of Educatíngn, ed. W.Taylor, Heinemann, London 1984, p.30. 
Aspin quotes Hannah Arendt (1963) "The categories and ideas of human reason have their ultimate source in the human senses and, all conceptual or aetaphysical language is actually and strictly metaphorical."

Aspin also refers to Bollinger who said "Metaphor...brings us to a 2

world to sone extent prefabricated in our language." And Quine "Metaphor, or sonething like it, governs both the grovth of our language and our 3

acquisition of it." To Donald Davidson "Metapher belongs exclusively to 3

the domain of use.' He agrees also vith what I said earlier that metaphors can resenble jokes for they play with language, are a novelty, a surprise which captures the inagination, and create a response which sonetines guarantees their longevity and extended use. 'Dead' or 'cliche' aay be their eventual designation but in fact they do not die, they becone part of ordinary usage or part of our comon word stock.

There seel to be as any interpretations of metaphor as there are writers on the subject but without fail they all acknovledge a debt to Aristotle, as the first person to describe its use. According to Paul Ricoeur "It is he [Aristotle] who actually defined aetaphor for the entire subsequent history of Western thought, on the basis of a semantics that 5

takes the vord or the name as its basic unit." In his treatise on Rhetoric Aristotle gives advice, for those who vish to excel in politics, on hou to be an effective speaker, for to persuade people is to use vords with consumate

1. Davis Aspin, 'Metaphor and Mearing in Educational Discourse'in Metaghors of Education ed. W. Taylor, Heinenann London 1984, p.31.

2. Ibid.,p.32.citing Bollinger 1980 p.145.

3. Ibid, p.32.

4. Ibid, , p.33,

5. Paul Ricoeur, The Rulle of Metaghor, trans. by Robert Czerny, University of Toronto Press, 1975, p.3. 
1

skill. Persuasion is, he says, a sort of demonstration. One of the techniques for this is the use of the enthymeme, a sort of syllogism. Facts alone vill not always vin an argument: "Argument based on knowledge implies instruction, and there are people whon one cannot instruct.' Here one oust use persuasion. To argue vell is also to see both sides of an arguaent and rhetoric is useful "to discover the means of coming as near such success as 3 the circumstances of each particular case allov.' In this it resenbles other arts in that it depends on how and why it is used and on the user-man. It aay be defined as "the faculty of observing in any given case the available means of persuasion."

With the spoken word, persuasion depends on the personal character of the speaker, on how he puts his audience into a certain frame of aind as vell as on the proofs in his argument. A person of good character is more generally belieyed says Aristotle but persuasion should be achieved by what the speaker says rather than what people think of him. To do this he needs to stir the emotions of his listeners, for our judgaents are affected says Aristotle on the nood ve are in as ve listen. Persuasion therefore requires logical reasoning and an understanding of hunan character and huan emotions,

To Aristotle Rhetoric is an offshoot of Dialectic and of Ethical Studies which may be called political and sometimes masquerade as political 5cience. In Prior Analytics (9II 23.24) he says "Every belief cones either through syllogisn or induction.' The example is an induction the

1. Aristotle, Rhetoric Bk. I, Encyclopaedia Brittanica, University of Chicago 1952 trans, by W. Rhys Roberts p.594.1355a [5]

2. Ibid, p.594, [355a [25]

3. Ibid.,p.594. 1355b [10]

4. Ibid.,p.595, Chap.2. 
enthyeme a syllogism--and everyone who affects persuasion through proof does in fact use either enthymenes or examples.

Aristotle states that when ve base the proof of a proposition on descriptions of siailar cases this is called deduction in Dialectic, example in Rhetoric. Having shown that certain propositions are true and that another proposition aust in consequence be invariably or usually true this is called syllogisa in Dialectic, enthymene in Rhetoric, Both occur in different oratorical styles,

Rhetoric deals with general subjects as does Dialectic but for a wore general audience i.e. Dialectic for the layman, thus ;

The duty of rhetoric is to deal with such matters as ve deliberate upon without arts or systems to guide us, in the hearing of persons who cannot take in a complicated argument, or follow a long chain of reasoning. 1

He proceeds to give us advice and says that nost of the things about which ve make decisions present us with alternatives i.e. "all our actions have a contingent character, hardly any of then are determined by necessity."

The varieties of thetoric are political (deliberative and dealing mainly with the future), forensic (legal) and epideictic (the ceremonial oratory of display). Each has a different audience and ain. He describes the nature of phetoric which he claims is a combination of science and logic, of the ethical branch of politics, partly like dialectic and partly like sophisticated reasoning and believes that if ve tried to wake it scientific we would destroy its true nature. In his day it dealt aainly with vays and means, var and peace, national defence, imports and exports and legislation. Not nuch different to our current affairs. The use of

1. Aristotle, Rhetoric Bkㅡㄴ Chicago 1952, trans. by W. Rhys Roberts, p.596, 1357a

2. Ibid.,p.597. 
persuasive speech was intended to lead to decision-making.

Maxias are parts of enthymeaes, and in arguments by exanple one variety consists of mentioning actual past facts, the other depends upon the invention of facts as in the parallel or fable e.g.( Aesop's fables). As he says, the illustrative parable is the sort of argunent Socrates used. [ ve are familiar with then in the Neu Testanent also I Fables, he says, are suitable for addresses and popular presentations, as they are easy to invent "all you require is the power of thinking out your analogy, a power developed by intellectual training."

When ve are unable to argue by enthyaemes ve are to use Examples and When we can use enthymenes to use exaaples as supplenentary evidence. Maxims are to be statements of a general kind about how to behave and not particular facts. The demonstrative enthymene is formed, he says, by the conjunction of comparable propositions and the refutative by incomparable, One example he gives of a naxin is:

Never should any man uhere vits are sound Have his sons taught aore visdon than their fellows (Euripides Medea 295)

Once the reason is added the whole thing becones an enthymeme;

It makes then idle; and therewith they earn Ill-vill and jealousy throughout the city.

(Ibid. 297)

Folloving on froe this he goes into all the various types of proef and lines of argument that rhetoricians can follow to be successful. He also makes an interesting coment on why the refutative enthymeme has a greater reputation than the demonstrative:

1. Aristotle, Rhetoric Bk $\mathbf{I}$, Encyclopaedia Brittanica, University of Chicago Pres5, 1952, trans. by W. Rhys Robert5.P.641. 1394 [5]

2. Ibid, p. 642. 
Because vithin a small space it vorks out two opposing arguments, and arguaents put side by side are clearer to the audience. But of all syllogisms..., those are most applauded of which ve foresee the conclusions from the beginning, so long as they are not obvious at first sight-- for part of the pleasure ve feel is our oun intelligent anticipation; or those which ve follow vell enough to see the point of thea as soon as the last vord has been uttered. 1

The sane I believe is true of netaphors also. Aristotle has made an inportant point here relative to vhat one night call the rhetoric of teaching, that is the art of 'leading on' one's listeners to take note of an important fact and also the necessity of keeping them with you along the way. What he says applies to both metaphors and jokes. They both invite and need participation fron listeners, who enjoy recognizing and making the links which the speaker has led then to. They nay be an iaportant useful clue also to our vay of thinking, the fact that ve cope vith two ideas sometimes wore easily than with one. One balances or 'feeds' the other--do we in fact register and manipulate data in a binary fashion-nust we always be aaking links and chains such as those which computer programers call 'loops'?

There are as Aristotle points out spurious enthymemes based on false misleading statements, but usually enthymenes are based on one or other of four kinds of alleged fact--they are, probabilities, examples, infallible signs and ordinary signs.

In his treatise on Rhetoric Aristotle also analyzes 'style', for as 2 he claias "the way a thing is said does affect its intelligibility" even though its purpose aay be aerely to chara listeners for no-one neads fine language to teach geometry. Dramatic ability, which he considers a

1. Aristotle, Rhetoric Bk. I, Encyclopaedia Brittanica, University of Chicago 1952, trans. by H. Phys Roberts, P.649 [25]

2. Ibid., p. 654 . 
natural gift, can also be used to good effect.

To poet5 he ascribes the developaent of fine language in oratory: It vas naturally the poets who first set the movement going; for vords represent things and they also had the human voice at their disposal, which of a!l our organs can best represent other things. 1

To be good, style must, he 5ays, be clear and convey a plain meaning.

Moreover it oust be appropriate, but some novelty in language is appreciated by listeners "people like what strikes then, and are struck by what is out 2

of the vay." Naturalness he considers persuasive and he does not approve of strange, compound or invented words. On the other hand "metaphorical teras can be used with advantage..." for they occur even in conversation, and are of "great value both in poetry and prose."

Prose vriters nust however pay careful attention to their use of metaphor because they have not got the saae resources as poets.

Metaphor, noreover, gives style, clearness, chara and distinction as nothing else can: and it is not a thing whose use can be taught by one man to another. Metaphors, like epithets, must be fitting, which means that they aust fairly correspond to the thing signified: failing this, their inappropriateness will be conspicuous: the want of harmony betveen two things is eaphasised by their being placed side by side. 4

Aristotle also draws attention to the need for metaphoric expressions to sound vell: "A aetaphor may be aniss because the very syllables of the words conveying it fail to indicate sveetness of vocal utterance.' The beauty of a aetaphor can be, he says, in the sound or the neaning for he does not follow the school of thought which says there can be no foul

1. Aristotle. Rhetoric Bk. Chicago, 1952, trans, by W. Rhys Roberts, p. 654.

2. Ibid.,p.654.

3. Ibid.,p.655,

4. itid., p.655.

5. Ibid, p. 655 . 
language: "The aaterials of aetaphor nust be beautiful to the ear, to the

1

understanding, to the eye or to sone other physical sense." As an

example he says it is better to say 'rosy-fingered sorn' (11iad I 477) than

'crisson' or 'red-fingered'.

Metaphors can be inappropriate even ridiculous. Soane he thinks are too grand and theatrical and if far-fetched may be obscure. This seeas an inportant point for as he has said earlier in his vork people like to feel they are a step ahead of the speaker or at least cone to the same conclusion finally--so presunably when using metaphor we have to bear in mind that the reader or hearer has to be able to follow our train of thought and find our natching of ideas appropriate and convincing--almost as if he or she had thought of them.

Aristotle believes the Sisile also to be a metaphor with only slight differences and aore natural to poetry:

They are to be eaployed just as aetaphors are employed since they are really the same thing .... and those [ideas] which succeed as metaphors vill obviously do well also as siailes, and similes with the explanation onitted vill appear as metaphors. But the proportional metaphor aust always apply reciprocally to either of its co-ordinate teras. For instance, if a drinking boul is the shield of Dionysus, a shield may be fittingly called the drinking bowl of Ares. 1

He gives auch advice on good style. One example is the right use of connecting vords and punctuation, the avoidance of anbiguities and the need for clarity to ease delivery. Language of prose way use the devices of poetry such as aetaphor but above all language must be appropriate. Enotional speeches can he says use compound words, fairly plentiful epithets and strange words, as can ironical speeches also, but they are nore "fitting

$\therefore$ Aristotle, Rhetoric Bk_L, Encyclopaedia Brittanica, University of Chicago, 1952, trans. by W.Rhys Roberts, p. 656.

2. Ibid, p. 657 . 
in poetry, which is an inspired thing." The adin difference is that prose is to be rhythmical but not metrical and he explains the various types of rhythas. It is when he coaes to describing how to aake speeches lively and interesting that he deals again with metaphors in a vay which is perhaps particularly interesting to teachers:

We vill begin by remarking that ve all naturally find it agreeable to get hold of new ideas easily; vords express ideas, and therefore those vords are nost agreeable that help us to get hold of new ideas. Now strange words siaply puzzle us; ordinary words convey only what we know already; it is from metaphor that ve get hold of sonething fresh.2

He considers the sinile less attractive because it is longer; with which I agree, It is a characteristic of human nature as he says to find an idea attractive uhich is not eade too obvious "We see then that both speech and reasoning are lively in proportion as they make us seize a nev idea 3 promptly."

Aristotle describes the characteristics of netaphor:

1. The antithetical which aight include opposing ideas.

2. Use of metaphorical words--provided they are not far-fetched.

3. Those in which the vords vividly create a scene for us, an 'actuality' by using expressions that represent things as if in a state of activity, 4. The proportional (which he sonsiders the nost attractive) e.g. Pericles describing the 1055 of young oen fron the country tas if the Spring were taken out of the year.'

He considers Homer to be a master of metaphor for he creates an illusion of activity and often personifies othervise inanimate objects e.g. 'And the

1. Aristotle, Rhetoric Bk. of Chicago, 1952, trans. by W. Rhys Robert5, p, 659 .

2. Ibid., p. 662 .

3. Ibid, p.662. 
point of the spear in its fury drove full through his breastbone.'

(Iliad XV 542) As Aristotle say5:

tiveliness is especially conveyed by ataphor, and by the further power of surprising the hearer, because the hearey expected something different, his acquisition of the new impresses hin all the more. His aind seens to say 'Yes, to be sure; I never thought of that.'1

Acquisition of nev ideas, vords and concepts is a large part of learning.

Epigrans and riddles and jokes are sinilar. The nore briefly and antithetically a saying is expressed 5ays Aristotle the wore effective it is "for antithesis iapresses the nev idea nore firaly and brevity more 2

quickly." The best ones have personal application as vell as merit of expression and are true vithout being comnonplace. The nore of these qualities that can be incorporated the better i.e. to be netaphorical, antithetical, balanced and conveying a sense of activity.

Each kind of rhetoric says Aristotle, has its own style. The vritten is more finished and the ceremonial wore literary. It vould seem from Aristotle's account that a metaphor is like the conclusion to an argunent without the arguaent that leads up to it, a contracted of compressed syllogisa.

Aristotle's analysis of poetry includes for hi i Tragedy, Comedy, Dithyrambic, Poetry and Flute and Lyre playing--all arts of imitation (aimesis) their common elements being phythm, language and harnony. He claims that the origin of poetry is due to two characteristics in human nature:

Initation is natural to an from childhood, one of his advantages over the lover animals being this, that he is the wost iaitative

1. Aristotle, Rhetoric Bk. I, Encyclopaedia Brittanica, University of Chicago,1952, trans. by W. Rhys Robert5, p.664 [20]

2. Ibid., 0.665. 
creature in the vorld, and learns at first by initation.

It is also natural, he says, for us to take pleasure in vorks of imitation for:

To be learning soaething is the greatest of pleasures not only to the philosophep but also to the rest of mankind... for learning is the gathering of the meaning of things. 2

So initation is natural to us, as is the sense of harnony and rhythm which in poetry we call aetre and from this research I have come to believe that a sense of pattern is also probably innate and iaportant.

Aristotle is mainly concerned with epic poetry on serious subjects and grand scale, such as Honer's Odyssey. He says such vorks are pleasurable and contain certain general truths and represent human action, for $;$

All human happiness or misery takes the fora of action; the end for which ve live is a certain kind of activity, not a quality. Character gives us qualities, but it is in our actions, what ve do, that ve are happy or the reverse, 3

This is why in a tragedy the plot is of utaost importance. And in a painting even the nost beautiful colours will fail in their affect he says if they are laid on without order. Beauty is a matter of proportion "of size and order " and aust be "of a size to be taken in by the eye." In all of these aspects Homer is to him the artist par excellence.

Of poetry he says that it is "something aore philosophic and of graver iaport than history, since its statements are of the nature rather

1. Aristotle, Dn Poetics, Encyclopaedia Brittanica, University of Chicago, 1952, trans. by W.Rhys Robert5, p.682.

2. Ibid., p.682.

3. Ibid., p, 684.

4. Ibid., p.685. 
of universals, whereas those of history are singulars." ${ }^{1}$ It depends on certain elements of language for its art. Among these are nouns which (an be 1) the ordinary word for the thing 2) a strange vord (foreign) 3) a metaphor 4) an ornamental vord 5) a coined vord 6) a lengthened word 7) a word curtailed 8) one altered in form. It is to this statement that many later vriters turn and are critical because it tends to deal vith setaphors as single vords. Aristotle's actual definition of metaphor follows:

Metaphor consists in giving the thing a name that belongs to sonething else the transference being either fron genus to species, or from species to genus, or on grounds of analogy. 2

He gives examples of these and then says there is also another for that qualifies as metaphor "Having given the thing the alien name, one may by a negative addition deny one of its attributes naturally associated with its 3

nev name." He gives the example of 'the cup of Ares' referring Literally to a shield, as 'a cup that holds no wine.' 'Coined' vords appear to be those created by the poet I which we vould probably term examples of poetic licencel. A word lengthened is one with a short vovel made long of an extra syllable inserted.

Perfection in diction Aristotle says, is "to be at once clear and 4 not mean." Clear, by using ordinary vords as far as possible, and 'mean' is illustrated by reference to the poetry of Choptra and Stenelus. For meaning can become unclear by use of unfamiliar teras i.e. strange words, metaphors, lengthened terms etc., for overuse of these leads to barbarisn and

1. Aristotle, On Poetics, Encyclopaedia Brittanica, University of Chicago, 1952, trans, by W.Rhys Robert5, p.686.

2. Ibid., 0.693 .

3. Ibid.,p.693.

4. Ibid,, p. 694 . 
riddles which provoke laughter. What Aristotle advises is that "d certain adnixture ...of unfaniliar terms is necessary"...[for] the strange word, the metaphor the ornamental equivalent etc. vill save the language fron being mean and prosaic, while the ordinary words in it vill secure the requisite clearness."

The poet is not to be ridiculed Aristotle says, for his unusual use of vords but aust be avare that "the rule of moderation applies to all the constituents of the poet's vocabulary; even with metaphor, strange vords, 2

and the rest..." Abuse nakes for a laughable effect but on the other hand one has only to substitute ordinary language into poetry to see sonetines what effect is lost by this. Choice of vords is critical, for changing a single word can wake the difference between a fine line or otherwise.

It is at this point that he gives his vell-known comment on netaphor:

It is the greatest thing by far to be a waster of aetaphor. It is the one thing that cannot be learnt from others; it is also a sign of genius, since a good metaphor ioplies an intuitive perception of the sinilarity in dissioilars. 3

Of the kinds of vords that he describes, he believes that compounds suit the dithyramb, strange vords the heroic style, and metaphor iambic poetry. Iambic verse aodels itself on the natural rhythms of speech and can contain the vords one aight have in an oration, such as ordinary words, metaphors and ornamental equivalents. Epic poetry can contain this same nixture for "it is to be renenbered that there is not the same kind of

1. Aristotle, On Poetics, Encyclopaedia Brittanica, University of Chicago, 1952, trans. by W. Rhys Robert5, p. 694.

2. Ibid, $, 0,694$.

3. Ibid.,p.694. 
correctness in poetry as in politics, or indeed any other aft."

This does not excuse faulty expression, but he does say that critics need to be avare that expressions which seem strange any in fact be instances of metaphor and "For the purpose of poetry a convincing impossibility is preferable to an unconvincing possibility, " Where confusion and contradictions seen to occur Aristotle believes these can be tested by dialectical argument. Finally he states that of the two arts Tragic and Epic Poetry the first is to his aind superior.

Aristotle's statements about the nature and use of metaphor have, ds I said previously, become the basis for all subsequent study of metaphor which is why I have sumarised his vork. His influence has been acknowledged by nost writers and he is also blamed for what sone see as a rather limited vieu. One thing is certain he has established an ongoing dialectic on this now controversial topic.

Max Black is currently recognized as a seminal uriter on metaphor and he poses questions that he would like answered e.g. how do ve recognize then--can ve translate then literally--are they sere decoration--what are the relations betveen metaphor and sisile--is setaphor creative--what is the point of using it--and what do ve really mean by metaphor? This in spite of the fact that "To oraw attention to a philosopher's netaphors is to 3 belittle him."

Black's choice of quotation in his introductory chapter gives a clue as to why metaphors are considered vith some contempt:

1. Aristotle, On Poetics, Encyclopaedia Brittanica, University of Chicago 1952, trans. by W. Rhys Robert5, p. 696 ,

2. Ibid., p. 698 .

3. Max Black, Models and Metaghors, Cornel1 University Press, New York 1962, p.25. 
"Metaphors are not argueents,

My pretty maiden." 1

Black selects a bundle of 'obvious' metaphors which he trusts we vould accept as such (like Booth he obviously believes ve do easily recognize metaphors) and makes the stateaent:

In general when ve speak of a relatively siaple metaphor we are referring to a sentence or another expression in which SOME words are used metaphorically while the remainder are used nonaetaphorically. An attempt to construct an entire sentence of vords that are used etaphorically results in a proverb, an allegory or a riddle... cases of symbolisa also need separate treatnent.2

His first example is the sentence "The chairaan plowed through the discussion'... 'ploved' being the vord aetaphorically used he calls this the FOCUS of the metaphor and the rest of the sentence the FRAME. In a different FRAME the sane word aight not create a metaphor. The metaphor used (i.e.the vhole statement) could be translated into another language which leads him to infer that "to call a sentence an instance of metaphor is to say something about its MEANING, not about its orthography, its phonetic pattern, or its gramatical form." Metaphor therefore belongs to semantics not syntax and, as he adds in a footnote, "any part of speech can be used metaphorically."

Using the same vord 'ploved 'metaphorically in different frames he says it vould be difficult to decide whether this constituted two oetaphors for 'metaphor' is a vord ill-defined and 'the established rules of language leave vide latitude for individual variation, initiative and creation."

1. Sir Walter Scott, The Eortunnes of Nige1, Book 2, Chapter 2.

2. Max Black, Models and Metaphors, Cornell University Press, New York, 1962, p.27.

3. Ibid, ,p.28.

4. Ibid.,p.29 
Therefore one has to note the "particular circunstances " of its use. How serious, intense or meaningful a metaphor is intended to be, is alvays dubious, because, as Black says there are "no standard rules for the degree of WEIGHT or EMPHASIS... yet this somewhat elusive 'veight' of a (suspected or detected) wetaphor is of great practical iaportance in exegesis."

Because the 'rules of language' are not a great deal of help there is a sense in which he believes aetaphor also belongs to 'pragnatics' rather than to semantics. Where anyone believes that a metaphor is used in place of a literal expression Black calls this a SUBSTITUTION VIEW OF METAPHOR. According to hin nost uriters have held this view of aetaphor and he gives examples such as:

1. Whately Elements of Rhetoric 7th rev. ed London 1846 p. 280

2. The Oxford Dictionary definition: "Metaphor: The figure of speech in which a nane or descriptive term is transferred to some object different from, but analogous to, that to which it is properly applicable; an instance of this, a metaphorical expression." [Interesting to note that a later version has no reference to analogy: "application of name or descriptive term to an object to which it is not literally applicable (2,g,a glaring error), instance of this; mixed metaphor, combination of inconsistent metaphors." This is from the Pocket Qxford 1964. The example given is actually one of personification].

3. Owen Barfield in "Poetic Diction and Legal Fiction", in Essays presented to Charles Willians (Oxford 1947) pp.106-127 who defines metaphor as "saying one thing and seaning another".

The substitution view aeans aetaphors have a literal equivalent:

The author substitutes $A$ (meaning the metaphorical expression) for L (literal expression); it is the reader's task to invert the substitution, by using the literal meaning of $M$ as a clue to the intended literal weaning of $\mathrm{L}$. Understanding a setaphor is like deciphering a code or understanding a riddle.2

This is only true I believe with newer metaphors. Many are understood as a

1. Max Black, Models and Metaphors, Cornell University Press, New York, 1952, p.30,

2. Ibid., p. 33. 
code e.g dead metaphors, jokes, jargon. For Black, netaphor 'plugs the gaps 1

in the literal vocabulary", by supplying vords of equivalent aeaning where no substitute ones exist. Science and maths for example use aetaphors in this vay. So used, says Black, "metaphor is a species of CATACHRESIS" i.e. "the use of a vord in sone new sense in order to renedy a gap in the vocabulary; catachresis is the putting of new sense into old vords." IIt also usually aeans inproper use of words, which he acknouledges but chooses to ignore.) He feels that any living language absorbs 'nev' meanings for vords in this way--and cites as an exanple the vord 'orange' for both fruit and colour; which ve would no longer consider as metaphor. Hovever "when catachresis cannot be invoked, the reasons for substituting an indirect, metaphorical expression are taken to be stylistic."

Words are used to give pleasure to readers--both in the solving of analogies and inages created, and to add novelty. This subter fuge explains the function of aetaphor when there is no real explanation for its use. This is therefore the decorative use of aetaphor and Whately is quoted as saying that they are always a deviation fron the "plain and strictly appropriate style." If this is 50 Black says they are scarcely useful for philosophy. His viev of nost figurative language is that it likevise inverts aeanings as in e.g. irony, saying the opposite to what one neans or hyperbole when one exaggerates meaning. What then he asks is the characteristic TRANSFORMING FUNCTION involved in wetaphor? He sums up what he has said so far:

[It is 1 either ANALOGY or SIMILARITY. M is either similar or

1. Max Black, Models and Metaghors, Cornell University Press, New York, 1952, p.32.

2, and 3. Ibid, , p.33. 
analogous in aeaning to its literal equivalent $L$. Once the reader

has detailed the ground of the intended analogy or simile (with

the help of the frame, or clues drawn fron the vider context) he

can retrace the author's path and 50 reach the original literal

neaning (the meaning of $L$ ).

My criticism of this view of metaphor is that it is assumed that the receiver of the aetaphor wants to get back to the original literal aeaning Which if this is so, does make the use of metaphor aerely a trick or decoration, an unnecessary difficulty for the listener of reader. If he/she is struggling with the metaphor this may be needed. However, an apt metaphor tunes in as it were to its audience, is clever and yet reasonably obvious in most cases as with jokes e.g. a Fijian chief recently in an intervieu ( at time of the Fijian coup) cleverly twisted the usual translation of Aotearoa "Land of the long white cloud" to "Land of the wrong white crovd'. Fev Nev lealanders vould need to have this pun explained and traced back to the original expression. This sharing of autually understandable information reflects our ability to play imaginatively vith words and ideas, part of a necessary ability to cope with a complex world.

Black says that "if a writer holds that a metaphor consists in the PRESENTATION of the underlying analogy or sinilarity, he will be taking... 2 a comparison view of metaphor." This is really the sane as a condensed or elliptical SIM1LE "for it holds that the metaphorical statenent might be 2 replaced by an equivalent literal comparison." He quotes Whately as saying: "The Simile or Comparison aay be considered as differing in for only from a Metaphor; the resemblance being in that case STATED, which in in the setaphor is iaplied."

1. and 2. Max Black, Models and Metaghors, Cornell University Press, New York, 1952, p.35.

3. Ibid, p.36. 
An objection to this description or definition can be ade on the grounds that LIKE or AS is not as strong (in veight or suggested emphasis) as IS; that in fact a metaphor is auch more a statenent of fact than a sinile which simply invites comparison and can be tather tentative whereas a metaphor sakes a definite declaration e.g. If I describe a place saying "It is Hell" rather than "It is like Hell" surely the latter expression is saying it is similar to or resenbles Hell but gives no idea how much like Hell it is. It could also be like any other places also, whereas the metaphor states categorically IT IS HELL which nust embrace every possible connotation of that place. Ironically my choice is a place of which ve have no concrete evidence but nevertheless we have a concept of Hell (from religion, literature, aythology) as the ultiate in discomfort, degradation, wisery and hopelessness. If this IS Hell can ve go further?

This same strength can be seen in aetaphor even when the copula is not used e.g.' Thatcher the milk-snatcher' a catch cry some years ago in the U.K. No doubt as to what the original inventor of that epithet thought of the British P.M. Who was then Minister for Education and had stopped free ailk issue in the schools. If we change this to Thatcher is like someone who snatches ailk fron young children' the force of the expression is gone, partly because of wordiness which yeakens it.

Alexander Bain, quoted by Black says that "the metaphor is a comparison inpliad in the mere use of a term," This idea of metaphor as condensed simile or comparison was a videly held view. Yet surely sosething condensed is aore compressed and generally stronger than the original. Black thinks the comparison view steas from Aristotle in all probability because in the

1. Max Black, Models and Metaphors, Cornell University Press, New York, 1952, p.36. 
POETICS he says:

Metaphor consists in giving the thing a name that belongs to something else; the transference being either froe genus to species, or from species to species, or on grounds of analogy.1

Black says the comparison view is accused of vagueness, but "metaphorical statement is not a substitute for formal comparison or any other kind of literal statement, but has its own distinctive capacities and 2 achievements".

Another view of metaphor which Black describes is the INTERACTION VIEW of aetaphor, as expounded by I.A.Richards, "vhere the reader is forced to 'connect' the two ideas. In this 'connection' resides the secret 3

and aystery of metaphor." Further reference to this view is aade in more detail in the next chapter.

Black says we now have to use metaphor to explain metaphor, a point I aade previously. For instance he uses the metaphor 'filter' to analyse What a metaphor does. It assists the reader to use his systen of associated comeonplaces (this is a kind of folk-visdon or accunulated experience). So the important fact here is not that the reader knows exactly what all the associations are, for a vord used as a metaphor, but he has a $r$ ange of experience which is 'readily and freely evoked'. For this reason a aetaphor does not alvays translate into another culture or language vith precisely the same impact. What I believe is being called on here is that cultural experience we all acquire, possibly some nythology, beliefs, ideas philosophy, religion, common practices and knowledge, the lore of one's

1. Max Black, Models and Metaphors, Cornell University Press, New York, 1952, p.36.

2. Ibid, p.37.

3. Ibid.,p.39. 
time and place. It does not even have to be first hand experience, for example one need not have experienced an earthquake to have some idea of the effect of such an event. Likevise vicarious experience from literature can also be part of our knowledge. As Black says of the 'man as wolf' metaphor "it suppresses some details and eaphasises others, in short tand this I feel is VERY iaportant) ORGANIZES our view of man."

Another analogy Black draws on is that of looking through the night sky through snoked glass which has some cleap lines. What one sees is liaited and controlled by those clear lines or spaces. Metaphor thus focusses our attention on just sone aspects of a field of vision. Sinilarly in a gane of chess the language used circuscribes how the gane can be described to anyone else.

This circular account takes in all the yarious metaphorical shifts that occur in the understanding of particular metaphors. If there is too much metaphor, confusion occurs, as in mixed netaphors. In literature Black suggests the writer creates his own field as "a novel pattern for iaplications for the literal uses of the key expressions, prior to using thea as vehicles for his metaphors," or, as he says, "they can be made to measure and need not be reach-me-downs." ${ }^{2}$ This is like the author drawing us into his night sky or chess gane. He reninds us also that a metaphor works in two directions e.g.if ve call a man volf-like ve are also attributing something of human characteristics to the wolf.

It is probably worthwhile to give in full, Black's suanary of the 'interaction' view and its seven claias:

1. Max Black, Models and Metaghers, Cornell University Pres5, New York, 1952, p.41.

2. Ibid.,p. 43 . 
(1) A wetaphorical statement has two distinct subjects--a "principal" subject and a "subsidiary" one.

(2) These subjects are often best regarded as "systems of things" rather than "things."

(3) The netaphor vorks by applying to the principal subject a systen of "associated inplications" characteristic of the subsidiary sub ject.

(4) These inplications usually consist of "commonplaces" about the subsidiary subject, but say, in suitable cases consist of deviant iaplications established ad hoc by the writer.

(5) The metaphor selects, emphasises, suppresses, and organizes features of the principal subject by inplying statesents about it that norwally apply to the subsidiary subject.

(6) This involves shifts in meanings of words belonging to the same fanily or system as the metaphorical expression; and sowe of these shifts, though not all, nay be netaphorical transfers. (The subordinate netaphors are, hovever, to be read less "emphatically.")

(7) There is, in general, no simple "ground" for the necessary shift of meaning--no blanket reason why some aetaphors vork and others fail, 1

As he points out (1) is incompatible with the siaplest foras of a "substitution viev", and (7) is formally incompatible vith a "comparison viev", while the remaining points elaborate reasons for regarding "comparison views" as inadequate.

Black's analysis makes it clear that the term 'metaphor'as ve have traditionally used it is too loose, too vague, too vide. Within the set of metaphors there are obviously many sub-sets. There is roon as he says for the 'substitution view', the 'comparison view' and the 'interaction viev'. These 'labels' fit different situations and different examples, but he beliaves it is the latter group which are of interest to philosophers. I would add that this area must also be of interest to teachers. He says:

Substitution-metaphors and comparison metaphors can be replaced by literal translations (with possible exception for the case of catachresis) by sacrificing some of the chara, vivacity, or wit of the original, but vith no loss of cognitive content. But 'interaction -metaphors' are not expendable [an important point]. They require

1. Max Black, Models and Metaghors, Cornell University Press, New York, 1952, p. 44 . 
a distinctive intellectual operation (though one faniliar enough through our experiences of learning anything whatever), demanding simultaneous awareness of both subjects but not reducible to any conparison between the two.1

Any literal aeanings we try to replace the with will lack force and effect- nost importantly "it fails to give the insight that metaphor did." Explication of such setaphors does not reduce this pover viz: literary criticisa or Black's example of analysis of nusic.

His final coment in the chapter is "no doubt metaphors are dangerous and perhaps especially so in philosophy. But a prohibition against their use vould be a vilful "and haraful restriction upon our pover of enquiry." He wight have added that they are also exciting, intriguing and endlessly fascinating,

Has Black in fact answered the questions he posed? He has given us clues for recognising aetaphors but there is no specific definition or criteria to measure the vith. His reference to a frame, a focus and a context are useful. He says translation is possible vith those that dre nore nearly literal i,e. the analogous of comparative type (i.e. akin to simile) and that soee are aerely a foro of catachresis. They can be decorative and used for creating interest, surprise and novelty. At their most creative they involve their readers. Black alvays refers to readers and never listeners as if the metaphor were peculiar to uriters only, yet they are iaportant orally too. The term 'netaphor' is too vague to give a definitive definition. To recognize a metaphor is to understand its allusive meaning (sonetimes elusive). It vill draw our attention either to an analogy

1. Max Black, Models and Metaghors, Cornell University Press, New York, 1952, p.45.

2. Ibid.,p.46.

3. Ibid, ,p.47, 
or the equivalent of a literal transcription (substitution) or to a network of linked ideas to form nev aeanings. The traditional view has tended to be dominated by the aetaphor as a type of simile and eaphasis has been on its stylitic use. The ney viey sees a potential in the study of aetaphor for revelations about how ve think and perceive and conmunicate i.e. the focus now is on how and why we create metaphors--how they work-- what effect do they have--rather than whether they are really necessary. It is for this reason that philosophers and others are interested in then especially in the 'interaction viev' of metaphor as first propounded by I,A.Richards. Their greatest merit then is the challenge presented by trying to understand their construction and their function.

One noted expert on metaphor is Paul Ricoeur of the universities of Paris and Chicago. His preoccupation vith metaphor steas partly fron his philosophical studies of such teras as evil, guilt, sin etc. because direct language does not adequately describe then: "Ke speak of evil by means of aetaphors such as estrangement, errance, burden and bondage," These teras are also often interwoven with narratives of ayth explaining for exaple the origin of evil. First he vanted to inquire into the structure of symbolism and myth--then into hermeneutics as a genera! theory of symbolic language, before it became for hic less romantic and aore objective through the influence of structuralism:

For structuralism, language does not refer to anything outside of itself, it constitutes a vorld for itself. Not only the reference of the text to an external world, but diso its connections to an author who INTENDED it and to a reacer vho INTERPRETS it are excluded by structuralism.2

1. Paul Ricoeur, The Rule of Metaghor, trans, by Robert Czerny, University of Toronto Press, 1977, p.316.

2. Ibid., p.319. 
Thus he distinguishes betveen the tobjective' meaning of text as opposed to the 'subjective' intention of the author. What has to be interpreted in a text is what it says and what it speaks about, the 'vorld' it creates. So first he questions what it is to interpret syabolic language and secondly What it is to interpret text but the connection between the first and second definition is he says an unsolved problen. His concern therefore is for a philosophical heraeneutics.

Ricoeur's conclusion is that ordinary language in no way approxiaates to those 'ideal' languages constructed by logicians and aatheaticians.

The variability of semantic values, their sensitivity to contexts, the irreducibly polysemic character of lexical terms in ordinary language, these are not provisory defects or diseases which a reformulation of language could eliainate, rather they are the permanent and fruitful conditions of the functioning of ordinary language. This polysetic feature of our vords in ordinary language now appears to me to be the basic condition for syabolic discourse and in that way, the wost prinitive layer in a theory of metaphor, syabol, parable etc. 1

Influenced by Wittgenstein and Austin, he also believes that ordinary language is

... a kind of conservatory for expressions which have preserved the highest descriptive pover as regards human experience, particularly in the realms of action and feelings.... the whole problem of textinterpretation could be reneved by the recognition of its roots in the functioning of Ianguage itself.2

Ricoeur seens to be saying 'back to basics'..look closely at language first to understand its uses, and also that in any discourse, conaunication, there are three alements the sender (whose exact meaning aay not be clear in his vords) the receiver (who interprets according to ability with that node of (iscourse) and alternative interpretations which nay be construed

1. Paul Ricoeur, The Rule of Metaghor, trans, by Robert Czerny, University of Toronto Press, 1977, p.321.

2. Ibid., p. 322 . 
by other listeners, readers, observers. They are not necessarily fused as in 'understanding',... can one ever know what interpretation another puts on What one has said or written? A word oay not have meaning intrinsic to itself but once it is patterned in language it assumes shades of meaning as difficult to understand sometimes as to translate into another language, Is this unknown eleaent the 'world' of structuralism? It is certainly the challenge to the poet, to create this vorld. In functional discourse as in commands this is the elenent which one tries to eliminate. In areas vhere personal interpretation is important as in say prayer the language is oore open. Who worries for instance what our interpretation of heaven is whereas it is vitally important in human terms to be able to read, for example, a poison warning or a job instruetion.

Rhetoric vas originally important because speech vas? 'A veapon, intended to influence people before the tribunal, in public assembly, or eulogy and panegyric; a veapon called upon to gain victory in battles where 2

the decision hung on a spoken vord." But phetoric died when the fashion for classifying figures of speech supplanted its political function. A clever Thetorician could be dangerous. Qne reason why Plato condemed it, because it could be an art of illusion and deception. Rhetoric and sophistry created doubt and suspicion. Metaphor has inherited some of this and been stignatised as aere decoration or as lies until quite recently when the mystery of how it actually works has become of more concern, particularly as we have developed more insight into thinking processes and the nature of creativity in humans.

1. Paul Ricoeur, The Rule of Metaghor, trans, by Robert Czerny, University of Tor onto Press, 1977, $\mathrm{p}, 16$,

2. Ibid, $, 0,10$. 
Aristotle's RHETORIC according to Ricoeur vas an attempt "to 1 institutionalise thetoric from the point of viev of philosophy", especially the skills of argument from which it later got separated. He developed a link between the rhetorical concept of persuasion and the logical concept of the probable, as a necessary component of philosophy. Greek rhetoric "had not only a wuch broader progran, but also a problematic decidedly more dranatic than the modern theory of figures of speech." Poetics vas a separate field of study:

Poetics-the art of composing poems --as far as its function and its situation of speaking are concerned, does not depend on rhetoric, the art of defence, of deliberation, of blame, and of praise. Poetry is not oratory. Persuasion is not its aim; rather it purges the feelings of pity and fear.....Metaphor however has a foot in each domain. With respect to structure, it can really consist in just one unique operation, the transfer of the meanings of vords, but with respect to function, it follows the divergent destinies of oratory and tragedy. Metaphor vill theyefore have a unique structure but two functions: a rhetorical function and a poetic function.3

Thus Ricoeur perceives the problem of defining metaphor to lie in these two differences in structure and function. The semiotic description I have quated earlier does not distinguish these two aspects, it is more concerned with structure. The rhetorical (in the sense of political eloquence) or what Aristotle defines as 'the art of inventing or finding proofs' is one field of metaphor and the poetic another where the ain is not to prove but to speak the truth by means of fiction, fable and tragic nuthos, what Ricoeur calls two distinct universes of discourse. These divisions persist in some winds to the present day.

To Ricoeur metaphor is a strategy of discourse and he thinks that

1. Paul Ricoeur, The Rule of Metaphor, trans. by Robert Czerny, University of Toronto Press,1977, p.11,

2. Ibid.,p.11.

3. Ibid.,p.12. 
Inagination must cease being seen as a function of the isage, in the quasisensorial sense of the word, for it consists rather in 'seeing as', a Wittgensteinian expression. So for Ricoeur "metaphor is the rhetorical process by which discourse unleashes the pover that certain fictions have to redescribe reality." By linking fiction and redescription in this Way he believes that ve restore full depth and meaning to Aristotle's discovery that the POIESIS (poetry) of language arises out of the connection betveen MUTHOS (fable or plot) and MIMESIS (initation). He therefore concludes that:

...the 'place' of metaphor, its nost intinate and ultimate abode, is neither the name, nor the sentence, nor even discourse, but the copula of the verb TO BE. The metaphorical 'is' at once signifies both 'is not' and 'is like'. If this is really 50, we are alloved to speak of aetaphorical truth, but in an equally 'tensive' sense of the word 'truth',2

Ricoeur concludes that there is a plurality of modes of discourse and each impinges on the other but no philosophy for instance flows directly from poetry. Nor is there "a non-netaphorical standpoint fron which one could look upon aetaphor and all the other figures for that matter, as if they vere a game played before one's eyes."

More recently Ricoeur has considered a particular aspect of aetaphor theory, exploring the metaphorical process as cognition, isagination and feeling--a problem falling between semantic and psychological theories of metaphor. He is interested in the capacity of metaphor to give us information and insights about reality in a fora not easily translated. Images and feelings, he says, are usually only considered in those theories which do

1. Paul Ricoeur, The Rule of Metaphor, trans, by Robert Czarny, University of Toronto Press, 1977, p.7.

2. Ibid,p, p.

3. Ibid.,p.18. 
not infora or clain to reveal truth, in such they are considered "substitutive explanatory factors," that is they evoke inages and feelings which are aistakenly taken as truths or insights.

Ricoeur's thesis is that 'it is not only for theories which deny metaphors any inforaative value and any truth clain that iages and feelings have a CONSTITUtive function. ${ }^{2}$ He believes that theories such as those of Richards, Black, Beardsley and Berggren, fail to achieve their goals, If not "dssigning a SEMANTIC function to what seen to be mere PSYCHOLOGICAL features and without, therefore, concerning itself with some accompanying factors extrinsic to the inforative kernel of aetapher, " He clains that feeling as vell as inagipation are genuine components in the process described in an interaction theory of aetaphor "They both achieve the semantic bearing of metaphor." It is also Heidegger's thesis that we are attuned to reality mainly through feelings.

Ricoeur believes that Aristotle hinted at the semantic role of imagination, and therefore by implication, feeling also, in a metaphorical sense for he refers to the PICTURING FUNCTION of metaphorical neaning. We speak says Ricoeur of FIGURES of speech "as though tropes gave to discourse a quasi-bodily externalization. By providing a kind of figurabiity to the message, thumanizing then the tropes anke discourse appear." other writers such as Jakobson, Todrov and Genette have also comaented on this giving of form to language. What therefore is this semantic role asks Ricoeur. "It seems that it is in the work of RESEMBLANCE that a pictorial or iconic

\footnotetext{
1. Paul Ricoeur,'The Metaphorical Process as Cognition, Imagination, and Feeling', in Qn Metaphor, Sheldon Sacks, University of Chicago Press, 1978, p.141.

2. 3. and 4. Ibid., p.141.

5. Ibid., p.142.
} 
aoment is iaplied."

Metaphor in classical rhetoric vas described as a ter a of DEVIANCE, but, "this deviance vas wistakenly ascribed to denonination only," serely a change of name, So chiefly it vas used to name new things, to decorate discourse and to persuade or please. In Black's interaction theory las opposed to substitutive theory) ve see that "The bearer of the oetaphorical 3

meaning is no longer the word but the sentence ds a vhole." It is no longer simply a nane for a name, which is really aetonyoy but "an interaction betveen a logical subject and a predicate."

If metaphor consists in some deviance--this feature is not denied but is described and explained in a new vay-- this deviance concerns the predicative structure itself. Metaphor then has to be described as a deviant predication rather than as a deviant denouination," Jean Cohen has described this as seantic iapertinence. A nev pertinence of new congruence arises as a result, Classical rhetoric overlooked the production of this "semantic twist" at the level of sense and "While it is true that the effect of sense is focussed on the word, the production of sense is borne by the whole utterance.,., the theory of aetaphor hinges on a 6

semantics of the sentence," Ricoeur focusses now on the metaphor-aaker:

The MAKER of aetaphors is this craftsaan with verbal skills WHO, from an inconsistent utterance for a literal interpretation, draws a significant utterance for a new interpretation which deserves to be called metaphorical because it generates the metaphor not only as deviant but as acceptable,"7

There are two aspects of this which I vould draw attention to, one is that where he uses the term 'inconsistent' it is suggesting that the aaker of

1. 2. 3. 4. and 5. Paul Ricoeur, 'The Metaphorical Process as Cognition, Iargination, and Feeling', in 트 Metaghhor, Sheldon Sacks, University of Chicago Press, 1978.p.143.

6. and 7. Ibid.,p.144. 
aetaphor is perhaps not avare of his inconsistence but presumably he is in fact deliberately inconsistent for a metaphorical purpose. Acceptance of a aetaphor is not guaranteed either. What a netaphor-maker considers a metaphor can in fact fail like a misunderstood joke can fail, This also does not take into account the reception of the metaphor by the listener or hearer, a factor scarcely ever considered by the various theories of metaphor, it only implies that the maker is avare of his own netaphor. However wat Riccoeur says is true and disagrees vith Mooij's idea of a 'clash':

In other words metaphorical aeaning does not merely consist of a semantic clash but of the NEW predicative meaning which energes from the collapse of the literal aeaning, that is fron the collapse of the meaning which obtains if we rely only on the comnon or usual lexical values of our vords. The metaphor is not the enigma but the solution of our enigna.t

Ricoeur's ideas put sore emphasis on the creativity of the person constructing the netaphor and also on the effect it has even if he does not specifically aention the receiver. He is concerned then with the received weaning which arises d5 a result of the aaking of a metaphor.

It is in the autation characteristic of the semantic innovation that Ricoeur says that similarity and imagination play a role--not in Humean teras of the inage as a faint impression or perceptual residue--or the tradition inherited by Jakobson in which inagination "can be reduced to the 2 alternation between two aodalities of association," What we have to understand says Ricoeur is:

...a mode of functioning of sinilarity and accordingly of imagination which is imanent--that is, nonextrinsic--to the predicative process itself. In other vords, the vork of reseablance has to be appropriate and homogeneous to the deviance and the oddness and the freshnesss and of the semantic innovation itself. 3

1. and 2. Paul Ricoeur, 'The Metaphorical Process as Cognition, Imagination, and Feeling', in On Metaghor, Sheldon Sacks, University of Chicago Press, 1978, p.144.

3. Ibid.,p.145. 
The answer, Ricoeur thinks, began with the interaction theory of aetaphor in delineating but not solving "the transition from literal incongruence to aetaphorical congruence betven tvo seaantic fields." He now uses a metaphor of space, a logical space.

It is as though a change of distance between meanings occurred vithin a logical space. The NEW pertinence or congruence proper to a aeaningful aetaphoric utterance proceeds fron the kind of senantic proxiaity which suddenly obtains between terms in spite of their distance. Things or ideas which vere remote now appear as close. Resemblance uItiately is nothing else than this papprochement which reveals a generic kinship betveen heterogeneous ideas. 2

This transfer or shift of aeaning is what Aristotle called the epiphora of the metaphor. An appropriate theory of inagination aust drav on Kant rather than Hume, thinks Ricoeur, and on Kant's concept of productive inagination as "SCHEMATIZING A SYNTHETIC OPERATION." There are three steps; in the first, imagination is understood as the 'seeing', still homogeneous to discourse itself, which effects the shift in logical distance. This is insight into likeness which is both a thinking and a seeing and he suggests that ve call this productive character of the insight "PREdicative assimilation." This is likened to the attraction of atons. It is interesting that he uses a scientific analogy to explain what has traditionally been considered a literary phenonena. "The assinilation consists precisely in MAKING sinilar, that is seantically proxieate, the teras that the metaphorical utterance brings together. ${ }^{3}$ The tension created is not that betueen a subject and predicate but between semantic incongruence and congruence. Inagination therefore produces under what Ricoeur calls its quasi-verbal aspect rather than its quasi-optical aspect new kinds of

1. and 2. Paul Ricoeur, 'The Metaphorical Process as Cognition, Inagination, and Feeling', in Dn Metaphor, Sheldon Sacks, University of Chicago Press, 1978.p.145.

2. Ibid.,p.146. 
assimilation,

"Remoteness" is preserved within "proxiaity". To see THE LIKE is to see the same in spite of, and through, the different. This tension between sameness and difference characterizes the logical structure of likeness. Isagination, accordingly is this ABILITY to produce new kinds by assinilation and to produce the not ABOVE the differences, as in the concept, but in spite of and through the differences. 1

Gadaner has concluded says Ricoeur that oetaphors allow us to glance at the general procedure by which ve produce concepts. Presumably concepts are nore enbedded in our geological layers as Vygotsky calls thea. This whole process Ricoeur describes as schematise of etaphorical attribution. He believes that the visual or what he calls the pictorial dimension is not fully accounted for by Richard's distinction between tenor and vehicle. Henle has said that "If there is an iconic element in aetaphor it is equally clear that that the icon is not presented, but aerely described," And further "What is presented is a formula for the construction of icons," It is the discourse which sets the ivaging in ootion:

Iasging or imagining, thus, is the concrete ailieu in which and through which ve see sinilarities. To inagine, then, is not to have a mental picture of something but to display relations in a depicting mode.3

This is why as previously mentioned Ricoeur sees Wittgenstein's 'seeing as' as apt. In The Meaning of Poetic Metaghor says Ricoeur, Hester has extended this concept to poetic or bound inages where "the metaphorical sense is generated in the thickness of the imagining scene displayed by the 4 verbal structure of the poem." Ricoeur sees that the intuitive grasp of a predicative connection functions in a similar way.

1. Paul Ricoeur,'The Metaphorical Process as Cognition, Inagination, and Feeling', in On Metaghor, Sheldon Sacks, Univer sity of Chicago Press, 1978.p.146.

2., and 3. Tbid.,p.148.

4. Ibid., p.149, 
Metaphorical seaning is then says Ricoeur "the inner functioning of 1

the proposition as a predicative operation" as in Black's 'filter'

or the 'screen' effect of the subsidiary subject on the aain one. Meaning

is what Frege calls SINN (sense) as opposed to BEDEUTUNG (reference or

denotation). The referential and the poetic function of metaphor seem

somewhat problenatical. Ricoeur says that there is a point when the theory

of metaphor tends to merge vith that of models and they become a vay of

looking at the vorld. They are what has been called 'insightful.' Besides

reference ue assume some search for truth. Ricoeur suggests that the

expression 'split reference' takes care of this problen, and he reminds us

of Majorcan storytellers who begin their tales with: AIXO ERA Y ND ERA (it

was and it vas not). Likewise the poetic netaphor. What this suggests is

that we can find in a metaphor several levels of reference which way relate

to various levels of thinking of which ve are capable. Cirlot describes

various levels: "the subconscious (instinctive and affective thought);

consciousness (ideological and reflexive thought; and superconsciouness

(intuitive thought and higher truths)", though in Jungian terms he says

that 'subconscious' vould be called 'unconscious'. This ady be what Riceour

is suggesting when he speaks of prinordial reference that "suggests, reveals, unconceals...the deep structures of reality to which we are related as 3

portals who are born into this vorld and who DuELL in it for a while."

One can see that to explain aetaphor becones aetaphysical for there

is an element of nystery not about how a metaphor appears to be constructed

1. Paul Ricoeur, 'The Metaphorical Process as Cognition, Imagination, and Feeling', in Qn Metaghor, Sheldon Sacks, University of Chicago Press, 1978.p.146.

2. Ibid, , p.149,

3. tbid.,p.151. 
or recognized but both hov it comes about and how it achiavas its effect.

The sense of a novel aetaphor says Ricoeur "is the emergence of a new semantic congruence or pertinence from the ruins of the literal sense shattered by seantic incompatiblity or absurdity." All of which has led people such as Berggren to conclude that: "The possibility or comprehension of maphorical construing requires, therefore, a peculiar and rather sophisticated intellectual ability" which has been described by W. Bedell 2

Stanford as "stereoscopic vision," Ricoeur believes this to be the saate as. 'split reference', Jakobson's tera, or abiguity in reference. Inagination he thinks does not nerely SCHEMATIZE or PICTURE the sense from the inages aroused it is also involved in what Ricoeur terms EPOCHE or suspension, that is to the PROJECTIDN of nev possibilities of redescribing the vorld. I have said elsevhere that in aaking setaphors ve are only ever truly creative and this assertion by Ricoeur upholds this idea. He says the poet is "this genius vho generates split references by creating fictions," Inagination and feeling have alvays been linked in classical theories of aetaphor, and he believes that feeling and iaggination are genuine components in the process known as the interaction theory of metaphor "They both achieve the semantic bearing of aetaphor." Ricoeur distinguishes between emotion and feelings which accompany imagination in the work of SCHEMATIzation, For the new congruence is 'felt' as vell as 'seen'. As a person ve are assinilated in the predicative and "We feel LIKE what ve see

1. Paul Ricoeur, 'The Metaphorical Process as Cognition, Imagination, and Feeling', in On Metaghor, Sheldon Sacks, University of Chicago Press, 1978, p, 146,

2. Ibid, ,p,151.

3. and 4, Ibid., p, 153 . 
1

LIKE." Feelings help to make the schenatized thought our own. When ve speak of poetic feeling he says that it abolishes the distance betveen knower and known, it is not contrary to thought "It is thought aade 2 ours." Frye explains this, when he speaks in Anatgny of Criticise of 'nood', which is how the poen affects us as an icon, and according to Goodman's concept of DENSE v.DISCRETE syabols "Dense syabols are felt as 3

dense." Feelings also have split reference for when reading says

Ricoeur we do not literally feel e,g, anger or fear. The terror and pity experienced in tragedy for example "are both a denial and transfiguration of fear and compassion." Ricoeur's suggestion is that:

There is a STRUCTURAL ANALOGY between the cognitive, the imaginative, and the emotional components of the complete aetaphorical act and that the metaphorical process draws its concreteness and its completeness from this structural analogy and this complementary functioning. 5

Yetaphors then are quite complex even if they are easy to recognize. A ausical analogy seens appropriate, for like the separate notes which nake up a new sound or chord in music the parts of a aetaphor create new meaning.

Nelson Goodman has described aetaphor as both inportant and odd for:

Metaphorical use of language differs in significant vays from literal use but is no less comprehensible, no aore recondite, no less practical, and no sore independent of truth and falsity than is literal use. Far fron being a mere matter of ornament, it participates fully in the progress of knowledge: in replacing some stale "natural kinds vith novel and illuminating categories, in contriving facts, in

1. Paul Ricoeur,'The Metaphorical Process as Cognition, Inagination, and Feeling', in On Metaghor, Sheldon Sacks, University of Chicago Press, 1978, p.154.

2. Ibid, ,p.154.

3. Ibid, p. I54,

4. Ibid.,p.155

5. Ibid, p.156. 
revising theory, and in bringing us nev vorlds.

In one of the most recent works on metaphor David Cooper explains why an understanding of the phenosenon of aetaphor is "an urgent task for the philosophy of language', and not just for poetics and rhetoric. He recalls little useful teaching on setaphor at school, but two vriters have iapressed his with their vork on netaphor-Nietzsche and Pascal. Nietzsche, because he considered aetaphor the basic principle of language and so-called 'lfteral' talk "a kind of frozen sedisent of metaphor." Pastal was interested in the figurative language of the Bible which he believes is in ciphers which only the good can truly understand but which has some weaning for all of us for ve are fond of syabols and "the things of God are inexpressible, thay cannot be said in any other way." He is intrigued, as is Hegel, as to why people talk wetaphorically. As Cooper says, of Pascal "his thoughts on metaphor nicely encapsulate some of the perennial tensions in reflections on this subject," even if he himself is not aware of this tension.

Most other writers are divided, he believes, on whether metaphor is a 'cognitive' tool of an 'aesthetic' device. They vacillate between "a metaphor is a condensed nodel" or "a aetaphor is a poen in ainiature." The first thing ve need to know about aetaphor says Cooper is what it is,

1. Nelson Goodman, Metaphor as Moonlighting, in On Metaghor, Sheldon Sacks, University of Chicago Press, 1978, p.175.

2. David Cooper. Metaphor, Basil Blackwell, Oxford 1986, p.12.

3. Ibid., p.2,

4. Ibid,p.3.

5. Ibid.,p.4,

5. Ibid.,p.5. 
but there are no definitions available, therefore ve wust see where metaphor resides or "What are the bearers or vehicles of netaphor."

First Cooper thinks ve should decide on two aajor categories--the literal and the non-literal and how to distinguiah these; also how to distinguish metaphor from its relatives such as aetonyay, irony and synecdoche. He looks at various examples of figurative language and decides "there is no generally intuitive ability to identify metaphors, " Aristotle included them all under the umbrella of metaphor and was criticised for 50 doing. Now says Cooper ve are seeing a reversal to his nore generous tern because of dissatisfaction with terns such as trope, figure etc. This reflects a general shift, he believes, from an intellectual preoccupation vith classification to aore recent deaands for theories of language.

Hobbes and Locke typify the old school who sav aetaphor as an 'abuse' and ininical to 'ratiocination'. Max Black rescued metaphor and shoved it to be a distinct node of activity. Cooper says that Symbolic theories such as those of Mallarme and Valery were influential also. Valery believed aetaphor evoked earlier stages of language and that the poet who multiplied figures was only finding within himself language in its natural state and seeing a world of extraordinary associations. Among others U11man subordinates metonymy to aetaphor and Umberto Eco vrites:

A metaphor can be invented because language, in its process of unlinited seniosis, constitutes a aulti-diaensional network of netonyoies...all associations,...are (first) grasped as a contiguity internal to semantic fields. 3

It is difficult to distinguish metaphor from so-called literal

1. David Cooper, Metaghor, Basil Blackvel1, Dxford, 1986, p.5. note: not vehicles in Richards' sense of the word.

2. Ibid.,p.ll.

3. Ibid.,p.20. 
Language because some vould assert that even vords like 'at' or 'up to' can be used metaphorically and literal translations can also contain aetaphors. Sone authors insist that phrases such as 'vin an argument' or 'attack another's position' are not poetic, fanciful or thetorical and cannot be clained to be metaphoric--they are to all intents and purposes literal-Cooper would say they vere aerely dead netaphors and I would agree with him. People who refuse to accept such as metaphor are avoiding the issue and the fact that the most 'ordinary' language is inbued vith metaphor, it is alaost inescapable. Cooper states his viev quits clearly "If expressions really are metaphorical, then they are not literal--hovever faniliar and oundane they aay be,"

Jacques Derrida's work says Cooper, 5hows us how 'the language of metaphysics--the language of 'ideas', 'concepts'; 'substances', 'essences', and 50 on is iabued vith faded metaphor," "White Mythology', to which Cooper is refeyring is apparently taken from Anatole France's story and the vords "sad poets, they take the colour out of ancient fables, and are no nore the collectors of fables. They produce a white aythology."

Hegel said dead metaphors had lost their power to call up ideas and Heidegger that "the metaphorical exists only within metaphysics." Derrida sums up the difficulty..." what constitutes the concept of aetaphor is the opposition of literal (propre) and non-literal... of intuition and speech, of thought and language." This statement comes closer to enbracing the complexity of aetaphor. As he says senses although non-physical, have to

1. David Cooper, Metaghor, Basil Blackvell, Oxford, 1986, p.21.

2. Ibid., p.23.

3. Ibid.,p.23.

4. Ibid., p.25. 
be portrayed in "a language saturated with the terminology of the physical." That is to say that ve only have the physical to explain the non-physical. It rests as Derrida says on "l'unique these de la 2

philosophie."

Cooper agrees that aany theories so far have siaply confused the issue. The nominalist perspective says that siailarity is an illusion Which ve create vith words, so the nominalist aust either, says Cooper, Jeny the literal aetaphysical distinction or drav it in a totally circular manner and thus metaphor rejects noninalism. The aost obvious signal for metaphor is that of the falsity of any literal 'translation', but those analysing it so far have usually concentrated on "the reality of otherwise of certain related distinctions: the necessary and the contingent, the conceptual and the empirical, and above all perhaps, the analytic and synthetic...Any definition of wetaphor which relies on unreflective adherence to these distinctions is unsatisfactory for this reason alone, " So those Who focus on hov a aetaphor "violates the semantic rules and boundaries betveen categories' are wrong in Cooper's estimation, for the terns they use are equally unclear. Such a one is Jean Cohen who says that

"all semantic figures of thetoric [are] violations of fundamental principles 5

of logic"... He adnits to a degree of violation but Cooper argues that there cannot be degrees of contradiction or validity. He has also compared speaking to chess-playing where 'unstable' or 'iaplicit' rules can be broken. If there are rules says Cooper, he fails to give an account of thes.

1. and 2. David Cooper, Metaghor, Basil Blackwell, Oxford,1986, p.26.

2. Ibid.,p.30,

3. Ihid, ,p.31.

4. Ibid., p.32, 
Recent philosophizing on aetaphor has therefore looked to a wore holistic vieu of metaphor and the division between the literal and the nonliteral The disciplines particularly involved are senantics, pragnatics, poetics and rhatoric-but it has also come to the attention of psychologists and sociologists. Jakobson has told us how sufferers from aphasia confuse aetaphor and aetonymy--handling only one or mistaking one for the other--which has led hin to consider that we have two basic nodes of relation "the internal relation of siailarity (and contrast) underlies the aetaphor; the external relation of contiguity (and remoteness) deternines the metonymy." Cooper agrees with this and considers this vork seminal but not with Jakobson's attempts to integrate his idea with Saussurean semiotics and a theory of discourse, because such attempts "treat nonliteral talk as if it were a detachable linguistic skill which oight be studied in isolation."

Sociologists have been interested, particularly since the Frankfurt School, in social intercourse and the politica! functions of metaphor. Lakoff and Johnson wrote that "a metaphor in a political or economic systea by virtue of what it hides, can lead to human degradation." They give us an example, the persistent metaphorizing of human labour as a natural resource to be tapped. This is endenic in current job advertisenents vhere the phrases 'human resources' and 'huoan resource developaent' are used. Roland Barthes dravs interesting links vith myth where the speakers can never be pinned down to be responsible for what they speak of. This device is used in ordinary language and can becone a poverful tool, in his

1. David Cooper, Metadahor, Basil Blackwel1, Oxford, 1986, p.35.

2. Ibid.,p.3B.

3. Ibid., p. 40 . 
eyes, the hands of the bourgeoisie. So language is a poverful force which pover groups can use to vield control even by suggestion. Advertisers exploit this pover also. Cooper speaks also of the Child as poet ayth. 'This is one favoured by 'progressive' educators, of the child as a naturally creative being, the organic development of whose talents must not be interfered vith, but gently nurtured by his green-fingered teachers," ${ }^{1}$ He suspects this myth as vell he wight for we are aware that even gardeners can poison plants and the environment is not alvays healthy for groving organises. The metaphor of education he is 50 sceptical of is discussed sore fully in a later chapter of this vork.

As Cooper sees it aetaphor has becone an iaportant topic because of three wain factors: Our need to fit aetaphor into an overall account of language, our awareness of how pervasive aetaphor is and therefore of the need to understand its workings and the recognition of its pover "as a vehicle of knoviedge and truth." Cooper looks at netaphor from a philosophical angle though he is aware of al! the other interested vievpoints too. Hovever, like them, even when he describes their definitions and standard vievs he still seens to be searching for one hinself. The problem seens to be hov to define the undefinable.

Reading a setaphor aight vell be likened to reading a very conplicated map and trying te discern not only the direction of a route but all the relational aspects such as road levels, nature of the locality, flora, fauna and veather conditions, all in an instant. Familiarity vith the terrain would be helpful but the impact of a metaphor comes fron its novelty so one is never to know in advance what map page one will nead to read.

1. David Cooper, Metaphor, Basil Blackwell, Dxford,1986, p.43.

2. Ibid.,p.43. 
Many uriters testify to the rich use of metaphor in the uritings of Nietzsche. J.P.Stern finds it difficult to decide whether Nietzsche's style is philosophic or literary. He tells us that Nietzsche had a loathing of democracy and for the fragaentation of knowledge. He also claimed that language "far from giving us a true account of things as they are in the vorld, and far from having its grounds in reality, is in fact no more than a referentially unreliable set of almost arbitrary signs." Language, he said is related to 'the hygiene of life', its principal function to hide the hostile universe from men and froe it we would get no knowledge of a world beyond.

In 'The Birth of Tragedy' says Stern, "a pre-rational, instinctive Intuition of prial suffering and fear is postulated as the grounding of 2 huaanity." The vorld, to Nietzsche, works on an illusion, on an 'as if' principle. We act as if ve vere in touch with a benevolent reality. This is a key theme in his work says Stern and explains his style which captures "vith setaphorical intimations of divers spheres of experience...the metaphorically inexact intination of our being in the world." That is, that the relationship between words and the real world is a metaphoric or aesthetic one. To Nietzsche all words are netaphors:

What then 15 truth? A nobile army of metaphors, metonyaies, anthropomorphisas--in short, a sum of human relations which poetically and rhetorically intensified, became transposed and adorned, and which after long usage by a people seen fixed, canonica! and binding on thea. Traths are illusions which one has forgotten ARE illusions... 4

1. J.P.Stern, 'Nietzsche and the idea of metaphor', in Nietzzsche: Inagery and Thought ed. Malcoln Pasley, Methuen,London, 1978.p.67.

2. Ibid., p. 67 .

3. Ibid, p.68.

4. Ibid.,p.70, 
They are likened to coins no Ionger current. Concepts are describad as 1

"the residue of aetaphors" and scientific language is said to cone also from the comaon ground of aetaphor. So truth is 5omething ve agree on merely to play a game as ve aight do vith dice.

Nietzsche considers language priaarily as an aesthetic phenosenon. Metaphors becone 'hard' and 'fixed' in meaning froe long usage and can become instituionalized just as individual experience can. Stern finds that Nietzsche seens to have little tine for single discrete insights or feats of human endeavour "he alvays favours the unique against repetition, genius 2

against justice" and assigns to aesthetic activity a central role in human experience: "his understanding of it as a sode of experience which, more than any other node, escapes the sphere of association and lives by the appearance of uniqueness."

The person who epitomizes this, says Stern, is not Goethe but Rilke "ONCE, each thing but ONCE, DNCE and no more. And ve also are ONCE. Never again..." Nietzsche's rejection of the sphere of association is criticized by Stern and seen by hin as a German tradition which can be traced back to Luther and beyond.

Our real experiences, Nietzsche believed, cannot be comounicated with words:

...Whatever ve have vords for, we have already outgroun. In all talk there is a grain of conteapt. Language, it seens, has been invented only for the average, for the aiddling and comaunicable. Language vulgarizes the speaker. 5

1, J.P.Stern, 'Nietzsche and the idea of metaphor', in NietzzschetInagery and Thought ed. Malcoln Pasley, Methuen, London, 1978.p.71.

2, 3. and 4. Ibid,, , 73 .

5. Ibid.,p.74. 
Yet, he had a passion for writing. Perhaps he should have been a painter for art can also be seen as metaphor. Metaphor5, Nietzsche thinks, are perhaps as near as ve can get to an ideal word-free vorld. In the vorld ve have, the artist is supreae "Art is then neither esoteric and marginal, nor in any way dispensable, but becomes the human activity PAR EXCELLENCE; it IS creative existence."

Our existence appears to be justified by aesthetic experience and expression. Meaning is iaprinted on the vorld by an-made metaphors. Nietzsche has suggested "the existence of a hostile universe of silence before and beyond language vithin which the little human vorld of language Is an gasis of life, of comfort and sustenance, but not of truth. "Language then aerely enables us to cope with living in the world, it is not truly part of it.

Man can only experience harnony with the world in the act of creation. The artist is nevertheless auare of the mataphorical and '1ying' nature of all his productions. This is what Nietzsche calls the divine comedy of life--living and suffering with the scenes or shadous of life. For Nietzsche life is never a concept but a vision, a metaphor: "The metaphysics of metaphor is a sample and paradigm of the metaphysics of being."

Life is seen by Niatzsche as a game, a sport the are as vanton flies to the Gods ?] His ideas have been criticised and he is seen as indulgent in metaphor-mindedness. Critics try to demythologise hin says Stern and others see hie as a poet. Stern sees hill as using "a node of vriting

1. J.P.Stern, 'Nietzsche and the idea of aetaphor', in Nietzsches: Inagery and Thought ed. Malcolm Pasley, Methuen, London,1978.p.75.

2. Ibid.,p.76.

3. Ibid, , p.77, 
somewhere between the individualism and concern with particulars which is the Ianguage area of fiction and poetry, and conceptual generalities and abstractions which nake up the language area of traditional Kantian and post-Kantian philosophy." The aetaphor that he uses for language that of currency or coinage "is intended as an intermediary betveen two modes of thinking and uriting, as a pattern which determines neither a narrative line nor a piece of philosophical poetry or 'Begriffsdichtung' but a 2

philosophical argunent." It is neither poetry nor prose nor aphorism but a middle mode which Stern calls 'literary-philosophical' to preserve "the dynanic, unsteady, the irregular and above al! the individualized nature of 3 life."

Nietzsche therefore created a style of his own as if he refused to acknouledge any order, fules or lavs because in reality there are none. As Stern says "Language, metaphor and thought are related to the real vorid as patterns and paradigns of our being" and Nietzsche challenges the divisions we aake 50 artificially betveen science and inagination, between 'concept' and 'metaphor', 'abstract' and 'concrete'. For kin philosophy and literature intertvine. The fragmentation of knowledge, says Stern, Marx, Carlyle and Mathew Arnold also saw as one of the chief blights of Nestern civilisation. I believe they would now also consider then one of the greatest blights in education where the various disciplines find it difficult to comunicate with each other.

1. J.P.Stern, 'Nietzsche and the idea of metaphor', inNietzzsche: Inagery and Thoughted. Malcola Pasley, Methuen,London, 1978.p.79.

2. Ibid., p.79.

3. and 4. Ibid.,p,80. 
Ted Cohen sees that attitudes to setaphor have changed particularly since Max Black's seninal vork, arguing as ve have seen for their "cognitive" status. To prove whether aetaphors do contribute to meaning Cohen considers that we have to explore and understand hov metaphors are made and responded to and whether they are satters of meaning. For his oun part he is content to consider what use they are and he is led to believe that they are peculiarly crystallized vorks of art which achieve intimacy.

Even though there can be intimacy in the literal use of language sometimes we wish to share a "cooperative act of conprehension... something more than a routine act of understanding." Metaphors create aore than basic comaunication, they offer a sense of comunity. Like jokes and jargon they create a sense of comradeship, "for a figurative use can be inaccessible to all but those who share inforation about one another's knouledge, beliefs, intentions and attitudes. I think the comaunity can be as small as you like, even a solitary pair...surely the self-dialogue of the soul is often figurative."

Cohen concludes that "There can be no effective procedures for 4

dealing with metaphors" no routine method, for one nust detect them as one does jokes and unravel then as they come. One must not presune hovever that such intinacy is always desirable for it can be generated as he says for alicious purposes. The cruel joke is one example but propaganda and advertising also exploit the power of metaphor.

1. Ted Cohen, Metaphor and the Cultivation of Intiacy, in On Metaghor, ed. Sheldon Sacks, The University of Chicago Press, Chicago, 1979, p.4.

2. Ibid.,0.7.

3. Ibid.,p.8.

4. Tbid, p.9. 
Susanne Langer in her study of the symbolism of reason, rite and art seens to favour a theory of language origin which relates to how sound became syabolic, particularly to one advanced by J. Donovan, that the voice was used like a zusical instrument which played vith thythe and patterns of sound enjoyed particularly in early dance and ritual rites. His theory is interesting because it advances the idea that the original use of Janguage consisted in "NAMING, FIXATING, CONCEIVING objects" and the comaunicative use of vords is a secondary application of something already developed at a deeper psychological level, Langer favours this idea because "it suggests the very early, very prinitive operation of METAPHOR in the evolution of 2 speech," for to her mind the nature of aetaphor cannot be understood vithout a symbolistic rather than a signalistic viev of language. Literal language she describes as 'a stiff and conventional aediua, unadapted to the expression of genuinely new ideas, which asually break in upon the find through sooe great and bevildering metaphor," The strength of metaphor is its generality, a vital principle of language and perhaps all synbolisa. Our language is of course full of now 'faded' metaphors and "only the novel predication can be metaphorical."

Metaphor is our most striking evidence of ABSTRACTIVE SEEING, of the pover of human ainds to use presentational syabols. Every nev experience, or new idea about things evokes first of all sone aetaphorical expression.... The use of metaphor can hardly be called a conscious device. It is the pover whereby language, even vith a very saal! vocabulary, manages to eabrace a aultiaillion things; whereby new words are born and nerely analogical meanings become stereotyped into literal definitions...

1. Susanne K.Langer, Phi losoghy in a Ney Key, Harvard University Press, Canbridge, Massachusetts, U.S. A., 1942, p.132.

2. Ibid., p.132.

3. Ibid, ,p.201.

4. Ibid., p.140, 
One wight say that, if ritual is the cradle of language, aetaphor is the lav of its life. It is the force that aakes it esentially RELATIONAL, intellectual, forever showing up neu, abstractable FORMS in reality, forever laying down a deposit of old, abstracted concepts in an increasing treasure of general vords.1

Every vord has a history says Langer and Vygotsky who speaks of language and speech as a psychological tool also says that, like the genetically differentiated layers in human behaviour a concept aay have different roles depending which layer is activated. He found that vord aeanings are dynawic rather than static formations, and that thought and vord are not cut from one pattern "The structure of speech does not simply mirror the structure of thought; that is why vords cannot be put on by thought like a ready-made 2

garment." To understand another's speech it is not sufficient to understand his words ve must understand his thought and also his cotivation. This is the point Cohen makes about understanding metaphers. Vygotsky concludes from his research into the relation between thought and speech that:

Thought and speech turn out to be the key to the nature of hunan consciousness... Consciousness is reflected in a yord as the sun in a drop of vater. A word relates to consciousness as a living cell relates to a vhole organisa, as an aton relates to the universe. A vord is a microcosn of human consciousness. 3

A metaphor as we have seen can be constructed from one vord or many. The origin of language is still in dispute but what ve know of the nature of metaphor, even if it is alnost impossible to define, is obviously significant, for we are metaphor-nakers moulded in part by the metaphors of those whe have gone before us.

1. Susanne X.Langer, Philosophy in a New Key, Harvard University Press, Canbridge, Massachusett5, U.S. A., 1942, p.141.

2. Lev Vygotsky, Thought and Language, MIT Press, Cabbridge, Massachusetts, 1987, 219.

3. Ibid.,p.256. 


\section{CHAPTER 11}

\section{METAPHOR AS LITERARY DEVICE}

The poet by his conscious use of metaphor, is actively engaged in a 'stretching' process whereby new areas of reality are constantly enclosed in the language, nev dimensions of experience recorded, and ade available vithin its confines. 1

Terence Havkes gives a clear overviev of aetaphor in literature. Froe an explanation of the original neaning of the vord META neaning 'over' and PHEREIN 'to carry', to a realisation that the very notion of aetaphor "itself is shaped at any given time by linguistic and social pressures, as well as by its own history: it has no pristine fora." Quintilian, he think5, summarises the classical attitude to netaphor as something to be used on appropriate occasions, to achieve the 'subliae'. This is the legacy inherited by vriters since.

Where Aristotle had simply isolated aetaphor and distinguished four types of it ...Quintilian and others seemed to REDUCE metaphor to one of a group of tropes which themselves forn part of the aerely decorative category of Figures of Speech. As such, it has no real clais to positive 'meaning' in its own right, since it vorks negatively by subverting the proper meanings of vords.3

Consequently some have considered that we could vell do vithout metaphor.

1. Terence Hawkes, Metaghor, Methuen, London, 1972, p. 63.

2. Ibid.,p.5,

3. Ibid.,p.14 
To the Christian aediaeval society the world appeared, says Havkes, like a book written by fod and the world was full of His metaphors. The poet's task vas not to express his own viev of the vorld but to discover God's seaning. And by the tise of Donne poets looked for order in the world not to express personal responses to it. So "The seventeenth century poet...constructs his metaphor fron 'public' elenents with 'established' 1

ranges of relationships." To us they may seen rather artificial, but they act, says Havkes, as an 'ordering' inposed on nature, "Elizabethan metaphors speak, and they ask for a response" as if to drav their audience into completing the metaphor. One influential voice at this time vas that of Rauus who defined aetaphor in teras of a logic. To the Ramist 3

metaphors are arguments. This further emphasised the additive or artificial aspect of metaphor. An effect of this influence it is nou thought, vas to create a division between speech and the written vord giving a superiof status to the latter.

Not surprisingly the Puritans favoured what was called Plain Style. Metaphor, if used, was for a rhetorical purpose rather than a sesantic one. The notion of metaphor as ornament is a result of such attitudes. The search for clarity also meant a loss of the wulti-level nature of meaning in language. This search for plain clear language vas given the blessing of the Royal Society. So that by the tine we cone to Johnson's dictionary definition says Hawkes there is a sense of metaphor being an ABUSE of language.

1. Terence Hawkes, Metaghor, Methuen, London, 1972, p.19,

2. Ibid.,p.22.

3. Ibid.,p.24. 
It vas the Romantics who rejected this classical view of aetaphor and could find soae justification in Plato's notion of organic unity. It is important to understand, Havkes stresses, that "the Romantic notion of the ivagination establishes and stresses that faculty's CONNECTIVE pover, and sets it against the DIVISIVE character of another faculty sometines terned the Reason, but which for convenience aay be thought of as a faculty of 1

discursive analysis." So for then the difference between Plato and Aristotle could be siaplified as the difference betveen Iagination and Reason, and "It follows that Imagination vill embody itself in an's distinctive 2

feature of language in the for of aetaphor." Shelley thought all language 'vitally aetaphorical' and that ve had all been poetic originally and now the poet

...arks the before unapprehended relations of things and perpetuates their apprehension until the vords which represent then becoae, through time, signs for portions or classes of thoughts instead of pictures of integral thoughts. 3

Vico in Italy had also said that primitive nan possessed an instinctive 'poetic' visdon "which evolved through metaphors, symbols and ayths tovards modern abstract and analytical modes of thought." He say the development of children as a mirror of what had happened to us vith language, and believed that nyths vere not 'lies' but 'poetic METAPHORICAL responses to the vorld on the part of wholly responsible people." Metaphor therefore is not merely fanciful but a vay of experiencing reality.

Hordsworth in the same Ronantic mode as Shelley also sought for metaphors which would nost naturally express his vision of the vorld. He

1. Terence Hawkes, Metagehor, Methuen, London, 1972, p.36.

2. Ibid., p.37.

3. and 4. Ibid, p, 38 .

5. Ibid.,p.39. 
say no essential difference betveen the language of prose and that of poetry. So now ve see a move away fron the idea that setaphor is an ornament to be applied to language. Likevise Coleridge sought to establish the link between inagination and language. To hin says Havkes the aind was "an active, self-foraing, self-realizing systea" and ieagination played the Most important part in its work, so that "the process, whereby words construct a 'reality' fron within themselves, and impose this on the vorld in which we live, is a process of metaphor." He even went so far as to say that Ianguage is the "armoury of the human mind" containing the "veapons of its 2

future conquests." I.A. Richards said of hi "Mith Coleridge we step

across the threshold of a general theoretical study of language capable of opening to us new povers over our winds." We aight say the same of Richards hinself for nost writers on etaphor acknowledge a debt to him as one of the first to analyse setaphor aeaningfully with his context theory of meaning.

In 1936 Richards gave a series of lectures on Rhetoric which he called 'a tangled subject'. These lectures are now his book The Philosoghy of Rhetoric. He begins and ends it vith an injunction that "Rhetoric...should be a study of aisunderstanding and its remedies." Bad writing he says spreads false ideas but is good uriting necessarily plain or simple? He believes not. A study of vords in isolation is not fruitful either, for a chief cause of nisunderstanding is he thinks 'The Proper Meaning

1. Terence Hawkes, Metaghorg, Methuen and Co.Ltd, 1972, p. 47 .

2. Ibid.,p.50.

3. Ibid.,p.56.

4. I.A. Richards, Philosoghy of Rhetoriç, Oxford University Press, New York, 1936, p.3. 
1

Superstition' or comaon belief, supported by the traditional textbooks,

that a vord has a meaning of its own. To study merely the vords of a

discourse is to aisunderstand its conposition in toto...

We have to shift the focus of our analysis and attempt a deeper and auch oore ainute grasp of the STRUCTURES [ay eaphasis] of the smallest discussable units of meaning and the ways in which these vary as they are put with other units.2

Because vords change meanings over time and in different contexts

Richards believes that a theory of language nay have something to learn

froe the notion of 'stabilities' in physics "But auch closer analogies are

possible vith sone of the PATTERNS [ny emphasis] of biology ${ }^{3}$ and its

theory of interpretation.

Some traditional aistakes causing confusion, according to Richards, have been the opposition betveen for and content and betveen eatter and form. For, he says, language is not a dress which thoughts put on "we shall do better to think of neaning as though it vere a plant that has grovn -not a can that has been filled or a lump of clay that has been 4

moulded." (Croce is cited as an example of a perpetrator). Even worse he thinks are oversimple sechanical analogies such as Associationism which doesn't go far enough, for "Language and Thought are not ...one and the same. '..."Thought is accessible to study largely Through language."

1. 1. A. Richards, The Philosoghy of Rhetorics. Oxford University Press, New York, 1936, p.3.

2. Ibid., p.9.

3. Ibid.,p.12.

4. Ibid.,p.12.Sinilat setaphors are often applied to children. See Ch.IV this text.

5. Ibid., p, 13 
Rhetoric in the olden days as ve have already seen vas concerned mainly with skills of dispute but persuasion is only one possible ain of discourse. Richards asks us to consider two problens, the functions of 1 anguage and the relationship between things and names, which leads us inevitably to considering the origins of thought. It is in our nature he says that "ve are things peculiarly expressive of other things." We respond to stinuli, for example, loud music, not merely physically but with experience also. He asks: "Do ve ever respond to a stinulus in a vay which is not influenced by the other things that happened to us vhen nore of less similar stinuli struck us in the past?" This factor has to have relevance to our reaction to metaphors or any language to which we react vith our whole person.

Richards says if ve try to trace meanings we go back and back in time, for "aeanings grow out of one another auch as an organisn grous," We do not nerely have sensations but perceptions also from the past as vell as the present. Which leads hil to a major statement that: "All thinking fron the lovest to the highest--vhatever else it may be--is sorting." He believes that a lack of awareness of this factor led to the development of Noninalist, Realist, and Conceptual controversies of the eighteenth century about the origins of abstract ideas and their nature. Richards' theorem is that: "meanings from the very beginning have a prinordial generality and

1.I. A. Richards, Philosoghy of Rhetoric, Oxford Univer sity Press, Neu York, 1936.p.29.

2. Ibid, p.29.

3.Ibid.,p.30. This 'grouth' metaphor dominates the literature on education.

4. Ibid, p.30. This relates al 50 to the importance of patterns. 


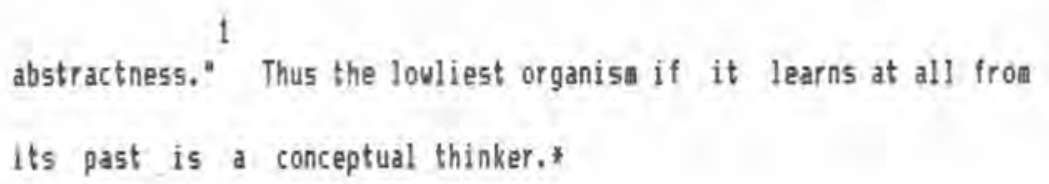

The theorem hol ts that we BEGIN with the general abstract anything, split it, as the vorld akes us, into sorts and then arrive at concrete particulars by the overlapping or connon membership of these sorts, 2

Meaning, to Richards then is "DELEGATED EFFICACY, that description applies above all to the meaning of words, whose virtue is to be substitutes exerting the povers of what is not there. They do this as other signs do it, 3 though in more conplex fashions, through their contexts." One can see how this is pertinent to metaphor also.

\section{'Context' is a faniliar literary tern and can be extended he says} to include the circumstances in which anything was written and said--or to the period, as for exanple the Shakespearean age--but for this particular purpose it is none of these but more particularly 'given conditions' as ve vould have in any cause and effect situation--i.e. ve say under certain conditions, of two events, if one happens then the other does, or vice 4 versa. Richards' theory of meaning is a causal theory of meaning:

The modes of causal theory on which meaning depends are peculiar through delegated efficacy.... in these contexts one item --typically a word-takes over the duties of parts which can then be onitted fron the recurrence. There is thus an abridgenent of the context only shown in the behaviour of living things, and most extensively and drastically shoun by man. When this abridgement happens, what the sign or word--the item

1.I.A.Richards, The Philosgehy of Rhetoric. Oxford University Press, New York 1936, p.31.

F The ability of even the saallest organisos to learn is illustrated by the body's imune system defence against invading germs.

See Iine May 23,1988 .

2.Ibid., p.31.

3.1bid., p.32.

4. Ibid, p.33. 
with these delegated povers--means is the missing part of the context.1

No one knows exactly how this happens, how a sign evolves from an original cause and condition. [ One night call it a theory of 'invisible' context.1 If ve did know, Richards says ve would cone nearer to understanding the nature of life itself. In sumary then "what a word means is the nissing parts of the contexts from which it draws its delegated efficacy." Meanings come from "sortings, recognitions, loss of 3

response, recurrences of like behaviours." He goes so far as to say 4 that "Things... are instances of laws." They evolve over time or as Bradley to whom he refers, says, "association aarries only universals, and out of these lavs, these recurrent likenesses of behaviour, in our minds and in the vorld--not out of revived duplicates of individual past inpressions-the fabric of our oeanings, which is the vorld, is composed."

Meanings develop then over tiae. To appreciate this one only has to reflect on how a current 'nev' word is changing slightly every day. The acronym AIDS for acquired immune deficiency syndrone has become, in a relatively short time, a vord synonynous not only with a medical condition but linked to all kinds of public fear and prejudice. The acronym has become the disease itself and a social or rather antisocial one at that. So auch so that I doubt at the noment if one could read the word aids such as in 'visual aids' without associating this vith the other AIDS even though

1.I. A, Richards, Philosoghy of Rhetoric, Oxford University Press, Nev York, 1936.p.34,

2.Ibid., p.35.

3.1bid.,p.36.

4. Ibid., p. 36 .

5.1bid.,p.36. 
there is no noraal connection and hovever absurd this aay seem on reflection. In tine it aay become a label for a period of medical history in the same way that we refer to the Black Death. In teras of 'context' then this 'nev' vord as it has become is peculiar to our tiae, has entered general vocabulary extraordinarily fast because it has an enotive context as vell as medical. Nevertheless the ter will mean different things to different people depending on their eedical knovledge, their experience of people vith or likely to get the disease etc. What each person understands by the tere depends on personal context as well as the public one. A definition of the word can never include all of one's personal aeaning or the aeaning of it as used at any one particular time--even while it is nevly coined it is gvolving in meaning, in reference--in contexts. This is how I interpret Richards' description of meaning context.

Richards' theorem discourages us fron treating any passage as having only one possible meaning: "This theorea... regards all discourse-outside the technicalities of science as over-determined, as having multiplicity of 1

aeaning. "An awareness of this he says could even help people to settle controversies, as these nornally exploit wisunderstandings:" The context theory of meaning will wake us expect ambiguity to the videst extent and of the subtlest kinds nearly everywhere." Classical Rhetoric vould have considered this a fault, but as Richards sees it this is the source of its potential power and only in very limited situations can language be neutral.

We discover by the study of rhetoric that "the world 50 far from

1.1. A. Richards, The Philosoghy of Rhetoric , Oxford University Press New York, 1936.p.39.

2. Ibid, , p. 40 . 
being a solid atter of fact--is $r$ ather a fabric of conventions, which for obscure reasons it has suited us in the past to eanufacture and support." Richards says that ve have tended since the seventeenth century "to take rigid discourse as the nora and iapose its standards on the rest of 5peech. At the other end of the scale in poetry the virtue of words is 'to have no fixed and settled meanings separate from those of the other vords 2 they occur vith." What ve have in an utterance he clains, is "not one 3

meaning but a MOVEMENT anong meanings." There is progressive movement in the logical progression of any sentence but what he is suggesting is that meaning grows as ve extend our appreciation of e.g. some lines from Shakespeare and "in the extreme case it vill go on woving as long as ve have fresh vits to study it."

To return to poetry. Where does one find the 'meanings'? Certainly not in any book--they have to come fron us--there are no fixed meanings.

In prose, which is more akin to the scientific or rigid, one has to vait for the sense. As Richards points out, the virtues of prose style come from skill in combining various language functions, such as those which aight be indicated by voice tone and intonation. As a consequence the words ve use to judge language in a literary context are rather mysterious e.g. hareony, grace, tone, thythin, texture, etc.

A word has no intrinsic worth, goodness or badness, nor can it be considered correct or incorrect, and it is for this reason that he criticizes

1. I. A. Richards, The Philosophy of Rhetoric 6 , Oxford University Press, New York, 1936.P.41.

2. Ibid., 0,48 .

3.1bid., p. 48

4. Itid., 0.49 
the doctrine of Good Usage and textbooks purveying this idea, even though they suggest that usage is based on the practices of the best uriters and speakers, for who can objectively decide on these. He adaits that comon usage demands some degree of conformity in vord interpretation but this in no way fixes vord meanings for ever. Wordsworth apparently had this same problen vith people who confused the poetic product vith the poetic process, and expected poetry to conforn to styles and standards of previous authors. Richards says aeanings are "resultants ve arrive at only through the interplay of the interpretative possibilities of the vhole utterance...ve have to guess them and ve guess them such better when ve realise ve are guessing..." He aight have approved of adern teachers of reading who have learnt to appreciate the inportance of guessing. What Richards is emphasising is probably what wakes language such an attractive study because it is dynanic, creative, innovative, peculiar to mankind and interpretative of times, moods, dreans etc.

Because vords sometimes sound akin to that which they are describing it has often been imagined that this is a possible basis of their origin. Richards discounts this theory. What links vords, he says, is very often their comon morphenes and "the existence of a group of vords vith a comanon morpheae (as e.g.flash, flare, flame, flicker etc.) has an influence on the foration of other vords, and on the pronunciation of other vords--assinilating then to the group." The sound in itself is virtually meaningless and the context theorem of meaning oill help us to avoid assumptions and false beliefs. Aristotle also said that there can be

1. I. A. Richards, The Philosoghy of Rhetoric, Oxford University Press, New York, 1936.p.55

2. Ibid, ,p.59. 
no natural connection between the sounds of any language and the thing signified. Richards takes note also of the fact that "The meaning of a vord on some occasions is quite as auch in what it keeps out, or at a distance, as in what it brings in." To use the language as a whole or in a asterly vay vould he clains be to use it as Shakespeare uses it but not as technical discourse does.

To exanine a vord in isolation is to have no appreciation of its real value--behind it is a vealth of history, meaning and interconnections vith other words and other meanings; 50 ve begin by analysing it not as a single unit but as part of the sentence or utterance in which it occurs. Richards seems to ne to be saying that to examine vords in isolation is like trying to understand a complex organism merely by scrutinizing a sanple of its tissue under a microscope. Much can be learnt from this but it gives little idea of the whole. His view would nowadays probably be labelled a holistic approach. It is not difficult to accept it if ve relate it to usic and the yay a single note aakes harmony with others and likevise a colour is only significant in relation to the whole range of colours or those near to it: "Everywhere in perception ve see this 2 interanination." The aore ve focus narrovly the aore ve lose sight of this interrelatedness of vords. Richards is adamant that "the viev that meanings belong to words in their oun right--and the more sophisticated vievs which have the sase effect--are a branch of sorcery, a relic of the 2 magical theory of names." He believes that obsessive 'naming' as in many

1. I. A. Richards, The Philosoghy of Rhetoric, Oxford University Pres5, New York, 1936.p.63

2. Ibid., p. 70 .

3. Ibid.,p.71. 
schools of study is that hinders their progress. This desire for fixed meanings "leads us to think that a shift of meaning is a flav of discourse, a regrettable accident, instead of a virtue" but outside the technical languages of the sciences such are not possible. We aust assune then, if ve are to follow Richard's thinking, that words have a life of their oun to live and even though they are our servants ve do not oun then. What ve have to do he says is to learn to follow and interpret shifts in araning. "They recur in the same foras vith different vords; they have sinilar plans and common PATTERNS [ny emphasis] which experience enables us 2

to observe and obey in practice." [Who is master and servant here?]

Richards beligves that "A nev era of husan understanding and cooperation in thinking vould be at hand" if only we vould take "5ystenatic cognizance of even a small part of the shifts ve fleetingly observe". This night seem an incredible clain but if it is true then he is saying that any of our probleas come simply from rigidity in thinking based on the belief in fixed vord meanings or what he calls the 'Proper Meaning Superstition' and it is of course vith abstract vords that ye have the aost difficulty but if ve can aster abstract vord shifts "thereby we may better find out what ve and others are thinking." Writers he says often have their greatest successes by "aaking a single phrase pull with or against large ranges of 5 I anguage. "

1. I. A.Richards, Philosoghy of Rhetoric, Oxford University Press, New York, 1936, p.72.

2. Ibid, p.73,

3. Ibid, p.73.

4. Ibid., p.74.

5. Ibid.,p.75. 
Our language grows faster and faster and new vords create problems in pronunciation, and aven in this convention dominates. Deviations fron custon are frowned upon because there is a large degree of "social or snob 3 control" in language and "one of the tasks of improved Rhetoric is to question it, whether it concerns pronunciation or atters of meaning and 4

interpretation." In Shakespeare's day he believes there was less of this snobbery but since the seventeenth century it has increased and becone a measure of class and status. This preoccupation vith 'correctness' has created what he calls a 'Club Spirit' and has becoue the obsession of gramar book serchants. At the same time a real sense of culture has been lost. So vital is this appreciation that he vould be happy to see it become the central discipline of education. It is for this reason that I feel symathetic to his cause. There is definitely a need at some level of schooling not for traditional gramar study but for courses which give young people an understanding not only of their ovn language but also an appreciation of others.

Richard's analysis of aetaphor begins with Aristotle's definition which to ay aind he misinterprets slightly. He says that there are three assumptions which have marred our thinking since his time. One--that the ability to create netaphor is a gift only sone have. Two--it cannot be iaparted to another. Three--It is something exceptional or a deviation fron the norn. What I believe Aristotle is saying, is about aetaphor, not

1. I. A. Richards, Philosophy of Rhetoric, Oxford University Press, Nev York, 1936.p.74.

2. Ibid., p.75.

3. and4. Ibid., p.78.

5. Ibid., 0.86 . 
about metaphor-aking. It is a self-taught process perhaps fron experience. One cannot be taught a metaphor because it has to come nev-ninted as it vere from the aind. One can only be shown types of aetaphors [nodels of metaphors? I how to recognise a metaphor and be taught how they seen to be constructed and work. We cannot invent metaphors for someone else no more than we can compose ausic or poetry for another person. Even in advertising, copyuriting or ghost-vriting where metaphor is sold for public use, it belongs even if only for a short tiae to its inventor just as a painting is the 'property' of its painter whereas a business letter for exaople is hardly personal property in the same sense. This is a difficult area to define in the same vay that one can doubt whether one teaches children to be poetical, ausical or artistic by training and teaching or how wuch is one only modifying what is essentially innate. It is possible that there are people who have never uritten or spoken in metaphor i.e. created or coined a new original phrase or yord use but they may still think metaphorically as children appear to do e.g. a four-year old who thought ny conb was a 'bridge' something I could not appreciate until I looked at its curved shape and teeth and began to 'see' what he aight be seeing, the curved back as a bridge top and the 'teeth' as its supports. Whether this is how he 'sees' it is sonething I can never know.

Perhaps aking aetaphors is not common but surely everyone has the potential and if it is a question of genius I am inclined to believe like Katherine Mansfield that "genius lies doraant in every soul". Richards is right, language is inparted to us by others but the ability to create netaphor is part of our unique creative ability perhaps our nost individual

1. Kather ine Mansfield, Journal of Katherine Mansfield 1904-1922, ed. John Middleton Murry, Hutchinson, Nev Zealand, 1984, p.37. 
talent. As a result of Aristotle's influence Richards believes metaphor has been treated as "a sort of happy extra trick with vords therefore in brief, a grace or ornament or ADDED power of language not in its constitutive 1

form." It vould I feel be fairer perhaps to blame the influence of sophistry and

the subtle arts of rhetoric which it exploited as being at the root cause of of the tarnished iagge of aetaphor. Richards agrees vith Shelley who said that:

Language is vitally metaphorical; that is, it marks the before unapprehended relations of things and perpetuates their apprahension, until vords, which represent them, become, through time, signs for portions or classes of thoughts: and then, if no nev poets should arise to create afresh the associations which have been thus disorganized, language vill be dead to all the nobler purposes of husan intercour 5e.2

Richards is sure that the iaplications of this 'exceptional' utterance have never been realised. Historians of language he says have known that intellectual operations are described with setaphors based on physical happenings and Jereny Benthan, Bacon and Hobbas likevise realised also that "the aind and all its doings are fictitious." It is easy to observe says Richards that "eetaphor is the omi-present principle of 3 language." Even in science it cannot be avoided, and in philosophy the more abstract it becomes the more it relies on metaphor. Thus "d word is normally a substitute for (or means) not one discrete past iapression but 4 a combination of general aspect5." [that is, Richards'context-theory of meaningl So "In the simplest formulation, when ve use a mataphor ve have tvo

1. I. A. Richards, Philosoghy of Rhetoric , Oxford University Press, New York, 1936. p.90.

2. Ibid.,p. 90 .

3. Ibid.,p.91.

4. Ibid.,p. 92. 
thoughts of different things ACTIVE [ny eaphasis] together and supported by a single vord, or phrase, which meaning is a resultant of their (1)

INTERACTION." This same idea led Dr Johnson to the view that "it is a great excellence in style, when it is used vith propriety, for it gives you 2

two ideas for one." What is missing in this viev says Richards is the "ineense variety in these nodes of interaction." This leads hin to speculate that the Elizabethans were probably wore avare of and sensitive to metaphor than ve are. Chas language becone more fosssilised and therefore we too ?] This he says nade Shakespeare possible, whereas later centuries have narroved their skills until the Rosantic rebellion. Traditionally metaphor vas limited:

And thereby it made aetaphor to seem a verbal atter, a shifting and displacement of vords, whereas fundamentally it is a borroving between and intercourse of THOUGHTS, a transaction between contexts. THOUGHT is metaphoric, and proceeds by coaparison, and the netaphors of language derive ther efrom. 4

Therefore he believes we aust analyse what exactly skill in thought aeans, which supports ay contention that a study of metaphor is vitally important for teachers above all, because if ve are aware of metaphor and attempt to appreciate its existence, persistence and complexity "ve find that all the questions that atter in literary history and criticisa take on a nev 5 interest and a vider relevance to huan needs," What ve are really doing is asking "how thought and and feeling and all other nodes of the mind's 6 activity proceed" --which must surely interest those responsible for

1. I. A. Richards, Philosoghy of Rhetoric, Dxford University Press, Nev York, 1936. p.92.

2. and 3. Ibid., p. 93.

4. Ibid.,p.94.

5. and 6. Ibid, p.95. 
teaching young people. The neasure of our success in this says Richards vill be what practical application ve nake with it. It is significant only in its applications and implications.

Having put metaphor in a historical perspective and benoaned its historical neglect Richards then gives his ovn analysis of eetaphor. For the two essential parts of a aetaphor he uses the terms 'TENOR' and 'VEHICLE', The word METAPHOR is reserved for the whole double unit. A lack of definitive teras has helped to create confusion, siailarly with teras such as meaning, expression etc. and especially figure and isage: "they bring in a confusion with the sense in which an inage is a copy or revival of a sense-perception of some sort... no inage of this sort need come in at any point." This fact is stressed by him repeatedly, that words way conjure up mental inages, but they do not necessarily have to do so "for vords can do al nost anything vithout them, and ve must put no assumption about their necessary presence into our general theory. " For this reason he berates teachers of poetry who suggest such a necessity to their pupils, [Presuably where one does inagine 'pictures' which illustrate metaphors these would be a kind of mental metaphor--an extra metaphor?] Two morals he drays froe Elements of Criticism by Lord Kanes are, first "not to see how a vord CAN vork is never by itself sufficient proof that it vill not work... and to see how it ought to work will not prove that it does."

Apparently Kames makes clear that rules about metaphor as

1. I.A.Richards, Philosoghy of Rhetoric, Oxford University Press, New York, 1936. p.98.

2, and 3. Ibid, p. 98 ,

4. Ibid, , p.106. 
comparisons are exposed as faulty when ve exanine those which do not rely on resemblances betveen tenor and vehicle. Kames argues that when attributes are bestoved on a subject to which they do not belong this is not mere licence on the writer's part but based on a principle of 1 'contiguous association'. The aind works in such a way that it easily passes along a linked chain of objects. This leads Richards to state that "the process of metaphor in language, the exchanges betueen the meaning of vords which ve study in explicit verbal netaphors, are superiaposed upon a perceived vorld which is itself a product of earlier or unvitting 2

metaphor..." Richards believes ve need some general theories of meaning but Coleridge perceived this vith his theory of isagination and conception of inaginative grouth. For hin a symbol represents a whole but is still part of that which it represents. So meditation on one aspect of nature for example helps us key in to the 'universal sode of inagination', In this way nature itself has fed the inagination of 'gentle and pious ninds' and assisted their understanding of the spiritual world. ( A quote from Appendix C of The Statesman's Journal - Coleridge)

This point leads in to Richard's sixth and final lecture on The Comand of Metaphor. First he stresses the importance of the study of metaphor which vas abandoned in the nineteenth century as unprofitable. Skill in using aetaphor and understanding it are different things but ve need the latter to help teach eastery of the skill.

He divides metaphors into two broad categories, those which are based on resenblance of two things--the tenor and the vehicle--and "those

1. I.A.Richards, Philosoghy of Rhetoriç, Oxford University Press, New York, 1936.p.107.

2. Itid, p, 109 
1

which work through some common attitude" (for reasons not always recognised), "A word aay be simultaneously both literal and aetaphoric, just as it may simultaneously support wany different metaphors, way serve to focus into one aeaning any different aeanings." Failure to realise this, he says, causes nisinterpretations, and whether a vord is being used literally or metaphorically is not alvays easy to decide. "If ve cannot distinguish tenor from vehicle then ve nay provisionally take the vord to 3

be literal." Richards is avare also that, it is "a contemporary fashionable abberation to juxtapose extrenely unlike things for conparison" and he cites Andre Breton leader of the French Super-realists as an exponent of such doctrine. Johnson, he says, vould never have approved of far-fetched comparisons vhereas Max Eastaan in The Literary Wind apparently does. Richards puts extreme vieus down to excessive reaction to former views and asks us to consider more closely what happens to the mind when ve push it to connect disparate ideas:

The mind is a connecting organ, it vorks only by connecting and it can connect any two things in an indefinitely large number of different ways. Which of these it chooses is settled by reference to sone larger vhole or aim, and, though ve aay not discover its aim, the aind is never aimless, 5

He says that in all interpretations ve are aking connections. In poetry ve have more vork to do to aake these connections. Deliberately straining this process of connection by presenting ideas difficult to connect ultimately baffles, fatigues and bores the mind la faniliar classroon

1. and 2. I.A.Richards, Philosophy of Rhetoric , Oxford University Press, New York, 1936. p.118.

3. Ibid., p.119,

4. Ibid., p.123.

5.Ibid,,p.125. 
syndromel unless the discourse containing then helps us tovards understanding. This is I believe an iaportant aspect of literature. It seens to ae that the writer who knows the breaking-strain point for his/her readers, who knows how to stretch our ainds and imagination in making connections, is the skilful one i,e, vho respects the reader's intelligence and offers puzzles just challenging enough to tease, to titillate, to carry the reader's interest along. At a basic level this is probably the attraction of 'who-dun-its'. Is this also the attraction of the poen to which ve keep returning and frow which ve extract deeper and deeper levels of meaning? Our ainds vant to be challenged and stimulated, not merely fed. So wuch teaching forgets this aspect of learning, the thrill of discovery, of making our oun connections instead of being offered a 'readysix' in the for of notes, vorksheets etc.

Forgetting the extremist viev, Richards insists that differences are as iaportant in metaphor as sinilarities. He calls this 'disparity action': ...talk about the identification or fusion that a metaphor effects is nearly alvays aisleading and pernicious. In general, there are very fev metaphors in which disparities between tenor and vehicle are not as auch operative as the siailarities. Soae siailarity vill commonly be the ostensive ground of the shift, but the peculiar nodification of the tenor which the vehicle brings about is even aore the work of their unlikeness than of their likenesses.1

Critics he says, have neglected to take full enough account of this and do not fully understand the nature of language as a medium. One exaaple he gives is that of T.E. Hulae whose doctrine of setaphor vas, to Richard's viev, incomplete, because he considered "Plain speech as essentially inaccurate. It is only by new aetaphers... that it can be ade precise,"

1. I,A.Richards, The Philosophy of Rhetoric, University of Oxford Press, Ney York, 1936.p.127.

2. Ibid., p.128, quoting T.E.Hulae. 
One can appreciate what he probably meant by this that seeing things in a new vay makes us really see thee, but Richards objects to his use of 'alvays' 'visual' and 'see' and proves his point by quoting fron Shakespeare Where one does not alvays have to 'see' what one reads for sometines the abstract cannot be ade concrete. He adoits that Hulae may have used the word 'see' metaphorically. If 50 his statement is acceptable but otherwise not. According to Richards teachers constantly ake this aistake, exhorting children to 'see' and 'look' for things. He reminds us:

...language vell used, is a COMPLETION and does what the intuitions of sensation by themselves cannot do. Words are meeting points at which regions of experience which can never combine sensation or intuition, cone together. They are the occasion and aeans of that grouth which is THE MIND'S ENDLESS ENDEAVOUR TO ORDER ITSELF. Imy aaphasis 1 That is why we have language. It is no mere signalling system. It is the instrument of all our distinctively human developaent, of everything in which ve go beyond the other animals.1

Coleridge said "I vould endeavour to destroy the old antithesis of vords and things; elevating, as it were Words into Things and living things 2

too." This is not so far-fetched an idea. Hords are created, 'born', have their idiosyncratic life, just as humans do. They are also a human creation which nothing else truly is. Richards accepts that Coleridge says. He wust do 50 if ve are to study metaphor profitably.

Analogies taken too far break down says Richards but the relation of tenor and vehicle are not limited, Writers hovever often strain vords by trying to use them to copy life vhereas "their true vork is to restore life itself to order." Mistaking tenor-vehicle relationships for the relation between tenor plus vehicle together has consequences beyond literature, Is the Divine Conedy or the Bible, he asks, one vast netaphor? Taking an

1. 1.A.Richards, Philosoghy of Rhetoric, Oxford University Press, New York, 1936, p.130.

2. Ibid, , p.131. 
utterance literally or metaphorically or analogically there are four levels of interpretation, for us to consider:

He can extract the tenor and beliave that as a statenent, or extract the vehicle; or taking tenor and vehicle together, conteaplate for acceptance or rejection sone stateant about their relations which together they vould give to our living. 1

A coamand of metaphor is therefore important to hou ve understand our vorld. In psychoanalysis the notion of 'transference' has illuainated understanding of psychological problems for "In happy living the same PATTERNS [ny eaphasis] are exemplified and the same risk of error are 2 avoided as in tactful and discerning reading." Therefore understanding of the nature of aetaphor is akin to under standing ourselves our relationships, our vorld. Richards believes that a study of Rhetoric leads us along the same path as Plato and Spinoza towards the only end for the sciences, and that "Above all things a method aust be thought out of healing the understanding-purifying it at the beginning, that it ay with the greatest success understand 3 things things correctly."

A study of rhetoric can help us and therefore we can help children to see true. Richards ends with Plato's ayth fron Tinaeus, with the hope that aan wight learn to:

regulate the Revolutions in his Head which were disturbed when the Soul yas born in the Flesh and by thoroughly learning the Harnonics and Circuits of the AIl say ake that which understandeth Iike unto that which is understood, even as it was in the beginning; and having made it like, may attain unto the perfection of that Best Life which is offered unto the by the bods, for the present time and for the time hereafter. 4

1. I.A. Richards, Philosophy of Rhetoricic, Oxford University Press, New York, 1936.p.135.

2. Ibid,, 0.136 ,

3. Ibid., p.137.

4. Ibid.,p.138. 
C. Day Levis claiss that aetaphor is the life-principle of poetry and calls on Herbert Read to support hia, who says "ve should alvays be prepared to judge a poet... by the force and originality of his metaphors' and also Middleton Murry who has said that if one tries to be precise one 1 is inevitably bound to be metaphorical. Metaphor is necessary says Lewis to express the relationship between things, and aoreover vithin a poem there should be some linking, that is "images should be linked by some internal necessity stronger than the mere tendency of vords to congregate in 2 patterns." Yeats, he says, stated that "wisdom speaks first in iwages" and H.W.Garrod said that aetaphor vas in earlier times the natural yay to 5peak. Several people mention this facility as though it is a pover that with the exception of poets ve now have only in diainished fore. For example Vico is quoted as saying:

Poetry.... is the prinary activity of the human wind. Man, before he has arrived at the stage of forming universals, forms inaginary ideas. Before he reflects vith a clear aind, he apprehends with faculties confused and disturbed: before he can articulate, he sings: before speaking in prose he speaks in verse: before using technical teras, he uses metaphors, and the metaphorical uses of vords is as natural to hin as that which ve call 'natural' 3

This seews to imply that we have not only fallen from a state of Grace but have lost powers ve once had, which makes one vonder if ve are searching to find this again and whether prophets, poets and perhaps artists have either retained it or rediscovered it.

Poetic truth unlike scientific truth does not have to be verifiable says Levis rather it causes pleasure of the kind that Kant has said is a furtherance of life. Lewis quotes Keats who said that "The imagination may

1. C.Day Lewi5, The Poetic Itogge, Jonathan Cape, London, 1947.p.17.

2. Ibid.,p.25.

3. Ibid.,p.26, 
be compared to Adan's dreas--he avoke and found it truth." and Blake who said that "Everything possible to be believed is an iage of truth."

Poetry gives us an isage-pattern of the real vorld "Metaphor is the medium through which these correspondences are made known to the reader....the poetic isage ...tells us that, in the real world too, there is a pattern." Because metaphors deal vith relationships they give us partial intuition of the vorld which Blake says we would see as infinite if our perception vere clear. The poet's task is to recognize pattern, Myths created by a collective consciousness brought us forward fron our brute state, says Levis and now ve have outgroun then "they have performed their evolutionary 3

task" and are needed no core. Now ve have the poetic iage which he calls the ayth of the individual:

It is not aerely that, tise and again, we find in the ioages of modern poetry forms and impulses derived from the myths; but the very nature of the image--of poetry in its aetaphysical aspectinvokes that consciousness, as though san, even at his nost individual, still seeks emotional reassurance froa the sense of comunity, not community with his fellow-beings alone, but with whatever is living in the universe, and with the dead. 4

What poetry tells us says Levis is that, like the Ancient Mariner discovered, if we shoot a bird we shoot ourselves, or as Hardy said "The huadn race...[is] as one great network or tissue which quivers in every part when one point is shaken, like a spider's veb if touched." And Shakespeare also told us that there is a special providence even in the 6

fall of a sparrov.

1. C. Day Levis, The Poetic Inage, Jonathan Cape, London,1947.p.27.

2. Ibid.,p.28.

3. and 4. Ibid.,p.32.

5. Ibid.,p.33.

6. Willia Shakespeare, Hallet, Oxford edition, V,ii, 232. 
Classical poets says Levis tried to ake horrible things pleasing but aodern poetry tries to accept them as part of the pattern. I suppose this is similar to the vay in which humans try to accept aisfortune and ill-health as part of life that they do not understand nor seea to have control over.

There is considerable unaninity over this idea of haraony, unity or pattern in the vorld says Lewis and "poetry's task is the perpetual discovery, through its iuaging, eetaphor-making faculty, of new relationships vithin this pattern and the rediscovery and renovation of old ones." Hovever because the pattern is always changing, absolute truth is never achieved which reninds one of the atoms which scientists can prove to us exist but yet ve cannot see then or at least not until very recently for since I first urote this there is a report that in fact this is now possible. Levis states that "the poetic inage ...searches for connections by the light of an iopassioned experience, reveals truth and makes it acceptable 3 to us." As he says we nay ask why we need poetry when ve have science. His answer is that there are unverifiable truths which in poetry carry the conviction of truth. Even with an iage that can be construed literally as true, ve vill not get the sane effect as the pattern the inage creates in the poem because it is the pattern which gives us pleasure and satisfies our human need for order and completeness; "Beneath the pleasure ve receive fron the verbal music, the sensuous associations of a simile or a metaphor, there lies the degper pleasure of recognizing an affinity. It has been

1. C.Day Lewi 5, The Poeteic Image, Jonathan Cape, London, 1947.p.34.

2. Dowinion Newspaper, New Zealand 10/9/87 Reporting on the work of Dr Peter Knight and Or Richard Thompson in London, who have discovered a method of capturing and suspending individual atoms by using laser from which they absorb radiation and are revealed to the naked eye as tiny spots of fluorescence.

3. C. Day Levis, p.34. 
called the perception of the siailar in the dissinilar..." Levis

describes the threefold effect of a metaphor by Ben Jonson describing

lilies as light and the richness of this and its layers of aeaning.

Cynics aay scoff he says but the vords of a Danish physicist Niels Bohr

bear vitness to siailar thinking: "the abiding iapulse in every huasn being

[is] to seek order and harwony behind the manifold and the changing of the 2

existing vorld."

So the poet seeks patterns say5 Levis, and looks for the love which binds the vorld. He has tried to express this in poetry of his ovn but doubts if words suffice. Like Nietzsche he uses the metaphor of dance "Perhaps one should be content to let the principle energe of itself from that dance of words in which life and art, the real and the imagined, so delicately interveave themselves that even the poet can hardly tell one from the other." For as Yeats said "How can we know the dancer fron the 3 dance," Keri Hulne speaks sinilarly of this same "strange-paced dance" of "the dance of ecstasy" and "the aead-reel, his dance" as if ve are all partners in a universal dance yet ve are unavare of the tune and who plays 4 it.

Levis believes that poetry appeals to the unconscious in us and art is to give pleasure. Inages he says are to be distinguished fron syabols which are denotative and stand for one thing only, whereas images, in poetry are rarely simply syabolic for they are affected by their context and by the reader's response. I find it difficult to accept this totally

1. C. Day Levis, Ihe Pogtic Image, Jonathan Cape, London,1947.p.35.

2. Ibid,,p.36.

3. Ibid., p.37,

4. Keri Huloe, Ihe Bone People, Spiral, Nev Zeal and 1983,pp.2,459,461. 
for after all if a symbol e.g. a cross or a croun, is a vell-knoun and entrenched syabol in our culture each person still has individual responses to or connotations of that syabol. If one vere for example to ask people about the syabolisn of the narriage ring there vould be a variety of responses. Symbols differ from metaphors 1 believe because they lack the novelty and hence dramatic inpact of nevly-coined aetaphors. A symbol can spring from a metaphor, such as the fan used to denote radio-activity danger. Levis says Shakespeare understood the consummate art of fusing intellectual and sensual seaning in his inages. This is one key to the lure of literature, it invites intellectual and aesthetic response of an intensely personal kind.

Drana gave great scope to iagery which has had to be nore restricted and confined in lyric verse which vas also often meant to accompany music, 5ays Levis, "bold, intense and closely urought images are inappropriate to verse uritten for music, since they tend to destroy the balance betueen the word pattern and the aelodic line." Moving avay from music affected poetry, it moved tovads the metaphysical school and the pursuit of the 'conceit'. Symbolic of the seventeenth century says Levis is Donne's notion of man as a telescope. One sees here the beginnings of introspection and also of scientific observation leading on to our even more self-conscious post-Freudian times. Eventually soas poets developed medleys of inagery which vere labelled 'vit-uriting'. Mathev Arnold condenned poetry which vas merely "a shov of isolated thoughts and iages."

In Romantic poetry says Lewis "the image-making facility is unleashed and vanders at large, whereas vith the Classical it is tethered to a

1. C. Day Levis, Ihe Pogtic Ingge, Jonathan Cape, London,1947.p.49.

2. Ibid.,p.54. 
thought..." The Romantics observed the vorld of nature and the human condition but the aoralizing elenent becane nore concealed in the inagery. Whatever the style or the statement it nakes, it still seems to Levis that Aristotle's stateaent is true, that Poetry is the most intense and philosophical of the arts.

The creative inage comes from inagination which is difficult to define. To Shalley inagination vas a fod and he a prophet. It is, says Levis, sioply the capacity to put oneself in the place of another-a going out froe onesel f--the nature of poetic sympathy is revealed in inages and "The identification of the poet vith objects which appeal to his sense in the initial stage of image-naking." It was Keats who spoke of 'negative capability' as a state of aind necessary to creativity.

The creative aind does not iapose pattern but perceives it as Louis Mac Niece said "The poet is often not completely sure what he is trying to say until he has said it. He vorks up to his meaning by a dialectic of 3

purification." A key inage night lead to others and a process of revising and revieving leads to the final vork. Much the same happens in science When a creative thinker breaks out from a fairly fixed pattern of thinking and in the desire to solve a problen sees a nev possibility. I believe that a siailar process goes on in metaphor-making in ordinary language, it is the fast thinker, the intuitive person, who produces a nev vay of using vords.

Inage patterns aust in fact be patterns and not random collections of 'yord-pictures'. A mixed aetaphor, says Levis, Iacks

1. C.Day Lewis, The Poetic Inage, Jonathan Cape, London,1947.p.59.

2. Ibid.,p.67.

3. Ibid.,p.71. 
'congruity of inages'. Consistency is important, othervise statements lack poetic truth and cannot be comanicated. Richards has said that the poet's capacity "is only part of a more anazing capacity for ordering his 1

experience." Inages have to persuade the reader that they are natural language and that they cane from the poet vithout strain but "unless passionately realised... [they tend to] produce conventional ornament." Levis admits that some poetry is flaved, and obscured by a surfeit of inagery for poetry needs a good aind behind it: "Behind the conscious gift that creates coherent inage patterns there lies the deep pover to organize 3 experience." He says that Rilke, in his Notebook of Malte Larids Brigge vrote of this need to have seen, felt and lived through the experiences one vrites of at the point where "they have turned to blood vithin us."

All iaaginative uriting, says Levis, goes through this process, which is presuably why ve use the vords 'creative' and 'creativity' to indicate the giving of life or for to ideas to be shared whether in poetry, music or art. Sometises, he says, poets are criticized for excess of this pover, as when Trevelyan wrote of Meredith, telling us "...you are aeant to catch the first light that flies off the metaphor as it passes: but if you seize and cling to it, as though it vere a post, you vill be drouned in the flood of fresh metaphor that follows,"

A poet, says Levis, is a person of intense sensitivity to the times in which he lives. Inages therefore are often conteaporary and poets attempt to come to grips with their experiences through metaphor which is "the

1. C. Day Levi 5, The Poetic Inage, Jonathan Cape, London, 1947.p.74.

2. Ibid., p.82,

3. and 4. Ibid, p. 85 .

5. Ibid., p.83. 
1

language of tension* which helps us to face reality. Arnold believed ispatience to be a poet's fault and this causes his probleas vith inages that fail. Rilke agrees that patience is needed and Professor Livingston Loves believed vitality al so to be necessary othervise poets vere like her ait crabs living in the shells of their predecessors. "Levis says these qualities cannot be developed like one builds body nuscle but when they exist the vork survives for posterity. Teachers of literature like to believe I think that 5ome of these qualities can be developed. More and wore ve are finding that given the right conditions wany ainds can flourish, Those who are nov aware of the right and left brain dichotony which has influenced education know that many talents have atrophied through lack of 3

use. However ve can appreciate what Lewis is saying, that a poet say speak vith a voice that is not understood in his time [likevise the arist] for he sees as no-one else sees at that tine.

Even traditional themes $c$ an be seen vith nev iages as in the seventeenth century poetry which collected aetaphors from science and developments in adchinery. Sone think that increasing urbanisation drove nineteenth century poets to a keener appreciation of and observation of nature. Even war kindled insights which were presumably heightened by the intensity of var experiences. "In general poetry uritten during the vat vas less strained, less anxious, less eccentric" says Levis.

1. C. Day Levis, The Poetic Inage, Jonathan Cape, London,1947.p.74.

2. Ibid.,p.100.

3. See Betty Edvards Drauing on the Right Side of the Brain, Fontana/ Collins, 1979 which describes a cognitive-shift model of teaching, encouraging a mental shift from verbal, logical thinking to a more global, intuitive mode.

4. C. Day Levis, p.t10. 
Sadly though, when var is over these poets becose nonentities, the fate of any poets. Even in our oun tiaes it is true that poets are not alvays valued for their insights or their prophecies. Inagination, says Levis is the instrunent vith which the poet explores the patterns of reality. He also thinks that religion and poetry overlap and that atrophy of the general inagination is the result of a divorce between the spiritual and the material aeanings of things. Graves considered that we had concentrated on developing analytic povers and neglected the co-ordinating arts of the poet, to this he attributes "the modern cona of religion among our educated classes and for the disrespect into which poetry and the fine arts have fallen." This neglect of poetry and poets creates a nervousness in their work, and conscious sannerisms to clain our attention: "the violence and discordance of his imagery is partly a aore or less deliberate shock treatment, by which he hoges to break down this reader's 2 too civilised resistance." A good example I believe vould be the vork of New Zealand poet David Eggleton whose iage-packed 'shock' poetry like auch modern music seeas to have fen spaces for silence, no aelody to the ear, only the jarring of nerve-endings.

Levis believes that images which are too personal fail "Iages must 3 have sone enotional or sensual source outside the poet." Modern poetry aay reflect, with its intensity of imagery, the complexity of modern life but this cannot justify, in his eyes, a disintegrated poen. Levis gives a lean and simple definition of what a poen is to hin:

A poen--let us be quite frank about the physical facts of it--nust

1. C. Day Levi 5, The Poetic Inage, Jonathan Cape, London,1947.p.113.

2. Ibid.,p.114.

3. Ibid.,p.116. 
have a beginning, a niddle and an end, othervise it vill not be a whole thing. It sust have rhythn, which aeans one group of inflections not aerely folloving but caused by another. Its iagages drawn from the vorld of time and space, must develop its theme, or devel op out of its theme, in a certain order and a certain relationship: one inage begets another as surely as one day telleth another. Moreover, the reader vill not take in the vhole of a poen sinultaneously: for hin too it is a series of experiences. Whatever nodern philosophy ady do, the poet cannot in fact discard sequence, cannot discard cause and effect, cannot work to a continuous present. 1

So the poet creates order out of cha0s and produces formal pattern. Levis is critical of Gerard Manley Hopkins because he occasionally fails to create structure with his isages. Herbert Read clains that poetry which is pure iagery is too fragile for use. An incomplete poen is likevise flaved for it vill fail to satisfy.

Because inagery is destroyed by our too curious probing much like a delicate specisen being rudely dissected, ve can never be fully satisfied vith our study of it, and this has caused Middleton Murry to say that such work can drive us to insanity. The poet "can only arrive at the truth of his own experience by a circuitous route, by an indirect use of language." Spender's poem Seascape proves, for Levis, that there is a law of inagery and that is, that vord-pictures only becone iages in relation to a general truth. Keats has said that a reader should find the vords matching his oun highest thoughts as if he remeabered thea. Which again supports the idea that inagination may be aemory. Levis's quote from Coventry Patmore bears this out with reference to the vords 'Let not my heart forget the things mine eyes have seen.' And Spender also believes that memory is a faculty of poetry, and iagination an exercise of memory. I an inclined to believe that the sane is true of dreans, that ve can in fact only dream

1. C. Day Levis, The Pogtic Inage, Jonathan Cape, London, 1947.p.120.

2. Ibid, , p.136, 
What ve already know, no matter hoy confused, distorted or strange it seems. But as Levis says the poet applies his experience to different situations and thus aetaphors or mearies are created.

A thene, says Levis, is the individual poet's interpretation of a general truth or one interpreted through the Ianguage of the poet's experience. This gives us two levels of inagery in a poen, those relating to a theme and the these inaging a general truth. Not the sane truths of science and philosophy but recognizable through their enotional effects. There are truths of unusual potency and universality. Jung has attributed these effects of 'great' poetry to unconscious forces or 'prinordial images' or archetypes. So, as Levis sees it, ve have private memories which are expressed in one's poens, but beneath this are "archetypal patterns of response to nature, inherited from numberless generations of ancestors."

Jung apparently distinguished two types of artistic creation, the 'psychological' and the 'visionary', the first draving on ordinary experience but raised to the level of poetic experience and the second surfacing fron 'the hinter-land of an's oind'. Levis hiaself does not see such a clear division--he believes that the aesthetic enotion derived from a poen "arises 2 from the satisfaction of man's desire for pattern, for vholeness" and that the archetypal inages of poetry indicate our desire, even when we drav apart from fellow human beings, to associate vith the community. For he believes "they point us back to a vorld where the community, hardly as yet differentiated into individuals, felt as one and projected its feelings 3 into myths." This desire for contact with comaunal experience is part

1. C.Day Levis, The Poetcic Inage, Jonathan Cape, London, 1947.p.141.

2. Ibid., p.143.

3. Ibid.,p.144. 
also of the vish for wholeness and way be as T.S.Eliot said:

...the end of all our exploring

vill be to arrive where ve started

and know the place for the first tine, 1

Levis says that Maud Bodkin has suggested that The Ancient Mariner for example portrays the 're-birth archetype'--of one who descends into Hell and is, as it vere, reborn to rise again.

The theory of archetypes, is, just a theory, but appeals to Levis. He believes that no subject is unvorthy for poetry, if the poet "brooding passionately over the object" sees it as part of the schene of things, the 2

universal pattern. To vould-be-poets he vould say, that the poem is a re-birth, a re-creation or resurrection of the body after its life journey, and will affect other sen too. He is conscious that the new generation after his lives in a different world, one threatened by atonic varfare--but he still believes that the poet can create "gestures of peranence anid the passing, signs of love in the valley of the shadow."

A brooding concentration is what produces poetry, says Levis, or what he calls 'the prayer of the intellect' which interprets in iages. The ney inages needed in this new vorld are "images of virtue--natural, consoling, heartening." To poets is revealed the aystery and vision of these things.

Richards hinted as others have that ve may have lost some of our poetic povers. Robert Graves has an interesting theory that the Ianguage of poetic ayth anciently current in the Mediterranean and Northern Europe Vas:

a adical language bound up with popular religious ceremonies in

1. C. Day Levis, The Poetic Inage, Jonathan Cape, London, 1947.p,144,

2. Ibid.,p.154.

3. and 4. Ibid.,p.156. 
honour of the moon-Goddess, or Muse, some of the datirig from the 01d Stone Age and that this remains the language of true poetry-'true' in the nostalgic modern sense of 'the unisprovable original, not a synthetic substitute'. The language vas tampered with in late Minoan tiass when invaders fron central Asia began to substitute patrilinear for atrilinear institutions and renodel or falsify the myths to justify social changes. Then cane the early Greek philosophers who vere strongly opposed to magical poetry as threatening their nev religion of logic, and under their influence a rational poetic language (now called the Classical) was elaborated in honour of their patron Apollo and inposed on the vorld as the last vord in spiritual illuaination: a view that has prevailed practically ever since in European schools and universities, vhere myths are nov studied only as quaint relics of the nursery age of sankind.1

So the nyths by the time of Socrates became forgotten or kept a close religious secret which ve only have evidence of in religious art and fairy tales. Graves proves for hinself that the study of mythology "is based squarely on tree-lore and seasonal observation of life in the fields." He also believs that Socrates in rejecting poetic ayths vas really turning his back on the Moon-goddess and replacing vorship and love of her with Platonic love, that is away froe vosen and representing "the wale intellect 3 trying to ake itself spiritually self-sufficient." The reification of Socrates after his death further helped to push the poetic ayths into the background, so that they vere only preserved in secret aystery cults until suppressed by the early Christian enperors. So for Graves English poetic education should not begin vith the Canterbury Iales (as it still does in U.K., with Shakespeare in N.L.J, the Odyssey or even Genesis, but with the Song of Angrgin, an ancient Celtic calendar-alphabet. His theory helps to explain how 'mythical' has come to mean 'fanciful, absurd, unhistorical'.

"The function of poetry is the religious invocation of the Muse"

1. Robert Graves, The White Goddess, Faber and Faber Ltd, London, 1961, p.9

2. Ibid.,p.11.

3. Ibid, p.12. 
says Graves, but poetry is now dishonoured for in our vorld "the Moon is despised as a burned-out satellite of the earth and voman reckoned as 'auxiliary State personnel'. In which money vill buy al aost anything but truth, and al aost anyone but the truth-possessed poet." The concept of a creative goddess vas, he say5, banned by Christian theologians al most two thousand years ago and by Jevish theologians long before that. It seeas to Graves that it is just as unscientific to believe in a father or wother authorship of the universe. If the source of poetry's creative pover is inspiration and not scientific intelligence then he can see no reason why ve cannot attribute it to the Lunar ause. For hin:

True poetic practice implies a aind 50 miraculously attuned and illuninated that it can forn vords, by a CHAIN [ay eaphasis] of more-than-coincidences, into a LIVING ENTITY [ay emphasis]--a poea that goes about on its own (for centuries after the author's death perhaps) affecting readers vith its stored magic, 2

The links between literature and religion are evidenced in priaitive song as C.M.Boura illustrates when he examines the songs of prinitive 2

people. As he says the story of man covers a nillion years but ve have records only for the last five thousand years. Songs he says are one of the most elemental foras of poetry. Early man alvays had nusic of some kind for flutes and pipes have often been found, so ve can presuae that he al 50 danced.

Bowra's study looks at sone groups which are still living as the Stone Age peoples did. Their lives he finds indicate a common pattern evolving around hunting, nomadic habits, social groupings such as families etc. and usually living a very hard and exacting life. Change is very slov

1. Robert Graves, The White Goddess, Faber and Faber Ltd, , London, 1961, p.14.

2. C.M. Boura, Prigitive Song, Weidenfield and Nicholson, London,1962. 
and custon is extreaely important.

The vords of the songs are only part of a complex unit we cannot

take them at their surface meaning to us. "They take us into the consciousness

of primitive man at its sost excited or exalted or concentrated nonents,

and they throv a light, [that light setaphor yet again] which alnost nothing

else does, on the aovenents of his aind."

Singing is usually a communal activity and words are traditional,

passed doun fros one generation to another. They are spoken not written.

An Eskino, Drpingalik, said of songs :

Songs are thoughts sung out, sung out vith the breath when people are noved by great forces and ordinary speech no longer suffices... When the vords ve vant to use shoot up of thenselves--ye get a nev song. 2

Sonetines there are formulas and ready-nade phrases one is expected to use.

Special occasions such as a burial aay call for a sacred song.

Sacred songs are in the first place, intended to establish a relation vith supernatural povers and to influence then in a direction desired by the singers. They are conposed against a background of accepted beliefs, and use its assuaptions to ake thenselves felt. Primitive an is surrounded by forces which he cannot control or understand, and he hopes that by finding the right vords he may gain soae hold on thea. 3

One cannot help thinking that perhaps the prioitive has an adavantage here over so-called civilised people vho also cannot understand any of the forces ruling their lives. We seen to lack abic metaphors for this purpose.

Sone sounds in prinitive song have no knovn meaning 5ays Bovra, and prinitive language uses iages vithout the least effort or preaeditation.

1. C.M. Bowra, Prinitive Song, Weidenfield and Nicholson, London, 1962. p.29.

2. Ibid.,p.36.

3. Ibid.,p.48. 
They also fall easily into syabols, which are not the same. The povers of nature for instance are often described in hunan teras. For example, soae lines froe an Australian song of the Mudbara Tribe of Wave Hill in the Northern Territory celebrating the sun:

The day breaks--the first rays of the rising Sun, stretching her arns.

Daylight breaking, as the Sun rises to her feet....

Hearing her waistband of husan hair.

She shines on the blossouing coolibah tree....1

The sun is portrayed as a kind of goddess in human form. Such songs says Boura contribute to the general task of elucidating universal aysteries, enabling us to coaprehend the inconprehensible. The use of syabols differs from that in civilized poetry says Boura, where ve use an inage to give a nev significance or cast a nev light on something dulled by faniliarity, to echo or revive a aystery rather than explain one. They are not as vital to modern poetry as they are to the priaitive. He concludes"In their use of symbols prisitive song and modern poetry differ not in kind but in degree." They are used to express something ordinary vords do not adequately deal with. With regard to nature "Prinitive an is so deeply rooted in his setting that he does not treat it as a mere setting but for as some more 3 intimate tie vith it in the belief that it affects his life."

Bowra finds that dance has priority over song "Dance is one of aan's earliest atteapts to ove in an inaginary vorld of his own creation, which none the less stands in a close relation to the actual vorld and fulfils some function in it, whether agical or religious or ceremonial or aerely diverting. 4

1. C.M.Bowra, Prinititive Song, Weidenfield and Nicholson, London, 1962. p. 252 .

2. Ibid.,p.260.

3. Ibid.,p.151.

4. Ibid., p.261. 
The adaptation of words to songs must he thinks have been a very slow process but songs arose fron dance. It is definitely not art for arts sake. When ve speak nov of the enchanteent of vords yhat is now a metaphor was once a reality. Prinitive song is close to prayer where a sense of aystery pervades.

Elizabeth Cook considers the Mythological tradition in European art to be ieportant. Her reason is that "these stories fit into the pattern of children's lives, and provide an answer to some modern probleas in 1 teaching." They also have inherent poetic greatness for "The best stories are like extended lyrical iages of unchanging huan predicaments and strong, unchanging hopes and fears, loves and hatreds."

Jung has fold us that myths eabody 'race memories' and there are many other theories. Cook believes none of then to be exclusively right but all of them collectively, for "The human experience brought to aind by ayth and fairy tale extends beyond the situation described by psychologists and anthropologists." Susanne Langer says that myths are essentially drean material:

Its ultiate end is not vilful distortion of the vorld, but serious envisagevent of its fundanental truths; noral orientation, not escape... Because it presents, hovever metaphorically, a vord picture, an insight into life gener ally.4

Childhood reading contributes something irreplaceable cook believes, to later literary experience. Like Frye tho advocates a reading of the

1. Elizabeth Cook, The Ordinary and the Fabulous, Cambridge University Press, 1969, p.vii.

2. Ibid.,p.2.

3. Ibid.,p.4.

4. Susanne K. Langer, Phil 1050ghy in a Ney Key, Harvard University Press, Canbridge, Masachusetts, 1942, p.171. 
Bible as a story of human tribulation and hope she believes, that mythology conveys a sense of the nysterious of which ve are all avare:

Religio, in one Latin sense of the vord, iaplies a sense of the strange, the nuainous, the totally other, of what lies quite beyond human personality. This kind of 'religion' is an indestructible part of the experience of any human ainds, even though the whole teaper of a secular society does not encourage it, and the whole movement of adern theology runs counter to it."1

Provided they have access to eyths children can experience "those queer prickings of delight, excitement and terror." Magic, she says, is not the same as systicisa but it eay lead toyards it.

Fairy stories vere not originally for children they vere traditional folk tales which nurses often passed on to children. It yas the nineteenth century she tells us that sav a natural affinity between the childhood of the race and the childhood of the individual huean being.

In present day schools cook sees that stories are often read to children which bear little relationship to the lives and experience of sone of then who ay cone from different races, cultures and socio-econonic classes. Thus "Children cannot be expected to share a JOKE about the lives 3 of people very like some of then and very unlike others." She could have said netaphor for joke because the sane is true, but everyone can identify in some vay with the situations and emotions in ayths and fairy tales. They can grasp the patterns at least. Such stories also encourage active response as they lend theaselves to interpretation in drad, ausic, song, dance and painting etc., that is they can be recreated in individual vays.

1. Elizabeth Cook, The Drdinary and the Fabulous, Cambridge University Press, 1969, p.5.

2. Ibid.,p.5.

3. Ibid, , P. B. 
According to Lionel Trilling "The piety which descends frow

religion is not the only possible piety" though that is likely he thinks to have the quality of transcendence ve expect literature to have. He sees this quality aissing in what he calls the present day liberal and democratic writing, which lacks to his aind "The sense of largeness, of cogency, of the transendence which largeness and cogency can give, the sense of being 1 reached in our secret and prinitive ainds." Perhaps this is something ve can give to children with ayths and folk tales to begin vith, progressing Iater to the classics of Iiterature. Trilling thinks that religion has in the past been an effective means of transaitting this and the current lack is not necessarily because liberal and denocratic ideas are unworthy. It is he thinks because if:

ve conceive ideas to be pellets of intellection or crystallisations of thought, precise and coapleted and defined by their coherence and their procedural recomendations, then ve shall have accounted for the kind of prose literature ve have. But if ve are or ann to revise our habit of conceiving ideas in this vay and learn to think of IDEAS AS LIVING THINGS Cny eaphasis] inescapably connected vith our vills and desires, as susceptible of grouth and development by their very nature, as showing their life by their tendency to change, as being liable, by this very tendency, to deteriorate and become corrupt and vork hara, then ve shall stand in a relation to ideas which aake an active literature possible.1

There are other voices speaking for the pover of literature. Maud

Bodkin examines Jung's hypothesis that the psychological significance of

poetry is attributable to

the stirring in the reader's aind, vithin or beneath his conscious response, of unconscious forces which he teras 'priaordial iages', or archetypes... 'psychic' residua of numberless experiences of the sane type, experiences which have happened not to the individual but to his ancestors, and of which the the results are inherited in

1. Lionel Trilling, The Liberal Imagination, Mercury Books, London, 1950, p.301.

2. Ibid., p. 302-3. 
the structure of the brain, A PRIORI deterainants of individual experience." 1

Bodkin examines this hypothesis. Gilbert Murray she finds also believes that any stories and situations are "deeply iaplanted in the seary of the 2

race" She uses the ter archetypal patterns in her consideration of

tragic poetry in particular and she assumes that:

ve may identify thenes having a particular for or PATTERN Iny eaphasis] which persists anid variation from age to age, and which corresponds to a pattern or configuration of emotional tendencies in the ainds of those who are stirred by the theae. 3

Her difficulty lay in assessing the responses of those experiencing a play or poen which is exactly the difficulty teachers have in schools trying to assess the interest in, understanding of, and appreciation of literature. Her own interpratation of the Ancient Mariner for instance leads her to conclude that it syabolizes for the reader the consciousness of lonely frustrations and personal nortality varring vith an inperial vision of a vast inheritance and far-reaching destiny--that is its emotional meaning. The design of such a vork is she believes deterained by forces that do not lie open directly to thought. With the assistance of a psychologist and his analysis of works for their enotional syabolisi she concluded that it represented a Rebirth archetype.

Bodkin perceives that a magic is comaunicated in such vorks that would not be in a drean where ve find it hard to remeaber enough to, as it 4 vere, translate its symbolisw. The patterns or ain theme of the Ancient

1. Maud Bodkin,Archetypal Pattererns in Poetrry, Dxford University Pres5, 1963, p.1

2. Ibid.,p.2.

3. Ibid.,p.4.

4. Ibid.,p.64. 
Mariner can be coapared says Bodkin to the theme of the 'night journey' or rebirth in the Book of Jonah, and she states that Jung has noted hov a state of introversion and regression precedes a kind of rebirth into a new vay of life, has been recognized and organized by religions of all tiaes. Poetry uses what Bodkin calls the sensuous resources of language:

Just as the undifferentiated beliefs of 'everyday' are intellectually ordered, extended and criticized, by the help of an exact terainology, till they becone science, so they are eaotionally ordered, extended and criticized, by help of the sensuous resources of language, till they becone poetry.2

Dne aight call this an expression of the distillation of human experience. In this sense, art, says Bodkin, has been said by T.S. Eliot to approach the conditions of science. It is observation from a distance--Jung used the tern 'psychological reality'. Richards she says is afraid that if ve coin teras for this experience ve say be led inte 'intellectual bondage', Middleton Murry describes it as a unity of aind and heart.

Nietzsche speaks of the essential nature of tragedy as that of a vision generated by a dance "Poet and spectator, he says, undergoing the Dioysian excitement are enabled to transfora themselves and find expression through the bodies and souls of others--the actors upon the stage."

Bradley speaks of Shakespeare creating "d mass of truth about life, Which vas brought to birth by the process of composition, but never preceded it in the shape of ideas, and probably never, even after

1. Maud Bodkin, Archetygal Patterns in Poetryy, Oxford University Pres5, 1963, p.73.

2. Ibid.,p.77

3. Ibid.,p.79.

4. Ibid.,p.83. 
it, took that shape in the poet's aind." Shelley thought that a poen's truth vas recognized by successive readers and which asybe even the poet does not understand. When ve viev Hamlet or Lear perhaps Bodkin sugggests "that sosething is present corresponding to the enotional neaning that belonged to ancient rituals undertaken for the reneval of the life of the 2

tribe." Our tragic heroes aay die but their stories live on. Which reninds one of what Robert Graves said in his poen 'To Juno at the Winter 3

Solstice' "There is one story and one story only"

Virginia Woolf noted this sane sense of participation says Bodkin when she said "Let us trace the PATTERN lay eaphasisl, hovever disconnected and incoherent in appearance, which each sight and incident scores upon the 4 consciousness." Bodkin concludes that the function of poetry

and in particular of poetry in which ve feel the pattern ve have called the Rebirth archetype, ve alay say that all poetry, laying hold of the individual through the sensuous resources of language, comunicates in some aeasure the experience of an enotional but supra-personal life; and that poetry in which ve relive,..... affords us a means of increased auareness, and of fuller expression and control of our oun lives in their secret and aonentous obedience to universal rhythas. 5

These archetypes which she discusses further in her vork seen to characterize the flov, or texture of universal experience. The patterns do not arise casually and can illuminate that other source of great isages, religion.

To critics who say that analysis destroys the very principle of

1. Maud Bodkin, Archetypdl Patterns in Poetry, Dxford University Pre5s, 1963, p.84.

2. Ibid., p.85,

3. Robert Graves, quoted by R.S.Crane in Languages of Criticise and the Structeture of Poetry, University of Toronto Press, 1953, p.131.

4. Bodkin,p.86.

5. Ibid., 0.89. 
poetry she replies that it nead not be criticisa of the hard destructive type but can treat the poen vith the reverence it deserves. Mainly she finds that "The patterns here illustrated in detail fron different kinds of poetic material seen to converge upon this relation of the individual to a Life vithin and beyond hin.... pover present vithin the comanity."

This sense of comaunity she finds present in our literary heritage and in religion where for instance the notion of 'comeunion' is an inportant one and where the uritings embody the same archetypes as found in poetry and fros vhence any of the poets have dravn some of their inspiration. He cannot escape setaphor because as Karsten Harries says "We do not have an unmediated understanding of anything real, not even of our oun 2

selves." Heidegger she says has alerted us to the vay netaphors, their origins effaced, continue to shape philosophical dscourse and his ovn metaphor of a clearing that lets in light joins "the distance and light wetaphors that have long governed philosophical speculation, which has tended to take for granted that the nodel provided by vision is adequate to 3 husan understanding" but this is about as useful as saying that metaphors give us pictures in our aind. As Harties says each philosophical text refers us back to others, to what Derrida has dismissed as white mythology. We cannot he says find a saying of unveiled presence "lie cannot step outside language...... What remains is play with words....ve are inprisoned by 4 Ianguage" But even if there can never be a fully adequate description of what it is says Harries ve can nevertheless distinguish between wore or

1. Maud Bodkin,Archettypal Patterns in Poetrry, Oxford University Press, 1963, p.328.

2. and 3. Karsten Harries, Metaphor and Transcendence, On Metaphor, Sheldon Sacks, University of Chicago Press, 1978, p.83.

4. Ibid, p. B4. 
less proper descriptions. As soon as ve recognize a perspective as just that then ve have transcended language and it is no longer a prison.

We are urong to treat the poet as a godlike creature she thinks because his work is as nuch a gift of the earth as his own. We have to remain open, both the poet and the listener to what transcends us and vill illuninate. "First ve have to listen more attentively to the any voices of 1

the earth." Which is difficult vhen ve are already caught up as she says in vays of looking, seeing and thinking. "We understand things vithout having ade then our oun. The adequacy of words is taken for granted, 2 their origins forgotten. It is only against the background of silence that the presence of things anifests itself. ${ }^{3}$ Such vords captured sonetimes in poetry close the gap betveen language and reality. "Things speak to us' if ve allov ourselves to hear. This viev sees poetry not as an aesthetic self-sufficient unity but as "d nore or less inadequate and fragmentary repetition of that speech in which nature, or perhaps God, addresses us."

The current metaphor for the study of literature is an architectural one--structuralisa, which according to Barthes is a descendant of Rhetoric Science is a structure already in existence which ve describe and nane in our atteapts to understand and exploit it. Literature says Barthes has a "grand cosmogenic unity" and like science it is methodical:

Like science, literature has its morality; a certain vay of extracting its rules and procedure from the image it assumes of its being, and consequently of subnitting its enterprises to a certain absolute spirit, 5

1. and 2. Karsten Harries, Metaphor and Transcendence, On Metaphor, Sheldon Sacks, University of Chicago Press, 1978, p.87.

3. and 4. Ibid.,p. 88.

5. Roland Barthes, The Rustle of Language,trans, by Richard Howard, Hill and Wang, Nev York, 1986, p.3. 
One feature both unites and divides them; both are discourses. For science, language is an instrument ade as neutral as possible vhereas "language is the BEING of literature, its very vorld:..."

It occurs to that if I catch a fish already naned and classified according to science, it will be labelled as such by ayself or any onlookers even if we do not know the correct official Latinate or Greek name. If I catch a hither to unknovn species which I nane ayself, is ay speech act literary or scientific? If I tell a story in vriting about ay catch it is literary. If on the other hand an account is vritten as a piece of research and ay fish is officially named perhaps even with sy name then this constitutes science. Explanations frod the past which are not deened scientific are of course referred to as ayths. There does seen at times to be a very fine line betveen the aythological or the literary and the scientific.

Structuralis is a science created to explore and understand language, particularly literary language. Words are explored at different levels. A sentence has not only a literal or denoted aeaning it is "cramed with supplementary significations" It can be at the same time a cultural reference, a rhetorical odel, a deliberate anbiguity of the speech act, or a siople unit of denotation. Barthes introduces his recurring notion of 'space':

...the "Jiterary" vord has the depth of a space, and this space is the field of structural analysis itself, whose project is much greater than that of the old stylistics, entirely based as it vas on the erroneous ided of "expressivity. 3

Literature retains what Barthes thinks science rejects, that is the 5overeignty of language. He sees a change coning hovever:

1. Roland Barthes, The Rustle of Language, trans, by Richard Howard, Hill and Wang, New York, 1986, p.4.

2. and 3. Ibid.,p.6 
...science vill become literature, insofar as literature--subject, moreover, to a groving collapse of traditional genres...--is already, has alvays been, science; for what the huaan sciences are discovering today, in whatever realn: sociological, psychological, psychiatric, linguistic etc., literature has alvays known; the only difference is that literature has not SAID what it knows, it has WRITTEN it.1

In sany areas of science scientists are aluost lost for vords to describe their findings and the truth of Barthes' statenent becones apparent if one looks for instance at the current uritings on the brain and narvous system. Jeffrey Saver revieving a vork by Allan Hobson refers to this phenomenon. Hobson has presented an activation-synthesis model of the huean capacity to drean; one which dravs on introspection as vell as techniques of neurophysiological inquiry, and built up a granaar of dreams. He and his colleagues have sought to nake a science of dreans. Saver says of these findings: "Hobson's integrative, synthetic, interdisciplinary spirit is palpable on every page. His interpretations of neurophysiological findings 2

yield an enriched viev of mental function." Siailarly Bergland also speaking of the brain uses figurative teras which one vould never norwally expect fron a scientist. He believes the brain is a gland and therefore has to vork in haraony sith the vhole sytew:

Those who discern the pattern of the tapestry vill stand in ave, knoving that its [the brain's] static for a cannot produce thought: olecules, some from the brain and other 5 from the body, oust caress each other --as the violinist's bou kisses the violin strings--to create the ausic of the aind. 3

Which suggests that we HAVE reached a point in tine where the poet has become a scientist and the scientist a poet. The traditional divisions

1. Roland Barthes, Ihe Rust!le of Language, trans. by Richard Hovard, Hill and Wang, New York, 1986, p.10.

2. Jeffrey Saver, revieving The Dreaging Brain by Allan Hobson, London Reviegy of Books, August 4, 1988, p, 1t

3. Richard Bergland, The Fagbric of Mind, Penguin Books, Australid, 1985, p.176. 
betveen then vere only inaginary.

Barthes believes ve should change our attitude to literature reified as it has been in the division of subjects and the pursuit of the history of literature as an end in itself. We should now he thinks treat history backwards, beginning vith the text and aking ourselves the centre of this history, substituting TEXT for author, school and movement; treating it not as a sacred object but essentially as a space in language, the site of an infinite nuaber of digressions, and trace the codes of knouledge invested in then. Like Ricoeur he advocates the polyseaic reading of the text.

In Barthes' viev the reader becomes the iaportant factor not the vriter. For toolong he thinks ve have concentrated on authors and been distracted fron the reality of the text which is meaningless vithout the active involvement of the reader. "The most subjective reading inaginable is never anything but a gane played according to certain rules. 1 rules do not cone fron the author:

...these rules cone fron an age-old logic of narrative, fron a symbolic form which constitutes us even before ve are born--in a vord, fron that vast cultural space through which our person (whether author or reader) is only one passage.2

The gane hovever is not a mere idleness but a piece of vork involving the body and by which "ve iaprint a posture on the text."

Where the author was previously considered to have fed or 'fathered' the book the adern SCRIPTOR is not the subject of which his book vould be the predicate "there is no time other than that of the speech-act, and every text is written eternally HERE and NON." The text is "a fabric of

1. Rol and Barthes, The Rustle of Language, trans. by Richard Hovard, Hill and Wang, New York, 1986, p.31.

2. and 3. Ibid, , p.31.

4. Ibid.,p.51. 
1

quotations, resulting from a thousand sources of culture." So there can

be no clain to ounership for "life aerely iaitates the book" and once

the author is distanced in this vay any clain to decipher a text becomes

futile, al though this is what critics have traditionally done.

...by refusing to assign to the text, a "secret" i.e,an ultinate meaning, liberates an activity ve ay call countertheological, properly revolutionary, for to refuse to halt meaning is finally to refuse fod and his hypostases, reason, science, the lav.3

To Barthes this is illustrated in the Greek notion of tragedy where the listener realises the tragic double aeanings of which the speakers are unavare. Likevise a text:

...consists of multiple vritings, proceeding fron several cultures and entering entering into dialogue, into parody, into contestation; but there is a site where this aultiplicity is collected, and this site is not the author, as has hitherto been clained, but the reader: the reader is the very space in which are inscribed, without any of then being lost, all the citations out of which the uriting is ade; the unity of the text is not in its origin but in its destination...4

The reader is a repository of all those sane traces from which the uriting itself is dravn so "the birth of the reader wust be requited by the death 5

of the author." The oetaphor Barthes uses to describe a Text is that of

a network whereas the traditional text is seen as a developing organisn

like something one gives birth to.

Barthes' eaphasis on the reader appeals to ae because I believe the receiver of aetaphors has likevise been neglected in theories of metaphor. No eatter what the author of a metaphor literary or scientific intends,

1. Roland Barthes, The Rustle of Language, trans. by Richard Hovard, Hill and Wang, New York, 1986, p.52.

2. Ibid.,p.53,

3. and 4. Ibid., p.54.

5. Ibid.,p.55. 
in the eetaphor, it has almost a literal seaning, as Davidson says, to the one who reads or hears it, it has one meaning, for that person even if other levels of meaning occur later or are hidden vithin it as in poetry where layers of aeaning become apparent on further readings. The aaking of metaphors and the reasons for their use seen to have been the sain preoccupation of vritings on metaphor rather than their effect. The signification of a netaphor is entirely personal or idiosyncratic to the receiver whether or not that is appreciated or understood by the metaphor-maker.

Barthes has stressed the iaportance of a study of psychoanalysis (as vell as psychology and linguistics) for students of language, particularly liter ary text. Robert Rogers does precisely this in his study of metaphor from a psychoanalytic viev. He is concerned with "the dynamic processes involved in creating and responding to setaphor, with the anbiguity underlying these dynanics, and vith the correlation between inagery and 1 iagination."

The nost expressive artists rely on the resources of inagery, or metaphor which in Havthorne's Scarlet Letter as Rogers explains is syabolized by the "tongue of flane" uhich Dinesdale the preacher possesses to the annoyance and chagrin of his othervise superior colleagues and to the delight of his vorshipping congregation-an irony of course because he is a guilty an, but he has this eagical ability to conmune with people through the use of FAMILIAR vords and figures.

This kind of agical ability to transait turbulent messages through unconscious channels accords vell vith a vide array of modern assumptions about the psychology of artistic communication. Communication of this kind can only involve the old, not the new, the known, not the unknown, the universal, not the arcane. It qust be based on a

1. Robert Rogers, Metagehor A Psychoanalytic View, University of California Press, 1978, p.4. 
measure of shared life experience or else no significant connunication of the kind Dianesdale specializes in can take place. Psychoanalysis locates this shared life experience in man's epigenetic developaent.1

The "tongue of flame" is a aetaphor and Metaphor is the Tongue of Flame"

that is to say it is a source of pover. The poet's use of such pover is already vell docunented. Shelley has said that poetry is "vitally 2

metaphorical" Gaston Bachelard decided that "a poetic nind is purely 3 and simply a syntax of metaphors." Metaphor focusses both thought and emotion in a particularly intense, economical way, says Rogers, and one which has led critics and others to describe it as having verbal tension and verbal energy which is transferred from the poet to the reader.

Having rejected the static conception of aetaphor as an ornament derived from the Renaissance idea of style as a garment, modern uriters al nost alvays speak of metaphoric intensity in dynanic ter as of some kind.4

Unfortunately it is true, as I.A. Richards has said of Max Easton's view of art arousing reaction and yet iapeding it, that "We do not yet know enough about the central nervous system." Trilling says that "the devices of art --the wost extrene devices of poetry, for example--are not particular to the aind of the artist but are characteristic of mind itself."

Rogers' ansver to this dileana is to explore psychoanalysis as a franevork for the study of metaphor--not because psychoanalysts have had much to say about metaphor-but to formulate a model for the dynanics of

1. Robert Rogers, Metagehor A Psychoanalytic Viege, University of California Press, 1978, p.3.

2. and 3, Ibid.,p.6.

4. Ibid.,p.8.

5. Ibid.,p.9.

6. Lionel Trilling, The Liberal Imagination, Mercury Books, London, p.179. 
response to significant metaphor. Sohn Middleton Murry believed that exploring any prieary data of consciousness could lead to the borderline of sanity for "it vould be nothing less than an investigation of the genesis 1

of thought itself." [Interesting that he uses this vord genesis for the book of Genesis opens with 'The Word'l Rogers' study therefore explains elemental types of sental functioning in order to better understand etaphors, even though, as he is avare, they are not simply souething one finds fixed in a text but dispersed even among reader 5.

Lionel Trilling tells us that the aind, as freud sav it "is in the 2 greater part of of its tendency exactly a poetry-making organ." even though he considered metaphor unreliable as a sethod of thought he vas forced to use it himself, as in his aetaphors of the topography of the aind, but, Trilling points out, that, as it is not a thing of space at all, his metaphors are inexact.

In the eighteenth century Vico spoke of the netaphorical, imagistic languages of the early stages of culture; it vas left to Fraud to discover how, in a scientific age, ve still feel and think in figurative foreations, and to create, what psychoanalysis is, a science of tropes metaphor and its variants, synecdoche and netonony. 3

It has been said by people such as T.S.Eliot and Middleton Murry that artists do not begin with ideas but perception, intuition and emotional conviction. Coleridge also spoke of two distinct types of thought, one of which controlled the other. Rogers says that instead of accepting Murry's idea that artistic thought does not involve reason, it might be better to

1. Robert Rogers, Metaphor A Psychoanalytic Viey, University of California Press,1978,p.10.

2. Lionel Trilling, The Liberal Iaggination, Mercury Books, London, p.52.

3. Ibid.,p.53. 
go along vith Coleridge, supposing it to be dual in nature "coabining a 'streaning', associative, pictorial kind of thought vith a nore rigorous 1

and rational type."

If there are two levels of thought, one "concrete, pictorial, perceptual, enotional, intuitive and more inaginative" the other, "abstract, conceptual, less emotional, analytical, wore controlled, and less spontaneous" then language will reflect this. Psychoanalysis seens to Rogers to have the descriptive terms ve nead. Fraud called then "prinary process" and 'secondary 3 process" mentation. The first ay be unconscious as in dreass--and take over during periods of reduced ego control--and sometices in this state ve 4 express vhat is known as "onnipotence of thought." This is seen in the mental activity of neurotics, schizophrenics and people under the influence of drugs, in highly enotional states, and in the inspirational phase of creative imagination. All of this suggests that it is somevhat chaotic.

For the cost part, primary-process mentation is concrete, usually pictorial, as in dreans. It employs symbolis in a crudely associative vay..... It can equate al nost anything with anything else vhere even the aost rudientary siailarity exists, such as an isomorphic one. According to the priary process the symbol equals reality. 5 Language can reflect this priaitivism. Thus we begin to see that aetaphors sonehow conbine aspects of both of these processes, building associations that are dissinilar and similar and both creative or imaginative and rational or logical. In ordinary language the vord as a syabol is not the object or

1. Robert Roger s, Metaphor A Psychoanalytic Viev, University of California Press, 1978, p.14.

2. Ibid, p.14,

3. Ibid, ,p.15.

4. Ibid.,p.16.

5. Ibid, ,p.17. 
reality. Another characteristic of the prinary process says Rogers is that

there can be no negation, except indirectly.

The priary process operates ainly in the service of the id as a node of discharging free, mobile psychic energy, It eaploys a crude, analogical, associative for of symbolisn in a agical, vishful fashion vithout regard for ordinary reality, time, space, and logical consistency. While the mentation itself ady be conscious, its sources are apt to be dynatically repressed, The secondary process operates mainly in the service of the ego. The psychic energy at its disposal is bound, or neutralized, or subliated energy. As a sode of expression it is rational, conceptual, analytical. It utilizes higher, more abstract foras of discourse such as conventional lexical language and standardized sathenatical signs.1

Analog and digital conunication have siailar differences. The first compares categories, the second operates by substitutions. "Metaphor 2 consunicates both analogically and digitally." It says sonething IS and also says it is LIKE.

In simple nursery rhymes and nonsense verse like Three Blind Mice and Jabbervocky "coamunication takes place in an astonishingly effective way but not at conscious levels. The priary process as a channel of comanication is in many vays equal--and in sone superior-- to that of the secondary process, but the aessages are encoded in a different vay." Such aessages also translate easily from one language to another. The reader therefore responds to fiction alnost as a child responds. In the case of naive metaphors, they are " words with fairly concrete referents Which appear to be literal but which attain a metaphoric dinension by effecting a symbolic transfer, usually an unconscious one."

Rogers says that in the Ancient Mariner for instance ve weet a

1. Robert Roger 5, Metaghor A Psychoanalytic Vieu, University of California Press,1978,p.18.

2. Ibid.,p.19.

3. and 4. Ibid.,p.23. 
nixture of prisary and secondary process material which is noral in literature but in Kubla Khan "which radiates emotion and floods us with 1 associations" ve have that is closer to pure prinary process. Some have attributed the latter to the belief that Coleridge vas under the influence of opiun when he vrote it. He hisself apparently published it "rather as a psychological curiosity, than on the grounds of any supposed poetic 2

merits.'

There is no such thing says Rogers, as a primary process vord, so the division into priaary and secondary is an artificial one, to indicate "that certain vords in certain contexts have potential for sobilizing prisary or secondary process aentation--as the case nay be -in the 3

reader." It is rather like saying they are childish and adult but it is alnost inpossible to separate then in literary criticisa, and "neither can the prisary and secondary components of an inage be distinguished with scientific rigor by sone kind of fractional distillation." For analytical purposes some useful presumptions are made "as to the type or degree of mentation a given word or phrase IN A PARTICULAR CONTEXT vill express or generate.

Rogers has developed a psychological theory of poetic language based on the tension modal:

Under certain contextual conditions language nobilizes prinary and secondary process sentation in the reader in such a vay that endopsychic tension develops, a passage being felt as vital or poverful or inaginative in proportion to the amount of tension generated

1. Robert Rogers, Metaghor A Psychoanalytic Vien, University of California Press, 1978, p.27.

2. Ibid.,p.26.

3. Ibid,,p.27.

4. and 5. Ibid., p.28. 
between drive and defense structures--including semory structures and identity configurations.1

According to this theory and assuming the reader to be what he describes as a self-regulating honeostatic system, a aetaphor pronotes a homeostatic shift in the reader's cognitive and enotive equilibriun. Each metaphor is a puzzle [ a shock to the systea?] containing a variety of possible interpretations but at the tiae there is no expectation that it vill confor vith reality. Scientific aodels are siailar but used vith the full realisation that they are merely pragatic devices which can be disposed of after use. Psychoanalysis hovever relies as Crevs has said on the relative precision of the metaphors it uses, what he calls "their relative capacity for economically describing a vast range of evidence for which no 2

other descriptive teras have been found."

To Coleridge the ideal poet could bring "the whole soul of nan into 3

activity." He also believed that poetry had "a Iogic of its ovn as severe as that of science." Rogers is convinced that the nore ve know about the mind and how it vorks the more ve can understand the movement of poetry, He says that Ella Freeman Sharpe vas the first analyst to give explicit attenton to the role of aetaphor in ther apy--she said; "vords both reveal and conceal thought and emotion...metaphor fuses sense experience and thought in language. The artist fuses then in a aterial nediue or in sounds with or vithout vords." She also had a theory "that metaphors only evolve in language or in the arts when the body orifices become

1. Robert Rogers, Metaghor A Psychoanalytic Vien, University of California Press,1978, p.28.

2. Ibid,, p.30.

3. and 4. Ibid.,p.36.

5. Ibid.,p.37. 
controlled" and concluded that aetaphor "is personal and individual even 1

though the words and phrases used are not of the speaker's coinage.'

The patterns of a uriter's inagery way even be as individual as his fingerprints Rogers believes. Clinical interest in isagery is groving as patients aetaphors are utilized to assist in comunication at a suitable distance and in training patients to explore their oun iadgery as part of their treatent.

After exanining some of Keats' poetry Rogers reiterates that it may be impossible to discern the anount of priary process and secondary process in any piece of poetry--1ikevise as Ray Schafer has said the sane is true in clinical vork, vhen trying to "assess the balance of the priary and secondary processes and shifting levels of organization in the patient." This variation is particularly arked in schizophrenics, according to Harold Searles.

When Rogers speaks of regression to the primary process, he eaphasises that this is not pejorative, "on the contrary, such regression operating synergistically with higher ego functions is a vital aspect of the 3

creative process and the responses it evokes." It is difficult hovever to denonstrate in any direct vay "that the sensed vitality or beauty of a passage of poetry for a given reader at a given time is proportional to the 4 anount of tension created." For one thing, response way be unconscious.

Ernst Kris and Abrahas Kaplan have, says Rogers, produced a classic psychoanalytic paper on the subject of aesthetic abbiguity, in which they concluded that:

1. Robert Rogers, Metaphor A Psychoanalytic Vien, Univer sity of California Press, 1978, p.37.

2. and 3. Ibid.,p.49.

4. Ibid, ,p,50. 
The potential of a syabol contributes to a specifically desthetic experience only if the interpretation of the syabol evokes the resources of the priaary process. 1

They speak of aesthetic DISTANCE and psychic LEVEL and draw attention to the vay that an artist vill criticise a vork in progress. The intellectual component of the aesthetic process is in their consideration iaportant.

Good netaphors, says Rogers, unlike dreans which are alsost pure primary proces5--are characterized by a combination of prisary and secondary process. "In poetry, enotion gets incorporated in language, especially in 2 body ieagery." Bovlby has also noted the human dependency on attachment, which leads Rogers to coment that :

People spend most of their lives clinging to one another, in one vay or another--and of course sonetines at several renoves, where the attachment is to pets, oney, material goods, or rituals. Whatever forms they take, from an hierarchical point of viev these attachnents aust necessarily hark back to an original clinging of one body to another. 3

Psychosis can be vieved as a meeting place of aind and body "..integrity of the body self underlies the integrity of the behavioral self..... The intimate relationship of soma to psyche appears in its most dranatic manifestation through the distorting airror of psychotic thought processes." One can see this when vieving psychotic art which "reflects the serious iapairaent of the body ego" and not to be confused with deliberately playful art. Rogers describes the poet Sylvia Plath as symptomatic of schizoid entanglement, a confusion of love and hate, which ended tragically in her self-destruction. "In psychotic art the prinary process overvhelas

1. Robert Rogers, Metaghor A Psychoanalytic Vieg, University of California Pres5, 1978, p.65.

2. Ibid.,p. 94.

3. Ibid.,p.96.

4. and 5. Ibid., p.98. 
1

the ego." In Plath "auch of the power of her work to touch us to the quick lies in the vay her body inagery generates an alnost cancerous priaary-process mentation in the reader. ${ }^{2}$ Because she dravs so auch on 3

"the vellsprings of her oun priary process."

People need psychological space for their inaginations to relieve the strain of relating inner and outer reality according to Ninnicot and "Artspace is therefore the playspace of grownup children.' Metaphor serves to generate an expanded boundary or potential space in the eind of the reader. By creating what has been called void or absence the vriter "creates the space of illusion vhere the reader can enter into literature's 5 symbolic discourse." He concludes that "everyone possesses a magical tongue of flane alnost from birth except for those unfortunate emotional outcasts vho becone autistic and who often relapse into nutism." The rest of us ay lose some of this power but yet re-experience it through the vork of the poets. This can only happen when children develop a love of literature, but this is something the community must also possess as they seen once to have had.

Beggren tells us that the coaprehension of metaphorical construing requires a peculiar and rather sophisticated intellectual ability which W. Bedell Stanford called 'stereoscopic vision'. Black and Richards have given us the aain theory of etaphor and the tension theory as described

1. Robert Rogers, Metaghor A Psychoanalytic Vien, University of California Press, 1978, p.112.

2. and 3. Ibid.,p.107.

4. Ibid., p.111.

5. Ibid.,p.112.

6. Ibid., p.140. 
by Berggren is that:

any vital aetaphor should be defined as a plurisignificative sign focus whose referents can be univocally conjoined or fused only at the expense of absurdity, but which iaplicitly involves a process of assiailative construing whose cognitive iaport cannot be entirely resolved into literal or non-tensional assertions.1

So aetaphor can never more be considered a aere comparison or type of synonya. Poetic seaning and poetic truth he says aust alvays be tensional in character. We have to conceive of setaphor says Robert Weisann no longer as a figure of speech but as "a process of language, and, what is more, ve have to inquire into the historical forces underlying the tension and energy that infore this process."

Poets says Wayne C. Booth have alvays given their vision of vhat stands for human happiness and "aetaphor in this viey is not a means to other ends, but one of the main ends of life; sharing metaphors becomes 3

one of the experiences we live for." He sometines turn to literature and not religion he thinks because it contains clains to universal truths. Janes Deese a psychologist clains that after a metaphor is said one is in fact a different person and "a good wetaphor allows into the wind just those intersecting features between the literal and figurative concept that are the right onas--not the right ones in the objectivity of the vorld but the right ones in the subjectivity of huan experience in that vorId." He examines metaphors fron the perspective of a theory used in linguistics

1. Douglas Beggren, The Use and Abuse of Metaphor, The Revien of Metagehysics, Vol,XVI, No.2, Issue No.62,p.244.

2. Robert Meinann, Shakespeare and the Study of Metaphor, Ney Literary History, Vol.6, No.1. Autuan 1974, p.166.

3. Wayne C. Booth, Metaphor as Rhetoric, in Dn Metaphor, ed. Sheldon Sacks, University of Chicago Press, Chicago, 1979, p.67.

4. James Deese, Mind and Metaphor:A Comentary, Ihe Ney Literary History, Vol.VI, Autuan 1974, p. 215. 
that of arking. The arked tera is derived, specialized and less cononly used. Deese concludes that value cannot be extricated fron aeaning or from the structure of the language as a vhole:

Any utterance reveals a total state of aind, our feelings and attitudes as vell as the foral aessage ve vish to convey...So wuch is true of the language of the grocer as that of the poet, of the scientific docusent as of the oration. There is no videspread or universal negation attached to the metaphor, as linking it vith the theory of marking night suggest, but it is the case that each decision to use a vord, etaphorically or not, carries the potential of revealing something; not only of our intellectual processes but those that are indissolubly linked with the intellectual, our enotional ones. And there is no escaping.1

F. T.C. Hoore al so rewinds us that setaphor is not merely a senantic phenomenon that ve do in a sense take eetaphors literally by exploring relationships 2

and aeanings othervise unobserved in ordinary language, Jonathan Culler

says no statement is metaphorical in itself, we aake it 50 "by taning the strange" when reading poetry ve "read the constructed detour as an index of 3 vonder and poetic intensity." But to ake a kind of sport of identifying metaphors is to trivialize the process of interpretation. It is not for this reason that ve read literature.

We all seen to need a deeper understanding of metaphor than is currently prevalent. As Richards said "A better understanding of netaphor is one of the aias which an improved curriculun of literary studies aight vell set before itself."

1. Janes Deese, Mind and Metaphor:A Coneentary, The Ney Litererary Histsory, Vol.VI, Autuan 1974, p.217.

2. F.C.T. Moore, On Taking Metaphors Literally, in Metaphor:Problens and Persegectiveses, ed. David S. Miall, Harvester Press,1982.

3. Jonathan Culler, Commentary, Ney Literarary History, Vol.VI, No.1, Autum 1974, p.225.

4. Warren Shibles, Metagehor an Annotated Bibliograghy and History, Whitevater, Wisconsin, 1971, p.XL. 
CHAPTER III

METAPHOR IN RELIGION

Every theology entails a metaphor for man's relation to God, and the great theologies are those that have survived after generations of criticisas. 1

David Tracy has said that "the study of metaphor may well provide a clue to a better understanding of that elusive and perplexing phenomenon our culture calls religion" for all ajor religions contain certain root metaphor5. "These netvorks describe the enigata and pronise of the hunan situation and prescribe certain renedies for that situation." ${ }^{3}$ Western theology has paid little attention says Tracy to the links between the poetic and religious aspects of the human spirit which surprises hin particularly because Western religions are based on books which codify root metaphors.

The earliest Christian texts (the parables of Jesus), as recent scriptural scholarship has clarified through the use of aodern literary-critical aodes of analysis, achieve their parabolic status as conjunctions of a narrative genre and a metaphorical process. 4

1. Wayne C. Booth, in Sheldon Sacks On Metaghor, University of Chicago Press, 1978, p.66.

2. David Tracy, 'Metaphor and Religion: The Test Case of Christian Text5', Shel don Sacks, On Metagher, Uni versity of Chicago Press, 1978, p. 104.

3. Ibid.,p.89,

4. Ibid, p.90. 
They have previously of course fallen victin to the fashion of considering metaphor as aere synony or substitute and have been interpreted as literal paraphrases vith ethical, conceptual, dogatic or political aeaning or been seen as aere ornament to dress the vords.

Religious language vithin ordinary language has also been scrutinised says Tracy by people such as Tillich and Jaspers influenced by Kierkegard, and al so by Gabriel Marcel, Ransey, Frederick Ferre and Stephen Toulain. Each analysis yields characteristics of a religious dimension which is liaited by ordinary language. Such are recognized in what Tracy calls 'liait experiences' such as anxiety, or belief in wan's vorth.

The central concern of theologists is hovever vith root aetaphors says Tracy. In Judaisa and Christianity God is referred to as father, lord, shepherd and king or as light, truth, love and visdoa. If these vords are substitutions for real, literal, ideational meanings then as Tracy says ve do not need to study thea, but "if they function by aeans of sone theory of tension or interaction (on the three levels of the vord, the phrase and the text, then the aove to replace these decorative inages with concepts seews a precipitate one."

To understand the Christian religion's metaphorical netvork one must, as Iracy acknovledges, study the adjor metaphorical expressions of the New Testament which Northrop Frye does in a vork I will refer to later. Has netaphor a specific religious function Tracy vonders, and exaaines two exaaples for consideration, the parables of Jesus and the expression "God is Love."

Most parables begin says Tracy, with the vords "God is like... and

1. David Tracy, 'Metaphor and Religion: The Test Case of Christian Text5,' Sheldon Sacks, On Metaghor, University of Chicago Press, 1978, p.93. 
nodern Nev Testament scholars often employ a tensive or interaction theory of metaphor to interpret the narrative and setaphorical eleaents in the stories. Many follov the lead of Paul Ricoeur vho also uses the theory of sodels developed by Max Black, and Mary Hesse who interprets heuristic nodels as heuristic fictions which serve to redescribe reality. Likevise the metaphor in parables way be so interpreted and redescribe huaan possibility. In Aristotelian language says Tracy the parable is a oythos (a heuristic fiction) which has the aisetic pover of redescribing human existence. "The metaphorical PROCESS, therefore, is the epiphor or the diaphor which transfers the meaning of the story fron fiction to redescribed reality."

The extravagant actions in the parables such as the feast for the prodigal son disorient the reader, but in so doing:

serve the function of reorienting the reader by disclosing a nev religious possibility: a yay of being in-the-yorld not based on the ethics of justice and aerit but pure gift, pure graciousness, indeed in Wesley's fanous phrase, of "pure unbounded love." 2

The opening phrase "God is like"... serves a siailar function, by serving as a radical qualifier upon the whole oodel. The referents of the parables are therefore concerned vith Christian love. The narrative is a heuristic aodel of extravagant actions set into a realistic narrative.

The stateant "God is love" is set vithin John's letter. The focus in this metaphor is on the vord "love." Nygren has clarified the central tensions between the two types of love in his study Agape and Eros. Agape is a higher, sacrificial, spontaneous, overfloving love conferring value on the loved object. The other is desirous, acquisitive, egocentric, hunan, recognizes value (e.g. beauty) and then loves. One cannot therefore

1. David Tracy, 'Metaphor and Religion:The Test Case of Christian Texts,' Sheldon Sacks, On Metaghor, University of Chicago Press, 1978, p.98.

2.Ibid.,p.98. 
substitute love in this statement by an Eros type of love. The tension in the statement can only be appreciated says Tracy if one is avare of the religious-as-liait language and the available interpretations of the metaphor in its Christian context. "The stateaent "God is love" does not say literally What fod is but produces a metaphorical eeaning for what fod is like. In this redescriptive sense, the statement defines who, for the Christian, God 1 is." One vould need the sane care in interpreting the Buddhist idea of "coepassion" or the Jevish understandings of "covenant" as the study of metaphor in these circunstances is not a Iuxury but a necessity and "moves 2

to the very centre of conteaporary theological studies."

Hernann Hesse speaks of this sane nysterious 'love' in the expression

"Love thy neighbour as thyself" as one of the visest sayings ever: ...the equilibrium of love, the ability to love without being at fault here and there, this love for oneself that is not stolen froc anyone, this love for others that does not diainish one's oun I or do violence to it! The secret of all happiness, all blessedness is this saying. And if one vishes, one can turn to its Hindu side and give it the aeaning: Love your neighbour for he is yourself!...Ah, all visdon is so siaple, has been 50 precisely and unanbiguously expressed and formulated for so long! 3

His conclusion vas that all opposites aerge into each other and:

For we the highest utterances of mankind are those fev sentences in which this duality has been expressed in agic signs, those feu aysterious sayings and parables in which the great yorld antitheses are recognized sinultaneously as necessaary and as illusion.4

The Chinese Lao-tse invented such sayings, says Hesse, and Jesus did this even nore nobly, more siaply even more intinately. The irony to his is

1. David Tracy, 'Metaphor and Religion:The Test Case of Christian Texts,' Shel don Sacks, On Metaghor, University of Chicago Press, 1978, p.103.

2. Ibid.,p.104.

3. Hermann Hesse, 'A Guest at the Spa', Autobiographical Writings, Jonathan Cape, London, p.162.

4. Ibid., p.168. 
that all this "nost precious and dangerous visdon" is offared free and it sight be a good thing if it vere not and ve had to struggle to obtain it. Northrop frye developed, for teaching purposes, a course based on a literary critical study of the Christian Bible. He reainds us that it is not really one book but a collection of books beginning with the Creation and ending vith the Apocalypse, in which there is also a body of concrete inages: city, eountain, river, garden, tree, oil, fountain, bread, vine, bride, sheep and wany others which recur so often that they clearly indicate some unifying principle. What Frye observes is a unified structure of narrative and inagery that Blake called the Great Code of Art.

To frye, a teacher is one vho atteapts to recreate the subject for the student's aind by getting hin to recognize what he potentially already knovs. A study of the Bible is pertinent to us frye beligves because:

Man lives, not directly or nakedly in nature like the aniaals, but vithin a aythological universe, a body of assumptions and beliefs developed from his existential concerns. Most of this is held unconsciously, which means that our isaginations way recognize elenents of it, when presented in art or literature, vithout consciously understanding what it is that ve recognize. Practically all that ve can see of this body of concern is socially conditioned and culturally inherited. Beloy the cultural inheritance there aust be a conaon psychological inheritance, othervise forms of culture and inagination outside our oun traditions vould not be intelligible to us.1

Criticisn can help, Frye believes, to make us more avare of our mythological conditioning, The Rowantics vere accused of confusing literature and religion but there is awareness he says of the relevance of Biblical criticisa to secular literature. Many people are sensitive to such a study because it involves their personal belief systea.

Frye is concerned then with the Bible as an imaginative influence on

1. Northrop Frye, The Great Code The Bible and Literatature, Harcourt Brace Jovanovich, Nev York, 1982, p.xviii. 
us. The first thing our attention is orawn to is the fact that ve have received it in translation fron Hebrey and Greak. Being in a poetic style also makes it more difficult to translate. According to Vico, ve continually live through repeating cycles: a aythical age, of age of gods; a heroic age, or age of an aristocracy; and an age of the people, Each stage has its oun distinctive language which he calls the poetic, the heroic or noble and the vulgar. Frye labels then the hieroglyphic, the hieratic and the deaotic. If this is true the earlier languages vere signs and often powerful and dynamic. He gives, as an example, the vord sana as alaost untranslatable. Words tended to be concrate e.g. a study of Hower's vocabulary shows how concepts such as aind, soul etc. are decribed with physical iages. Consequently expressions ve construe as eetaphorical ay not have been so to him. The central aetaphoric expression is that of a god identified vith nature. Nietzsche affiras this sase idea says Paul Cantor: Ancient an did not have any notion of the spiritual as distinct fros the aterial and hence did not ake setaphoric leaps from one real to the other. We aisread ancient texts by trying to find a eetaphoric depth beneath their surface aeanings. For ancient wan cleanliness is not next to godliness, or even syabolic of it, cleanliness is godliness.1

Aphorisas abound in many early vorks says Frye because of their didactic function. By the tiae of Plato an intellectual elite is established, Words becone priearily the outvard expression of inner thoughts or ideas. Subject and object also becose further separated. Its best expressions are of thought in conmand of feeling:

The basis of expression here is moving from the ataphorical, with its sense of identity of life or pover or energy between wan and nature ("this is that "), to a relationship that is rather eatynonic ("this is put for that.") Specifically vords are "put for" thoughts

1. PauI Cantor, 'Friedrich Nietzsche: The Use and Abuse of Metaphor.' in MEIAPHOR Probleas and Perspectives ed.David S.Miall, Harvester Press, Sussex, 1982.0.73. 
and are the outuard expression of an inner reality. But this reality is not werely "inside." Thoughts indicate the existence of a transcendent order "above," which only thinking can conounicate vith and which only words can express. Thus metonymic language is, or tends to becoee, analogical language, a verbal initation of a reality beyond itself that can be conveyed nost directly by vords. 1

So the first phase of language vas poetic, the second that of Plato is dialectical. Synonymous with this says Frye cones the development of continuous prose vhich does not have the loose associative rhyth of natural ordinary 5peech. He also believes that there vas a movement in philosophy fron aetaphor tovards what ve now think of as science. The influence of Aristotle vas that,

He worked out the organon of a deductive logic based on a theory of multiple causation, and provided a technique for arranging vords to wake a conquering sarch across reality, subjects pursuing objects through all the obstacles of predicates... 2

In what Frye likens to the ailitary style of the conquering Alexander.

In etaphorical language says Frye the central conception which unifies human thought and isagination is that of a plurality of gods which in setonyaic language becones a sonotheistic "God" and as Christian theology developed thought became nore deductive and folloved from the perfection of God. Where inconsistencies arose they vere saoothed out by allegory. This development of a continuous deductive prose style led, says Frye, to sose confusion vith older stories and also to a tendency to rigidity in thinking. "Analogical language thus cane to be thought of as sacrasental language, a verbal response to God's ovn revelation' and retained its cultural ascendancy up to the time of Kant and Hegel.

1. Northrop Frye, The Great Code The Bible and Liter aturere, Harcourt Brace Jovanovich, Nev York, 1982, p.7.

2. Ibid,,p.9.

3. Ibid,,p.11 
Before this says Frye a nev style vas developing as in the vork of Bacon and Locke "Contínuous prose is still employed, but all deductive procedures are increasingly subordinated to a prisary inductive and fact 1 -gathering process" and language is treated as prisarily descriptive of an objective natural order. This phase fits into Vico's 'vulgar' cycle or Frye's 'deaotic.' Meaning and truth become aore abstract and in this inductive scientific era illusion and reality are a problea. As frys says after Copernicus, expressions like 'sunrise' and 'sunset' becane metaphors or illusory descriptions. Einstein likevise changed atter to an illusion of energy. Now the observer becane observed also.

If ve have cospleted the cycle says Frye, from Hower where vord evokes thing to our oun tian vhere the thing evokes the vord we sees once are to nead aetaphor. He observes that ve are currently vitnessing auch interest in language and linguistics. Mark Johnson has also said that "We are in the nidst of a metaphormania."

'Metonymic' to Frye means:

1) a figure of speech in which an inage is "put for" another iage: this is really a species of etaphor.

2) a aode of analogical thinking and vriting in which the verbal expression is "put for" something that by definition transcends adequate verbal expression

3) it is a mode of thought and speech in which the vord is "put for" the object it describes (the descriptive phase)

1. Northrop Frye, Ihe Great Code The Bible and Literatature, Harcourt Brace Jovanovich, New York, 1982, p.13.

2. Mark Johnson, Philosoghical Perspectives on Metaghor, University of Minnesota Press, Minneapolis, 1981, p.ix. 
The language of iatanence is founded on ataphor and the language of transcendence on aetonyey.

So in the first aetaphorical phase of language the unifying verbal eleaent is the "god" or personal nature-spirit. In the second a transcendent "God" is at the centre of the order of things and in the third phase the criterion of reality is the source of sense experience in the order of nature. In the latter there is no "God" and "gods" are no longer belíeved in. Mythological tine and space becoue separated from scientific tiae and space and help to push the concept of fod alsost out of the third phase. Frye says ve aight cone closer to an understanding of the word fod if ve understood it as a verb as in the early metaphoric phase but which in fact aight also nake sense in terus of wodern physics. Words in the metaphoric phase were el eaents of power says Frye as in 'vord' itself, for in Genesis 1:4, "God said, Let there be light, and there vas light." Hayavaka says that priaitive people believed the name of a person to be part of that person and to know someone's nane vas to have pover over his. Thus 'real' names vere sometines known only to parents. This belief is illustrated he says by the story of Runpelstilskin.

The language of the Hoeeric age has a vitality ve can never repeat says Frye but "It has been recognized fron earliest tiaes that the priaary social function of the poet is connected vith something very ancient and priaitive in society and society's use of vords." In the second phase netaphor is recognized as a figure of speech. It is surprising that Aristotle praises Honer's netaphors when he aust have known that to his they vere

1. S.1. Hayavaka, Language in Thought and Action, George Allen and Unvin, London, 1966.p.88.

2. Northrop Frye, The Great Code The Bible and Literature, Harcourt Brace Jovanovich, Nev York, 1982,p.22. 
not netaphors. By the third phase use of aetaphor is conscious and deliberate and a tension arises says Frye between figurative and what is called 'literal' aeaning and soee uriters vill deliberately avoid aetaphor as inter ference. Frye says it is difficult for sose people to accept that poetry is genuinely priaitive. I can syapathise vith their viev. If ve have been conditioned to think of poetry for example as high on a hierarchic scale of literature it is likevise difficult to equate it vith priaitiveness even though prinitive in the artistic sense aeans more pure and unadulterated than it means base or inferior. To be RADICALLY etaphorical is the only vay, says frye, that language can convey the presence of a numinous personality in the vorld.

It is poetry which keeps metaphorical language alive says frye even though it has lost the agic pover of original metaphor. When vords vere treated as agic they could not vary by a syllable, Now the poet is free to say what he likes but whether ve believe what he says is for us to decide. 'Existential' vriting as it is knoun is synonyous with the second period "that conveys the sense of anchoring an interest in the transcendental in the seabed of huaan concern. ${ }^{1}$ Frye illustrates this developaent or evolution of language expression in the forn of a diagram:

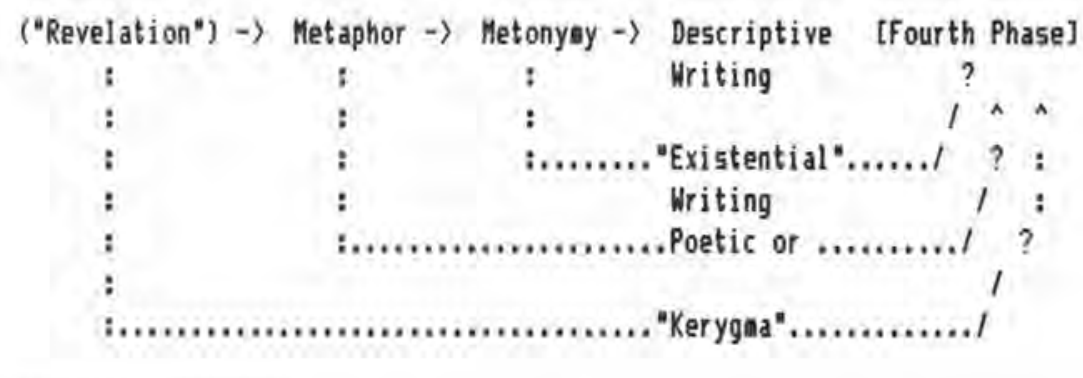

1. Northrop Frye, The Great Code The Bible and Literatefure, Harcourt Brace Jovanovich, Nev York, 1982,p.25.

2. Ibid., p.26.

3. Ibid.,p.26. 
The Bible originates in the first stage but auch of it is conteaporary with the second, hence its aetynonic "God". Rational argument is not a feature of its style. Oratorical rhetoric is a transitional stage between one and two for "oratory at its best is really a combination of aptaphorical or poetic and 'existential' idions: it uses all the figures of speech, but vithin a context of concern and direct address that poetry as such does not eaploy." It is a poverful use of language for good or evil. Novadays ve rarely experience its use except in advertising and propaganda. Husanise rose in the third phase says. Frye and clarity and lucidity of style became its ain concern to distinguish reality from illusion.

The idion of the Bible is essentially oratorical says frye. In such figurative language the reality of subject and object becones tenuous. It is thought to cone fros a tiae alsost before time and to be the rhetoric of God spoken through his agents. It really therefore does not belong to one particular phase but has a style of its oun which he calls 'kerygat or proclamation, the vehicle of revelation, and as he says "The Bible is far too deeply rooted in all the resources of language for any simplistic approach to its language to be adequate." This ter 'kerygua, is usually associated says frye vith the theology of Bultaann vho sees it as opposed to myth. Frye on the other hand believes that ayth is the linguistic vehicle of kerygas,

Frye's definition of ayth is "aythos, plot, narrative, or in general 3

the sequential ordering of vords." To hin all verbal structures are

1. Northrop Frye, The Great Code The Bible and Literature, Harcourt Brace Jovanovich, Nev York, 1982, p.27.

2. Ibid.,p.29.

3. Ibid.,p.31. 
ayths in this prinary sense. In the aetaphorical phase nost verbal

narratives take story fora, where the propelling force is the link between personalities and events. In the aetonyaic stage this narrative is generally an argunent.

The word ayth has tended to becone linked to story rather than history. Even vorks ve have thought of as histories are aythical, and he cites Gibbon's Decline and Fall as an example, because it follows a narrative thread. So to frye the Bible tells a story and is a oyth,

Soae stories hovever have special functions over tine they are not for entertaineent as folktales aight be but to tell what is isportant for society to know, and becone 'sacred'. They also interconnect in a oythology or canon and deal with specific aspects of a culture. Frye describes then 1 in another diagrae:

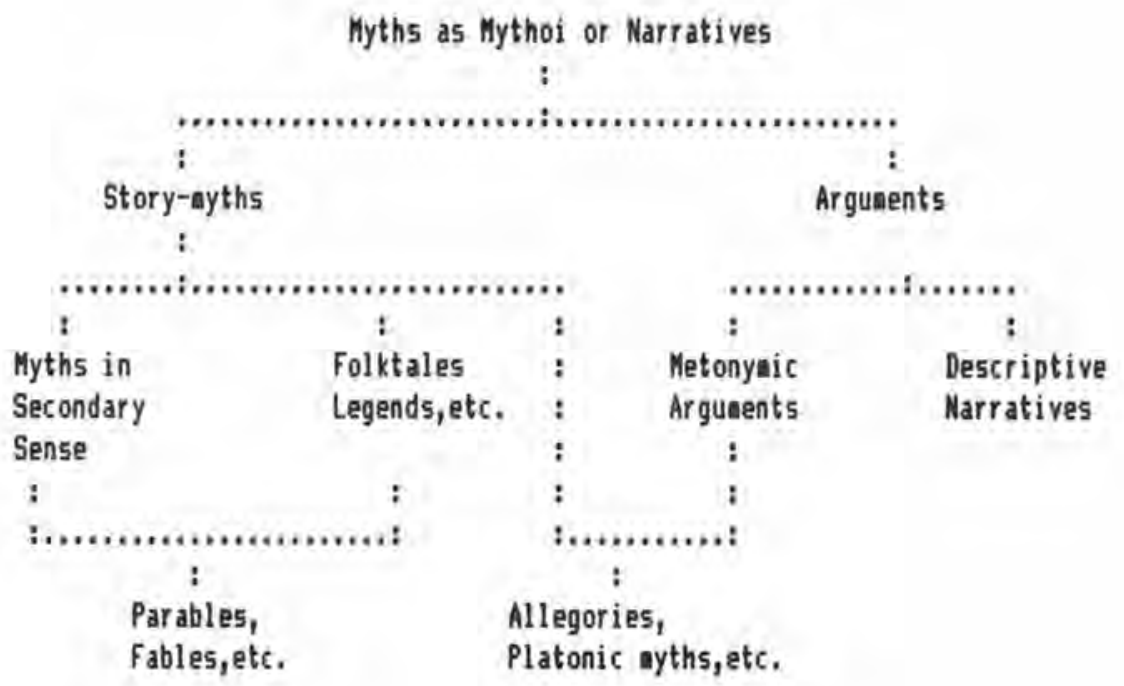

Mythology is important because "rooted in a specific society [it] transmits a heritage of shared allusion and verbal experience in tine, and so

1. Northrop Frye, The Great Code The Bible and Literatare, Harcourt Brace Jovanovich, Neu York, 1982,p.34. 
aythology helps to create a cultural history."

Frye comoends the vork of the scholar Frazer because he treats myths "as interlocking story patterns like a literary critic." ${ }^{2}$ He believes that "myth is not a direct response to the natural environaent; it is part of the inaginative insulation that separates us fron that enviroment.: As literature develops says Frye, mythology is absorbed into it and indeed inspires later authors. And as to the truth of ayths he says that 'A ayth is designed not to describe a specific situation but to contain it in a vay that does not restrict its significance to that one situation, Its truth is inside its structure, not outside." Running throughout the Bible is a legal metaphor as if man vere on trial and through ayths he is shown what to do or what is possible. The central ayth of the Bible is one of deliverance.

It is ironic says frye that ve use the expression 'gospel truth' to swear to the validity of sonething when in fact the Bible is full of ligures of speech, wany puns and wuch hyperbole. Metaphors of the type this-is-that or A is B abound, and yet they are profoundly illogical if not anti-logical. Jesus also refers to hinself metaphorically, as in 'I an the vine, ye are the branches." So prevalent are such expressions that ve cannot consider thea as eeraly incidental or ornamental.

Iranslators have had difficulty with any Biblical sayings especially the oore metaphysical, but it is "d linguistic fact that many of

1. Northrop Frye, The Great Code The Bible and Literatequre, Harcourt Brace Jovanovich, Nev York, 1982, p. 34 .

2. Ibid., p. 35 .

3. Ibid.,p. 37

4. Ibid.,p.46. 
the central doctrines of traditional Christianity can be gramatically 1 expressed only in the for of eetaphor." The doctrines ay be "nore" than metaphor, says Frye, but they can only be stated in metaphorical thisis-that fors. For Biblical purposes metaphor is functional.

Explicit wetaphor according to Frye, usually contains a predication in the vord 'is', but other sore iaplicit setaphors do not have this. He calls this metaphor by juxtaposition. The iapact a vord has may convey the dictionary or conventional seaning but also what he calls invard specific contextual meaning. As ve read saterial it is unified syntactically as a Gestalt. This centripetal organizing effort of the oind is prisary. The referents for a secondary layer of meaning which we can pursue if ve vish. Novadays ve scan wuch uritten aterial of which there is increasing abundance, merely in this prinary fashion e.g. newspapers, selecting from this first visual scan those parts ve actually vish to read and assiailate,

Figures of speech, says Frye, becone the focus of our attention in literary language because they eaphasise the interrelatedness of vords. The juxtaposition of vords creates aeaning 50 that a vord changes meaning according to its position. Hermeneutics apparently began in the exegesis of the Bible vhere wuch attention is given to 'hidden' meanings based on word juxtaposition. Accuracy of description is not possible vith vords so:

The events the Bible describes are what some scholars call "language events," brought to us only through vords; and it is the vords theaselves that have the authority, not the events they describe. The Bible eeans literally just what it says, but it can mean it only vithout prisary reference to a correspondence of what it says to sonething outside that it says... He could alnost say that even the existence of God is an inference fron the existence of the Bible:

1. Northrop Frye, The Great Code The Bible and Literature, Harcourt Brace Jovanovich, New York, 1982, p. 55 . 
in the BEginNing vas the Nord.

To Frye all verbal structures have a centripetal (literary) and a centrifugal aspect. The prinary and literal eeaning of the Bible is its centripetal or poetic aeaning. "This prisary aeaning, which arises siaply froe the interconnection of the vords, is the aetaphorical maning" and there are secondary meanings subordinate to the metaphorical oeaning. If we read the Bible sequentially, he says, we read it as a myth (all ayths are narrative). As a complete unit it is a giant complex metaphor.

With the Bible ve are involved in a more complex theory of weaning and truth than ve are with other books. The sequential stage of reading any vork is the pre-critical phase. "After the experience has been coeplete, ve can move fros experience to knovledge." ${ }^{3}$ detail then becoses relevant and isages are linked to fit into a structure or pattern.

It has been questioned why poets and syth-eakers express theaselves in such a coaplex vay. The ansver has been "They urote this way to conceal their deeper aeanings fros the profane and vulgar, and reserve then for an initiated elite." ${ }^{4}$ this vas the metonywic or 'hieratic' answer, and one ve ay syapathise vith for in past tiaes it has been an elite such as priests who have had responsibility for establishing noral codes and for teaching. As this lore passes on it is obvious that those responsible must interpret it according to their own mental 'set' also. Perhaps it is in our ovn sore 'denotic' era as Frye vould call it, that individuals feel

1. Nor throp Frye, The Great Code The Bible and Litergature, Harcourt Brace Jovanovich, Neu York, 1982, p.60.

2. Ibid.,p.61.

3. ibid.,p.63.

4. Ibid.,p.66. 
more confident to take on this responsibility for thenselves.

A siailar situation exists in other religions. This is illustrated by Lufti Abas in his study of conaunication by aeans of poeas vith esoteric symbolic meanings. He gives as an example poetry from the vork of Keala (pen-nase used by Ahead Kasal bin Abdullah of Malaysia), It is clained that only those of us who have shared the same nystical experiences as the vriter can understand soee of the vords. Certain abbreviated letters 'separate non-aystic and ordinary Muslius fron aystic Muslias. The former are happy to believe that the abbreviated letters are knovn only to fod hieself, while the latter clain that, by God's grace, they know the meaning of the abbreviated letters."

Apparently, when a aystic is enlightened about certain aysteries he cannot reveal the truth as he is under oath. It is believed that the truth vill confuse ordinary non-aystic Muslies so it nust be indicated to then syabolically. Another reason given is that "Truth is beyond language to 2

explain." For instance, a wetaphor in Al-Quran Story XXIV refers to

'glass', and :

...the glass is regarded as the transparent aediun through which the Light (symbol for Truth) passes. On the other hand, the glass protects the light from woths and other forms of low life (lover motives in aan) and fro gusts of vind (passions), and on the other hand, it transaits the light through a medius which is ade up of and akin to the grosser substances of the earth (such as sand, soda, potash, etc.) so arranged as to adoit the subtle to the gross by its transparency. So the spiritual truth has to be filtered through huadn language or human intelligence to nake it intelligible to nankind. In other words, it is only a grosser Truth, a simplified Truth, an indication of Truth which is revealed to the non-aystics, and this is the only thing that a huan language can do, 3

1. Lufti Abas, 'Syobols in Kemala's Poess:AStudy of Signs in Mystical Poens', in Seniotics Unfolding, Vol.II, Mouton, 1979, p.682.

2. Ibid., p. 682 .

3. Ibid, ,p. 683 . 
Language is too constricting for a aystic to express his experience. Poetry is the one aediun of conanication open to his "which is filled with metaphors and siailes whose aeanings are to be understood only by other aystics..." Soue aystic poets throughout history have died, says Abas bec ause their vork vas aisinterpreted. Conaunication is therefore, anong Islanic nystics, not a two-vay but a one-vay process and "there is no agreenent betveen the eaitter and the receiver explicitly or iaplicitly. The codebook is then just the sisilarity of the spiritual experience 2

between the two."

As Abas illustrates, coanunication is not alvays a reciprocal process. His description fits in quite vell with what Frye explains about the Christian Bible as repository of a siailarly mystical and sonetimes obscure code.

Brunton says sonething sinilar in his work, to the effect that those who seek Divine enlighteneent should not be over-eager to pass on the truths they know to those who may not be ready for them: "Do not aake a spiritual or intellectual gift to a person tho is not ready.... as Jesus said 'cast not pearls before svine'," "This ay seen harsh and elitist as I suggested previously but perhaps human spirituality develops or evolves to various stages or levels in each individual and enlightenment has to be sought for. As Brunton later says, Christ did not refuse help or teaching to any who desired it, regardless of their intelligence, vealth or status. If this is true then perhaps we should not force people to accept truths

1. Lufti Abas, 'Symbols in Kenala's Poeas: AStudy of Signs in Mystical Poens', in Segiotics Unfolding, Vol.II, Mouton, 1979, p.683.

2.Ibid., p. 687 .

3. Paul Brunton, Ihe Inner Realitity, Rider \& Co., London, 1970, p.181. 
they are not ready for or are not seeking.

Metaphor both obscures and enlightens which is vhy Paivio likened it 1

to a solar eclipse. What is nystifying is whether an understanding and

appreciation of it is soaething ve had and then lost or whether it is

something ve strive yet to fully understand and perfect. According to

Jacques Derrida :

Since the first otives which led an to speak vere passions, his first expressions vere tropes. Figurative language vas the first to be born, and proper weaning vas the last to be discovered.2

It is particularly in the East, especially the later literature of Mohanedan poetry, which akes use of the indirect or figurative modes of expression, says Derrida. He suas up what metaphor is to philosophers:

...provisional loss of meaning, a forn of econony that does no irreparable daage to what is proper, an inevitable detour, no doubt, but the account is in viev, and vithin the horizon of a circular reappropriation of the proper sense. 3

Evaluation of it is therefore alvays anbiguous:

...the vhole teleology of sense, which constructs the philosophical concept of metaphor, directs it to the anifestation of truth as an unveiled presence...4

Atteupts to define truth are as any and as varied as those of netaphor.

The 'God' of the Bible and 'Christ' of the Nev Testaaent appear to be netaphorically one, says Frye. The two testanents airror each other but are not a raflection of the vorld outside of then. There is for instance no evidence for a 'real' life of Jesus. This is generally explained in the expression 'In the 0ld Testanent the Nev Testament is concealed, in the Nev

1. Allan Paivio, 'Psychological Processes in the Comprehension of Metaphor', in Metaghor and Thought, ed. Andrev Ortony, Cambridge University Press, New York, 1980, p.150.

2. Jacques Derrida,'White Mythology: Ketaphor in the Text of Philosophy', Nev Literary History Vol.VI Autunn 1974 No. I, p.72.

3. and 4. Ibid.,p.73. 
Testament the 01d Testaaent is revealed'.

There is, says frye, another forn of identification other than the simple type of aetaphor of the illogical A is B type, one that ve do not think of as metaphorical but as the basis of all ordered thinking. That is when ve identify not only WITH but AS, and $A$ is identified as an individual of the class to which it belongs. "When ve combine these two foras of identification, and identify an individual WITH its class, ve get an extresely poverful and subtle type of setaphor." He calls this the 'royal' aetaphor because it syabolizes kingship, as a king syabolizes the unity of his subjects in their society. The sane technique is used vhen one speaks of a person but identifies a vhole country vith the name. In earlier tines as Frye says a ruler did physically appear to enbody his country, he vas assuaed to have 'Divine' attributes and if his country suffered or flourished likevise so did he. He speak sonetines nockingly of the Royal 'WE' which I suppose represents that frye is referring to, a head of state is in sone sense the state. When Paul speaks of Christ living vithin his, this, says Frye is the same kind of royal metaphor, but inverted.

Instead of an individual finding his fulfilleent vithin a social body, however sacrosanct, the metaphor is reversed from a metaphor of integration into a vholly decentralized one, in which the total body is coaplete vithin each individual [collective responsibility?]. The individual acquires the internal authority of the unity of the Logos, and it is this unity that nakes hin an individual." Such aetaphors are so forceful they can be difficult for us to accept, particularly those who

1. Northrop Frye, The Great Code The Bible and Literatarere, Harcourt Brace Jovanovich, Nev York, 1982,p.87.

2. Ibid.,p.100. 
seak an equivalent or alternative metaphor for society.

Frye questions what it is about the Bible that attracts poets and other creative artists especially of the Mestern vorld. To hie each of the main phases of the Bible gives a broader perspective on the earlier parts. The Christian Creation ayth speaks of a father figure and life is SPOKEN into existence. "The Genesis ayth starts vith what Aristotle vould call the TELOS, the developed for tovard which all living things grov, and the cycle of birth and death follovs after."

The 'beginning' which is the central aetaphor is not really birth, says Frye, but an avakening "a sudden coning into being of a vorld through articulate speech (another aspect of logos), conscious perception, light 2

and stability."

In the Genesis account the vorld of the Fall is syabolized by the serpent and "the assumption that the serpent vas a disguise for Satan cane 3

wuch later." It is vith this Fall, says Frye that the persistent

'legal' metaphor begins "of human life as subject to trial and judgement, with prosecutors and defenders." Jesus represents the counsel for the defence--Satan the accuser. An all-seeing, ever vatchful, potentially hostile God is presupposed by the Creation ayth.

Frye speaks of the recurring symbolism of light which is not the light of sun or moon. Jesus is described as a light shining in the darkness and after the catastrophe a nev light, the original light of

1. Northrop Frye, The Great Code The Bible and Litertature, Harcourt Brace Jovanovich, New York, 1982, p.106.

2. Ibid.,p, 108 .

3. Ibid, p.108.

4. Ibid., p. 110 
creation, vill enlighten the redeeened. There is al so the netaphor of creation as a designed unity, the work of a craftssan, which has been interpreted as our ability to create or recreate, "a transforming of the chaos vithin our ordinary experience of nature."

Frye notes that in the second phase of the Bible the eaphasis is on Metaphors of the ear as compared to the eye and thare is avoidance of any suggestion of the possibility of actually seeing God. As he expreases it "History is a period of listening in the dark for guidance through the 2 gar." There is a great deal of visual inagery in the Bible which he believes has to be internalized and ade the nodel of a transforwed vorld.

The Bible seems to regard aoral and natural order as controlled by the same divine vill says frye. Nisdon is initially interpretation of and cosment on the lav, with experience and tradition as a guide. Education is "the attaining of right fores of behaviour and the persistence in thes, hence, like a horse, one has to be broken in to then. " Can unfortunate metaphor on which subsequent treataent of children has often been based] Secondly visdoe is prudence in facing the future, and advice is received fron Proverbs, and Fables for the "lover ranks of society." ${ }^{4}$ The proverb vas cultivated, says Frye, throughout the Near East, often in the for of a father's advice to his son.

The central source of visdon in the Bible itself is the Book of Ecclesiastes and the key word here is 'vanity'. 'This yord has a wetaphorical

1. Northrop Frye, The Great Code The Bible and Literature, Harcourt Brace Jovanovich, Nev York, 1982, p.112.

2. Ibid,,p.117.

3. Ibid.,p.121

4. Ibid,, p.122. 
kernel of joy, aist or vapour, a aetaphor that occurs in the Ney 1

Testament (Jases 4;14)." There is also the suggestion that fod put something like OLAM into an's aind $(3: 11)$. "This vord usually means sonething like "eternity," but in this context has rather the sense of 2

aystery or obscurity." Keats has said this teases us out of thought

because ve do not know what it means and akes us dissatisfied with simplistic solutions. The main idea seens to be that in life ve are as in a fog searching for a vay out--which is via visdon.

The origin of the vork ethic also springs fron this source. We are behested to live joyfully $(9 ; 9)$. Frye prefers the Latin Vulgate translation from the Book of Proverbs LUDENS IN ORBE TERRARUM, playing all over the earth. Interesting that the notion of play which is to loon Iarge in educational theory later is emphasised here.

Prophecy faded as a cult says Frye, and he notes that Milton thought that odern prophecies cone from the press. Prophets often aake unpopular prophecies he says, wuch like nodern creative artists or scientists do. One thinks imaediately of 'ozone' predictions and the like, or the vorks of rebel uriters. These people aay be obeying the dictates of the laws vithin their own sphere even in the face of public opposition.

Kany netaphors refer to 'level' as in the higher level of heaven compared to earth, but, "It seems clear that the real distinction between initiated and uninitiated is between those who think of achieving the spiritual kingdon as a way of life and those who understand it as

1. Nor thr op Frye, The Great Code The Bible and Literature, Harcourt Brace Jovanovich, New York, 1982, p.123.

2. Ibid., p.124. 
1

Eerely doctrine." This vay of life is described in the Authorized version as METANOIA, translated as repentance, which really aeans 'a change of outlook or spiritual eetamorphosis, an enlarged vision of the disensions of 2

husan life." The vord 'sin', says Frye, eans nothing outside of a religious and individualized context. It does not sean illegal or antisocial behaviour but the 'deadly' or mortal sin which destroys the soul-pride, wrath, sloth, envy, avarice, gluttony, lechery. Sin is what blocks God's activity and curtails human freedom. The inagery of Hell is described as 'an undying vore and an unquenched fire."

Frye finds that "vhat distinguishes Christianity (and Judaisa) froe most Oriental religions...is this revolutionary and prophetic eleaent of 4 confrontation vith society." Thus the root of evil is not ignorance nor is the cure enlightenment. Jesus vas not sioply conpassionate as vas Buddha, Christ vent through artyrdon and death which signifies to Frye that was to fight his vay out of history and that any society is incapable of conpletely absorbing the individual. The death of socrates vas an illustration of this fact.

The radical meaning of atonenent, says Frye is 'unifying'--that of God and an. The aetaphor is not one of an invisible objective pover to vhom ve ake conciliatory gestures--but of a pover that can do anything through the an who is a channel of Divine energy.

Theist and Atheist are one in regarding personality as the highest attribute known to experience. Whether it is possible for hunan

1. Northrop Frye, The Greast Code The Bible and Literature, Harcourt Brace Jovanovich, Nev York, 1982, p.129.

2. Ibid.,p.130.

3. Ibid., p.130.

4. Ibid, $, p, 133$. 
personality to be connected vith and open to a divine one that is its own infinite extension say still be a question, but the more solid the metaphorical basis for each side, the more possibility there is of autual understanding. 1

Truth vas originally thought of as a kind of unveiling but in modern teras says Frye "perhaps what blocks truth and the energing of revelation 2 is not forgetting but repression." The last book Revelations and Apocalypse is a sass of allusions to the old Testasent. There is transforation pronised for those vho persist in faith--but this is not a notice of things to happen externally--they are the inner for of what is happening noy--what ve call history.

What is syabolized as the destruction of the order of nature is the destruction of the vay of seeing that order that keeps man confined to the vorld of tiae and history as ve knov thea. This destruction is what the Scripture is intended to achieve, 3

At the first reading of this book of Revelations, frye says ve night consider it an insane rhapsody but it reflects nothing vorse perhaps than the repressions in our oun ainds--nightares of anxiety and triumph. As in The Tibetan Book of The Dead which the priest reads to a corpse, telling hin that these visions are his ovn repressed ental foras nov released by death. Perhaps this is siailar to our dreans where ve orean of things that we already know but in a chaotic, distorted for with no logical plot (narrative or nythos). Likevise the 0ld Testamant gives us 'dreans' or 'nightaares' based loosely on the kinds of experience ve do know are possible or can at least inagine as possible but put into a larger than life scenario, as ve aight now viev the fill of a preposterous S.F.story.

1. Northrop Frye, The Great Code The Bible and Literature, Harcourt Brace Jovanovich, Nev Yor k, 1982, p. 134.

2. Ibid.,p. I35.

3. Ibid, , p. 136 . 
The apocalyptic or ideal vorld is expressed in inagery of sheep and pasture, harvest and vintage, cities and teaples and also oasis iagery of trees and vater, the latter a strong and relevant iaga as frye says, for desert people. The garden of Eden is just such an itage.

Each apocalyptic or idealized iadge has a denonic counterpart, for example water as a blessing, or as a deluge. There is the tree of knovledge, and all mythologies have the tree of life as a syabol of a food provider of of life itself. "The Scandinavian Yggdrsail and the beanstalk of a fanous nursery tale are relatives of this vorld tree, whose roots are in the lover world but whose branches rise into or beyond the sky." Apparently Blake suggested that before his fall Adas vould have been wetaphorically hinself a tree of life. The cross also has two significations, a demonic inage (crucifixion) and one of of salvation.

Pastoral and agricultural isagery overlap vith the oasis inagery of paradise. The denonic side of anial inagery is represented by birds of prey but the horse conveys a varrior aristocracy. The ass too has high syabolic value. In the Bible the dragon is a sinister symbol but in other aythologies it vas a fertility syabol.

In the 6ospels, harvest and vintage are often syabols of the apocalypse, and the eucharist a fusion of the vegetable vorld and the body of Christ. If ve ask, says Frye, what is the apocalyptic or idealized isage for huan life itself ve return to the royal aetaphor. The relationship of God and man is symbolized by the bridegroon and and bride in their union as one. Thus all 'souls' are symoolically female and he is the only individual tho can truly say "I am". Wedding inagery is

1. Northrop Frye, The Great Code The Bible and Literature, Harcourt Brace Jovanovich, Nev York, 1982, p. 149. 
frequently used in parables of Jesus about his kingdom. The deanic parody of the bride and groos is the Great Whore of Babylon, aistress of the Antichrist--vho holds in her hands the cup containing the blood of saints and martyrs. Note, says Frye, the metaphorical identification of blood and vine and the sexual isage of the cup-its apocalyptic counterpart the cup held by Jesus when he instituted the Eucharist, which becones al so the Holy Grail.

The ayth of a Mother Goddess of Nature vas videspread in ancient tiaes. The sky vas associated vith male and the earth fesale. The Bible counteracts this and de-idolizes nature "to suggest that there is no nusinous presence or personality in nature that responds to such gestures, except sonething evil and treacherous."

As the Bible proceeds says Frye, the area of sacred space shrinks "The conception of a violation of the sacred space is a very ancient 2 one." It can be seen in the elaborate precautions taken for instance to protect royal tonbs in Egypt.

There are any urban inages of cities and highways, and above all this vorld is a place of spiritual beings or angels, metaphorically associated with the sky. Life is imaged as a fire which does not burn up "On aetaphorical principles all the categories of apocalyptical existence can be thought of as burning in the fire of life. ${ }^{3}$ The Holy Spirit is imaged as a bird. Devils are also associated with sky imagery. Satan falls fron heaven. "No deaonic God...c an exist as such, but the chief of the

1. Northrop Frye, The Great Code The Bible and Litergature, Harcourt Brace Jovanovich, New York, 1982, p.152.

2. Ibid.,p.159

3. Ibid.,p.162. 
devils say set hioself up as fod and be incarnatad in various agents of 1

Anti-christ.

Saint Paul, says Frye, tends to think that the powers of nature are the aost foraidable eneaies of God and aan. " Whenever they are taken by an to be, not creatures of God and therefore fellov creature of hisself, but to be charged vith nuninous and aysterious pover independent of san." Then becones enslaved--nindlessy observing rituals out of superstition-or custons out of habit. Demonic povers therefore are granted through hunan ignorance.

In the Apocalyptic vision the body of Christ is the netaphor holding all categories of being in identity. There is only one knover existing also within our consciousness. The eucharist is the enduring symbol of this, but, as Frye says, our avareness of this has tended to dvindle to the mere ritual of comanion.

Frye says he pursues this study of the Bible not as an interest in doctrines of faith as such but in the expanding of vision through language. This is the very sane rationale that ve usually have for teaching literature in schools. His royal aetaphors are interesting because on reflection they are fairly pervasive. As I vrite this there is a toffee tin turned tea caddy in front of inscribed 'A Royal Assorteent', the picture on the tin hovever is not one of royalty but of mediaeval peasants labouring industriously in field and cottage. They are syabolic presunably of a busy organized vorld, where the ruler has established order, and suggesting a

1. Northrop Frye, The Great Code The Bible and Literature, Harcourt Brace Jovanovich, New York, 1982, p.164. The ain inages of Apocalyptic and Deaonic inagery are given by Frye in sumary table for on pages 166-7

2. Ibid.,p.164. 
state of peace vhere in Brouning's vords "God's in his heaven all's right with the vorld." Perhaps this is one of the nost enduring theaes in our literature. Man loves to york and play and he loves to vorship. To do this requires stability and order and a sense of direction. The source of this direction has traditionally cose froe 'inspired' vorks such as the Bible but interpreted for us by those in pover. This is the traditional source of metaphor, to help us understand our oun metaphoric condition. We have a duality in our nature and an indefinability just as metaphor has. We are a puzzle ve spend our life solving.

Frye suggests we turn the traditional setaphor inside out. "Instead of a setaphor of unity and integration ve should have a metaphor of particularity, the kind of vision Blake expressed in the phrase 'ainute particulars' and in such lines as 'To See a vorld in a grain of sand'." He can all identify with this sense of our ovn ainuteness and yet distinctive existence in the vastness of tiae and space. Frye says such thinking leads us to notions such as that of interpenetration in Buddhism, a type of visionary experience which has been described as "an infinite wutual fusion or penetration of all things, each with its individuality yet with 2

sonething universal in it." But he reninds us that "Hetaphors of unity and integration take us only so far, because they are derived fron the finiteness 3

of the human aind." We have to follow a way beyond this where ve are both innocent and lost again, but in a nevly lighted direction.

Frye sees the Bible narrative as a $U$ shaped pattern sinilar to that

1. Northrop Frye, The Great Code The Bible and Literaterere, Harcourt Brace Jovanovich, New York, 1982, p.167.

2. Ibid.,p.168.

3. Ibid.,p.168. 
in a conedy where a series of aisfortunes brings the drana to a low point but which eventually reaches a happy conclusion. One can view the Bible in its entirety as a 'divine conedy'. All the high and low points relate etaphorically to one another. In a sense the exodus is aythically the only iaportant event says frye, it is " the definitive deliver ance and type 1 of all the rest." The Resurrection of Christ in the Nev Testament is its anti-type. The Gospel vriters synchronize the Crucifixion and the feast of the Passover and see the Passion as the anti-type of the Passover sacrifice. Frye reainds us that aythological and typological thinking are not rational thinking and ordinary distinctions such as tioe are irrelevant. The 'hero' of the Bible, if ve consider it a narrative, is the Messiah, whose nane and identity are vithheld, as 50 often happens in romances, until the end:

he is the creator of Genesis, the secret presence in the old Testanent history, the rock that followed the Istaelites vith vater, ... He enters the physical vorld at his Incarnation, achieves his conquest of death and hell in the lover vorld after his death on the cross...he reappears in the physical world at his Resurrection and goes back into the sky vith Ascension. 2

One can see this Messianic quest as a cycle, paralleled by a denonic cycle. As a 'hero' all types of authority figures are represented by Christ--prophet, priest, king. Such prophets as Frye points out are often artyred. But the Bible is not concerned vith the Greak idea of a her 0 , "the figure greater than ordinary human size, power, descent and articulateness, who 50 often 3

seens to have a divine destiny al eost vithin his grasp."

In all great tragedy there is a suggestion of walice vithin the

1. Northrop Frye, The Great Code The Bible and Literature, Harcourt Brace Jovanovich, Nev York, 1982, p.171.

2. Ibid.,p. 175 .

3. Ibid.,p.181. 
divine nature [ keeping an doun to size?]. The Romantic movement syapathised with those heroes who vere its victias. The theae of the neglected heir or the passed-over firstborn son is conaon. It is a husan characteristic says Frye, to vish for a clear line of descent. The choice of a younger son which occurs so often, represents a divine intervention in human affairs "that breaks its pattern." Another seeaing contradiction by human standards is the birth of sons to women late in life, another syabol of God's revolutionary activity. Israel represents the hero and one is reminded of the folktales where it is the younger son who succeeds after his brothers have failed in the quest.

Man's creative vork is an expression of hunan energy. He struggles against natural human enenies and the chaos of nature. In huan teras the hero is usually not the vorker but the Ieader against the enemy, Nature is propitiated with sacrifices because its forces are a aystery. Israel represents the human condition. As in the structural pattern behind any stories, the hero has to enter a place of danger perhaps to rescue a heroine. The heroine of the Gospels says Frye, is the 'bride' Jerusalen "the total body of redeened souls who are symbolically a single fenale." In the Jonah story uhich represents the Passion of Jesus the sea, the monster and foreign lands vhich he experiences are syabols as is his redeaption from the subterranean depths.

There have traditionally alvays been two monsters, says frye, as in the book of Job, Behemoth and Leviathan, land and sea monster respectively. This is because our habitat can be thought of symbolically as subterranean

1. Northrop Frye, The Great Code The Bible and Litargature, Harcourt Brace Jovanovich, Nev York, 1982, p.182.

2. Ibid.,pl91. 
or subarine in comparison vith the reality of the restored vorld of Istael. The strong tradition of associations vith the sea persist in the fishing stories of the Gospels. The figure of the vise teacher or culture hero as a fish is an ancient one. If the oonster that swallows us is netaphorically death then vhoever delivers us has to be dead too. This happens in the tale of St. George and the Dragon where he dies and is revived by the doctor. The narrative of the Bible is a series of ups and douns, bondage and rescue.

Frye suggests that the Book of Job is the epitone of the narrative of the Bible and the Book of Revelations, of its inagery. "The Book of Job is usually classified among the tragedies, but it is technically a comedy, by virtue of its happy ending...he attains the flash of prophetic insight that breaks the chain of visdon, and on to the final vision of presence and the knovledge that in the aidst of death ve are in life."

The Bible is concerned vith narrative or MrTHOS wheras the the Buddhist sutras eaploy little nartative and the Koran consists of revelations with no visible narrative sequence. In most scholarly fields there is a central body of data generally treated as established fact, In the sphere of Biblical studies he finds this is surprisingly snall. Authorship has been the ost researched aspect, unnecesarily so he thinks. He believes it is futile to try to establish what is 'original' in the Bible, because editing and translating have ade this too difficult. A siailar process vent on trying to establish the authorship of the Iliad and the Odyssey until a metaphoric 'Hooer' vas established and the poeas read as unities.

1. Northrop Frye, The Gresat Code The Bible and Literature, Harcourt Brace Jovanovich, New York, 1982, p.197. 
The Bible displays a unity. "Fron one point of viev the Bible is as unified and continuous as Dante...froe another...it is as epiphanic and discontinuous as Riobaud." 1 In its linguistic conventions frye says it is close to the conventions of the spoken word and the oral tradition. Poetry developed before prose in the history of literature. The devices of poetry such as metre, rhyee, alliteration etc. "make verse the simplest and most direct vay of conventionalizing yords for comonication." The parallelisn of Biblical style has this advantage also. "It is an adairable rhyth for conveying the feeling of a dialogue initiated by God, which the reader coapletes siaply by repetition. " He chooses Psalla 91:2-6 as an exanple. This antithetical rhyth of hebrew verse persists also in the Nev Testament but the editorial process has probably obliterated many aetrical patterns which existed. An authoritative voice tends to be iapersonal says frye which is another reason for less concern about authorship. The Bible's primary interest is in ethical action "its style.,.,is of the battlefield rather than the cloister..."

The rhyth of the Bible expands fron what Frye calls 'kernels' proverbs, aphorisas, or acles. comandaents, pericope. In Paul's letters there are any business and connercial metaphors and a wore continuous

1. Northrop Frye, The Gregat Code The Bible and Literature, Harcourt Brace Jovanovich, New York, 1982, p.197.

2. Ibid.,p.209.

3. Ibiid,,p,110,

4. Ibid.,p.214.

5. 'pericope' is described by Frye as a short discontinuous unit norally arked by a paragraph sign in the Authorized version. It is the crystalisation as it vere of the parable or the clinax to an event, the 'kernel' of a story or 'nugget' of truth. 
prose but still exhortative in style. In the Bible the spoken vord takes precedence over the uritten. Spoken verse says Frye, as in Beovulf, has auch repitition. Shakespeare often sueaarised his plots and ausic repeats its themes for "In listening ve deaand that a certain rhythaical period be filled out, regardless of the repetition involved." An illustration of such repetitive detail is seen in the instructions for the building of the ark of the covenant (Exodus 25ff). Detail is meant to iepress but it is al 50 oral literary convention:

Traditionally, the Bible speaks with the voice of God and through the voice of san. Its rhetoric is thus polarized between the or acular and the authoritative, and the repetitive on the one hand, and the nore inediate and faniliar on the other. The oore poetic, repetitive and aetaphorical the texture, the oore the sense of external authority surrounds it; the closer the texture cones to continuous prose, the greater the sense of the human and faniliar. 2

The rhetorical style of the Bible is oratorical "it conbines poetic vith 3

adgical influence.

In Shakespeare's youth says Frye, there was much more interest in extracting fron literature, truths about the human condition and the vork of art becane part of one's oun life and possesssions. This is one of the arguments for the study of literature in schools. Literature therefore has the sane decentralizing element as the Bible, and vice versa. There is also a certain effectiveness in the Bible, created by sone of its ioages, which have iaposed themselves on our consciousness, such as can only be achieved by a unity of context, which frye calls RESONANCE.

The Bible includes an inmense variety of saterial, and the unifying forces that hold it together cannot be the the rigid forces of

1. Northrop Frye, The Great Code The Bible and Literature, Harcourt Brace Jovanovich, Nev York, 1982, p.214.

2. Ibid.,p.214.

3. Ibid., p.216. 
cultural stress, but the ore flexible ones of inaginative unity, which is founded on metaphor. Metaphor...is an identity of various things, not the shan unity of uniforaity in which all details are alike.1

This is an example of the kind of unity of detail one stands in ave of before a cathedral's architectural design. Likevise the Bible is a single creation put together by sany people but inspired by one designer. Shakespeare's genius says frye displays this sane decentralising ability and is the result of exquisite care and craftsmanship in the unity of his design.

He need to return, says frye, in our atteupts to interpret the Bible, to the neglected theory of polysenous aeaning. Ricoeur also refers 2

to this need. That is, ve look for the layers of aeaning to be gained from any readings--just as ve do vith poetry when each reading reveals wore to us. 'This 'sonething new' is not necessarily sonething we have overlooked before, but say cone froa a nev context in our experience." In Dante's Epistola $X$ he explains such a scheata and says that polysemous meaning is a feature of all deeply serious uriting for which the Bible is a codel. Meaning therefore is relative "what is implied is a single process groving in subtlety and coeprehensiveness, not different senses, but different intensities or vider contexts of continuous sense, unfolding like a plant out of a seed."

Polyseaous meaning, says Frye, is the development of a single dialectical process as in Hegel's Phenomenology. In Dante's scheaata the literal level, hearing the word or seeing the text, is sense experience.

1. Northrop Frye, The Great Code The Bible and Literature, Harcourt Brace Jovanovich, New York, 1982, p.218.

2. Paul Ricoeur, The Rule of Metaghor, Univar sity of Tort onto, 1975, p.321

3. Frye, p.220.

4. Ibid.,p.221. This idea utilised in notion of a spiral curriculun. 
The allegorical level is that of contenplative reason uhich sees the vorld objectively. The third one is the noral level of faith "that transcends and yet also fulfills the reason, and the anagogic level is at the centre of the beatific vision that fulfills faith." So, literally, the Bible is a gigantic ayth:

... a narrative extending over the vhole of tiae fron creation to apocalypse, unified by a body of recurring isagery that 'freezes' into a single etaphor cluster, the metaphors all being identified vith the body of the Messiah, the aan who is all aen, the totality of LOGOI who is one Logos, the grain of sand that is the vorld.2

So ve start vith the 'literal' Bible of syth and netaphor--the centripetal body of words or prisary data. This gives us in Horace's phrase a 'speaking picture' (ut Pictura Poesis) a kind of verbal wagic which distils the past into the present. Then there is the 'royal' aetaphor--the sense of individuals forsing one body and a sense of unity and identity. This represents a aove fros the level of knowledge and understanding to an existential level, fron Dante's 'allegorical' to his 'tropological' and Kierkegaard's 'either' and 'or'. This is a soveant fros knowledge to action--froa aesthetic pleasure to ethical freedon leading to 'faith'. Professed 'faith' is adherence to a body of belief for a specific comanity. [Patriotisn seeas like a form of this.] Professed belief is instinctively aggressive--it is lieited too by ean's finite capacities. Doubt is not an eneay of faith says frye but its complement, it expresses the search for something aore and beyond the comanity to one of vision. The only thing ve know beyond life is death.

Paul speaks of enlightenent, says Frye, as vhere the ego dissolves

1. Northrop Frye, The Great Code The Bible and Litergatures, Harcourt Brace Jovanovich, Nev York, 1982, p.223.

2. Ibid.,p.224. 
and there is an uncertainty of whether one is ' $\mathrm{in}$ ' or 'out' of one's body, and he speaks of an unintelligible and avful language which he is unable to translate or connunicate. The language of the Bible, says frye, is the language of love which is said to outlast all foras of conaunication. It ady be that "only through the study of vorks of hunan inagination that ve can aake any real contact vith the level of vision beyond faith." Frye says man's fear of freedon way be sysbolised by original sin, Milton said wan did not naturally seek or vant freedon, it is sosething given because God vishes his to have it. Man in fact prefers a aster-slave duality and builds structures to preserve it. Our attitude to the Bible reflects therefore our oun anxieties and prejudices and as Frye finally says "anxiety is very skillful at distorting languages."

What Frye says is largely corroborated by Professor Phylis Trible Baldvin, Professor of Sacred Literature at New York's Union Theological Seainary when she vas visiting Nev lealand recently. She explained her theories about the Bible yhich is speaking to us in teras of our oun tiae:

Every culture lives by ayths. By that I mean stories, not falsehoods. Stories that tell then about their origins, what they are and who they wight become. For the Nestern vorld the wajor ayth has been the biblical text. 3

She believes that it has emotional and intellectual appeal whether one accepts its teachings or not. As a feainist biblical scholar her specialist interest is in researching the Bible frow this perspective, Dur culture is predowinantly patriarchal she says, but even Israel had a counter-culture

1. Northrop Frye, The Great Code The Bible and Litergature, Harcourt Brace Jovanovich, New York, 1982, p.232.

2. Ibid, p.232,

3. Phyllis Trible, 'Feninisa and Scripture', reported by Yvonne van Dongen, Auckland Star, Nev Zealand, 27th July 1986. 
of women. Some of the Bible ay vell have been written by vomen; she cites the Song of Songs and the story of Ruth. In the Genesis story an and woman vere both made in God's image. She also finds much female inagery in the Bible, for instance the metaphor for fod using the Hebreu vord for woub (its plural aeans compassion). There are also inages of fod the mother, God the aidvife assisting vith birth and God in labour pains. ("You forget the God who writhed in labour at birth" Deut 32:18) We need she believes, a feainist translation of the Bible. Already she has revritten 1 some of the stories fron the vievpoint of women.

As for the archetype hero of myth to which the story of Christ and a Redeener belong, they occur in every generation. Says Jung "The hero figure is an archetype which has existed since tiae immenorial," The tern archetype to hin means conscious representations that can take any form "they reproduce theaselves in any time or in any part of the vorld--even Where transaission by direct descent or 'cross-fertilisation' through aigration 3 can be ruled out." The figure of the Cosaic Man appears in many myths and religious treachings according to von Franz. He appears as Adan to Christians, as the Persian Gayomart, and as the Hindu Purusha. This figure may even be described as the basic principle of the whole vorld as vith the Chinese P'an Ku who created heaven and earth. In the Jevish tradition Adan personifies the total oneness of all human existence,

Jung states that it is the role of religious syabols to give meaning

1. Phyllis Trible, reported by Yvonne van Dongen, Auckland Star, New Zeal and, 27th July 1986.

2. Carl Jung, Man and his Symbols, Picador, London, 1964,p.61.

3. Ibid.,p.58.

4. Ibid., p.211. 
to the life of nan. He need, he says, to cultivate thoughts that cannot be proved and "Myths go back to the prinitive storyteller and his dreans, to aen aoved by the stirring of their fantasies." Jung tells us what happens to societies which lose their spiritual values:

In earlier ages, as instinctive concepts velled up in the nind of wan, his conscious aind could no doubt integrate them into a coherent psychic pattern. But the 'civilized' an is no longer able to do this. His 'advanced' consciousness has deprived itsef of the means by which the auxiliary contributions of the instincts and the unconscious can be assinilated. These organs of assivilation vere nuninous syabols, held holy by comnon consent. 2

Today for instance when ve talk of 'matter' it is merely a concept, there is no associated syabol to indicate the psychic significance this tern aay hold and no sense of eactional energy. The only source of this that is left to us says Jung is in our dreass and herein may be the answer for modern mechanized man "For God speaks chiefly through dreans and visions." Lloyd Geering speaks of myths as creating order from chaos and believes that ve cannot live adequately vithout a complex series of myths. Myths possess organizing value. We recognize in myths not the truth but a truth. For instance the Last Judgment is no longer taken at face value. What it is saying is that everything you do in life has ultimate significance, there is judgment on you all the time. A myth can become the organizing principle in your life e.g. If you believe in flying saucers. With this new appreciation of ayth the Christian sees other religions in a new light, for myths have an internal logic self-evident to the culture they belong to. To the Aboriginals of Australia for instance there is the wyth of the Dreantive. In collective consçiousness we can share in basic symbols which

1. Carl Jung, Man and his Symbols, Picador, London, 1964,p.78.

2. Ibid.,p.84.

3. Ibid, p.92. 


\section{1}

occur in all cultures irrespective of race.

An interesting coment on cross-cultural communication was made by Father Ton Ryder of Auckland who believes that the Christian message has been communicated by the Catholic church in a style that is foreign to a Maori vay of thinking. He believes that they are a profoundly religious people because of their tradition of mystery, magic and stories. He noticed in his vork with then how well children responded to stories and that the language of the Bible vas in a style they did not find unfaniliar. "They took it for granted that there vas a message behind the stories...they would respond to images rather than matter-of-fact things like a European aight do." His findings have obvious implications for teaching. The language of mythology is not alien to these children and use could be ade of it for their learning experiences, if this is not already being done. Biblical language is also faniliar to many Polynesian inmigrant children in Nev lealand who hear the Bible read at church and at home, and evidence of its style is sometimes seen in their oun uriting.

Geering says there are those who believe ve need to fevise the religious syobols and doctrines inherited from the past. Such a one is Gordon Kaufman of Harvard Divinity School who says in his Theology for a Nuclear Age that our capacity to self-destruct aakes it urgent for us to re-evaluate our religious stance and construct religious concepts and syabols that vill enable us to respond to current human needs.

A cultivation of Eastern aysticism has enjoyed a vogue in the twentieth century Western World, The allure is often the deceptive simplicity of

1. Lloyd Geering, Lecture at Dowse Art Gallery, New Zealand, on Myth the UItinate Truth, 23rd April 1986.

2. Father Tom Ryder, quoted in the Auckland Herald, 29 th June 1987. 
Eastern faiths as opposed to the aterialish of the West. Even a slight exploration of the literature in the field reveals eany proverbs, aphorisas, and guides to living. The Enneagran for instance taught by Jesuits in South Aaerica, caee from Afghanistan two thousand years ago where the oral tradition was known only to the Sufi wasters. Once again the nain syabol is that of a journey, of discovery of the self. It is a process of self-enlightenent. The basic step is to discover which of nine categories of human personality one most closely fits into. One then applies this knovledge to guiding precepts from the scriptures. Df interest to teachers is the analysis of the teachings of Jesus as used by those who follow the enneagrat. They note his love of syabols and analogies and the vay he simplified things, reducing the comadndments for instance to two precepts, Love of God and of one's neighbour (i,e, anyone of husan race). His forte as a teacher was speaking sinply as he did in the parables and alvays being ready to repeat his explanations. The uriters who extol this systen of enlightenent tell us that the word religion cones from the vord religare root vord for 'rely'. The aetaphor of the universal dance comes in here too. "Ones [i.e. one of the personality 'types'] nay becone avare of a wonderful harmy of complementarity in creation as a sacred dance of opposites attracted to one another and then see theaselves vithin that Whole as dravn by the agnetis of an all-pervading love."

The same symbols occur again and again in different belief systeas and all are couched in sinilar language. Frye referred to the cycles of husan development and Parasahansa Yogananda in his autobiography also speaks of cycles the yogis have described such as "The 3600 year period of

1. Maria Beesing O.P., Robert Noyosck C.S.C.,Patrick H.O.Leary S.J., The Enneagrage, Diaension Books, Ney Jersey, 1984, p.195. 
Treta Yuga vill start in A.0.4100; the age vill be arked by conson knovledge of telepathic comunications and other tiae annihilators. During the 4800 years of Sakya Yuga, final age in an Ascending Arc, the intelligence of san vill be highly developed; he vill vork in harnony with 1

the divine plan." These cycles are the eternal rounds of MAYA. The Vedic scriptures declare that the physical vorld operates under one fundamental lav of Maya, the principle of relativity and duality. God the sole life is Absolute Unity; to appear as the separate and diverse manifestations of a creation. He vears a false or unreal veil. That illusory or dualistic veil is Mayd. Yogananda explains that Nevton's lav of notion is a lav of Mayd. To have a single force is impossible there aust alvays be equal and opposite forces. Studies of electricity and the aton reveal sioilar opposites. Maya is therefore the very fabric and structure of creation a aetaphor for the illusion of reality. To one who is avare of this says Yogananda "creation is only a vast aotion pícture."

Because he depends on his senses san can never have proof of God says Yogananda shose oun faith vas inspired by the teachings of his guru Who also explained the Christian aythology to hiv. He waintained that the great Yogis of India noulded their lives by the sane ideals as Jesus. He explained to his student that "Genesis is deeply syabolic and cannot be grasped by a literal interpretation...Its 'tree of life' is the huan 3 body." Yogis believe that the Lord is heard only in silence, hence their practice of deep concentration and eeditation. The divine purpose of

1. Paramahansa Yogananda, Autobiograghy of a Yogi, Self-Realization Fellowship, Cali fornia,1979p.194.

2. Ibid, p.320.

3. Ibid, p.196. 
creation is explained for then in the Vedas. The Rishis taught that all aen are endoved vith a facet of the Divine Individuality and are equally dear to God. 'Distinctions by race or nation are eeaningless in the realn of truth where the only qualification is spiritual fitness to receive... God is Love... Every saint who has penetrated to the core of reality has testified that a divine universal plan exists and that it is beautiful and full of joy." One of the aies of Yoganandas devotees is to unite East and West and to unite science and religion through realization of the unity of their underlying principles. Kuch of his book is devoted to draving analogies fron scriptures and scientific discoveries which point to the same truths.

'Truth' is a debatable concept. Frye has said that truth has been defined as whatever doesn't disturb the pattern of what ve already knov. This hardly fits nev knowledge in all cases. Just a few days ago a fanily oriving across a central Australian plain claised to have been folloved and harassed by an unidentified flying object. The press is full of coment and speculation fron eyevitnesses and 'experts'. The fanily is still convinced that it experienced contact vith extra-terrestial beings, this is what they believe so for then that is the truth. Their experience has been enlarged by sonething they did not expect or presunably wish to undergo, they nov have to internalise it into their oun personal aythos. The rest of us can either dismiss it as an illusion or categorize it as a scientific phenowenon for which there vill eventually be a rational explanation. The vritings of Kahlil Gibran the Arab mystic and poet are adaired by any people. His words especially in The Prophet are very

1. Paraaahansa Yogananda, Autobiography of a Yogi, Self-Realization Fellovship. California, 1979, pL.572. 
appealing and 5oothing, but it is not easy to vork out exactly what he is saying. His statements are full of vonderful aetaphors but they are often enigmatic puzzles just as many of the biblical sayings are. The imperative voice is the most significant trait in such vritings which $I$ have found to be a dominant feature of writing that stirs the enotions.

One is reminded for instance of a New lealand short story Tangi by Witi Ihimaera where the simple command "Do not look up" is repeated and has an amazing effect on the reader although it is supposed to be an admonition to the young boy in the 5tory, One thinks also of lines such as "Do not go gentle into that good night"... equally as conpulsive and noving in its effect. We seem to have a basic drive to obey an inner or higher voice or an innate desire for a guide, for a leader, someone who can tell us what to do, hov to behave, how to succeed. This may be a factor ve look for in our religions. To understand this use of imperative language would be a key I believe to understanding religious language. We all seek guidance, to know right froc urong, to find the ultimate Platonic food and to understand our individual place in the temporal tive sphere. If our unique asset, compared to the rest of creation, is language, it is not surprising that it is in language that ve look for signs of understanding. Our nature reflects some reanant at least perhaps of its creator. Those with greatest power over language seem to have had greatest power over their fellow creatures. Even today those who control communications vield enor nous pover. Perhaps a better understanding of language, religious, scientific or literary, vill help us all to share our planet and understand each other better and live aore peacefully. If we all share a priaitive metaphorical mythology it should be possible for us to identify those religious or spiritual dimensions to human life which are necessary or desirable for the race and for the individual. Adhering to our differences 
has produced nothing but bigotry, bloodshed and aisery. The idea suggested by frye in his final analysis in his study of the Bible as literature was that the individual has to find his own personal aeaning eventually. This fits in to the Eastern philosophies also and to Nietszche's idea of establishing personal authenticity by 'genealogical' enquiry, that is, establishing the basis of one's beliefs, values and attitudes.

What Urban says about religious language summarizes many of these findings so far. The philosopher he says, atteapts to understand religion from a scientific or objective vieu. He vonders if this is possible or desirable for he believes that one aust first have an understanding of one's oun comaunal religion. If we vish to understand a poet it is necessary he thinks, to share sone of the emotional attitudes which his beliefs generate even if we do not share his beliefs. And what is true of poetry is true also of religion. "In order to understand the essence of religion it is necessary to live it only on the plane of the developed religious consciousness, on that level on which the values which religion eabodies and expresses tend to become universal. ' He uses the analogy of a pyranid to describe at the base various levels of religion according to race, time and culture, but at the top he places the moral geniuses such as Jesus, Buddha and Confucius, where "We find a striking unanimity and, as it vere, completeness of comaunication."

Abelard tells us, says Urban that "What is said of God in bodily for is not to be understood as the laity comeonly do, corporeally and

1. Wilbur Marshall Urban, Humanity and Deitty, George Allen and Unwin, London, 1951, p.19.

2. Ibid, p.19. 
literally, but nystically and allegorically." ${ }^{1}$ There are therefore

says Urban, two kinds of truth, the human and the Divine. Reason leads us to truths of nature but "The truths of Grace need not theaselves be rationalized in order to be accepted."

In his exanination of the language of religion Urban finds that there is a principle eabodied by the theory of Croce, that intuition and expression are inseperable. One does not intuit and then find vords-the two come together. Urban says that there is also no expression vithout the correlative understanding "Comanicability is not an irrelevant ADDENDUH of expression--even in the aesthetic--it is the very heart of 3 it." The mystical experience has been explained as one of pure immediacy but to be expressed, it "can only be in the language and syabols of the native region of the aystic."

The first characteristic of the language of religion then, is that it is poetic. It is therefore emotional in character. It is also intuitive and figurative, but it is not MERELY poetry, its 'aliveness' is heightened and deepened in a unique vay. "It is so to speak, poetry transposed to another scale, a scale 50 transcendent that to call it any longer poetry, in the ordinary sense of the vord, is to stultify both poetry and 5

teligion." This is the lyrical language of hymn, psalas and prayers-which cover the vhole $r$ ange of huan enotions. There is also says Urban, a

1. Hilbur Marshall Urban, Hunanity and Deitty, George Allen and Unvin, London, 1951, p.21.

2. Ibid.,p.23.

3. Ibid.,p.54.

4. Ibid, p.54.

5. Ibid.,p.56. 
tonal quality, which has been described as 'holy'. This can be seen in songs of praise and of love divine.

Religious language is then evocative and invocative, it evokes feelings but it also invokes objects--spirits, saints, angels, even fod hiaself. Religious language can also be drasatic, as in the way the 'actions' of the deity are described. "It is therefore priaarily the language of 'AYTH' frow which the original syabolisa of all priaitive religion is derived...a dranatic and anthroponorphic vay of relating the events of nature and history in contrast to the physico-aatheatical vay of science'."

The primary forms of the language of religion are the lyrical and the dranatic but there is also theological language. The latter is vhat is 'urapped' as it vere into the poetry "certain relations of the divine subject or objects to real life." This is presumably the 'kernel' of which Frye spoke, the lesson of punch line hidden as in a parable.

Urban describes the poetry of religion as numinous--a tera taken fron Rudolf Otto, which refers to the sacred or nysterious eleant vith which the language is charged. The vords 'sacred' and 'holy' refer to it. This is its unique aspect. It is our recognition of the nuainous which is at the heart of vorship and of religion. Not even ausic with its range of expression can express 'holy', says Urban

He states that the language of the Bible is 'alive', it has not been devitalised for the purpose of science. It is an's humanity which sakes hin a poet and his poetry is not a special language or 'language of the

1. Wilbur Marshall Urban, Hyganity and Deity, George Allen and Unvin, London, $1951,0.57$.

2. Ibid,,p.58. 
Gods'. 'Nuninous poetry is the suprese expression of a power shared by all for as of poetic language--to convey the sense of things which lie in the twilight zone between the finite and the infinite--a sense of things which the language of science cannot express." Urban is speaking two decades ago and in this tine as Yogananda says the theories of science, and of physics particularly, cone nearer to religious language as in describing energy or light which is alnost indescribable, Urban says that the Russian theologian Nicolai Berdyaev has said that "behind oyths are concealed the greatest realities, the original phenomena of the spiritual life."

The syabolic fore of poetry, according to Urban, is anthroponorphic and its opposite is mechanosorphic, a fora developed not for understanding but for control, according to Bergson. It aight alnost be said that in order to control one aust renounce real understanding of aan, and in order 3

to understand one aust cease to control." Poets and artists believe what they say and in order to understand then ve wust beli gve also.

There are clearly no explicit propositions in painting or ausic he says, but linguistic art contains both explicit and iaplicit assertions about its objects. What poets say "is potentially propositional and aust be taken up into discursive knovledge." Poets and artists have a philosophy and what they tell us about an and human life is aore representative and more revealing than science which has no interest in persons, as such. Only the poet can 'objectify' the meanings and values that make hia human.

1. Wilbur Marshall Urban, Hunanity and Deity, George Allen and Unvin, London, 1951, p.64.

2. Ibid.,p.83.

3. Ibid.,p.399.

4. Ibid.,p.402. 
Scientific psychology, says Urban, is alvays psychology vithout a souI, Poetry alvays speaks of 'souls' even when, as in naturalistic poetry, it denies their existence. "The tension betveen vhat is and what ought to be, whether the 'is' be a Iaw of society or a lav of nature, is ean's deepest character and to have this character is to be a'soul'. The language of science therefore destroys poetry.

What poetry does alvays say is that wan is unique, free and selfdetersining. This is said iaplicitly in the dranatic way of presenting life, especially in tragedy. "A naturalistic viev of san--cannot rise to 2

tragedy." The death of a wan is tragic as that of a tree or a dog cannot be. There are sose tho vould disagree vith this. Urban says this is the basis of a dileana in modern drana.

All art says Bergson is "une netaphysique figuree" and to Coleridge a "covert metaphysic". This metaphysic nay be little more than vague pantheisa says Urban, but can rise to a full and rich theisa in which "even a comaon dandelion has a quality and a glory vhich takes the thought ful wan beyond nature; the iaportant point is, that, whatever its forn, it is alvays a setaphysic in which nature is a syabol of the divine."

The iaplicit pronouncenents of poetry are siailar to those of religion -which suggests a close relation between the humanities and religion. Urban tells us that this has given rise to a Humanisa, in which what is hualn can only be understood then related to the Divine and negates pure Naturalise. "that same presupposition of the MORE THAN HUMAN is necessary

1. Wilbur Marshall Urban, Hyannity and Deity, George Allen and Unvin, London, 1951, p.404.

2. Ibid., p. 404 .

3. Ibid.,p. 407. 
to the very existence and meaning of the human, is rather videly felt.. Urban is not accepting of ney scientific theories of God. To his when ve speak of God ye alvays have in aind the idea of a perfect being, in knouledge, pover, goodness, holiness and beauty--this is the only adequate idea of God, he thinks. "To take the notion of the superhusan seriously is 2 also to iaply the notion of the supernatural." Huanity and Deity are the tvo fundanental issues of the philosophy of religion, says Urban.

Mystic experiences, Urban says, are difficult to explain vith language yet everyone experiences aments of insight and realization, usually at a tiae of concentration or stress. He should therefore have sone appreciation of what aystics are trying to do when they tell us of their experiences of God. "Even aystic experiences of God cannot be wholly 3

unsediated." They have to be expressed in language. Mysticisn appears to be a characteristic of human consciousness--an essential element in religion, theology and philosophy. It vas this eleaent in Plato for instance which gave us says Urban the explicit systics of Plotinus and siailar elenents are seen in Aristotle. If God is siaply an idea, says Urban, then the life of religion is an illusion and the life of reason also. It has to be ore than this he thinks. The fusion of which Plato speaks, can only be realized in experiences that trench on the eystical." Teaporal forms of expression are therefore symbolic and with then is the underlying assuaption that a Being aust exist to whon nothing eay attach

1. Milbur Marshall Urban, Hunanity and Deity, George Allen and Unvin, London, 1951,p.414.

2. Ibid., p. 422 .

3. Ibid.,p.447.

4. Ibid.,p. 432 . 
which could present itself to thought as an iaperfection; only a most perfect Being can, for religious thought--and ultioately for religious 1

feeling also--be called God." Men constantly talk as though they have had experience and knovledge of the tiaeless:

With respect to the highest poetry, there is a language in vhich 'tiae,place and nuaber are not,' and this is one of the chief characters of the language of aysticism--that language vhich, as ve have seen, has as one of its ajor characters the pover to 'sting to life' those absolute qualities and essences which are tineless and to sake of then the aedium of conaunication of the intense and eternal life which is hid with God.2

Space and tiae are linked vith atter and if ve speak of God as teaporal ve reduce hin to bodily forn. The Christian nystics vitnessed a fod vho transcends tine and space, Yogis such as Yogananda quoted earlier speak of a transcendental state where travel through time and space is part of their spiritual pover, We have the capacity to understand these things says Urban, just as ve have the capacity to becone 'lost' in a piece of music, at one vith it, and yet this experience vould be hard to describe and define. Of those whon ve deen aystics their doainant attitude has been one of acceptance and transcendence and this he believes ve sust respect. Their humanity also is their endearing quality.

We cannot escape the 'snares of eetaphor' says Urban, and anthroposorphisa is inevitable. The aystics rescue us he thinks from the delusions of the literal aind. Religions of mere Huanity and Deity have no place for the aystic. For the Huanist the infinite is husan. For the others they think the aystics are deluded in thinking they can see fod. It is only a recognition of the natural aysticisn in every soul that nakes

1. Wilbur Marshall Urban, Hunanity and Deity, George Allen and Unvin, London, 1951, p. 454.

2. Ibid, , p. 458 , 
possible a real understanding of the Mysticiso of Grace according to Urban, and it is only in our hearts that ve can know this is true for our faith is based on reciprocal love betyeen God and an.

When ve exasine the language of religion Urban says ve see that it is unique, and that vhile the yords are human and the eaotions they express, they are transposed on a scale which renders then revelatory of the object tovards which they are directed. This is the nuainous quality which akes huan language that of God. A quality of Deity in the vords akes the no longer huan but Divine and if ve exanine the vords of the Song of Songs he says ve vill vitness how what can appear a bighly erotic poen becones the mediun of the nost exalted experience of nan's relations to the Divine. There is a quality in religious language which eakes it speak for all tine.

Frye has said that the Bible is a complex metaphor and the anthropologist Fernandez conceives of religious experience as the actualizing of metaphor "Religious metaphors recast the inchoate (and ineffable) whole of primary 1 experience into various manageable perspectives." He cones to this conclusion after exanining the religious rituals of various tribes such as the Fang reformative cult of Bviti a polymorphous one combining ancestor vorship of various tribes and some elements of Christianity. His proposition is that wetaphors provide organising isages which ritual action puts into effect. In their cerenonial religious rituals 'in acting as vell as in speaking persons have an iage of the pattern to be completed and ake plans according." This vas observed by Frake (1964) but Fernandez believes that these inages

1. Jame5. W. Fernandez, 'The Perfornances of Ritual Metaphors,' from The Sociall Use of Metaghor ed. J.D.Sapir \& J.C.Crocker. University of Pennsylvania Press, 1977,p.126.

2. Ibid.,p.109. 
ate contained in metaphors. In their veekly all-night cerenonies he identifies four key metaphors for as he says "netaphor is an organising element in all 1

of these cult movements." These metaphors are;

bi ne esaaba--We are a trading tean (in file through the forest). bi ne ayong da--We are one of a clan.

we ne (e ne) emvan not-I an(he is) the son of an (aan child). bi ne nles avore--We are one heart.

These netaphors eaerge in the liturgical comentary says Fernandez but they also run through cult life and provide a periodic faniliarizing reinforcenent or leitmotif. COne cannot help but think of sinilar wetaphors arising at professional and trade conferences or in any other Western institutions which deliberately try to create group solidarity.]

"The fitness of ritual," says fernandez, "lies in the aptness of

metaphor." The metaphor of one-heartedness is affirmed in their ceremonies by the candle-lighting, filing out into the forest and back into the chapel, spiralling wore and more closely until as 'one' they raise their candles to for one flane. Their liturgy is also laden vith syabols such as the cult harp.

Fernandez questions what role aetaphors play in such rituals. His analysis was based on a model which suggested that a metaphor is not only an iasage but also a plan for behaviour. If ve inagine a cult nember hypothetically, as isolated, alienated or vhatever, it is not difficult to see that he emerges frou the cerenonial "incorporated, empovered, activated and euphoric." Lfrou a more sophisticated society one can also eaerge in

1. James. W. Fernandez, 'The Performances of Ritual Metaphors,' froe The Social Use of Metaghor ed. J.D.Sapir \& J.C.Crocker. University of Pennsylvania Press, 1977, p.107.

2. Ibid.,p.109

3. Ibid.,p.t15. 
these states--I envisage gregarious drinkers, or fanatics exiting fron a

concert or sports arena.] In a religious cult, such as fernandez

describes people escape their corporeality. His observations lead hin to

deduce that metaphors provide a sufficient base for the understanding of

ritual as change in sotion:

...one nust suppose that at some point in the history of the cult these aetaphors vere ejaculated out of the inchoate 1 , ve, they etc. by the visionaries vho gave and continue to give prophetic iapetus to this religion. Metaphoric innovation like innovation of any kind rests with the fev and not with the wany. 1

Those vho are attracted by these visions, says Fernandez, need only entertain social consensus tather than cultural consensus, but over time they inductively cone to an understanding of the aetaphor that controls it. The pover of a leader operationalizes a metaphor, and dispute, vhen it arises is often over the aptness of a aetaphor. He can see that this same principle fits our own social vorld even in metaphors of education which are accepted then ultiately questioned and ney ones take their place. As Fernandez say5, each participant has different levels of participation and focus nay be heightened by nev aetaphors or other aids as in this case the use of narcotics in initiation.

According to Fernandez as 'tiae-binders' ve need to fill the inchoate present with activity, and religious movenents, as a particular paradige of aetaphors, do this. Metaphor becomes metonyay or as LeviStrauss says "the transfornation of netaphor is achieved in setonyay."

This is illustrated for hin by Mr Weanick of Great Expectations whose lifestyle is transforaed into ritual actions by "the paradigatic relations

1. Jaaes. W. Fernandez, 'The Performances of Ritual Metaphors,' ${ }^{\prime}$ from The Social Use of Metaghor ed. J.D.Sapir \& J.C.Crocker. University of Pennsylvania Press, 1977, p.115.

2. Ibid.,p.119. 
between two equally unreal syntagaatic chains. That of the castle which has never existed and that of the village which has been sacrificed."

Fernandez says wost metaphorical inages potentially iaply action:

The utterance of eetaphor itself as vell as the actions undertaken to realize it is attended by a set of associations which "belong" to it by reason of contigiuties in previous experience. The assertion of metaphor thus provokes a metonymous chain of elenents or experiences associated with it as part to vhole, cause to effect, or other contiguity in time or space. 2

A Metaphor does not sieply excite associations says fernandez but iaposes a sthead on thea. It is a hypothesis which aakes other things in the vorld relevant or irrelevant, that is, the associations are conceptually mediated by the metaphor. Apt metaphors in religious experience "conbine in themselves. soae satisfactory representation of both social experience as vell as priaty experience...a fundanental transforation is thus accomplished by netaphor..." Victor Turner has argued he says, that the apt metaphor is the fundanental capacity of dominant religious syabols and the ritual draeas in which these syabols are anipulated create an exchange betveen physiological and social experiences, ennobling the former and investing the latter with enotional significance. Religion, particularly Christian, dims to do wore than this, says Fernandez, it ains to transcend the physiological and the social, What is difficult to understand he says is how chains of association appear in relation to each aetaphor and how wetaphors are associated vithin paradigas, even how they first appear. It is thought that nost associations rest on culture-bound analogies. He

1. Jaees. W. Fernandez, 'The Perforsances of Ritual Metaphors,' from The Social Use of Metaghor ed. J.D.Sapir \& J.C.Crocker. University of Pennsylvania Press, 1977, p.119.

2. Ibid., p. 126 .

3. Ibid.,p.127. 
gives an exaaple of hou 'snake' for instance is linked vith vell-being by association vith honey, itself intrinsically attractive, and which is associated vith the season of fine veather. The aind, he thinks, is bound to realize the unity of its experiences at sone level of abstraction... (and * To a sufficiently religious aentality practically everything in the vorld can be brought into association as uanifestation of spirit." He suggests that the latent principle by which religious associations are brought into being is the inchoate itself. It is 'eetaphors [which] start up the syntactic achinery focusing our intentions by their predication " but their origin is still a aystery. Fernandez concludes that for social structural experience ve need aetaphors for--ideas of adequacy, inadequacy and exaltation. These are social and corporeal needs, which are aediated as the cult under his observation shoved, by religious celebration.

Metaphors vill differ according to the needs or frames of the group involved. Everything he has vitnessed anong the Banzie supports the idea that "...the prinordial self can first be incoroporated into some body social and these together can be surpassed to the quite insubstantial 3

spiritual. " His evidence seeas to be a microcosaic view of what Frye and others have surnised fron their study of the Bible particularly. The religious metaphors are the glue which velds the prinitive society together. They are expounded in ayths and acted out in rituals. It is not difficult to see analogies between the way such etaphors occur and permeate religious history and the 'netaphors ve live by' of Lakoff and Johnson.

1. James. W. Fernandez, 'The Performances of Ritual Metaphors,' from The Social Use of Metaphor ed. J.D.Sapir \& J.C.Crocker. University of Pennsylvania Press, 1977, p.129.

2 Ibid.,p.130.

3. Ibid.,p.131. 
The eaphasis in this chapter has been on Western and Christian religion because this is more faniliar to me, but there is evidence that all religions share coman syabols and forms of revelation. They all have their special people to interpret truth for then, and this truth is often in the for of ayth. The syabolise of a father figure or source of enlightenent is endeaic. The language uhich expresses religion is in all instance poetic and sometises aysterious. Myth, syubol, metaphor and poetry are natural methods of teaching us about huaan nature and husan values. He neglect this rich source of knovledge in our schools, particularly where they are secular and where the emphasis in curriculus has fallen on the practical career-oriented training as in Comennications English in place of Literature. Our literary heritage includes the Bible as Frye demonstrates and is a source of inspiration to other races and cultures also. In his opinion "It should be taught so early and so thoroughly that it sinks straight to the botton of the aind, where everything that 1 cones along later can settle on it." When people refer to the importance of 'basics' this is not the kind they usually have in aind. If, as Hoggart has said "Education ast ain to introduce us not just to intellectual values but to human values and to the assive contemporary challenges to those values..." we way find that classical aythology has auch to offer us which ve have neglected to our cost.

1. Northrop Frye, The Educated Inagination, Indiana University Press, 1964,p.110.

2. Richard Hoggart, An English Ieseger, Chatto and Windus, London, 1982, p.40. 
Other areas of huan behaviour besides religious beliefs are also prescribed by metaphor as Crocker points out and he refers to sexual mores and eating rituals as examples. Rhetoric, he says "does ore than just encoapass these diaensions: it creates then." Anthropologists have denonstrated the social impact of certain analogic systeas and "The 5ocial utility of the analogic capacity derives, iaplicitly, fron its ability to handle a virtually unbounded range of recurrent issues vithin a single 2

paradigatic foraula." It is language he concludes which dictates action. Lloyd Geering tells us that vorship as the etymology of the word reainds us is, any fors of activity in which ve are "celebrating or sanifesting the 3 values, hopes and goals, which are the greatest vorth to us." And it is in this sense that life itself can be an act of vorship, an idea which is probably rarely explained to young people.

Theories about the nature of religious practices and beliefs are supported by what Eaile Durkheia has said about the nature of religion, that it is eminently social and that religious rites are 50cial affairs, the product of collective thought. We inherit vhat he calls intellectual capital. Furtherare "Religion has not confined itself to enriching the hunan intellect, foraed beforehand vith a certain number of ideas; it has 4 contributed to forning the intellect itself."

1. J. Christopher Crocker, The Social Functions of Rhetorical Foras, in The Social Use of Metaghor eds.J.D.Sapir and J.C. Crocker University of Pennsylvania Press, 1977, p.46.

2. Ibid.,p.55.

3. Lloyd Geering, Acts of Hor ship,Listener, Nev Zealand, April 2 1988, p.77.

4. Emile Durkheis, Elenentary Forms of Religious Life, in School and Societsy, Routledge and Kegan Paul in assoc. vith Open University, $1971, p .206$. 
We ove wuch of our knovledge and the for which knouledge has taken, to religion. The basic essential ideas which doninate all of our intellectual life, says Durkheia, what have been called by philosophers since Aristotle, categories of the understanding such as notions of tine. space, class, nuaber, cause, substance, per sonality, atc., correspond to the aost universal properties of things. "When prinitive religious beliefs are systeatically analyzed, the principal categories are naturally found. They are born in religion and of religion; they are the product of religious thought."

The eternal debate over knowledge is whether it is innate or constructed by the individual. Durkhein states that if ve recognize their social origin We can accept a nev attitude accepting that there are individual and social levels of meaning.

Collective representations are the result of an inaense co-operation, which stretches out not only into space but tine as vell; to aake then a nultitude of ainds have associated, united and combined their ideas and sentiments; for then, long gener ations have accunulated their experience and their knouledge. A special intellectual activity is therefore concentrated in then which is infinitaly richer and complexer than that of the individual.2

Man is double says Durkheil, there are two beings in hin, the individual, and a social being "which represents the highest reality in the intellectual and moral order that ve can know by observation--the individual transeends hiaself both when he thinks and when he acts." So auch 50 that there is an inner authority which he aust obey, and which is why wen do not feel completely free. This is presunably what Korzybski refers to when he says that "healthy vell-balanced people are naturally

1. Enile Durkhein, Elementary Forms of Religious Life, in School and Society, Routledge and Kegan Paul in assoc, vith Open University, $1971,0.206$.

2. and 3. Ibid.,.209. 
'moral' and 'ethical', unless their educations have tuisted their types of 1

evaluations."

Bergland also speaks of this capacity to pass on information fron one generation to the next, using the tera 'aemes' developed by R. Davkins 2

in The Selfish Gene. The idea is that genes pass on physical characteristics which enter a conson pool but culture is passed on by menes which spread like an infectious virus.

One aight still ask vhat is the place for religion in education even if convinced that literature and particularly aythology are a source of spiritual nourishment for sankind. Professor Jeffreys answers this question from a Christian vieupoint for he is concerned that we have lost important personal values in the oodern vorld. As he says "there is no magic in deacracy that aakes it self-supporting and self-perpetuating" and our educational systeas have encouraged an individualisa which in the end is self-destructive. Education he believes must be seen in relation to the ultioate probleas of life. It can never be a mere watter of adaptation because culture is in a state of tension vith civilisation and education cannot be discussed in general teras only for "If the general aia alone is stated, ye find our selves presented vith indubitable but useless truths." So we need to state both general and special ains for education.

Tension exists also says Jeffreys betwen the individual's needs and

1. Alfred Korzybski, Science and Sanity, The International NonAristotelian Library, Lancaster, Pensylvannia, 1941,p.xi.

2. Richard Bergland, The Eabric of Mind, Penguin Books, Australia, $1985,0.7$.

3. M.V.C.Jeffreys, The Ains of Education, Pitan Publishing, London, 1972,p.xv. (First published as 6laucon 1950)

4. Ibid.,p.9. 
those of the community. All the vi sest sayings so far point to the fact: that not Iove of oneself but love itself is the sectet of a successful life. We need freados but "Ke begin to approach true freedoa in proportion as ve lose ourselves in sosething greater than ourselves." The greatest artists have knovn this experience. Not every kind of service is liberating. This love he speaks of is that which is personal.

Love aight in fact be defined as the relationship that treats people as persons--i.e. treats thee as sacred. It is love that CONSTITUTES the personal: it is through loving and being loved that persons grou as persons. 2

In hunan Iife it is found only imperfectly. Some institutions says Jeffreys are are cospatible vith the principle of love than others.

Man transcends the tiae process because he is able to think about it and relate events across tiae, so he /she is both imanent and 3 transcendent. Korzybski speaks of our tiae-binding capacity. Collective an appears to be under the same constraints as individual man, as history shovs us, but wan has the pover of aaking reasoned choices.

It is by virtue of the power to transcend the strean of events that the self can act as a coherent whole, in relation to a situation as a whole, sumoning all resources of knowledge and imagination, aaking the action his own, taking full responsibility for it--acting that is to say, as a person. 4

This pover of choice needs to be educated says Jeffreys. "Freedon ensues, therefore in proportion as the self transcends the strea of events, acting as a whole in relation to the situation as a whole. Fron a

1. M.V.C.Jeffreys, The Ains of Education, Pitan Publishing, London, 1972,p.17. (First published as Glaucon 1950)

2. Ibid.,p.18.

3. Alfred Korzybski, Science and Sanity, The International NonAristotelian Library, Lancaster, Pensylvannia, 1941, p.39.

4. and 5. Jeffreys, p.37. 
behaviourist point of vieu this vould be seen as merely stiaulus and response. The historian aight view it all aainly as series of causes and effects. But both vieus only see hunans froe the outside not vithin. The vork of art or the truth of philosophy hovever has to be understood in teras of entering vithin it "to enter the transcendent invardness of personal experience." The vork of art is a personal creation "it is the personal quality of the activity that aakes it art. When ve say colloquially that an artist put his whole soul into his vork ve are saying 2 something quite literally true." The sane is true says Jeffreys of all activity intellectual or noral which has this quality of identification betveen the activity and the person. "The same is true of the prophet and his message. The san is his vision and the vision is the man."

In Jeffreys' vieu it is only in proportion as a person approxiates to full personal stature that one can expect to be aster of oneself and history. In a vorld with deterainistic viev there is less personal responsibility and aore ass activity "In such a society the aasses vould be are or less blindly imaersed in, and therefore subject to, the process of cause and effect, while the ruling group vould be living on the advantage that the process happened to bring to thea." This coanent seeas particularly apposite in our oun times. What ve can see says Jeffreys is increasing tension in modern Western civilisation between technological devlopment on the one hand and hunan bevilderaent on the other. So in his estivation "It is clear that the supreme need of the aodern vorld is for

1. M.V.C.Jeffreys, The Ains of Education, Pitan Publishing, London, 1972,p.40. (First published as Glaucon 1950)

2. and 3. Ibid, p, 40 ,

5. Ibid, , p.45. 
the adintenance of personal values and the creation of personal living. Any atteapt to achieve the truly personal level in living and thinking sust also be an attenpt to create true freedon and true comunity." Which latter are two sides of the same thing, true freedon found in the service of conaunity "in shich persons are treated as ends and not aeans." Therefore for Jeffreys the true ain of education is the creation of personal freedon in the comaunity. No one style of education is good for all times and places Jeffreys thinks, and the charateristic of our tines is the increased tension in the aicroscosa and the eacrocosa. One aight say that we are in fact stretched on a rack of nuclear tension.

For any centuries in England at least says Jeffreys conaon knouledge of the Bible vas a factor in creating a sense of conaunity. No other source gives so auch access he thinks to the neaning of life. To create unity aaong people and classes of people he thinks as Berdaev saying:

Only religion is capable of aking such a conbination neither philosophy nor science nor enlightenment, neither art nor literature can do this. Deprived of religious basis, any high and qualitative culture inevitably becones separated fron popular life and an isolated cultural elite is produced, which keenly feels its uselessness to the people. 3

Tension increases as the self-interest of the successful are continually forced to ake concessions to the have-nots. So there is tension betveen the classes and between the individual and the state.

It appears that ve lack a bonding agent. Fernandez said it vas religion which acted as this glue. "The failure of aodern individualized

1. M.V.C.Jeffreys, The Ains of Education, Pitan Publishing, London, 1972,p.45. (First published as Glaucon 1950)

2. Ibid.,p. 46 .

3. Ibid.,p.49. (The Fate of Man in the Modern World p/114.) 
wan to create comeunity accounts for his loneliness and his bevilder went" for taken to its liaits individualise means the negation of conutnity.

Education therefore in Jeffreys eyes has to be the agent of redeaption. We need he says a faith by which to live. For hic this weans the "indoctrination" of people for he believes that "The cult of the open aind is a way of casouflaging the poverty of an education which has no view of 2

life to cossunicate." To hiv indoctrination, the very idea of which eany of us vould find repulsive, is not a criae but as necessary as learning table wanners. The challenge as he sees it is to present it in such a vay that the recipient cooes to teras with it on his ovn responsibility. We need he thinks a vay to understand our vorld and our place in it, and to recover a sense of vocation. This cannot alvays coee through vork except for those fortunate enough to vork at what they love.

This idea of the inportance of vork is confiraed by vriters like Willis Harman who says that "Work is placed at the heart of husane living-not a conpulsive Protestant vork ethic, nor vork for econonic gain, but 3

the joy of vital and creative vork." This is a challenge which vill never be easy to oet. Jeffreys thinks ve can gain much insight frow the voluntary vork done in comaunties and the joy and love vith which people are prepared to offer their services. This was illustrated in a recent 4 report on ambulance officers vho often take a drop in salary fron previous

1. M.V.C.Jeffreys, The Ains of Education, Pitman Publishing, London, 1972,p.52. (First published as Glaucon 1950)

2. Ibid.,p.56.

3. Willis Harman, The Coning Transforsation, The Euturtist, April, $1977,0.110$,

4. Iona McNaughton, Life at the sharp end of an eaergency, Doginion Sunday Iines, Nev Zeal and, October 23, 1988, p.19. 
jobs to do this vork, for the satisfaction it gives thas. Perhaps ve need to give nore people opportunities for this kind of fulfilaent. Both Jeffreys and Harman see hope in the groving decentralisation of pover and in increasing voluntary social comanity effort. Jeffreys thinks that ve also need to recover the aeaning and importance of the fanily. He actually acknouledges the value of housevi fery "The aost inportant thing of all, perhaps is to get society at large to take the housevife's job seriously as one that calls for auch specialized knouledge in varied fields, wuch skill, and great persoanl qualities." Wherever the state seeks oanipotence he sees the fanily unit as veakened.

The oost serious veakness in education to Jeffreys is its lack of 2

dias. This etaphor is discusssed by Peters. He can appreciate vhat Jeffreys means, for as he says, and it is borne out by those ubiquitous researches into excellence, "the wost vital systeas of education have envisaged their objectives quite concretely, in teras of personal qualities 3 and social situations." This is not to say that he necessarily accepts their aiss, but finds that, by contrast, in liberal denocracies the aias. often seea fairly nebulous. Even a glance at our oun recent policy docuaents on education such as the Curriculun Reviev and the Picot report alake very generalized statenents and lack a clear philosophical stance as to what their conception of education is or is for. Jeffreys quotes a Harvard Report which said that:

The ideal of free inquiry is a precious heritage of vestern culture;

1. M.V.C.Jeffreys, The Ains of Education, Pitaan Publishing, London, 1972, p.59. (First published as Glaucon 1950)

2. R.S.Peters, Athority, Responsibility and Education, George Allen and Unvin,London, 1973, p.87.

3. Jeffreys,p.61. 
yet a measure of firm belief is surely part of the good life. A free society oans toleration, which in turn cones from openness of aind. But freedoe also presupposes conviction; a free choice-unless it be vholly arbitrary (and then it vould not be free)--cones from belief and ultinately from principle. A free society then cherishes both toleration and conviction. I

And therein lies our problea. Jeffreys says there is only one possible solution of the contradiction betveen individual freedoa and a coason faith in which personal freedon is central, and the husan soul of infinite value. Education has to enable people to reach deep and strong convictions about the nature and destiny of an. The Renaissance he thinks freed an from the old authorities but noy an has to synthesize individual and societal liberty. If we fail to achieve comanity it means a choice between anarchy or depersonalized collectivisa. That is yhy depersonalization is the great and disconcerting fact about modern civilization, and why the redeaption of the personal is the supreae task of education."

Jeffreys believes that the curriculum has drifted avay from real needs. A prise need is to understand the vorld in which ve live. The curriculun needs to be both reate and contenporary for ve can learn from the past and the present. Secondly he thinks ye need direct experience of comounity living. He also need to reveal what has been called the "Vision of Greatness" by a knovledge of our heritage in history and literature. Fron this vision we way hope that faith vill grov for it is something we cannot anufacture. Through knoving of great persons Jeffreys believes that ve can cone to learn the meaning of the personal in human life. "The true aristocrat in any age and in any country is he whose behaviour is most

1. M.V.C.Jeffreys, The Ains of Education, Pitean Publishing, London, 1972, p.61. (First published as Glaucon 1950)

2. Ibid.,p.66. 
fully personal." His vieus do not seen far-reaoved, at this point, from those of Nietzsche and his pursuit of autonosy, soreover Jeffreys is convinced that right thinking is connected vith right feeling and the Vision of Greatness can release intellectual as vell as enotional forces, proeoting behaviour more noble and sore intelligent which is sore the seasure of a person than is I.Q.

School itself does not have to be an isage of the vorld says Jeffreys but has to connect vith it at as eany points as possible. He reiterates that the real seasure of a society is how wuch it values personal values. For those vho consider that producing good citizens is its highest ain he argues for a liberal education for "The highest purpose of education is to produce good aen, and the production of good tradeseen and even of good citizens, is an inferior operation which wust not be alloved to inter fare with the other."

Jeffreys tells us that the nodern vorld originates vith Christianity "and its keynote is the affiration of the divinity of nan." ${ }^{3}$ Our civilisation and the value of the individual springs for this. This idea and the spirit of experieental science can be traced back says Jeffreys to roots in Hebrev culture. Science and reason appeared to be a path to perfecting our vorld, a faith which has been badly shaken but by this tiae he says we had less religion to fall back on. That this kind of humanisa has failed us leads us to despair says Jeffreys. The answer aay be to seek a synthesis of humanis with Christianity which respects human dignity

1. M.V.C.Jeffreys, The Aing of Educaticion, Pitman Publishing, London, 1972,p.72. (First published as Glaucon 1950)

2. Ibid.,p.87.

3. Ibid.,p.129. 
vithout vorshipping an. The only alternatives see to be those which set 1 up the ass, the class or the party as god. Then in his vieu love, pity and aercy lose their clain. The irony of our situation, in his viev, is that it vas Christianity which gave human personality value, so that people fight for such things as equality uho are anti-Christian yet this is a Christian concept. So "the Antichrist arises out of the failure of Christians." 2

The real struggle as he sees it is not betveen classes but betveen good and evil. Any system can provide the context of the perfect conounity with enough goodvill, but no systen can guarantee such. Christian goals therefore can never fully equate vith political goals. The churches thenselves have shortconings says Jeffreys but Christianity alvays oant reception into a conaunity. Modern psychology has not shoun us nev truths but shed light on old truths, about childhood for instance.

The central revelation of nodern child study is the ol dest truth of all about education-- that the first and last principle of education is love, that is to say that ve must respect the personality of the child and treat his as an end in himself and secure his PRESENT needs. 3

What has been teraed original sin represents to Jeffreys the essential conflit vithin an hisself not with his environment. For Jeffreys the task. of the teacher is to lead others to the same conviction that he has that Christianity is a faith of redeaption. This vill meet yith resistance because "The language of religion has become not only metaphor but dead metaphor" yet to his nind religious experience is not:

1. M.V.C.Jeffreys, The Ains of Education, Pitaan Publishing, London, 1972,p.135. (first published as Glaucon 1950)

2. Ibid.,p.137.

3. Ibid.,p. 155. 
a strange and uncanny sort of experience but is noraal experience understood at full depth. If ve can help people to discern the religious truth inplicit in everyday experience which they take for granted--the painfulness of creation, the varfare of love against its rejection, the pover of love to redeen where other forces have failed-ve shall have done a great deal to break down the barrier which the aodern aind has erected against the light.1

That inpenetrable and apparently inescapable setaphor of light again.

Jeffreys concludes that ve need to be reeducated which is difficult as ve have becose ignorant in his view of the Bible particularly. To have a right to an opinion should necessitate understanding which presunes study which requires discipline. A panic return to religion would not achieve What is necessary nor can one plead a rational 'case' for this return. 2 "Conviction cannot come by intellectual processes alone" one needs to study not only the books of religion but the vorld also. He even speaks of the need for an aray of nissionaries. At the heart of the school's teaching would be the Christian gospel "and this Gospel wust spread its light out through all the other subjects of study." and "At the heart of the school life wust be vorship." Above all its supreae concern vill be vith persons.

What Jeffreys says does not shed any aore light [!] on the nature of netaphor but it does explain why those aspects of the curriculun most involved with metaphor and metaphor-making and understanding are absolutely vital to the young. Much of what he says affirms the findings of Northrop Frye and remphasises the iaportance of the development of a strong and individual personality which wany others also stress, but unless one is of

1. M.V.C.Jeffreys, The Aing of Eductation, Pitman Publishing, London, 1972,p.158. (First published as Glaucon 1950)

2. Ibid., 0.159.

3. and 4. Ibid., p.162. 
Christian faith or inclination then his conclusions lose their force because thay lack universal application.

Peters has pondered on sivilar probleas and comes to the conclusion that schools CAN set guidelines for moral behaviour or a rational for of morality " For science and a more rational, universalistic type of morality gradually energed precisely because social change, econonic expansion and conquest led to a clash of codes and conflict between competing vievs of 1

the world." Certain underlying principles as he calls then gradually energe. Rather than supplying a code they sensitize us to vays of thinking of people for example. This is not to circunscribe individuality but to give paraneters vithin which the individual can ake choices vith knowledge of likely consequences. The content of science is, he says no wore uniforaly acceptable than the content of morality, and like science the principles or theory can be taught but the actual practice is left to the person "The content of aorality, therefore, can be taught; but its for develops.' This idea comes adinly from Piaget and from Kohlberg's study of the development of molity. He apparently is opposed to a "bag of virtuas" conception of morality but as Peters says vithout adequate experience one way stay at a very base level of eoral conviction. The difficulty as Peters sees it is to inculcate a sense of honesty for exaple vithout coercion or revards or siaply relying on good aodels of behaviour to have sufficient influence. Indoctrination he says is getting people to adopt a fixed body of rules and vhere a person has no critical or autononous attitude tovards then. In the past it vas embedded by contrivances such as the shaning techniques described

1. R.S.Peters, authority $y_{1}$ responsibility and education, George Allen and Unvin, London, 1973, p. 143.

2. Ibid.,p. 150 . 
in the folloving chapter and is often a sethod to develop strong loyalty to a group. Peters concludes that these are the probleas teachers and parents need to address.

One vonders if it will ever be possible for the spiritual values of diverse religions such as are enbodied both in aythology and in religious uritings to be coabined so that ve can find some oeasure of haraony for us all to share in a reeducation, if not for the faith Jeffreys vishes for us, then at least a faith in our oun ability to learn fron our aistakes and to heed the visdoe gathered for us in the past. Perhaps vhen ve no longer educate for vork only vill ve discover what other aies there any be for education and then the uneaployed vill in fact be the richest.

If religion is prinarily social and natural and necessary as these authors all seen to suggest; and it has a purpose, to help the individual cone to teras vith hia/herself in the foraing of relationships vith others and society at large, then ve can hardly afford to ignore it. It has its oun language and literature and if Dakeshott is correct one vay into the language of any for of activity is through its literature. There is a vast treasury of religious literature--not only that in the Christian Bible-which many children and probably some teachers are not faniliar vith. If ve vere able to explore this, vithout preconceived ideas of meaning or truth, then ve aight profit fron the richness of its any wetaphors. The wost poverful metaphors have a oystery and sagic that aight only be appreciated vith enlightensent, vhatever that really means. Perhaps it coeses eventually to those who bother to look for it. Religion is said to be social but what one learns fron this participation eay be uniquely personal as a nystic Arabic poet Kahlil Gibran suggests in The Prophet:

And even as each one of you stands alone in God's knovledge, 50 oust each one of you be alone in his knovledge of fod and in his understanding of the earth. 


\section{CHAPTER IV}

\section{DUR PERCEPTION OF CHILDHOOD}

The literary historians, nistaking books for life, construct a fictional picture of childhood; as though one could knov what really happened in the nineteenth century Anerican hoae by reading Ton Savyer, 1

In this chapter I an not concerned to document in detail the rigours of childhood such as have been portrayed by historians nor to catalogue the children in literature but to extract from both the viev each century has of children, what status they have as a group, and in a subsequent chapter how this has influenced their education. This overviev vill exanine particularly the language used to describe children, the epithats and wetaphors which reveal attitudes towards then, of parents, churchoen, reforaers, teachers; and wherever possible to suppleaent this vith aemories of childhood recorded for us in diaries, letters, journals and biographies. Metaphors of childhood and parenting emerge which are distinctive at different periods and in different countries but in evolutionary teras possess a discernible overall pattern. It is quite a long journgy frou the child as gere animal to Erikson's notion of a partnership of equals and one which

1. Lloyd de Mause, Ihe History of Childhood, Souvenir Press, London, 1976, p.4. 
aany people are still travelling.

Readers of literature over the past three hundred years could be deceived into thinking that the children portrayed there are realistic, According to Pattison they are merely figurative. It is religious and intellectual debate which gives rise he believes to the child figure ve observe in literature which is a symbol of two fundanental approaches, one, that the child is inherently evil, the other that it is innocent and good. These attitudes obviously affect child care in the hone and fanily.

Classical literature apparently al wost ignored children. The only instance Pattison could find of an affectionate scene betveen parents and 2 children vas that between Hector and his vife and son Astyanax. The reason for this neglect vas the prevalent attitude to children in early times. Greaks and Ronans considered then alwost as lover order aninals. Plato says of thea:

Of all the animals, the boy is the wost unmanageable; inasmuch as he has the fountain of reason in hic not regulated, he is an insidious and sharp-vitted animal and the nost insubordinate of then all.'3

His ideal Republic is an atteapt to correct this bestial condition.

Aristotle says: "Both children and the lover anials share in voluntary action, but not in choice, and acts done on the spur of the mosent ve 3

describe as voluntary, but not as chosen." Aristotle refers also in his

'sermon' on self-indulgence in adults, to childish appetite "children in

fact live at the beck and call of appetite... and as the child should live

1. Erik H.Erikson, Childhood and Societs, Penguin Books, London, 1950.

2. Robert Pattison The Child Figure in English Literature, University of Georgia Press, Athens, 1978, p.1.

3. Ibid, ,p.3.

3. Ibid.,p.2. 
according to the direction of his tutor, so the appetitive eleaent should 1

live according to rational principle."

To the classicist the child vas not iaportant because it vas unforaed, unreasonable, reflecting prinal chaos. Its char as vere rarely recorded in literature. Boas says "The only child in classical literature vho is presented to us at length, as far as I know, Ion in Euripides tragedy of 2

that name." Denocritus said that if children vere allowed to do as they pleased they would not learn music and letters or understand virtue. He even vent $50 \mathrm{far}$ as to recoanend adopting a child rather than begetting one 3 for then you could choose what you vanted. No doubt he vould have approved of sone of the latest aedical technology which gets nearer to ordering the type of child one vants. Socrates in the Lavs speaks of children as creatures vhose first sensations are pleasure or pain and this is how vice and virtue enter their soul for they are incapable of reason. He betoans the fact that some never develop beyond enjoying children's puppet shovs and conedies. Such complaints are still faniliar to us.

Boas reninds us hovever that it is ispossible from such $5 c$ ant infornation to state what "Greek opinion as a vhole vas on anything or even 4 if there vas a Greek or Ronan opinion as a uhole." He is surprised that one phrase uhich occurs in Cicero several tiaes did not receive more attention.

It was when he described beasts and children as SPECULA NATURAE, airrors

1. Ar istotle (384-322) Niconachean EthicsBook 3111btrans.by W.D.Ross.Great Books of the Nestern World, Chicago: William Benton, 1952, 0. 356 .

2. George Boas, The Cult of Childhood,London:The Marburg Institute, University of London, 1966, p.13.

3. Ibid, ,p.14,

4. Ibid.. 
or reflections of nature. But to Stoics and Epicureans alike they vere dark sirrors.

Education vas seen as a means to bring order to the chaos. Without education Plato thought they vould turn into the vildest creatures on earth. The child was important for his potential only. What vas really prized vas aaturity. The Stoics thought the age of reason was fourteen. Therefore no peculiar interest was shown in children or childhood or in personal biographical details such as for a large part of popular literature howadays. Modern interest in psychoanalysis has also helped to develop this genre.

Plato's contribution to education and the formation of a concept of childhood lay in his belief that the seeds of huad knovledge exist in every soul "the teacher's task is to help the soul in its oovement tovards the light, a aovement which is entirely natural ${ }^{2}$ and vill help the learner to discover the truth for hiaself. He recognized sone of the stages of grouth and developaent in children. He had little influence Castle thinks on the ordinary Greek citizen. They had no vievs on child care, They gave toys to infant children, employed nurses (often Spartans) for their care and limited fanily size by exposing infants at the father's discretion. Parents appeared to be reasonably tolerant and look upon childhood as a tive of vaiting. "The purpose behind Greek education was to wake good adults, particularly good aen, and they did not believe that infancy had auch to do vith the process."

1. George Boas, Ihe Cult of Childhood, London:The Harburg Institute, University of London, 1966, p.14.

2. Elizabeth Lavrence, The Origins and Grouth of Modern Education, Penguin Books, England, 1970, p.26.

3. E. B.Castle, Ancient Education and Ioday, Penguin, London, 1961, p.63. 
Aristotle realized the iaportance of faelings and the nead for their education, for, "a right disposition of the feelings seems to be the principle that leads to virtue rather than the reason." for the Greeks selfrealization and developaent fron vithin, vas the aeans and aic of education. It vas a process of evolution of the soul. The theory of INNATE IDEAS in the Phaedo aakes the infant the repository of IDEAS in their purest form, since the child coees directly fron that vorld of Ideas.

As Boas states, "though there are hints of the cult of childhood in classical antiquity, it does not seen to have had much popularity." Lywan found the same. Some vords of Juvenal suggested a tender nature tovard children "You ove the utmost reverence to a child" he said and also 3 spoke out against abortion and infanticide fron exposure, Killing of children by this aethod vas rampant and persisted for centuries. Girls particularly vere more likely to be the victios as vere illegitinate children. So-called Barbarians, says Lyman vere sonetios less brutal to children than the Rowans, but where there vas interest, concerns seemed adinly to centre around fertility, paternal power and education. He also perceives signs of sone positive contributions from the tovards a perception of childhood as a time of slov grouth, and enjoyment of children as an integral part of fanily life.

It vas Quintilian who said "boys cossonly show prosise of sany accomplishments, and when such pronise dies avay as they grov up this is

1. Elizabeth Laurence, The Origins and Grouth of Kodern Education, Penguin Books, England, 1970,p.31.

2. George Boas, The Cult of Childhood, London:The Warburg Institute, University of London, 1966, p.12.

3. Richard B.Lyman,Jr, 'Barbarisn and Religion:Late Rowan and Early Medieval Chidhood', inThe History of Childhood ed.de Mause, Souvenir Press, London, 1976, p.82. 
plainly due not to the failure of natural gifts but to lack of requisite

attention." He recognized the ioportance of the early years and the fact that a child should enjoy learning. For his reason he approved of learning through play, considered corporal punishnent undesirable and sav the need to cater for the individual learner and his level of abilities. He advised on the need for a good relationship betveen teacher and pupil and vas also avare of the needs of disadvantaged children. The soil aetaphors, as Carol Clark notes, are favourite metaphors of Quintilian uhich he uses sensitively and vith variety, it is later in the sixteenth century that she finds then 2

falling into rigid categories. Erasaus observed in 1512 that Quintilian had already told us all ve needed to knov about education. Frou this stage of thinking says Lyaan it is but a short step to the notion that each child has a soul to be saved. In spite of some signs favourable to children wuch ambivalence towards then carries over from the Pagan to the Christian era for "the conservation of old custoas and belief systeas is a poverful, tenacious and resourceful force."

To the early Rosans, says Laurence self-control, wodesty and obedience were wore important than intellectual achieveaent. "Children and youths learned by vatching and initating, at howe, on the farms, in the army and 5 in the forun." Under Greek influence this changed to the point where

1. Richard B.Lyoan,Jr., 'Barbarisa and Religion:Late Rosan and Early Medieval Childhood', inThe History of Childhood ed.de Mause, Souvenir Press, London, 1976, p.83.

2. Carol Clark, The Heb of Metaphor, French Forum Pubs.,1978.

3. Elizabeth Lavrence, The Origing and Grovth of Modern Education, Penguin Books, England, 1970, p.44.

4. Lyøan, p.84.

5. Lavrence, p. 35 . 
education becane overorganised and as Pattison notes the treataent of

children in Rosan schools in the first century of the enpire becane nechanistic, unreasoning, students given "assignments the modern vorld reserves for lunatics--repetitious measuring, counting and reciting." To produce eloquent orators vas the nev ideal, but the basis vas laid for the narrou curriculua of future schooling.

There vere people who spoke out in defence of children in every age. Plutarch said "Childhood is a tender thing and wost easily urought into any shape. The very spring and root of honesty lies in the felicity of lighting 2 on good education." In his treatise on the education of children he uses a faraing aetaphor for he sav education as a grouth process:

For lyke as in tillage fyrste it behoveth that the aoulde... be good. Secondarily that the husband or ploughan be experte in sovinge. Thirdely that the sede be clene and vothout faute, So (in bringinge up of youre children) ye shall applie and reseable to the moulde your childrens nature, to the ploughaan, their instructour or naister, to the sede, instruction of lernynge and precepts.... If a grounde fertile of nature be yll housbandried for lacke of good tillage it appereth foule and yl favored. 3

Moreover he believed that a child's aind is not "a vessel to be filled", but

"a fire to be kindled" and that "children of gentle nature take more 4 profite by praise or lyghte rebuke, than by stripes." He did not believe either in overtaxing children with work for they needed recreation also, one nust seek balance just as the Graeks had believed.

The Christian concept of original sin, according to Pattison reversed all of this. The child, says 8oas, becones a aicrocosa or metaphor of fallen an,

1. Robert Pattison, The Child Figure in Englich Literature, University of Georgia Press, Athens, 1978, p.2.

2. Elizabeth Laurence, The Oriqins and Grouth of Modern Education, Penguin Books, Engl and, 1970,p.39.

3. and 4.1bid., pp.40-41. 
wan dooued for everlasting hell. What ve can see developing alongside the nev consciousness of the nature of children is an inevitable concern vith wethods of education.

According to Laurence the Taloudic uriters also case to recognize children no longer as possessions but as personalities in their ovn right. Early education cane fros vithin the fanily and was ainly concerned with spiritual watters although fron the tiee of Ezra a book becase the centre of Jevish religion and necessitated the teaching of reading.

Sone spoke on behalf of the child, but now in the Christian era there is a notion of sin and shane revealed perhaps by an obsession in the writings, which Lywan notes; vith mothers, fathers, floving breasts, semen and birth pangs predoninating. Tertullian for example referred to "The man that is hardened in the voab of uncleanness and cones forth through the 1 parts of shase." Mothers vere expected, until quite recently to attend a church purification ceresony after giving birth and known ds 'churching'. Jerome praises satrinony because it produces virgins, but at the same tine this reduces the arried vosan to a lover status than a nun. The pinnacle of human desire has to be not human birth but a rebirth in the faith. There is also the aystery of the virgin birth for people to accept. Dne early figure stands out speaking favourably of the child--Pelagius, a Briton tho defended his faith in the innocence of children, vas opposed by Augustine, a proponent of original sin, vhose vievs becane doctrine and thus vas bred a nev and what Boas considers a perverted interest in childhood and children though this took aeons to fully develop. Quintillian spoke of children as "vessels vith narrow mouths, enpty creatures into whon the soul

1. Richard B.Lyman,Jr., 'Barbarism and Religion:Late Roman and Early Medieval Childhood', inThe History of Childhood ed.de Mause, Souvenit Press, London, 1976, p. 85. 
of granaar and oratory is to be poured once they break out of the shell of 1

childhood." This 'eapty vessel' metaphor persists to the present and has aore recently been dubbed the 'banking' aethod. A sore idealistic viev vas enshrined in the theory of innate ideas in Plato's Phaedo for there the child in essence has the potential for huan perfectibility, Pelagius eight hundred years later believed this too but the doctrine of original sin negated this:

In this inclusive, religious viev of the original nature of an, in which the accent has been shifted fron reason to vill as the primary object and vehicle of human aelioration, the child rose to a station of great iaportance. 2

Pelagius believed in the perfectability of man vithout God's grace, This vas of course heresy to the Church which propagated belief that even the infant bore the burden of Original sin. This vas to be expiated by baptise initially. All are considered sinners living in a perpetually flaved state to be absolved only by the redeaption.

Pattison researching the child in English Literature perceives this to be the wost sarked influence on attitudes to children since classical tianes. He says that "if a concept of Original sin did exist in the classical aind, it vas not poverful enough to stinulate the elaborate mechanisms of expiation which cone with the Christian notion of universal Fall and personal responsibility."

So far fron early tines ve have had the metaphor of the child as a rejected unvanted object to be killed, sacrificed or exposed, as an aninal or vild creature, but al 50 as a tender plant, as a vax tablet and an eapty

1. Robert Pattison, The Child Eigure in English Literature, Athens: University of Georgia Press,1978,p.2.

2. Ibid.,p.4.

3. Ibid.. 
vessel or as a fire to be kindled and childhood itself a shall to be broken out of. The sore positive ones are still current but all vere to be modified by Christianity fros which a nev aetaphor arises, the child as the 'fruit of sin'. The earlier aetaphors suggest sonething wild or subhuman which has to be relined and doaesticated like an aniasl, the religious one presupposes a tendency to evil which wust be curtailed. Both vievs are to give a strong basis to notions of correction, obedience and discipline as a necessary force to be applied to children. As a result, in both eras, corporal punishaent vas practised with justification in spite of the ninority who perceived it as less than hutan behaviour towards other albeit undevel oped husan beings.

To Christians the child seened a replica of Adan before the Fall, unspoiled by knouledge and civilisation. The problea of innate visdon versus acquired knouledge vas not nev. Boas says it was aooted by Theognis and Pindar that "If there is such a thing as congenital yisdoe and other virtues, then it ought to appear in childhood." 1 , and he akes a siailar conent to Pattison that in general the Ancients had a lov opinion of children if they appraised the at all. Their nature is described and their education discussed but no-one vishes to enulate then for they are in general irrational, disorderly, and according to Aristotle 'duarflike'. Cicero described children as 'specula naturae' but this idea vas never taken up even during the Renaissance or age of Enlightenaent. It vas Christianity which developed new ideas about children. One vonders what influence the concept of an infant saviour had on attitudes to children but the paradox of the vise child as saviour Boas downplays because he believes that an

1. George Boas, The Cult of Childhood, The Warburg Institute, University of London, 1966, p.11. 
incident such as the child Jesus preaching in the teaple refers to a particular precocious child and is described as such even in Milton's Paradise Regained. Oft-quoted references such as "suffer little children" Iikevise have no particular significance for: "The early Christian Fathers and ecclesiastical vriters ade little use of these New Testament verses which aight induce then into an adoration of the child as such. " There is one positive element in this earlier concept, that, in Pattison's vords "the chaotic state of childhood contains in it the possibility of human, rational perfection, and the attainment of this goal is entirely vithin the reach of 2 human effort." Fron nov on ve see an evergroving effort to educate children and perpetual controversy over whose responsibility it is, what its ains should be and the ways and means of providing this. This study vill show the church taking on auch of the responsibility at first and its control gradually being encroached upon by the state.

By the end of the Fourth century John Chrysoston in Antioch 388 advises parent5: "If good precepts are iapressed on the soul while it is yet tender no an vill be able to destroy the when they have set firm, 3

even as does a vaxen seal." He is reaarkably huane concerning discipline which he thinks should be by stern looks and reproachful vords or with gentleness and pronises, so that the child fears blows but does not receive then. Christian griters did not have the same distaste for children as earlier ones 5ays Pattison but it was soae time before they did urite about

1. George Boas, The Cult of Childhood, The Warburg Institute, University of London,1966, p.18.

2. Robert Pattison, The Child Figure in English Literaturere, Athens: University of Georgia Press, 1978,p.4.

3. Richard B.Lyman, Jr., 'Barbarist and Religion:Late Rowan and Early Medieval Childhood', inThe History of Childhood ed.de Mause, Souvenir Press, London, 1976, p.87. 
then. Augustine $(d, 430)$ was to have the greatest influence, he stressed that one's place in a fanily is physical but each of us belongs to a spiritual fanily far nore iaportant, for 'our real selves are not our 1

bodies." Nevertheless he advocates discontinuing some of the old childrearing practices based on custon--such as hitting innocent children. He considers children to have unreliable judgments for they vould value a pet's life above that of a ean but they are educable, and relatively guileless. Infant deaths vex his for all creatures have a place in God's plan:

In viev of the encompassing network of the Universe and the vhole creation--a network that is perfectly ordered in tiae and place, where not even one leaf of a tree is superfluous-it is not possible to create a superfluous wan. 2

Although it is not part of this study to exanine hunan treatment of animals one vonders how this aight parallel the attitudes to children and whether the Christian viev iaproved their lot as well as that of the human infant, to a certain extent. Distress caused to parents by the ailaents of their children Augustine sees as a ooral lesson for then to pursue wore virtuous lives-- it is a varning. One aight refer to this as the Christian 'artyr' metaphor. He sees that children are not truly innocent at birth for they are self-centred and grasping but have had no tine to sin. Church councils frequently inveigled against infanticide which was still endeaic. By 500 A.D. progress vas ade says Lynan but enpathy was still not part of the psychological equipaent of parents.

Pelagius' theory of the pefectible soul net Augustina's fir opposition. At the Council of Carthage in 416 ost of Augustine's thought

1. Richard B.Lyman,Jr., 'Barbarise and Religion:Late Roman and Early Medieval Childhood, inThe History of Childhood ed,de Mause, Souvenir Press, London, 1976, p.88.

2, Ibid., 
passed into Christian doctrine "aking infant baptisa a central feature of 1

doga opened a vhole neu role for the child," Now he/she was the centre of attention which had once been an object of neglect. The child is now a creature of vill, a sinner fros the aosent of conception. "This stress on corruption of the vill, even in childhood, renoved reason frow the supreae position it had held in the aainstreas of Greek and Ronan thought." As Pattison expresses it Autobiography and Driginal Sin enter the vorld together and the author of then both is Saint Augustine. Interestingly this doctrine gave us the beginnings of the child as a literary inage "He had ade the infant an adult of sorts" where Pelagius had argued for prinary innocence. The only concession was the notion of Liabo "a void spot for the innocent but unbaptised child."

$$
3
$$

These nev doctrines did not ioplant thenselves innediately, they took a long tive to be absorbed into general belief. As Lyman says "the influence of ideas on daily lives is informal, slow and hard to pin doun." "The evidence is found in the literature and art of each period as vell as in the scant gvidence ve have of household managesent and of the organisation of the provision of education for children. There is sone confusion caused by the fact that the ter a 'child' is used to refer to anyone depending on context and literary convention, from infancy to old age. But from now on the child eaerges as "a literary figure around vhon ideas of our original

1. Robert Pattison, The Child Figure in English Literature, Athens: University of Georgia Press, 1978,p.17.

2. Ibid.,p,19.

3. Ibid.,p.18.

4. Richard B.Lywan, Jr., 'Barbarisin and Religion:Late Ronan and Early Medieval Childhood', inThe History of Childhood ed.de Mause, Souvenir Press, London, 1976, p.76. 
nature, our fallen condition, and our hope for salvation cluster." This

view persists dovn to our own century. Arthur Adrian finds that discipline

of children vas especially stern in Dissenting and Evangelical fatilies of

the nineteenth century. Murdstone in David Cogegrfield refers to all

children for exaeple as "a swarn of little vipers". Discipline vas based

on belief in original sin. They vere, ${ }^{*}$ considered innately depraved, for 2

they had been conceived in sin." Sensitive children therefore suffered

guilt and shase.

Erikson aakes interesting comaents on the nature of shane which show

What effect it has on a developing child:

Shase....is essentially rage turned against the self. He vho is ashaeed vould like to force the vorld not to look at hin, not to notice his exposure. He vould like to destroy the eyes of the vorld. instead he must vish for his own invisibility. This potentiality is abundantly used in the educational mothod of 'shaning' used so exclusively by sone prinitive peoples. Visual shane precedes auditory guilt, which is a sense of badness to be had all by oneself when nobody vatches and when every thing is quiet--except the voice of the superego. Such shaming exploits an increasing sense of being small, which can develop only as the child stands up and as his awareness pernits his to note the relative neasures of size and pover. Too auch shaning does not lead to genuine propriety but to a secret deteraination to try to get avay vith things, unseen--if, indeed it does not result in defiant shaeelessness. 3

Parents of earlier tiues obviously had little idea of the psychological effects of their beliefs, attitudes and practices but by the seventeenth century and even later ve will see this shating anthod being used quite extensively in schools.

Poetry of earlier periods also has some references to children which

1. Robert Pattison, Ihe Child Figure in English Literature, Athens: University of Georgia Press,1978,p.20.

2. Arthur A.Adrian, Dickens and the Parent-Child relationshig, Ohio University press, $1984, p .2$.

3. Erik H.Erikson, Childhood and Societty, Penguin,London, 1950,p. 244. 
give a hint of concerns at the tine. 'The Rape of Proserpine' by Claudian vritten probably towards the end of the fourth century highlights the distress of a nother vho finds that her daughter who vas sent avay to be brought up elsevhere, has in fact been kept a prisoner. The nother's guilt says Lyaan probably found expression in wany of those who read it. Situations could be reversed hovever and he gives an exaaple of schoolboys who surdered their teacher vith their uriting instrueents. The story indicates he thinks the anount of repression and buried hostility in these children. Basic patterns becone established says Lywan. Infanticide, for instance, public consciousness is gradually turning against it. It still occurs as do abortions but they are disapproved of particularly by the church. Children are seen as needing 'strengthening' in order to be noral, those who shov any tendency to becose religious are idealized and parental love is by nov recognised as a normal thing.

Another record of child rearing practices is found in Einhard's Life of Charlenagne who was educated as a boy in a monastery. His oun sons vere brought up to ride, fight and hunt, buk girls vere taught household skills "rather than fritter ayay their tioe in sheer idleness." So beautiful vere his daughters and 50 protective of the was he that they never arried but did produce sone illegitiate children which he describes as "a nuaber of unfortunate experiences." A child's level of skill development vas probably the threshold thinks Lyean between childhood and adulthood.

One thing becomes patently clear, that throughout our history the attitude tovards children is a reflection of the society vithin which they live and is particularly influenced by the selfconcepts parents have.

1. Richard B.Lyman,Jr., 'Barbarism and Religion:Late Rowan and Early Medieval Childhood', inthe History of Childhood ed.de Mause, Souvenir Press, London, 1976, 9.95 . 
Aries studies the art of a pariod to see how it reflects the concept of the child and fanily fron the tenth century on particularly in france. Major influences appear to be the gregarious nature of fanily living which in a large household often couprised any people including relatives, servants, apprentices froe other fauilies and visitors including professional people tho in those days visited their clients. Recreational activities were shared by young and old in the house or at public festivities. The street vas the eeeting place for the large society. Work doninated life to a degree reflected in their art and definite notions of behaviour proper to each 'age' or part of the life cycle. Children vere vieved as niniature adults and subservient generally to the lord of the household. Education yas largely in the for of observation and participation in the seasonal or household activities unless in the more privileged instances there vas tutoring in susic, use of ares and dancing--the courtly arts which were prized as a sign of a gentlewan. The effect vas a paradox in that childhood vas not seen as special, children vere petted, played vith, given asusements but no-one took then seriously or gave then special attention. The death of an infant vas scarcely wourned vhen not unexpected and large fanilies wade up for the losses. Nursing vas often the duty of a surrogate nother or vet-nurse till the child vas veaned. Schooling as a foral institution was the prerogative only of clerics. The break fron childthood to sanhood came with the independence of starting vork or joining the aray in which any of the soldiers vere in their teens.

Aries segs the inception of organized schooling as the product aainly of a small group of influential pedagogues concerned vith protecting the innocence of childhood fron the coarse attitudes and anners of the

1. Philippe Aries, Centururies of Childhood, Penguin, London,1973. 
servant class particularly. Anong these influences vere the Jesuits and the founders of Port-Royal. The fashion of boarding sons out vith neighbours friends and relatives vas seen as barbarous by visitors from sone countries. The division between childhood and adulthood vas fairly abrupt, for vonen it usually caes vith arriage for which they had been trained in household duties and nanagement of servants all their young lives. The duties of the head of household raflected strong noral duties also for he was responsible for everyone vithin it.

Major influences cane fron the priaitive belief in the cycle or ages of san, a lack of avareness of child psychology or biological development, and church influence on morals and its attitude to arriage which vas seen as inferior to a vocation. The nature of the home itself varied froe extreaes of large, busy and productive households to inadequate hovels which barely sustained any notion, if they had one, of convivial conjugal fanily life. Society tended to be ade up of interdependencies, so individuality and private space vere not a consideration. Aabition vas esteemed a virtue and good manners vere the gloss on a successful life. Politics of course played their part but often sheer pressure of public usage established nev custon as in the case of the gradual extinction of the rule of prinogeniture. Those who advocated forsal institutionalised schooling began a sovement vhich Aries thinks they could hardly have anticipated. Its success vas immediate. No longer did children have to live avay fron home for long periods. Rich and poor aixed together in classes which vere too large and a curriculun developed which later becane divided between two types of school. This re-affirsed class status, for only the rich could afford the extended classical education. Others had to be content vith a more practical or technical curriculun which prepared then for the vorkplace.

Modern educationists such as Bovles and Gintis vith their reproduction 
theory would no doubt see this as a prine example of a pover group in society ensuring its oun survival through the education systea, by reproducing 1 its ovn kind in linited nuabers. So far fron establishing an egalitarian society with the passing of prinogeniture the country established a nev privileged social class group by reason of its education systea. Girls and younger sons did hovever benefit to sose degree. It is easy to see how the schools gradually took over any of the woral and socialising duties of the family. At the same time vith new interest in education the parents focussed sore attention on their children's health, hygiene and acadeaic progress, and discipline becane a ajor concern.

Aries observes that in the tenth century artists vere unable to depict a child except as a wan on a saaller scale. The mediaeval concept of the 'ages' of the cycle of life vas a scientific categorisation and one of the comonplace ways of understanding huan biology, in accord with the universal syste of correspondences (synbolisa, of numbers, patterns). The first age recognised is childhood to age seven, then pueritia till fourteen; the third adolescence at twenty-one, which can last to thirty-five. After follows youth to forty-five and then senectitude folloved by old age. By the fourteenth century this vas syabolised in wuch of the art, the first an age of toys, the second the age of school, the third the age of love of courtly and knightly sports, folloved by the ages of var and chivalry. The sedentary final age is depicted by aen of law, science and learning.

All ages vere typified by their social roles. He says that "It yill be noticed that since youth signifies the prine of life, there is no roon for adolescence" as ve know it for until the eighteenth century it

1. S. Bowles and H.Gintis, Schooling in Capitalist Aneriça, Routledge and Kegan Paul, London, 1976. 
vas confused vith childhood. In school Latin the vords puer and adolescens were interchangeable.

Mary McLaughlin, in her study of childhood in earlier Mestern 2 society explores the oore intinate vorld of feeling and relationship and says that when people say there vas no place for children in the aediaeval vorld they aean no specially designated place for children only, such as nurseries and schools, but they vere everywhere in society. She exanines records of the life of Peter Danian of the eleventh century who becane a leading spiritual reforner of his tine in Italy. He vas born into a large poor fanily to a wother worn vith child-bearing, whose elder son criticized her for bringing another child into the vorld. The nother's distraught reaction was to reject her baby. Fortunately a woman soved by conpassion for the child upbraided the aother to such effect that she thereafter lavished care and affection on this son. He was orphaned while still young and left to the untender aercies of the older brother and a harsh vife. After being a swineherd for some tise he eventually by age twelve vas vith another kinder brother who provided care, and gave hic an education vhich eventually led to his priesthood. So far his life airrors any of the comon probleas of his era as detailed by other uriters also. First the dejection of a wother in such circunstances often led to rejection, exposure, infanticide or 'accidental' death such as overlaying, that is where the infant saothers in the adult bed. To lose a parent very early vas comon bec ause of var, disease, plague or childbirth maladies. To be then sent to another fanily vas as comoon as it was to have one or aore step-

1. Philipe Aries, Centuries of Chidhood, Penguin Books, England,1973, p.23.

2. Mary Martin McLaughlin, 'Survivors and Surrogates: Children and Parents frou the Ninth to the Thirteenth Centuries', in The History of Childhood, ed.de Mause, Souvenir Press,London, 1976.p.101 
parents especially step-nothers. Mothers thensel ves were often very young. Half a century later Guibert of Nogent born to a noble family entered a monastery at age tuelve, but urote his oun story, a precedent for the tise. The ain these of this vork is a passionate attachent to his mother. At birth he vas not expected to survive. By eight wonths his father vas dead. Henceforth the nother expended all her care on this child. She vas a naturally religious even ascetic wouan tho resisted pressure to renarry and reaained a vidov, a state she preferred. She eaployed a strict tutor for the boy and he vas excluded from the company of other children. The tutor's excessive discipline of the boy distressed the mother but he refused the chance to become a knight and vished to be a clerk. He seens to have been extremely avare of what this unnatural life vas doing to hiv for he records that "uhile others of ay age vandered everywhere at vill and vere unchecked in the indulgence of such inclinations as were natural at their age, I hedged in by constant restraints and dressed in ay clerical garb, vould sit and look at the troops of players 1

like a beast avaiting sacrifice." This vas said in retrospect as an adult. One wonders if his father had been a knight to lose his life so soon and this ay have influenced the boy' choice.

It is typical of the tine to put so young a child into the service of the church. McLaughlin vonders if the nother's reclusive life style ade the boy feel rejected and guilty creating in him a jealously possessive and dependent child. It is probably truer to say that the yord 'sacrifice' which he hisself used was indicative of perhaps the nother's vish, by offering him to the church, to expunge her oun distaste for arriage--vho knovs--ye

1. Mary Martin McLaughlin, 'Survivors and Surrogates: Children and Parents fron the Ninth to the Thirteenth Centuries', in The History of Childhood, ed.de Mause, Souvenir Press,London, 1976.p.108 
cannot easily analyse historical figures in the light of nodern psychological thinking but his story does give a huan dieension to a child's history which vas probably fairly typical of one section of the society.

As Mc Laughlin says it is rarely parents vho speak of their role it is others vho coment on it. She says something which appears to contradict other vriters, that about the tvelfth century "For all classes the nother Who nursed her ovn children reflected the iage of the ideal waternal 1

iage." Bartholonev of England praised natural feeding for the bond it produced betveen the aother and infant but the practice of vet-nursing still multiplied. There alvays seem to have been a ainority of vonen who fed their oun children but fron aost authors one gets the iapression that it vas sore often among the poor and then it vas done from necessity rather than fron choice, Fron the Tvelfth century on McLaughlin notes a nav tenderness and concern for babies. This is seen in the exhortations not to take children into parental beds and by this time infanticide vas a criee. The father's role she describes as anbiguous for in a military and expansionist society he vas often avay from hoae and rarely do ve get a father and son relationship portrayed syapathetically. The practice of 'oblation', of sending sons into monasteries she sees as one vay of providing lor one of the fanily, which vould be a consideration when the estate had to go to one son. Another stress factor of such life for young people vas the constant supervision and discipline, Guibert refers to the "omipresence 2 of the Devil and his ainions, the lurid visions and nightaares' which he experienced.

1. Mary Martin McLaughlin, 'Survivors and Surrogates: Children and Parents fron the Ninth to the Thirteenth Centuries', in Ihe History of Childhood, ed.de Mause, Souvenir Press, London, 1976. p.115.

2. Ibid.,p.128. 
One consolation for boys of poorer lanilies was that even if they worked hard they vere less likely to be separated fron their parents. Not all vera tyrannical towards children. Ansel was certain that continual beating vas unnecessary for it ade the in turn suspicious and jealous and he urged his superiors to feel some enpathy for children. Ailred of Riveaulx vas understanding and considerate. A nev piety and devotion to veneration of Mary and her Son also engendered a nood of emotional tenderness. Signs of this can be seen in painting, sculpture and in liturgy and drana:

The dramatic enacteent of the gospel story in art and liturgy, vas in fact, anong the novel experiences of the the late eleventh and tvelfth centuries, and here a groving stress on the Infancy of Christ and especially on the Nativity and the Adoration of the Magi, gave the inages of Mother and Child a wuch greater proninence and often an appealing huaanity. 1

As time vent on the 'poses' of the Madonna became more affectionate and there was a nev isage of naternal tenderness expressed in vorks such as the Massacre of the Innocents. Gospel stories being told in the vernacular must also have had some influence. Poetry also often has separation of sons from athers as its theae and the nothers becone idealized distant persons.

It appeared to Aries, judging by its art, that there vas no place for childhood in the Mediaeval vorld. Pictures of children when they do appear are simply ainiature adults. Not until the thirteenth century do they appear more realistic to our eyes and "the touching idea of childhood remained linited to the Infant Jesus until the fourteenth century, when... Italian art vas to help spread and develop it." Gradually other children

1. Mary Martin McLaughlin, 'Survivors and Surrogates: Children and Parents from the Ninth to the Thirteenth Centuries', in The History of Childhood, ed.de Mause, Souvenir Press, London, 1976. p. 133.

2. Philippe Aries, Centuries of childhogd, Penguin Books, London, 1973, p.33. 
vere added to holy pictures and later by the fifteenth and sixteenth centuries children vere frequently included in paintings.

Ross believes that the children in sany paintings are idealized inages rather than real. He finds it difficult to explain the apparent obsession vith children in Florentine art. The children portrayed are vell-fed, naked and happy, the antithesis of reality where a baby vas svaddled and put in the care of a vet-nurse or balia. He believes such paintings say represent a secular fantasy of unknoun naternal intisacy, perhaps to blot out painful childhood aenories, and that:

Pictorial recognition of the sall child as a distinct individual easerges in the fifteenth and sixteenth centuries and reaches its culaination in the work of Titian in the 1540's, nost notably in the portrait of a little girl, age tvo, full length, alone except for her dog. ("Clarice Strozzi", Berlin State auseun) 1

In Italy aerchant fathers vere often avay from home for periods up to several years. Sonetians vills specified that a vidow should not readry; this was to preserve the inheritance for the children. Advice from one Doainican Giovanni Doninici vas for mothers not to pet or eabrace their sons between the ages of three and tventy-five and in this period they should be separated from the girls and become used to harsh conditions. Boy babies yere more velcome than girls because of doury probleas. Parents are varned to keep girls busy and avay fron doors and vindows vhere they wight be seen acting frivolously,

There is no doubt that some parents enjoyed their children and dressed the up. If fathers vere not alyays present they vere troubled by their children's illnesses. Italian physicians vere pioneers in uriting about the diseases of children, nost of their information hovever case froa

1. Janes Bruce Ross, 'The Middle-Class Child in Urban Italy, Fourteenth to Early Sixteenth Century', inThe History of Childhood, ed. de Mause, Souvenir Press, London, 1976, p. 224. 
classical treatises rather than clinical observation. PIague vas a real threat and one froe which only the rich could afford to flee. In the fourteenth century a father vas considered responsible for his son's education, if this vas not possible he eaployed a tutor. Hiddle class children at about seven entered 'conaune' or comeon schools which vere vieved as dens of iniquity by Dowinici who reconnended small bribes and inducenents to encourage children to learn. The norsal stages of learning for a verchant's son were, learning reading and accounting, and apprenticeship in a bank or shop. Teachers and tutors vere changed as often as the balia which the children had been subjected to earlier.

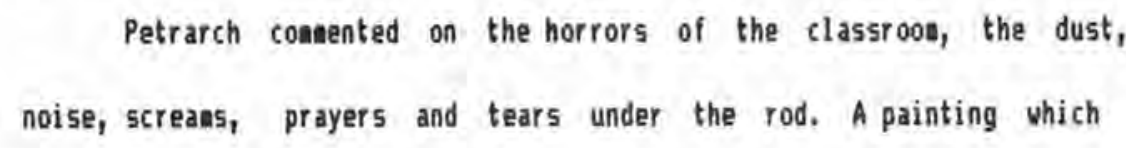

At the left stand the parents, the sad-eyed Monica lightly resting her left hand on the boy's head, the stern father raising his hands as if to project the child into the eager hands of the black-clad aster vho is about to seize the boy by the neck. The child whose head is thus betveen three sets of hands stands proudly, aras crossed, but fixes an uneasy eye, not on the naster but on one of the big boys to the right, who holds a saall bare-backed boy on his oun back to receive the blows of a rod held aloft by another aster, accompanied by a good little boy reading a book. Within the arcaded, crowded schoolrooe in the background, confusion reigns; sone little faces look out curiously at the nevcomer. 1

As Ross says all the elenents of the schoolroon are depicted here vith special emphasis on the rod which would be approved of by the traditiinal moralists but challenged by humanist educators. One such vas Guarino of Verona (1435-1460) who thought it inflicted aral and intellectual injury.

1. James Bruce Ross, 'The Middle-Class Child in Urban Italy, Fourteenth to Early Sixteenth Century', inThe History of Childhood, ed. de Mause, Souvenir Press, London, 1976, p. 224. 
There were sose parents such as Paulo of Certaldo vho also sav the value of gentle and cautious correction.

A child's life vas arked by severe physical and emotional adjustments, separated from his mother to be nursed by a stranger, returning hoes to be reestablished vith his fasily, at seven being thrust into the classroon, and eventually the shop. For a girl the choice was a nunnery or arriage. All this coobined vith risks of natural disastars or a loss of a parent and reaarriage. One positive refora is in the Indictment of infanticide though the punishaent is horrific. An exauple is pecorded of one francesca of Pistoria, found guilty of infanticide, who vas "led through the steets vith her dead child tied to her neck and burned to 1 death" in 1407. Ross is bemused by the paradox that the comparatively neglected infants of these tiaes developed the vigour and creativity to herald the Renaissance. We ay understand this better he believes by using the aethods of inquiry of psychology and psychoanalysis.

By the thirteenth century there are increasing nuabers of didactic works displaying sone sense of the different stages of child developaent and needs. They are popular and there is a growing number of people able to read thes. One of the earliest and nost influential yas by Bartholoaev of England which conveys "a nov more articulate sense of early childhood as 2

a carefree and playful stage of life." Such ideas vere beginning to gain hold in learned circles. Philip of Navare as one such reconmended affection towards children but with restraint. He still believed in beating

1. James Bruce Ros5, 'The Middle-Class Child in Urban Italy, Fourteenth to Early Sixteenth Century', in The History of Childhood, ed. de Mause, Souvenir Press, London, 1976, p. 220.

2. Mary Martin McLaughlin, 'Survivors and Surrogates: Children and Parents froa the Ninth to the Thirteenth Centuries', in The History of Childhood, ed.de Mause, Souvenir Press, London, 1976. p. 136. 
and imprisonaent for boys who aust be prepared for the noble profession of 'clergie' or 'chevalrie'. As for girls:

...they vere to be indoctrinated frou the beginning in the one virtue that vas sufficient for thea, obedience; for the Lord vished vonen to renain alvays in subjection,1

Only those who vere to be nuns neaded to learn how to read and vrite and careful custody of a girl's chastity vas to be the priae concern of parents, an idea nost of his conteaporaries shared.

The first work of vernacular literature in which a child is the 2 central figure throughout is Hartaann von Aue's Der arae Heinrich. This book gives the inpression that the children of prosperous parents vere treated sore indulgently and gently than the children of noble birth and such works says McLaughlin lead us to the inage of the evolving conjugal family. Bad child rearing practices still exist and opposition to then is groving over tiae, but "The idea of the child as the possession and property of its parents continued to doninate parental attitudes and actions in 3 these, as in earlier and later centuries." She suns up her oun findings:

Tenderness, coapassion, the capacity to coaprehend the needs and emotions of others; these are fragile and late-naturing plants of feeling and they flovered slovly in the hard and sometioes violent lives of parents vho vere thenselves often literally as vell as enotionally, little more than children. 4

Other yriters confirn that girls often ved at twelve and boys at fourteen. One cannot help thinking of Shakespeare's Roaeo and Juliet as typifying any of these findings. The fact that Juliet is fourteen, the only surviving child of her parents, doninated by a tyrannical father and neglected by a

1. Mary Martin McLaughlin, 'Survivors and Surrogates: Children and Parents from the Ninth to the Thirteenth Centuries', in The History of Childhood, ed, de Mause, Souvenir Press, London, 1976. p. 137.

2. Ibid., p.139.

3. and 4. Ibid.,p.140. 
wother submissive to his, she turns for help to the nurse who mothered her as an infant, and tho sentions using voravood to vean the child. Her father threatens that she vill "hang, beg, starve, die in the streets" if she dares to disobey hin.

In France especially among the nobility marriage vas at a very young age and a bride of twenty vas considered undesirable. At the start of the eighteenth century the legal pover of a father over his household vas virtually absolute, Literally pover over life or death "A 1611 reviev of the criainal code enumerates the conditions under which a father has the right to kill an adult son or daughter."

In the fourteenth century Chaucer used a child, the young aartyr, as a veapon against the sentiantality of the prioress but it vas the Pearl poet who invested the infant vith its full Augustan soleanity to give English literature its first true child figure, according to Pattison. One of the functions of the poen is to correct the Pelagian complaint sade by the dreaner of the poea. The young girl in the poen sho died in infancy, is at once a child, a pearl and a maiden, three aspects of one phenomenon, an innocence possible to all Christians. The dreaner strives touards this state of 'adult' perfection achieved by the child. ${ }^{3}$ The preaiss of Pattison's vork is that children are figurative, at least as they appear over the the past three hundred years. Readers are teapted to believe in the child figure "The fact that the child is not regarded as a figure gives

1. Willian Shakespeare, Romege and Juli ett, Act III Scene V Line 194.

2. Elizabeth Wirth Marvick, 'Nature Versus nurture:Patterns and trands in Seventeenth-Century French Child-Rearing', in The History of Childhood, de Mause ed. ,Souvenir press, London, 1976, p282.

3. Robert Pattison, The Child Figure in English Literatarere, University of Georgia Press Athens, 1978, p.22. 
it added potency, for the truth is that this particular depiction of reality is relativaly new to English literature." The Ancient world vas little interested in the child as ve have seen. It first becomes prominent

in the early church's debate over original Sin, and:

...religious doctrine requires a substantial incubation period before it can translate itself into syabolisa and inagery.... a thousand years vere required before this idea vas felt as part of the unconscious view of lifa fron which literature dravs its figures and syabols." 2

So ve observe the gradual evolution of the child figure as it begins to eabody certain thenes such as the question of free vill, innocence and the means of salvation, which says Pattison had previously been expressed aythically, allegorically, and through other conventional inagery.

Gradually by the sixteenth century says Aries the iconography included significantly the farily as a subject and one which became increasingly popular. Even the calendars depicted the oonths and ages of aen as fanily aeabers. Most of the iconography of the Middle Ages depicted the outdoors or public places. Before the fifteenth century interior scenes are rare. But nov pictures becone not only ornaments for public or sacred places but more frequently for hooes too and fanily portraits become popular. In wany of these never paintings the action is centred on a child, in the cradle, at the breast, even having head lice removed. Aries believes that the concept of the fanily, which vas unknown in the Middle Ages eaerges in the sixteenth and seventeenth centuries, and is inseparable from the concept of childhood.

A child's nature vas considered to cone fron his basic constitution (complexion), any one of four types--aqueous, aelancholic, choleric or

1. Robert Pattison, The Child Figure in English Litgrature, University of Georgia Press Athens, 1978,p. 44.

2. Ibid.,p.45. 
sanguine. Heroard the Dauphin's physician for instance pronounced hin to be basically sanguine but on the choleric side. He left us intioate detailed records of his saall charge but aainly the practices are "governed 1 by unuritten tradition" which is why it is difficult for us to know precisely what vent on. Fron bitth to age six or seven the child's vorld vas one of face-to-face contacts and the spoken vord. Aries way see attention to children in plastic art says Marvick but 'The classical Renaissance in French iaginative literature ignored the infant and sall child." Conson to all French vieus of infancy she finds that the survival in the first fev months depended absolutely on the foreation of a satisfactory nursing relationship with a voan "the nursing relationship vas seen as wore profoundly influential on the developng nature of the child than the 3 pre-natal experience." To suppress the wilk vas equivalent to abortion. Doctor's believed that mother's milk vas enstrual blood diverted, and that with this ailk a child absorbed the nurse's characteristics. Children tho failed to thrive vere sometines considered to have been conceived from inseaination by the devil. Children often developed a close and loving relationship with their nurse rather than their nother. A good nurse therefore became 'a jevel beyond price'.

Suaddling vas still practised ostensibly to encourage good posture and Parisian children had their heads bound to such an extent that their shape becane recognizable. The use of enemas and purgatives vas videspread and children vere held down to have then forced upon thea. The seventeenth

1. Elizabeth Wirth Marvick, 'Nature Versus nurture:Patterns and trends in Seventeenth-Century French Child-Rearing', in The History of Childhood, de Mause ed., Souvenir press, London, 1976, p260.

2. Ibid.,p.261.

3. Ibid.,p.264. 
century vas unavare says Marvick, of stages of natural development. To encourage valking 'leading strings' vere attached to clothes for children, and 'valking' stools vere in comon use as vell as cane baskets to keep babies upright, These helped to keep then off the floor, which was often earthen, but did not prevent persistent skin complaints fron which even aristocratic babies suffered. Washing vas not considered good nor vas soap on the Continent, but in England, vater, often icy cold vas considered heal thy and bracing. Children tended also to be overdressed. Robertson says that Geruan babies vere also suaddled to six wonths of age and only changed 1

twice a day. In Russia the practice vas to swaddle for nine wonths and persisted to the tventieth century:

While the custo of svaddling newborn infants is videspread, the ancient Russian extrene insists that the the baby be svaddled up to the neck, tightly enough to aake a handy ' $\log$ of wood' out of the whole bundle, and that suaddling be continued for nine aonths, for the greater part of the day and throughout the night. Such procedure does not result in any lasting loconotor deficiency, although the svaddled infant apparently has to be taught to cravl.2

What interests Erikson is whether this has psychological effects on the child and he believes it is a symptom of the inage of the whole culture, and aay partly account for the nature of characters in Russian literature. Dunn's study of Russian childhood found that in the eighteenth century it vas an ordeal, a precarious existence. Only about half survived to adulthood because of poor diet, clinate, inadequate medical care and tradition as conpared to Norvay vith only one third loss in sinilar cliatic conditions.

Parents in Russia considered children and childrearing uniepertant;

1. Priscilla Robertson, 'Hose as a nest: Middle Class Chidhood in Nineteenth Century Europe', in The History of Childhood, ed.de Mause, Souvenir press, London, 1976.

2. Erik H.Erikson, Childhood and societety, Penguin, London, 1950, p. 378. 
children had to be cared for, but underlying that care vas parental neglect, even hostility towards the children. The convenience of the parents had priority over the vellbeing of the child.l

No-one hither to has spelled out the basis of child neglect as being parental sel fishness before. This aust be an iaportant factor especially to explain the abandonment of babies through the centuries and the practice of faraing children out for nursing particularly. We know little about the relationship for instance between husbands and vives and whether they felt that a child interfered vith their work or their lifestyle. Were husbands jealous of children and vere parents as sone vriters seen to suggest rather infantile theaselves in their needs and expectations. These are areas of history ve can only guess at. Lack of understanding of child needs and the harsh times people existed in are problems ve can have sone idea of but how wuch people vere influenced in their attitude by such things as inability to plan children and personal inadequacies we do not knov. We have svung as Boas says to a cult of the child in which it is sentimentalized and conercially exploited but the reality is that a nevborn child requires a comaitment to its care for nearly quarter of a century and at inevitable cost both financial and enotional to the parents. A realistic viev of childhood cannot ignore these factors.

Once the seventeenth century Franch child vas veaned it vas considered eligible for corporal punishment. The traditional aethod vas for one child to bear the other on its back. Henry IV reconaended whippings for his son and adninistered 50me hisself, His vife disapproved and believed that it betrayed failure of those in charge. A leading educator Jeanne Freyot said that children could respond to kindness just as vell as to harshness.

1. Patrick P.Dunn, "That Eneay is the Baby": Childhood in Iaperial Russia', inThe History of childhood, ed.de Mause, Souvenir Press, London, $1976,0.385$. 
"Manipulation rather than doaination vas the key to a nevly popular strategy: aore flies could be caught vith honey than vith vinegar." fear of bogeymen vas still used and of castration. Shane is appealed to in order to get coupliance. Even at Port Royal a girls' convent school the 'lazy', the 'negligent' or the 'liar' aight have to vear labels designating then as such. The dia vas to substitute inner aotivation for good behaviour as soon as possible. Religious asceticisa vas enjoying a revival and had its influence "The nev tactics vere designed to heighten guilt $r$ ather than 2

induce shane." In schools such as Port Royal every activity was designed to encourage this and children vere vatched over at all tiees. Jacqueline Pascal adnitted that it was easier to control such a regine in her institution than it would be vith an individual at hose.

Before the Catholic refor aovement the old style of frightening children vas vith fear of the devil, hellfire and possession, which haunted then. 'In contrast vith this itagery of extreae dangers, the 'nev style' of fantasy shoved the effects of an ain to refor conscience and character HITHIN the child rather than to achieve mere foral compliance vith adult deaands...the nev aodel vas the invard-looking self-abnegating an or voaan. Aggression vas to be turned against the self." Everything vas to be offered up for God's greater glory even forbidden desires and incestuous vishes. Dedication to Christ as in beconing a nun is the 'ideal' for a woman,

Marvick reainds us that children still vitnessed brutal aniaal

1. Elizabeth Wirth Marvick, 'Nature Versus nurture:Patterns and trends in Seventeenth-Century French Child-Rearing', in The History of Childhood, de Mause ed., Souvenir press, London, 1976, 277.

2. Ibid.,p. 278 .

3. Ibid., p. 279 . 
killings and public executions which probably also haunted their minds. The religious revival preached the virtues of a large fanily and advised that one should not vish only for sons. Bourdaloue a popular preacher at the end of the century admonished parents vho dragged their daughters off to convents "feet and hands tiad, not daring to coaplain for fear of unleashing the rage of her father and the obstinacy of the nother." The vorld cared little about the souls of fewales said one reforn leader. Orphanages which had been for boys only now acconnodated girls also. The fate of discarded children vas often ghastly, and they vere sometines sold or adined in order to beg alas. Vincent de Paul vorked to save such children. Maternal affection tovards children was not taken for granted says Marvick. The nother's role vas prescribed as was the father's. When a mother died another was quickly put in her place.

The seventeenth century in France vas one of reasonable stability. Aries thought the high infant death rate oade tenderness towards them taboo says Marvick tho beliaves it vas werely suppressed. When children did survive some of the rituals associated vere propitiatory acts such as proaising to offer the child to the church. Ssynbolic of earlier blood sacrifices?] Sone catholic reformers protested at too much saternal tenderness, even affection they thought should be diverted to Divine service,

It could be suggested that PROPITIATION was the traditional sode of coping vith anxieties and longings that concerned children; subliation vas required by the nev morality. But in neither case was there a denial of the tender feelings felt for children in spite of the cultural overlay that half-disguised thes. $292 \mathrm{M}$

Marvick believes that parental sentiaents are universal and increase once a

1. Elizabeth Wirth Marvick, 'Nature Versus nurture:Patterns and trends in Seventeenth-Century french Child-Rearing', in The History of Childhood, de Mause ed., Souvenir press, London, 1976, p285.

2. Ibid, ,p.292. 
bond is forged by the child's developaent even when it aay appear lacking at birth.

Illick finds evidence of wuch the sane attitude to children in seventeenth century Engl and and America. In England life expectancy declined and the fertility rate, perhaps due to contraception. The aidvife had been ecclesiastically licensed since the sixteenth century and physicians still did not attend births. "She engendered both respect and fear, as did the 1 act of childbirth over which she presided." The first treatise on childhood diseases vas Thonas Phaer's Boke of Childreng. He reconended that nothers nourish their babies and also looked on vet-nursing practices as tantanount to abortion. Some even called it a for of infanticide. Lavs concerning bastardy usually shoved no concern for the child involved excepting the Act of 1623 "to prevent the Murthering of Bastard Children" but it was not alvays executed.

Teething vas alvays a vorrying time for children and parents and Robert Pesell physician first suggested the lancing of guas. It has been claimed says Illick that the middle period of the century vitnessed the avakening of medicine froe its sleep of nearly two thousand years. Generally speaking "It seens probable that the child care manuals were reaching oore people in the late seventeenth century, and that children vere receiving 2 more attention." An earlier fascination vith magic still persisted but a concern vith religion could be noted as also a nev analytical spirit. Lady Warvick for example on the loss of her father and two children is said to have tried not to grieve too auch for she felt "sone invard persuasion that

1. Joseph E.Illick, 'Child-Rearing in Seventeenth-Century England and America', in Ihe History of Childhood, ed. de Mause, Souvenir press, London, 1976, p. 306.

2. Ibid.,p.313. 
God vould, in sose yay or other, punish ae for ay doing so." Resignation to the vill of God vas paranount and girls vere taught to subliate anger of aggression through religion, thus "repression and religion vere complimentary."

Education was seen by the sore puritanical as sainly necessary to protect a child against his ovn self destruction ( auch like the arguaents for swaddling]. "The attitude to be fostered in a child vould have to be one of constantly questioning hisself, aking hisself feel inadequate, 3

engendering self-doubt." others considered the child to be totally innocent. This vas the viey of John Earle (1628): "A child is a an in a sadll letter, yet the best copy of adan before he tasted of Eve or the apple.,.,His soul is yet a uhite paper unscribbled vith the observations of 4 the vorld...he knovs no evil." The tabula rasa eetapher once nore. Education would fight the vorld's corrupt influences. It vas religion which taught a child about his ovn nortality and there vas in the seventeenth century says Illick a child's literature which energed concerned vith iapending death. Jane Janevay's A Ioken for Children (1671) vas full of stories of children converted just before death, and adeonishing parents not to grieve but to rejoice in their deaths.

The aristocratic ideal of the Seventeenth century vas soderation which hinged on self-control. John Locke is a syabol of this and he believed that "little or aluost insensible iapressions of our tender infancies, have very iaportant or lasting consequences." He stood betveen the two poles of infant innocence and depravity. He is one of the first to

1. and 2. Joseph E.Illick, 'Child-Rearing in Seventeenth-Century Engl and and Anerica', in The History of Childhood, ed. de Hause, Souvenit press, London, 1976, p.315.

3. and 4. Ibid.,p.317.

5. Ibid., p.318. 
aention boilet training and is against corporal punishaent "The rod should be avoided as vell as revards. Shame should be the instrument used to ootivate children." But he did appreciate the iaportance of play and of dancing and "took an honest (and refreshingly realistic) viey of educational approaches to children." ${ }^{2}$ He recoanended that early reading be entertaining, as in Aesop's fables, and comaended learning the Lord's prayer, Creed and Ten Conandenents--also learning of a foreign language. Surprisingly he considered the benefit of studying granat as of negligible use, a lact still not recognized generally. He believed each parent should ake his ovn decisions on child-rearing.

Encouragement for education cane fron several sources, those tho vished to initate the gentry--humanists who sav schooling as the road to a universal ioprovesent which vould eliainate the need for special protection of the innocent-and puritans vho vieved ignorance as the root of all evil. One can perceive as Illick does that a separate vorld for children was gradually energing and is reflected in the art, costune, leisure activities and literature of the period. Parents vere tending to keep children howe longer by the aiddle of the century. Gramoar schools now proliferated in England--only two counties did not have one. Parents ady have had wany reasons for sending children to school says IIlick. One way have been to keep then avay fron the servants or out of the vay of stepparents for they vere not uncosmon. One vonders if this is the reason for their preponderance in children's literature.

The typical seventeenth century father vas apt to be secularist

1. Joseph E.Illick, 'Child-Rearing in Seventeenth-Century England and America', in The History of Childhood, ed, de Mause, Souvenir press, London, 1976, p.319.

2. Ibid, , p. 320 . 
while his vife vas inclined to religiosity and inculcated these values in her children. The Iatter say have been a syapton of oppression rather than a question of free-thinking. Discipline in the schools vas harsh and the regianen folloved strict principles in keeping with its aissionary spirit.

God having ordained schools of learning to be a principall aeans to reduce a barbarous people to civilite..." and Christianity. The challenge vas to gain "the verie savage anongst thea unto Jesus Christ, whether Irish or Indian..." or Brinsley wight have added 'child'.1

Apprentices vere equally beleagured by rules and prohibitions against "dance dice cards mun or any ausick" anongst other things such as extravagant dress and long hair. They could also be fined or inprisoned for "toying vith the adids, teaching children bavdy words" or even vearing 2

"a foul shirt on Sunday." Autonomous developeent vas not considered or allowed for. As Erikson says this sense of autonony is vital to the preservation in econonic and political life of a sense of justice.

Those tho enigrated to America often felt like children leaving a wother. The novelty of their situation says Illick vas even revealed in the names they gave their children such as Oceanus, Mercy, Reform etc. At one time in history siblings often shared the same name but as tiae goes on one's nane becomes aore ioportant and distinctive. In the nev country even the practic of taking one's parent's forenane declined. There is no evidence of children being svaddled and they appear to have been breastfed. John Cotton (1646) taught his charges to recite "I vas conceived in sin and born in iniquity...Adam's sin ieputed to me and a corrupt nature dvells in me." So even in the nev country the same beliefs in inherent

1. and 2. Joseph E.Illick, 'Child-Rearing in Seventeenth-Century England and Aaerica', in The History of Childhood, ed. de Mause, Souvenir press, London, 1976, p.323.

2. Erik H.Erikson, Childhood and Societey, Penguin, 1950, p. 246. 
evil and propensity to vickedness vere carried vith then over the seas. We can judge the affection felt for the young hovever by the considerable tiae and care devoted to making christening gouns, coverlets, children's furniture and so forth. Infanticide was the fate of bastards only. Parents vere still exhorted to oppose self-assertion or vilfulness in their children so that "The child vould doubt his oun abilities, repress his strivings and 1 look to a higher authority", initially the parent. In sose places it vas a criae for a child of more than sixteen to strike his parent. The rod was still applied unless other weans vere used such as emotional blackmail which Cotton used, telling his daughter he was about to die and therefore she must not dishonour his. Most education took place in the hone and at six children began to dress as adults. Practices in the United States more nearly atched the ideas of John Locke says Illick. Parents were being led avay from the concept of 'calling' as a suanons to the priesthood ---the never nethod was "the use of the gifts of God", which neant sublimation of sexuality and a caring concern for cosounity through one's vork and relations in the fasily. These seen like rather convenient and practical precepts for beginners in a new country.

A historial change in attitudes to primogeniture in Europe had also had far-reaching effects on the developaent of the farily as a social unit and on attitudes to children other than firstborn sons. Historians distinguish say Aries between the blood line for a single ancestor and the faaily or mesnie with all its relatives and with a tendency to joint possessions, which gave rise to nineteenth century theories on the patriarchal fanily: "The modern conjugal fagily is thus considered to be the consequence of an

1. Joseph E.Illick, 'Child-Rearing in Seventeenth-Century England and Aner ica', in The History of Chidhood, ed. de Mause, Souvenir press, London, 1976, p.327. 
evolution which, at the end of the Middle Ages, is supposed to have veakened the line and the tendency to joint possession. Aries offers Duby's findings that lineal solidarity and joint possession developed as a result of the dissolution of the State uhich led to the knights, after the year 1000, seeking refuge in lineal solidarity. In the tenth century a husband and vife anaged their ovn property. By the eleventh and tuelfth joint ounership vas established protecting lineal right over an estate. The village conmunity becane to the peasant what the blood line vas to the nobles a source of strong support and shared possessions. By the thirteenth century because of political and econonic changes joint ounership tended to be abandoned but the father still retained the authority he had established over the joint estate. In the thirteenth century the lav of prinogeniture spread anong the fanilies of the nobility in the Macon country.

The substitution of the lav of prinogeniture for joint ounership and the joint estate of husband and vife can be seen as a sign of the recognition of the iaportance of paternal authority and of the place assuned in everyday life by the group of the father and children.2

The blood line alvays aroused wore feeling says Aries and this no doubt explains its pre-eminence in literary theaes: "In the donain of feeling, the farily did not count as wuch as the line. One aight say that the concept of the line vas the only concept of a faaily character known to the 3

Hiddle Ages." The vife's position slowly eroded until the "husband is finally established as a sort of donestic nonarch." Thus a value vas attributed eventually to the fanily which had previously gone to the blood line.

1. Philippe Aries, Centurieses of Childhood , Penguin,London, 1973, p.341.

2. and 3. Ibid., p.343,

4. Ibid.,p.344. 
The attitude of the church did not glorify aarriage, it vas a legitinate contract but also a concession to the veakness of the flesh. It was not until the end of the sixteenth century that "the church recognized the possibility of sanctification outside the religious vocation, in the practice of one's profession." One sign of a new development vas the donating of stained glass vindous portraying faailiss, to the shurch. Sometioes in the sixteenth century a patron saint is included with the fanily and "the cult of the patron saint becomes a fasily cult.' Meddings had previously been portrayed as taking place outside the church, now the ceremony moves to the interior. The great collective festivals also give vay to more intinate scenes of fanily celebrations such as Christuas vith its emphasis on gifts to children. Stein's picture of the feast of Saint Nicholas shows "the same nodern feeling for childhood and the fasily, for childhood in the fanily" that ve experience in Nestern countries nov.

The saying of grace at the end of meals becomes the task of the youngest child as described in sanuals of etiquette in the sixteenth century, another indication of growing focus on the child, "Grace had becone the nodel for the fanily prayer." Artists liked to portray such scenes because they evoke three enotional forces, piety, the concept of childhood and the concept of the fanily. The Holy Fanily vas considered a model and was portrayed frequently, an obvious link vith the concepts of childhood and fanily. The fanily alvays existed in the Middle Ages but never aroused such sentiaent to inspire artists for it held little value. Erasaus held the codern idea that children unite a fanily and one of the reasons is

1. Philippe Aries, Centuries of Chil dhood, Penguin,London, 1973, p. 345.

2. and 3. Ibid.,p,347.

4. Ibid., p.349 
the habit of looking for faaily likenesses. "What counted nost of all vas the enotion aroused by the child, the living iage of his parents."

An Italian writing in the fifteenth century criticized the English for putting their sons out to sarvice in other people's howes at age seven: The alleged aie was to enrich their anners: "It vas by means of domestic service that the aster transaitted to a child, and not his child but another an's, the knowledge, practical experience, and husan worth which he was supposed to possess." Parents often complain nowadays that children are prone to listen to anyone's advice but that of their ovn parents, 50 perhaps our forefathers understood nore of child psychology than ve give the credit for, As Aries notes sany tises in his study children's education really cane fron participating in adult life and this rich source is often noy denied to thes. There vas no existential attitude existing between children and parents says Aries, they vere valued for the real contribution they ade. The fanily vas a noral and social rather than d sentimental reality, especially anong the poor sho identified with a village or farn rather than their oun hone, if they had one.

The ost enduring influence on the changing nature of the fanily vas the provision of education:

Starting in the fifteenth century, the reality and idea of the faaily vere to change: a slow and profound revolution, scarcely distinguished either by contemporary observers or later historians, and quite difficult to recognize. And yet the essential event is quite obvious: the extension of school education. 3

Apprenticeship in another's house vas the first type of education. We have international exchanges for secondary school students nowadays which are in

1. Philippe Aries, Centuriries of Childhood, Penguin, London, 1973, p. 352.

2. Ibid.,p.354.

3. Ibid., p. 357 . 
some vays a sodern version of this idea. Early schools vere confined to clerics but eventually they became "the normal instrument of social 1 initiation, of progress from childhood to anhood" due to the influence of the pedagogues who vished to protect the child from adult teaptations and the desire of fanilies to have theif offspring supervised wore closely. Apprenticeship persisted at both social class poles but the origin of the modern fanily arises alongside the groving habit of educating children at school.

Schools vere to grow in number and in influence and to considerably extend school life. Aries believes that once a person's loyalties vere renoved from the street or comanity or vorkplace they vere replaced by a ney concept of fanily consciousness. The art of succaeding had alvays previously been based on "the art of being agreeable in society". As Cassio benoaned in Othello 'reputation' vas everything. Friendship bonds vere also iaportant as vere good anners and sociability and apprenticeship had been the school for these. Writing had never been very iaportant. In the schools there vere nev priorities and not everyone vas happy about then. Debate about the value of private tuition versus public began to be yaged. Sose vere appalled that what had once been the exclusive right of a few should now be ade available to wany. Sone things did not change :"The great development of the school did nothing to diainish the conteapt felt for the schoolnaster." People began to question the traditional celibacy of the teaching profession. One aight assune that the increasing nuaber of arried teachers had beneficial influences as did the fawily aen in the

1. Philippe Aries, Centuriries of Childhood, Penguin, London, 1973, p.357.

2. Ibid.,p. 363 .

3. ibid, p. 365 . 
clergy. No-one actually refers to this.

At the sane tine as schools were naking their iapact the changing nature of fanily loyalties vere also having some effect:

Primogeniture which had favoured one child in the fanily had declined by the eighteenth century "this [nev] respect for equality anong the children of a fanily bears vitness to the gradual nove fron the fanily vieved as a 'house' to the oodern sentinental viev of the fanily. People tended to attribute a new value to the affection betueen parents and children.t

Some thought school discipline vas too strict and nany opposed the passing of practical apprenticeship, others did not approve the nev eaphasis on learning from books. As one seventeenth century critic said "The vorld is a great book [and]...habitual conversation vith two or three vits can be are useful to us than all the university pedants in the vorld..." In defence of education Coustel said that it provided regular hours of study and children did not run the risk of being spoiled. They vere also renoved from the conpany of levd persons and talk, particularly of servants. Apparently this latter argument found much favour. Furthermore said Coustel in colleges friendships are formed and they enjoy the benefits of enulation. They also gain confidence on speaking in public. All of these points concern social or civil behaviour 5ays Aries rather than tuition.

Classes hovever were too big, sometimes a hundred, and the children vere unruly. "As soon as young children set a foot in this sort of place" said Cordier" they start losing that innocence, that siaplicity and that aodesty which hitherto ade then so pleasing to fod and aen alike." Erasous favoured small groups vith one tutor in a private house. In spite

1. Philippe Aries, Centurieses of Childhood, Penguin, London, 1973, p. 359.

2. Ibid., p. 366 .

3. Ibid.,p.367. 
of such criticisas the deaand for college places increased. Handbooks of etiquette had flourished because of the importance of anbition and reputation. They nou said it vas unseesly for a child to be dressed like a wan. Anbition vas considered a virtue, one should better oneself but what was valued vas not intellectual or technical conpatence but the adeiration of one's peers, which required dedication to the heroic ideal and persisted as a vay of thinking to the aiddle of the seventeenth century. This Renaissance ideal which looked to the nobility as endoved with Divine attributes which everyone should seek vas gradually replaced says Aries by the concept not of a courtier ideal but a nev one of the 'honnete honee' and now the court influence vas replaced by society. There vas a search for the happy mean "d distinguished ediocrity." Good eanners vere still iaportant but less elevated as a noral virtues. Manuals of etiquette now included how to behave in school "This was a consequence of the development of the school and of the groving avareness of the special nature of childhood." One such manual Le Civilite Nouvelle of 1671 recomanded chastisement of the child by the parent for ainor of fences and birching for any acts verging on crive. Practical treatises telling parents their duties and responsibilities proliferated influenced especially by Port-Royal.

The 'little schools' of seventeenth century france are the origin of the priary school systea. Their curriculue couprised reading and singing, etiquette, arithaetic and writing which vas studied as a craft rather than a for 1 of self expression. Pupils vere betveen the ages of seven and tuelve. An inspector of 1833 recorded "Children cannot be sent to school before the age of seven or eight... at the age of eleven of tuelve thay are

1. Philippe Aries, Centuries of Childthood, Penguin, London, 1973, p.376. 
sent to work." These schools replaced the lower college classes of

former tiees and private pensions. One influence says Aries vas the developent

of a new piety towards the poor in England and a movement to cater for

their needs:

In those circles ost affected by the nev piety in France and England it vas felt that the children in question should be given the religious instruction hitherto reserved in practice for the choirboys of the Latin school, and at the sane tive taught reading and writing, which vere nov regarded as necessary for the exercise of any trade, even a manual job. In this vay it vas hoped to ake pious, serious vorkers out of what had been depraved adventurers. 2

Thus ve see the beginnings of the social notion of organised training, discipline and deployment of children who vill devel op into'human resources'? Classical husanities vere not the concern of these schools but a 'nodern' curriculun to stanp out poverty and isnorality. Such charitable Christian schools proliferated in France, evidence of what Aries calls pious husanise. The schools flourished and attracted not only the poor but the better off even though they vere often segregated within the school;

The segregation of rich and poor at school offends our modern sensibility. But the spatial proxinity which it iuplies and the faniliarity inevitable vithn the sane roos if not on the sane benches are also repugnant to us. And here ve have the great difference between the two societies, that of the seventeenth century and that of the twentieth or at least the nineteenth century; the difference between a society in which people vere carefully ranked but vere aixed up in a cononon space, and a society which is egalitarian but in which the classes are kept apart in separate spaces. 3

Their grouth bears vitness to an increased interest in younger schoolchildren. Hovever a new spirit of social conservatiso in the eighteenth century denied access to secondary education for lover class children. It was to be confined to the rich othervise there vould be a shortage of sanual

1. Philippe Aries, Centuries of Childhood, Penguin, London, 1973,p. 288.

2. Ibid.,p.291.

3. Ibid.,p.294. 
labour. Ideas about educating people for their future roles in life began to surface. The development of the boarding-school systea which only the rich could afford and the disappearance of the country colleges both kept the lover classes out.

These pupils could not hope to go to the big colleges in the great urban areas, there life vas aore expensive, where the mediaeval tradition of lodging students had disappeared and where the school authorities no longer tolerated day boys who vere free fros both parental control and acadenic supervision. Having rid itself of it lover class pupils, the college vould becone exclusively aiddleclass.1

The rise of public schools in England vas a parallel movement. "The result vas that what had been a virtually unrestricted secondary education becane a class sonopoly, the symbol of a social stratum and the weans of its 2

selection." The little schools rearained for the lower classes who vere debarred fron the secondary schools. Aries sees in these developuents clear indications of a trend tovards distinguishing and separating thildren fros their parents and rich fros poor "a tendency not unconnected vith the Cartesian revolution of clear ideas."

As Aries sees it "a ninority vedded to ideas of order, clarity and authority tried to introduce into society by aeans of education a new way of life opposed to the anarchical inpulsiveness of the old manners." This ainority was to influence childhood particularly.

Changes in the style of hoaes dre also significant. In the fifteenth century they vere at two extreaes, large and filled vith dependants and servants or so saall they hardly fit our idea of a house. The 'chaos' of

1. Philippe Aries, Centuries of Childhogd, Penguin, London,1973, p.299.

2. Ibid.,p. 300 .

3. Ibid.,p.301

4. Ibid., p.302. 
the large house vas one reason why the pedagogues reconanded schools, but they were social centres vith any coaings and goings. The children were part of the scene and the servants vere often young. The idea of service had not yet been degraded. One nearly alvays 'belonged' to sonebody...society still appeared as a netvork of 'dependencies'" Where good relations obtained between asters and their servants strong bonding occurred. The head of the household vas recommended 'to control his vife, bring up his children and govern his servants" Servants vere not paid but revarded for "a master's relationship vith his servant vas not based on justice but on patronage and pity, the sase feeling that people had for children." Scarcely anyone lived alone, not even the king "until the end of the seventeenth century, nobody vas ever left alone. The density of life ade isolation virtually iepossible...", and those who sought solitude vere 4

considered odd. This highly social nature of everyday life hindered the foration of the concept of the fasily as ve perceive it nou. It is probably true to describe the earlier fanilies as nicrocosas of the entire society. As tine vent on rooes in houses becane aore specialised in use and oore private, for example beds confined to bedroons rather than all over a house. This change satisfied a nev desire for isolation. Servants began to be called by bells from their own quarters rather than being part of the general selea. The never code of manners respected privacy. Practices such as the use of visiting cards indicated this. Meals became briefer and less formal and "The rearrangesent of the house and the reform of sanners left aore roon for private life; and this was taken up by a fanily reduced

1. and 2. Philippe Aries, Centuries of Childhogd, Penguin, London,1973,p.299.

3. Ibid.,p.384.

4. Ibid.,p.385. 
1

to parents and children." The formal address of voaen changed fron Madane to Manan, which even a husband used, Children vere given nicknanes. Correspondence betveen a husband and wife often vas concerned vith children's health, behaviour and hygiene. Health and education vere beconing the chief preoccupations of parents and rather than being accepted stoically the death of an infant vas a tragedy. The correspondence of Montaigne reflects this nev attitude. Fron the end of the sixteenth century all of the children of a fanily vere supposed to be treated equally and Aries believes this was the result of the influence of anners and custon rather than any legislation or the revolution. The greatest change vas that the child was no longer put out to strangers. "This return of the children to the hoae vas a great event: it gave the seventeenth century fanily its principal characteristic, which distinguished it fros the mediagval fanily."

By the end of the Middle Ages the vord enfant extensively referred to saall children and adolescents. In the seventeenth century it vas applied to a boy of fourteen who was teaching younger children. By this tiane the vord child becane aore restricted anong the middle class to its aodern meaning. Childhood vas alvays synonymous with dependence rather than biological developaent. The ter 'little boy' aight refer to a young servant. Furetiere's dictionary of the eighteenth century explained that " 'Child' is also a ter of friendship used to greet or flatter someone or 3

to induce hin to do sonething."

Lack of yords for children haspered expression in seventeenth century French and English whare 'baby' vas still applied to big children. Schools

1. Philippe Aries, Centuries of Childhood, Penguin, London,1973,p.387.

2. Ibid.,p. 390 .

3. Ibid.,p.24. 
such as Port Royal inspired nev terainology. Jacqueline Pascal's pupils vere 'little ones', 'aiddle ones' and 'big ones'. She said that "vith regard to the little children, they even aore than all the others must be taught and fed if possible like little doves." People began to refer to 'little souls' and 'little angels'. So even though the seventeenth century seened to scorn children it brought into usage expressions says Aries Which ve still have today. Diminutives gradually became more common but peopla had no idea of vhat ve call adolescence. The first typical adolescent of nodern tines says Aries vas Wagner's Siegfried:

The ausic of Siegfried expressed for the first time that conbination of provisional purity, physical strength, naturisa, spontaneity and joie de vivre which was to ake the adolescent the hero of our twentieth century, the century of adolescence. ?

By 1900 Youth had becone a literary thene and a subject of concern for soralists and politicians. In France vriters such as Massis and Henriot explored the youthful aind. Society passed says Aries fron a period ignorant of adolesence to one in which it is the favourite age. "We nov vant to cone to it early and linger in it as long as possible." He thinks that the technological idea of preservation is replacing the biological and noral idea of old age. The findings of Boas are sinilar. It seems to Aries that each century has a corresponding privileged age. Military youth is the privileged age of the seventeenth century, childhood of the ninateenth and adolescence of the twentieth.

At one tiese records and pictures of children vere rarely kept. To lose children early in life was such a commonplace event people seemed to

1. Philippe Aries, Centuries of Childhood, Penguin, London, 1973, p.25.

2. Ibid.,p.27.

3. Ibid.,p.28. 
become al oost indifferent and not so far renoved froe the callousness of

Rowan or Chinese societies. "Nobody thought, as ve ordinarily think today, 1

that every child already contained a san's personality." By the sixteenth

century the appearance of the portrait of the dead child marked a development

in attitudes tovards children. One of the first to record her sentisents about young children vas Madame De Sevigne but to Aries she represents vhat he calls a 'coddling' attitude to children, anused by their antics but not vith the nev intense concern which focussed on children. Marvick tells us that everyone in France wished for 'un beau fils' and girls vere unvanted. Madane de Sevigne rejected her daughter at birth. She vas cared for by a grandaother and incarcerated in a convent at nine "a burnt offering to the 2

future of her brother: vho when he vas born vas doted on.

By the seventeenth century children's clothes no longer ivitated those of their parents. There vas, up to the nineteenth century, little to distinguish boys fron girls by their clothes. School uniforas vere inspired by ailitary dress and rapidly adopted by the aiddle classes. Trousers and the ubiquitous sailor-suit also became populay because of ailitary influence.

The idea of childhood profited the boys first of all, while tha girls persisted much longer in the traditional way of life which confused then vith the adults: we shall have cause to notice more than once this delay on the part of vonen in adopting the visible forms of the essentially asculine civilization of adern tises. 3

Lover class children for wuch longer vere undifferentiated in their dress fron the adults.

The childhood of Louis XIII vas recorded in detail by the court

1. Philippe Aries, Centuries of Childhood, Penguin, London, 1973, p.37.

2. Elizabeth Wirth Marvick, 'Nature Versus Nurture: Patterns and Irends in Seventeenth Century French Child-Rearing', in History of Childhood, ed. de Mause, Souvenir Press, London, 1976, p. 283.

3. Aries, p.59. 
doctor Heroard, so ve know that he vas for instance introduced to ausic and dancing at a very early age and this custoe is the reason for so many infant prodigies Aries thinks. We have little appreciation he says of just how iaportant nusic, singing and dancing vas in ordinary everyday life. Even wonks and nuns danced on occasion as the style of dancing did not evoke the sexual overtones of its modern expression. By four Louis vas being taught to read and urite. Whilst still playing vith toys and dolls he practised archery, played cards, chess and wany adult games for there seesed little division betveen adult and child gases. He vas in fact vell socialised by the royal family and the court and participated in seasonal festivities. By age seven he vas in the charge of a naster and still occasionally received a uhipping. At age fourteen he vas arried,

Gases vere generally enjoyed vithout discrinination except by a powerful and rigid ainority of rigid noralists tho also frovned on games of chance which enjoyed trenendous popularity. Children are often portrayed playing many of these ganes. As late as 1830 there vas gaabling and heavy betting in English public schools. Attitudes changed later when people attempted to protect young people's aorals nore assiduously. The Mediaeval church frowned on ganes especially among student scholars but according to Aries the Jesuits restored then to favour in the seventeenth century and even included soae for of thea in their curriculun. The need for physical exercise was recognized and by the eighteenth century exploited for war training.

Listening to story telling vas also a popular pastive up to the time of popular printings of stories and neuspapers and it vas not confined to children. A5 Aries says most of the gases and pastimes of the past vere enjoyed by young and old and all classes which ve now see ainly as the province of the young. 
One of the oldest taboos is that of referring to sexual atters in the presence of children. In the records of Louis's upbringing the freedou of expression concerning sexual aatters amongst the courtiers, servants and children would seea shocking to us today, but by the age of seven which Aries calls the 'fateful' age the child vas expected to suddenly becone more reserved "The boy of ten vas forced to behave vith a nodesty which nobody had thought of expecting of the boy of five. Education scarcely began before the age of seven. One historian urote: "The respect due to children vas (in the sixteenth century) conpletely unknown. Everything vas peraitted in their presence: coarse language, scabrous actions and situations; they had heard everything and seen everything." It is interesting that the same charge is laid now against the aedia particularly television for its albeit vicarious exposition of the best and vorst of huaan nature to children. But scenes such as those depicted by Heroard are still played out in the tventieth century says Aries relating an incident in the novel The Statue of Salt by Albert Menai, where a small boy in the care of his father is publicly accosted wuch to his discosfort and the aerrient of the onlookers. It is a vell known fact that children in wany parts of the vorld are still bought and sold and exploited in vays that aore fortunate parts of the world are shocked and sickened by. Amesty International can bear vitness to this, but even in Ney lealand there is anple evidence of current child sexual abuse and incest and there is little legislation to protect the rights of children.

Aries says there was a reason for the attitude which allowed children to vitness public festivals such as circuacision:

In the first place the child under the age of puberty was believed

1. Philippe Aries, Centurieses of Chi1dhood, Penguin, London, 1973,p.101. 
to be unavare of or indifferent to sex. Thus gestures and allusions had no meaning for hia; they becaae purely gratuitous and lost their sexual significance. Secondly the idea did not yet exist that references to sexual matters, even when virtually devoid of dubious meanings, could soil childish innocence, either in fact or in the opinion people had of it; nobody thought that this innocence really existed.1

Gerson's studies of 1706 showed an understanding of childhood sexuality which vas to influence childrearing. He advised that one should speak decently to children and avoid promiscuous situations for thea. His theories vere put into practice in the school of Notre-Dame-de-Paris and influenced the Jesuits, Port Royal and the Christian brothers. By the seventeenth century says Aries a graat movenent which recognised the innocence of childhood vas under way, evidenced in a rich moral and pedagogic literature, in devotional practices and a nev religious iconography. It is illustrated by the caption to an engraving by F.Guerard:

This is the age of innocence, to which ve aust all return in order to enjoy the happiness to come which is our hope on earth; the age when one can forgive anything, the age when hatred is unknown, when nothing can cause distress; the golden age of human life, the age which defies Hell, the age when life is easy and death holds no terrors, the age to which the heavens are open. Let tender and gentle respect be shown to these young plants of the Church. Heaven is full of anger for vhosoever 5 candalizes them. 2

The plant metaphor is one which vill occur often in the uritings about child care and education. This nev noveanent which led to a proliferation of educational institutions being set up also advocated more supervision for children and laid greater emphasis on discipline.

As Aries says ve in the twentieth century can see a contradiction in this idea of childish innocence, which protects the young but also develops youthful character and reason, for on the one hand childhood is preserved

1. Philippe Aries, Centuries of Childhood, Penguin, London, 1973, p.103.

2. Ibid, ,p.108. 
[and extended] and on the other hand it is ade older than its years.

Changes in attitudes to discipline also earked nev attitudes to childhood. Aries recounts the brutality often suffered by vandering aediaeval scholars and the tortures of initiation into sale societies which nevertheless bred loyalty and coaradeship. Aries says references to corporal punishment before the end of the fourteenth century are rare because it vas accepted as a nora. "Fron the fifteenth century on, the whip takes on a degrading, brutal character, and becones increasingly comoon." By the sixteenth century 'Corporal punishaent had becose the 'scholastic punishment' par 2 excellence." Montaigne testifies to the brutality of school punishnent as does Watson vho refers to school as 'a place of execution'. The degrading character of such punishments nevertheless did not deter parents fron inflicting the sane on their children. The birch, yas used on pupils of all ages:

...confined at first to the youngest children, it was extended after the sixteenth century to the vhole school population, uhich often approached and sometiaes passed the age of twenty. There was therefore a tendency to diainish the distinctions betveen childhood and adolescenca, to push adolescence back tovards childhood by subjecting it to an identical discipline. Inside the school vorld, the adolescent vas separated from the adult and confused vith the child, with whon he shared the huailiaton of corporal punishaent, the chastisenent handed out to villeins. 3

Huailiation vas therefore a method of control. It vas usually the Church authorities especially the Jesuits vho brought nore order and discipline into education. Parallel vith this vas the developing notion says Aries of the veakness of childhood and the concept of the noral responsibility of the master. By the sixteenth and seventeenth centuries it became one of

1. Philippe Aries, Centerries of Childhood, Penguin, London,1973, p. 247.

2. Ibid., p. 248.

3. Ibid.,p.261. 
the essantial principles of education. By the eigtheenth century aore people vere opposing the harshness of corporal punishment. St. Jean Baptiste de la Salle for example did not ban the birch but did not reconend it.

This developnent did not necessarily reflect the progress of liberal ideas says Aries, for harsh discipline still existed in the aray. The explanation lies in "a nev orientation of the concept of childhood, which vas no longer associated vith the idea of the veakness of childhood and no longer recognized the need for its huailiation." Nov it vas a question of avakening in the child an adult sense of responsibility and dignity, and this vas to be a gradual process. "This vas the nev concept of education 2 which would triumph in the nineteenth century" the idea of avakening the an in the child. In France no-one vould revive the for ser harsh disciplines but under Napoleon his penchant for order and discipline perseated fron the forces into education where the use of the uhistle, woving about in squares, lining up in coluans, and sometiaes solitary confineaent becase practices not unfaniliar even in schools today. Military ideas appear in parallel vith rising liberalisa says Aries and arise in the second half of the eighteenth century. Previously schools had been ecclesiastic, even nonastic but as the Jesuits becane suppressed their style vas supplanted by that of the ailitary in French schools. The aediaeval schools did not distinguish betveen the child and the adult. Colleges aerged adolescence and childhood and conbined ailitarisa. The consequence vas that unifora and discipline became part of the aystique of education. The concept of adolescence had energed says Aries and a new value vas put on toughness and virility.

Boarding schools of the English type never flourished in France

1. and 2. Philippe Aries, Century of Childhogd, Penguin, London, 1973, p. 253 
until the late eighteenth and early nineteenth century and caused Taine to vrite "In order to receive a secondary education, sore than half the boys in france have to endure seclusion in ecclesiastical or lay boarding schools, seclusion under nilitary or monastic discipline. " In earlier tiaes boys vere sent to college and boarded in private dvellings. Later, because sore discipline vas required they vere often under the supervision of college staff but still boarded out.

The developaent of the boarding school systea after the end of the eigtheenth century bears vitness to a different concept of childhood and its place in society. Henceforth there vould be an atteapt to separate childhood fron the other ages of society: it vould be considered iaportant-at least in the aiddle class- to shut childhood off in a vorld apart, the vorld of the boarding school. The school vas substituted for society in which all the ages vere aingled together; it vas called upon to mould children on the pattern of an ideal human type. 2

By the end of the nineteenth century Aries notes that day boys proliferated but still there persisted this tendency to set children apart. Now hovever it vas the fasily which vas the dominant woral influence. "The central concern of the individual fanily yas its oyn children." Which according to hia represented the triumph of demographic Malthusianism. If fanily control eases then he sees childhood and youth regaining sone of the freedoo they enjoyed as far back as the eighteenth century. Childhood he believes. has nov lost soae of its special characteristics in favour of adolescence. Children once went to school araed with veapons which they had to hand over for safe keeping. Riots and rebellions of young students vere not unknown. Sometiaes they even turned the tables on those vho had inflicted corporal punishaent on thea. Violence flared in England too especially in the late eighteenth and early nineteenth centuries. Students of the Middle

1. Philippe Aries, Centuries of Chilghogd, Penguin,London, 1973, p. 271.

2. and 3. Ibid.,p.273. 
Ages had been fairly lauless and often feared by the populace.

In the sixteenth and early seventeenth centuries public opinion regarded the student as a libertine and the terror of fathers and husbands, a sort of adventurer after the fashion of Villon, vith all the risks that that iaplied. The Jesuits exhorted stricy norality in their colleges and "this vas the beginning of the sexual claustration which vould henceforth characterize college life." Honen vere either exalted or ridiculed depending on their status "woman was the intruder, ridiculed by a oasculine comanity which desired her and excluded her at the sane tiae.' Schoolboys vho lived avay from howe often lived by their vits if gifts from home vere insufficient. Begging by children vas accepted practice in the sixteenth century Geraany. Attendance at school was also often lax. The day school systen and the practice of living in lodgings ade this easiet than when the boarding schools operated or children schooled froe hoae. Students vere variously described at the tiae as 'varuin' and 'free men' and a version of our godern word truant which meant vagabond. The concept of the vell-bred child scarcely existed in the sixteenth century says Aries a nev eoral concept in the seventeenth set hin apart "it vas the product of the reforaing opinions of an elite of thinkers and soralist tho occupied high positions in Church or State" and vas to protect the little bourgeois and little English gentlenan froe the roughness and iemorality of the lover classes and effectively protect a threatened aristocracy froo the progress of democracy. The hooligan ve nou despise is in Aries' vieu the last vestige of Mediaeval unruliness.

1.Philippe Aries, Centuriries of Childhood, Penguin, London, 1973, p.309.

2. Ibid.,p.310.

3. Ibid, p.315. 
Aries overviev of childhood in historical terms sees tvo diffarent vievs of children emerging. One of creatures to be coddled, that is in infancy only, and a second which vas avare of the veakness and innocence of childhood and the adult's duty to protect and safeguard it. The latter attitude being ainly restricted to a suall ainority of lavyers priests and aoralists. Childhood was alvays brief in the lover classes.

These aen of influence on childhood and who extended its duration vere:

The moralists and pedagogues of the seventeenth century, heirs of a tradition going back to Gerson, to the fifteenth century reforaers of the University of Paris, to the founders of the colleges in the late Middle Ages....

Age groups in society tend to be organised by institutions. Thus adolesecence, never defined or recognized under the ancien regiee, vas distinguished in late eighteenth and early nineteenth century by conscription and later by ailitary service. Schools vere indifferent to age differences for a long time because education was not their chief ais. The aediaeval school was not designed for children but as a technical school for clerics. To describe someone as being of school age had little significance unless it indicated that person's linited learning ability. Education yas confused vith culture says Aries both by the humanists of the Renaissance and the pedagogues of the Middle Ages "vithout giving a special value to childhood or youth" The real innovators vere the scholastic reformers of the fifteenth century, Cardinal d'Estouteville, Gerson, the organisers of the colleges and pedagogicas, and particularly the Jesuits, the Oratorians and the Jansenists of the seventeenth century. With then we see the appear ance of an avareness

1. Phillipe Aries, Centuries of Childhood ,Penguin, London, 1973, p.316.

2. Ibid.,p.317. 
of the special nature of childhood, knouledge of child psychology, and the desire to devise a sethod suited to that psychology."

Woaen of the seventeenth century vere excluded from education so they changed little fron the Middle Ages in that their childhood vas brief, wost of their early life spent in the household preparing for when they vould have one of their oun which aight be at a very young age. A fev schools for girls vere set up but they vere not catered for generally for another tvo centuries.

The youths whe attended the colleges vere subjected says Aries to a discipline grounded in ecclesiastical or religious discipline and concerned with ooral behaviour and spiritual ieprovenent. Authority over the young gradually devolved therefore froe the fanily to the schools, and parents began to observe and respect the school cycle. Dne effect of this deprivation of liberty and enforced years of discipline vas to extend the length of childhood. Up to the eighteenth century there vas in France virtually one education systen and genarally of no distinguishable class. Sone youths escaped it to join the ariny and girls vere excluded. The dual educational systen which cane later vas based not on age group but on class, the lycee or the college for the aiddle class (secondary education) and the school for the lover class (primary education). As Aries points out the longer the education cycle the less likely sone students are to vish to profit by it or to be able to do so.

Those who helped to establish the education system vere sometimes appalled by their success for they began to see the probleas which could arise from an overabundance of intellectuals and a shortage of manual labour. They vere unable to halt what they had started says Aries but not

1. Philippe Aries, Centuturies of Childhogd, Penguin,London,1973,p.318. 
everyone reained faithful to the principle of universal education. Those weabers of the Enlightensent who vished to call a halt tried to do 50 by liaiting access to a long classical education to a privileged class and condenned the lover classes to an inferior, exclusively practical type of instruction. The concept of childhood "found its nost aodern expression in these sane circles of enlightened bourgeois vho adnired Greuze and Read 1 Enile and Pamela." The deand for child labour in the nineteenth century probably he thinks created a retrogression and sone aspects of the old ways of life renained in the lover classes "Child labour retained this characteristic of mediaeval society: the precocity of entry into adult life." De Mause has criticised Aries for implying that children vere happier in former times because their lives vere are social, they took aore part life of the community. He does suggest I think that the nodern youth has lost a sense of affinity vith the comanity and the vorkforce particularly. This is a aodern problea, how the two can beneficially overlap. Perhaps the odern street kid or vagabond is also trying to capture this lost freedon which has come about through enforced schooling. Rousseau sav that childhood had lost its essential joie de vivre as did the Romantic poet5. De Mause is critical of what he calls Aries' etyological viev, and approaches the study of childhood fros another vieupoint, his psychogenic theory. Although he does not define the tern it appears to hie that society evolves. There have been references for instance to the 'childishness' of parents in foraer tines but with the acquired visdoe of the ages the huan psyche atures and over time ve see evidence of this in changing attitudes to children.

1. and 2. Philippe Aries, Centuries of Childhood, Penguin,London, 1973, p.323. 
One effect of the French Revolution and the Napoleonic Wars had been to ake public life insecure and any of the religious educational institutions had been closed. Fanilies vere driven into their hones and parents particularly aiddle-class took more interest in their children. Robertson quotes C.H. Cunninghan as placing the changeover fron physical to aental punishaent at about 1840 , though in the British schools caning never ceased to be used and ve still have it to this day in Nev lealand. Corporal punishment for girls vas hotly discussed in the pages of the Englishuoan's Donestic agazine fron 1867-1869. Its adherents supported it strongly, whilst others abhorred it but it vas aore prevalent in England than in France. Foreign observers often considered French children rather spoiled. They in turn vere astonished at the precocity and discipline of Geran children. Deprivation of food vas alvays a common punishment and often children did not dine vith their parents but ate siaple food in theit nursery. Masturbation vas believed to lead to insanity so children sometimes had their hands tied in bed. One of the first to speak out against this vas Dr Albert Moll in his Sexual life of the Child early in the twentieth century. Other vriters passed on Rousseau's ideas. Maria Edguorth in Practical Education concluded that "ve should not prejudice either by our visdon, or by our folly, children's assertion of their oun values." But Hannah More in 1820 had the opposite view that children are naturally bad. A cheap french paperback handbook the Livre de Fanille, later in the century "described the child as cruelty and egoism personified-- an angel only when he sleeps. Waking, he had to be brought into absolute subnission."

1. Priscilla Robertson, 'Hone as a nest: Middle Class Childhood in Nineteenth-Century Europe', in The History of Childhood, ed, de Mause, Souvenir press, London, 1976, p.420.

2. Ibid, , p.422, 
Nevertheless children had becone interesting and a serious concern, and people becane divided says Robertson into those vho liked then and those Who did not, and still believed in their need for a harsh regine. It was at this tiane that Ellen Key predicted that the twentieth century vould becoese the century of the child.

Those vho believed in the newer ideas set out to prove then and sany began to think that a happy hone life was indeed the best preparation for life. Eleanor farjeon recounts hov her father told stories on their valks, an art Robertson believes is being lost. Visitors to Paris often comented on the happiness of the fanilies visiting the Tuileries or the Luxeabourg Gardens. Faailies vere often saaller. The nev concept of a People's State way have inspired ore paternal feeling thinks Robertson and the nev laus of equal inheritance gave value to each child but boys vere still preferred bec ause the arny needed then.

Society in the nineteenth century vas itself beconing more paternal. State-run orphanages vere set up in france and at this tine the first factory Acts were going through in England. Only later was the state to consider that it aight be responsible for education generally:

It is clear that the Government interest was not exclusively humanitarian, for it becane apparent to econonists and especially ailitary strategists that the prosperity and safety of the State depended on having a class of healthy citizens.1

This vas something they could have learned fron Plato but now Rousseau vas interpreted as "giving citizens to the country, while he appeared only to think of giving oothers to their children." Thus ve see that those in pover were not slov to capitalize on the new wave of childrearing

1. and 2. Priscilla Robertson, 'Howe as a nest: Middle Class Childhood in Nineteenth-Century Europe', in The History of Childhood, ed. de Mause, Souvenir press, London, 1976, p.427. 
phil osoghy. In 1895 The society for the Prevention of Cruelty to Children received its Royal Charter, a hunane nove but nevertheless an indictaent of a society that needed it and unfortunately still does. Robertson said that the "The chief enenies of children vere poverty and ignor ance" but to this one aight also add superstition. In general says Robertson:

The nineteenth century vas the time when public bodies began to think of children as children, vith special needs because of their helplessness and vulnerability, rather than as saall adults vith the right to hire thenselves out for sixteen hours a day, or as the chattels of their parents. 2

This change affected not only children but society itself.

Walzer tho looks at attitudes in eighteenth century Anerica is surprised at the aubivalence people had tovards children, that they could in fact be both desired and unvanted and "Quite normal parents harboured unconscious vishes of such an extreae nature that they could not be adnitted to the conscious aind." One aight iagine that in a new country the need for people vould sving the balance. Certainly in America babies vere rarely abandoned as they had been so often in the hone country. Infanticide also vas practically unknoun though chidren often faced risk from accidents and carelessness and they vere still put out to nurse where possible, put into schools and sent to relatives. "The situation aight be said to have been closer to that which exists in a pritaitive tribe where the child is seen as a child of the tribe as auch as a child of a particular couple." Nalzer does not develop this idea but is obviously interested in the strange [to us] psychological make-up of these early

1. and 2. Priscilla Robertson, 'Home as a nest: Middle Class Childhood in Nineteenth-Century Europe', in The History of Childhood,ed. de Mause, Souvenir press, London, 1976, $p .428$.

3. Ibid, , p. 352 .

4. Ibid., p. 353 . 
eaigrants winly froe Europe. Children of Puritans vere constantly described as 'seed' which were to give rise to a new generation to serve 6od. Parents obtained a sense of duty fron their children to the extent he thinks that they seened to have more care for parents than they for then. This is a paradox several authors have conented on. "The child held on to properly, becoses the parent, and the aging parent can return to the confortable encapsulation of chidish dependency." Perhaps this goes back to those calendars of the cycles where the aged are seen as feeble and childish or in what ve more recently have labelled second-childhood, a state that oodern society is fighting to postpone as Boas says but which aight have concerned earlier fanilies in different vays.

We can learn far more about the cultivation of flax than ve can about their child-rearing practices says Nalzer. The 'book' hovever symbolized civilized refinement and children vere constantly nagged to be busy with their books. A feu parents could afford a tutor. Putting then out to school Walzer sees as a forn of abandonment and "What children in school vere protected fron vas a world which of fered too auch freedon." The rod and uhip vere still used for punishment and for vetting the bed one father made his son "drink a pint of piss " yet the saee an reaonstrated vith his wife who had her waid burned for some small wisdemeanour. Painful forms of medication vere also often administered as vell as bleedings and suchlike and the subtler forms of shaning which have been referred to earlier vere used as was the practice of shutting children in dark closets and threatening then vith death. One increasingly has the

1. John F. Walzer, 'A Period of Aabivalence: Eighteenth Century Anerican Childhood', in The History of Childhood ed. de Mause, Souvenir Press, London, 1976, 0.363

2. and 3. Ibid., p. 368 . 
feeling that parents in fact vere afraid of children.

Gradually the voices pleading for ailder treataent of children vere beginning to be heard and by the second half of the eighteenth century books for children vere coning from the Aaerican presses. Instruction for children vas nov more often in language suited to thea, but as Walzer says "A heavy dose of sugar sveetness vas no substitute for real eapathy." The same ambivalence is seen in children as in parents for they vant to be both dependent and independent. This desire for independence becones a stronger force:

Both are clearly related to two of the cost central developents of modern Western history: the grouth in the inportance of the individual as an increasingly independent and responsible entity who was no longer prinarily a member of a corporate body and the replacement of hierachical relationship by egalitarian relationships as an ideal.2

These people who travelled across the world have noved not only physically but psychologically avay fron the traditional interdependencies of the 'families' of mediaeval and even later periods in Europe. He vonders if ve have in fact evolved psychologically as vell as biologically aven if slovly. Melanie KIein he says once thought that in pre-Hellenic tiaes there ay have been no super-ego. Our attitudes to children nov are both possessive and desirous for their independence. This say change "to a new state characterized by interdependence, or the recognition of the ature dependence 3 of equal and fully developed individuals on one another" which is sinilar to Erikson's idea of equal partnership. Whatever the outcome Walzer believes that attitude is shaped by a linear sense of tise and history.

1. John F.Malzer, 'A Period of Aabivalence: Eighteenth Century American Childhood', in The History of Childhood ed. de Mause, Souvenir Press, London, 1976, p.372.

2. and 3. Ibid., p. 374 , 
In the history of Russia biographers apparently give some consideration to childhood but there is little attention to it in other literature. Russians vere influenced by Western vritings of the 1760 's but what particularly appalled thes when they did study the situation vas the incredibly high rate of infant deaths. Half of five hundred thousand infants died before they reached three. The persistence of svaddling has already been mentioned. The bath house public or private vas often the delivery roon. Babies vere also subjected to great extreaes of teaperature to harden then and the early baptisa meant they had to endure inaersion in icy cold vater, Hoaes for foundlings adnitted thirty seven thousand betveen 1766 to 1786 and thirty thousand of these vere lost.

In a traditional agricultural society nev nouths meant nore denand on food supplies rather than more production. Knouledge of birth control sethods vere lacking. In Russia also the eaphasis was not on the individual and the position one achieved but on the fasily and the position ascribed to one by virtue of birth into that fanily. The good of the fanily superseded that of any of its aenbers." patriarchal, either the father or eldest ale reigned.

Russian parents in general in the eighteenth and nineteenth century can be described as detached rather than involved vith their children, hostile rather than wars in their interaction vith them, and restrictive rather than peraissive in handling the spontaneous behaviour of the child. Life for the child was doninated by a detached, hostile, sometines violent father who deternined the course of the child's life, and by the lack of a vara relationship with the mother. 2

The latter is indicated by the use of vet-nurses and the use of servants as supervisors and playsates. When the nother of Sergei Aksakov

1. Patrick P. Dunn, "That Eneay Is The Baby": Childhood in Iaperial Russid, in Ihe History of Childhood, ed. de Mause, Souvenir Press, London, 1976, p.391.

2. Ibid., p.391. 
personally put her infant daughter to the breast of the nurse and rocked her child to sleep she was told "Such exaggerated love vas a crine against 6od, and he vould surely punish it." this vas reinforced by the child's subsequent death and turned the oother's heart against later children. One vonders hov wuch jealousy arose between mothers and nurses and what the attitudes of nost mothers vas in any country to these surrogate 'mothers', whether they treated then merely as a convenience or as a partner in the process of child-caring--little is said on this aspect.

The Donostroi a guide for parents penned by churchaen varned fathers not to be soft with their sons "Do not saile at his, do not play vith his, for having been veak in little things, you vill suffer in great ones." The Eighteenth century nobility lived by this guide says Dunn, and 6ogol reconaended it. One Novikov varned then in 1783 that such severity vould eventually cause their children to treat their parents with contempt, Alexander Herzen renembers his childhood in the first quarter of the nineteenth century

Mockery, irony, cold, caustic; utter conteapt, were the tools which he this father] vielded like an artist; he eaployed then equally against us and against the servants. 3

Baron Hrangel believed that such harshmess reflected a society where it had becone a moral principle with then that to show benevolence vas to be veak, to be cruel vas to be strong. Dunn conments that "Pover assertive discipline, like the disinclination to care for one's oun children, correlates highly vith parental hostility toward their offspring."

1. Patrick P. Dunn, "That Eneny 1s The Baby": Childhood in Iuperial Russia, in The History of Childhogd, ed. de Mause, Souvenir Press, London, 1976, 0.392.

2. and 3. Ibid.,p.292.

4, Ibid.,p.393. 
Parents seemed to have little understanding of chidren's needs and they looked elsevhere for company and affection. "Parents especially fathers, conceived of children as lobjects, to be nourished and directed but not 1

understood." This extended to careers and arriage vhere the parents

did the choosing. What Erikson calls the battle for autonomy prevailed throughout childhood. Parents continually blocked their childrens' delineation of autonony and "personal autonony vas not traditionally valued in Russian society, and it vas in the fanily that the personal autonomy of 2 future citizens vas repressed," obedience vas obligatory. Father even sent their nevly arried sons avay to vork and appropriated the bride. Even married people vere still under the jurisdiction of the head of the household which ended only with his death. The Tsar was the aodel. Dunn believes that one cannot blane the State for the fanily situation for blind tyrannical power over their children aight represent blocked autonoay in their own early lives. In 1767 the Aristocrats deaanded fron Catherine even sore power over their sons, to send the aore shiftless off to poor houses. Not all sons became tyrannical fathers theaselves. Dunn says that the key to change appears to be when some external force allows the individual to begin to delineate autonony outside of the family, as "repressed drives can surface if social conditions allov their expression." Which aeans presumably that a concept of autonony has to first be formed through experience. Individual Russians through circunstantial change and government action found theaselves in nev situations. Dunn believes one has to experience

1. Patrick P. Dunn, "That Eneny Is The Baby": Childhood in Iaperial Russid, in The History of Childhood, ed. de Mause, Souvenit Press, London, 1976, p.393.

2. Ibid.,p. 396 .

3. Ibid., p.399. 
autonony onaself in order to be able to grant it to someone else.

Catherine II sav that traditional Russian fasily patterns vere holding her people back and she favoured education to begin at age five. Those tho did eventually by force of circuastance and opportunity acquire new ideas faced considerable conflict vith their fanilies. We call this the generation gap, for even now parents and grandparents look sometiaes vith disfavour on 'nev' ideas concerning child care. An intelligentia, says Dunn beginning in the eighteenth and extending into the nineteenth century stressed personal values over traditional values and brought up their own sons and daughters vith more varath and understanding than the previous generation.

De Mause vho has been a leader in this recent research on the history of childhood found that it is a subject neglected by historians as if not worthy of consideration. The further back he goes in this history the vor $5 e$ he finds the treatoent of children. His study of the history of the attitudes and practices of parents tovards their children concludes that there has been a general iaprovement in child care over the ages.

His evolutionary 'psychogenic theory of history' attempts to prove that the central force for change in history, in this case, is "neither technology nor econowics, but the 'psychogenic' changes in personality occurring because of successive generations of parent-child 1 interactions." what he describes is something like a mirror-effect. The parent sees his foraer self in the child, the child sees a nodel of his future self in the parent; throughout their relationship this reflective effect is like a airror reflecting another airror so that the original

1. Lloyd de Mause, 'The evolution of Childhood'.inThe History of Childhogd, ed. de Mause, Souvenir Press, London,1976,p.3. 
becomes distorted and hard to distinguish. De Mause likens it to the experience of regression in psychoanalysis. He is interested then in the psychological influences and effects thereas Aries puts the eaphasis on societal influences.

Froe both angles ve get clear gliapses of what it vas like to be a child or parent in forner tines. De Mause is critical of Aries believing that he perceived childhood in earlier ages to have been a happier experience. Aries did see that personal freedon and social experience (particularly mixing vith all ages and classes) had diminished through enforced institutionalised and extended education, implying that ve have both gained and lost sonething over time in the development of the concept of childhood, ve have aore care for and interest in children and their education but wore public control over individual lives. It is true, for a child can no longer 'run avay to sea' or wherever, his/her life is aore regulated and docusented than ever before. Ton Savyer would probably find it intoler able but the aodern schoolboy even if he goes unvillingly to school is compelled to go either by law or in the later stages by necessity, for entry into the workforce or for further education and training.

Even though they viev their field differently both writers are concerned vith the raised consciousness in the public and private ands about what it means to be a child and the corollary of this is what a complex and perhaps daunting task it is to be a parent. It is after all one occupation for which there is little or no training and almost unlinited access. Works such as these vhatever their particular acadenic bias wust surely help us to assess what ve have done in the past that is vorthuhile in child-rearing practices and influence our thinking and planning for future generations. Leavis puts a perspective on this in the preface to Coveney speaking of Blake's thought that '...lives can't be aggregated, 
generalized or dealt vith quantitatively in any way" such studies like nassive detective vork can only give us parts of any pattern or general outlines. De Mause does recomend the vorks of George Payne, G.Rattray Taylor, David Hunt and J.Louise Despert for their insights into this area. De Mause's interest in childhood then is to discover what goes on betueen parent and child which vill influence the psyche of the next gener ation. According to his findings adults have three adjor reactions to children:

1. The adult uses the child as a vehicle for projection of the contents of his oun unconscious (projective reaction).

2. He can use the child as a substitute for an adult figure iaportant in his own childhood (reversal reaction).

3. He can empathize with the child's needs and act to satisfy the (eapathetic reaction).

An example of the first would be people towards psychiatrists, the second 'battering' parents and the third siailat to free-floving attention or what Theodore Reik calls listening vith the 'third ear'. According to De Mause "projectives and reversal reactions often occurred siaultaneously in parents in the past producing an effect... where the child vas seen as both full of the adults' projected desires, hostilities and sexual thoughts, and at the same moent as a mother or father figure." The child is thus both bad and loving. This could account says De Mause for some of the more bizarre treatments of children in the past. When a child is cruelly beaten it is justified for instance with reaarks such as that of a father horse-whipping his four year old for not being able to read soaething "I felt all the

1. Lloyd de Mause, 'The evolution of Childhood'. inThe History of Childhood, ed. de Mause, Souvenir Press, London, 1976, p.7. 
force of Divine authority and express conand...it eade alsost sick to whip 1

hin " but he feels worally justified and proceeds reaorselessly.

Adults often believed too that accidents which befell their children vere some portion of blane for their oun past aisdeeds. This notion of the child as a "toilet" for adult sin is synonyous vith the concept of original sin, says De Mause. There was also the belief in demons and changelings which provided thenes for literature also. One thinks of Heatheliff the foundling in Wuthering Heights referred to as though he vere some denonic changeling. There vas also no reason for svaddling children so tightly even though it night be asserted as it still is in sone places that it protects the child from self-injury.

The frightening of stall children vith stories of ghosts vas comaon practice. Like religion, based on fear of Hell and the Devil, this vas to create fear of vrongdoing. No doubt it also gives some people a thrill of sadistic pover to vield such pover even over children, though De Mause claiss that "Even contemporary child-beaters are not sadists." ${ }^{1}$ Perhaps each age has its 'baddies' to haunt childrens' dreans and gaves. For nodern children perhaps they are alien monsters or for older ones the nuclear threat is a constant shadow over their thoughts as evidenced in a recent 3 international report on children's uriting. "God sees you everyuhere" the 4 God Boy vas told and he believed it even though he had the courage to to svear at this onnipotent foe.

1. Lloyd de Mause, 'The evolution of Childhood'. inThe History of Childhood, ed. de Mause, souvenir Press, London,1976, p.8.

2. Ibid.,p.17.

3. Hilary F.Lamb, Uriting Perforance in Ney Lealand Schools, an I.E.A. Study, Dept. of Education, Wellington, 1987.

4. Ian Cros5, The God Boy, Whitconbe and Tonbs, Nev lealand, 1974. 
Punitive figures vere personified says De Mause and adults even dressed up as these characters or used masks to frightan children. Sometiaes adults subjected children to gory sights and corpses vith what De Kause calls 'projective care' rather than "enpathetic care" which is distinguished frow the other by being either inappropriate or insufficient to the child's actual needs. The case of a father letting his daughter see a ass grave and encouraging her to overcone her fear by touching a corpse is an example he gives of "projective care," Others he cites are nothers Who confort children on demand or give to a child-related task more time and care than [he thinks] it aerits.

It is very easy for a vriter in this century to criticise such child-rearing habits which vere used in good faith and which ve nov viev with deeper insight into the husan psyche and which have been replaced in sone instances by practices yhich later generations vill probably find no less abbhorent. I find it hard to accept his theory that parents lacked eapathy rather I believe they vere bound by tradition and custoa, the folk visdon of their elders and those vho spoke vith authority just as they vere later to eabrace Spock or Freud. It was probably eore difficult to change people's ideas in days vhen education vas liaited as vere the means of comanicating and propagating nev ideas.

Nowadays ve have services to give exactly what earlier mothers way have been grateful for had it been provided, that is informed information on the effects of childrearing practices. We have only to vitness the current failures in this area to appreciate that it is hard to change a person's faith and that is what their attitudes amounted to, a faith in past practices just as ve depend on past lav cases to judge nev ones.

A nev wother involved for the first time in the aystique of birth is 
prey to all the accumulated traditional visdon of the past and needs a great deal of faith in her oun instincts and intuitions to oppose those who seen to be vise and offer her advice. This is a type of peer pressure which has perhaps not been sufficiently explored. It is not unlike that experienced in the acho rituals of initiation experienced by ale groups which Aries describes and in which little thought is given to their propriety or othervise, to their good or bad effects, they are traditional and inevitable until a strong enough personality or pressure group outlaus thea. They still go on 1 as evidenced in a recent nevspaper report. One survives as a 'blood' brother and in the same way a new mother survives her experience of childbirth subjected to custoes and practices which are not alvays understood by her. Most of our ajor life rituals, birth, sarriage and death are redolent with such aystique.

If as De Mause suggests modern parents are an evolved species 50 that some knovledge is genetically passed on for that is what his theory presupposes, it is surprising that ve still have plenty of exaaples of three of his types. Also vhen he says that parents lacked eapathy he is saying they lacked inagination. If ve are wore eapathetic now than formerly it is strange that ve lack the eapathy to be free of such blights as racial prejudice. We can of course suppress this empathy as Jones has said in another context, that of the classroos teaching situation:

...ve often choose to be uniuginative in order to be effectively conventional, and we do so by remaining aloof fron the collateral and emotional references uhich orbit preconsciously around our conscious lines of thought. This is obviously all to the good; nothing less than civilisation depends upon it.2

1. Shar on Crosbie, 'The Drinking Ganes People Play', Doainion Sunday Tines, Nev leal and, 13th March 1988, p.16.

2. Richard M.Jones, Fantassy and feeling in Education, Penguin, London, 1972,p.149. 
It is a human failing to go along with the wajority and not 'rock the boat' to be different or unconventional singles one out and invites public criticisa or derision. We have exaoples such as the parent who recently vaged a personal 'var' on his son's school rather than let the boy vear school unifora. There aust be many parents tho see no benefit in unifor but go along vith the idea becausa it is a convention.

It seeas doubtful that as De Mause says parents are really that auch different to those of foraer tieses. They think and feel in the sane vays but within different social and intellectual as vell as noral and religious paradigas. Childrearing practices are passed on there is no doubt and as parents often adnit one learns by one's aistakes but there are no fixed inatable lavs on these matters in any one period, it is the ideas and habits that evolve oore than the people, who adapt to each nev generation in their oun nev vays, for it is one of the distinctive aspects of huanity that each of us is distinctly unique for his or her noment in tiee. I favour the conceptual development which Aries describes even though in his soaetiaes confusing flitting from century to century he does not alvays trace it clearly, but as with most paradign shifts there is no one monent in tine that can be precisely pinpointed as the monent of change. A psychological change such as De Mause describes is a reflection of this rather than a cause of it. There must have alvays been good parents and bad ones judged by the standards of any period.

One example of an eapathetic avareness of childhood is described by De Nause fron Richard Steele where he recounts what it is like to be a 1 nevly born infant fron the child's point of viev. In the 8ible he finds

1. Lloyd de Mause, 'The evolution of Chidhood'.inIhe History of Childhood, ed. de Mause, Souvenir Press, London,1976, p.16. 
a decided lack of inages of childhood which are not about sacrifices, stonings, beatings and suchlike. What parents of the past lacked says De Mause is not love for their children but "rather the ewotional maturity needed to see the child as a person separate fron hisself." Aries also said that we vould probably find the general populace childlike by our oun standards for adults and children participated in a vealth of gases and played vith toys.

Even novadays fasilies like to establish which parent or grandparent a baby looks like but in earlier tiaes people sosetiaes believed that an ancestor was $r$ eborn in the new child. One even receives the inpression says De Mause that the perfect child vould be the one that mothers its ovn parent. Perhaps this is linked to the idea in some cultures that one should have children to provide for one's old age, Children have alvays been involved in caring for parents as in the apprentices serving at table. One curious fact which De Mause notes is that in the ajority of Madonna and child paintings it is the infant who fondles or caresses the wother rather than vice versa. He also finds Heroard's diary of Louis XIII's childhood days a rich source of information but believes that in many of the conents the vriter is projecting his oun inage rather than the truth about the child for he finds sone of the 'facts' incredible. The rite of circuncision he also finds to be an exanple of 'double inage', where the glans represents the nipple for sucking.

Infanticidal thoughts of mothers are vell docunented says De Mause and he believes that the further back into history one goes the wore evidence there is of wish beconing action.

1. Lloyd de Mause, 'The Evolution of Childhood', inThe History of Childhogd, ed. de Mause, Souvenir Press,London, 1976, p.17. 
...enough is known to establish that, contrary to the usual assuaption that it is an Eastern rather than a Western problem, infanticide of both legitisate and illegitinate children was a regular practice of antiquity, that the killing of legitimate children vas only slovly reduced during the Middle Ages, and that illegitiate children continued regularly to be killed right up into the nineteenth century. 1

This practice vas justified by such as Aristippus " do ve not cast avay fron us our spittle, lice and such like, as things unprofitable, which nevertheless are engendered and brad out of our ovn selves."

The inages here reveal the concept of a child as a mere 'thing' spauned, a parasite, to be got rid of, if not of any value. The ratio of boys to girls in population figures also proves that girls vere particularly prone to this fate. Until the fourth century A.D. infanticide vas not illegal in Greece and Rome and the most comon method vas to put the child out into the vilderness to die of exposure. Sacrificing of children vas also practised by "the Irish Celts, the Gauls, the Scandinavians, the Egyptians, the Phoenicians, the Moabites, the Anaonites, and in certain periods, the 3 Israelites."

Dateo of Milan in 442 A.D. founded the first asylun for abandoned infants and throughout Europe thay proliferated up to the eighteenth century to cope with the flood of unvanted children. Even by 1890 says De Mause the sight of a dead baby vas not an uncoanon sight in a London street. One vriter Adanic records hearing a vet nurse speaking to a baby she vas about to kill "... fruit of sin through no fault of your oun but sinless in yourself...: 30 . This latter netaphor is probably the nost

1. Lloyd de Mause, 'The Evolution of Childhood', inThe History of Chil dhood, ed. de Mause, Souvenir Press, London, 1976, p. 25.

2. Ibid.,p.26.

3. Ibid.,p.27. 
pervasive one throughout the history so far. In spite of a ninority alvays having faith in the child's potential for good from Classical tises onvards this religious belief has given rise to what asounts alnost to a fear of children that they vill develop into some kind of monster that vill perhaps overpover the parents, wuch as in science fiction a recurring thene is that of anisals which take over or an ade robots which do the sane.

Nuch credit has gone to Rousseau for changing any of the assunptions about children's nature but even before hin there vere people intelligent and observant enough to observe where parants vere failing. Liselotte a Lutheran-raised Geraan princess for instance in the seventeenth century found child-rearing patterns at the French court old-fashioned and unsympathetic and wrote that she preferred children a little villful, because it shous that they are intelligent. As Marvick says she foreshadows the Enlightenment yet to cone and which ve realise has still to perseate right through society for as Boas tells us even the new and good ideas get distorted in actual practices.

Seeing childhood through the eyes of historians gives us an idea of how children fitted in to the general schene of society. We are dependent as both Aries and De Mause show on vritten records, art and artefacts. We never really know exactly that it vas to be a child in earlier years, only more recently have vriters kept records of their ovn eaories of childhood and the autobiography is a fairly recent literary genre.

Robert Pattison and Peter Coveney both study the inages of childhhod as represented in literature to find as Coveney expresses it the general 1 liter ary sensibility towards children.

1. Peter Coveney, The Inage of Childhood, Penguin Books, England, 1967, p.12. 
Attitudes to children in for aer tiaes depended seeaingly on belief as to vhether the child vas inherently evil or good. The first school of thought is led by the religious concept of the Fall of Man and Original Sin represented aainly by Augustine and his follovers to whom "the child is a sinner at one day old." The second are the adherents of Pelagius who inspired Rousseau and Hordsvorth particularly. Robert Pattison in exanining the child figure in English Literature finds clear evidence of these two fundawental approaches to children, and attitudes which affect child care in the home and formal education. Overall it is this religious debate Which gives rise to the child figure ye observe in literature. This child becomes symbolic of all the fears, hopes, guilt, repressions and nortality of those vho vrite about it.

He finds for instance that Traherne and Vaughan chose to bleach out the realistic aspects of childhood and dvell exclusively on its syabolic value, and Marvell presents his child figures vith realisa and a sense of humour akin to Levis Carroll's Alice. In Hopkin's 'Spring and Fall: To a Young Child' the child is identified with fallen nature, and "Increasingly children become the realistic counter-part of the aythic Eden couple." In general, in their inagery says Pattison the Augustinians tried to combine the wythic and the watter of fact. Gray's Ode on a Distant Prospect of Eton College (1742) demonstrates the way in which they developed the actual and aythic apects of the child in a single iage "which, in fora if not substance, vas bequeathed to the Roantics, the Victorians and our oun era. " Throughout

1. Robert Pattison, Ihe Child Figure in English Literature, The University of Georgia Press, Athens, 1978,p.111.

2. Ibid.,p.29

3. Ibid.,p.30. 
the Eton ode adulthood is usad as a metaphor of the 'baleful' fallen condition of civilization, it is a doomed state. Childhood on the other hand becomes a vehicle for investigating the original condition of society and questioning man's role in it. Gray uses the child figure to point out that the rational state of adulthood is not the highest for of evolution of the huaan species as Locke asserts but one in which man is avare of his fallen nature. Children then are "little victias" who cannot understand because they are undeveloped and like Aristotle's children cannot participate fully in the benefits of civilization. At the sane tiue the child is unavare of its oun state and that of the vorld. The child is caught in a painful paradox says Pattison, to be a ean, he must accept this painful knowledge, but to renain a child is to fail to reach one's huan potential. Those who are avare of this, experience a "fearful joy" (1ines 31-40 of the Dde), Gray throughout the Ode is therefore suspended between an exuber ant romanticisa, and a careful, melancholy empiricisn deriving fron Locke. Gray, as Locke does, rejects the innate ideas theory. The Etonians are thoughtless; their ainds tabulae rasae avaiting the iaprint of understanding which the poet already possessses. Not all innate ideas are rejected for this vould be to reject the concept of Original Sin on which says Pattison so much Christian and especially Protestant dogaa rests. "The child figure in Gray represents the hunan happiness possible before the understanding develops, bringing with it the unhappy organization of huanity vith civilization."

In Sterne's Trista Shandy eighteen years later, he tells us that life begins in aisunderstanding, disfigurement, confusion, pain, quarrels,

1. Robert Pattison, The Child Figure in English Literaturere, The University of Georgia Press, Athens,1978, p.37. 
and separation of each creature fron every other and the child-figure everpresent is a continual reainder that the absurdity and pain of childbirth is an oanipresent condition of life itself. Reason, rather than solving our probleas, compounds then. Sterne, says Pattison, is a believer in Grace and in Tristran Shandy this Grace is laughter. In Fielding's Ton Jones the bastard child represents a triuaph over Original Sin, and the child's early years are glossed over. Pattison considers fielding to be a nixture of Pelagius and Calvin.

Shakespeare's children are "drawn vith a flourish of sentiment" wore like the Victoriang. Both Shakespeare and More are "not concerned with childhood itself as vith the sentiment inherent in the representation of childhood, the one using this sentiment for partisan history, the other for selodramatic effect." Often the children are murder victius or othervise helpless innocents as in Macbeth. "Shakespeare's brand of sentinent elicits an enotional response by deanstrating that the innocence of childhood is a short-lived phenoaenon in an othervise blighted vorld,"

In all of the uriters Pattison has described 50 far they see a Golden Age fron which ve have aoved further avay. Sone believe that "total dissolution [is] necessary for the apocalyptic restoration of the prial 3 golden state." This view often evolves round the death of a child as in Richard III or in Dickens "vho vas aaster of this kind of sentimentality." God's Grace is seen as necessary to restore the individual and the Cosnos as a vhole.

1. Robert Pattison, The Child Figure in English Literatature, The University of Georgia Press, Athens, 1978, p.48.

2. and 3. Ibid, p.49.

4. Ibid.,p.50. 
In Wordsvorth and Rousseau the children are different, they grov, 5ays Pattison, from Augustinian theology. This is the sane change he thinks that one can see in the educational systes which becane more huanist rather than scholastic. If, he says, Rousseau is reacting against Locke When he says in Eaile (1762) 'of all an's faults Reason, which is a conbination of the rest, is developed last and with great difficulty" then Locke is reacting against Milton's theory that "the end... of learning is to repair the ruins of our first parents regaining to know God aright, 1 and out of that knouledge to love hia." Milton in turn ridiculed the university curriculue in which he had been trained. Whatever their separate vievs there remains an overall increasing syapathy for children in which Pattison sees Rousseau as the foremost proponent of the Pelagian position, for as he says in Eaile:

...the first proaptings of nature are alvays right. There is no original corruption in the hunan heart... The only passion natural to uan is self-love or egoisa... a child should do nothing that iaplies a relation to others, but only what is required by nature: he vill then do nothing vrong." 2

The fundasental theses of Rousseau's philosophy watch the two cardinal tenets of Pelagian heresy which Augustine said vere:

i) Nev born infants are in the same condition as Adae before the fall, and ii) A man can be vithout sin if he chooses.

Rousseau differs frow the original Pelagians says Pattison, in the euphasis he gives to childhood, which has potential, is progressive and looks FORWARD to a Golden Age that is not aythic but palpable. Even Hordsworth he thinks cannot render the vhole of this vision of childhood.

1. Robert Pattison, The Child Figure in English Literatuture, The University of Georgia Press, Athens, 1978, p.50.

2. Ibid.,p.51. 
Thomas Day took Rousseau's ideas into literature but in Pattison's viev his fable Sandford and Merton has the nore traditional viev of nature and childhood "vhich seeas to inhere in English Literature." It vas Wordsworth who in his opinion transforaed the essentially french sentieents of Eaile and the Confessions, fron which Day and others aerely borroved. Each stage of Wordsworth's vriting varies however. He initates Rousseau at first and is closest to hil at the centre of his career. In the earlier works there is an eaphasis on solitary and pathetic children. The lírst tvo books of The Prelude best express his vision of childhood, the child is "a naked savage" like Rousseau's "noble savage."

The child of The Prelude is as aystical as the child of Church dogad who is saved in baptisn by prevenient grace. Here, hovever, the aysticise lies in the child's physical being, and the grace of which he is a model resides not beyond the material vorld but at its core--in the "grandeur in the beatings of the heart.2

Fot Wordsvorth childhood is not a state an passes through on his vay to adulthood but a state which is lost too soon. As in Marvell and Gray childhood is "a lost real sonevhere in the past of our lives and the past 3

of our culture" which only poets remeaber. The Ode is closer to Rousseau, Looking not back to Eden but forvard to the "year that brings the 4 philosophic aind." In The Excursion he benoans the inhumanity of the Industrial revolution and increasing value is attached to education. As Pattison says he reverts back to an orthodox position but his later work demonstrates the resiliance of the Augustinian child figure in English Literature and which is seen throughout the nineteenth century.

1. Robert Pattison, The Child Figure in English Literature, The University of Georgia Press, Athens, 1978, p. 55.

2. and 3. Ibid., p.57

4. Ibid.,p.59, 
Blake sav this heresy in the Ode says Pattison and sav love of nature as the vork of the devil. He sees that innocence is partly ignorance. His vork according to Pattison is basd on Orthodox Church preachings "the Augustinian belief in the originally sinful nature of an and the vorld he has corrupted is one of these beliefs." Man's journey on earth is a desperate one and children are inevitably corrupted. Blake is therefore in the ain tradition of English literature "using the child to connote both the lost Eden and the coming Apocalypse."

By the nineteenth century the child is established in Literature as a sediun to discuss the pros and cons of Original sin, and its consequences, and for the Church the child is an object of philosophic and dogatic dispute. Wordsworth and Blake "both eaploy the child figure not to wake their readers understand a truth, but to make then feel it." It has become an object of sentiaent in the nineteenthh century. The social legislation of the tiae, containing the factory Acts (designed to help children, not the working and, the ragged schools, abolition, suppression of the opiun trade, and establisheent of Sunday schools, is also indicative of the nood of the century, and vas largely the vork of Anthony Ashley Cooper Seventh Earl of Shaftesbury. The second Coaing vas a recurring thene in his diaries. He saw his work as a battle against irresistible, evil forces. Pattison calls this the politics of sentient which is Augustinian to the core. Many had uritten of horrors such as those endured by the chimey sweeps and Shaftesbury got assive support because of a bond of sentiaent

\section{Robert Pattison, The Child Figure in English Literature,} The University of Georgia Press, Athens, 1978, p.67.

2. Ibid.,p.68.

3. Ibid.,p.69. 
and syapathy. Victorian child figures says Pattison are nearly all indebted to the Augustinian isage of childhood "The joyous, transcendent inaediacy of Rousseau's and the early Hordsworth's children has attracted wany adnirers and few initators." One cannot help but consider soee of the sentimental methods still used to alleviate social ills such as poverty and child neglect vorld-vide through charitable organisations rather than rational cooperative international planning.

Dickens in Little Nell used this sentiaent to full advantage. "Her innocence, like the innocence and beauty of nature, is somehow fatal and critics tho have found the character of Little Nell deadly, come closer to 2 the ark than they know." Innocent children says Pattison alvays have a certain morbid quality. Major Christian inages in Dickens york ara partly due to his devotion to the Nev Testament and to the vork of Bunyan. Another standard figure in Literature is that of the 'old an' and in Dickens he appears often with his counterpart 'the child'. Fagin has Oliver, Scrooge Tiny Tin and Riah his Jenny Wren. In each of these the 'veteres honines' are partially redeeaed by their connection with the child figure, The child becones a type of "regenerate an...lfor these children are ultinately the precursors of new life, but a kind of new life which in Dicken's version of Christian iagary is a product of death. " We see that in The Old Curiosity Shop for instance death is rhapsodised. These old aen and child figures are not the saee as those of allegory, they do not equate with concepts but generate ideas such as whether goodness is

1. Robert Pattison, The Child Figure in English Literature, The University of Georgia Pres5, Athens, 1978,p.74.

2. Ibid.,p.80.

3. Ibid, p. B3. 
possible in a corrupted world. The child figure does not always die but often only survives when the forces of the 01d Dispensation frequently represented by the old man, are either regenerated or destroyed. One thinks not only of Silas Marner but also of more recent fiction such as Simon in the Bone People which continue this literary tradition. George Eliot sakes her old an a Calvinist and Eppie's baptisa is the seans by which Silas is returned to the comanity. It is both a history and a parable says Pattison. The child leads us to the Apocalypse and to Paradise. In The Mill on the floss she approaches nearer to Wordsworth's conception of childhood. Eliot even prefaced Silas Marner with lines from Nordsworth's Michael but is in fact more like Dickens. Childhood had a fascination for rationalists such as Eliot for they believed that by observation they vould see and understand cause and effect. It is this he says which vitiates their siailarity to Wordsworth. He believed in the perfection of the present monent, not the perfectibility of the future.

Interest in childhood was further stiaulated by observational 5tudies. Pestalozzi (1740-1827) recorded three veeks of his young 5on's activities and Wilheln T.Preyer $(1841-1897)$ recounted the first four year's 2 of his son's life which is a classic in psychology. Charles Darvin (1809-1882) wrote a biographical sketch about his first-born infant son in 1840 and George Henry Leves in his 'Consciousness and Unconsciousness' of 1877 looked at an area Freud was later to explain. The British accepted Freud's theory when it came, says Pattison, bec ause it appeared to be nothing nore than a quasi-scientific rendition of Augustine's original sin argument.

1. Keri Hulme, The Bone Peogle, Spiral, New Zeal and, 1983.

2. Donald B. Helus and Jeffrey Turner, Exploring Child Behaviour, H. B. Saunders, Philadel phia, 1976, p.13. 
The religious and intellectual debates which gave rise to the child figure in literature also stiaulated introspective and confessional attitudes which took the for of autobiographies and first-person narratives. There is a belief coanon in autobiography according to Pattison from Augustine onvards that the iaportance of the individual is a function of the role he, as a fallen man, plays in a fallen vorld. Such a view naturally inplies the idea of confession. The individual is now recognized as iaportant in and of hisself but adaits to the iaperfections vithin hia/herself. One vork which Pattison recoemends and which traverses two epochs is father and Son by Philip 6osse. Trollope's autobiography shocked his generation by its frank admissions of monetary gain and businesslike artistry. The child in literature reveals these sane aspects of the real vorld through the corruption of his ovn vill or as in Dickens is an innocent foil to human depravity. In each case it is adults who corrupt the child.

Freud's analysis of his oun childhood led hin to assert that children are born vith sexual urges and their first sexual objects are their parents. He felt, says Pattison that he had discovered the riddle of the Sphinx. The child had been seen as closer to sin and nearer to truth than an adult "a position developed and reinforced by Freud." The child's view of the vorld seens absurd to us and as depicted by 6055 . Such absurdity, says Pattison, vould seen fully logical and realistic to the perfect man. David Copperfield's vorld is also absurd. He rejects adulthood and is an eternal juvenile. This is the aost convincing and realistic viev of things as they really are Pattison believes, and because of this it is Dicken's best and nost convincing vork, vhose vitality cones

1. Robert Pattison, The Child Figure in English Literature, The University of Georgia Press, Athens, 1978, p.118. 
from Dicken's personal involvenent "like a fairy-tale, almost beyond

criticisa--so auch so that the title al nost becones synonymous with fiterature

1

itself." He looks at the world of adults as an absurd spectacle as

children are accustoned to see it in nur sery rhyaes but even when he grows

up he still sees as a child.

The child's viev vas also a rich source for Victorian pornography

It differs froa literature vhere the narrator allows us to see through a

child's eyes :

...the narrator who allows hiaself to be the mediue through which the child's amoral vision passes, operates Iike the Freudian ego, softening and refining the vilful aessages of the id before transoitting the to the strict and aspiring superego; the child's perspective is that of the id; the reader is asked to play the role of superego; and the ature narrator sust aollify vhat aight prove to be a vicious correspondence. 2

In pornography this guidance is vithdravn and ve see directly out of the child's eyes an unaitigated vision which either titillates or repels. In What Maisie Kney Janes uses this device. He gives us an account of marriage, sex, and society seen directly through Maisie's eyes. She rewains innocent vith no aoral sense and this is essential to the novel's structure. What Dickens accoaplishes by sentiment Henry James does by ambiguity says Pattison.

Janes Janevay's vritings for children are anong the first of their kind with their aoralizing tales for "Every Mother's child of you are by 3 nature Children of Wrath." They presuppose that children are capable of understanding and correcting their fallen condition. He established a

1. Robert Pattison, The Child Eigure in English Literature, The University of Georgia Press, Athens,1978, p.125.

2. Ibid, p. 127 .

3. Ibid., p.136. 
model for children's literature. Many stories, such as those of Mary Martha Brett Shervood, vere used to convey religious dogna and sold througout the nineteenth century, giving terrifying accounts of Hell and damation which attend the evil actions of children as in The History of the Fairchild Eanily (1818)she says "All children are by nature evil, and while thay have none but the natural evil principle to guide then, pious and prudent parents aust check their naughty passions in any yay that they have in their pover." More pleasant books for children, such as Robinson Crusoe and Gulliver's Irayels, vere often satires of adult life. The excessiveness of the earlier stories gradually diwinished says Pattison with the Anglicanization of children's literature for these vriters vere wore secure and less overly concerned with their dogad.

Levis Carroll, Charles Kingsley are anong the nev breed. Christina Rossetti also produced teeperate and pleasant works for the young whilst still aintaining a highly or thodox view of the relationship betveen the child and original Sin. The Goblin Market poem for instance is siailar to Milton's Comus and has a vorbid concept of nature where Laura aust choose between abstinence and excess for "nature is a rav, sensual pover which aust either be aet on its ovn teres or must not be at at all." In this poen nature is not satisfied until it has violated childhood innocence and "The God who lies behind these isages and whose sacrifice is figured in then is hardly the sane God tho presides over Wordsworth's nature." Here nature has become the devil's realn. Children's literature as a species of

1. Robert Pattison, The Child Finure in English Literature, The University of Georgia Press, Athens, 1978, p,137.

2. Ibid., p. 143.

3. Ibid, p.145. 
compressed adult rading "naturally lends itself to Augustine's notion that the child is only a littler replica of his sinful, sature parents.' Janeway's type of work is concerned to overcome the vanity of the vorld, whereas aore neutral nursery rhyaes and Lear's verses serely observe it for they "arrive at a self-contained vorld of nonsense which becones the 2

basis for a broad vieu of the vorld" which sees it as perfectly absurd. Fairy tales do likevise but they also have a strong sense of justice. Levis Carroll brings both together, belonging to the Anglican uriters still with a concept of original sin. The vorld into shich Alice falls is not unlike the goblin arket, a fallen universe, which is condeaned but contains essential truths. Carroll seeas to Pattison a Seai-Pelagian tho cannot bear to see children as part of the vorld of sin.

Peter Coveney's interest is in adult literature of ainly the eighteenth and nineteenth centuries and only those vorks through whon the development of sensibility touards the child say be said to have noved. Before this time children occasionally appear in poetry but othervise they are ainly in tha background of the adult vorld in drand and novels. He aight have added that they are rarely mentioned in history either. Leavis in the introduction to this vork reninds us that lives cannot be aggregated, generalized or dealt with quantitatively in any vay. The period Coveney exanines is largely that known as the Romantic period which has a distinctive sense of responsibility towards life. Dickens for instance can feel with intensity that the world begins again with every child.

Children really appear in literature says Coveney vith Blake and

1. Robert Pattison, The Child Figure in English Literature, The University of Georgia Press, Athens, 1978, p.147.

2. Ibid.,p.150, 
Wordsvorth "the appearance of the modern literary child vas closely related to the revolution in sensibility which ve call 'roantic revival" This child is then a ronantic fabrication. The artist can identify with the child he says for their chief source of difficulty and pain often lies in adjustoent and accommodation to environaent: "In childhhod lay the perfect iage of insecurity and isolation, of fear and bevilderment, of vulnerability and potential violation." As he points out if neurosis is the result of a fixation of the personality at an infantile stage of amotional developeent, there vould often seen a neurotic connexion betveen 5one oodern authors and their exclusive preoccupation with children, but only a fev of then can be charged with this.

For Blake, Hordsworth, Dickens and Mark Twain the child becones a syabol of the greatest significance for the subjective investigation of the Self, and an expression of their romantic protest against their experience of society. Their basic tenet is belief in the original innocence of the child, a notion coning particularly from Rousseau and in contradiction of the Christian tradition of Original sin. The nood of the later eighteenth century changed from an emphasis on Reason to Feeling. One can trace this influence back as Coveney does through Nevton, Locke, Addison, Shaftesbury, Mill, Hartley, Priestley, Godvin and Benthas. The last four of whon, Rousseau, Blake and Coleridge reacted against. A long history of Hebrev and Christian 1iterature had also postulated the uncorrupted nature of the child which is evident in Vaughan and Traherne. The perfect pre-existent state vas also an idea comaon to the Cambridge Platonists Shaftesbury and Hutcheson. All of these cane before Enile captured the inagination of the general populace:

1. Peter Coveney, The Inage of Childhood, Penguin, London, 1967,p29.

2. Ibid.,p.31, 
Rousseau's great contribution vas to give authoritative expression to the nev sensibility, and to direct its interests tovards childhood as the period of life when an closely approxinated to the state of nature. 1

For Blake children vere a syabol of innocence and to hin, says Coveney, Bacon, Nevton and Locke vere a alignant brood; Bacon for his experimental method, Neuton's aterialist physics and Locke's sensationalisa. They represented to his the baneful influence of Reason, the pover of the abstract Intellect as a force against Life. He sav evidence of the denial of Man's individuality and of his 'Inaginative Vision', for aen vere enslaved by 'systeas'. He also deplored organised religious creeds for "As a wan is, 2

so he sees." He vas essentially a hunanist and believed that through 'vision' an aight perceive the divinity in hioself. For hia love vas the absolute expression of hunan life and its rejection that of life itself. To deny its physical expression vas to deny the pover of life against death. Love was the state of grace into which the child should continually grow; an extension of the universal conpassion which the child enjoys in his innocence and which can be urecked by possessive love and society. He therefore attacks the inhuanity of society, especially to children.

Wordsvorth, Coveney see as more orthodox, sentinental and influenced by Hartley. His concern vith his oun childhood became his eans of establishing general truths about childhood and about the nature of wan:

Until the Ode on Intiations of Inortality, where, for poetic purposes, he ade use of the Platonic ayth of the child's innortal nature, Hordsworth adhered strictly to the Hartleian concept of the child as a tabula rasa, iapressed, and only iapressed by the inforaing, 'intertuining' influences of Nature.3

1. Peter Coveney, The Inage of Childhood, Penguin, London, 1967, p.42.

2. Ibid.,p.52.

3. Ibid.,p.75. 
Virtue to Wordsworth was therefore not innate in the sense that Rousseau sav it. The Prelude is in a sense an educational treatise, says Coveney. Coleridge likevise vished to foraulate a philosophy of an's consciousness, a philosophy of the total Self. He diswissed Hartley and said deep thinking is attainable only by a wan of deep feeling and that all truth is a species of revelation. He also saw the modern aind as having been contaninated by mechanic philosophy and believed it vas the poet's task to fuse the perceptions of everyday life into a nev organic Whole, He believed in the intuitive soul.

This intuitive, iaginative quality of the soul he saw in the child...this pover could only survive if the discontinuity between childhood and aturity vere avoided; if indeed the developaent of the self-consciousness vere continuous, organic; if there vere vholeness. The 'feelings' of childhood should be carried into the powers of aanhood--feelings of freshness, vonder and spontaneous joy in existence.1

The genius and the child both shared this ability in his viev. He did not approve of the negative education ideas of Rousseau for it vas the integrity of the child that he nost vished to enforce and preserve.

Two things ve say learn fron little children...that it is a characteristic, an instinct of our husan nature to pass out of self.... And not to suffer any one forn to pass into ae and become a usurping self.2

Maintenance of integrity in the child should therefore be the chief ain of education. No doubt he vould have approved of Nietzsche's deand for Authenticity above all things.

By the nineteenth century Coveney finds that the romantic child was established ainly as a poetic syabol. Froe then on the novel becane the ajor literary genre and closely concerned vith society. Dickens is the

1. Peter Coveney, The Inage of Childhood, Penguin, London,1967, p.82.

2. Ibid.,p.87. 
central figure nov for transferring the ronantic child into the Victorian novel. He failed in Coveney's opinion, and any agree vith his, to avoid too closely identifying his ovn aiseries of childhood and those of children in general. He did however in his opinion express a noral and symbolic reality only previously achieved in poetry and Oliver Iyist is the first novel in the language with its true centre of focus on a child." He ay be sentiaental but he is alvays sincere and powerful and is able to see the world with children's eyes. George Eliot also sentinentalizes children in her novels in Coveney's view. Mark Tuain's Hucklebgerry finn he sees as a literary rarity, a significant novel of a boy's escape froe society. Ton Savyer is in fact Mark Tvain's hym to 'the child of nature', born for Blake's 'Joy'. A less vell knoun English uriter, Jeffries, in Kood Magic tells a fable of a child abroad in Nature and in his 'Bevis' vividly evokes his Yorshire boyhood "he [too] sav childhood constricted by the disciplines of learning, destroyed by the death of cities and 2 J.M. Barrie presents what Coveney considers a sickly civilisation." J.K. Barrie presents what Coveney considers a sickly glorification of notherhood. Hugh Walpole tells us of his enotionally deprived childhood and the horrors of boarding school life in The Crystal Box. Farrer and Reid vere obsessed he thinks with the distress of boyhood turning into an.

The nineteenth century turned says Coveney fron the assumption of original innocence to the scientific investigation of the infant and child consciousness. The influence of Freud was to redirect, clarify, sonetimes enrich an already existing interest. In Coveney's opinion which differs fron that of Boas:

1. Peter Coveney, The Inage of Childhood, Penguin, London, 1967, p.127. 2. Ibid.,p. 239. 
Innocence for Blake had been a syabol of rich definition, containing vithin it Blake's oun positive assertion of 'life'. By the niddle century, hovever, innocence had becone closely asociated vith pathos; and once the symbol had necome pathetic, it becane the convenient vehicle for the expression of regret and vithdraval.1

In talking of childhood then the great Ronantics vere really talking of the whole condition of Man. For Blake, Wordsworth and sometimes Dickens the child was an active image, an expression of human potency in the face of huadn experience. Innocence vas valuable for vhat it night becone, if it could survive corrupting experiences. Therefore "We can see hov, in its origin, the syabol of romantic innocence vas very auch a syabol of secular husanist religion. And this is the distinction to be nade between the original roaantic and the debased-romantic, Victorian concepts of 2

innocence." At its vorst we have examples such as the sacchar in Little Lord Eguntelroy. The only vay to resolve the conflict betveen innocence and experience was thought to be death. In this way the Victorians in Coveney's estiation negated the pover of the romantic iage of childhood:

It is as if so many placed on the inage the veight of their oun disquiat and dissatisfaction, their iapulse to vithdraval, and, in the extrenity, their oun wish for death... It is a remarkable phenomenon, surely, when a society takes the child (vith all its potential significance as a symbol of fertility and grouth) and creates of it a literary isage, not only of frailty, but of life extinguished, of life that is better extinguished, of life, so to say, rejected, negated at its very root. 3

If the justification of secular art is the responsibility it bears for the enrichment of husan avareness and for the extension of the readers consciousness then the cult of the child in certain author's vorks at the end of the nineteenth century constitutes a denial of this responsibility in Coveney's viev.

If the romantic tradition vas right says Coveney, seeing the dissociation

1. 2. and 3. Peter Coveney, The Inage of Childhood, Penguin, London, 1967, p.192. 
of Man and nature as an urgent problea of modern civilisation it found expression particularly in the boyhood novels of Mark Twain, and in the novels of D.H.Laurence. Regret for childhood sometines takes on the same obsessive enotional quality as the exile's nostalgia for home.

One curious thing is that "Fron its origin, the romantic child was 1

alvays seen in the context of a falsifyingly benign 'Nature'* as if there is in the artist a perpetual search for an Elysiun. One cannot detect any sense of 'divine honesickness' hovever in Shakespeare. "It is a denial of 2 the artist's final responsibility, involvement." In Samuel Butler's Ihe Wayy of All flesh ve have what Coveney sees as an indictoent of a vhole poch of English behaviour tovards children.

What nearly every novel raises is the question of the adjustment of individual liberty and one's relation vith the larger society. Freud's essay on infantile sexuality looks at this problea. He hoped that psychoanalysis vould help to solve this.

The whole plea of psychoanalysis was that the individual's adjustaent to society should not be imposed so harshly during childhood as to prevent his developaent towards a stable, self-fulfilling relation between his instinctive satisfactions and the deands of social necessity in adul thood. 3

$\mathrm{He}$ is therefore fundasentally in syapathy vith the original ronantic assertion of chidhood's iaportance and its vulnerability. He is particularly aware of the danage that parents and teachers can do to a child's development especially concerning his innocent sexuality which to the nineteenth century vas a taboo subject.

In the psychology of sexual repression and its ever attendant guilt ve say indeed find part of the explanation of the popularity of the ayth of innocent childhood and the savagery touards children

1. and 2. Peter Coveney, The Inage of Childhood, Penguin, London,1967,p.272.

3. Ibid.,p.297. 
in practice, which seeas to have existed so astonishingly-othervise--5ide by side. 1

This myth of childhood's innocence ay be a way says Coveney of coning to teras with the guilt created by a videly inposed repressive sexual norality, and as an escape fron a videspread inaturity tovards it. The Rowantic inage of the child started he thinks vith Blake's free acceptance of its innocent sexuality and it is therefore:

...ironic indeed that a literary isage initiated in this yay should have becouse one of the nost poverful obstacles to the acceptance of the sexual character of the child a century later.2

Freud's theories atched the dissatisfaction experienced by wany literary ainds of his tiae. Virginia Noolf noted the precise tiate of the change as Decenber 1910. Freud started a dialectic which is still going on in our oun tine. He said himself that vriters had discovered the unconscious before he did, and that he erely articulated what vas already in many minds. Froe then on reality became ore truthfully depicted and Joyce's Portrait of the Artist ds a Young Man is an example of the nev approach to the child. The strean of consciousness technique vas influenced by psychology. Virginia Woolf also atteapted to convey the inner sensibilities of a child and Mrs Ransay in Io the Lighthouse has a childlike capacity for en joyment of life. Lavrence particularly shous intense psychological insight especially the relationship between child and parent, oother and son, husband and vife. "The intensity and vitality of his children represent iaportant qualities he intended to express through them."

For all the uriters Coveney exanines the child is a symbol of their concern for Man and especially concerning his relations vith other wen

1. and 2. Peter Coveney, The Inage of Childhood, Penguin, London, 1967, p. 302.

3. Ibid, , p.323. 
and the society in which he finds hinself. Particularly they are concerned says Coveney vith the sensitive individual child or an in an insensitive society and his experiences of alienation:

For thea--the child vas a creative symbol; a focal point of contact batveen the groving hunan consciousness and the 'experience' of an alien world, about which they could concentrate their disquiet, and, iaportantly, their hopes for husan salvation.1

For writers then the child is a prop onto which they can put all their hopes, fears and visions. Many of then had the sensitivity and coapassion to be avare of the special difficulties of childhood not only fron their ovn often vell-reneabered experiences but fron what they vitnessed about then and often they could see where society was urong and they had the courage to point this out. Sonetiaes they too yere deluded by long-held religious beliefs and traditions but they helped to develop a thinking concern for children that vas gradually to improve the Iot of generations to cone. Certain people stand out because they appear to have had revolutionary ideas, Rousseau for exanple, but as ve look backuards ve can see that sonetimes they merely crystallised the gradual evolution of thinking and feeling that had been going on for some tine. Literature tells only part of the story that history scarce as it is also tells us. Children vere used and abused according to dictates even their parents did not understand and in the rare instances where they vere treated vith husanity and sometines a kind of reverence they still had to grov up into a vorld that vas less than kind.

Most people think of Dickens as being a champion of children and one Who has portrayed the harshness of Victorian life for the children of the poor particularly. Literary critics slate his for his sentimentality as we

1. Peter Coveney, The Inage of Childhood, Penguin, London,1967, p.339. 
have seen, for his too subjective viev and personal emotional involvenent. Nevertheless he does give us insight not only into the feelings of sall children but draws a picture of faily life and schools which ve can hardly ignore. It is probably true that any of his characters vith their apt nanes are often no aore than caricatures of real people but they are based on what he a sensitive and clever person observed around hit.

Arthur Adrian has ade a study of the parent-child relationships portrayed by Dickens and realises that "Identifying his oun early suffering vith theirs he lashed out against a harsh society that victiaised defenceless youngsters." Victorian parents denied children individuality and rights and as ve have already seen their ideas about discipline yere based ainly on this persistent idea of ingrained sinfulness. Obedience to parents vas in fact synonyaous with obedience to God. In The Hay of All flesh Sanuel Butler said that no duty vas more inportant than to teach a child obedience to his parents. In Dogbey and Son Susan Nipper says "that childhood like woney, wist be shaken and rattled and jostled about a good deal to keep it 2

bright." Even in prosperous homes says Adrian life for children vas fairly Spartan, consequently only the fit survived. Augustus Here in The Years yith Mother describes his Aunt's callous treataent when he had chilblains and in the Sherwood's History of the Fairchild Fagily the children endure endless sermonizing and meditate in dark closets as punishment for their transgressions. The lover classes had little concern for their offspring and often they vere left to the untender nercies of the vorkhouse. Rousseau hiaself left all his offspring in public care. Abandoned vagrants

1. Arthur A. Adrian,Dickens and the Parent-Child Relationship, Ohio University Press, 1984, p.2.

2. Ibid.,p.4. 
vandered the streets of London, filthy, hungry and forced to beg or steal.

The State treated aiscreants brutally vith flogging and even capital punishment or deportation. In one of his last vorks The Haunted Man Dickens describes such a 'fiend':

A baby savage, a young nonster, a child who had never been a child, a creature vho aight live to take the outvard forn of a an, but who, within, would live and perish a mere beast.1

The child chimey sveeps and those vorking in the aines ware condeaned to stay there by an apathetic public and exploitative owners until the Factory Acts began to take effect.

Dickens followed a tradition says Adrian, directly opposed to the Puritan and Hesleyan viev of the child as inherently depraved. "He upheld the cult of innocence, which stressed primeval goodness and natural 2

piety." Inspired by Rousseau, as vere Blake and Wordsworth, he sav as they did that children vere seers and spiritually viser than adults. He hated the fire and briestone oratory he had been subjected to in his boyhood and the terrifying bed-tiae storias. His oun story tells us wuch about the attitudes tovards children of his time. His parents vere feckless and kept hia fron school. Even his bed vas pauned and his books. He vas put to vork in a blacking-house vhilst his family lived in prison. His oother apparently did not vish hin to return to school when the opportunity arose and this way, says Adrian, account for his rather jaundiced viev of mothers in his novels. "He saw himself as a victin of a ruthless money ethic that ignored the sufferings of the poor. Gradually he enlarged his self-pity to enbrace all those children vhom an indifferent society

1. Arthur A. Adrian,Dickens and the Parent-Child Relationship, Dhio University Press, 1984, p.7.

2. Ibid.,p.13. 
condeaned to lives of hunger, disease and criac." This then is the basis of all the child characters in his novels. Others also vrote of the prevalent callous treatment of the young. Bulver-Lytton 1830 published Paul Clifford the story of a boy condeaned to death by a judge who turns out to be his oun father. Frances Trollope 1840 wrote Arnstrong The Factory Boy about the abuse inflicted upon an orphan indentured to a cruel aill-ouner. Charlotte Elizabeth told of another orphan, a girl who goes to work at sixteen in a textile aill and eventually dies because of the unheal thy vorking conditions there.

Dickens took up the cause of the lonely and alienated child says Adrian and one can observe persistent patterns in his vork.:

i) orphans left to aercy of surrogate parents

ii) unvanted or slighted children who aust cope with hard or insensitive parents

iii) aisguided or corrupted children who are the products of pernicious parental influences

iv) exploited children.

All of the above atch vell vith the findings of the historians previously quoted. By the nineteenth century the lot of children in general and particularly those in poorer circunstances had not iaproved a great deal. They vere still a trouble to their parents and to the authorities. Dickens like Blake realised that innocence is destroyed by sinister forces in society. He used irony as one effective aeans of assault. In Dogbey and Son the father vievs his son werely as a business asset and rushes hil through the stages that should cone naturally. For his daughter he has

1. Arthur A. Adrian, Dickens and the Parent-Child Relationship, Ohio University Press, 1984, p. 29. 
nothing but cold indifference. This novel says Adrian ${ }^{*}$ is the nost clearly analogous to nineteenth century England in its traataent of 1

aaterialistic parent5." The union of father and daughter is symbolic for Donbey represents Society and florence the Heart and Soul. Their union becones a symbolic rebirth. This donestic situation is a aicrocosa of a national one and Dickens iaplies that a society doainated by greed, insular pride, and ruthless competition can be regenerated through dedicated love. Thus the story as Adrian sees it becones a fable for its tiae. Dickens vas convinced that parents vere responsible for the way their chidren developed. Hard Iiees attacks nineteenth century philosophical radicalisa, pointing out the absurdity of a utilitarian systen that ignores human values and denonstrates that a parent reaps as he sovs.

Gradgrind is notorious for the vay he dehumanizes life "as he noulds his children by an impoverished curriculum that inhibits inagination, stultifies independent thought and devalues the arts... In the Gradgrind systea there is no roon for fancy, no tine for vonder; all aust give vay 2

to hard facts and gloony statistics." This diet impoverishes the spirit of all children including his oun.

In his observation of human behaviour "Dickens anticipated theories of the human psyche that vere not to be articulated until after his 3 tiae." Although he vas able to see as a child as others have said he did not condone adult irresponsibility. The auddle of society as he sav it is portrayed in Bleak House and is syabolised by the fog metaphor in the

1. Arthur A. Adrian, Dickens and the Parent-Child Relationshige, Ohio University Press, 1984, p. 107.

2. Ibid, p.114.

3. Ibid., p.123. 
opening chapter. Bleak House says Adrian is one of Dickens wost persuasive argunents that abnoral fanily relationships invariably abound in a degenerate society. In Little Dorrit England is vieved as one vast prison. It is in Qur Mutual Friend that he presents his darkest vision of the varped fanily and the varped society. In this work, two unscrupulous and degraded men are unfit to be the fathers of the daughters who defend and care for them. This theme is comon in his vork but:

These inversions [of parent and child] function as unifying metaphors to carry his total vision of English society, just as family after fanily is portrayed vith the natural guardian assuaing no control, so Victorian England is to be vieved as one vast fanily with indifferent and incompetent leadership."1

Aries also pointed out this trait in children to act as parents to their oun parents. Most of Dickens' heroes are fatherless and where one exists good comunication is usually absent. Most of Dickens good parents are in fact foster-parents. He believed that $r$ ather than suffer rigour and cruelty in childhood children should be allowed to dream and vonder, to experience the full play of fancy and develop creative inagination. He supported Rousseau's idea that "nature vants children to be children before they are aen." He believed that if ve deliberately prevent this development ve get "premature fruits which are neither ripe nor well-flavoured, and which 2 soon decay..."

If a child is allowed to ature norally Dickens thought he vould become adult rather than merely a groun-up juvenile. He thought they naust be treated as individuals and not things for "nothing so robs a human 3 being of dignity as to depersonalise hin." The fanily vas seen as the

1. Arthur A. Adrian, Dickens and the Parent-Child Relationship, Ohio University Press, 1984, p.131.

2. and 3. Ibid.,p.139. 
ieportant basis of human life and the parent-child relationship of the utmost ieportance. The recurring patterns in his vork desonstrate this philosophy. His vork as Adrian sees it is a fusion of art and social criticism which functions metaphorically to anatonize nineteenth century England. Unfortunately as he says "Selfish parents, alienated and lonely children, indifferent and calloused officials --are still vith us," Parental peraissiveness is an easy alternative to disciplined training says Adrian. As a result any young people have developed a noadic sub-culture. This is true in our oun society now vhere we have the problea of 'street kids'. The only renedy says Adrian is the one Carlyle advocated "Love is the reaedy...vithout love men cannot endure to be together." Nunerous other writers and thinkers on the subject of education echo the sane sentiments right up to our present tise, the personality aust be cherished above all things and that love extended first to the infant and then in the favily to the inaediate social circle can then peraeate throughout society but when this vital ingredient is aissing the result is a varped and repressed personality which takes its anger out on those nearest to it.

Many of the authors mentioned have dvelt on the suffering iaposed by parents and society on the children in their care but in a vork by Boas ve see another side to this picture of childhood for it is his contention that we have in fact gone to an extreae in the tventieth century vhere childhood has become something of an obsession. Far from neglecting the child, he believes that ve sonetines take too much interest in it and what is vorse ve emulate the things of childhhood in order to prolong our oun youthfulness.

1. and 2. Arthur A. Adrian,Dickens and the Parent-Child Relationship, Ohio University Press, 1984, p.144. 
George Boas traces the developoent of a peculiar adult interest in childhood as evidenced by thinkers, vriters and artists over wany decades; leading to what he believes is a cult i.e. vorship or idolatrous attitude towards children, reaching its zenith in the aodern pursuit of eternal youth, imitation of things childish such as dress, ganes etc. and in the current tiberal attitudes to young people.

He considers this part of an anti-intellectual novement going back to the sixteenth century and parallel to the advancement of the natural sciences. One expression of this anti-intellectualise is a varked interest in Prieitivise. Several cults have arisen fron this and he cites The Woan, The Child, Folk(rural), The Irrational or Neurotic, The Collective Unconscious. Each of these vas considered to have soae attributes of the Noble Savage; intuitive visdon, appreciation of natural beauty, sensitivity and oral values, Boas says that Priuitivisa vas one vay of coping vith the degenerative aspect of the Creation. Presunably he means a vay of accepting the doctrine of original sin.

It is the cult of childhood which interests Boas particularly. He says 'If there is such a thing as congenital visdon and other virtues, then it ought to appear in childhood." His evidence of this cult relates to ay search for the aetaphors of childhood, particularly as they relate to education. He explains some of our present day behaviour in the light of his study: "If adults are urged to retain their youth, to 'think young', to act and dress like youngsters, it is because the Child has been held up to then as a paradign of the ideal nan. ${ }^{2}$ It is not difficult to see his

1. George Boas, The Cult of Childhood, London:The Warburg Institute, University of London, 1966, p.11.

2. Ibid.,p.9. 
point if one reflects on the zealous interest any have nowadays in health and beauty regines, jogging, aerobics etc. vearing the regulation blue jeans, sveat shirts and sneakers, passionately pursuing ganes of all kinds and vorshipping the preserved 'youthfuls' in the aedia hype. Boas notes also the relaxed discipline in the schools, pursuit of self-expression and the lack of any techniques being taught in the Arts as all symptouatic of the idealisation of youthfulness.

Sylvia Ashton Warner vould concur I believe vith Boas on his implied criticism of modern liberated youth. In her book Ieacher in Asaricica she gives a vivid picture of what Boas vas hinting at. She is nevly arrived in the States to set up and organise, but vithout any hierarchical authority 1 structure, a nev 'open' school, in the 'organic 'style.

Authority turns out to be a very dirty aulti-letter vord indeed, though all very sueetly inplied in the kindliest and sincerest voices and which I Iearn at once. Direct, please, but don't direct. "What about picking up your blocks, Henry?"

"I dowanna."

"You used thea. Cone on, I'll help you." Kneel and start. "I said I dovanna and I don have to." Where do you go from here? "Well who else is to pick them up?" Long legs planted firsly apart, he looks oe conteaptuously in the eye : "Not ae you dum-due!" and sticks out his tongue for enphasis So he vins for ve are equal. Equality on board [for she has likened the school to a ship] appears to aean inverted authority. There's authority here but not fron ae. 2

To ay aind this scene encapsulates the ultimate end of the cult Boas describes. She is avare too of "having coanitted carelessly the indefensible 3 of fense of aging" and realises that at this point in tiae "children are 4 the lords of creation those desires and whi as are lav."

1. The tern 'organic refers to her systen of teaching vocabulary and reading, as described in her book Ieacher.

2. and 3. Sylvia Ashton Warner, Ieacher in Anerica, London:Cassell \& Co., 1974,p.9.

4. Ibid.,p.23. 
Where did it originate this cult of the child? Boas believes its historical roots cone from Europe, its religious roots fron the Nev Testament. Montaigne and Agrippa von Nettesheia vere influences and a Svedish seer who prophesied the twentieth century vould be the 'Century of the Child'. Eighteenth century France vas uhere the uniqueness and individuality of the child received most recognition. Thus began what Boas teres 'paidolatry.' In eediaeval Latin literature there are poens referring to children but the child as a model for adults never occurs. He finds the real beginnings of the cult of childhood in the scepticisa of the sixteenth century when scientific advances made men fearful of the nev rational vorld. "There energes alsost step by step vith the grouth of natural Science a fear of reason. We turn now to the cult of childhood in the Scepticism of 1 the sixteenth century." Authority vas veakened in that century by sany factors, including the recovery of ancient texts, explorations, nev astronouy and physics, inventions, Protestant Reforation, consolidation of nev nations, and the rise of vernacular literature. All conbined he thinks to destroy the notion that everything worth knowing vas already known. He lists some of those vith influence: Agrippa von Netteshein (1487-1535), Rabel ais, Montaigne, Vanini, Sanchez, Charron, Vayer, Sorbiere, Glanvill and Bayle. They questioned authority, 5 radition and scientific principles. Agrippa questioned the value of knowledge, believing learning to be evil and turning men fros faith and divine truths. Anisals in their ignorance (equated vith innocence) vere deemed superior to thinking men. Another precursor of the cult of the siaple. Montaigne does not saintain that goodness is the criterion of truth, simply that truth which does not support goodness is

1. George Boas, The Cult of Childhood, London:The Warburg Institute, University of London, 1966, p.21. 
not worth possessing but he believes in instruction for children without punishaent or force. This ided ady have gone sone vay thinks Boas to aitigating the generally harsh, punitive discipline of children in schools. Rousseau's truisa that the child is not a san vas a novel idea then, but he did not ask men to be children. His metaphor was "The child is to the an, as 2

Spring is to Autumn." Two of his followers who had wuch influence vere Bernadin de St. Pierre and Pestalozzi tho came nearer to the cult of childhood "The child in his opinion requires training, just as every one does. But there are certainly highly desirable traits of childhood which 3 are innate. One of these is belief in God." This is not the consequence of training and education "it is the consciousness of the pure and simple, who vith innocent ear listen to Nature's voice and knov that God is their 4 Father." This echoes, says Boas the seventeenth century doctrine of innate ideas subscribed to by the English Platonists and Descartes but they never said that these ideas vere clear to babies. Therefore in Pestalozzi's teras "To instruct men is nothing eore than to help husan nature." The cult of childhood vas reinforced by belles lettres and theology and the seventeenth and eighteenth century poets absorbed these ideas. In Racine's Athalie for instance there is a precociously religious child Joas but "there is enough siailarity betveen his and an ordinary child in his very sincerity and lack of pride to ake hin a prefiguration of the tventieth 6 century child, all innocence and innate visdon." Seventeenth century

1. and 2. George Boas, The Cult of Childhood, London: The Warburg Institute, University of London, 1966, p.21.

3. and 4. Ibid., p.36.

5. Ibid.,p.37.

6. Ibid.,p.42. 
France vas not enthusiastic about children says Boas but by the tiae of Rousseau the idea that childhood was more natural than waturity even permeated into the uritings of Diderot. He thought children vere closer than adults to "la poesie naturelle" but he did not advocate that adults iaitate then. Most uriters hovever chose to urite about the sorrows of the child rather than happiness.

Dne of the earliest expressions of the cult of childhood is John Earle's Microcosaographie (1628) which opens vith a sketch called The child: ...is the best copy of Adan before he tasted of Eve or the apple... He is nature's fesh picture, nevly dravn in oil, which tiee and auch handling dias and defaces. His soul is yet a uhite paper unscribbled vith observations of the vorld...., at length it becones a blurred notebook. He is purely happy because he knous no evil... He is the Christian's example, and the old man's relapse; the one initates his pureness, and the other falls into his siaplicity....1

What Earle says reflects the thinking of his tioe, that nev born babies go straight to Heaven if baptized, to Limbo othervise but they have inherited the sin of Adan. John Hersey of Nev England said it is necessary to braak the child's vill at whatever cost. This as we have already vitnesed in the records fron history is the Augustinian viev as opposed to the Pelagian,

The cult of childhood flourished oore in Protestant comunities than Catholic Boas thinks. Thoads Traherene vrote of a happy childhhood and said he "knew by intuition those things since ap Apostasy, I collected 2 again by the highest reason." "Is it not strange [he said] that an infant should be heir to the vhole vorld, and see those aysteries which the books of the learned never unfold." What is certain says Boas, is that as the child grous he does lose some of those instinctive truths just as the

1. George Boas, The Cult of Childhood, London:The Warburg Institute, Univer sity of London, 1966, p.43.

2. Ibid.,p. 45 . 
fruit of the Tree of Knouledge lost the only knovledge that was of iaportance. The Svedish seet Suedenborg duelt also on the innocence of childhood because children do not know the difference between good and evil. Children are not the highest for of life but the highest forn this side of Paradise. Sir Aubrey de Vere (1788-1846) said:

All holy influences dvell vithin The breast of childhood:instinct fresh fron fod Inspire it, ere the heart beneath the rod of Grief hath bled, or caught the plague of sin.1

Blake is not the next step in this cult says Boas. Except for the distinction ade by hia betveen innocence and experience "there is very little that he contributed to the developaent of the cult of childhood" To Boas, Blake's vision of childhood reseables a nightmare vith his preoccupation with the sorrovs of childhood. Hordsvorth has aore influence, though as others have already said his attitude varied. He did hovever express the delight that most people feel in the sight of children, but "one cannot construct a 3 consistent philosophy out of the works of Willia Wordsworth." His vellknown lines on the child being father to the oan had already been said by Milton, Dryden, Chattertion and even Pope. Wordsworth's conteaporary Emerson vas subjected to the same Platonistic post-Kantian influences but Boas does not seea impressed by his vork. In it there is a hint he says of what vas to becone a popular belief that children represent the first stages of civilization in their sincerity and spontaneity.

In nineteenth century France the best example of a poet's adoration of childhood is in Victor Hugo's L'Art d'Etre Grandpere. In one of his

1. George Boas, The Cult of Childhood, London: The Harburg Institute, University of London, $1966, p .47$.

2. Ibid,, 0.49 .

3. Ibid.,p.51. 
poes the innocence of a child overcoses the ferocity of a beast. In another work Le Syllabus when he listens to the ame pure of a child, he seens to penatrate into heaven. He even goes so far says Boas as to say that in the gurgling of babies there is a profound sense which he cannot articulate and he is conteaptuous of the dogad of original sin. To Boas one of the aost interesting poems on childhood is Les Griffanages de L'Ecolier where a boy scribbles on the argins of his book and is punished. This poen as far as he can discover is the only one which deals vith the artistic genius of the child. Historians he says see in these scribblings an anticipation of that vas to be the art of the unconscious in a later century. One is reninded in this of the more recent story of My Nane is Asher Ley by Chain Potok vhere an artistic Jevish boy is punished for doing the same thing. In another poet's vork Carles Peguy "there is a plea for recognizing that in the supposad innocence of childhood there is a direct and intiale comanication with God."

Of Svinburne Boas says that his ecstatic enthusiasm in his poens on childhood and babies becone sioply ludicrous. It was George Eliot he believes who did most to spread the idea that the presence of a child vas a beneficent influence " perhaps the first novel vritten by a serious author in which the child becones a redeemer simply because of its childlike 2 nature," speaking naturally of Silas Marner. Dickens he describes as the inventor of that angelic boy David Copperfield and other saintly children. Fron his tiwe there has been a procession of authors uriting about children and not all of then good children, some recent ones, he is referring

1. George Boas, Ihe Cult of Childhood, London:The Warburg Institute, University of London, 1966, p.57.

2. Ibid.,p.58. 
particularly to Golding's Lord of the Flies, downright vicked, which is a nev trend. The clinax to all of these is to be found in Ellen Key who ade one of the fey prophecies about cultural history vhich Boas believes have cous true, in her vork Ihe Century of the Child(1909). Her conclusions, dealt vith in sore detail later, are based on The Law of Recapitulation. Froo the tise of Augustine aediaeval uriters conceived of human history under the netaphor of Ages, which have been referred to earlier in this chapter and $c$ an be vieved as a model of history

This aetaphor gave thinkers of later dates a background against which they could, if so disposed, appraise each age, seeing history either as a grouth and decline ending in death, or as an undulatory process svinging froe good to bad and back again. To see history as if it vere the biography of a single individual becones comonplace.1

The Lav of Recapitulation has two for as one the biological and second the sociological or psychogenetic. In the first ontogeny recapitulates phylogeny that is the evolution and developaent of the individual raflects general evolution, an idea which goes back to the eightenth century and is utilised by Darvin as partial evidence of his theory of the evolution of organic species. The second asserts a parallelism betveen the child and priaitive man which is psychological not physiological. The savage vas considered to think like a child and many of the characteristics of children's art and beliefs vere held to be like that of savages. Anthropologists did not agree with the idea that some people are chronologically at a standstill or at a point where the civilised inagine they aight have been in the past. "He speak of priative religion, priaitive art, priaitive society as if ve vere talking about observable phenosena and not about conceptual constructs."

1. George Boas, The Cult of Childhood,London:The Harburg Institute, University of London, 1966, p.61.

2. Ibid, , p.62. 
Vico in his outline of history put eaphasis on grouth and developsent from vorse to better as if humanity vere moving in a definite direction. History is seen to begin with the age of gods, proceed to an age of heroes and end vith the age of humanity, Each age has features which are comon to its custoas, lavs foras of government, language and culture. The first, the religious, was the nost poetic. All things vere supposed to be aninated by spirits or gods. Vico does not consider these prinordial ancestors as in any vay inferior even though not so rational ve are. The heroic age vas aore pugnacious in character and aristocratic in governaent. The hunane age is supposed to be intelligent, aodest, benign, and reasonable, folloving the lavs of conscience, reason and duty. It believes in the equality of intelligent citizens, and governs by eans of argument not force.

Boas says that sinilarity betveen the development of a nation and that of an individual is obvious. Because children enjoyed fables and rhyes and suchlike they vere considered pre-rational and adolescents vho enjoy rough and tunble seen are like the heroic. Vico hisself did not enphasize these analogies but Boas thinks they lie behind his thinking as a basic metaphor and Herder seened to think likevise. Anyone biased in favour of the poetic therefore especially if they have a priaitive bent vould all too easily in Boas' opinion idealize the stage of collective childhood, Whereas the rationalist and anti-priaitive vould be unlikely to do this. In general the tendency of the eighteenth and nineteenth century philosophy of history vas to be optiaistic and look forvard, expecting that the future vould iaprove on the past. It was Auguste Coote "who did nost to create the belief that the child represented the childhood of the race as a whole."

1. George Boas, The Cult of Childhood, London:The Warburg Institute, Univer sity of London, $1966, p .64$. 
He agreed vith Vico that the vay to interpret history vas on the basis of how wen think. His lav had three stages. Vestiges of earlier aodes of thought can be found in any period later than when they first occurred, Conte thought that there is a tendency to believe that change is produced by sone agency conceived in anthropomorphic terms and this is the vay the child thinks. According to his thinking the life of an individual reproduced in ainiature the life of the race, beginning vith the theological stage and passing through the ataphysical and on to the psychological. "The social and psychological applications of this lav belong on the whole to the twentieth century."

As late as 1911 Boas says ve find in an Encyclopaedia of Religion and Ethics the folloving statement;

'The childhood of the race', originally a metaphor, has become an al sost technical tera, through the establisheent of the lay of recapitulation...2

It explains that this lav connects the development of the individual vith the evolution of the race, that is not that the child vill be first a savage, then a barbarian etc. but that it vill indicate what kind of interest vill prevail in each period of grouth. This vhole thesis Boas see as being fortified by Freud for in his uritings the psychology of the child is frequently utilised as a substitute for that of prinitive or ancient man and the adult is said to retain infantile desires and aggression. He ady, thinks Boas, have been influenced by Schopenhauer who sav in the child something akin to genius. His ided of a genius was of someone tho could not be objective about hinself. He also considered the brain to be developed by the age of seven. He speaks of "childhood is the time of innocence and

1. and 2.George Boas, The Cult of Childhood, London:The Warburg Institute, University of London, 1966, p. 65. 
happiness, the paradise of life, the lost Eden on which ve look longingly back through the reaaining course of our life." Children have in his opinion the naivete and subliae siaplicity which is characteristic of true genius. Freud's theory of infantile sexuality contradicts Schopenhauer. Norman D' Brown an exponent of Freud sees a siailarity between the life of the artist and that of the child. Art is he says a for of play which recovers childhood. Schiller equates the child vith nature and naturalness. To Kant the child represents a 'holy object'. He thinks ve are nostalgic for childhood and in the vork of artists and poets he looks for the quality of naivete or the childlike.

Ellen Key thought that the development of the child airrored the development of ankind as a vhole for children combined realisa and idealis as epic national poetry does. Boas believes she is influenced by Heder and the popular notion that all people vere once able to vrite ballads and epics. She says that chidren are not dravn to abstract things and have a ralistic conception of heaven which is the gift of the poetic inagination. Children in her vieu also have invulnerable logic. They are clear-sighted in their viev and cannot reconcile vhat they are taught vith what their teachers acually do. When they question us they are given religious answers. She also believed that the child vas a natural aesthete and appreciated art, he is therefore an ideal being and superior to nost adults. Some, like Rilke found this too idealised a concept of childhood. What happens to spoil this ideal child asks Boas. Rousseau, Pestalozzi and Froebel vould blane education, for all these adnirable qualities vith which they cone to school are gone by the end of it.

1. and 2.George Boas, The Cult of Childhood,London:The Warburg Institute, Univer sity of London, 1966, p. 65. 
As art became less constricted in style vith the advent of Dadaisa so art becane praised for its natural, childlike qualities. The nineteenth century sav the rise of psychological studies of childhood and the beginnings of scientific anthropology. Childrens dravings vere now studied as evidence of their mental functioning and people became interested in the aesthetics of children's art and creative vork. Toepfler's work combined both says Boas and he said that beauty was to be found in vorks of art as sign of an ideal beauty, which idea when pursued to the ultinate is a sense of fod hinself. Hegel defined beauty as a a sensuous anifestation of the Absolute. We can all conceive of beauty but some are nore capable of creating signs of this and this is the reason Why he exanines the art of children. By loooking also at graffiti in Pompei and the sculptures at Easter Island he fused ideas of the imature, the ungducated and the savage. Attention to reality and detail vas not art to him and stone inages vere only gross if considered to be representations. Their beauty lay in their conception. This pover which children once had, they lost through schooling.

One of the first psychological studies of childhood vas by James Sully in 1895 and because the fusion of child art and the savage vas such a well established concept by now he did not question it. To his the child's dravings vere pre-artistic, the first atteapts aialess and chaotic but they vere not destitute of artistic qualities. His acceptance of the status quo did in fact strengthen the ideas of the cultural priaitivists. Others after hin accepted it as incontrovertible truth. By 1922 Hartlaub say the art of siaple folk and children as based on anthroponorphic materialisa*

1. George Boas, The Cult of Childhood, London: The Warburg Institute, University of London, 1966, P.B7. 
and he has little faith in Freud's thery of infantile sexuality.

There is anple evidence as Boas sees it of a nostalgia for childhood. Sylvia Ashton Warner in 1963 considered that ve should encourage the child to express "inner vision" and ve should avoid forcing our ideas and emotions onto them for "The expansion of the child's aind vas 1 to be a beautiful grouth." . Boas can accept this but vonders whether this prepares the child for a life in which disequilibriun, discord and movement will be the rule, I believe that her conaents in her last book quoted earlier vould find aore accord vith hia.

The theory of pedagogy in the United States is in opposition 5ays Boas to the long tradition springing fron the Nev England Calvinisa "For if ve are all born in sin and elected by God regardless of werit, then 2 there is no likelihood of setting up the child as an ideal " Education vas organised to prevent badness escaping. As adults are the ones accused of introducing evil into the vorld of the child and these adults vere themselves children can ve ever solve the question of uhere the evil originally comes from. Marion Richardson had no illusions about the inner vision of children, she believed that the importance of a child's art is what it does for the child in feeling his inagination and many of the conents about children's art are loose stateaents which should not be taken too seriously. Kleee tho vas quite frank about a desire to return to childhood reffered to Herder's sinile of art as a tree. The artist is the trunk in this figure of speech and his vork of art the crown. but though the croun has its origin in the roots, it does not reseable them. There is says Boas a mysterious sosething in the conception of all vorks of art just as there is

1. and 2.6eorge Boas, The Cult of Childhood,London:The Warburg Institute, Univer sity of London, 1966, p. 90. 
in the foration of scientific hypotheses.

Klee believes that the spectator has no right to demand anything of the artist. A painting says Spulages is a eetaphor ade by an artist vho lives suspended between two worlds that of his aind and the external vorld. Even when painters do not clain the status of children critics often give it to thes. The adjective sost often used in praise of the child is 'innocent':

Just what aesthetic innocence consists in is sore difficult, if indeed possible, to define, the question boils doun to vhether the incapability of coniting an act should be called innocence or siaply incapability..... One aust revert to Rousseau and declare flatly that the child is a special variety of the species HOMO SAPIENS, vith standards of his own to be understood in his ovn terms, 1

This being the case ve cannot judge adult art by principles only relevant to the child, Likevise one should not judge a child by adult standards. The fact that children because of the lav of recapitulaton were confused with prinitives "Ied to the vogue of innocence, naivete, freshness, 2 and kindred qualities" The tradition of uriters thinking childhood to be specially blessed aerged with the identification of the child with priaitive man and led a cult which becale reflected in everyday lives and led to :

... an eaphasis upon the necessity of looking young, feeling young, thinking young, acting young, that in sone cases vas grotesque..... it became general to deny the reality of death as vell as of old age, and all the evasions of the Aaerican funeral rites seea to have resulted fros this denial... The ultinate in the cult of childhood .... in ...the opinion of Dr Noraan 0. Brown [is that] life vill conquer death only when we accept the excremental vision of the child as final. 3

1. George Boas, The Cult of Childhood, London:The Warburg Institute, University of London, 1966, p.100.

2. Ibid.,p.101.

3. Ibid.,p.102. 
Jeffreys in the previous chapter thought the only hope for society was to become Christianized. Ellen Key of Sveden, lauded in her tine but now apparently aleost forgotten, sees our salvation as lying in a different direction. She believes that ve need to transfora huan nature itself, and this vill happen not vhen the vhole of husanity becomes Christian, but when the whole of humanity avakens to the consciousness of the "holiness of 1 generation." The central vork of society vill then becone the new race, its origin, its aanagenent, and its education, for she sees the training of youth as the highest function of a nation.

It is her belief that ve must in fact abandon the Christian viev because it has given us the wrong attitude to arriage, to our bodies, to the begetting of children and their education. Instead of seeing aan as 'fallen' ve vill see a nev an come into existence for she thinks that we can transfore to a higher type than known $50 \mathrm{far}$, by use of the human vill. It will take the scientific viev of an to restore vhat the ancient vorld saw as the significance of the body which after Plato and Socrates vas looked down on. The Renaissance she thinks tried to restore this view but did not go far enough. Goethe in her opinion say that this task oust be faced vith sone seriousness, and ve are only just beginning to understand the reciprocal relationship of soul and body and to be avare of "a second higher innocence in relation to the holiness and rights of the body."

The greatest obstacle to our development, is she thinks the Christian vay of looking at the origin and nature of adn, which sees everything concerning the continuation of the race as impure, as "For Christianity,

1. Ellen Key, The Centurgy of the Child, G.P. Putnan and Sons, Nev York and London, 1909, p.2.

2. Ibid, , 0.6 . 
eternal life, not life in the vorld, is ever the significant factor."

She vould prefer that ve treat all the questions children have with complete honesty so that they develop personal responsibility, thus ve 2

vould achieve "a higher type of sex with a higher type of arality."

School she thought vas not the place to give this kind of inforation, but literature vas iaportant "As erotic idealisa can avaken enthusiaso for chastity--as found in stories, histories and belles lettres." She is convinced that ve need to revive antique love for bodily strength and beauty. One wonders what she vould think of the wodern cult of the body decried by Boas, perhaps she would see it for what it aight be, a step on the road to her ideal. Likevise the intense international pursuit of sport night be part of this evolution towards a greater respect for the human body even though at the monent it seens soaetimes alnost to be to be an anology for traditional varfare.

Ellen Key is interested in genius and how it cones about and what she appears to believe is that ve can do auch to encourage the production of superior children and that this in fact should be our ain in life, alnost to a degree that ve aight find repulsive, for there are alnost faint odours of Nazisa, in her statement that ve have been amiss in the past in encouraging the veak to wultiply. She cites the Middle Ages for instance as a period when the human race deteriorated because the best 'stock' fled to the monasteries and the vorst reproduced.

Nietzsche, says Key, considered an as a bridge betveen the aniaal and

1. Ellen Key, The Century of the Child, 6.P. Putnan and Sons, New York and London, 1909, p.8.

2. Ibid.,p.10.

3. Ibid.,p.11. 
superaan, speaking she thinks vith poetic and prophetic voice rather than vith scientific prool, and she believes his ideas are a consequence of Darvinisa which he did not foresee. She also akes an interesting coment that exceptionally gifted aen have aostly inherited their characteristics from their nothers and daughters fros their fathers. The eaerging viev hovever is that ve devel op through adaptability to our surroundings, so ve need to look at the best conditions which do not ovar-exert us. It is a tiae she thinks when "wan's spirit is resting on the vaters; gradually a nev creation vill be called forth fron thea."

She does not seen averse to the idea of euthenasia for she sakes the coment that heathen society used to expose veak or crippled children whereas Christian society prolongs life to ake it a torment yet condones var and the death penalty. She aight also have added corporal punishment. However she feels that only "When death is inflicted through coapassion, vill the husanity of the future shov itself in such a vay, that the doctor under control and responsibility can painlessy [but not to him one presumes] extinguish such suffering." ${ }^{2}$ She certainly touches on issues which are still contentious and I dray attention to this feature in her uriting because it say seen at odds with her regard for the 'holiness' of the child, hovever this reverence for childhood is not the sentimental or the possessive attitude perceived by Boas in the cult of childhood, it is a recognition of a kind of holy duty that one generation should have for the next, alvays caring for the future.

Her attitude to arriage is not conventional either for she believes

1. Ellen Key, The Century of the Child, 6.P.Putnan and Sons, New York and London, 1909, p.32.

2. Ibid.,p.33. 
it should be a bond of autual respect and fidelity, not a religious or civil contract; a notion which drew criticisa in her day. The Christian concept of legitinate and illegitiate children she believes has obstructed a real ethical conception of the duties of parents:

Every child has the sane rights in respect of both father and sother. Both parents have just the same obligation to every child. Until this is recognized there vill be no basis for the future vorality of the common life between man and voman. 1

Perfect fidelity betveen couples could only be possible in her estination by perfect freedon which alone creates conplete unity. Whereas the type of fidelity proposed by the church has developed a sense of possesssion. To 2

her "Voluntary fidelity is a sign of great nobility." Society tries

to sould and pressure us into a sphere of duty imposed upon us, but narriage nust be free. Above all the child nust not be born into a discordant aarriage and love oust not be debased as simple sensuousness. She believes that antiquated legal conception started our training in morality but wust give way to a higher worality so that "The time vill come in which the child vill be looked upon as holy...'

Frou the earliest age she vould like to see people taught about their future duties as parents :

Children must be taught from their earliest years about their existence and their future duties as nen and vosen. So nothers and fathers together can iapress on the conscience of the children not any abstract conception of purity, but the concrete coamandaent of chastity in letters of fire. So they vill keep their health, their atractiveness, their guilel essness, for the being they are to love; for the children who fron this love will receive their life. 3

1. Ellen Key, The Century of the Child, 6.P. Putnan and Sons, New York and London, 1909, p.32.

2. Ibid.,p.36.

3. Ibid.,p. 44 .

4. Ibid.,p.5t. 
What we lack in Ellen Key's estination is aesthetic feeling and religious reverence for the systery of existence and that "In this aystery there are

still hidden fields only penetrated by the intuition." She consider that

Nietzsche who in her opinion knev little about wowen nevertheless spoke

more profoundly on the subject of parenthood than any contemporary vriter.

He saw what iapurity, what poverty are concealed under the nane of arriage. He sav hov eeretricious, hov ignorant education is. In his uritings are to be found prophetical and poetical vords describing the end ained at in parenthood, and shoving what true parenthood should be. "Living enorials shalt thou build for thy victory, and for thy eancipation 2

To Ellen Key Nature has decided the role of vomen and she cannot or should not go beyond these bounds for to do so is to inter fere vith the rights of the child. This is not to say that every woman should be a mother, but for those who do desire it she believes that they need to be protected.

It does not occur to the dogatic advocates of vomen's rights that their talk about individual freedon of the vonan to control her oun career, their contention that no liaitation should restrict vonan's pover of deciding her ovn vocation, because they are aarried or are mothers, mean the most crying injury, not only to children, but to vonen theaselves. For the deand of equality, where nature has ade inequality, brings about the injury of the veaker factor. Equality is not justice. Often it is just the opposite, the oost absolute injustice. 3

She believes that Ruskin's judgaent on aodern industrialism which kills the real huarity in an holds good for both men and vosen. He are so taken up with the iaprovement and use of nature we neglect the improvement and refinement of our oun souls. By conpeting vith aen in the vork force she claias that men's work is reduced and women's bodies are worn out by vork making then unfit to be wothers. In the future she sees a tiae when it

1. Ellen Key, Ihe Century of the Child, G.P.Putnan and Sons, Nev York and London, 1909, p.56.

2. Ibid.,p.61.

3. Ibid., p.76. 
vill be a criae for a voaan to neglect her body in this yay, or by use of stimulants etc.

The wother is the nost precious possession of the nation...so precious that society adyances its oun highest vell-being when it protects the function of the wother.1

She foresees a tiae when the cost of adintenance of children vill not fall solely on the parent but on the state because this vork vill be valued. In this respect she and Jeffreys are in agreenent. Like hia she vishes to see fasily life strengthened.

In her view individualisa leads to conflict, class against class, sex against sex, unaarried against arried, young against old, therefore ve need a different transformed society, one where wowen are not forced into coapetitive struggle, for occupation does not equal eaancipation for them. Moreover every social regulation should be tested to see if it brings us nearer to a society uhere all york aoderately under healthy conditions for an adequate wage.

Woaen have begun to treat love as a game she finds but they are not solely sexual beings dependent on man, the home, and the faaily and must have free choice to fulfil their destiny as wothers. The transformation necessary to society vill begin she thinks vith the unborn child

This requires an entirely new conception of the vocation of nother, a treaendous effort of vill, continuous inspiration.... The long continued habit of alternately caressing and striking one's children is not education, It needs treaendous pover to do one's duty to a single child.2

This eans that one's soul has to be filled entirely by the child just as the scientist or artist is is consuned by his vork, for the child

1. Ellen Key, The Century of the Child, G.P. Putnam and Sons, New York and London, 1909, pp.84-85.

2. Ibid.,p.101. 
aust be alvays in one's thoughts. At present no-one is trained for wotherhood or fatherhood but this she thinks must change 50 that together they can bring up a nev generation.

Ellen Key is iapressed by the vords of Madane de Stael who said that only people who can play vith children are able to educate then for one wust becone a child oneself, be absorbed in his or her life and treat the child as an equal, vith confidence; not to influence the child to be what ve wish, nor to deceive but to treat with seriousness and sincerity. The greatest evil ye perpetrate in our ralations with children is not leaving then in peace. To understand thes the deepest characteristic of love aust be present but ve are over tender, ever vigilant, zealous, interfering, advising, helping the child "to becone a complete exanple in a model 1 series."

The art of natural education she beilieves is to ignore the faults of children nine tines out of ten. The ideal is to be a companion which requires that one also develops under the constant influence of the best things in one's oun tine. The child's chief work is to think over those things with which he comes into contact. and "even aild pressure tovards conformity can sake the vhole of childhood in torsent." ${ }^{2}$ The vays of injuring a child are infinite she says and the vays of helping hin are fev. We need also to preserve the individuality which interference destroys.

Because people do not realise how new types are formed the old ones constantly repeat themselves and the old fashioned crude training produced characters of what she calls a fixed type. Dur crude methods of education

1. Ellen Key, The Century of the Child, G.P.Putnan and Sons, New York and London, 1909, pp.111.

2. Ibid, p.116. 
vill change and aust change for "A grown aan vould becoae insane if joking

Titans treated hin for a single day as a child is treated for a year."

Her prediction for the future is that as "as the evolution of an's soul

advances to undreamed of possibilities, of capacity, of profundity; as the

spiritual life of the generation becomes manifold in its coabinations and in its distinctions....* Children she thinks vill be restored to

the hoae which vill becone a hone for the souls and not bodies alone. He already see in our oun tive a distinct novenent away from formal schooling institutions by a groving nuaber of people who are dissatisfied vith the effects of formal educational institutions. Key says ve create artificial environaents for children tho no longer vork alongside us, but thay need real occupations. Mothers she thinks do too auch for then and train then to be alvays receptive rather than giving. He encourage acquisitive iupulses and "The vorst feature of our systen are the playthings which initate the luxury of groun people." Anyone tho has recently toured a toy store vould probably agree vith her on this point. To play with children in the right way she says is a great art.

We must realise that every pebble by which one breaks into the glossy depths of the child's soul vill extend its influence through centuries in ever videning circles... ve can in a certain neasure, as free beings, determine the future destiny of the human race...by seeing the whole process in the light of the religion of devel opment. 3

This will happen when ve learn how to treat children and ve will thereby becone are like the ourselves for getting old is not a necessity she says but a bad habit. Of the true artists in education she includes, Socrates,

1. Ellen Key, The Century of the Child, 6.P.Putnam and Sons, New York and London, 1909, pp.130.

2. Ibid.,p.162.

3. Ibid.,p.183. 
Jesus, Comenius, Nontaigne, Basedov, Pestal ozzi, Salzaann, Froebel, Herbert, Lesing, Herder, Goethe, Kant, Locke and Spenser.

Ellen Key is convinced of the theory which says that the history of the species is repeated in the history of the individual. Of the school curriculua she says that it "files down aan's brain." and she refers to "soul murder" in the schools for what she thinks they have destroyed is the desire for knouledge, the capacity for acting for oneself, and the gift of observation. She criticises the pursuit of individualis but nevertheless advocates the training of the individual as the basis of schooling developing towards advanced independent study. Sone free time wust be given and only the study of literature for homevor $k$ is what she recomends. Class sizes should be no nore than tvelve in number. She is also aware of the need to give a holistic viev of a subject or period as in history and thinks that no more than tro subjects should be studied at one tiae, for: "The isagination of children requires full, deep iapressions, as aterial for their energies that are incessantly creating and reconstructing."

High schools and colleges she considered absolutely destructive of personality. Exaninations she vould obliterate fron the face of the earth. 3 "Our age cries for personality" she says and this is the very thing that ve suppress. She blames parents for accepting the system as it is and the incapacity of teachers to critically evaluate it. Schools she says are everlastingly talking about the child but harmony cannot be worked up from pedagogical foraulas. Nothing less than a revolution vould satisfy her for

1. Ellen Key, The Century of the Child, 6.P. Putnan and Sons, New York and London, 1909, pp.189.

2. Ibid.,p.223.

3. Ibid, $, p, 232$. 
the school she thinks has only one great end, that is to wake itself unnecessary.

At the tiae of her uriting Ellen Key considered that schools "noulded" children, a metaphor ve have seen in use for some centuries. In her school for the future there vould be no reports, rewards, exaninations. Each scholar vould keep his/her oun records and observations. The "reader' vould disappear and the school library vould be the largest and nost attractive roon. The school vould be set in attractive gardens. One recomendation Which way surprise wodern readers is that kindergarten and prisary schools vould be replaced by instruction at hone, for these places are sere substitutes in her eyes for the quality education that can go on at home.

One of the tasks of the future is the creation of a generation of trained oothers, who awong other things vill eaancipate children froe the kindergarten systen.1

Her reason is that she believes that uñrestrained play deepens the soul, increases the capacity for invention and stivulates the inagination d hundredfold. She is convinced that "The kindergarten system is ... one of the ast effective aeans to produce the veak dilettante and the self2 satisfied average man." Children need freedon as animals do and mothers need to be acute observers learning to know their children. "The 3 kindergarten is only a factory" The esprit de corps breeds passivity and lack of public conscience she thinks rather we should be aiming to produce people not asses. Schools encourage only superficial relations but in the hooe which is a natural community, emotional eleaents can be

1. Ellen Key, The Century of the Child, 6.P. Putnan and Sons, New York and London, 1909, pp.235.

2. Ibid.,p. 236 .

3. Ibid.,p. 240 . 
deepened and tenderness can be developed. In schools ve attain only a standard of stupidity. Some of our most successful people as she says had little foral schooling. Goethe as an exaple learnt the Bible at his wother's work-table, french fron a theatrical company, English from a I anguage naster in conpany vith his father, Italian fron hearing his sister being taught, Maths froe a household friend, he corresponded with relatives around the vorld in different languages, studied geography fron books of travel, accoapanied his father frequently on travels, observed different kinds of handvork and tried experiaents of his oun skill.

Ellen Key has little good to say about schools for she believes that they destroy aemory, stifle the eaotions and generally belittle life. She sees the values of legends as suitable for children's minds before they cone to great literature. Her idea that all study should be voluntary has great personal appeal. She has great faith in the ability of children to recognize and choose the best. Speaking of teachers she reconaends that they have iaproved conditions of work and a shortened work life so that they can only give of their best.

Key akes an interesting observation on the teaching of religion in schools to the effect that it shows how deeply religious ve are by nature when religious instruction has 50 far not anaged to destroy religion. Like frye and Jeffreys she sees value in letting children read the Bible but without fornal instruction. She considers that it has been a grave eistake to teach the Old Testanent as if it vere binding truth. Rather she would let people cone to their oun conclusions about truth and aorality. She sees people abandoning formal religion because it is unnecessarily authoritative yet religion is a natural element in our nature. For children the most iaportant consideration is to alvays tell then the truth and not offer the piety and hypocrisy. She abhors the concept of an as sin-laden 
because this in her eyes has kept him where he is. Rather she thinks:

We aust bou doun before the infinities of our earthly existence and of the vorld beyond. We aust distinguish between and select real ethical values; ve aust be conscious of the solidarity of mankind, of an's individual duty, to construct for the benefit of the vhole race a rich and strong personality. We oust look to the great aodels. We oust reverence the Divine and the regular in the course of the vorld, in the processes of the developaent of man's aind. These are the new lines of aeditation, the nev religious feeling of reverence and love that vill ake the children of the new century strong, sound, and beautiful. 1

Patriotisn she sees as a godlessness nourished by egoisn and both ailitarisa and clericalisa representing authority opposed to individual standards of right. He vill continue to be burdened by ailitary preparations:

until nothers iaplant in the souls of their children the feeling for huanity before the feeling for their country; until they strive to eabrace all living things, plants, anieals and oen; until they teach then to see, that syapathy involves not only suffering vith others but rejoicing with others, and that the individual increases his own eational capacity, when he learns to feel vith other individuals and with other peoples. 2

The vord soldier vould eventually becone ennobled when patriotisa diad and

come to eean one who protected sacred human and civil rights. Children

vill understand that evil not resisted becones pover over others 50 they

vill learn self defence as a personal and natural duty.

Considering the fact that Ellen Key urote this nearly a century ago

it is rearkable how sany of her ideas are very ouch in vogue now and how sensitive she vas to the problems both of child care in the fasily and foral education. What she says of children is true as ve have seen from both history and art but the scientific theory she claims to start from is not very convincingly explained. As alvays the nature of the relationship

1. Ellen Key, The Cengtury of the Child, G.P. Putnan and Sons, Nev York and London, 1909, pp.308.

2. Ibid.,p.311. 
between the body and any notion of a soul are difficult to justify. Her perception of the need for freer discussion of sex has been realised to some extent since her time. The idea that an appreciation of chastity could come from simply reading literature is possible but once are hard to prove. It is true as she says that religious and scientific instruction do not alvays educate in such matters satisfactorily. It is noticeable that she puts the ain burden of education on the nother a factor which would be resisted by any in the vomen's movement at present and also the responsibility for developing the idea of peaceful coexistence. Her ideal schooling reflects sany ideas already explored but the concept of voluntariness, and home schooling for the youngest children have yet to be realised. She gives a varning that Sylvia Ashton Warner vould doubtless concur vith, and Boas, that there is a tendency with any parents to aake the child the centre of their universe and to do too nuch for then, even sometiaes 1 treating then as equal to adults. This is not what she means by reverence for the child, for the parent needs a personality and life too and the richer this is the better parent they vill aake. As a realist she knovs that "My school vill not cooe into existence while governments ake their 2 greatest sacrifices for ailitarisa." .

It is noticeable how often the sane values are cherished by the recent vriters, the importance of personality, faeily and conaunity but there is still no universal consensus on the true nature of children, their ideal nurture and education. They reain in the pover of often wisguided adults.

1. Ellen Key, The Centurey of the Child, 6.P.Putnan and Sons, New York and London, 1909, pp.195-6.

2. Ibid., p. 283. 
Fron the evidence surveyed so far ve see that in earlier tiaes the husan child vas sometimes seen merely as huad excrement, something to be destroyed vhen spavned, of no practical use to the parent but an object to be exposed to perish in the vilderness or when older to be sold into slavery or prostitution or bartered as a political hostage or sacrificed to an offended God or Gods.

For centuries those infants which did survive and vere not smothered or over-layed in bed, vere svaddled like a parcel which vas left in any convenient place and throun about for a joke. A baby was rarely breast-fed by its ovn nother up to the eighteenth century but put out to nurses where conditions for child-rearing vere often abyswal or vhere alternatively the infant formed an affectionate bond with his surrogate aother fro whon he vas eventually suddenly separated to return hone at his natural parent's convenience.

Fron this point it was chastised harshly and suffered agonies of abuse in the for of enewas, purgatives and poor diet. It vas often left in the coupany of servants if noble-born or aixed up in the general aelee of street, lara or workplace in the lower classes. At the hands of servants vith whon it sometines slept it aight also suffer sexual abuse.

Having survived this far the child dressed like a niniature adult but treated often more like a domestic animal and at the beck and call of his elders, aight not only experience frightening oreas due to the earlier traunatic events in his life but also be scared by stories of ghosts, devils and demons and be forced to vitness horrific events such as executions and circuncisions.

For centuries children of vealthier parents vere farmed out to other hones to be trained in social wores. Where formal schooling did exist they were still the victias of harsh corporal punishaent and a 
restricted style of teaching which suppressed their natural curiosity, ebullience and need for physical activity. They lived in constant fear not only of punishment from parents and teachers but of an all-seeing fod who aight strike then dead. They vere also riddled vith guilt because they carried the stigma of original sin and vere consequently ashased of their oun bodies and feelings. All of the above vas conpounded for feade children because initially they vere not as desirable as boys, who carried on the fanily blood line, and like their nothers before the vere expected to stay at home and vithout benefit of education prepare to raise the next generation of children by being a housahold drudge.

Parents of the past vere obviously in a quandary as to how to treat this 'object', often regarded as a product of sinfulness. It was therefore a receptacle of guilt which they tried to purge by acts of purification and atoneaent which included sacrifice in earlier days, circuncision and other barbaric practices and beating the evil out of children the moment they appeared to do wrong. In each age thare have been sone vho recognized the value of children and their potential for grouth both intellectual and spiritual and the basic need for a loving care. Whatever they said the more perverse habits seen to have survived for ve are still left with many of these prial patterns of child care.

There appear to be only two alternative vieus, either to look back like some of the classicists, the Pelagians and the Ronantics to a tiae of innocence, joy and beauty, the prinal garden of Eden metaphor where the infant is innocent and pure and sullied only by human baseness; or to the Christian concept to who life is a process of searching for reneval. redemption and grace, that is looking to an after life for the highest level of being, in imitation of Christ. One thing is clear, to construct 
any kind of philosophy about childhood ve cannot ignore our past any aore than ve can be sure of our future. Our only hope seens to be to learn fron our past aistakes and select those practices which produce the kind of people ve vould vish our children to be, but there's the rub, for ve none of us agree apparently on this basis preniss. He have an advantage over our ancestors because ve have their experiences to drav on as vell as the benefits of scientific knovledge. Perhaps Ellen Key is right, if ve began with the child's needs for the future and let every other concern flow on from this. If she is right then vomen have sade the urong choice to compete vith men on their teras for an ade the same error says Robert 1

Graves when they turned frow vorship of women and the Moon Goddess and idolized themselves and their own thoughts. If they are both right then ve nay sioply replace the patriarchal heritage vith a matriarchal one and we fall into the sane trap. Our metaphors of childhhood vill reveal our stance.

We cannot escape having a state of childhood for each generation is succeeded by another. Attitudes to childhood can change and be reflected by each nev decade possibly reversing everything a previous one believed. He still live vith vestiges of for aer beliafs for exanple the adage that children should be seen and not heard, that one spares the rod and spoils the child. Innumerable people still believe in corporal punishaent. In yesterday's news in this country a judge publicly exonerated a father for

1. Ellen Key, The Century of the Child, 6.P.Putnan and Sons, New York and London, 1909.

2. Roberts Graves, The White Goddess, Faber and Faber, London, 1975, p.11. 
beating his two young sons. The folloving day I read of a healthy baby a fev weeks old killed by its parents, and there are still numerous abortions perforned [7,130 in N.2. 1986] and occasional cases of infanticide. In Thailand scientists are over joyed to find that they have discovered a method which alnost guarantees the chances of a woman bearing a son, at least $3: 1$, In general it is observed by social scientists that fanilies tend to repeat the patterns of child rearing that they thenselves have experienced. Thus ve find that child-beaters produce child-abusers and 50 forth. Feninist Germine Greer has said that the Mestern vorld had becoee a child-hating society and the current accounts of child abuse corroborate 1 this.

It is obvious that parenting is a traumatic experience especially for young inexperienced couples or parents coping vith social probleas such as poor housing, arital breakdouns, sickness etc. This role of a parent requires fairly complex and sophisticated skills in husan relationship such as redeployaent of pover and responsibility, physical and emotional adjustment. It is also circusscribed by status, income, and social ailieu, subject to the influences of fasily, advice from medical experts and sore mysteriously a heritage of folk visdon which is a sixture of archaic superstitions as vell as much conoon sense. In the nornal or average situation hovever it is also obvious that knouledge of vorthuhile parenting practices could be taught to people. The fact that society virtually ignores this need in its citizens is surprising. We tend to assune that parenting is instinctive like the procreative act itself. It is obvious from even a quick glance back at history that its path aight have been different if people had wore

1. Germaine Greer, quoted in the Editorial, The Errening Post, Wellington, Nev leal and, Harch 16, 1988. 
idea of vhat effect their child rearing patterns can have and understood the rationale (when there is one) behind some of them. There seeas to be no excuse novadays for neglecting this vital area of hunan knovledge. It is not only teachers who need a basic knowledge of child developaent and psychology.

Our current situation is probably a reflection al 50 of a tendency in the past for the young child's care to be principally the mother's donain and as she has not been educated to the same extent as wale children her learning of these skills has been passed on in inforaal ways vithin the family. Now that both parents acknowledge nore and wore their dual responsibility for a child and as vomen achieve a core equal status perhaps this need for parent education vill be acknouleged and catered for. He knov enough about children now to help parents avoid adjor errors in their childrearing even if we know that every child is unique and every parentchild situation to sone degree.

There are comon patterns which a study of the evolving concept of childhood shous. It is true that even an interest in children has not alvays been healthy but ve have developed beyond that self-conscious stage of seeing ourselves too much in our children and sacrificing then for our own ends or of seeing children as a distinctly separate category from us. The empathy ve need, to share our lives vith the as partners, is not something we are magically endoved vith at the wowent our children are born, it is accuaulated froe our ovn upbringing and our fornal education vininal though this aay be at present.

In every age there have been people vith the insight and understanding necessary to iaprove the lot not only of children but consequently of parents also, but their ideas have to be known and passed on re-gxanined and adapted to effect ongoing change and inprove the quality of a child's 
life experiences.

Erikson cane to the conclusion that:

in our tioe man must decide vhether he can afford to continue the exploitation of childhood as an arsenal of irrational fears, or whether the relationship of adult and child, like other inequalities, can be raised to a position of partnership in a nore reasonable order of things.1

Whatever we decide children always have to accept, for they are dependent on us. It is unlikely that there vill be a perfect childhood for all children for any decades yet and ve are of course haunted by the fact that there aay be no vorld for then to be born into. At present vith our fairly rigid systea of compulsory schooling which tends to becone longer they are virtual PRISONERS serving a sentence filling nearly a sixth of the average lifespan. If we do not ieprove our record of child care they are also likely to be, like so any children in the past, helpless VICTIMS.

1. Erik H.Erikson, Childhood and Society, Penguin Books, England, 1967, p.42. 
CHAPTER V

METAPHOR IN EDUCATION

The metaphors and inages of schooling and teaching that ve acquire have profound consequences for our educational values and for our vievs of hov schooling should occur.1

Many people with a particular interest in education have cone to recognize the insights that can be gained froe a study of setaphor, even though it has been accused, as David Aspin says of "one of the cardinal errors of logic--that of fallacy of analogy." Educational discourse is nevertheless replete vith metaphors, beginning vith Plato's Myth of the Sun and Cave in Book VII of the Republic doun to a aore nodern example in the Plovden report which informed us that "At the heart of every educational processs lies the child." A wore recent example closer to home occurs in the the Treasury brief to the inconing governaent in Ney lealand in 1987 which speaks of institutionalized education as a 'service': "Education can be analysed in a siailar vay to any other service in terns of

1. E.H.Eisner, The Educational Igagination, Macnillan, New York, 1979, p. 261.

2. David Aspin, ' Metaphor and Meaning in Educational Discourse' in Metaghors of Education, ed. W. Tayl or, Heinewann, London, 1984.p.21.

3. Ibid.,p.22. 
interaction and exchange in the face of uncertainty, inforeation costs, scarcity, interdependence and opportunism." Avare, that these terms which to then are "analytically robust," aight seen harsh to educationists, they camouflaged then slightly in the chapter of the report entitled the Nature of Education', as, 'functions' of education: fulfil ment, integration, econoaic, custodial; and the government's role vas described as 'intervention'. Metaphors of and in education are not aeant to be taken literally. They serve as tools for describing, for analysing, for guiding teaching theory and practice. Many of then have becone outdated, In this chapter I refer to sone of the aore connon or persistent ones and their origins and how these have influenced educational philosophy and teaching practice, for each nev setaphor becoses a label for a nev school of thought and influence, although, as R.F.Dearden varned, they function "as a syabolic inage, 2 pregnant vith meaning, and rich in enotional appeal"-- which is in itself a statement filled vith metaphor. Slogans become diffuse in their meaning and open to various interpretations. Worse still these 'catchphrases' often stand in place of true theory, and give rise to a belief that setaphor ought to be eradicated fron education altogether. Tin Linzey finds that aetaphors in educational discourse have "putatively pernicious effects" and wuch aetaphor is "aerely aphoristic reference, " although he is villing to use then as heuristic dids once they are reduced to siailes or nodels. Aspin disagrees: "It is arguable that our educational theories vould become sharper instruents, less liable to fallacy, if ve vould dispense with

1. Governgent Managenent, Brief to the Inconing Government, Vol,Il, Education Issues, published by The Treasury, Hellington, New leal and, 1987.pp.6,24,25,41.

3. T.J.Linzey, University of Otago, 'How to Kill a Metaphor,'a paper presented to the P.E.S.A. Conference Melbourne, August 1987.pp.28-9. 
aet aphor altogether."

Aspin says that Stebbing also considers metaphor as siaply confusing and esotional use of language whereas Science is seen as a vodel of logic, truth and reality; a belief wodern philosophers and sone scientists question [gee chapter on Science]; and positivists, by eradicating aetaphor, vould also rule out auch of our language, especially in the areas of religion and literature. This is ong reason why aetaphor has become once sore the concern of philosophers.

The use of metaphor, depends, in Aspin's opinion, on what ve believe about the nature of language and the function of aetaphor vithin it. He concludes that "there is a theory of meaning that gets over the probleas that have to be faced by verificationist, entalist, causal and other 2 accounts of linguistic aeaning." It requires us to look at how language is USED; whether vith comon agreeaent and definitivity, as in comon usage of vords like 'table' 'desk' and 'chair,' or in the more 'open-textured' use of vords. In this theory, context and sanner of word use is of iaportance and by "a process of interpretation or negotiation, ve can establish our ovn agreements as to meaning and significance for the purposes ve have in mind and in the particular institutional contexts in which ve operate."

That metaphors lose their novelty and becone part of standard usage is part of the nornal developaent of language:

Metaphors such as 'core curriculun' gain currency in proportion as they encapsulate and present particular conceptions of which the participants in educational discourse had previously an ill-informed avareness only, in a form of such innovation and attractiveness that

1. David Aspin, ' Metaphor and Meaning in Educational Discourse' in Metaghors of Education, ed. W. Taylor, Heinenann, London, 1984.p.23.

2. and 3. Ibid., p.27. 
their appropriateness is imediately judged by all to be beyond question.1

Aspin's 'by all' way be a slight case of hyperbole but ve can appreciate his aeaning. What he does not aention is that it is generally one person or a group such as a research tean who crystallise this process or developeent of thought by cosing up vith an ided, phrase or vord to act as a catalyst. In this vay ve get expressions such as 'tean-teaching' vith its sporting connotation or 'prograned-learning' in the era of computers and suggesting a quasi-logical operation.

Taylor believes that in trying to ake education comprehensible ve pile one aetaphor on top of another "Ordering and classifying for our oun purposes phenomena ve have already metaphorised, and often in the process destroying the meaning that these phenomena have acquired for those closest 2

to thea." An example of what he describes is the videly prevalent use of the term 'vocational' which originally aeant a 'calling' and yas used to describe a life of work in a religious institution and vas often applied to medicine and teaching. Now it is used to describe any educational course designed to lead to eaployent.

It is iaportant therefore in Taylor's viev to have a reflective avareness of netaphers and hov ve use thea for they can be "seductively 3 peductionist" and ve need to be avare that "The aetaphors of education represent the claims aade by groups to inpose their own sets of meanings on

1. David Aspin,' Metaphor and Meaning in Educational Discourse' in Metaghhors of Education, ed. W. Taylor, Heineaann, London, 1984.p.28.

2. Hillian Taylor, 'Metaphors of Educational Discourse,' in Metaghors of Education, ed. W. Tayl or, Heinemann, London, 1984.p.23.

3. Ibid.,p.11. 
1

experience." Educational metaphors comprise what he calls "a shared 2

referential library" to those vho participate in educational discourse and they are also dravn froe wany disciplines.

There is another interesting factor which Taylor points out, that ve have aetaphors such as Meber's 'vorld inages', Popper's 'vorld hypotheses', Black's 'archetypes' and Macrae's 'root metaphors,' all referring to ideas and principles which ady in fact never influence classroon practice, and that educational discourse can be far removed fron the task of teaching. Many current reports on education reflect this problen. Taylor hioself uses an architectural aetaphor to suggest the necessity of marrying [another coanon metaphor!] theory and practice. What is said, thought and vritten about education, even when presented in scientific fora, is, as he says, intended to persuade or to convince, One might al most say that there are no right ansvers and only strong argument and opinion prevails. When backed by research it is all the more convincing, so it finally cones down to rhetoric and the pover to convince and persuade, an ancient art as ve have already saen and one areover in which only a ainority are highly skilled and can therefore vield considerable pover. All of which leads hi to conclude that educational discourse is for the nost part "a trop(e)ical 3 jungle."

As Eisner sees it we have been drawn too often into the trap of enulating scientific, ailitary and industrial language to describe education, and often this results in simplistic, mechanical solutions being sought. Control and standardized outcones have been a preoccupation. He

1. and 2. Hillian Taylor, 'Metaphors of Educational Discourse,' in Metaghors of Education, ed. H.Taylor, Heinemann, London, 1984.p.17.

3. Ibid.,p20. 
sees that ve need oodels that are heuristic and useful and that teaching needs to be recognized as an art. It is ironic as he says that education usually coaes under the uabrella of the arts, yet the conceptual tools for studying and criticizing the arts are rarely used. For hin the culture of the school functions as an organic entity that is ever changing yet seeks stability. This fits in with ore current paradigms of education and other disciplines also.

Eisner sees that because language derives fron a set of ieages which are often visual, when ve consider what education is and what should be taught "Language seens to reinforce and legitiaize these iaages," A new vord CAN create a new vorld. For this reason he agrees that we ought to be critically avare of this factor:

The dominant image of schooling in America has been the factory and the dooinant isage of teaching and learning the assaably line. These isages underestinate the conplexities of teaching and neglect the differences betveen education and training. 2

The use of such metaphors implies technical acumen, suggesting systeaization and rationality; an illusion of control is created. What should concern us is that: "Eventually the use of such language changes the dias of the enterprise...Education becones converted fron a process into a 3 coanodity, sonething one gets then sells." The lay public is reassured by such metaphors for ;

Rationality has been conceived as scientific in nature, and cognition has been reduced to knoving in vords, as a result, alternative vieus of knovledge and aind have been onitted in the preparation of teachers, adainistrators and educational researchers.4

1. and 2. Elliot W.Eisner, The Educational Inagination, Macaillan, Nev York, 1979, p.262.

3. Ibid., p. 263 .

4. Ibid., p. 264. 
In this kind of atnosphere the intelligence needed to create poetry, ausic, or the visual arts simply does not count but only that which is aeasurable as in the for of scholastic achievenent tests, for our vieu of learning is shaped by what ve measure, the tacit ideal being as he says that of the hard sciences, Eisner believes that: "The model of natural science on which much educational research is based is probably inappropriate for aost of the probleas and aius of teaching, learning and curriculua development." Hence there is little in research that guides practice.

Knoving, like teaching, requires the organisa to be active and to construct meaningful PATTERNS (ay emphasis) out of experience. At base such patterns are artistic constructions. d weans through which the human creates a concept of reality...Pattern is an inescapable quality of the organization of thought. 2

The husan organisa is structure-seeking and pattern-forning in his vieu, and to ake such patterns requires an environaent supportive of exploratory thought, but because the factors that influence schooling often have their origin far fron the school such an environment rarely exists. Like others he see the dangers in aere slogans for they replace real thought and enable school practitioners to avoid dealing vith persistent problems of practice. We talk about excellence in teaching says Eisner as if it vere a single set of qualities and evaluate teaching vith a single inage of pedagogical aerit.

Taylor believes that an unreflective use of metaphors is dangerous and Aspin says they can also stop thought and developeent of ideas if ve cling to then, he gives examples: 'child-centred', 'education for citizenship', 'teacher-accountability.' If these are never questioned they becowe not

1. and 2. Elliot W.Eisner, The Eductational Imagination, Macmillan, Nev York, 1979, p.265.

2. Ibid.,p.271. 
agents for change but ends in thenselves in the narrow perspective of one metaphor. It has been said so often that the sediun is the aessage and can massage us into lethargy.

There is no doubt that "netaphors help us the better to strive towards grasping the visions and truths of their artificers and atteapting however ieperfectly to share in them." Hovever they can wislead us and sake us believe that ve have arrived at a 'truth' or 'lav' or a conclusive answer of some kind when in fact they ady be only another step in our search for such. 'Truth' is an elusive concept and perhaps truist is a wore apt vord in many cases. As Aspin says "The creative inagination vorks in and through metaphor and presents 45 vith an increased avareness 2 of alternative possible worlds." Goodman, he says has expressed this perfectly ...' a metaphor is an affair betven a predicate vith a past and 3 an object that yields while protesting." To extend his analogy, the liaison can be fruitful and give birth to nev insights and nev direction in teaching practice and to research in education. On the other hand such products can be veak, or flaved. They can also die or outlive their usefulness. Aspin agrees vith Davidson's statement that ;

Metaphor is the dreanuork of language, and like all dreanwork its interpretation reflects as auch on the interpreter as on the originator. The interpretation of dreass requires collaboration between a dreaner and a vaker, even if they be the sane person; and the act of interpretation is itself a vork of the imagination. So, too, understanding a setaphor is as auch a creative endeavour as aking a wetaphor, and as little guided by rules.4

1. David Aspin,' Metaphor and Meaning in Educational Discourse' in Metaghhors of Education, ed. W.Taylor, Heinesann, London, $1984, p .34$.

2. Ibid.,p.34.

3. Ibid.,p.35.

4. Ibid.,p. 36 
It is interesting to trace vhere some of the aore dowinant eetaphors of education have come from. For a history of metaphor one has to turn back to Aristotle and for one of the earliest inages of education ve al so go to the Greeks as oentioned in the opening of this chapter. The first metaphor and nodel comes originally from Socrates and his approach to the slave boy "It is a view of knouledge as a mode of vision or insight which aust be stiaulated by a teacher and what a teacher does in encounters vith 1

a student." In the Republic "the metaphor for this kind of selfinitiated activity ( in the section dealing vith the ayth of the cave) is an eaergence out of the darkness into the light." Aristotle spoke of self-realization as the attainaent of happines or eudainonia. The teacher's task vas to encourage the habits of good disposition and woral behaviour and to instruct the developaent of the intellect, two separate areas of concern.

The dowinant uetaphor in Aristotle's thinking vas a hierarchy, a kind of pyranid arising out of inchoateness, culainating in the abstraction of pure forn. we wight think of Dante's later representation of it in the INFERNO, describing the continual clinbing in order "to gli mpse those things whose beauty nothing aars....."3

In his SYMPOSIUM Plato describes the phases of his oun intitiation into visdon through the use of ayth and aetaphor to illustrate the pover of the principles of good and beauty and their iaportance in one's life:

Philsophers today rarely think in teras of a aetaphor of ascent; nor do they think of knowledge as a representation of nature or of ideal abstractions or "forms." But there renains the inage of the teacher struggling to nove others to become nor a governed, to choose to aspire and live according to principles, to create orders in experience by aeans of concepts and for as. Moreover, at least for sone, there

1. Maxine Greene, Philosophy and Teaching, Handbook of Research on Ieaching,ed. M.C.Wittrock, Macnillan Nev York, 1986, p.482.

2. Ibid.p.482.

3. Ibid., p. 483 . 
renains the society, with its cacophonous voices and points of viev; and there seens to be a desperate need to provoke individuals somehow to overcose self-interest, to achieve sone ultinate agreement, to transcend tovards the "real." The SYMPOSIUM offers a metaphorical paradige--perhaps of what education should be, 1

Greene notes that ve continually turn back to these early ideas and she cites the current preoccupation with excellence "prinarily cognitive excellence" as an exaaple.

Scheffler analyzed three dowinant early oodels of education the IMPRESSION, the INSIGHT and the RULE aodels derived respectively from the uritings of Plato, Saint Augustine, Locke and Kant. Each of these began vith a etapher used to describe hov the uriter perceived education.

The iopression nodel is the simplest and probably the nost videspread. It basically considers knovledge as input fed into the learner who in this case was seen as a TABULA RASA by Locke. In this nodel says Scheffler the mind is seen as blank or eapty at birth and increasing in grouth as information is deposited onto or into it. But as he perceives it, this:

Iaplicit conception of the grouth of knouledge is false, Knouledge is not a standardized processing of sensory particulars-knovledge is, first and forenost, embodied in language, and involves a conceptual apparatus not derivable fron the sensory data but iaposed upon thea.?

The wind alone does not cope vith inforation, there is also what he calls guessvork and invention as vell as culture and custon. Moreover knouledge involves theory, it is a creative and individualistic enterprise. Experience tests our theories but does not generate then. Many facets of this process

1. Maxine Greene, Philosophy and Teaching, Handbook of Research on Ieaching, ed. M.C.Wittrock, Macaillan Nev York,1986, p.482.

2. Israel Scheffler, 'Philosophical Models of Teaching,'Philosoghical Foundations of Education, ed. S. M. Cahn, Harper and Row 1970,p.387. Fron Harvard Educational Reviev; Vol.35, Spring 1965. 
of learning have to be considered and they are inextricably linked.

Context is important as many other writers al 50 5ay. Scheffler argues

that "We need to feed in not only sensory data but the correlated verbal

PATTERNINGS [ny enphasis] of such data, that is, the stateaents about such data that ve ourselves accept.'

To store all accepted theories, Scheffler says is not the same as being able to use then properly in context, so all versions of the iapression model finally have this defect: "They fail to ake adequate roos for radical INNONATION by the learner... There is a fundanental gap which teaching cannot bridge sioply by expansion or reorganisation of the 2

curriculue input." It is interesting that he uses the netaphor of a bridge here for the vord itself has this intrinsic literal seaning.

The storage nodel still persists and came under attack fairly recently by Profesor Marshall Gregory vho describes it as one of the governing metaphors ve rely on. He likens the storage nodel to the young bride's 'hope chest' into uhich she stuffs conaodities for her dreams of the future. In the same vay young people are encouraged to store inforsation as useful and "Menory is in fact the prisary mechanisn of modern education." Students believe that only factual aterial is true and important and they avoid problea-solving and discussion because it vastes tiae. Liberal education suffers as a result. Yet in real life as Gregory says nost iaportant decisions are ade in situations vhere facts are distinctly

1. Israel Scheffler, 'Philosophical Models of Teaching,'Philosophical Eoundations of Education, ed. S.M.Cahn, Harper and Rov 1970,p.388. Fron Harvard Educational Reviev; Vol.35, Spring 1965.

2. Ibid.,p.388.

3. Marshall Gregory, 'If Education Is a Feast, Why Do We Restrict The Menu? A critique of pedagogical netaphors, College Ieaching, Vol.35, Part 3, 1987, 0.102. 
lacking. Students are led to "think of all knovledge as consisting of 1

right and yrong answers." The effect of this is that they aust feel

that the knowledge they acquire does not really belong to then.

Learning is storage produces three corollary metaphors, all of them equally dasaging to liberal education; TEACHERS ARE EXPERTS, STUDENTS ARE CLIENTS, and EXPERTS ARE MORALLY NEUTRAL CONDUITS OF INFORHATION. To accomplish this delicate procedure vith efficiency and tact, it is necessary that they should shut up, avoid viggling, and above all avoid interrupting. Our pedagogy often tells them that they should behave in our classes the vay any lavyers and doctors expect us to behave in their offices. The relationship thus produced is not one of cooperative learning, but one of professional distance.2

His words ring very true in the light of the recent revelations about the paternalism in sedical treatment of vonen in Ney lealand. If teachers pursue this kind of professionalisa there is a danger that they becoae, thinks 6regory, experts who do not really live by their knovladge, that is do not practise what they preach, but transmit it dispassionately in professional settings; such teachers are not fellow learners with their pupils.

One concern he has is that under this aodel we siaply teach too such and give little tine to thoughtful reflection. This is a far cry he says from the aodel Socrates deployed even though we could hardly initate hin as a aodel in our times. Like Eisner he is dismayed by the inforation-factory aodel he sees being pursued then ve "should be helping our students to evaluate inforation..,teaching thea hoy to separate trivial fron iaportant inforation, by using critical judgments, ethical standards, and logic."

1. Marshall Gregory, 'If Education Is a Feast, Why Do He Restrict The Menu? A critique of pedagogical aetaphors, College Igaching, Vol, 35, Part 3, 1987, p, 103,

2. Ibid., p.103.

3. Sandra Coney, The Unfortunate Experingent, Penguin, Nev Zeal and, 1988.

4. Gregory, p.104. 
The storage metaphor is stultifyingly utilitarian and deceives young people into thinking that we are giving thea inforation vital for their survival in the adult vorld. This he considers coercive and hypocritical on the part of teachers. Gregory blames those who have been aade disheartened and cynical by the large and poverful forces vorking against liberal education. "All education is based on values and foras values as surely as sunlit 1 trees cast a shadow." A lovely inage he leaves us with for he believes that "the liberal arts are too valuable to be abandoned."

In the 1NSIGHT nodel as explained by Scheffler knouledge is conceived of as VISION. This idea derives from Plato and is found in the uritings of Augustine who said that words alone are mere noises and through then nothing is conveyed for "language aust have a function sholly distinct froe that of the signification of realities; it is used to prompt people in certain 3

vays." Siaply believing vhat one is told is not to know it. "For knouledge, in short, requires the individual hisself to have a grasp of the realities lying behind the vords."

Scheffler hovever believes that ve can understand stateaents before becosing acquainted with their signified realities for the syntax of a sentence is meaningful to us. He considers that Augustine confuses the aeaning of MORDS vith that of SENTENCES. Hord aeanings ve do have to knov in order to understand. To be informed however, he agrees, is no guar antee of knoving, for, "nev INFORMATION, in short, can be intelligibly conveyed by

1. Marshall Gregory, 'If Education Is a Feast, Why Do We Restrict The Menu? A critique of pedagogical aetaphors, College Ieaching, Vol.35, Part 3, 1987, p.106.

2. Ibid.,p106.

3. and 4.Israel Scheffler, 'Philosophical Models of Teaching, Philosoghical Foundations of Education, ed. S.M.Cahn, Harper and Row 1970,p.389. From Harvard Educational Reviev; Vol.35, Spring 1965. 
statenents; nev Knovledge cannot." 1 This notion of an "interior light" is one I vill return to later for it seems to ae as pervasive as the grouth metaphor but fails to attract as much attention and ay in fact be more worthy of interest.

Where Augustine's ideas vary slightly to Plato's is in his concept of vill and this has led Hannah Arendt to call hie "the first philosopher of 2 the Hill" This indicates a rejection of cyclical vieus of time and history and according to Greene "It opened the possibility of inagining what it aight aean to oove persons voluntarily to choose to learn.'

The insight and inpression models come from two opposing vievs but both are cognitive oodels. Scheffler says that the impression nodel preserves heritage and culture, but has little to do vith actual teaching and learning. He thinks that the concept of a vision of reality in the insight model is impossibly simple for it does not "wake adequate roon for principled deliberation in the characterisation of knoving." According to Scheffler Kant is linked with the RULE aodel where the eaphasis is on reason and reason is alvays a satter of abiding by general rules and principles. Where the iapression and insight model are peculiarly and narrowly cognitive in relevance, Sheffler sees the rule odel as eabracing conduct also. In this nodel "teaching should be geared not siaply to the transfer of inforation nor even the developeent of insight; but to the inculcation of principled judgaent and conduct, the building of

1. I5rael Scheffler, Philosophical Models of teaching, in Philosoghical Foundations of Education, Harper and Rov, New York.p.390.

2. Maxine Greene, Philosophy and Teaching, Handbook of Research on Iegaching, ed. M.C.Hittrock, Macmillan Nev York, 1986, 0.484.

3. Ibid.,p. 484 .

4. Scheffler,p.392. 
autonosous and rational character which underlies the enterprises of science, orality and culture."

Scheffler sees wuch value in the rule sodel yet finds it sonewhat fornal and abstract. As he says the rules of science are not fixed, they evolve and grow with the advance of knowledge and they too form a tradition.

For Kant, concepts and understanding are defined in teras of universals that serve as rules; and this view continues to have an effect on wany ways of doing philosophy vith respect to teaching today:

Kant's viev of conceptual ordering of experience continues to exert the greatest influence as wore and aore theorists of taaching call attention to the iaportance of introducing students, not siaply to specific nodes of inquiring, but to what Paul Hirst calls "netvorks of related concept $5^{\prime \prime} .2$

We are nov ayare says Greene that Kant's universals are not so, and that as cultures differ so do the oodels, but it is thought that his notion of structures has perseated Piaget's distinctive structuralisa.

Jerome Bruner also believes that "a principal task of intellect is 3

the construction of explanatory aodels for the ordering of experience."

With this viev the teacher's problen is to invent modes of access to the eapowering skills or techniques in the culture. This eaphasis on fora and structure Greene finds dowinant at present and can be traced back to Kant, its consequence is a cognitivist eaphasis in teaching which relates in part to the focus of this study:

Definiteness in cognition, it has been said is structure; what is involved is an organisation of aterials around focal ideas and relationships. Many teachers, therefore, are asked to focus upon

1. Israel Scheffler, Philosophical Models of teaching, in Philosoghical Eoundations of Education, Harper and Rov, Nev York.p.394.

2. Maxine Greene, Philosophy and Teaching, Handbook of research on Ieaching, ed. M.C.Wittrock, Macaillan Nev York, 1986, p.487.

3. Ibid, , 0,488 . 
systems of notation and general ideas, or on the "for as of knouledge" ve have already mentioned, the "symbol systens" or the languages by aeans of which ve construct our vorlds or, rather, "vorld versions", since (according to Nelson Goodwan, 1978) there is no world underlying our versions of it... "knoving is as auch reaaking as reporting....." Discovering lavs involves drafting then. Recognizing patterns is very auch a atter of inventing and iaposing then. 1

Greene coaments that "teaching very likely, vill be aore and aore oriented

to the stiaulation of rule-governed reasoning; conputational analogies 2

ady be taken aore and wore seriously by students of thinking."

Me aust pass on these multiple live traditions thinks Scheffler for teaching is not simply as in behaviourist teres 'a atter of the teacher's shaping the student's behaviour or of controlling his aind. It is a matter of passing on those traditions of principled thought and action which 3 define the rational life for teacher as vell as student." These for a what Peters has called standards, and he is quoted:

To liken education to ther apy, to conceive of it as iaposing pattern on another person or as fixing the environaent so that he "grous" fails to do justice to the shared inpersonality both of the content that is handed on and of the criteria by reference to which it is criticized and revised. The teacher is not a detached operator who is bringing about some kind of result in another person which is external to hia. His task is to try to get others on the inside of a public form of life that he shares and considers to be vor thuhile.4

Peters' oun model is generally referred to as INITIATION, and here he does sake it sound rather like getting inducted into a social club.

In his overviev of these models it is noticeable that the language Scheffler hinself uses cones from very recent educational terninology for

1. Maxine Greene, Philosophy and Teaching, Handbook of Research on Ieaching, ed. M.C. Wittrock, Macnillan Ney York,1986, p.488.

2. Ibid.,, , 488

3. Israel Scheffler, Philosophical Models of teaching, in Philosoghical Foundations of Education, Harper and Rov, Nev York.p.396.

4. Ibid, , p.396. 
exaaple: input, data and processing; all aetaphors fron coaputing.

For hisself the sodel of education he favours is that of INVITATION "ve do not iapose our vills on the student, but introduce his to the any aansions of the heritage in which we ourselves strive to live, and to the improvement of which ve ourselves are dedicated." His oun metaphor is that of the host who invites one to share vhat he has to offer and it resinds one of the vords from 5t. John'5 gospel "In ay father's house are many ansions." Quintilian aay have been the ast influential educational thinker of Ancient Rome but he sav chidren as "vessels vith narrow wouths" into which the teacher vas to pour oratory and granar uhilst Plutarch say that "Childhood is a tender thing and easily vrought into any shape." He cartainly did not see the child as an empty pitcher but rather as "a fire to be kindled" and that childcare and education reseabled good husbandry.

It is obvious that the setaphors of each decade will reflect the pursuits and interests current at that tice and it is no surprise that teaching is seen to be analogous with training animals, tilling the soil or 5kilfully woulding or shaping clay vood or metal. It is only in our ovn times of course that people have been likened to computers and autoatons. Quaint as some of the earlier inages now seen to be they are still prevalent. Each vriter on education is influenced by the language of the vorld he or she lives in. Montaigne is a typical example draving as he does from isages of horse training, faraing and even nutrition and digestion.

As Carol Clark points out in her study of his Essais these are not

1. Israel Scheffler, Philosophical Models of teaching, in Philosoghical Eoundations of Education, Harper and Rov, Nev York.p.396.

2. Elizabeth Laurence, The Origins and Grouth of Modgrn Education, Penguin, Engl and ,1970, p.39

3. Ibid.,p.41 
novel but stock inages and aost critics have seen in the striking iaagery of these essays a reflection of his original approach to educational questions, an approach which they have characterised as being practical and concrete, in contrast to the sterile dognatis of his predecessors. In Clark's opinion 'concrete' isagery had been a mainstay of arguaent on educational topics from ancient tiaes onwards. They vere a stock-in-trade of rhetoric, to convince and persuade there logic aight fail.

Dne of Montaigne's nost frequently used inages is that of nutrition and digestion as a sodel of the educative process and had been sivilarly 1

used earlier by Seneca and Erasnus. Where ve in the rventieth century turn to scientific language to explain e.g. the workings of the aind, the sixteenth century sav "the relation of the teacher to the minds of his pupils invariably as one of agent to patient." Teachers vere often likened to craftsmen: "the dyer [used al so by Plato], the potter, seal maker, and sost importantly fareer---and his pupil with the rav aaterial of the craft--vool, clay, vax, earth or tender plant." All iadges one notes are of things vulnerable to aking or breaking. Montaigne, according to Clark only uses such iages once, and then in a Latin quotation, for he did not see the child's aind as a 'tabula rasa' but in a less passive role. The inage of 'the anpty vessel' is likevise not used by him; "but he does show considerable interest in the inage of the aind as a clay vessel, partly permeable by its contents, but in turn reacting on then by imparting the flavour of things it has previously

1. Carol Clark, The Keb of Metaphor, French Forum Publishers, Kentucky, 1978, p.54.

2. Ibid.,p.55.

3. Ibid.,p.55. 
1

contained." Rather than being moulded the student is absorbent. In 111-12-

1015 this thene is reiterated in more complexity but the aost consistent and strongest image used is the agricultural one. Clark says that "eetaphors draun fron agricultural practice are found in vorks on all of the arts (they are comon in vritings on style and language).., but they dre comonest in uritings on education. "... "The picture is alvays the sane--the ever-vigilant saster extirpating the veeds, soving the good seed, his pruning knife alvays at the ready to el iainate any signs of unregenerate nature appearing in his charges." Sall vonder then that in "De L'institution des enfans" Montaigne begins with a coaparison from agriculture but this is not extended. The only other sinilar reference is then he describes the care his own father took of his education and regrets that ; "il n'a recueilly aucuns fruits repondans a une si exquise culture." And suggests that one reason was the "champ sterile et incoseode "of his oun 3

temper ament.

As Clark points out Montaigne does not see the pupil as 'a sprig of fallen nature' which needs pruning (this phrase is from Saliat). His more unconventional image is one likening the pupil to a colt being broken in by its aster. This night seen a harsh inage to us but as she explains elsevhere, the relationship betveen a horse and his master is one of respect and control. Montaigne does use agricultural inages because they are a liter ary convention, but as he believed in being inventive with language he uses stock inages in unconventional vays. "The idea of soil as redium,

1. Carol Clark, The Web of Metaghor, French Foruw Publishers, Kentucky, 1978, p.57.

2. Ibid.,p.60.

3. Ibid, , p.60. 
deternining the character of what is grown in it, is extended in 1,51 from its normal application to the aind and its productions, to society and its productions in the form of art."

If one vonders why agricultural and horticultural metaphors are so conaton in education, it is presunably because children are so vulner able, so dependent on adults for so Iong. This very vulnerability means that the adults have the pover to choose their role and attitude tovards them. Even now chidren are still waimed, neglected, tortured, bullied, sold and exploited as cheap labour or used as ailitary fodder. Legislation has been used to try to stanp out inhunan practices and the nore institutionalized ones such as slavery, mining, chianey sveeping have been prohibited but society cannot aerely by lavs prevent the abuse and neglect of children. When Montaigne used conventional education inagery it vas usually "to 2 stigatize the practice as he sav it." As a vriter of the pre-scientific period he uses inagery to convince rather than to prove, "the relative role of nature and nurture in the fornation of hunan behaviour or of literary 3 style." Writers of a later scientific age hovever still use inagery and aetaphors to explain educational iaponderables.

By the time of Rousseau "The paradign of the TABULA RASA has given vay to a paradiga of the groving flover or plant, iapelled to ripeness by its oun ELAN VITAL." It is the grouth metaphor which is the nost persistent. Peters according to Greene prefers Plato's inage of education

1. Carol Clark, The Heb of Metagehor, French Forue Publishers, Kentucky, 1978, p.62.

2. Ibid.,p.63.

3. Ibid, p.64.

4. Maxine Greene, Philosophy and teaching, Handbook of Research on Ieaching, Macaillan, London, 1986, p. 486. 
as a "turning tovards the light" to that of GRONTH for he believes that a

concern about grouth and self-deterwination "pay too little heed to the 1

transaission of vorthwhile content." He also said that the grouth

metaphor is "dressing up our value judgsents in seni-scientific cIothes."

and he and Hirst hold that the biological metaphor presents a moral

escape fros educational issues, social issues, and that behind the grouth

aetaphor is the value of autonomy, and behind autonony lie the social

values of toleration, respect for persons, and fairness, to name a fev."

Nevertheless:

Throughout the years the grouth entaphor has served educators and at least one poet in several vays: the student has been the soil, knouledge the seed, and the teacher the tiller and sover; students have been the plants, conunity the soil, the teacher the gardener or forester; students have been the fruit, experience the tree, the teacher the grafter; and of course students have been yeeds in the garden of life off and on forever. It is correct to notice also that opinion is not all in haraony as to whether or how auch "natural grouth" is to be valued, nor is it unanimous as to how the grouth setaphor should be used in defense of an educational theory.4

Dearden says that one searches in vain for an adequate definition of

this grouth concept, rather "it functions as a syabolic inage, pregnant 5

vith aeaning and rich in eaotional appeal." Such notions are found he

says in Holwes ("Our business is to grow") in Rousseau's Eaile (1762), in

Froebel's Education of Man (1826), in Holaes What is and What Might Be

(1911), in Devey's Democracy and Education (1916) and Experience and Education

1. Maxine Greene, Philosophy and teaching, Handbook of Research on Ieaching, Macmillan, London, 1986, p. 480.

2. David Nyberg, Pruning the Grouth aetaphor, The Educational Eorut Novenaber, 1975, p.27.

3. Ibid.,p.27.

4. Ibid.,p.26.

5. R.F.Dearden, The Philosophy of Prinary Education, Routledge and Kegan Paul, London, 1968,p. 25. 
(1938) and volumes on child development.

Children in the eleaentary tradition aged but did not grow in this sense, in fact everything designed for education fitted aore into the concept of noulding $r$ ather than encouraging any natural grouth. Grouth iaplies biological development and aturation, and child development is seen as a process of continuing readiness for nev activities such as walking, talking etc. Observation of such stages is vell docunented even though there vill be individual variations and the exact moment of change is alaost inperceptible. As Dearden says this leads to child development concepts being norative, based on the theoretical construction of an ideal developent pattern. This is vhere the teacher as gardener metaphor arises and the teacher is expected to be ever alert for the pight ooment of readiness to apply the correct kind of educational fertiliser, Dearden quotes Priestman:

[Teachers] aust regard theaselves as gardeners vatching developuent, ready to feed the grouth to the best he way be; not vorried to aake all the plants the same, but trying to bring about that they shall grow, so that the whole garden shall be a harmony.1

It is the vagueness of these admonitions which perplexes us 5ays Dearden for hov does one knov these signs of grouth and readiness and hov does one feed or stiaulate growth. It is assumed for instance that there is a point in time when one is ready for waths just as there is a stage in babyhood when one is able to develop bladder control. The grouth oetaphor is biological but vithout reference points that are biologically visible in the educational field [another physical metaphor]. This concept of readiness also creates situations where children are deprived of access to certain things e.g. books, because it is assumed that they will not be ready for

1. R.F. Dearden, The Philosophy of Prinary Education, Routledge and Kegan Paul, London, 1968,p.29. 


\section{1}

then but need arely to play.

The Froebelian doctrine of grouth expounded al 50 by Gessell and Stanley Hall presupposes an 'essential nature' of perfection which given the right conditions vill gradually emerge. Holnes describes this as akin to the acorn and the oak and Gessell sees it in terns of mirroring the cultural history of the race. The child in this viev is therefore innately perfect. The tendency in such beliefs says Dearden is to ignore the social nature of man.

Wordsworth and Rousseau vould say it was the social vorld of wan which destroyed this innate goodness. If ve are unable to present to the child perfect grouth conditions then ve will never prove the grouth theory to be right. On the other hand ascertaining what these perfect conditions vould be is an alnost impossible task. As Dearden sees it acceptance of this viey of our 'essential nature' can ask authoritarianisa. It suggests also that there say be no place for individual autonomy and iaplies a bel ief in the inevitability of PROCESSES.

The grouth ideology according to Dearden developed out of late eighteenth and nineteenth-century Rosanticisa "a nest from which both Marxisa and fascismenged as two of its broods." In the Marxist viev the individual is merely an aspect of historical deterainism. In the grouth theory the individual in the nost extreac viev is totally at the mercy of nature-and the individual is absorbed into history or 'denocracy'. Maslov's idea of self actualisation modifies this somevhat. Here grouth is still a matter of lavs which bring people to the point of

1. R.F.Dearden, The Philosoghy of Prinary Eductation, Routledge and Kegan Paul, London, 1968,p.31.

2. Ibid.,p.35. 
self-actualisation but they value privacy, detachment, editativeness and independence. Dearden describes this as an ethical stance which has yet to be defended. (See Peters he says 1958 ch5 sect.2)

Froebel ade the most vell known case for the grouth metaphor "draving on Schelling's strong sense of identity betveen aind and nature to construct a profound conviction about the unity in all Iife foras; and of course he left us the perfect single tera for the setaphor: kindergarten." In his Education of Man he said "the young human being is looked upon as a piece of vax, a lump of clay, which an can nold into vhat he pleases..... and said that parents could learn from conteaplation of even the hunble veed how perfectly nature creates beauty and harnony vithout force.

Grouth theory in Dearden's view does not bring us nearer to knowing what the ains of prisary education ought to be. Froebel's goal of "cosplete unfoldedness" has been criticised by Devey, for it "represents a vague sentiental aspiration rather than anything which can be intelligently 3 grasped and stated." Yet Devey said that the dim of education is grouth or rather that education IS grouth. Fron his vritings Dearden deduces that Dewey's belief is that nothing is of value to us unlesss it enters into our experience vith a realization of its value, and a valuable experience is one that has the two features of interaction and continuity. "For Devey, grouth is the enjoying and further developsent of experiences tealized by us to be valuable, and hence the aim of education is to bring about such

1. David Nyberg, Pruning the Grouth metaphor, The Educatitional Forun, Novenber, $1975, p .25$.

2. Ibid.,p.26.

3. R.F.Dearden, The Philosophy of Prinary Education, Routledge and Kegan Paul, London, 1968, p.37.

4. Ibid, p,39. 
1

grouth." But ve can be aistaken in our judgent says Dearden as to what is of value, for notions of what is of value are subjective and education is often valued only in retrospect. He also points out that "Devey's theory of value vould seen to share a general defect of all grouth theories in that rich and integrated selves can be realized which are nevertheless 2

mor ally evil." Which in turn presupposes that those vho are looking for a theory for the aiss of education cannot avoid the issues of sorality. Behaving morally as Dearden says is something that has to be learned, it is not a natural adjunct of grouth. He states that the theory of grouth has value hovever in the ideal of a personal autonomy based on reason and independent of authority and beligves that this is a basic or ainiaal ideal where grouth is seen to be tovards a chosen hunan ideal and not a aindless quasi-biological process.

Analogies, hovever, are not identities, and sufficient confusions have cone to light in the course of this critical appraisal of the grouth ideology to invite the question whether this notion, when taken as a nodel of the educatonal situation, say not have outlived its usefulness. 3

It is of little use in constructing a curriculum to look at the nature of plant grouth he thinks or to search for some hypothetical notion of the 'nature of the child', instead ve drav on the visdon of experience and what has been judged to be vorthuhile, and in a liberal denocracy it is possible to pursue the ideal of personal autonony.

It is not clear to now he extracts this ideal of personal autonony fron the ideology of growth unless he is saying that a concept of

1. R.F.Dearden, The Philosoghy of Prigary Education, Routledge and Kegan Paul, London, 1968,p.39.

2. Ibid.,p.44.

3. Ibid, ,p.49. 
grouth is acceptable if it includes personal autonony which is contrary to What he suggested about the freedon iaplied in the grouth concept as being open to authoritarian interpretation i.e. grovth alloved vithin iaposed constraints which is what schooling essentially is. One factor Dearden does not mention is that children vill grov vith or without an education system. Grouth is inevitable. What education tries to do is to have influence on the rate and nature of grouth encouraging it in certain directions through its formal institutions which are usually organised and controlled by pover groups.

The ideal of personal autonoøy vhich Dearden holds dear is hardly a major factor in such a context. Personal autonony is in fact anathena to sany of the ideals of schools and those who organise then. The curriculue for instance is designed for all children not for individuals. Teaching is done in groups. Testing is most often norn-referenced. Children vork to timetables and nove by bells. Their vork is measured, sequenced, tested. Often they have to vear a prescribed uniform and follow a code of rules peculiar to the institution in which they find theaselves. The only autonony a schoolchild has is in deciding whether or not to listen to or believe the teaching he/she is taught and to invent ways of flouting the rules. This power is ost fully exploited in the secondary situation. Autonoay and institutionalised coopulsory education appear to be iacoapatible.

In biological grouth says Nyberg a preexisting for is implied, which is either fulfilled or autated, and leads to a theory of innate ideas, as propounded by Plato and considered by Descartes, Leibnitz, Kant, Hegel and Chomsky. The grouth metaphor is in fact a paradox if one believes in innateness. The metaphor appears in several different forns says Nyberg:

\section{El Education is grouth \\ E2 Education for grouth \\ E3 Education as Grouth}




\section{Grouth is education \\ 62 Grouth for education \\ 63 Grouth as education}

He then proceeds to prove that 'Education IS grouth' and Grouth IS education' are illogical teras and should not be used. This also leads hin to speculate on the fact that any part ve as teachers play in education is a forn of interference in 'grouth', each tine ve wake a decision on choice of content or how to handle deviancy. He is assuning that people take grouth metaphors literally which is one of the dangers of any use of setaphor when in fact a metaphor is not a mere synonys.

The copula gives the netaphor the strength of a factual statement When it is in fact intended to promote sore than comparisons, analogies or siailarities. A aetaphor can go further than this. What it proposes is a way of looking, a new way of thinking. It generates a tension between ideas ve already are faniliar with and in this space creates room for innovation and imagination. If ve take any educational metaphor too seriously, too factually, then we are eissing the function of aetaphors. It is true that they often lead to theories and models of education, but if ve reify or institutionalize these then ve end up vith the equivalent of a dead metaphor and our attitudes and thinking become fossilized. A.S. Neill for instance ade the notion of grouth something peculiarly his ovn. To hin it meant freedon and he advised parents to leave their children alone, not to interfere so much in their natural development. "Neill took from the notion of the grouth the point that you cannot force the pace of develonent, nor can you turn a seed potato into a prize aarrow." The important idea was to create the optial conditions for growth. Rousseau and Neill are

1. John Darling,Education as Horticulture: some grouth theorists and their critics, Journal of Philosoghy of Education, Vol.16, No.2, 1982, p 179 . 
siailar in their thinking but Rousseau considered it necessary for Eaile to face up to the realities of life, harsh as they night appear. He is also anipulative in his use of pedagogical pover vhereas Neill is not. Rousseau has a blueprint in aind of what he vishes Eaile to be, Neill has none. Both hovever stress the ieportance of understanding the child's aentality. One of the basic tenets of Grouth practitioners says Darling is the need for protection of the 'plant'. There is hovever no notion of equality in the Rousseau Enile relationship. He fails to exhibit what Bertrand Russell felt one should have in such a position of authority and that is a sense of reverence.

Darling himself sees no reason to reject the grouth metaphor per 5e, linited though it aay be; and realises that it leads to concerns such as one expressed by Lavton that it is sometioes interpreted in a laisser-faire attitude which achieves nothing but chaos.

Those coanitted to the grouth aetaphor are concerned to highlight, through it, what they see as the perversities of traditional educational practice, vhile opposition to the metaphor reflects a oore conservative approach to schooling. One's view of the metaphor's vorth is thus a reflection of one's educational values. 1

Darling says that Carl Rogers who is influenced by psychotherapy as Neill was writes in a sinilar vein to Neill e.g.

if I trust the capacity of the human individual for developing his oun potentiality, then I can provide hi vith oany opportunities and perait hil to choose his ovn way and his oun direction in his learning. 2

Peters is very critical of the grouth theory says Darling and 50 to a lesser extent is Max Black tho says "It say vell be that the overworked

1. John Darling,Education as Horticulture: sone grouth theorists and their critics, Journal of Philosoghy of Education, Vol.16, No.2, 1982 , p.183.

2. Ibid, p.184. 
analogy of the biological organisa has served its purpose, " but he hioself believes that the metaphor of the plant still flourishes and rightly so.

Greene presents a metaphor about the range of educational philosophy she has surveyed and finds that "the searchlight of thought about teaching moves over siailar landscapes and sioply pauses in different places." The "triadic" process that is teaching involves the same teros and auch the sane dynanic for all. The poetic language of Buber tells us that we each have to establish a relation to our oun selves and Greene states that "Teachers wast have in their oun ninds and inaginations a viev of vhat is desirable when it coses to husan learning and huan life." This is why I believe that teachers need particularly to be avare of the language of education and especially the aetaphors uhich dominate and charge it. There are links to be seen betwen the eain sources of educational thinking and changes reflecting history, culture and politics. Sonetines one aetaphor doninates or becomes a 'bandvagon', but once avare of then one can be eclectic and profitably select or synthesize the cost appropriate and develop one's oun personal philosophy of teaching for just as no-one can ake a metaphor for you so no one else can tell you hou to teach nor vill it alvays be the same experience. There is little doubt that an appreciation of language is at the heart of any rational or huane perspective of teaching and learning.

Denis Lauton points out that the vord curriculun is itself a

1. John Darling, Education as Horticulture: some grouth theorist5 and their critics, Journal of Philosophy of Education, Vol.16, No.2, 1982 , p.183.

2. Maxine Greene, Philosophy and teaching, Handbook of Research on Ieaching, Macaillan, London, 1986, p.490.

3. Ibid., 491 . 
etaphor--'da course to be run' and that its original aeaning probably has little iapact on us. This area of education abounds vith metaphors such as 'core curriculua', 'spiral curriculua', 'streaming', 'setting' and 'banding' which are meant, as nost metaphors are, to be illuninating or enhance understanding. In this vein it is possible, he says to exanine curriculum metaphors as-- building structures--as a plant-- as a product--as a comnodity. He thinks it aight be more profitable to exanine their nature rather than their uses, whether for instance they are radical, conservative or reactionary, There are three concerns Lavton has vith curriculua etaphors. First, those which mislead rather than clarify and he draws on Dearden's work in this, here netaphors are stretched from one context and applied to another e.g. the notion of a 'balance' as in diet. Such teras are secondary rather than prisary principles, and it is no use appealing to the secondary principles until ve have sorted out the primary. There may be ore consensus also on what constitutes a 'balanced' diet than a 'balanced' curriculuan. The metaphor is therefore obscure, yet as he says there is often an assuoption that such consensus in fact exists.

Secondly Lauton attacks the use of the tern 'objectives' in curriculum planning because "it is over-specific: an objective is a clear and LIMITED educational intention indicating not only a directon but a finishing point, whereas the essence of education is that it is open-ended." An objective is often defined in terms of change in pupil behaviour which is measurable. Such teras are frequently used in business anagenent.

Teachers are often expected to plan in teras of 'units' of vork e.g. language unit on a particular topic. Once again the tern is overlaid with

1. Denis Lauton, Metaphor and the Curriculum', Metaphors of Education, Heineaann, London 1984, p.83. 
connotations of aeasurement or packaging of teaching and learning into definite specific amounts or 'doses'. Module is another 'in' vord. One effect of this style of vorking is to treat the 'units' as self-contained and with little reference to previous or later vork. This tendency vas brought hoae to ae recently when supervising a trainee teacher who had been given the slogan "Catch 'ell teach 'en test 'ea" which wight prove a practical philosophy for the linited period of a teaching practice and each lesson within it but ignores the overall purpose of the vork. It is little different fron the Ais, Content and Method approach uhich used to be applied to each lesson plan. All of these overlook the necessary span and scope of teaching and spontaneous teaching and learning situations. It is not something to be measured out like medicine or food but an ongoing process preferably at the learner's pace or to use yet another current tera the 'client'. The compartaentalizing of subjects and the pressure of exanoriented syllabi has probably led to this state. It is possibly inevitable to a certain degree but I suspect as Lauton seems to, that it is also the effect of a certain yay of seeing teaching, a metaphor taken froe areas such as business systeas with their efficiency studies. When we use such teros in teaching ve are in a sense dissecting a live organise and hoping it vill live through the process. Likewise the ter 'system' is also unattractive, redolent as it is of the 'mechanistic' nodel.

Lauton says the tera 'objective' is useful and useable in clear cases as when practical skills are to be acquired but any areas of the curriculun are indefinite in teras of objectives e.g. Literature. Yet this is exactly what teachers are often asked to do in the pursuit of normreferencing as in traditional examinations. Poetry vriting would be iapossible to assess yet ve do assess paintings. This difficulty is the reason also for the increasing use of multiple-choice tests where sometiaes 
even the authors cannot decide on the correct answers.

A metaphor that vorks in one part of the curriculun ady vell not work in another. Sequence aay be important in Maths but not in Literature. An obsession with 'sequence' is one of the pitfalls James Moffet points out II believe--that sequencing en masse can only occur grossly over a very long haul and that specific sequencing--day-to-day and even nonth-tononth--should occur on an individual basis." He beligves it to be the biggest snare in the curriculum "When educators speak of sequence, they virtually alvays aean for a group and aost often for a year." Moffet believes ve fail to distinguish betveen biological growth and sequence of subject atter and disregard how in fact people develop, which aeans "You can't GENERALIZE for a vhole peer group about anything 50 SPECIFIC as to what kind of reading or vriting its meabers' grouth denands .... ${ }^{3}$ for to be meaningful "Grouth weans being able to do nore things and to do old things better, not merely hopping frou one stepping stone to another." This is not to say that the teacher cannot vork out a desirable sequence but that it is then used to suit the pupil not vice versa. In fact he describes the nornal sequence in language development from speech to dialogue, fron intinate to renote audiences, from vernacular to literary style, from small inoediate subjects to more remote, fron recording-reporting-generalizing to theorizing, from perception to eenory to ratiocination, from present to past to potential and from chronology to analogy to tautology. This is not a 'fixed' progression but a general outline of how one can expect a reader and uriter to possibly develop.

1. James Moffet, Activive Voice, Boynton/Cook, U.S.A.1981, p.5.

2. and 3. Ibid.,p.9.

4. Ibid.,p.10. 
Janes Nattinger velcones the use of a nev sethod in language teaching. It is known as CLT or Connunicative Language Teaching, and he explains hov it is linked to metaphor in general and indicates a aove avay from metaphors comonly used to describe language teaching. He says "Any model, any theory, any description is a aetaphor of a sort, so most of the explaining and learning ve do takes place metaphorically." "The first to be used, according to Herron, says Nattinger was a GMNASTIC wetaphor. It used to be thought that just as muscles get stronger vith exercise so it vould be with the aind:

Some of the iaplications of this metaphor are that students are full of Iatent abilities yhich, because of lack of training, have never been developed; that teachers are trainers who vill discipline then into practicing these unused povers; and that language, the focus of this exercise, is a formal object uhich consists of meanings to be extracted and astered.2

Later audiolinguistic methods eabraced the PRODUCTION metaphor which linked language teaching to the development of arketable and usable skills. In this schools are like factories. This resenbles the iapression model described by Scheffler with its focus on input and storage.

More recent methods have called theaselves "humanistic" and "learner-centred" and in this the metaphor is that of the child beginning learning of its first language. Teachers respond here to emotional and cognitive needs of their students. Meaning itself is souething that 3 emerges as it is negotiated." But effective as it say have been, second language learners are not children but experienced language users and processors so a more acccurate metaphor is needed and sought which will

1. Janes R. Nattinger, Connunicatitive Language Ieaching: A Ney Metaghor, TESOL Quarterly, Vol,18, No. 3 Septenber 1984,p.392.

2. Ibid.,p.392.

3. Ibid.,p.393. 
retain the best of the foraer one.

Various strategies are used in the classroons. Role playing designed to promote extended discourse is one. Process uriting vith ample revision to encourage fluency is another. Readers are seen as "actively creating aeanings on the basis of the discourse clues they find, just as in speaking and uriting." 1 This follows Widdowson's idea that "reading is not a reaction to a text but an INTERACTION between uriter and reader mediated through the text." "This indicates a trend avay fron the ided that a text is siaply a container of vords siailar to the metaphors of the wind as a container to be filled. "In the new aetaphor.... oeaning is seen as being attached to vords vhen they are used in particular contexts." Reading is therefore not finding complete meaning but encoding. Stories with an element of surprise or aystery prove particularly useful as they encourage prediction and al so "folktales because they often contain interculturally predictable PATTERNS [ay enphasis]."

What energes fron this work is a realisation that rather than learning correct structures and applying the students learn by interacting verbally and as Hatch has said " out of this interaction syntactic structures 5

are developed. - Linguistics has usually been concerned vith the foral properties of language learning rather than knouledge. The neu findings contradict the former preaisses "that nonologue rather than dialogue is the basis of language; and that basic meanings are independent of an

1. James R. Nattinger, Congunicative Language Ieaching: A Ney Metaphor, TESOL Quarterly, Vol.18, No. 3 Septeaber 1984, p.396.

2. and 3. Ibid., p. 397 .

4. and 5. Ibid., p. 398 . 
individual's particular experience."

Nev oodels of language structure and cognitive discourse processing shov a close link betven language comprehension and production and language content and existing knowledge. Chafe has explored the relationship betveen language and consciousness, and language and seaory. We make meaning from language he thinks by focussing on senantic information, translating surface structures as quickly as possible, and storing then in neaory.

These stored semantic fact5, he says, are "schenatic STRUCTURES lay eaphasis] consisting of an "event," "action," "process," or "state," and a nuaber of "participants" having expected case roles. These schenatic strutures are thenselves further integrated into the user's vorld knowledge, which is itself organized in terss of prototypical situations called FRAMES and SCRIPTS. These are complex cognitive units that represent series of cause and effect relationships about particular subjects and frquently occurring episodes in our lives. Such knovledge-based structures are seen to provide a franevork for coaprehension PATTERNS [ay eaphasis] in discourse as vell as to account for interference strategies, which are an extranely inportant part of discourse processing. 2

Fros this description one's mental life appears almost like a movie record which can be stored, replayed, edited, rescripted and 50 forth. Where this fits in to ay proposition that learning is closely linked to metaphor lies in the fact that in this language teaching method, naking nistakes, dealing with incongruities, is all part of the process of learning. My contention is that a aistake or a aisunderstanding reseables a metaphor where the frames do not watch or aake sense just as if one fila had in the aiddle of it a frame that came from another fila. One aight call this a metaphoric model of learning which has implications for teaching.

1. James R. Nattinger, Comgunicative Language Ieaching: A Ney Metaghhor, TESOL Quarterly, Vol.18, No. 3 Septenber 1984,p.399.

2. Ibid., p.399. 
Nattinger says that research into artificial intelligence is vorking along the saae lines, that is, exploring how we think. Studies of chess nasters for exanple show that they do not 'see' individual chess pieces but clusters or chunks. These are again a for of patterning. What energes from these studies is the avareness that "If ve understand hov Ianguage vorks, cognitive researchers feel, ve vill be far along the path to understanding how the aind vorks--in reasoning, learning and reaeabering." Computational metaphors are therefore in vogue, though language teachers feel that these ady be nodelled on structures that are too fornal. They are also conscious that other factors such as environment and syllabus content also affect learning. Perhaps the nev seasure of the aind vill be not its storage capacity but its aetaphoric capacity.

Montaigne criticised the pedants for their isages of learning as he believed the huan aind vas not a thing of liaited capacity but infinitely extensible an idea accepted nov generally acknovledged. What he sav in the pedants vas a lack of elasticity of aind, they vere too rigid, His oun aind $r$ anged over the current metaphors of his tiae and as $\mathrm{Clark}$ says his 2 inagery never stands still. This is a facility ve need to encourage and develop, for to question old netaphors, to accept nev metaphors and to create new metaphors means to be forever adapting, learning and changing. The poet Rainer Maria Rilke said "Inagination is required if ve are to 3

create aeanings or to reinvent our traditions." Buber said that "The

1. James R. Nattinger, Comaunicative Language Teaching: A Nev Metaphor, IESOL Quarterly, Vol.18, No. 3 Septenber 1984,0.403.

2. Carol Clark, The Meb of Metaghor, French Foru Pubs., Kentucky, 1978, p.82.

3. Maxine Greene, Philosophy and teaching, Handhook of Research on Ieaching,ed.M.C.Hittrock, Macaill an, New York, 1986, p.490. 
teacher must institute the kind of dialogue that enables students to break with the 'collective' and establish sone relation to their oun selves."

Martin Heidegger saw that computing vas likely to become the dominant mode of cognition but if this yas fused vith "@editative thinking" in which one is avare of one's relationship to the vorld and to nature then this might prevent technology froa doninating cognition, which vas obviously the intuitive fear of those language teachers wary of the never language teaching oet aphors.

Similar fears have been expressed by people such as George Herbert Mead who sav the protection of self coning froe a aodel of 'education as 'conversation', belonging to a universe of discourse" and in which he thought that the personality of the teacher should disappear "behind the 2

process of learning." More recently Paul Hirst speaks of conceptual framevorks that are publicly shared. In this viev the capacity to syabolize is fundamental, Jane Roland Martin thought this gave too auch emphasis on developaent of aind rather than person.

Her challenge dranatizes a groving tension in approaches to education and to teaching in conteaporary philosophical thought. In one sense it aight be vieved as a tension between the pure cognitivists or the analysts and those vith a more experiential or action-oriented view.. It aight be regarded as a resurgent struggle betven those oriented to rules and noras in the Kantian tradition and those concerned with history, consciousness, and change. 3

The part philosophers play, says Greene, is in elucidating concepts and terminology. Wittgenstein for instance became concerned with discrepancies betveen what is said and what is actually meant and his vork is considered a bridge between analysis and contemporary phenomenology. Husserl said that what was perceived depended on the standpoint of the individual

1. Maxine Greene, Philosophy and teaching, Handhook of Research on Ieaching, ed. M.C.Hittrock, Macaill an, Nev York, 1986, p.490.

2. and 3, Ibid, , p, 492 . 
perceiver and that ve need to break with the attitude which believes that the outside vorld is nothing aore than a aass of sense data or a phenoaenon conclusively defined by science in its nost unreflective oode, "The significance for the teacher lies in the stress on standpoint and interpretation, on the importance of refusing the taken-for-granted, on the recognition that reality is constituted rather than siaply given."

The need for the school to foster inagination is also evinced fros the vork of Sartre tho sav that freedon involved having a vision of possibilities, of alternatives. One needed to develop therefore a posture of interrogation.

The general vieu seens to be that our vorld is only constructed through the meanings which ve impose upon it. Maurice Merleau-Ponty says Greene thought that it yas the realisation that there is sonething hidden or "in reserve" or still unknown that enables people to "break through the horizons of what they can grasp--to theatize, to articulate, to learn in 2 an intersubjective yorld." Teachers aay be doing little to get children to really think about this fact or to perceive that their taken-for granted vorld is a social construction.

Seldom do they [teachers] comunicate the idea that what is taken for granted as noral and unchangeable is a reality humanly constructed over time. That is why so little attention is paid to the interpretive aode of knoving. It is probably why there is so little questioning of the inequities in our society, the structures and organisations of schools, testing practices, regulations and controls.3

This is apparent to any teachers who do question the systea, the syllabi, the tests etc., but for sany the vorld-as-is suits then and they see no need for change. A focus on aetaphor in any sphere of the curriculum could help to avaken people to the false and epheneral nature of reality.

1. Maxine Greene, Philosophy and teaching, Handbook of Research on Ieaching, ed.M.C.Nittrock, Macnillan, Nev York, 1986, p.494.

2. and 3. Ibid, , p.495. 
In the introduction to Metaghors of Education Taylor says that:

In the literature on these topics it vas clear that ideas transported fron their original fields of application vere being eaployed to describe, to legitisate and sometines to explain, coaplex, nultideternined processes and procedures in ways that, hovever useful, vere often inappropriate to educational contexts. 1

Dnce removed aight have been inappropriate but tvice removed as many of the vere when applied to Third Horld countries or colonies they often proved voefully inadequate and inequitable as Mathew lachariah explains of the period fron 1950 to 1980.

The doainant metaphors have been traced back to Greece and Rome and then via Europe frow vhence they have percolated to other countries vhere educational institutions have been set up on the sane models. The agricultural and horticultural metaphors applied to education are two such exanples. Zachariah maintains that "Many of our thought processes about education's role in development are aniated largely by aetaphorical vievs 2 of people as clay or people as plants." He is avare that metaphors can guide and enrich but they can also distort and confuse for "as a seanticist vould say about the use of symbols, the aap is not the territory."

Post-war conditions necessitated a transfornational role for education and this in his opinion "bolstered the viev that it had a solding 4

mission." Seeing people as clay presupposes that they are inaninate until foraal education gives then life and this is given by people who have

1. Willian Taylor, Metaghors of Eductation, Heinemann, London,1984, p.1.

2. Mathew Zachariah, Luaps of Clay and Growing Plants:Doainant Metaphors of Education in the Third World, 1950-1980, Cogearative Education Revieg, Vol.29, No,1 1985, p.2.

3. Ibid.,p.3.

4. Ibid.,p.4. 
already undergone the process. Quality varies in people just as vith real clay and not all pots are expected to turn out perfectly so the results can be graded according to quality and finish. The molding process also has to be done quickly and efficiently and there vas alvays an assuaption that Western methods of clay-molding were the nost desirable until tiae proved that this vas not alvays so and critics spoke of 'dysfunctions' vithin the systen. After Vietnan sone Anerican scholars began to ask questions and to be prepared to listen to others from the Third vorld. Then the sore poverful countries began to be seen ds exploiters, and econonic grouth for its oun sake came in for criticisa. Grouth in fact was liaited to certain sections of society such as urban rather than rural. These sane problens were being airrored elsevhere and efforts to refor educational systens to be "aore affective in their molding and training wission vere meeting considerable resistance from entrenched bureaucracies and persons or groups with vested interest5." Questions nov familiar to us vere being asked such as tho benefits nost fron education.

One scholar David B. Abernethy came to the conclusion that popular education could both encourage and inhibit developent--and equality was not being achieved. The pervasive and deleterious effects of such things as hidden curriculun vere beginning to be realised. The never aetaphor of the growing plant energed vhere children are expected to thrive if given naturally conducive conditions.

Zachariah believes that dependency and conflict theories are also compatible with the groving plant aetaphor and that those who tend to Marxist theory are vorking with the plant metaphor where all are assumed

1. Mathew Zachariah, Luaps of Clay and Growing Plants:Doninant Metaphors of Education in the Third World, 1950-1980, Congarative Education Reviev, Vol.29, No.1 1985, p.12. 
equal. In the dominant Soviet and Eastern European states education nore closely resenbes the clay metaphor. In the vritings of those whe eschev dependency theory they do not suggest revolution or over throw of capitalisn and exploitation but developeent of the individual's potential to bring about change. He believes that this is because they inherited the groving plant perspective as heirs of Devey.

Freire's york in Brazil says Lachariah recognized that effective learning takes place when it begins where the learner is and vith his/her needs and creates opportunity to use learning. His concept eabraced aterial and spiritual diaensions, the concept of education as the practice of freedo (not indoctrination) and the conscientization of oppressed people. In his education process all grov, both teachers and students. Illich prefers the plant metaphor to the clay one says lachariah for he said:

Education iaplies a grouth of an independent sense of life and a relatedness which go hand in hand with increased access to, and use of, memories stored in the human comaunity...This presupposes a place vithin society in which each of us is avakened by surprise; a place of encounter in which others surprise with their liberty and ake avare of ay oun. 1

Samuel Boules appeared at first to uphold the clay metaphor says Zachariah but later vrote that "An econonic structure able to absorb all the educated is not possible under conditions of national dependency, and a syste of schooling which complements all people's social utility also is 2

not possible."

An alternative to the groving plant metaphor, Mao Ze Dong's China

1. Mathev lachariah, Luaps of Clay and Groving Plants:Doninant Metaphors of Education in the Third Horld, 1950-1980, Congarative Education Revieg, Vol.29, No.1 1985, p.17.

2. Ibid.,p.18. 
"apparently proved that sodern educational systems need not be heartless 1

sorting and selecting wachines" and to prove that self-actualization for individuals vas a possible alternative to alienation and exploitation. The ain vas a non-hierarchical social order. Whilst a state pays for education it vill necessarily become bureaucratized and the clay metaphor dominates says lachariah at the expense of the poorer people and Education vill not conpare vith armasents for priority of funding. Sone teachers vill still atteapt to nurture the individual he thinks but to be aore effective in terms of social justice schools have to become more autononous, in order to be agents for critical evaluation and refora. The odin question aust be who benefits and at what cost. The ain needs to be, thinks lachariah, to build culture vithout promoting one group at the expense of others, which vill necessitate a less hierarchical social structure--less differentiation betveen sanual and aental labour and sore serging of school vork and paid eaployment. One can only speculate says Zachariah where this evolution I a nev paradign] vill occur. He seens to think it aay be an endless Sisyphean task.

Metaphors of education arise to fill the human need to wake the passage fron childhood to adulthood aeaningful both for the recipients of education and those responsible for organizing it. Every 50 often a concept of what education aight be arises and captures the public inagination. The Dutvard Bound school is just such a concept. Stephen Bacon has uritten of it as a conscious use of aetaphor, a for of metaphoric education vith close affinities to a parable or allegory, an

1. Mathev lachariah, Lumps of Clay and Groving Plants:Dowinant Metaphors of Education in the Third Horld, 1950-1980, Cogegarative Education Reviegy, Vol.29, No.1 1985, p.19. Yet Cleverley J., The Schooling of China, George Allen and Unwin, Sydney 1985, says gardening and engineering metaphors prominent, see p.225. 
approach to metaphor that has he says been used in psychotherapy by Milton Erickson. In the outdoor experience students dre exposed to experiences that he says are isomorphic with their real life situations and they must use non-typical strategies to solve setaphoric challenges. This complex cognitive process he calls the transdirectional search. Essentially it means they are using past experiences to ake sense of the present.

In noral educational experience such as a lecture, the listener tends to perfor the transdirectional search on an intellectual level. Conversely when using metaphor, the transdirectional search goes beyond intellectual concepts and dravs upon inportant emotional experiences. In addition, the metaphor usually matches the pattern of experience rather than single concepts. The process of matching a whole PATTERN [ny eaphasis] is so poverful that the metaphor and its real life correlates becone inextricably linked.1

In some ways this seeas not unlike the total involvement sall children have with their play tasks. Action is the inportant ingredient says Bacon. There are covert psychological aessages inplicit in the activities of the course. The person undergoing the course is travelling an innet journey. What the instructor has to do is to find the meaningful context which ost benefits the students and then lead thea to it skilfully and elegantly. The vilderness represents a sacred space and has an archetypal attraction in Jungian terms which schools never have. The students thus participate in uhat are really age-old patterns of human developeent and this generates a special spirit on the course. The sense of a sacred space aakes transforsatory processes happen more easily and makes the changes more profound and more permanent. Bacon sees the process as truly holistic and siaultaneously pragatic and subliae. His viev is one alternative to the nore usual metaphors of education.

1. Stephen Bacon, The Conscious Use of Metaghor in Qutward Bound, Colorado Outward Bound School, Denver, Colorado, 1983, p.9.

2. Ibid.,p.58. 
Paivio has said that probably the most inportant practical outcomes of research on iagery and verbal processes vill be in relation to probleas of education. One of the main difficulties in teaching is that ve cannot see into the student's aind. We can only 'read' the external signs such as attention, apathy, or responses such as questions etc. Even if teachers believe in beginning where the students are and with what they already know there is no guarantee that a class vill all be at the same place. Every student is different and even teachers expert in their content areas and with good teaching aethods and objectives still have to 'key' in to each learner to help hic or her sake sense of nev uaterial especially. It is al nost like trying to tune in to a radio programe going on in each person's head and adding ore to it without creating too auch inter fernece or blocking what is already there. The old metaphor 5 of wax tablets, eapty pitchers and tender plants are no longer viable unless one still believes in what Freire calls the 'banking' aethod. The student is responsible for his/her ovn learning but the teacher is still the link in the process of acquiring nev knouledge, new techniques or improving on old ones. Metaphor can be seen as a kind of aicrocosı of the whole learning experience if ve consider it in the light of new knowledge of how the brain works, not merely as a vast catalogue systen nor a busy computer but sonething oore conplicated than either of these and capable of endless permutations of information.

Petrie sees metaphor as an inportant eleaent in the teaching method. His thesis is "that metaphor is one of the central vays of leaping the epistemological chas betveen old knovledge and radically nev 1 knowledge." What happens is that neu infornation is processed "from a

1. Hugh 6. Petrie, Metaphor and Learning, in Metaghor and Thought, ed. D. Ortony, Cambridge University Press, Nev York, 1979,p.440. 
given context of understanding to a changed context of understanding."

This a akes sense if we consider that to educate is to change a person. The material to be learned ay be factual or logical but if it is to be ade the Iearner's own then aetaphors, analogies and aodels can be crucial to that process of aking the nev aterial intelligible and accessible. When Petrie speaks of metaphors in this context he is assuning the interactive type of aetaphor rather than the siaply comparative. "The interactive level of uetaphor is particularly appropriate ... because it CREATES sinilarities.' Even though the metaphor any be a comparative one for the teacher who already knous the subject. To Petrie metaphor in this area is not merely a sentence in the linguistic sense but an utterance meaning or speech act because of the inportance of context.

This notion seems to fit also into the idea that Vygotsky has of geological layers of understanding vhere a new layer can only be added if the base layers are already there, that is to say that the new knowledge has to be understandable even through the aetaphor, in terms of what is already known. Petrie describes a student being told that "The aton is a miniature solar system. "The student transfers this knowledge of the solar system and applies it to a new understanding of atons recognising hovever that there is an anomaly, and accepting this. "There is no radically nev knouledge, for the cognitive structures remain the same; only their field 3

of application has changed." If the student has not got such prior knovledge then the aetaphor is aeaningless, is understood only as an anowaly

1. Hugh 6. Petrie, Metaphor and Learning, in Metaphor and Thought, ed. D. Ortony, Canbridge University Press, Nev York, 1979, p. 443.

2. Ibid., p. 442 .

3. Ibid.,p.444. 
or is taken literally.

Literal Ianguage requires only assiailation to existing framevorks of understanding. Comparative aetaphor requires simple extensions of the framevork in the light of a more comprehensive framevork. Acconnodation of anonaly requires changes in the frasevork of understanding.1

Petrie notices a strong sinilarity in this process to that ohich Kuhn describes in the changing paradigas of science. In the teaching situation it is the teacher who usually provides the metaphors. They dre sinilar to the exeaplars described by Kuhn, which allov theory to be applied to practice. It is the activity of the student or "ACTING in the ecology" that is a vital conponent in the learning process.

...metaphor is what enables one to pass from the more familiar to the unfaniliar in the sense that it provides one mechanism for changing our oodes of representing the world in thought and language. It provides this mechanisa not through a direct labelling, nor through explicit rules of application, but rather because in order to understand an interactive aetaphor one wust focus one's ACTIVITIES on nodes of relative stability in the vorld. Language bumps into the vorld at those places where our activity runs up against sisilar boundaries in diverse situations. 2

Petrie agrees vith Searle who has said that the process of construing a aetaphor is a natural extension of ordinary thought and activity. The teacher supplies a metaphor to help, which is in a way like setting a problem to solve a problem. The essence of its success seens to lie in the interaction and activity this generates. As Vygotsky says "frou action to thought" or Piaget "to understand is to invent."

Valerie Malkerdine is also interested in how children learn and considers the way children's thinking is initially tied to faniliar contexts and as Margartet Donaldson has said has to be "prised out of the

1. Hugh 6. Petrie, Metaphor and Learning, in Metagher and Ihought, ed. D. Ortony, Canbridge University Press, New York,1979,p.444.

2. Ibid.,p. 447 . 
old primitive atrix in which all thinking is containad" in order to approach formal reasoning. She believes that children are able to reason in familiar contexts because "their learning involves being able to adopt positions in discourse in relation to familiar practices and to operate 2

accordingly." She explores how children vork out context and considers that "the crucial moment of understanding lies in a specific relation of 3

signified to signifier." In this she is guided by seniotics which stresses that the relationship betveen signs is not to be understood sioply as a linguistic relation but as a social one. Unlike Saussure she does not believe that ve can understand the relation of language to thought vithout considering social practices.

A practical example of what she means is illustrated by the young parents of a new baby who are at a loss to interpret the baby's crying. To study their vords vould not fully explain their situation. Not only vould one need to exanine their language, but also gestures and actions and behind all of these is the knouledge they may or nay not have of baby care and current child rearing practices which ady be influencing them, "There is a historical and social dimension which ve must include to understand 3

their discourse" which does not create the context but influences it.

This approach is usually applied to the analysis of texts. As Devey said:

The conceptions of SITUATION and of INTERACTION are inseparable from each other. An experience is always what it is because of a transaction taking place between an individual and what, at the tiae, constitutes his environaent, whether the latter consciously

1. and 2. Valerie Malkerdine, Fron context to text: a psychosemiotic approach to abstract thought. fro Children Thinking Through Language, ed. M. Beveridge, Edvard Arnold, London, 1982, p.129.

3. Ibid.,p.131.

4. Ibid.,p.132. 
consists of persons with whon he is talking about sone topic; or the toys with which he is playing; the book he is reading (in which his environing conditions at the tine may be in England or Ancient Greece or an imaginary region); or the naterials of an experiaent he is perforaing. The environeent in other vords, is whatever conditions interact with personal needs, desires, purposes, and capacities to create the experience which is had. Even when a person builds castles in the air he is interacting vith the objects which he constructs in his fancy.1

Walkerdine has observed young children and how they suitch in and out of a vast repertoire of discourses. This has led her to recognize that there is an initial opening METAPHOR which children recognize and interpret and has the effect of 'calling up' for the participants the relevant discourse. Children in one instance played with Lego and the opening metaphor vas a coment about a big $\mathrm{crane}$, which object became, in her vords "a crucial link in the potential chains of aeaning." That is to say that it triggered off a uhole discourse as the children played.

...although features of the objects [as in the Lego] thenselves are crucial, what is important is that that these objects can never be understood except in teras of a specific discourse, such that the objects are read etaphorically to produce the actual linear sequencing of the gane. 1

This seems to me not unlike the vay adults deliberately use artificial starters such as the veather as topics for initiating discourse. In these children's ganes one vord or phrase seems to be the impulse which directs the flov of the discourse. Nor does it seen to the author that the children are acting upon the objects in such a vay that the language is a secondary process relegated to a level of representation AFTER concepts are formed. It seems more plausible to her to infer that it is the relation of signified

1. John Devey, Experience and Education, ins.M.Cahn Philosophical Foundations of Education, Harper and Rov, Nev York, 1970, p.236.

2. Valerie Walkerdine, fron context to text: a psychoseniotic approach to abstract thought. from Children Thinking Through Language, ed. M. Beveridge, Edvard Arnold, London,1982, p.134. 
to signifier which is determinant in structuring the course of the play, and it is the children who "construct METAPHORS out of signified/signifier relationships to 'read' the objects and that these are crucial in understanding the vay that a particular discourse is 'called up'."

Walkerdine uses Jakobson's use of the term 'metaphor', for he says that language is characterized in terms of two basic axes SELECTION (aetonymy) and COMBINATION (metaphor), Foraal reasoning involves the aetonyaic axis:

In practical reasoning we deteraine the truth or validity of a statement in terms of its corraspondence to the rules of a practice, whereas in formal reasoning truth is deterained in teros of the internal relations of the statement itself. To reflect on the internal relations alone ve have to ignore the metaphoric content of a statement which might distract from the focus on the logical relations entailed in the statement, nasely by directing attention to the practice to which the stateant refers.2

It is easier to look for internal aeaning in uriting or text, 25 is done vith the scriptures.

Walkerdine argues that the linguistic system itself provides the tools necessary to formal reasoning and so ve can exanine hov chidren learn to reflect consciously on their practices and on the internal relations of the statements thenselves, The psychologist Olson has clained that ve do not need to have recourse to explanations which focus solely on the properties of the aind, ve can observe then in technology such as writing, and Vygotsky and Luria thought sinilarly. What is important for children says Walkerdine is that the logical relations of a task are embedded in a meaningful context. As proof of this she cites tests done by McGriggle and

1. Valerie Walkerdine, Fron context to text: a psychoseniotic approach to abstract thought. from Children Thinking Through Languagage, ed. M. Beveridge, Edvard Arnold, London, 1982,p.136.

2. Ibid, $, p, 138$, 
Donaldson where the tasks proved easier to do on a aetaphoric rather than a aetonyaic axis. Formal reasoning she says dravs its validity from, and depends entirely upon, reflection on the metonyaic axis--on the relations betveen signs and not on their metaphoric content: in other words the 'meaning is in the text' as Olson says. In this situation oetaphor can cause confusion as it distracts from concentration on the task. Matheatical discourses for exasple aininize the presence of metaphor. It has been shown that children use metaphor in daily social practice but when approaching foral reasoning the metaphoric axis has to be suppressed. In test situations they vill relate even abstract tasks to things they see and know. Walkerdine states that children learn to treat statements in different ways at school and certain practices in early education lead the way to foral reasoning so that children are veaned from the authority of the teacher to the text. For instance in aaths games chidren find it hard at first to distinguish between the rules of the gase and the rules of discourse because they are all presented in the same uode. Gradually they learn what is accepted behaviour such as whether to orau oargins, use pencil etc. The emphasis is on the activity.

... while there is considerable attention paid to the rules of the practice, there is very little evidence of teachers encouraging children to approach the problens using the discursive patterns of reasoning either in relation to the limits of practices or in relation to statenents themselves. 1

This is because of the approach in prinary schools and accounts thinks Walkerdine for the development of reasoning in teras of the internalization of action and not in discourse. When children try to speculate they are often discouraged and led back to experience.

1. Valerie Walkerdine, From context to text: a psychoseniotic - approach to abstract thought. from Children Thinking Ihrough Lannguage, ed. M. Beveridge, Edvard Arnold, London, 1982, p.145, 
Whilst observing aths lessons she noticed that teachers describe giving children experience of objects in order to teach then particular mathenatical concepts but what the chidren actually do is perfor a series of translation exercises so that "a statenent embedded in a particualar practice is transforead into vritten numerals where the aeaning is internal 1

to the text." It appears that children have to be led to the discursive for of matheatical statements via a process which retains the same aetonyaic form but gradually strips avay the aetaphors. The teacher next leads then frou utterance to vritten foras of the nunerals and dravings are used as iconic metaphors for the blocks which have previously been used. The netaphor of 'aaking' is still used and is physically demonstrated by the teacher moving her finger down the line as she says "makes". The children begin to do the sane and speak of 'carrying' also. One can see the children visibly woving from utterance to text and in cases where a child is not noving the teacher goes back to the explicit use of metaphor even naming the blocks as 'houses' and 'people'. What is so crucial here says Halkerdine is that the use of these faniliar terms does not aake the task sore concrete or active but "allows it to enter into a system of meaning."

Children do not have raw experiences of concrete objects: meaning is created at the intersection of the adterial and the discursive, the fusing of signified and signifier to produce a sign. These meanings are located in, and understood in terns of, actual social practices, represented in speech as discourse. It is by analyzing the for and content of discourse, the processes of selection and combination, of metaphor and aetonymy, that ve can account for the origins of processes and reasoning. 3

1. Valerie Walkerdine, From context to text: a psychoseniotic approach to abstract thought. fron Children Ihinking Through Language, ed. M. Beveridge, Edward Arnold, London, 1982, p.146.

2. Ibid., p. 149 .

3. Ibid., p.153. 
Young children can shift in and out of discourses not because they possess reasoning skills but because "the metaphoric content of the task allows them to examine the task vithin the boundaries of a social practice."

This they seen to do quite naturally whereas forkal reasoning has to be learned by gradually akking eetaphor inplicit and leading students tovards a text.

Thomas Green agrees that metaphors are nice but not necessary to 2 learning except perhaps to gain religious knouledge. He clains reasoning to be a superior node. However, whilst Petrie aay be confusing in his coments on anomaly in the light of Walkerdine's observations and others it vould appear that children need them and young adults too at soae stages of learning. According to Steven Miller what is nore important than deciding whether metaphors are iaportant to teaching practice is to examine the theories behind the practices:

...the difficulty in understanding the proper use of metaphor as a pedagogical technique stens from a failure to see that metaphorical statements DUGHT to be applied and analyzed at the level of the social and psychological theories that are believed to be the theoretical (and hence professional) underpinnings of practice.3

Metaphor aay be central to the "conceptual structure" of particular subject matter and only indirectly (if at all) to the psychological theory. For the theory 'sets the stage' for a possible use of metaphor.

Miller believes that "metaphorical statements are 50 facilely employed

1. Valerie Walkerdine, From context to text: a psychosemiotic approach to abstract thought. from Children Thinking Through Language, ed. M. Beveridge, Edvard Arnold, London, 1982, p.153.

2. Thomas F.Green, Learning vithout Metaphor, inMetaphor and thought, ed.D.Ortony, Cambridge University Press, new York, 1979, p. 463.

3. Steven Miller, Some Coment on the Utility of Metaphors for Educational Theory and Practice, Educational Theory, University of Illinois, Sumaer 1987, Vol,37, No.3,0.221. 
in educational and other contexts that their question-begging nature is 1

often overlooked." and "they are at best partial explanatory accounts of processes or states of affairs not fully understood at the present and used to justify psychological and social theories for teaching practice." We cannot, he says, say whether metaphors help one group more than another. It may be just as iaportant as freen has suggested to train teachers hov to apply the techniques of logical inference to specific rontent areas.

Thomas Sticht who sees metaphors as condensed sibiles el aborates on their use in teaching as propounded by Petrie and says that it is possible to improve comunication and reasoning skills in children and marginally liferate adults in a very short training period which al 50 iaproves their ability to produce and comprehend metaphors. He sees metaphor as a tool which extends the capacity of active memory USING THE MEDIUM OF SPEECH to help us aeaorize, encode and decode. Rhyme and thyth are tools in a similar sense.

In 1975 Ortony discussed three ways in which aetaphors helped learning, by COKPACTNESS in that metaphors transfer chunks of experience frow well-known to less well-known contexts; by VIVIDNESS i.e. pover of inagery and by the INEXPRESSIBILITY thesis or the hidden aeanings which they carry and which are never encoded in the language, Compactness and expressibility both suggest that netaphor had its origins in oral language.

Petrie dvells on the use of metaphor as a teaching aid to tease and puzzle the learner of nev knouledge but as Sticht says metaphors thenselves

1. Steven Miller, Some Comment on the Utility of Metaphors for Educational Theory and Practice, Educational Iheory, University of Ill inois, sumaer 1987, Vol.37, №.3, p.222.

2. Ibid.,p.227. 
are not alvays comprehensible to students especially vhen they cone from different cultures i.e. the experience iaplicit vithin the is unknoun to the students, and etaphors rely on shared understanding.

To comprehend the aetaphor, the student aust first infer that the teacher aeans the student to shift from a ade of cognition in which ideas are being fitted to an existing knowledge structure, to a aetaphorical ade in uhich the construction of a third knouledge structure consisting of the relations educed betveen the two donains referenced by the aetaphor is accoaplished. 1

One can imagine that this could be as confusing as if one vas actually spoken to in several languages at the same tine. A possible analogy for this might be the changing of a key in ausic Students assune that utterances are sensible and the anomaly of a setaphor puzzles then as Petrie pointed out. The student has to find some basis for the similarity of the two domains in the metaphor. Both domains oust tharefore be explained by the teacher and student to establish the basis of the analogical relationship. There is a need therefore for interaction with the teacher. This observation by Sticht eaphasizes ay thesis that teachers need an acute avareness of the nature of metapor and its potential for teaching purposes. As Sticht says:

To understand the function of metaphor as a tool for thought, ve have to distinguish between the tool functions of etaphors when they are used in an intuitive anner, and those tool functions involved in the use of metaphor as a "metacognitive" tool for creative problem solving, for theoretical purposes, for literary effect, or for the types of educational purposes with which Petrie is concerned. 2

We are in fact says Sticht built to perceive relationally.

It has been found that adults sometises lack the skill to form categories inte which subjects and events aay be sorted on the basis of some sinilarity and their Iiteracy level is also inadequate. On a six week

1. and 2.Thonas 6, Sticht, Educational Uses of Metaphor, inMetaghor and Thought, ed. D. Ortony, Cambridge University Press, New York, 1979, p. 480 . 
course described by Sticht sone such adults practised producing classification atrixes--reading texts and then inferring superordinate categories. The course vas sinilar to one used by Silverman, Winner and Gardner to teach sensitivity to style in art, and comprehension and production of aetaphoric language, to pre-adolescents. Much discussion centred around similarities in text and differences and the need for labelling then. Such tasks use the "cognitive anomaly" described by Petrie in teaching situations. To sticht this veakens its value as a specific instructional aethodolgy but what is being learned in these situations is not a new mode of thinking. That is true, what is evolving is a nev perception for teacher practice and for facilitating learning and a realisation that "schooled persons seek relationships in a greater variety of situations by appealing to a broader range in which things, events, and processes 1 could be related." He says that Slobin has already told us that "New foras first express old functions, and nev functions are first expressed 2 by old forms." training in analysis skills may he thinks facilitate the developarent of setacognitive skill in the use of metaphor to stimulate knouledge INUENTION not simply knouledge RETENTION. Novelty and surprise are not the prerogative of metaphor says Sticht, insight of a similar type can arise even in aths and formal logic when an unexpected conclusion is reached.

Jardine and Morgan vere inspired in their research on analogy as a nodel for the development of representational abilities in children by an incident one of them observed. During a school lunchtime children lay on

1. Thomas 6. Sticht, Educational Uses of Metaphor, in Metaphor and Thought, ed. D. Ortony, Cambridge University Press, Nev York, 1979, p. 484 .

2. Ibid.,p.484. 
the ground with their feet on the school railings. They said that they vere

"playing at graphs" which led the observer to conclude that:

,...it aay not demonstrate the concrete ways in which children atteapt to produce the abstract sense and significance of mathematical representation, but may perhaps demonstrate precisely the opposite. Even at their most abstract, the sense and significance of athematical representations are sustained only insofar as they remain analogical to the concrete, eabodied inages or actions of the subject.1

Concerned, as these authors are with the training of teachers they used analogy as a means of stimulating undergraduate students who themselves had to physically represent the measurenents of a group, eventually reducing the inforation to figures as opposed to outlines, graphs etc., they case to an understanding of how the point of abstraction was reached and could presuably from this exercise appreciate a child's point of viev and how complex the learning process can be. Teaching addition for example vould not be simply a ritual that one vent through but a thoughtful process which included i agining how the children could aake sense of it. Fron these experiments the conclusions vere that:

The apparently univocal, unanbiguous concepts and categories acquired by children over the course of their development energe as the fossilized residues of poverful, dynanic analogical processes, in which features of experience are tuisted, fibre on fibre, and similarities, likenesses, patterns, correspondences and kinships are produced. This process ties neu levels of experience vith old vithout reducing one to the other and without denying or dispelling the kinship between them. This means that our experience and understanding of the world, as adults, itself bears a resemblance (sometimes a distant one, sosetimes a close one) to that of children. Our ways of understanding the world are not equal to the conventional, fossilized residues of our schooling, but are living analogues to those of children.2

Students in training cone vith fossilized ideas vary often and need to be

1. David W. Jardine and G.A.V. Morgan, Analogy as a Model for the Developent of Representational Abilities in Children, Educational Iheory, Sumer 1987, Vol,37, No.3,p.209.

2. Ibid, , p.217. 
ade alert "to confront the prejudice of their oun experience and understanding,... one could al ast say to stop taking their experience of the vorld literally and must begin to take it analogically.*

Tim Linzey was sinilarly inspired to use a metaphorical device vith trainee educational psychologists at the University of otago in order to make them aware of the inplications of some of the unintended influence of their assessaents and interventions on children. The students vere to approach people such as spiritual mediums, palnists and tarot card readers as clients, and to observe "the legitiate and illegitiaate processes that 2 these psychic health professional vere using." And in the ensuing class discussion they vere to compare the psychic's influential povers vith their own. This 'experiment' was designed to encourage the students to 'play' vith ideas, to extend the scope of their thinking in a novel vay:

My intention vas to ake a type of paradoxical injunction to engage in a particular type of heuristic activity; to look for senses in which it aight be 50. This type of activity is of course highly confirmatory, inferential, and inductive in its logic. The use of netaphor is a prompt to axinise the siailarities between the tvo uses of influence over clients. The ain was to broaden their understanding of hou the educational assessment process itself aight influence the client.2

This is no more absurd than teachers thinking of thenselves as gardeners or potters or doctors, or trainers or data programers but at least these students knev they vere using a metaphor. Siailar 'play' goes on in role-playing and in war-ganing. Teachers need to be avare of the metaphors they teach by and have a duty to continually examine and reassess their world, in fact to keep learning with their students.

1. David W. Jardine and G.A.V. Morgan, Analogy as a Model for the Developeent of Representational Abilities in Children, Educational Theory, Sunmer 1987, Vol.37, No.3,p.209.

2. T.J.Linzey, How to Kill a Metaphor, A paper presented to the conference of P.E.S.A., University of Melbourne, August 1987, p. 23. 
Nietzsche's educational philosophy as analysed by David Cooper is based on Nietzsche's criticisas of existing systeas and their ains. Cooper uses these as a basis for his oun critique of education particularly the the current obsession, as he sees it in Britain, with technical and vocational education and he is also critical of the concept of initiation into the disciplines or for as of knouledge, that is a reified for of knowledge as presented in a school curriculus.

"The death of God" says Cooper is Nietzsche's metaphor, not for the dissolution of religious faith, but for "the devaluation of our hitherto 2

highest values." This nihilistic or Godless age he sees as a failure to grapple vith challenge and to be a negation of our uniquely hunan nature, for "The individual is sonething totally new and creating anew, sonathing absolute, all his actions entirely his own. In the last resort, the individual derives the values of his actions from hinself alone." Authenticity or Eigentlichkeit is his metaphor for the individual. The pursuit of this authenticity can create problens for the individual uho reacts and cannot conforn with the rules for instance of an institution. An example Cooper gives is Rickie Elliot in E.M. Forster's The Longest Journey tho is faced vith the choice of resigning from the boarding school of becoming a 'poseur'. Hypocrisy is anathead to authenticity. Even 'child-centred' and 'discovery methods' says Cooper could compromise essential principles by forcing the pace. The teacher has to be avare not only of his/her onn beliefs and values but those of the pupils because of

1. David E, Cooper, Authenticitity and Learning, Routledge, Kegan and Paul, London 1983.

2. Ibid.,p.1. Cooper says, see, for example, Zarathustra's Prologue, Thus Spake larathustra, Vol.I p.277ff.

3. Ibid.p.3. 
being involved in the foraing of thea. Teaching nethods therefore need evaluation and decisions aade as to who has the responsibility, school or society. One can see the dileana here when considering current contentious issues in Nev lealand such as secular versus Christian values in schools, Peace studies, Sex education and Union studies. Values can be indoctrinated as ve are vell avare. To adapt one of Cooper's conents ve have to bevare of putting Buddha on the paths of pupils tho do not know that they should kill hia. The nature of one's schooling is therefore vital according to Nietzsche and he condones the need for discipline 'at the right tiae' For him learning and forging values is a personal endeavour. As Cooper says "there is necessarily soaething lonely about the quest to forge 2

values and beliefs for oneself" As Hesse shows in Denian it is

"the trying out of a vay, the intiuation of a path" or finding what Cooper calls 'the individual essence' He also says that the Polonius type of knowing oneself represents the person as a aultiplicity of selves and does not constitute the true search. Korzybski in Science and Sanity also has nuch to say on this. Solitary introspection of the kind recorded in Van Gogh's letters is he believes, not the way to self-understanding. Katherine Mansfield bears this out in her journal where she speaks of the reference to Polonius as typical of the kind of exhortation written in autograph books, to her disgust:

Of course, it folloved as the night the day that if one vas true to oneself.... True to oneself! which self? Which of many--vell really that's what it looks like coning to--hundreds of selves? For what

1. David Cooper, Authenticity and Learning, Routledge, Kegan and Paul, London 1983,p.5, citing Aus Dea Nachlass der Achtziger jahre, p.722.

2. Ibid, p.6.

3. Ibid.,p.8. 
vith complexes and repressions and reactions and vibrations and reflections, there are moments when I feel I am nothing but the small clerk of some hotel viithout a proprietor, who has all his vork cut out to enter the names and hand the keys to the vilful guests. 1

What people lack says Cooper is an ability to distance themselves and see the real self and situation. Sincerity as Sartre has said is the pover to reject and aake choices. No-one can justify values for another. Inevitably "A paramount and constraining feature of oneself and one's society is the language system--the language in which beliefs and values one way want to 2

entertain must be expressed." The Polonius nodel of inner search according to Nietzsche is urong because it believes self to be the source of thought, when it is through thought that the ' $\mathrm{I}$ ' is posited; "Your true being (vesen) does not lie hidden within you, but inmeasurably high above you, or, at least, above that which you usually take as yourself." Which seeas to suggest that we construct ourselves.

Tia Linzey speaks in the sane vein: "The self is not to be vieved as some entity that is there waiting to be discovered. Rather, we quite literally construct ourselves in the process of actioning the decision." He believes this is what Socrates meant in his Delphic aphorism "Know thyself ${ }^{\circ}$. Models or mental representations, he believes, play a crucial part in this self deternination. "The understanding of the self then earges from the apparent coherence or aptness of the aetaphor, embedded in

1. Katherine Mansfield, The Letters and Journals of Katherine Mansfield, ed. C.K.Stead, Penguin, England 1978,p.205.

2. David Cooper, Authenticity and Learning, Routledge, and Kegan Paul, London 1983, p.11.

3. Ibid., p.14.

4. Tin Linzey, University of Otago, 'Self Esteen, Self Concept and Self Realization', Paper given at N.Z.A.R.E. Conference, Wellington. p.2. 
1

the oodel." Models way of course be undesirabe or unheal thy. To Linzey

"This process of deciding or inventing oneself is one of the truly crucial human capacities."

Apparently no writer has been more insistent than Nietzsche that one's language is the repository of beliefs and values whose sudden 3

over throw vould divest that language of sense." So much so that he vould prefer his revaluations to be 'danced' rather than put into vords because values are inherent in our words. This explains his "aassive recourse to metaphor; for it is only through this that the intimate ties between vords and concepts can be loosened so as to free vords for new eaployaents."

For Nietzsche then metaphor gives pover and freedou and enables ney ways of seeing and thinking. He also believed that our capacity for self-concern was at the centre of authenticity. People vho are not authentic 'fall' into vays of thinking and behaving which seen to then the nors. They go along with 'Das Man'. This frees then from personal responsibility. Heidegger believed the authentic person had resoluteness and Cooper refers us to Lionel Trilling on the same topic. A corollary of authenticity then is honesty. Peters and Dearden sinilarly seek autonomy for pupils says Cooper but what Nietzsche demands of an is based not on rational calculations but on the essential nature of nan which should let hin be open to nev possibilities. It is not enough for us to trace the origins of our beliefs and values which is were 'geneaology' in Nietzsche's vords. His concern

1. Tim Linzey, University of Otago, 'Self Esteen, Self Concept and Self Realization', Paper given at N.Z.A.R.E. Conference, Wellington. p.6

2. Ibid., p.21.

3. David Cooper, Authenticitity and Learning, Routledge, and Kegan Paul, London 1983, p.14. 
is with a new kind of person who vill create new kinds of values, and who can be produced only through education or 'breeding', not through social, political, or economic reform and progress [ breeding in this sense is not eugenics 1 but he doubted whether educational institutions vere capable of this task. The fault of seeing knouledge as useful was demonstrated in the Geraan school systen then it abandoned the pursuit of the ideal an and concentrated on natural science and German studies with a consequence that Cooper calls 'the erosion of the original idealist spirit':

The growing needs of aray, state, and the industrial econony transforned the systen at every level: the curriculun becane nore 'relevant' ; teachers were appointed and disaissed according to political complexion; there vas a grouth in 'specialisas', especially in the natural sciences; and an examination system, for filtering the future servants of the state, developed assive proportions. 1

There are of course still people now who vould approve of just such a system. and this metaphor of education, as a fore of 'reproduction' or the vay a state or power group guarantees its oun needs are met and its ovn perpetuation, is vell documented by people such as Boules and Gintis. Cooper says acadenics retreated from this scene in late nineteenth century Germany and tried to pursue 'knovledge for its oun sake'. Nationalisa also, says Cooper became apparent even in the school textbooks and it was against such a background that Nietzsche developed his critique of schooling; "For Nietzsche, teaching which ains towards 'real' goals, such as economic ones, cannot belong to true education; nor can teaching those ain is the acquisition of 'knowledge 2 for its ovn sake'." His epithets about scholars who do this are derogatory to say the least. Cooper says this does not mean that Nietzsche disapproves of scholarship or practical arts but they are not wholly what education is

1. David Cooper, Authenticitity and Learning, Routledge, and Kegan Paul, London,1983. p.29.

2. Ibid., p.30. 
about. For hin it is concerned vith 'Life' and 'Nature' and is related to 'understanding' and 'visdon', even though he never gives a definition of what education is. Cooper says, there is in fact no equivalent vord in Gernan.

Nietzsche's criticis of modern education is that it tries to sake aen 'current'. This coinage netaphor inplies acquisitiveness, materialistic aias, economic concerns. In fact this night be applied to our present educational situation vhere life and therefore even education revolves around a stable or flourishing economy and the actual nature of our 'Iiving' is rarely exanined. In schools vhose diss are practical or utilitarian "pupils vill be trained to fill those roles which the econony of the day (or the day after) requires." Even 'higher' education Nietzsche believed, can often merely "furnish people vith the theories and ideologies that presently prevail." Much of Kuhn's critique of Science is on this theme of institutionalised paradigas within which acadenics work. This monetary metaphor also signifies what Cooper describes as a hedonistic or eudaemonian perspective. The cult of specialism prevails in this situation and thus ve lose any sense of holistic education. Exaninations become andatory and an eaphasis is put on menory and speed of learning such as fregory also decried, and which to Nietzsche is "incompatible with the developent of that state of aind which characterizes the educated spirit." Nietzsche had particular loathing apparently for the specious type of journalist who flourishes in this atmosphere, the media 'pundit', to hin a nockery of 'the universal man' who vould be symbolised by Goethe.

1. David Cooper, Authenticityy and Learning, Routledge, Kegan and Paul, London 1983.p.34.

2. and 3, Ibid.,p.34. 
The 'breadvinners' and the 'old maids' approach to education as Nietzsche calls then both stifle the 'solitary' and 'inner' an and consequently the authentic person. If you are not 'current' then you find yourself ostracised, outside the mainstrean. Cooper says the first approach is the 'technicist' viev 'the idea that the technological power at man's disposal is the fundamental feature of our tines, and that their energies should prinarily be directed touards utilizing this pover for the sake of increased aterial velfare." This model of an as exploiter of nature gives government the power to harness and channel this energy and then the ain purpose of schooling is to supply the technicists and the support systea they vill need.

A good example of this 'current' viev is seen in the present outcry about the lack of qualified science and mathenatics teachers in New lealand. Speaking to the Institute of Policy Studies Megan Clark described how "New Lealanders are avid consumers of the veritable feast of products and benefits of science and technology" but the education systen is failing to supply scientists and technicians, creating what she calls a "fasine in human 2

resources". This ay be fair comment on standards of teaching in science subjects because of poor training, conditions of work, lack of resources etc. but the interesting aspect of this is that such demands are based on the assumed need for a technologically-oriented society and the need to feed and supply industry with the technical personnel it needs. What

1. David Cooper, Authenticicity and Learning, Routledge, Kegan and Paul, London, 1983.p.36.

2. Megan Clark, senior lecturer Victoria University of Wellington, speaking to The Institute of Policy Studies Seminar on 'Science and Technology: Attacking the 21stCentury'. Reported in the Evening Post Hellington Septeaber 5th 1987. See also Royal Society report on Science in Education in Nev Lealand. 
Nietzsche and Cooper criticise is the narrowness of the technicist's and scientist's viev of education.

The voices pleading for a more humanistic culture are rare. In Cultures Education and Society Crouch speaking of the British experience says ' Worried sinultaneously by the country's declining ability to produce a labour force suited to the needs of employers and by the cost to the Exchequer of public education, the Conservative government is seeking to make education for the mass of children uho lack major acadenic ability 1

narrovly vocational." He is not totally opposed to this movement believing that good teaching overcoses all constraints put on Education, but Roger Poole in the same journal speaks of humanist education being driven back 2 by "monetarist philistinisa in ever more complex forms." What would Nietzsche say to us now? That technicisn is hostile to life and Nature for a "aan before all else learns to live... in the vorkshop of the only aistress 3

there is, Nature," Like Ortega y Gaset, says Cooper, who sone years later saw technicisa as the continuation of primitive pursuits by sophisticated means.

Nietzsche's 'natural' man is not the romantic or priaitive view such as that of Rousseau. He is not as Cooper says in that "'child-centred" horticultural pedagogy which portrays the teacher as a discreet nurseryman gently tending the natural grouth of the budding child." What setaphors

1. Colin Crouch, 'Education and culture: grounds for cheer fulness', Cultures Education and Society Vol.40, no.4, Autumn 1986.p.369.

2. Roger Poole, 'The end of a humanist enterprise', Culture Education and Societty, Vol.40, no.4, Autuan 1986.p.349.

3. David Cooper, Authenticity and Learning, Routledge, Kegan and Paul, London, 1983.p.36.

4. Ibid, p.38 
does he use? Education is "liberation, clearing avay of veeds, rubbish, and verain vhich attack the tender buds of the plants... it is the imitation of nature where Nature is aotherly and compassionate. " Which suggest to Cooper that Nietzsche sees discipline as part of this care.

The features which characterize the technicist viev are: a calculative mentality in which nature equals stock, or property to be used, and huean energy part of this. Its nature is to becone exclusive and drive others out and its mode of thought is calculative. 'Leisure' is the supposed antidote to this. Scientific mentality sees human suffering as erely another problen to be solved. In politics everything is measured in econonic terms and questions of whether for instance ve pay enough attention to education becoae whether we spend enough money on it. As Cooper says one of the nost power ful allies von over to technicisn is language and often by constant repetition and aisuse concepts change meaning to suit the purveyor:

A pervasive linguistic device, of the first iaportance, which technicise wins over is METAPHOR. I do not mean isolated setaphorical uses of individual yords, but whole fields or systems of metaphor in terms which we talk about, conceptualize, and display attitudes tovards, the vorld. For example, those systematic aetaphors which constitute 'organic' and 'contractual' theories of the state. In good times, people are free to create nev aetaphors, thereby suggesting new perspectives, dissolving old associations, and paving the vay for nev conceptions. But in bad times, when assmedia, public spokesmen, advertisers, and other mouthpieces share an outlook, metaphers can become one-sided and are varped to fit the outlook. 2

Cooper gives the example of Heidegger's references to 'duelling' and 'home' which have become inbued with overtones other than what he meant by 'home'. Likevise ailitary metaphors, Cooper sees proliferating in our technicist society. We nead to go no further than a focus on sports and business

1. David Cooper, Authenticity and Learning, Routledge and Kegan Paul London 1983.p.38.

2. [bid., p. 44 . 
journalisa and see how many are used there.

As for the notion of 'Ieisure', Nietzsche sees this as 'culture spice' or fairly meaningless. To hin the real life is a useful life. This is not to be confused vith education for employment such as Cooper says Mary Warnock espouses. She is influencing current thought but as Cooper says, nothing is said about the 'ethos' in which teaching is to be done. This seeas to be the reason for our arked lack of progress in education. We see it as a system and plan it as efficiently as any business but vithout an overriding philosophy about what it is to be human it is neaningless.

Education is often described as initiation into disciplines or subject areas. This organisation of 'Knovledge' Nietzsche sees as failing to help people to know how to live, for each person has to vork out values and coping strategies for hin or herself. 'Knowledge' is iniaical to authentic living, but philosophical understanding he considers as essential. Nietzsche believed that "guided in the right vays, he [the young person] vill succeed to that philosophical astonishment ...upon which alone... a deeper and 2 nobler education (Bildung) can grow." and that philosophical development vould teach one hov to understand situations and be an ongoing development whereas the usual emphasis in schools stifles philosophical thinking, which he claims is the 'highest need' and 'natural instinct' of the young. He does not see philosophy as a 'subject' or 'discipline to be killed by examinations but as a vay of understanding 'situations' and helping one to for a values and guide action, Moreover he thinks that scientific discoveries have ade

1. Mary Harnock, Schools of Thought, Faber, 1977.

2. David Cooper, Authenticitity and Learning, Routledge and Kegan Paul, London 1983.p.53. 
1055 inpact than the philosophical discussions they have given rise to.

Knouledge contrasts unfavourably with myth, religion and morality because according to Nietzsche it is not concerned with values. For him philosophy has a distinctive concern vith meaning and is occupied vith the hieroglyphics of existence', with providing 'a picture of life as a Whole...(to) learn from it the aeaning of your life'...to understand meaning is necessary before setting values, but 'meaning' is not in a graseatical or linguistic sense but a careful exanination of language:

...in particular the stocks and webs of cliches, metaphors, hyperboles, analogies, slogans, chatter and received truisus that attach to and envel op the 'situations' which love, wealth, death, and 50 on, present. But nore than that, these stocks and vebs constitute the 'situations'.... 'Situations' are encountered only in so far as they are conceived in certain vays by people. 1

Nietzsche stresses that one's Ianguage is part of one's situation and understanding of this situation; it is an integral and iaportant part of one's life and aust be acknouledged as such. And as quoted above metaphor is one part of this, part as it vere of the private and comaunal ambience in which one lives, thinks, acts and speaks.

Cooper says that Nietzsche treats 'practical training in speech' and 'linguistric self-astery' which will involve a sharp ear for cant, wisleading metaphor, and were chatter, as a 'holy duty' of education. What education can do is help people to cope in such situations. Simply offering inforation is no guarantee of relevance or usefulness for a person in a real life situation. One contradiction which Cooper points out, is, that defenders of liberal education point to the rules learnt as one of the advantages gained. But in fact there are no rules in for example criticisa in English, yet criticism is encouraged. People tend to assume rules which do not in

1. David Cooper, Authenticitity and Learning, Routledge and Kegan Paul London 1983.p.56. 
fact exist in subject disciplines. It is habit says Cooper which breeds an illusion of rules. "This is thy talk of a discipline's rules, metaphorical as it is, is a serious matter, for like vany metaphors it can be a dangerous 1

one." Cooper says it is the effect of the 'rule' metaphor on the initiates into a discipline rather than its effect on the disciplines thenselves which is the main worry, and tells us that R.K.Elliot has varned of this in 2

his talk of orthodoxy and its dangers. It is in schools especially

that time and freedon to explore alternative vievs is linited, unlike universities there feverish criticise may appear to be going on but much of this activity is 'aere virtuosity' says Cooper. More iaportantly, he declares that "Authenticity belongs to lives, and therefore eabraces nore than the beliefs, interpretations, and 'cognitive' activities of an. Feelings, emotions, and the 'affective' are also to have their place in duthentic living."

Nietzsche believed that 'Knouledge' threatened emotional capacity. We appear to think differently when, to solve probleas e.g. racial tension, ve set up comnittees etc. But Cooper sees that ve need what Schiller has described as the capacity "to aake alien feelings our oun" whereas simply piling up sore information about them vill not enable us to valk in their shoes or get into their skin as Harper Lee had Atticus tell his children.

1. David Cooper, Authenticity and Learning, Routledge and Kegan Paul, London 1983, p.61.

2. Ibid.,p.62, citing R.K.Elliot, Education and Human Being, in S.C. Broun(ed.), 'Phil 05ophers Discuss Education', Macaillan,1975, pp65-6.

3. Cooper,, 0.64 .

4. Harper Lee, Io Kill a Mocking Bird, Penguin Books ,England 1967, p.35. Atticus to his daughter Scout...' 'You never really understand a person until you consider things froa his point of view--' 'Sir?'

'--until you cliab into his skin and walk around in it.' 
George B.Leonard says we should not blase the schools for dewanding " Right ansvers', specialization, standardization, narrov competition, eager acquisition, aggression, detachent from the self," These are what society has deaanded of then. R.S. Peters has said that education of the emotions is "getting people to see the vorld differently in relation to theaselves" but the difficult question is whether this is a task for schools or one they are capable of dealing with.

Nietzsche borrows two metaphors from a long tradition in German thought. One is the aetaphor of 'knowledge' as 'destructive' and 'dissolving' and the other is of a 'screen' or 'veil'. The scholar by study and analysis tends to 'dissolve' people. We have probably all known professional 'experts' who appear to lack human symathy or empathy. More inportantly, he declares that "Authenticity belongs to lives, and therefore embraces more than the beliefs, interpretations, and 'cognitive' activities of an. Feeling5, emotions, and the 'affective' are also to have their place in 3

authentic living."

For Nietzsche it is not that the person is a metaphysical entity transcending whatever can be described in teres of cells, roles and the like, but that such descriptions are private and abstract, obtained in a parasitic way from the notion of the person as a unitary whole. Inamersion therefore in disciplines, way, Nietzsche feels, sever ties betveen persons and for this reason he extols the virtue of Literature, where people are

1. George B.Leonard, Educatation and Ecstatasy, John Murray, Great Britain, 1970, p.124.

2. David Cooper, Authenticity and Learning, Routledge and Kegan Paul,London 1983, p.64, citing R.S.Peters, 'Ethics and Education ', Allen and Unvin, 1970, pp32-3.

3. Cooper, $, p, 66$. 
treated as whole per 5ons. A good example Cooper gives of the scholar vith all his emotional capacity atrophied would be Casaubon in George Eliot's novel Middleanarch, who leads an arid emotional life whilst devoted to his vorthless work.

Nietzsche ascribes a central role in education to language. "Concepts... [are] only possible where there are vords,...ve cease to think when ve try to do 50 vithout the constraint of language.. Ke can only 'fix' experiences, and as it vere place then outside of ourselves when ve comanicate then to others through signs." ${ }^{1}$ The central thought here is attributed to Hittgenstein and his attack on 'private language'. As Cooper says "To have a concept is to clarify distinct itens of experience as being sinilar; but criteria of sinilarity are the interpersonal ones provided by a public language." This is what 1 believe we share mainly through aetaphor-making. Nietzsche says that only where there is "a uniforaly valid and binding designation of things" is a concept possible. In an early article he claimed that items in reality are not similar, "every concept originates through eaking alike what is not really alike" and "everything of which one becones conscious is thoroughly arranged, siaplified, schematized, interpreted." This prevailing desire for order and pattern, a central interest in this vork, is one he recognises. Language has to cope vith our ever-changing needs for interpreting the vorld.

Nietzsche believes that the 'vill to pover' rather than selfpreservation is the inspiration for our further development. Presumably here he means pover in the sense of control of our environment. Constructing a

1. David Cooper, Authenticitity and Learning, Routledge and Kegan Paul, London, 1983, p.68.

2. 3. and 4. Ibid, ,p.69. 
descriptive language is one forn pover takes. For Nietzsche philosophical accounts of the vorld are disguised descriptions of the GRAMMARS of language which have succeeded in their aission and object teras like 'tiger' or 'I' stand for 'fictions' constructed for interpreting 'the medley of sensations'. For Nietzsche there can be no descriptions of 'the true vorld' because there is no such world, as ve cannot think hou it vould be to be without thought. Truth and knovledge then, as standardly conceived, are necessarily unattainable--"the greatest fable is that of knovledge" --and ve continually 5eek nev concepts of truth and knowledge. This presunably is one of the tasks of education.

Granar, Nietzsche says, deludes us into thinking that what we describe vith vords is reality " because of the sharp gramaatical distinction between subject and predicate, ve think of the objects as substances distinct from the properties predicated by them". Granar seduces us into thinking of agents even where there are none. AN example is lightning. Which leads Nietzsche to say "I an afraid ve are not free of God because ve 3

still believe in granmar." This reflects a need that humans have for passing moral judgments, requiring us to "interpret events... as events caused by intentions." Which leads to a 'deception' the scientist fears to comait, as heir to earlier notions, deception as failure to live in the truth of God and to have produced an account of reality that matches the divine conception. Thus it is a moral, a metaphysical faith upon which our faith in science rests.

1. David Cooper, Authențicity and Learning, Routledge and Kegan Paul, London 1983.p.73.

2. Ibid.,p.75.

3. and 4. Ibid.,p.76. 
Dur standard notion of truth then is a Realist one. Which leads inevitably to the conclusion that our vill to truth is a vill to pover, meaning that people tend to accept those theories and beliefs which give then pover. Science for exampla helps to conquer our fear of the unknovn, once again this appeals to our desire for order. Once ve have a 'truth' ve. are reluctant to give it away. Knowledge itself becones a fora of pover. Words therefore are horizons to our knowledge rather than truths. Those who uphold 'truths' do so because of the inherent pover they receive from them. If we vere to understand the nature of 'truth' and 'knovledge' Nietzsche believes we vould better understand ourselves and our world. To unaask the falseness of truths is of course to threaten those in pover. Both Wittgenstein and Nietzsche, says Cooper, clearly think that any of our ways of talking aust be overturned and reconstructed and for this reason they both reject 'private languages', and both stress the intinate connection between grammar and thought.

The iaplications of such thinking are hovever far fron negative or depressing, for as Nietzsche says "The vorld has once again become 'infinite' for us, in so far as ve cannot disaiss the possibility that it contains infinite interpretations." Also if we are avare that the criterion of truth is pover we are less likely to be aisled or deceived. To hin the most subline for of power is that of the creative artist "the power of the creative, free individual"...vho can "fix an image of what should be--they are productive, in so far as they actually change and transform." If we reject realisa he believes we can be nore avare of this power and scope

1. David Cooper Authenticity and Learning, Routledge and Kegan Paul, London $1983, \mathrm{p} . \mathrm{B1}$.

2. Ibid, p. 82 . 
which knovledge shares vith art--interpretative, creative pover which is free and not constrained and narrowed. Concepts then can be remoulded and through the 'death of God' there vill be a new appreciation of individual creation and the interpretation of ideas.

In a sense Truth and Knouledge are unattainable and an artist senses this in his dissatisfaction with his vork. The artist goes on when others stop for he knows there is more to knov and see and do. He have exagger ated the iaportance of the factual and this has to be renedied through education. The disciplines as ve know then have so far have only been gropings towards answers, tovards this instinctive need ve have for order, sense of pattern and design. "Truth is no illusion if it is understood in teras of the order, coherence, and pover over 'the medley of sensations' which beliefs and theories can afford."

One of Nietzsche's nost important works, says Cooper is his The Gay Science which title refers to the gai saber, the poetic art of nediaeval troubadours from Provencal, for he believes that the pursuit of truth should share the sane vitality, exuber ance and joy they demonstrate, above all their inventivenes, with "the spinning of new metaphors, the suggestion of nev analogies, the cutting across old classifications, the refusal to be opposed by the veight of tradition and orthodoxy: these are sone of the ways truth should be pursued and education should encourage." Integral to this is the need also for a conscience that vould despise accepting any unquestioned belief. The greatest difficulty we face is in having to use the same language to reconstruct the ideas al ready embedded so deeply through language use so far.

1. and 2.David Cooper, Authenticicity and Learning, Routledge and Kegan Paul, London 1983.p.88. 
Moral betterment, says Cooper vas once considered the principal purpose of schooling. Fashion, he thinks has changed because of the eaphasis on 'child-centred' education. His view may be slightly exaggerated. I vould have interpreted this as what the child NEEDS rather than WISHES. The difficulty is how to create authenticity if there appears to be a need for woral training when one conteaplates the anarchistic tendencies of modern youth. Cooper seems alnost to accept that in many places indoctrination aight be necessary but in schools where moral education aight not be a sisyphean exercise he can see that a concern for authenticity has some value. Nietzsche thought that in his country there vas a failure to give attention to noral matters, and comended in his later notes the noral ideals of christianity, as a aoral code IS necesssary for social stability, that is, for nost of the populace. The 'overman' hovever has to be allowed to transcend this, as, to Nietzsche, there is nothing educative about moral training which aust use imoral means to gain its ends. He also sees that "suffering is often a precondition of individual achievenent, greatness and self-realization," This is a precept difficult to accept although it is a strong tradition in the Christian religion. Suffering can strengthen and refine people but it is difficullt to prove that such is necessary. Nietzsche gives a philosophical description of the nature of authentic existence and what his ideal man or overman could be if educated rightly. Some of his virtues vould be self-honesty; conquest of fear; mistrust tovards both received and 'scholarly' opinion; despising the petty and the mediocre; a developed sense of history; self-discipline; villing nothing beyond one's capacity; full avareness of what that capacity is;

1. David CooperAuthenticicity and Learning, Routledge and Kegan Paul, London 1983, p. 97. 
the ability to command and to obey; the refusal to regret or do the 'dirty' on one's chosen and considered purposes; abstention fron aerely negative criticisa; the ability to 'laugh at', hence stand at a distance from, hence be ready to alter how one has been; the pover to turn sufferings and illness into new sources of strength; spontaneous, as against brooding, 1

calculative responses to treatment by others. These values he calls extramoral or 'noraline free'. Whereas, Devey, in 'Moral Principles and Education' in Cooper's opinion, falls into the trap of saying that the woral worth and work of the school systen is to be measured by its social value and the prisary ain of the process is to produce the 'good citizen'. A current and interesting tendency [and a nev metaphor--a social one] which Cooper comments on, is the replacing of moral vieupoints eg. attitude to criae and punishaent, vith nev categories, in fact speaking of it as a social disease. Nietzsche's values are not altruistic or selfless they pertain to the individual's good, not conmunity welfare, nor do they rest on a notion of equality--conscience is rejected as a form of self-betrayal and some suffering is to be accepted. His values then cannot be in Kant's terms universal. Uniqueness of the individual precludes this for Nietzsche. He sets no prescription for what man ought to be "I am a lav only for my kind," says Zarathustra "I an not a lav for all,"

Cooper suggests that the imperative nature of noral judgments helps to distinguish noral fron aesthetic judgments and Nietzsche does not consider his values as imperatives. For his, as for Devey, a prisary aim of education is to develop harmoniously the powers of the individual. For Devey this is

1. David CooperAuthenticity and Learning, Routledge and Kegan Paul, London 1983,p.81.

1. Ibid.,102. frod Thus Spake Latathustra trans. Kaufman p.521. 
defined, as mentioned previously, in 50cial terms, but not for Nietzsche who sees the product of such a systen as unreal, unauthentic.

Pity, for Nietzsche is of two kinds; the veak Christian pity acting according to precept, and the 'moraline- free' or 'noble' pity. I inagine he means the kind ve are moved to by great drama as in Lear. This is the pity which is appalled at san's inhumanity to man, for in wan "creature and creator are united", whereas nost pity appplies to the "creature in aan." He says My kind of pity...is a feeling... I feel... when I see precious abilities squandered... or when I see someone...lagging behind what could 1 have cone of him." Many teachers I believe vould understand this kind of pity. Most of us, he says vear asks, in order to confora but the truly free spirit seeks solitude to shed this social mask. As he says there are literary characters such as the Master in The Glass Bead Gane and Siddartha who experience great difficulty in choosing between the two worlds.

Nietzsche is criticised because like Plato he speaks of educating an elite, but my impression, through Cooper's portrayal of him and his work, is that in his conception of education one must strive for what aight be, a perhaps inpossible ideal, the perfect person. Inevitably in each era there will be sose who strive or achieve above all others. These I take it vould be the overaen, most likely artistic, creative, free-minded creatures Whom we should respect and cherish, for they vill question our ares and force us to think ahead and think anew.

Nietzsche asserted al so that ve should judge a society, not by its political for $m 5$, its economic arrangements, or its legal system, but by the nature of its education. Progress, and denocracy as he vitnessed it, werely

1. David Cooper Authenticity and Learning, Routledge and Kegan Paul, London 1983.p.106. 
belittled man. For him the goal of education is "the production of genius"..."a justifying an' ...d"higher type of man". He says "My metaphor for the (justifying) type is, as one knovs, the vord 'overnan'..." by Which he means a truly authentic individual and the ideal product of an ideal education. In larathustra's fanous setaphor, wan, as he now is, is portrayed as on a rope slung betveen the beast and the 'overaan'. He can cravl further only through the provision by the agents of the state of true education. What he means by 'justifying', says Cooper, is that ve accord supreae value to this creature for through hin society itself vill energe into a nev phase. In this sense he is a figurative symbol not for what is or vill be, but what aight be, and society aust support his to this end. It is in this sense that his philosophy seens [to ae] to be antithetical to Christianity which sees God or Good in everyman but presumably those responsible for education must in Nietzsche's terms see a potential overman in every student. Our literary ainds have alvays pre-eapted us, for Katherine Mansfield anong others says the sane thing "Genius lies doraant in every soul.." Cooper can see that our methods of education at present tend to denigrate the outstanding, special, of different person vith our preoccupation for equality. We are in fact all trying to be 'current'. To attain the 'overaan' we have to be dedicated to Kultur, that is a transforaing process which strives to attain something superior and more human than the average person whose feelings are stunted by trivia, entertainment, stimulants etc. and vho envies the genius who has escaped this. For Nietzsche then education is not simply input of resources but a

1. David Cooper Authenticity and Learning, Routledge and Kegan Paul, London 1983.pp.114-5.

2. Katherine Mansfield, Journal of Katherine Mansfield, ed. Middleton Murry, Hutchinson, New Zealand 1984.p37. 
task for those with the right avareness of what confers value on hunan existence and vho allov each person to reach for his/her own potential as 'overman'. The person Nietzsche saw as exemplifying this ideal was Goethe, adinly because he vas avare of his ovn capacities and liaitations. He apparently also attacked many of the 'isms' of his day, this being the era of encyclopedic vritings. His notion of freedon also atched Nietzsche's for he believed it to be not a matter of possessing rights or of absence of interference from authorities but as a property of one's personality and to be displayed in disciplined creative activity. Two metaphors he used to describe types of people, they are 'aristocrat' and 'bourgeois' though not used in a social class sense. One is preoccupied with what one has, the other with what one is. What the aristocrat has is a sense of self-vorth. A key motif in Goethe also, says Cooper, is a sense of harmony and wholeness, saying that a person "only achieves the unique and wholly unexpected when all properties are uniforaly united in hin." It has been said of hin that he looked upon the vorld as an artist. Mansfield said of him " ...he did say marvellous things. He vas great enough to be siaple enough to say what ye all feel and don't say. And his attitude to Art vas noble." Cooper concludes from his study of Nietzsche that there are four foci for educators to consider, the philosophical; the linguistic; the aesthetic and the genealogical. The first means "the understanding lis to be I developed through education... of a type that is geared to the individual's self-conscious adoption of stances tovards the significant situations.

1. David Cooper, Authenticitity and Learning, Routledga and Kegan Paul, London 1983.p.129. Quoted from K.Vietor, 'Goethe: The Thinker', Harvard University Press, 1950, p. 143.

2. Katherine Mansfield Letterers and Journals' ed. C.K.Stead, Penguin, Engl and 1977.p.255. 
which he confronts as a human being." Especially inportant is a concern

with language:

...as long as (5chools) do not accept as a holy duty the most ianediate practical training (lucht) in speech and uriting, as long as they skirt around the nother-tongue as if it vere a necessary evil or a dead body, I do not count those institutions as truly educational.2

Assessment of one's beliefs and values is possible only when language nuances are understood. In his view "in a sense all vords are metaphors, since they serve to combine, in their fields of reference, radically dissinilar 3 items." Nietzsche calls vords 'pockets' into which people are constantly putting in or taking out. He vould probably agree vith the person who described the work of teachers of English as training pupils to be critic5, for he had a particular loathing for the crassness and insensitivity of much journalism.

The linguistic focus, will, says Cooper, be on aetaphor, with which sentianent I vould naturally concur.

By 'metaphor' I do not sean primarily individual vords or phrases used in non-literal ways, but those large, organizing segnents of discourse in which things are spoken about in teras literally appropriate to soeething else. Such metaphors are among the nost poverful deterninants of how ve conceive things...[such as] aetaphors which have had great influence in educational thought -the child as a plant to be reared, say, or as a container to be filled.... it is imperative to be sensitive to these metaphors...4

Nietzsche warned us to be shy of them, to nistrust them. Metaphors says Cooper can be insidious and 50 intervoven into speech that their iapact is not fully realised by us. Which leads him to say: "A teacher, it seems to

1. David CooperAuthenticityy and Learning, Routledge and Kegan Paul, London, 1983.p.133.

2. Ibid, p.136.

3. Ibid.,p.137.

4. Ibid.,p.138. 
ae, can have fev core important tasks than to alert the young to, and loosen the grip of, the nany netaphors ve live by."

Cooper discusses the probleas in schools now and what could be done about then. He does not seed to see hov Nietzsche's ideas could be implemented. One key he appears to wiss in Nietzsche is the essential need for activity. I believe that Nietzsche's reference to 'dance' gives us the clue. Not in the sense of aere busyness but the kind of activity in which the whole person is involved such as experienced in truly creative endeavour. The type of vork where pupils act and produce plays rather than werely reading then or vhere principles in science and waths are used and applied as described in In The Early World vould seen to be a nove in this direction. My interpretation of Nietzsche's 'death of god' is that we tend to reify the ungodly as godly and we are driving youth mad with aixed aetaphors, eliches and outeoded, even dead, metaphors.

This chapter has looked at sone of the doninant netaphors of education and some of the thinking about aetaphor itself and its relationship to education both theory and practice but not at educational administration as this is specifically dealt with in the following chapter. It is fairly obvious that the metaphors which influence educational theory cone from a wide range of sources and as Elliott says "The chief importance of metaphors of education, generally lies in their rhetorical function, which is to stimulate inagination, to arouse feeling and to prompt action." ${ }^{3}$ And "theories of learning are dependent on metaphors, because they are centrally

1. David CooperAuthenticicity and Learning, Routledge and Kegan Paul, London, 1983.p.139.

2. Elvyn S.Richardson, In The Early Horld, N.L.C.E.R., Wellington, 1972.

3. R.K.Elliott, 'Metaphor, Imagination and conceptions of Education,'in Metaghors of Education, ed. W. Taylor, Heineaann, London, 1984, p.44 
concerned with mental acts and conscious processes or with the operation of mental mechanisas belou the level of consciousness, all of which are describable only by metaphorical means."

Education is concerned with any abstract concepts and is difficult to evaluate. If education eans changing people ve need to know how ve are changing thea, why, and for what purpose. Certain assuaptions and beliefs are iaplicit in education, first that hunan beings 'au naturel' are unfitted for husan society and aust undergo socialization processes to fit them for a place in society. Decisions as to what this constitutes are based on authority, sometines clained to be God-given, tradition, physical exigencies, pressure groups, survival needs etc. Describing such necessary processes requires descriptive language which vill conjure up beneficial, philanthropic or nurturing iages depending on the experiences, beliefs and aias of the person/s with the pover to impose or create change. An educational vord such as kindergarten is filled with such meaning. As Elliot asks, if education is for instance all about PREPARATION what are ve preparing for? Philosophers and sociologists particularly take a nore holistic viev of mankind than cost of us and see the larger patterns. Theodore Brameld is such a person who sees philosophy of education as philosophy of culture and that aost of our concepts of education cone from sources dominated by four ain conceptual fields. Because of this he thinks that ve need to refine an anthropological philosophy of education for the future and one goal should be a transcending, converging ankind. He vrote this in the early seventies when the culture seemed to him to be one in a state of crisis, so we do not seem to have noved far in his chosen direction. He

1. R.K.Elliott, 'Metaphor, Imagination and conceptions of Education,' in Metaghors of Education, ed. W. Taylor, Heinemann, London, 1984, p.38. 
takes an anthropological approach because culture and personality are bipoloarities of the same reality, neither can exist vithout the other. He sees teachers as putting into action what he calls a culturology of knowledge. In his terms ORDER refers to PATTTERNS of relationship, and PROCESS refers to the DYNAMICS of culture and sense of purpose and direction within the ordered patterns of relationship. Institutions and faiths, rather than dealing with human crises, to his nind appear to create habits of acquiescence. To hin the U.S. seens a schizophrenic culture, both self-interested and competitive as vell as having generous, philanthropic 50cial interests, and where curiously he finds the culture saturated vith supernatural faith and science is seen as inferior to religion as a final source of protection 1 and authority.

Brameld believes that because psychological problens are dealt with psychologically the sociological problems are not dealt vith but he foresees a tiae of cultural revolution and a shifting of cultural patterns:

Frustrated as he so often has been by life-denying customs, by ignorance and superstitions, by cleavages in loyalty and other values, an has never approached anywhere near full command of his oun energy, creative intelligence, and strength. He has been ruled over far ore frequently than he has ruled. He has been starved, hoodwinked, exploited, cajoled, intinidated, frightened far nore often than he has been decently fed, vell-informed, respected. encouraged, aroused. 2

Everything Braneld says here has been reflected in education also and is observed particularly in the images of childhood and schooling in the previous chapter. We are often jolted into re-appraising our beliefs says Brameld when " our cherished patterns conflict vith 5omeone else's

1, Theodore Brameld, Patterns of Educational Philosoghy, Holt Rinehart and Winston, 1971, p.30.

2. Ibid.,p.36. 
patterns."

The history of philosophy attests to its age-old concern with the totality of life and philosophy of education is likevise concerned with characteristics of unity. Schools are seen by Brameld as "victios of specialization." He also observes that there have been four dowinant patterns of culture: essentialist, progressivist, perennialist and reconstructivist. They are only concepts, not real systens, and they each overlap. No one philosophy of education vill slot neatly into any of these, what I vould call sets and subsets within which one can identify various net aphors.

That part of his vork which looks at contemporary philosophic movements clearly indicates the sources of some of our current setaphors. They are: Existentialise and the quest for authenticity reflected in the vorks of such as; Soren Kierkegaard, founder of the novement, Kean-Paul Sartre, Gabriel Marel, Albert Camus, Karl Jaspers, Martin Heidegger, Ortega y gasset, Martin Buber, Paul Tillich. All testify to the struggle of the individual in the face of systemic, rational forms or 'essences' of thought. Friedrich Nietzsche vas eventually counted anong their number and the philosopher-novelist Fedor Dostoevski. The ruthless power of modern civilisations to overwhela individuality and personality was their concern and they particularly opposed objectivity, industrialism and var. Loneliness and suffering as part of an's struggle they are also sensitive to and in Buber there is an emphasis on dialogue as a necessity for full human development. Neo- Freudianists include Rollo May, Abraham Maslow and

1, Theodore Brameld, Patterns of Educational Philosophy, Holt Rinehart and Hinston, 1971, p.44.

2. Ibid, , p.56. 
Carl Rogers, all known as existential psychologists. Other names are Carl Jung, Alfred Adler, Harry Stack Sullivan, Karen Horney, Erich Fronn, Abran Kardiner, and Franz Alexander, all psychotherapists, and Harold D. Lasswell a political scientist and theorist. All of them recognize the seminal influence of freud but have oodified his concepts. They believe that environmental and especially social conditions are as influential as sexuality and aggression. For Sullivan interpersonal relations are a central concern. They also believe that civilisation can progress, and aany of the probleas people experience are seen as effects of outaoded and enslaving institutions. It is alnost impossible to distinguish clear demarcations betveen the different schools of philosophy and their adherents 50 aore than one label is ascribed to some of them; From for instance is regarded as both Freudian and Marxist.

Neo-Marxisa says Brameld, emphasises nan's struggle to fulfil human needs especially econowic ones. Terms formerly used such as classconsciousness have been aodified vith nev terus such as Brameld's ovn culturology. Tvo nanes he aentions in this sphere are the Yugoslav philosopher Gajo Petrovic and Herbert Marcuse. In the area of Philosophic Analysis which is concerned with conscious logical aind the names of Ludvig Wittgenstein, Bertrand Russell, G.E.Moore, Rudolf Carnap, Herbert Feigl, Moriz Schlick, Gilbert Ryle, C.E.Ayer, Hans Reichenbach and J.L. Austin are the ones he gives. Wittgenstein is recognized as the outstanding figure here particularly for his ordinary-language theory "which saintains that the reliability of thought is to be anchored less in the artificiality of philosophic and scientific constructions than in familiar, habitual usages of everyday discourse."

1, Theodore Brameld, Patterns of Educational philosoghy, Holt Rinehart and Winston, 1971, p.78. 
Both he and Cassirer favoured aultiple styles and levels of communication. len Buddhisa is not a philosophy according to the analytic philosophers says Brameld but has affinities with existentialism. Both challenge the objective, neutral and unenotional posture of scientific philosophers. Its history is ancient and anong those with a professed interest have been Alan W. Watts, Carl Jung, Martin Heidegger, Huston Smith and F.C. Northrop who ade a plea for "solid bridges of understanding across the vast distances of space and time that separate sone of the greatest of all civilisations in history." This is particularly interesting as the bridge metaphor is used once again. The leading exponent for the West has been the Japanese Zennist D.T.Suzuki. He describes Zen as being concerend with "the non-verbal, non-syabolic, and totally undefinable vorld of the concrete as distinct from the abstract... for len is to nove with life vithout trying to interrup its flow; it is an immediate avareness of things as they live and nove, as distinct from the mere grasp of ideas and feelings ABOUT things which are the dead syabols of a living reality." This rather succinctly indicates why aetaphors give us so wuch trouble. To understand len therefore weans to undergo an intellectual and emotional metamorphosis says Brameld. One can see even from this sketchy sumary of Brameld that many of the referencs quoted in this study have been influenced by some of the names he categorizes. Nietzsche particularly seems to we to encapsulate the essential probleas in education which include to ay aind autonony, responsibility, freedom, denocracy and accountability, a correlate of responsibility. How auch freedom do ve need,

1, Theodore Brameld, Patterns of Educational Philosoghy, Holt Rinehart and Winston, 1971, p.80.

2. Ibid, , p.81. 
or are ve entitled to, and our students, and is responsibility alvays the other side of this coin. Even the tern democracy has a false ting to it now and has become a metaphor for a kind of consensual form of represention vastly different to its original meaning. Teachers face a particular dileana in defining the terns as thay are in a special position in society, responsible as they are, like parents, to help the next generation wove forvard.

The metaphors of and in education sees to fall into two distinct spheres as articuated by David Pratt, they are either humanistic or technically oriented. My own impression from the literature is that before we reach a stage where the humanistic tendencies take over and hopefully have a paradign shift towards a synthesis of arts and science we will be subjected to a period of strife vithin education, during which period the dominant setaphors vill be the military ones.

The signs are already in evidence. One can see then in the panic reactions in America where there is great fear of being overtaken in the technological race by the Eastern countries, and a groving realization that education or lack of it is at the heart of their seening failure. Just as Sputnik caused aillions of dollars to be poured into science from the schools up, the pressure is on now to produce technocrats and technology when the needs for the future, if ve have one, will be be for people who are global in their vision of what it is to be human and whom one hopes will exist in a world that has achieved non-racism, non-sexism, and environ -mental balance and haraony. In the interin the ailitary metaphors will predoninate as they already do on the technological front. War on ignorance will be the new catchery as well as war on want and on drug abuse and this may deploy resources traditionally reserved for defence. Fortunately, we now know more about the needs of children and realise that social wellbeing 
is inextricably linked with education so perhaps the nev var on ignorance vill have sose spinoffs for youngsters even if the end at present, the production of supertechnicists, hardly justifies the means.

On the one hand there are the technologists, with their systeatic procedures, ailitary metaphors, and their behavioural and positivistic language. On the other hand, there are the humanists, vith their intuitive thinking, poetic language, and their subjective and interpersonal priorities, 1

In areas vhere conpetition is rife as in sports and business the language of var is already endenic, It vill all depend on tho controls pover what the outcome vill be, and at the monent the pendulum seems to be towards the technocrats vith their aggressive, industrial and econowic nuscles. Both sides use language as a poverful tool.

Roger Poole giving his impressions of ten years editing of the Nev Universities Quarterly journal of Education speaks of the changing face of education as reflected in the nev language of education. The hunanisa to which he and his editorial colleagues subscribe appears to be under flagrant attack. He goes so far as to say that under the present ainistry the educational establishment has been dismembered. The 5 chools look ravaged, local government passes on the resentment it feels, youth is disaffected by unemployment and teachers feel forced to strike in the face of continual disparagement of their status. Universities have also fallen prey to the new wave of Benthanite nonetarism and 'Managerial interest' which among other aoves iaplemented differential payments for teaching and research. This leads Poole to the conjecture that under such a regime the favoured will be those whose vork aligns most vith government policy, and the arts and humanities are the most likely to suffer.

1. David Pratt, 'Curriculum design as humanistic technology,' Journal of Curriculun Studies, 1987, Vol.19, No.2,150. 
In this monetarist climate the vord culture seens to Poole to lose

its weaning as:

We have watched as Sir Keith Joseph has incapacitated, then huailiated the universities; let the schools rot; and consigned nore and more young people of all ages to a future where there vill just be quantitatively less, and qualitatively less good, education for theri to apply for, 1

Education is nov interpreted he says, as 'skills' related to the needs of the warketplace. 'Performance indicators' are the new byword and applied even to the Arts.

An entire nev terninological 'tone-rou' has been put into place. 'Skills' have been noved in to take the place of 'abilities', of knouledge, talent, capacity. 'Funding' has been moved in to replace 'support'. 'Performance indicators' have been substituted for thought, research, teaching. 'Jobs' have been moved in to replace 'careers'. 'Tenure' has been moved in to replace a li fe-long devotion to a badly-paid and socially disesteemed choice of the low road. 'Grant' has been substituted for quinquennial plans'. 'Efficiency' has been substituted for 'quality'. 'Inprovement of management and cost-effectiveness', 'grant' for in-service training of teachers', 'training in management', 'appraisal of performance', 'redeployment of teachers so that their skills can be put to better use' -- d whole sub-language of Management has replaced the real language of Culture, Education and Society. 2

The age of Newspeak has finally arrived and the language of managenent is dominant and empovering to the point where Poole believes that the right to manage' appears to transcend all other rights. Succesful businessmen are thus noved across into erstwhile esoteric specialist areas such as education and hospital management usually to do a cost-cutting exercise in the name of efficiency and good managenent but in practice hurting the community it is supposed to serve. Even the term 'vocational' which originally meant 'calling' is now used to denote paid eaployment.

The vorst effect of this new philosophy of government by managers:

1. Roger Poole, Nㅡㄹ Cullture Education and Societety, Vol.40, No.4, Autumn 1986, p.350.

2. Ibid., p.351, 
Young people are regarded as vindovless nonads in a pan-deternined econonic universe, helpless before warket-forces ('Reality') and provided (or unprovided) with marketable 'skills'. An intensely Patrician order regards the young citizenry of these islands as nere Viconian 'clients'...1

Surprisingly he does not refer to that other populat euphenisu 'human resources' but as he speaks of the state of the nation in Britain ve in Nev lealand can vitness the same dehumanising movement here, where, as he observes 'efficiency' has replaced ethics, and where callousness has replaced concern.

Evidence has been drawn on to indicate that metaphors are too i aportant and too poverful for teachers especially to ignore. When people are unavare of how language is used to control them they are powerless. Without adequate understanding of language children are deprived and not merely in the sense of having a restricted code. They are less than whole persons and in no vay can they become autononous or authentic. Pratt speaks of the two poles of the curriculum continuun as humanistic and technocratic but perhaps the factor that should concern us aost is what many observers, such as John Goodlad, whom he quotes have observed in classrooms, a total ainlessness. "If there vere central concepts or children's needs and interests guiding the selection of specific learning activities, 2 they escaped our attention." Cooper says that we need to be avare of the metaphors ve live by. One aight add to this a message for teachers especially that unless ve are avare of the metaphoric aspects of education ve are literally the blind leading the blind.

1. Roger Poole, NuQ Cullture. Education and Society, Vol.40, No.4, Autumn 1986, p.354.

2. David Pratt, 'Curriculum design as humanistic technology, 'Journal of Curriculun Studies, 1987, Vol.19, No.2, 158. 
CHAPTER VI

EDUCATIONAL. ADMINISTRATION

A critical observation and examination of the metaphors used in schools should affect practice by exposing the often unconscious assumptions involved in the language ve use, 1

Forasl education has evolved from being the prerogative of royal and religious elites to gradually embracing entire communities and in many countries is largely a responsibility of the state. Consequently it has become institutionalized. Education is generally perceived as a universal need and the right of every child although there is no guarantee that he or she vill receive such. One reason is that provision of education is a costly undertaking, another is that this investaent can be a source of friction because of competing aspirations vithin a society. Educational administrators responsible as they are for large numbers of people and funds either private or public are inevitably concerned vith power and with politics. Criticism of education naturally devolves on administrators. It is currently endenic and reflected in the large number of conaissions of enquiry both here in New leal and and over seas.

It has been demonstrated in a previous chapter that our viev of the child is symptomatic of our viey of education. Likevise our concept of

1. Noeline Alcorn, 'Learning to Manage Educational Institutions: Some Theoretical Considerations', Deltta 35, New Zealand, May 1985 p.14. 
educational administration is influenced by our perceptions of teachers, principals and governaent agencies involved in education and also their perception of their role. An examination of the language used to describe educational administration reveals the doninant netaphors although Coladarci and Getzels varn us that;

An exanination of the language of administration indicates a rather videspread reliance on metaphor5, siniles and analogies. In one sense this can be viewed as the earnark of a young science. However ve must be sensitive to the possibility that such language vill lead to asking the wrong questions and defining the wrong probleas. 1

They are obviously of the school of thought which considers metaphorical Ianguage as unscientific and iaprecise even though they acknovledge that they can be useful devices for comunication. They are also concerned as they aight well be that metaphors are often treated as literal and this can be dangerous. It aay be that adninistration is as auch an art as a science. A survey of some of the literature on the subject soon reveals a dichotony between those who vould prefer to 5ystemize the whole area taking their models from systems theory particularly and those tho see it as a describable but not easily defined field of enquiry because it concerns hunan relationships and is inevitably influenced by findings in the Social Sciences. He speak generally of an education systen and this tere itself is called a root 2 metaphor by Tompkins.

This chapter looks at some of the dominant metaphors in educational adainistration, at the schools and their leadership and the vays in which they are organized and at the origins of some of their ideas and practices.

1. Arthur P.Coladarci and Jacob W. Getzels, The Ugee of Theory in Educational Adginistration, School of Education, Stanford University, 1955, p.13.

2. P.K.Tompkins, The functions of human comaunication in organization, in Handbook of Rhetorical and Connunication Theory, eds C.A. Arnold \& J.W. Bowers, Allyn \& Bacon, Nevton, MA, 1984. 
Schlechty and Joslin are convinced that metaphors shape behaviour and that some comonly used wetaphors shape the vay school probleas are defined but that sost of these are inadequate to the task. "Rather than liberating thinking about educational probleas, these aetaphors focus attention 1 on solutions that are pieceneal and at vorst aisguided." The ones they disapprove of are : the school as a factory; as a hospital; as a $\log ;$ as a fanily; as a var zone.

They vould prefer to use the metaphor of the school as a knowledge work organisation. The factory inage is scorned because "it shapes the way problems and solutions are defined, it also shapes perceptions about how roles and relationships should be defined in schools." ${ }^{2}$ Principals are vieved as managers, teachers as vorkers and students as products. It also emphasises doainance and suboission, superordination/subordination and passivity. In effect students are rav material to be processed and the worst tendency is that they are then vieved as objects which is dehumanizing. There is also a tendency to believe that to produce high quality output one must be very selective of intake and "defective products that vind up on the scrap heap of society can be justified as the necessary cost of quality control." In the hospital nodel can be seen a desire for teacher autonony and noves to diagnostic prescriptive individualized programaes of teaching. School psychology with its methods of testing also fits in to this model. If this nodel vere strongly enforced they believe ve vould see adainistrators relegated to a level below teachers and students and teachers would expect

1. Phillip C.Schlechty and Anne Walker Joslin, Images of schools, Ieachers College Record, Vol. 86, No, 1, fall 1984, p.156.

2. Ibid.,p.157.

3. Ibid.,p.158. 
a one-to-one relationship akin to doctor and patient or client. The log metaphor is the wish of some reformers such as Mark Hopkins and indicates to the a return to the classics, high honour for teachers who vill be more carefully selected and assurance of an environment with no discipline problems. In this model education is offered only to those tho desire it. The authors believe it is proaulgated by an elite in higher institutions of education.

The fanily metaphor is more often heard in schools theaselves where teachers speak of 'their' children. This model respects the uniqeness of the individual child, believes in teaching the vhole child and developing a relationship with his or her, and for this reason teachers do not like being separated from their children even for in-service. The var zone inagery is heard in teachers talking about their vork.

The battlefield imagery is sometimes used to convey the notion that students are "troops to be conaanded and araies to be deployed." At other times the suggestion is that students (and parents) are eneaies to be conquered, that classes are battles to be won, and that lesson plans are atters of strategy and tactics.1

Establishing authority becomes a prime concern, corporal punishment is approved of with expulsion as a threat. Teachers and administrators present a united front and sonetines expect extra pay for their dangerous working conditions.

All of the above are used to describe schools yet none of them adequately describes just shat a school is and hov it functions, there is some truth in all of them. As Schlechty and Joslin point out to mix these metaphors can result in confused thinking and planning. They believe that because a school is very wuch preoccupied vith vork it has taken on board

1. Phillip C.Schlechty and Anne Walker Joslin, Inages of schools, Ieachers College Record, Vol. 86, No. 1, Fall 1984,p.160. 
the language of the factory. I do not believe that this is so. I rather think that it arose originally from the need for schools to prepare vorkers for the factories of the Industrial Revolution and because administration techniques in industry increasingly influence hov schools are run. It also stens from the attitudes of adults towards young children which I have detailed in another chapter. Young children have traditionally been handled and catered for as if they vere objects or possessions. Adults have all the pover even in schools and results of schooling are measured in a siailar vay to industrial production models. This is seen in the current obsession with accountability and perforsance indicators as described by Marshall Saith and Jane David recently. Performance indicators are as she says: "Statistics that reflect the health of an education systew and that can be readily and repeatedly collected." 1 That is nor mreferenced test results from national standardized tests such as the scholastic attainment tests in the United States. Marshall sums up what wight be called the public perception of education " An education systen can be thought of as made up of three parts: input and resources, processes and 2 outcomes." Such a siaplistic, reductionist view gives no regard to the nature of the individual child or the finer shades of meaning in the tere 'education'. It is ainly considered as such by those who are responsible. for financing the system and those who viev education as preparation for the labour market. Nevertheless I agree with Schlechty and Joslin that a school is not or should not be seen as a factory or production line and for many of the same reasons which they give.

1. Jane L.David, Aid or Threat to Improvement, Phi Deltta Kapga, March 1988, p.499. Note also the use of a medical metaphor.

2. Marshall S.Saith, Educational Indicators, Phi Deltta Kagega, March 1988, p. 488 . 
Schlechty and Joslin believe that the medical metaphor cannot work because unlike doctors "teachers have not been socialised as professionals. Indeed, teachers do not even possess a comaon language to describe their actions. Without such a common language, practice cannot be submittted to critical evaluation." This same point is reinforced by Peters who says elsevhere that the teaching profession needs what other professions such as doctors and lauyers have, a body of special ised knowledge.

Mark Hopkin's ioagery of the $\log$ oetaphor is they think a nostalgic drean of bygone days and a panacea to weary teachers. This is so far renoved from the reality in which aost people teach and children learn that it is in their teras inpossible.

The appeal of the family model is obvious but "not only do teachers have too many children to know, they know students far too short a time." They dislike the var zone metaphor because of its negative connotations, although they adait that "vars do dislocate probleas and create the need for solutions" a point I shall return to later for as they say "What the persistent and videspread use of the var metaphor wight suggest is the need for a nev vay to frane the educational debate."

Their own conclusions on this theme are that "The purpose of the school is to provide youth with those experiences that adults believe vill foster the ability to master, articulate, and use the doainant systems of 5 our culture." Among some of these they mention the language and number systeas. Others convey the dominant values ve share and for this they

1. Phillip C.Schlechty and Anne Walker Joslin, Inages of schools, Ieachers College Record, Vol. 86, No. 1,Fall 1984,p.161.

2. 3. and 4. Ithid, p. 162 .

5. Ibid.,p.163. 
choose an overall aetaphor that of KNOWLEDGE.

Thus it can be argued that, broadly conceived, the purpose of schooling is to motivate, instruct, and support children in doing tasks that vill foster the ability to use knowledge. Hence, it can be argued that the purpose of schools is to get children to do knouledge work.1

Their rationale is that in our society "knowledge vork organisations have emerged as one of the most important organisational phenonena in our 2 culture" as if this proved it justified. Knowledge does not necessarily equate vith visdon and one could also say that var vas a doninant preoccupation of the twentieth century. However they cite Drucker as prophesying that in the next century knowledge vork vill be the doainant occupation of aost of those who graduate from our schools. No mention of any idea of the vision of the good but a utilitarian vision of job-filling for the future,

General managenent theory has in their vieu been of limited use in 5chools because as any critics have pointed out their models are based on factories, offices and military organizations. Moreover:

Implicit and explicit in this literature is the assumption that kinds of management styles and organisational styles that are appropriate to ootivating, instructing, and gvaluating persons tho sanipulate symbols and who anage people is fundamentally different from the organisational forms appropriate for dealing with persons who manipulate and produce physical objects.3

Such aisfits as, results-oriented aanagement, which became measurement dominated managemeant, and wanagement by objectives, which became aanagement by behavioural objectives, are their examples of illfitting techniques translated from business to education. Efficiency became confused with effectiveness. . The search for excellence in business had its appeal they say because there vere and are resemblances between businesses and school

1. Phillip C.Schlechty and Anne Walker Joslin, Images of schools, Ieachers College Record, Vol. 86, No, 1, Fall 1984, p.163.

2. and 3. Ibid., p.163. 
but not sufficient to aake the vork for schools.

Under their new knowledge work metaphor students become insiders for they are the priary vorkers, It vill succeed they believe because "the knouledge vork metaphor provides for interpreting and explaining some of the results of recent research on effective teaching." Here they see distinct parallels between what has been found true in industry with unskilled vorkers that "tight supervision, clearly defined tasks, ianediate corrective feedback, and careful inspection of how the task is done are all recomended strategies in the supervision of unskilled 2

workers." In schools the equivalents vould be careful monitoring, iamediate corrective feedback and the provision of clear tasks with a high probable success rate. Where they see a vacuu in the training of teachers is that teachers do not know hov to aove children on from being unskilled knouledge workers to higher order skills or abilities. They recommend teachers to look for their odels to the training skills of people in such places as IBM and Hewlett Packard.

So they replace the factory aodel with a business aodel taken from the computer world and the teacher now becomes an executive manager, hel she moves off the factory floor vhere the rav material (students) used to be procesed and now hel she oversee then in the role of supervisor. So convinced are they of the benefits of such a mental move that they believe that teachers will see themselves in a new light, their status will be enhanced and their previous authority relationship vill be redesigned. Seldom do teachers teach individuals nov, they say, 50 they can see no

1. Phillip C.Schlechty and Anne Walker Joslin, Inages of schools, Ieachers College Record, Vol. 86, No, 1, Fall 1984,p.164.

2. Ibid., p. 164 . 
anomaly in this nev role. Nov the principal becomes a anager of managers:

Results-oriented aanagenent vould probably replace anagement by behavioural objectives. It vould probably becone comonplace that evaluative conferences vould center on goal-setting, timelines to be aet, products to be presented, and autually agreed criteria for evaluating the aerit and vorth of these products. These goal-setting conferences vould probably be a time when when the teacher/oanager could indicate the resources he or she vould need if the timelines vere to be aet and the products to be for theoming. I

This model is scarcely an advance on the factory model. They still speak of products and there is a suggestion here of constant time pressure in the forn of tiae-lines. It describes a school as if it vere a robotic producer of information-filled personnel for the inforation aachines. The authors are full of adairation for those who already vork in this model, that is the leading computer companies vho create novel responses to arket conditions. This is a total acceptance of business efficiency and profit-aaking as the hallark of success, the very things they have criticised in previous 5chool models.

They also solve the problem of centralisation versus decentralisation by quoting their business gurus Peters and Katernan who say that "The establishment and articulation of superordinate goals and binding ayths is necessarily a function of the top adainistration of the organization......, what the school system is about, where the school systea is going oust be PREACHED [ay emphasis] fron the superintendent's of fice." Moral authority aust reside with the chief officer. In the school, the leader must be the chief teacher "the person vho defines problems and 3 inspires others to solve then." Leadership is more iuportant than anagerial skill and it is here that the responsibility for profits or

1. Phillip C.Schlechty and Anne Walker Joslin, Iaages of schools, Ieachers College Record, Vol. 86, №. 1, Fall 1984,p.166.

2. and 3. Ibid., p.168. 
results lies. What schools can learn from the best run companies is that "the function of the central office is problem identification, not problem solving."

What Schlechty and Joslin urge us to do is to forget the older metaphors of education and grasp at the same ideals which have created successful conpanies in today's competitive econony. They are convinced that these sane practices vill vork in the schools. No doubt that they would achieve results, any change usually boosts production, initially, because change itself is a stiaulus. Whether ve would seriously accept their suggestions is doubtful. They offer no proof that their nodel vorks. They presume that schools can function in the same vay that the coupetitive adult vorking vorld does. Their eaphasis on building in guarantees for success ignores the fact that a large part of learning involves aking mistakes.

The aodels of excellence quoted from the work of Peters and Watersan is in fact aisleading, for, in A Passion for Excellence by Ton Peters and Nancy Austin, one of the schools held up as a wodel of excellence wrote in its charter the following metaphors:

Education presumes a climate of care. The schoolhouse aust be a kind of home. the student should feel knovn but revered love of learning is an acquired taste Schools are...to serve their comunities as havens of learning 2 Factors such as environment, personality of leadership and vision were also considered iaportant: "Best private-sector leaders have a literal

1. Phillip C.Schlechty and Anne Walker Joslin, Inages of schools, Ieachers College Record, Vol, 86, No. 1,Fall 1984,p.168.

2. Ton Peters and Nancy Austin, A Passsion For Excellence, Collins, London, 1985, p.395. 
1

picture of their vision." Energy, commitment, involvement and empathy are also noted as essential prerequisites both in teaching and in leadership. They also quote from a successful leader the fact that the more power you give to people the nore responsibility they take, One ailitary an

speaks of 'rhytha' and another person, of "a visceral form of spiritual 2

energy" The last rewark say be aoving nearer to the truth of the

secret of success in education.

One wust be around that which vorks, which sings, which has rhytha, which has passion, which has enthusiasa, before one can understand just how broad the gulf is betven the losers (that's defeatist talk) but things that are humaing and things that aren't. 3

Passion appears to be the key to excellence, but it is a pity that they still talk as our education system does, of vinners and losers. We still seem to have a battle mentality in education as in sport.

It is no surprise to cone to the end of their exhortations and find that they are notivated not by their concern for every child in the next century but by their anxiety as to thether their country "America vill lead or follow in the search for excellence in the postindustrial society." They are prepared to sacrifice auch in order to be politically superior. One wonders hou such ends can ever justify the aeans they choose.

They believe that the fanily model requires too much individual attention and concern yet the nev model advocates close supervision during time on task and constant feedback which must also be deanding in terms of time. They dislike the Hopkins model which is concerned vith time for thinking, dreaming, and philosophizing, and is not work or task oriented.

1. Tom Peters and Nancy Austin, A Passion For ExcellIence, Collins, London, $1985, p .409$.

2. and 3. Ibid.,p.409.

4. Ibid, p, 169. 
Their ovn model appears to take no account of of the huaan nead for play as well as work activity. The companies they vish to emulate are involved in computer technology vhere the tasks are often repetitive IRSI a aetaphor for this ? I and where 'vorkers' are, even wore than in the factory nodel, part of a ecchanical process and one in which in fact they themselves can be controlled by the sane achines. Factories in the U.K. are using computers to monitor time at work, on task, punctuality, efficiency etc. and pay is automatically adjusted to output--the machine controls the person--it has no conception of dealing with a functionary tho is late, tired, or possibly ill.

Schlechty and Joslin speak of schools transaitting culture but their viev of culture seens very narrov al nost as narrow as that of E.D. Hirsch Who considers it to be a massive acquisition of general knouledge on Nationalistic lines as he portrays in his Cultural Literacy. Their aetaphor is not an attractive one for education in the broadest sense of the vord-school as knowledge and vork organization--suggestive as it is of concern mainly with symbol systems, iaportant though these are. They assume a heavy bias towards acquisition of this specific aspect of culture and with an emphasis on accountability, efficiency etc. They appear to forget that learning goes on all the time and is not alvays specifically task-based not does it all go on in school. Skills aay be transferred in this way but transferring them across disciplines and making the mental bridges between disciplines goes on through any other activities. For example one vonders how a school $d r a n d$ production would fit into their scheme of things.

1. Ton Peters and Nancy Austin, A Passion For Excellence, Collins, London, 1985, p.401.

2. Ibid.,p. 409 . 
One aetaphor persistently used in any discussion on what constitutes

a vell run school is 'clinate'. It is usually suggested that this is a distinctive characteristic and eanates particularly from the style of adninistration. It has led Nevell to say that:

No task of educational leadership is aore important than the creation of an enabling clinate, that is, a clinate which enables people to function with increasing effectiveness. It is in this vay that the leadership in an educational organization can provide for greater task accoeplishoent and continuing personal grouth. Clisate is an encoopassing dimension in a school, and educational leadership is effective only to the extent that it serves as a force for improving school climate.1

Finlayson believes that the tern 'school climate' ay be an anbiguous and outmoded metaphor. In his experience people find it hard to define. It is recognized, but its meaning is often personal and idiosyncratic.

Fron a study of bank customers by Schneider it was found that they for suamary or global perceptions of a bank depending on how they are treated and how they perceive employees' behaviour to each other. So in his viev "individuals act as information processors and derive meaningful abstractions fron sets of cues which they observe in their day to day 2

contact with the bank." These abstractions serve as frameworks for their

experience. If ve apply this to a school then according to finlayson:

This essentially psychological view conceptualizes the sense-making process at the level of the individual aeabers of the school. It does not offer any account of the interactional, organisational and cultural processes in the cour $5 e$ of which the meaning systens used by the members are collectively built up and, in turn, maintain those processes. 3

1. Clarence A. Newell, Human Behaviour in Educational Adninistratition, Prentice-Hall, New Jersey, 1978,p. 245.

2. D.S.Finlayson, School clinate: an outmoded metaphor?, Journal of Curréculue Studies, Vol.19, No.2,1987, p.163.

3. Ibid., p.163. 
This seems a strange comparison to make as pupils in a school ate not 'customers' and the school is not a financial service as is the bank, although there are people who see it in market terms as a client service. Hovever one can see a connection in that people do get an impression when they enter any institution as to its atmosphere or 'cliata', whether it be the behaviour they vitness there or details of furnishings which they notice, all of which register an impression and presuably leave a menory. Institutions are likevise often judged by externals. How a sense of school 'clinate' is built up is sonething ve know little about says finlayson for research has concentrated largely on a scientific search for 'knowledge', where 'effectiveness' is measured quantitatively in tern's of pupil achievement.

The term 'climate' itself creates a problem says finlayson, depending on one's viev of language, which is our " means of symbolizing and comannicating 1

experience" Empirical researchers use it as "a means of formulating 2

precise and unambiguous descriptions of reality" and consequently have problems with definitions as in most of the research he has exanined. For those who believe that language is essentially metaphorical he says there is no problem, for they believe that language itself partly shapes the construction of reality. This is Salmond's viev, that language is "an instrument for the negotiation of meaning." And Huff has said that metaphor offers a particular for of language for discussing organizations, a language which has a "logic and coherence drawn from human experience in another

1. D.S.Finlayson, School clinate: an outnoded metaphor?, Journal of Curriculum Studiess, Vol.19, No.2, 1987, p.164.

2. and 3. Ibid,,p.164. 


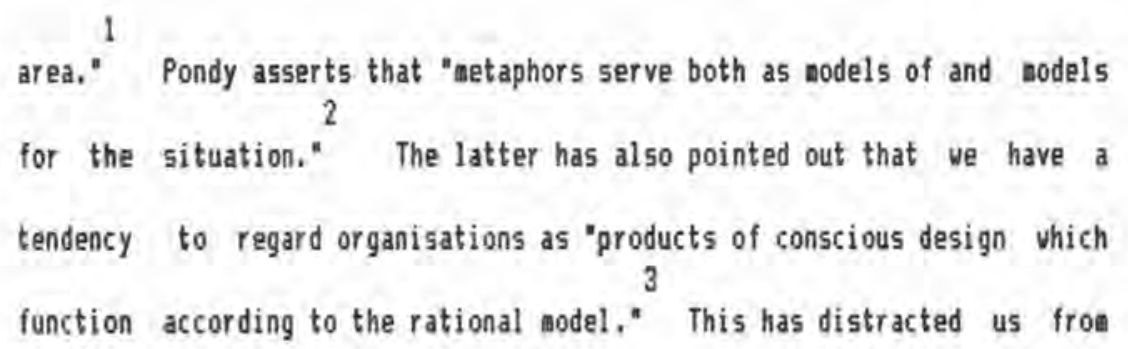

closely examining the aetaphors of organizational theory. Weick has apparently

vieved then as anarchies, seesavs, space stations, garbage cans, savage tribes, octopoids, warketplaces and data-processing stations. Others have compared then to football atches and theatre dranas but Morgan has said that no one metaphor fully accounts for the total nature of organisational life. Interesting that he uses the ter life which itself suggests that an organization has a life of its ovn.

Metaphors therefore are used to help describe and explain the design, function and vorkings of complex organizations. For social policy, Schon has said, that metaphors become "an interpretive tool for the analysis of that policy." First one has to be avare of the metaphors being used.

The other thing ve should be avare of says Finlayson is what Edelsan has pointed out that setaphors are not nerely linguistic devices or tools but have political iaplications: "By naively perceiving it as a tool, ve mask the profound part it plays in creating social relationships and the 'selves' of those involved in the relationships."

Both 'clinate' and 'system' have been described by Tompkins as 'root metaphors' which have in turn been defined by Brown as:

'those sets of assumptions, usually inplicit, about what sort of things aake up the world, how they act, how they hang together and,

1. D.S.Finlayson, School climate: an outmoded metaphor?, Journal of Curriciculua Studies, Vol. 19, №. 2, 1987, p. 165.

2. and 3. Ibid, ,p.165.

4. and 5. Ibid, ,p.166. 
by iaplication, how they be known. As such, root metaphors constitute the ultiate presuppositions or frames of reference for discourse on the vorld or any domain vithin it'.1

So those vho share siailar metaphors are looking at their vorld or organisation through the same vindow as it vere, they share the same paradige in Kuhn's terninology. Burrell and Morgan, Finlayson says, point out that the sajor paradign is generally functionalist which assuaes that the social world is of an objective nature.

In Finlayson's view the tern 'school climate' is an example of that type of metaphor which represents doainant orthodoxy rather than generating new ideas it "serves to inhibit creative thinking and to perpetuate approaches 2 and procedures of a particular kind." Research tends to define it in its geographical and aeteorological sense as something in the environment of the school. To identify this experience questionnaires have generally been used to deternine individual experience of the organisation, which is often described by respondents as if it vere a disension of a human personality. From research done so far he finds thare is no real consensus on the nature of 'climate'.

Anderson, in a review of the literature, tries to impose some order on this hunt for a nythical 'beast' which no-one can recognize. She assumes that 'cliaate' is a holistic concept embracing the whole school and her typology explores four dimensions: the ecology, which is the physical external aspect5; the milieu, characteristics of individuals in the school; the social systen' which includes the patterns of rules and operations; and the culture, which includes reflected norms, values, belief systems, cognitive

1. D.S.Finlayson, School climate: an outmoded metaphor?, Journal of Curriculue Studiegs, Vol.19, No, 2,1987, p.166.

2. Ibid.,p.166. 
structures, and meanings of persons vithin the school. There is no mention of whether she studied the metaphors her subjects used but as finlayson points out even the labels she used are metaphorical and function aerely to sort the literature on school climate. He believes that researchers thenselves are often wisled by the language they use and that the findings they consider statistical are often in fact social.

He is not surprised therefore that clisate studies tend to attract criticisa, he quotes Michael Rutter's Eifteen Thousand Hours as an exaaple, but he believes that to treat participants in a school aerely as a source of data as Ander son does is "to symbolically deny their identity as active, choice-aaking persons with values, feelings and concerns of their oun." In a causal nodel such as Anderson's, climate "is given the status of both a dependent and independent variable. As the latter, it is given an instrumental role; it is seen as a means of realising some good more 2

effectively." Reality is so defined that interaction and relationships becone statistical rather than of personal, social or political significance. "Such thinking is consistent with the dominant scientific orthodoxy, with a tational viev of decision-aaking in education, and vith a systems viev of 3 organization."

Researchers are therefore rather frustrated in trying to define cliate. It is almost a rhetorical mythical beast "The optinistic ones pin their faith on more sophisticated methodology while the pessinistic ones seen to be inhibited from evaluating and exploring other metaphors, " because they are considered as belonging to the realn of folklore and culture and

1. D.S.Finlayson, School climate: an outmoded metaphor?, Journal of Curricul un Studies, Vol, 19, No.2, 1987, p.169.

2. 3, and 4. Ibid, p. 169 . 
not scientific.

Anderson also believes that the aim of such research is usually for purposes of school control. Policy-makers vant to control that which may be controllable but as Toapkins has pointed out meteorology is not alvays controllable. Research so far has the effect of depersonalizing schools yet Finlayson asserts research into business organisations respects the individual as in Peters and Haternan's In Segarch of Excellences. Checkland also has shoun how individuals contribute to the creation of cliate. He has argued that " the hard use of the system aetaphor is inappropriate in organizations and that its assumptions about nethodology require considerable modification in order to accomodate the complexities of the social vorld."

Argyris and Schon see the organization as a learning system and identify some of the psychological and social barriers which serve as constraints on learning. This says Finlayson, adds to a new vetaphor current in DES publications, "the thinking school" which clearly appreciates the concept of climate and its importance. It is possible as finlayson says that the concept of 'cliate' to which every individual contributes may be at odds with the traditional concept of the leader who represents the group values and consensus model. The research into 'clinate' aight underaine acadenic traditional concepts of school leadership and control. Coping vith change vill bring new aetaphors, especially to symbolize nev structures and methods, for the old one of climate may deny the contributions of sone of the partcipants, in his viev.

The notion of 'clinate' is not in itself outmoded but the vays of

1. D.S.Finlayson, 5chool clinate: an outmoded metaphor?, Journal of Curriciculue Studies, Vol .19, No.2,1987, p.171. 
exanining it have been too narrov. A similar problem exists in Nev Zealand with the the expression 'special character' a term beloved of private schools which have integrated into the New lealand State school system. This special character is soaething the ouners of these schools and their comunities believe in, and which the Government recognizes in its legislation. What is it? It is alnost indefinable, but closely associated vith the philosophy or ideology of a school which often has particular religious affiliations.

Everything inpinges on and is influenced by the school's character. It is as variable as veather and nay be affected by quite sall details and changes; the furnishings, the colour schemes, the sex of its members, the size of the roll, the composition of the staff and the nature of the individuals vithin it, even their personal belief systens. It is, in a sense, a living ethos anifest only at any one moment for it changes over tive. It is that which is sensually, perhaps aeshetically or even spiritually or cognitively experienced by menbers of staff, students, parents or visitors. Many attest to its palpability. Yet it can be different for each person although nany aay identify fron their experience sinilar things such as perhaps friendliness, particular type of discipline, efficiency etc. It is a pattern of experience which that organisation deliberately or not, villing or otherwise, creates for individuals and for the public. It can be as allusive and elusive as the nature of a personal relationship but has in fact no permanent individual existence for it is only 'alive' when the organisation is in vorking aode as it vere. The eapty school in the holidays has lost it. Changes of staff upset its equilibrium. One has only to be in a school on a nufti day or during exams or when the whole shool receives good or even sad nevs to be aware of this 'Iiving ', changing and sometines ephemeral nature of the 'school', It is more than the anbience ve 
like or not in a restaurant, a force generated not only by the method in which the school is organised but coaposed of the individual personalities of both its adainistration and clientele, an energy both created and dissipated. It ay be as false as the school's Latin motto which no-one understands or as real as the soile vith which one is greeted at the door.

Climate is often described in teras generally used of human personality. Like human personality it has potential for good or evil, David Reynolds discussing 'The Delinquent School' and the factors which say encourage deviancy in pupil bahaviour in a particular school says that "Further research from the U.S. has also suggested that the acadenic 'climate' of high schools is an important influence on pupil's scholastic 1 attainment," Administrators in schools can make policy to create cliaate or influence it e.g. rules, uniform, imposed values, but like the 'hidden curriculua' the true character of an organisation vill nanage to show its ovn face because it is the sun of its parts, to every viever and researcher and even the people vithin it. If they look in a airror they vill see part of its akeup.

There seems to be general agreenent that education and its administration is influenced by netaphor 5, but to vhat degree, and whether those in vogue are useful, practical or even desirable, or defensible, is somewht debatable. The key figure in the school scene and considered particularly responsible for the 'climate' or 'tone' of the school [another abstract metaphor], has traditionally been the the head, whose role will now be examined, before looking at metaphors in organisations which have been the dominant influences in school adainistration so far.

1. David Reynolds, The Delinquent School, in The Process of Schooling, eds. M.Hamersley \& P.Hoods, Routledge and Kegan Paul and Open University, 1976, p.219. 
The key figure in any educational institution is of course the principal or headaster as he used to be called and this is a species which Robert Protherough has chosen to exanine through a study of literature, for he believes that books have helped to shape a notion of what they are or should be like. The general inage in the nineteenth century came from popular novels and he exanines twenty such school novels or novels set in school fron 1869 to 1914 . He finds in them that 'greatness' tends to be presented in superficial terms as a atter of presence, outstanding physique and a comanding aanner. So often are these described that they in fact seen to nerge into a composite figure:

...majestic figures, creating a godlike effect of ave and terror, outsize in terms of physique and personality and separated fron ordinary mortals by their povers of speech and by a special rhetorical style. 'Dignified', 'grave', 'stern' and 'solemn' are the epithets nost frequently used to describe these figures.1

The title 'doctor' also serves to separate hin and he is of course never seen without his cap and goun and appears only on formal occasions. This detachaent is a singular ark of his office. When he does appear he is described aost often as 'awful'. One is described as "the personification of majesty, dominion, ferocity and ave." Boys are therefore not only avestruck by his presence but rendered dunb.

These wen rarely display a sense of humour and in fact their voices often, bellow, roar and thunder. They are generally outstanding or ators and as they are often clergymen they give sermons in voices that instil the fear of God quite easily in their young charges. They have a style of language which Protherough calls "headmaster rhetoric". Even "Boyish

1. Robert Protherough, Shaping the Image of the Great Headmaster, British Journal of Educational Studies, Vol.xxxil, No.3, October $1984,0.240$.

2. Ibid.,p.241. 
aisdeneanours are described in elevated language, both to intensify their seriousness and to avoid the contanination of comonplace terminology." And punishment is also "elevated by appropriate metaphors" 50 that expulsion becomes surgical "pruning" or removal of a "malignant disease". The oratorical style is also evident in the habit of repetition for effect. So incomprehensible is the to schoolboys that one author puts a completely 2 unintelligible speech into the mouth of one of his headmasters.

The most outstanding characteristic they all have is that they appear to do no work:

Instead of being the leader of a group of 'assistants' essentially engaged in the same vork as hinself, the head is increasingly seen as the organiser of a tean of specialists; his authority rests less on scholarship and aore on his anagement skills; in particular he tends to be judged by his public appearances. 244

The antithesis of these figures is that of the Doctor in Ton Broun's Schooldays who is seen in a vide variety of roles but according to Protherough in a number of novels published early in the tventieth century the head is a very shadowy figure in the background. So in most of the novels he has exanined, the head's ajor role is that of judge, executioner, priest and monarch. He speaks to an individual only to admonish or punish, and lurid details of his provess at inflicting punishment are legion.

Virtually all the headmasters are described as preaching affecting sermons in chapel, addressing the school at prizegivings or other occasions and publicly denouncing urongdoing. Their position and pover are emphasised by the accompanying ceremonial, the thronelike chair, the surrounding acolytes. 3

His ultimate power is to destroy a boy by expelling hia, itself a ritual, In

1. Robert Protherough, Shaping the Image of the Great Headmaster,

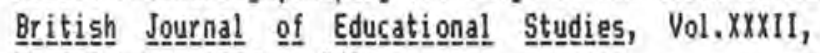
No.3, October $1984,0.243$.

2. Ibid.,p.244.

3. Ibid., p. 245 . 
essence what is described in nost of these stories is a stage performance

The essential quality of a headmaster, it seeas to be suggested, is that he should be able to act out the accepted role, to play convincingly what is becoming a stereotype. There is something theatrical about all the ajor set pieces in these books.1

Only in one is there a more human headmaster vho is avare of his role-playing, Grisstone of Vice Versa (1822) who acts the tyrant in school but is also portrayed as a loving fanily man. Nevertheless in school he behaves with all the mannerisms already described as typical of headmasters. He is particularly adept at aking boys feel shame and guilt. Protherough believes that Anstey is mocking "the unreal inage of an omnipotent figure vith unquestionad pover who suppresses any of the softer human qualities." Even later authors still subscribe to this notion of the headmaster as a "potentate", a "aajestic figurehead" before whon boys treable with fear but whom they secretly adnire. As Protherough sums up "Hunanity has 3

disappeared: the office swallows up the man."

What is the truth behind this vivid but unedifying picture of headuasters and how do they they see thenselves in reality? Colgate in a selection of reflections on The RoIe of the Head in 1976, edited by R.S.Peters claies that "The authoritarian head is obsolete today" and Peters hinself confirms that traditionally in Britain the autonoay of the head vas exercised in a very authoritarian and paternalistic vay, and although he recognizes a need for authority he believes that the arbitrary and dogmatic use of authority is uncalled for. The schools need professional

1. Robert Protherough, Shaping the Inage of the Great Headmaster, British Journal of Educational Studies, Vol.xxxII, No.3,0ctober $1984, p .246$.

2. Ibid, p.248.

3. Ibid, p. 249 . 
administrators but he sees also that the head should personify the values of the school, exercising visdon and giving noral leadership for a school can never be truly denocratic as nost of its nembers are inature and some are specialists vhose expertise should be respected. Peters varns that the adoption of business nanagenent techniques aight hovever be more damaging than paternalism because the leadership style becomes part of the hidden curriculum of a school and pupils nay learn fron it undesirable values. At the time of writing he vas unaware of any conception of a head which was not either paternalistic or anagerial and that the authors selected vould in fact contribute to just such a conception. I vill briefly sumarise their findings.

Bernbaum traces the historical position of headmasters and says that traditionally they vere chosen if they vere vell educated and had the right personality but the managerial function is becoming wore important because the job has becoae so coeplicated it aust be done in a professional manner. The unique position of the headmaster emerged in the nineteenth century where the head was usually a gentleman and a clergyman. As schools grew larger discipline becane a problen and the punitive disciplinary aspects of headship developed, the cane became part of the role.

In answer to aore stringent deaands from the public and after various enquiries and conaissions later in the century headships became open to laynen, the povers of the trustees declined, an independent professional career in teaching became possible and notions of responsibility and service energed. Arnold of Rugby typifies this new breed and teaching by example became a precept of the new style. A pattern emerges from the structures

1. 6. Bernbaum, in The Role of the Head, ed. R.S.Peter5, Routledge and Kegan Paul, London, 1976. 
and conditions existing then says Bernbaun which we can still discern today. They becase experts and vere paid a salary but shortage of aney vas al vays a constraint and it was largely their energy, comitament and skills which enabled thes to survive, They vere in charge of teaching some of which they did theoselves and al so anaged finance, accounting, recruitment, control of staff and pupils and kept up links vith the ouside comanity, After 1902 inspectors had a right to visit schools and Bernbaum believes that these wen largely draun from the major public schools vere mainly responsible for establishing the literary, classical, liberal ethos and diainished the scientific, technical and conmercial qualities of the Higher Grade Schools.

By 1914 biographies and memoirs vere testifying to the Christian leadership, benign authority and punitive povers of the schools. By the 1920 's the general quality of teaching staff had improved and the leadership rather than the pedagogic role of the head received nore eaphasis. Control of staff was done by the conventional system of testimonials and references.

After the Second World War and the 1944 Education Act the whole pattern of secondary education changed. The development of large comprehensive schools and the vider intake challenged traditional definitions of headship. With compulsory schooling heads no longer had to vorry about rolls tno longer truel but their work becane aore concerned vith control and motivation. In large schools they were also exposed to wore challenges to their power fro large departaental groups and specialists vithin their ranks. The head's previous control over the curriculum vas now dininished and there vere wore areas of potential conflict, politicians, teacher unions, local authorities, an increase in fact of what we vould now call 'pressure groups'. The nature of the head's role vas wore often analysed, and questions were raised as to whether he should have a detached or directive role. 
Many heads of course still envisaged thenselves in the traditional aode and a paophlet put out by the Headaaster's Association called for aintenance of the head's unique position for the ideal vas still conceived in charisatic teras. Outside of schools however there have been increasingly critical views of this role especially says Peters since the sixties for education is nov auch aore a matter of public concern than it used to be. Bernbaun refers to a head who has vritten fron his experience, F.J. Godvin, forner headmaster and HMI, who advises that control and discipline are the first priority. The main difficulties he lists as, leadership, discipline, organisation, adainistration and above all personal relationships. He tends to follow the authoritarian tradition for he says that one sust constantly walk about in the 'danger zones' and be suspicious of 'denocratic' schools and staffrooms. He rejects the never managerial and adainistrative approaches in favour of authority, leadership, dignity, control and independence. This confiras Bernbaum's perception that headmasters are generally reluctant to give up their traditional role. Another interesting facet of his study is the background of headmasters, for he finds that the majority as in previous decades cone from the sane fev schools and universities. They are more likely to delegate tasks which are specific but not those that relate to the generalised and personal qualities of leadership and control which they tend to see themselves doing quite well like 'getting on' with people, or anipulating people. Their lovest self assessments are mainly concerned vith improving teacher performance and helping staff with discipline probleas and they recomand their successors to be open to change and not conservative which in view of their own traditional stance seess anachronistic.

The idea of training for educational management troubles W. Taylor because he thinks that ve may thereby encourage people to behave in ways 
antithetical to certain fundanental educational values. He quotes Jules Henry in support;

One should not confuse the 50-called business ethics based on lavs of contract, the stability of currency, and the retention of the arket-a satisfied narket- vith moral principles that govern the relations betveen human beings.1

Taylor is sceptical even though others have found the approach vorthuhile for he believes that it can lead to a 'them' and 'us' relationship instead of stressing shared values in a comaunity and one of the ongoing tasks as he sees it in any society is to identify the ainiaum of rules necessary. Management practices moreover which rest on naively conceived principles are unlikely to be effective. One might replace principles here vith the tern metaphors for the same is true, Taylor observes that despite the custodial and socialising tasks thrust on to the school in recent years 2 "the school is priarily an educative institution" and everything else which goes on in school is aerely to this end. Which also leads one to consider just who the adeinistrator is vorking for.

Managerial training can never substitute says Taylor for the stature of the educated person as an educator. Professional competence is difficult to judge or to lay down criteria for:

The subtle and elusive nature of criteria of professional competence can take on meaning only vithin a comunity of practitioners, which alone can exercise the kinds of social control effective in maintaining standards. Without conscious and willing participation by the individual in such a comanity all attempts at external evaluation are likely to be ineffective. 3

Management in business requires institutional commitment vhereas.

1. Willian Taylor, The Head as Manager, in The Role of the Head, ed. R.S.Peters, Routledge and Kegan Paul, London, 1976.p.41.

2. Ibid.,p. 42 .

3. Ibid., p.43. 
professional comitment says Taylor is alvays to a set of values and principles for practice. Current trends are veakening professionalisan. Another suspect aspect of business managenent in his viev is that sanagenent principles are assuned to be scientific and that behaviour within the systen is rational. I find the sane quarrel vith the vork knouledge organisation model presented by Schlechty. Taylor refers to Brian Davies who has said that :

One needs to be thoroughly sceptical about the mixture of reification and over-generality constantly found in systeas approaches, without denying their possible heuristic value. 1

One danger pointed out is that content and aethod rather than being priorities may be ignored altogether in a systems approach so that one has structure vithout content.

Heads are paid to make judgemențs says Taylor and the answers to some of their problems have yet to be found. He doubts whether current trends really assist even though he acknowledges that there are aspects of management that can profit from a sytenatic approach. He place oore eaphasis on empathy vith individual pupils and staff, an ability to find the connections betveen seeningly unrelated facts, knoving when to conpronise and when to take a firm stand, as sone of the finer points required in a head. One priority must also be the kind of personal and professional growth that leads to an ability to make judgments for hiaself, his pupils and his staff. For this he see sore hope in the right kind of education in educational administration than he does in professional management training. What Taylor says here fits with my own viey that the managerial approach confuses education and training. They are not the same, but different and

1. William Taylor, The Head as Manager, in The Role of the Head, ed. R.S.Peters, Routledge and Kegan Paul, London, 1976, p.45. 
compleaentary.

Hughes has noted a tendency among professionals to despise adninistrative roles but to be accepting of adeinistrative responsibiity if and when these are offered to them. He states that:

The secondary school head is the CHIEF EXECUTIVE of a professionally staffed organization, and nay al 50 be regarded as the LEADING PROFESSIONAL of that organization.1

According to Chester Barnard "executive work is not that of the organization 2

but the specialized work in MAINTAINING the organization in operation'

and this vork has two aspects for it goes on within and outside of the organization.

What Hughes is draving attention to here is the fact that the head's role is one which more than any other in the school links the school as a system to the wider society and the systems within that. External influences on the head affect the school considerably.

In a study involving seventy-two heads in England and Hales, one of the findings was that:

the occupant of an executive position, tho is granted little authority and recognition by his superiors, tends to behave in relation to his subordinates in a cautious and defensive nanner, which exposes hin to as little riak as posaible.3

And the reverse was also true. This finding has been supported by other research in the United States and suggests a clear need for institutional autonony.

It may well be that professional initiative and the exercise of discretion cannot properly be expected from school executives tho

1. Meredydd G. Hughes, The Professional Administrator: the case of the secondary school head, in The Role of the Head, ed.R.S.Peters, Routledge and Kegan Paul, London, 1976, p.51.

2. Ibid.,p.51.

3. Ibid., p. 53 . 
are regarded and who regard thenselves, as the poverless minions of a centralised and powerful bureaucracy, 1

Fron the study, two distinct factors in the concept of the head as leading professional emerged: a traditional disension, and an innovating (or cosmopolitan) dimension. These two aspects generally proved to be independent of each other and not antithetical aspects of a head's role, and led to grouping of heads as ABDICATORS, TRADITIONALISTS and INNOVATORS. The extended professional Who vas above average in personal teaching and pastoral emphasis and in openness to external professional influences--whereas the others had one or aore of these qualities. An extreme abdicator he says is probably nonexistent. In the opinion of the researchers some heads vere over-extended and carrying too big a responsibility. In large schools they found that good intentions for pastoral care often became impossible to inplenent and counselling increasingly became a delegated task.

In conclusion Hughes states that analysis shows that the 'traditional' emphasis conflicts with basic features of the chief executive's role, but the 'innovative' emphasis fits more easily. A great deal depends on how the profesional adainistrator perceives his own role. If modelled on traditional stereotypes this may clearly create difficulties in a large organization. But if he takes a leadership role and encourages colleagues in their joint efforts "his contribution will be invaluable in enabling the combined expertise of a professional staff to be nobilised for the achievement 2 of agreed or ganisational ob jectives."

Robin Barrow considering the competence of heads explains that there

1. Meredydd G. Hughes, The Professional Adninistrator: the case of the secondary school head, in The Role of the Head, ed.R.S.Peters, Routledge and Kegan Paul, London, 1976, 0.54 .

2. Ibid, , p.60. 
is vhat he calls a natural conception of a head and one that he believes ve ought perhaps to hold on to even in changing tiaes. Because ve perceive headship as a complexity of adninistrative tasks does not necessarily aean according to Barrow that any of these are contingent factors regarding headship. Nor night charisad or the ability to handle relationships.

He also asks why an authoritarian concept of the head's role contrasts with a anagerial concept. We have a tendency he thinks to to make assumptions that one type is incompatible with another, and he lists some of the catchphrases: Christian, gentleman, authoritarian figure, paternal figure, manager, counsellor, priaus inter pares, administrator, chairean etc. He questions whether there is in fact a recipe for what constitutes a head. What ve can say is that he is responsible for policy decisions, for directing the school and deteraining objectives, not merely seeing that these are met or carried out. This he says is a mininal definition. It is conceptual rather than definitive. Most heads see their job as one of 'running' a school. So ve can define our conception of a head as "one who has responsibility for the running of the school in the sense of deteraining its direction or aias or objectives."

When ve ask what is necessary to be effective says Barrow then all that is needed is coapetence and freedom, competence in selecting educational objectives, deciding priorities and determining policy. There is no set deterainate body of knowledge to draw on yet no novice teacher vould be likely to have the philosophic competence required:

What I mean by a philosophic competence ay be characterized in terms of such formal rquireaents as consistency, coherence, concern for good reason, and iapartiality. But perhaps its two most iaportant

1. Robin Barrow, Competence and the Head, inThe Role of the Head, ed.R.S.Peters, Routledge and Kegan Paul, London, 1976, p.67. 
strands are the ability to recognize different kinds of questions for what they are and the ability to avoid conceptual muddle..... To have such competence is to be in a position to unravel complex issues and to treat them adequately, appropriately and reasonably.1

Such conpetence does not date and is not dependent on being up to date with 2 new theories, "it is a skill that is timelesss in its application."

Barrow does not accept the view that all knouledge is relative and 3

calls this idea "an alternative strange doctrine." His picture of a head emerges as one whose talent lies in breaking practical issues (in the sphere of education) doun into their separate parts; in recognizing what sort of procedure is appropriate to the resolution of each part; in knoving where to turn for expert advice and in understanding the limits of any particular expertise and in setting any particular problem in the context of a vider perspective, He is the theoretician rather than the practitioner in that his task and his skill lies in critical reflection on various possibilities and in deternining policy in the light of inforation, some of which ay be fed to him by members of his staff, rather than playing an active part in carrying out that policy. This defines the 'running' of a school.

There is also he says another dimension to be added to the mere skill of revieving alternatives competently and that is the inaginative element, this to him is not merely lateral or creative thinking. This definition of competence includes a "dispositional elenent or character 4 trait..." Yet even with all of these things freedon is still needed; to

1. Robin Barrow, Competence and the Head, in The Role of the Head, ed,R.S.Peters, Routledge and Kegan Paul, London, 1976, p.71.

2. Ibid, , P. 73 .

3. Ibid,, 0.74 .

4. Ibid., p. 75 . 
appoint staff, control the curriculun and allocate resources--othervise policy cannot be put into practice. This freedon may be curtailed by limitations vithin the staff.

Barrow makes no mention of the skills a head might have in influencing staff to do his behest. Charisad, he does not consider one of the prerequisite characteristics of a head, but where it exists it can be an asset if used with good intent. Nor does the head have to be a noral leader even though one night not wish hin to be an immoral influence but as far as administrative excellence is concerned this is not an issue, according to Barrow. His point is that qualities often perceived as desirable are not necessary whereas competence and freedon are vital. Many of these other aspects are ones which can be delegated, and the ability to delegate is another dimension of competence, as is the ability to recognize and appreciate talent in other people.

Barrow is of the opinion that no aanagement course could ever adequately equip one vith the diverse types of expertise a head needs. To assume that all heads should have all of the generally listed is to expect too much. He sees a head as a director of policy not an administrator--and on sharing decision waking vith staff he says:

There is only one purely rational vay of distributing authority and that is on the grounds of appropriate competence. He should be placed in any sphere who has authority deriving from his expertise in this sphere, 1

The rationale for a head vill be that "by definition he vill have the sort of expertise that makes him an autherity in the sphere of selecting educational objectives and issuing practical directives." Such

1. Robin Barrow, Competence and the Head, in The RoIe of the Head, ed.R.S.Peters, Routledge and Kegan Paul, London, 1976, p.71.

2. Ibid., p.85. 
expertise vill differ fros that of doctors "in that it does not guarantee the same degree of unaninity amongst those vho possess it and does not consist in cooing up with answers to probleas that can be denonstrated to be unequivocably 'right', "If all staff had equal philosophic competence then decision making could be shared. The head's philosophic competence gives hin a right to resist consensus. "For consensus aay sometines be the outcome of prejudice, ignorance, inability to see the force of an arguaent 1 and 50 on." The situation would be different if the head vere not wuch more competent than his staff. If he is to be simply a chairman then there is a need to develop the philosophic competence of all teachers.

Authority is not easily accepted says Barrow and he questions whether any particular authority can be justified. His concern is to argue that a certain kind of competence is necessary to the proper running of a school and that possession of that competence is the justification for an individual's being trusted with authority. If heads are inadequate it may be because their authority is resisted or that pover does corrupt.

One thing is obvious to Barrow and that is that they are often badly chosen, either because selectors are looking for the wrong qualities or because it is difficult to judge degrees of philosophic competence in different people, and perhaps ve should lay nore stress on educating people for leadership. It is ironic he thinks that those who call for more democracy in schools are also those who would like to see less study of educational theory but in his viev "There never has been, and there never will be a short cut to competence."

1. Robin Barrov, Competence and the Head, inThe Role of the Head, ed.R.S.Peters, Routledge and Kegan Paul, London, 1976, p.87.

2. Ibid.,p, 90 . 
The emphasis in Peter's selection is adinly on secondary schools but Coulson exasines the role of the priaary head and looks at soae of the factors which sustain the concept of the traditional paternal form of headship in English privary schools. In his study vomen are acknovledged because of their being in the ajority in infant schools.

Heads, says Coulson, have sone discretionary freedom but are not autonomous:

The rules of manageaent are made by the Local Authority under powers delegated to then by the 1944 Act: they therefore lay upon the head inescapable duties. 1

Much depends on local conditions but a head is generally free to interpret his role in a personal fashion. Coulson thinks that traditionally in Britain the head is seen wore as a teacher than as an administrator "the head expects to influence teachers by his own example and to persuade then to identify thenselves vith his aias and aethods." He also usually tries to know every child in the school and uses asseablies to conmunicate with then as a group. The head is also expected to protect his staff from criticism and interference by parents, and the children from the pernicious effects of the connunity's values. IInteresting that the staff do not apparently view themselves as part of the community] Change is also usually brought about by the head.

This very traditional concept of headship, combining personal control and moral authority, comes originally fron the public school tradition which has been described previously, it reseables very closely, thinks Coulson the Victorian pater fanilias and is favourad by principals thenselves. He

1. A.A.Coulson, The Role of the Primary Head, in The Role of the Head, ed. R.S.Peters, Routledge and Kegan Paul,London, 1976,0.93.

2. Ibid., p. 93 . 
believes that prinary school heads and teachers fael thenselves to be more in loco parentis than do teachers in secondary schools. It is also seen, because of its caring nature to be vomen's vork. The close resemblance to the maternal role also contributes to the paternal inage of the head. He believes vomen are less conaitted to their careers and value pleasant social relations at work. They are therefore more accepting of authority and so cultural nores of ale superiority at vork are thus upheld. Teacher iamersion in the classroom vork also removes her from concerns with general school policy and administration,

Coulson reiterates what several authors have already said about teaching: "There is no agreed body of generalisable, pedagogic knouledge underlining primary school teaching." Personality is preferred above professionalism. This may rest on a popular assumption that child-bearing is natural and intuitive, All of these factors combine to aake the privary school resemble a fanily.

A more rational concept of headship say come he believes once teachers abandon what Hoyle has called 'restricted professionality' and move towards 'extended professionality' where the work of teachers is seen in a broader context. This vould lead, he thinks, to greater involvement in educational decision-naking. The role of the head must develop, for no longer can we presune that the traditional head's values vill match those of society. Extended curriculum input from specialists outside the school and vithin a staff have combined to remove the onus of all decision aking frow the head. Practices such as tean-teaching have also lessened the autonomy of the teacher who has also had to become involved in more collaborative

1. A. A.Coulson, The Role of the Primary Head, inThe Role of the Head, ed. R.S.Peters, Routledge and Kegan Paul, London, 1976, p.76. 
decision-making. The role previously held by the head has also become shared by tean leaders. No longer either is the head a kind of buffer betveen the school and and the community, but more often now he is the link with it and even brings outsiders into his school. He is also more involved in social and velfare problems than previously. He takes this on mainly because he is the only one who has the time.

The traditional centralised authority pattern persists says Coulson because "At the root of the priaary head's paternalism lies the ego identification which he noraally has vith the school." He tends to overidentify with it. This is an obstacle to the general professionalization of teachers generally--for "the other side of the coin of the head's freadom is the teacher's subjection. Hovever benevolent and supportive the head's paternalism may be, it curtails the authority and responsibility of other teachers and therefore adversely affects their professional 2

status." The pattern needs to change says Coulson from a paternalistic one towards a more collaborative one. This could be achieved he believes by separating the head's legislative and executive functions. This could be done with a collegial systen--a collective type of authority but the head would still be needed as a coordinator. Teachers he feels should participate in the appointaent of a head. Career teachers as Coulson calls them i.e. long-5erving highly qualified teachers could absorb many of the head's traditional administrative and public relations functions. For this he believes that they need to be trained in structuring and analysing their own experience for nore effective use.

1. A.A.Coulson, The Role of the Primary Head, in The Role of the Head, ed. R.S.Peters, Routledge and Kegan Paul, London, 1976, p.102.

2. Ibid., p.104. 
Coulson has referred to the aajority of women in primary education and nearly always at the assistant teaching level which he seems to believe is due to their being less career oriented and subject to normative pressures fron society which have becone reflected in the traditionally paternalistic attitude of heads. In Nev lealand Margaret Malcoln found also that "the sex role stereotypes are strongly ingrained." One reason is that "In general, marriage is a career ASSET to a man, whereas it is a career DETERRENT for women." This is true in areas other than education also. Overseas reaearch has shown she says that vomen vith careers in adainistration are more likely than men to be unarried. One vonders if the pattern vas different and women predoninated vould we speak of a maternalistic or matriarchal school administration. She says that research in Aaerica showed that women principals vere more denocratic; had schools with oore positive teacher, pupil and parent attitudes towards education; had higher degrees of professionaliso; and demonstrated superior pupil performance. These vere all in primary schools and as Malcoln says the findings do not prove superiority but that there are more differences between people than between aen and vomen. What is clearly evident though is that "men are the gatekeepers to positions of school management." And she noted as I have found also that with very fev exceptions the literature refers to male heads. Peters does say in his forevord that 'head' is seant to indicate both sexes but nost of his writers refer to heads as aales. The word 'head' is itself a metaphor suggesting presumably an important part of a body and the thinking centre. We speak of the 'body politic' and it vould appear that a school is also thought of in anthroponorphic terms.

1. and 2. Margaret 5.Malcolm, The Almost Invisible Woman, Set 78, No.2, Iten 12, N.Z.C.E.R., Wellington. 
Colgate says that in 1972 there vere calls for teachers to have a say in the selection of heads, wale or female; for he is one of the rarer uriters who recognize that both exist. Fev heads in his opinion today presune to be the soral and spiritual leaders that they vere once expected to be but he also believes that if they become too self-critical and doubtful about their capacity to be leaders revolution vill erupt. To be a head in his terms ioplies a duty to lead but this does not mean that one can ignore changing attitudes to authority.

Colgate supports what Peters has said that authority vhen questioned is not necessarily superseded but becomes rationalised and adapted. The comaon analogy comparing the head to the captain of a ship generally draws criticism says Colgate but to hin, the school, like the ship, needs someone who knows where the school is going, for "Schools which do not change are not stable, they are stagnant. The head oust be an innovator."

Colgate seems to assume that only the captain of a ship can know where it is going and how to get there. He accepts the managerial concept of the head's role because it is nore rational than the traditional authoritarian one and because the four questions which Barry and Tye have suggested that any head should ask himself vill require consultation with colleagues (Where are you? Where are you going? How do you intend to get there? and how will you know when you have got there?). The franing of these questions refers to 'his' objectives not those of the school collectively, This reminds us of the kind of 50-called 'democratic' discussions which Peters has referred to and which in reality are merely consultation.

A head nust take responsibility for all that takes place says

1. H. A.Colgate, The Role of the Secondary School Head, in The Role of the Head, ed. R.S.Peters, Routledge and Kegan Paul, London, 1976, p.112. 
Colgate but he does not say how a head copes vith ideas and aims and values which conflict with his own. Presumably he vould overrule dissension and use other people's ideas only when they vere in line vith his. It is true what he says hovever about the risks involved in bringing about change for students way suffer in the process and he also reainds us "No two heads are alike.... just as no tvo schools are alike." He believes that there is need for a nev concept of headship which permits leadership but is not autocratic

Another question he raises is uhy is it that we have difficulty getting children to come villingly to school, getting them into the 'citadel' as Peters has called it. His oun broad philosophy is to prepare pupils for life--as they see it, in a tine of rapid changes. Such a sweeping ain is liable to drav fire because it is open to such diverse interpretations, for some see school aerely as a ticket to a career and others looking further ahead see survival as the nain task.

Colgate acknouledges that outsiders, his tern, vill expect schools to teach skills to enable youths to becone self-supporting and many vill judge by exam results. "The society which foots the bill for education relies on competition for its very survival." He himself vould still base his noral values on the commandments even though sany would consider this an old-fashioned vieu. Colgate thinks the head should be the decision maker but agrees that the terms on which people are being consulted should be aade clear. If the head consults only yith senior staff then oligarchy is being substituted for despotisn. His answer vould be to set up some form of conmittee structure. He dgrees vith Bernbaua's perception that since 1944

1. H. A. Colgate, The Role of the Secondary School Head, in The Role of the Head, ed. R.S.Peters, Routledge and Kegan Paul, London, $1976, p, 115$. 
a pyramid type of career structure has arisen in schools.

The head therefore in CoIgate's viev has a managerial and a pastoral role. Allotment of time is one crucial task and one probles in schools is the rigidly controlled use of time, In Britain he says that nost courses for school adoinistraters allot some tiae to aethods of curriculua analysis because of its perceived inportance.

Delegation is a necessity for "He [the head] cannot and should not even try to know all that is going on in the school." Not enough time is given for senior staff to accept a share of delegated tasks. "As a result senior staff are forced into a situation where the routine thinking gets 3

done and planning gets shelved." It is easy to see that this leads to the continual crisis or maintenance type of management that others have criticised as a faulty management style. It also results in experienced teachers rarely getting the opportunity for 'hands on' type of administrative' experience which would be a useful training for senior positions. In most LEAS says Colgate only the head is supernumerary to the staffing allovance and until some senior staff at least are taken off this there is little hope for improveaent.

Colgate also believes that teachers cannot undo dasage done to children during their early years by circuastances beyond their control. There is a linit to what schools can be expected to do and they need to be avare that change can have drastic effects upon children.

Heads usually use the assembly to communicate with children but he

1. H.A.Colgate, The Role of the Secondary School Head, in The Role of the Head, ed. R.S.Peters, Routledge and Kegan Paul, London, $1976, p, 113$.

2. Ibid.,p.119.

3. Ibid., p.120. 
does not see this as desirable because it is a nonologue rather than a dialogue with the pupils. On assessment he notes that "As a profession, teachers do not take kindly to assessment of themselves."

Colgate thinks ve have tended in education to believe that leaders are born not nade but it is his belief that training is just as necessary as it is for teaching. Heads are limited in their range of control. They usually have no control over salaries and size of plant, they also often work on shoestring budgets in the public glare. "Few people know how d factory, a ship or a hospital is run but everyone has been to school and has ideas on hov it should be run."

John Watts does not believe that authoritarian leadership is inevitable or necessary, and speaks on the nature of participatory school government from his experience as principal of Countesthorpe School in Leicestershire. Most heads clain that decisions are based on consultation. "Yet none of this consultation constitutes participatory government in the sense... in Which [it] has been practised at Countesthorpe since it opened in 1970." Here change vas envisaged as a continuous process. One way to ensure this was to involve all staff, for "With the general grouth in the size of the schools there is a danger that the teacher may come to feel depersonalized 4 and alienated."

1. H.A.Colgate, The Role of the Secondary School Head, in The Role of the Head, ed, R.S.Peters, Routledge and Kegan Paul, London, $1976,0,124$.

2. Ibid.,p.125.

3. John Watts, Sharing it Out: the role of the head in participatory Governaent, in The Role of the Head, ed.R.S.Peters, Routledge and Kegan Paul, London 1976, p.127.

4. Ibid, , p,128, 
Heads usually initiate change but their impact, in Watts viev, generally dwindles after about five years and where an 'authoritarian progressive' is in pover he often creates division which outside agencies can exploit. It is usually the head who defines the schools objectives and values and curriculun-- what is taught, and controls internal organisation--who does what, and also organises the tiaetable, and distributes available money--which is the nost common cause of friction, chooses staff and controls aedia comunication. At Countesthorpe all of the sajor policy decisions are based on staff consensus, and student contributions also, and sonetines input from parents and governors. A general meeting or Moot is open to all, including non-teaching staff and students.

A final proposal will be the vork of any hands, a sodification of aany ideas. Once it is ratified though everyone is comitted to making it work, because no one has imposed it from above vithout opportunity to shape it.1

Watts says that he enjoys adainistrative tasks but even these could be delegated, and he spends tventy-five percent of his tiae teaching. The head's influence on committees may be authoritative but not authoritarian, and this authority is a trust that has to be won. For example he can give inforation to which he is privy from local authorities and knowledge of legal obligations. External authorities still contact hiv, for outsiders seen to need one person to represent the school. He is sensitised to all the participants and to outside agencies and feels that "The transaission of pressure is through ay bloodstrean and I feel no guilt about being paid 2

danger money." His metaphor of headship appears to be that of a

1. John Watts, Sharing it Out: the role of the head in participatory Governaent, in The Role of the Head, ed.R.S.Peters, Routledge and Kegan Paul, London 1976, p.131.

2. Ibid., p.133. 
pressure in a yay suggestive of the notion of steady state in systems theory.

At Countesthorpe conflict is resolved by open discussion and this works provided all participants can tolerate conflict, use it to identify issues and make compromises to reach consensus leading to commitment. This requires regular time for talking, and in the event of insoluble conflict then Watts feels he vould have to leave. This time taken for decisionaaking tests one's patience which is one stress of the job. Another is the need to svitch roles to please outsider 5 who still expect to deal with the school as an entity through hiv alone, this factor vill serve he thinks to preserve the extant traditional authoritative odel and even prevent the establishaent of revolving headships. Also he found that there are people including staff vho alnost seem to need an autherity figure to rebel against, For such reasons he believes it vill take a long time for people to accept this concept of participatory adninistration more generally.

That Watts has faith in the systen is obvious and indeed he varns that he has "argued for a spreading of this pover, for sharing it vith teachers before it is taken into the hands of non-educationists," With groving pover in loçal government "Heads vould become accountable direct to councils, and education officers give place to chief executives, civil servants with who knows what notions on education. " Crystal-ball-gazing he sees the schism between heads and teachers as leading to a situation Where they vill both lose pover "that vill be garnered in County Hall where the old autocratic head will then sit in all his remoteness under the new

1. John Watts, Sharing it Dut: the role of the head in participatory Government, in The Role of the Head, ed.R.S.Peters, Routledge and Kegan Paul, London 1976, p.135.

2. Ibid, , p, 135 . 
guise of efficient corporate managenent."

The words of John Watts now seen strangely prophetic as we see education increasingly controlled by econonists. More recently Paul Bredeson of Ohio University asked the students in an educational administration course to identify the aetaphors of adainistration as evidenced in current literature and from observation of five school principals in order to exanine the isplications of these, for:

Although metaphors, like language itself, are atteapts to find a unity of experience and understanding for a field of study, practice -or even an entire culture, the very vords and analogies used--nay linit the viev that one has of phenomena and the vorld.2

Behaviour thus becomes a function of the vords ve use rather than the opposite.

Social systems theory placed importance on ROLE and BIunberg and Greenfield said that "Principals daily face pressures of competing isages 3

about what their role should be," In research on effective schools it

was also found that the "behaviour of the school principal is the single

most important factor supporting high quality educational prograns" and

that "while schools adke a difference in what students learn, principals 4

nake a difference in schools.:

For ten days they shadowed the principals and found that "None of the principals vas radically deviant from the principal's role described in 5

most textbooks on educational adninistration." But they had adapted the

1. John Watts, Sharing it Dut: the role of the head in participatory Government, in The Role of the Head, ed.R.S.Peters, Routledge and Kegan Paul, London 1976,p.136.

2. and 3. Paul V.Bredeson, An Analysis of the Metaphorical Perspectives of School Principals, Educational Adninistration Quarterly, Vol.21, No1, Winter $1985,0.30$.

4. Ibid.,p.31.

5. Ibid, p. 32 . 
The researchers found in the literature a "rich tapestry of aetaphors 1 of the principalship." Historically from the 1880's a functionalist view has dominated. They range fros "principal teacher" to "building administrator 5." Knezevich has described the principalship as "a constellation of positions." Others have emphasized the sanagement and leader functions.

The school principal also has been characterized as a consuanate sanager using Mintzberg's typology as employed by Kuetz and Willover; a combination administrator-manager and educational leader by Roe and Drake; a leader vith technical, huan, and conceptual skills that are practised in five major functional areas--the instructional progran, staff personnel services, student personnel services, financial physical resources, and school community relations--by Lipham and Hooh; an organisational change agent by Sall; a synthesis of applied philosopher, school manager, and behavioural scientist by Wayson; a politician and facilitator by Miklos; and a vide variety of other characterizations including broker, negotiator, gameswan, missionary, social person and theraostatic person still by others. 2

Coombs and Thurston have, says Bredeson, suggested that "øetaphors go beyond

mere theory building in administration and represent crucial links betveen 3

theory and practice." According to Sergiovanni the ajor views of educational administration and their predominant concerns are contained in three generative metaphors; EFFICIENCY (the rational mechanistic), the PERSON (the organic), and the POLIIICAL DECISION MAKING (bargaining).

From the principles of scientific management and the influence of Frederick Tayler and Franklin Bobbit 'The rational mechanistic metaphor of a vell-oiled achine epitonizes the notion of efficiency in education." And Weber's notions of bureaucracy have given us theories of management.

Bredeson says the custodial functions of schools have been and still

1. Paul V.Bredeson, An Analysis of the Metaphorical Perspectives of School Principals, Educational Adginistration Quarterly, Vol.21, Not, Winter 1985, p. 33 .

2. 3. and 4. Ibid.,p.34. 
are doninated by metaphors fron these areas. Fron these ve have inherited perforance objectives, conpetency testing, anagement by objectives, manageaent information systens, and planning, programing and budgeting systeas.

The organic aetaphors generally guide the huanistic principal concerned with grouth and feeling. Bredeson believes that "Getzel's and Guba's 'social systems model' provides a two-dinensional way of combining the concern for efficiency, the nomothetic, with the needs of the individual, 1 the idiographic." This model he favours because of the wix of metaphors it dravs on, such as the eissionary and the gardener, thus conbining care for nurture with purposeful action, though one vonders how psychologically healthy it is to give staff sailey stickers and personal gifts as revards for aiding the principal in his/her vork. This seems redolent of behaviourist applications removed from the classrooss into the staffroons.

The third aetaphor reflects the links of the school with its environaent:

The metaphors in this sense envision the individual and organization as players and actors in a game, bounded by rules, vith divergent stakes and interests in the outcome of decisions that are ade as the "gane "is played. Bargaining and negotiating for solutions that satisfy the competeing demands are the metaphorical milieu of this strand. 2

Among the descriptions these have led to are the the garbage can aodel, and loosely coupled systens of administration. Principals become, amongst other things, ombudsmen, advocates, orchestrators, jugglers and brokers.

This study of principals found that each of then displayed evidence

1. Paul V.Bredeson, An Analysis of the Metaphorical Perspectives of School Principals, Educational Adninistratation Quarterly, Vol.21, Nol, Ninter $1985,0.35$.

2. Ibid.,, 36 . 
of efficiency, huanism and political bargaining. To describe each

principal in terms of one of these three dominant metaphors vould in Bredeson's view be an oversioplification and a distortion of the role of the head in the school context. He reninds us that it wight be sore significant to look at metaphors of purpose "vhich are nuch nore deeply enbedded in the principalship."

Principals brought to their task their own perception of their role as vell as there being a role envisaged by the traditions of a school, comanity expectations and such. How they adapted and set up routines reflected all of these things.

The principal who envisioned the role as that of a chief executive officer carried out the responsibilities froe the aain office and functioned from behind a desk, much like the comon conceptualization of a comand center. The disciplinarian differed in that he involved hinself in almost every aspect of school operations and decision aaking in which school discipline could possibly be an issue, 2

The affective or person-oriented principal kept out of the office. Each one therefore played his part according to his ovn personal and profession nal strengths.

Metaphors in this sphere "reveal a great deal about the the shared cultural associations of the principals as yell as provide a profile of individual creativity and adaptability to the role of principal... [and] each practiced [practised] the craft of the principalship vithin the 3 parameters of three broad eetaphors of purpose." They are: MAINTENANCE, SURVIVAL and VISION, which can be envisaged on a continuum.

1. Paul V.Bredeson, An Analysis of the Metaphorical Perspectives of School Principals, Educational Administration Quarterly, Vol.21, No1, Winter 1985, p. 37 .

2. Ibid.,p.37.

3. Ibid.,p.38. 
Maintenance, that is keeping the school open and running is seen as an ongoing task and a sajor responsibility, Where other people have often defined one of their ajor roles as that of curriculun leadership, but many admitted that in this area they vere aware of their shortconings. The eaphasis on aintenance led also to comennication as a priority often through foraal netvork5. "Communication vas seen as the lubricant to help things run saoothly and to help provide and aaintain a sense of security and a positive situation for learning."

Few of then saw the need for nuch change in their schools except in their perceived need to replace some teachers. "The systea and its continuing operational process were accepted as givens."

Other research attests to the fact that the doainant concern of principals is maintenance activity. The aaintenance metaphor doninates the daily vorktiae and tasks, leading Bredeson to wonder whether principals are thus able to aeet other responsibilities such as external adaptation and goal attainment. The metaphor of survival has severe limitations as he points out:

The emphasis on survival for principals and for the schools in which they operate is one that focuses on meeting imnediate needs and the mustering of the rost vital resources available for continued existence. the inmediacy of crisis-based managenent is characterized by: short range planning, the need for dramatic, often harsh and autocratic, actions; an environeent that is likely to be stressful; educational priorities and time, resources, and energy allocations skewed towards the present; and little attenton to long-range outcomes or to the inplications of activity for the schools and the people in then. 3

Socio-econonic conditions are partly to blame for the prevalence of this

1. Paul V.Bredeson, An Analysis of the Metaphorical Perspectives of School Principals, Educational Adginistrattion Quarterly $y_{1}$ Vol.2l, No1, Winter 1985, p.39.

2. Ibid, p.40.

3. Ibid., p. 42 . 
situation Bredeson believes: "Financial survival vas a pover ful influence on 1 the principal's priorities and activities." This is not hard to believe as we are all faniliar with the cake-stall syndrome which helps to keep our own schools supplied, sonetiaes vith absolute necessities, so it is easy to accept his perception that survival is a key aetaphor in school administration.

At the other end of the continuun is the metaphor of vision although all three are interrelated. One head sav this as her most important task whilst survival mechanisms vere delegated in order for her to concentrate on policy guidelines and fiscal andates.

Broadly conceived vision is the principal's ability to holistically view the present, to reinterpret the aission of the school to all its constituents, and to use imagination and perceptual skills to think beyond accepted notions of what is practical and what is of inaediate application in present situations to speculative ideas and to, preferably, possible futures.2

[Interesting also that the longstanding netaphor of 'mission' is used here] Tasks of this 'visionary' nature took up less than five and one-half per cent of the principal's total nuaber of daily tasks, Yet they saw that one of their ain tasks was to communicate this vision to the school conaunity. Parents vere seen as good if they supported the school but fev heads desired more active participation from then.

Bredeson's findings were "That all five principals shared a comon 3

culturally standar[d]ized inage of the principalship." Role expectations were Jargely set by teachers, administrators, students, parents and professional training institutions all of whom stressed the

1. Paul V.Bredeson, An Analysis of the Metaphorical Perspectives of School Principals, Educational Adginistration Quarterly, Vol.21, No1, Winter $1985, p .39$.

2. Ibid.,p.43.

3. Ibid.,p. 45 . 
dominant maintenance aetaphor. So auch tiae vas spent in this area that vision became iapossible. And nost of then recognized the importance of curriculun involvenent and leadership yet failed to denonstrate this. The principal in the researchers' view "has become the dumping ground for all of the adintenance responsibilities in the school." The role has become complex and "The principalship has becone a catch-all for all of the tasks not accepted by other adainistrators, by teachers or the conanity."

Principals can of course, as Bredeson points out, feel aore comfortable with all their BusY tasks. Sonetianes this is easier than long-range planning which provides no immediate tangible revards. Avareness of this needs to be built into training for adainistrators.

In conclusion Bredeson finds that "The metaphor of vision offers the 3

most hope of the principalship, but it is al so the nost problenatic."

Each head, in this study, vas frustrated by the frenetic pace of their vork. The role of the principal has becose "stagnant" and a hotchpotch of jobs:

The challenge for principals is to examine their daily routines, their priorities, and their resources and see how they aight best function through being knowledgeable of the past, remaining vell grounded in the present, and continually looking to the future, 4

Young children's perceptions of principals are equally interesting. In a study done in Nev Zealand Anne Saith found that the ajority viev of principals is that they are people vho punish, and it appears that children see the principal as quite a punitive figure. There vere tvice as many

1. Paul V.Bredeson, An Analysis of the Metaphorical Perspectives of School Principals, Educational Adninistration Quarterly, Vol.21, No1, Ninter 1985, p. 46 .

2. Ibid., p. 46.

3. Ibid, , p. 47 .

4. Ibid., p. 48 . 
ansvers indicating the principal vas a punisher than there vere indicating that he or she was a revarder. The principal was certainly seen as a poverful figure tho has control. Sose thought one had to pay to be a principal and others thought you had to dress up in principal's clothes. These inages do not seen far removed from the forbidding and theatrical figures Protherough portrayed even though Colgate believes that the authoritarian figurehead is obsolete.

The same principals vieved theaselves very differently. They sav theaselves as revarders and as liason people betueen the school and the conounity, male heads focussing on their position as boss and the women stressing organisation. Smith suggests that children judge principals and teachers by surface appearance or by reputation. She says that Rogers in another study had sinilar findings.

Peter din a New Zealand secondary school headnaster believes that in the selection of principals physical strength and stentorian voice are still qualities some people look for in Ieaders. The stereotype prevails. His belief is that the demise of corporal punishoent vill eventually eradicate 2

this invalid conception of the ideal head.

My oun viev is that the maintenance of any school can be divided roughly into two ain areas, the building and ITS maintenance and the aajntenance of the school as an educational or learning centre. I can see no rationale for expecting an educational leader to concern hiaself with the physical aspects of the school or any function that is not more directly involved with the teaching and learning that is presumed to go on and is

1. Anne B. Smith, Children's Ideas About Teachers and Principals, SET No.2,1985,N.Z.G.E.R., Nev Zeal and.

2. Peter Quin, Authority Figures, Ie Ava-Itii, Porirua, Nev Zeal and, June 10, 1988. 
the natural purpose of its existence. In every school there is a need for two functionaries, one dealing vith the building per se as a place where the other work can go on. In this respect al nost every school has the sane requireaents so this should not be difficult to organise and as this is an drea of high cost it might even be centralized and run to a strictly mechanistic model, as a building is, in a sense a achine for living and vorking in. The 'factory' model still has some uses, for managenent of things, but not people.

The multiple roles of heads are often compared to managers in other spheres than education. Henry Mintzberg says that thare are key roles in any management position. The overall impression his studies gave vas that managers are not the reflective, systematic planners one night suppose. They in fact work at a relentless pace, their activities characterized by brevity, and discontinuity. They are strongly oriented to action and actually dislike reflective activities. And unlike the headmaster in fiction these anagers "perfora a number of regular duties, including ritual and ceremony, negotiations and processing of 'soft' (informally acquired, unofficial) information that links the organization vith its environment." Contrary to folk visdom managers did not need a formal information system, they in fact favoured the verbal media especially telephone calls and meetings. The job is complex and forms a gestalt even though patterns are hard to detect. The strategic data bank of the organization is therefore not in the menory of its computers but in the ainds of its managers and the best of then vill use the bast of the management nodels used elewhere.

1. Henry Mintzberg, The Manager's Job: Folklore and Fact, set, No 1, 1985, N.Z.C.E.R. reprint from Harvard Business Reviev. 
Having looked at sone of the practices and principles of heads it is interesting to compare these with a recent vork on theories of educational management by Tony Bush who believes that saking relevant theory available to practitioners can promote a greater understanding of the wanagerial problems they neet daily. He stresses the inportance of purposes or goals for anagers of educational organisations and considers the relationship betveen theory and practice. Using a building metaphor to explain that theories and concepts provide the franevork for managerial decision-making he presents for consideration five ajor aodels of educational aanagenent, FORMAL models which emphasise hierarchical structure, rational processes and official authority--DEMOCRATIC, which stress authority of expertise, shared values and objectives and consensus decision-aaking--POLITICAL models vith competing interests--SUBJECTIVE models open to individual interpretation and AMBIGUITY aodels which eaphasize the unpredictable nature of organisations, their lack of clear goals and the fluid nature of participation in decision-aaking. The variety of approaches reflects the adny disciplines on which educational anagement dravs and an examination of these models vill undoubtedly reveal the metaphors on which they are partly based.

Bush finds Glatter's definition useful. It states that educational management is concerned vith;

...the internal operation of educational institutions and also with their relationships vith their environaents, that is, the conaunities in which they are set and with the governing bodies to which they are formally responsible. 1

Defining goals and purposes which are considered an important part of management is ade difficult by the vagueness of stated aims of education.

1. Tony Bush, Thenories of Eduscational Management, Harper and Rov, London, 1986, p.2. 
The individuals involved in schools do not necessarily share the same purposes but the principal is obviously in a strong position to assert his. An examination of the language used by administrators has already revealed sone of the aetaphors which deternine their policies. A head is caught between the bureaucratic and professional deands of his tor her I role.

Bush believes that the grouth of the subject of educational adainistration reflects the viev that training in manageaent is iaportant, hovever he finds that practitioners in school are vary of theory and there is a great variety of styles in decision making. He believes in the use of theory for as Bolman and Deal have said "We have to develop patterns and franes in order to make sense of the conplexities of everyday life," Reliance on one's ovn experience ignores the value of other people's experience and a change of context aay require a change of style.

Bush finds no one doninant theory in use, though there are three characteristics. They tend to be noraative, selective and often based on observation of practice. Theories which have cone originally from industry or comerce often undergo different labelling in their new applications. As Cuthbert says: "The study of management in education is an eclectic pursuit. Models have been borroved fron a vide range of disciplines..." Bush has distilled these into five models. In each one Bush says the school and the role of the head are perceived differently, as Mangan expresses it:

Like it or not we do not see a REAL world that is truly here; each of us INTERPRETS his ENVIRONHENT and copes with it by fitting it into meaningful patterns.3

1. Tony Bush, Theories of Educational Management, Harper and Rov, London, $1986, \mathrm{p} .14$.

2. Ibid.,p.18.

3. Ibid.,p.20. 
Patterns once again. It does begin to seen that whatever area of huaan life one examines, patterns are important to recognise. Parts of the pattern will be discernible from the language used and the metaphors therein.

FORMAL models tend to treat organisations as systeas i.e. a complex of interdependent interacting units. The organisation is often hierarchical which can be demonstrated by charts showing the pattern of foral relationships between individuals and the institution--the inforaal are not accounted for. Which has Ied Renshav to comment that "most schools reaain static, hierarchical and paternalistic in character. Internally they retain a tight authority structure." Schools as has already been demonstrated reflect the patriarchal nature of society. In formal models schools are seen as GOAL-SEEKING organisations. The head especially is seen ds having a particular ain for his school's development. Formal models represent AUTHORITY as a product of position in the HIERARCHY. There is an emphasis on ACCOUNTABILITY--usually [in U.K.] to the local education authority and to the director of education. The head has RESPONSIBILITY for everyone in his school. All of these factors suggest an authoritarian, fairly rigid structure of devoluted mainly sale pover. Such an organisation we wight suspect could lack appreciation of the individual, of autonomy, of the unusual or the unexpected. Like other systens aeant to produce goods of a regular standard to a 5et procedure there is a tendency for the 'person' to be lost or alienated by the sheer efficiency of the organisation. If the 'status quo' is satisfactory it is perpetuated and change is unlikely. For ad adels therefore tend to enclose the school and to close it off from

1. Metaphors are emphasised with bold type in this section on Bush.

2. Tony Bush, Theories of Educational Managenent, Harper and Row, London, 1986, p. 23. 
the environaent. Yet as Talcott Parsons asserts the school is alvays part of a vider systen "it is never vholly independent." Structures can become so rigid they are difficult to change. Such models stress coherence and identity vith the organisation is encouraged. The key concepts appear to be responsibility, hierarchy, accountabillity, authority and goals,

STRUCTURAL aodels are essentially sivilar to formal nodels. Becher and Kogan have recognized the difficulty of introducing change into such models e.g. changes in curriculum--they say that: "Many changes, including those generated from vithin, fail because they are unable to acconmodate to existing structural constraints." Much depends they believe on the nature of relationships betven the central authorities, the institution, the basic units of the systen and the individuals. It has been pointed out that even where structures are not explicitly labelled differential salary and status distinguishes the PECKING ORDER of an institution. The style of organisation aay also be perceived by staff or head as being denocratic when the structures aake it definitely HIERARCHICAL. As Bush says "Structures remain poverful influences on the nature and direction of developoent vithin institutions," or what Clark refers to as "the heavy hand of history."

The advocates of SYSTEM nodels emphasize the UNITY and integrity of the organisation and focus on the interaction betuen its component parts for "QUALITY CONTROL and maximus effectiveness in a large educational organisation are possible only by the use of the systems approach"... say

1. Tony Bush, Theories of Educational Management, Harper and Row, London, 1986, p. 44.

2. Ibid., p. 25.

3. Ibid.,p.28. 
1

Lauder and Myers, but one wonders what control a school vould have over

e.g. Adrian Mole's acne, his enotional development, his relationship vith his fanily his girl friend Pandora and his neighbours--or vhether in fact school has auch control over quality excepting in regulating what clothes to vear, times of attendance and behaviour in school time to some degree. We can all testify to the fact that thankfully 'quality' is a factor schools have had little control over 50 far.

The dangers of a very successful systems approach seens to be to endow the institution with a 'character' as if it were an entity in itself. We see this in the 'old school' affection and the 'alna eater' concept, the exhortations to think of the school's name and reputation as something one is personally responsible for. Greenfield has noted this tendency to teify organisations. It is assumed in the systems approach that cembers share sutual goals. One consequence of this is that such organisations close themselves off from external contact and criticisa. More open schools cultivate relationships vith their environment e.g. parents, neighbourhood etc. Community schools are more often 'open' and colleges which forge links with work places. Highly selective schools and universities are often 'closed'.

Hoyle criticizes the assunptions of systen models

Schools are certainly not organisations consisting of carefully articulated parts functioning harnoniously in the pursuit of agreed objectives. They are characterized by conflict, alintegration and the pursuit of individual and group interests. Nevertheless a certain degree of systematic integration is necesary for their effective functioning. 2

He might have also added that they often spend a good deal of energy on

1. Tony Bush, Theoriges of Educational Management, Harper and Row, London, 1986, p. 29 .

2. Ibid.,p.31. 
promoting the idea that they are successful.

BUREAUCRATIC nodels as praised by Weber for their EFFICIENCY stress the importance of HIERARCHICAL authority structures. Such organisatios are al 50 60AL-ORIENTED with power and decision aking flowing down from the apex of a PYRAMID. Nork is specialised and governed by RULES and REgULATIONS and advancement is on MERIT. Robots would do vell in such a systen which does not eaphasise personal relationships. It has been suggested by critics of this type of organisation that it encourages COMPETITION.

RATIONAL nodels emphasize managerial PROCESSES and the focus is on DECISION-MAKING. The manager rationally and systematically analyses situations, identifies and evaluates possible action. As Cuthbert says "The aanagenent process is depicted as a atter of systematic, informed, rational decision aking." They also depend on agreed ORgANISATIONAL OBJECTIVES and HIERARCHICAL STRUCTURES. Even though such models may be extreaely difficult to put into practice "Rational perspectives are the deminant normative aodels despite their practical liaitations."

HIERARCHICAL models stress VERTICAL RELATIONSHIPS, vertical comaunication patterns and ACCOUNTABILITY of leaders who must take responsibility for the work of their subordinates also. One factor which encourages the dominance of hads in such structures is their defined LEGAL AUTHORITY. As Bush expresses it:

In education several factors tend to support this characteristic of unidiansional leadership. Official bodies and individuals behave as if the head or principal is the fount of all knovledge and

1. Tony Bush, Theories of Educational Managenent, Harper and Row, London, 1986, p.33.

2. Ibid., , 8.35 . 
authority. The Departaent of Education and Science (DES) model articles of school managenent are unequivocal in stating that the headteacher shall control the internal organisation, wanageeent and discipline of the school'.1

Yet the head's difficulty in aintaining this role novadays has been videly testified. The literature of education tends to describe a nor of behaviour in schools which is not alvays a reality, They ady describe the organisation as it has been set up without reference to how it vorks in reality. As for specified goals, as Bush says "It is often difficult to ascertain the goals of educational institutions. Few schools have fortal yritten statements of their objectives such as exist, for example in 2

University Charters." [This vill change in Nev Zealand if and when the 3

Picot report is adopted and ioplemented] Whether goals, when articulated are ever ast is hard to judge. To assume that all behaviour in an organisation is rational is a aisconception in human teras for

"Professional judgment is based as auch on intuition and background of the individual as on rational processes conditioned by the rule book."

Shaw, has gone 50 far as to describe reality by drawing an analogy with guerilla varfare tactics as opposed to guided aissiles. Theorists also anthropomorphize institutions, speaking of schools as if they were human entities capable of articulating objectives. A fornal vieu of schools with its emphasis on authoritative leadership tends to assume that policy flows fron the top doun, as it aight do in a military organisation--

1. Tony Bush, Theories of Educational Managenent, Harper and Row, London, 1986, p.39.

2. Ibid., p. 40 .

3. Adninistering for Excellence, Report of the task force to review educational administration, Nev leal and, 1988.

4. and 5. Bush, p.41. 
but in reality schools have a variety of people with expertise, authority and ability, to ake their vishes heard. This is in fact one area of tension and sometimes stress among professionals who do not like being criticized by anyone they deen less competent than thenselves. As Bush says "authority of expertise...aay come into conflict with positional 1 authority." Foraal nodels also take little notice of change. Speed of change may preclude such things as rationality 50 they are only " partial descriptions of organisation and managenent in education.

All theories tend to be nornative says Bush but denocratic aodels are particularly so and reflect the prescriptive viev that anagement OUGHT to be based on agreement. Professional members have an authority deriving from their specialized expertise rather than any official authority vested in them as in fornal nodels. Democratic nodels assune a RIGHT to SHARED DECISION MAKING. Consensus is really compromise reached by force of ARGUMENT and RATIONALISATION rather than by voting.

DEMOCRATIC models assume that organisations deteraine policy and make decisions through a process of DISCUSSION leading to CONSENSUS. Power is shared anong sone or all members of the organization who are thought to have a mutual understanding about the objectives of the institution. 3

This style according to Bush originated with the Collegial model in universities and an extensive comaittee system but is limited in some universities by franchise which makes it someuhat elitist. Polytechnical colleges have al so largely adopted this systen. Problens occur where 'There is a dichotomy in colleges between academic policy which is generally the

1. Tony Bush, Theories of Educational Management, Harper and Row, London, 1986, p. 43 .

2. Ibid, $, 0,45$,

3. Ibid, , p.4B, 
responsibility of the 'denocratic' acadenic board and resource management which is usually the preserve of the principal and heads of departaent."

This creates a tension between participation and accountability,

In schools teachers generally vant to participate on decision making and it is generally considered that the quality of decision saking is inproved by their participation. Job satisfaction is increased which leads to greater commitment. Participation is also important says Bush because staff usually have to inplement any changes in policy. Whicher has described six styles of decision making:

1. head controls decision aking and announces these to staff whe are expected to comply.

2. same as above but head gives reasons.

3. Head begins process and leave staff to discuss before final decision.

4. Head invites colleagues to join the early stages but then ake final decision.

5. Staff involved at all stages but head defines criteria determining choice of solution.

6. The head becomes an equal aember of a corporate decision aaking body.

All of the above can be seen in the styles of the heads previously described. The last is the only truly democratic model and is seen at Countesthorpe where the first head of the college said;

The Moot establishes its own constitution, procedures and chairmanship.

It neats as necessary, about once in six veeks. Other decision making groups are responsible directly or indirectly to the Moot and any individual ady challenge their decisions through the Moot.2

At Countesthorpe Bush says this is a normative approach because it reflects

1. Tony Bush, Theoríes of Educational Managenent, Harper and Row, London, 1986, p. 52 .

2. Ibid.,p.55. 
Watt's vision that participation is the most appropriate vay to deteraine policy. Only one further step, that is involving the outside comounity, could be added here and this is catered for in the Picot recommendations.

Where a head chooses his own staff and vhere the staff is fairly homogenous consensus is more likely to occur. Conflict breaks down the democratic model. One difficulty with such nodels is that it is no easy task to establish responsibility for organisational policy. Responsibility becomes diffused and as has been mentioned previously accountability is aore difficult to pinpoint. External groups find this a particular difficulty. In the traditional structures the head is the first person outsiders look to, he represents the school to them. But as Bush says "Heroic aodels of leadership are inappropriate when influence and power are widely distributed within the institution."

The democratic principal according to Bush is almost alvays a successful practitioner responsive to the needs and vishes of colleagues and uses formal and informal means to test and elaborate policy initiatives. Authority in these situations cones from expertise rather than officially vested authority, Such a head's control is more subtle and "typified as the FACILITATOR of an essentially participative internal process." The role is described as 'pivotal' for it is still that of a leader constantly negotiating for his or her position. The nost favourable aspect of such leadership is that he/she has as it were a finger on the pulse of the school and is not removed from even its most ninor activities by virtue

1. Tony Bush, Theories of Educational Management, Harper and Row, London, 1986, p. 60 .

2. Ibid.,p.61. 
of office, Such models says Bush are highly norwative and idealistic. It is also a slow process and demands adequate constant participation, for enthusias and interest can dissipate anong participants. Decisions ady also be made vithout adequate understanding and such models ay underestimate conflict vithin education--conflict uhich ay be long and dravn out in the battle to win consensus. It is feared also that "The ideal of deacracy may succumb to the reality of bureaucratice pover " and experts vill hold svay.

Iaportant questions of accountability also "lead inevitably to the conclusion that in educational institutions there cannot be wore than a conditional denocracy." Critics believe that it is an unrealistic ideal and that the denocratic aodel veils the persistent power of headship and the existence of inevitable conflict. Baldridge has even said "Collegial management is probably dying--if it ever existed at all..."

In POLITICAL models decision making is a bargaining process in pursuit of the self interest of groups. Conflict is a natural part of this process and pover is the prerogative not of formal leaders but of dominant groups such as departnents. We usually regard central and local government and political parties as being concerned vith politics and as Bush says "It is useful to loosen this close identity betveen government and politics before seeking to apply political metaphors to educational 3

institutions." He therefore recognizes that these 'labels' are netaphors for they indicate styles of administration approxinating to those of

1. Tony Bush, Theories of Educcational Management, Harper and Row, London, 1986, p. 64 ,

2. Ibid.,p.65.

3.Ibid, p.68. 
government. Some have described such as 'micro-politics.'

In forsal models it is the head vho usually introduces outside influences, but in political models groups are swayed by external forces and factors which they introduce into the systen. Resource allocation is alvays crucially iaportant but in tiaes of scarcity the pressures created aggravate the conflicting denands for them. Baldridge in sunary says;

The broad outline of the political systen looks like this: a complex social structure generates multiple pressures, many fores of pover and pressure iapinge on the decision akers, a legislative stage translates these pressures into policy, and a policy execution phase finally generates feedback in the for of nev conflicts.l

A good example of this kind of conflict and pressure occured in recent years over falling rolls in the secondary schools in Nev lealand, when adainistrators vere forced to consider staff cuts which had to be discussed and negotiated vith staff.

Five different for as of power are described by Bush; that deriving fron official position; specialist expertise; personal pover; and that which comes from having control of the revards, which creates coercive pover, or the ability to enforce compliance which is more akin to authority than influence. Heads can wield all or nost of these and therefore "have the capacity to deteraine to a considerable extent the behaviour of their 2

colleagues." Each compliance reinforces this pover by a submission to the power of that leader.

A never and aore equal concept is that of relationship exchange. Bush believes the concept of EXCHANGE is a profitable vay of examining relationships in education. The head exchanges the 'goods' he has to

1. Tony Bush, Theories of Educational Management, Harper and Row, London, $1986, p .76$.

2. Ibid.,p.78. 
offer in exchange for cooperation. [ this concept sounds like bribery or barter] Both parties profit. Teachers may negotiate exchanges thenselves as in alliances or coalitions. Bush obviously considers this theory a potentially useful one, and Baldridge is the leading uriter on this.

Political aodels focus more on goals of sub units than on the total organisation. Critics say that political models focus on conflict and aanipulation and policy formulation rather than iaplementation, considering group interests wore than the institution as a whole, but it is obvious that the political aodel is often practised if not in toto then vithin institutions that profess to be something different.

SUBJECTIVE nodels clain to consider the individual: "Organisations are regarded as complex notions which reflect the nunerous meanings and perceptions of all the people in them. I have used this notion myself in speaking of a school's character. So in subjective terms schools are social constructions. Greenfield, says Bush, has been the main promotet of this viev of schools which counterbalances the doninant aodel from systems theory which has been criticized for its focus on the institution as a concrete reality,

Where individuals compete or conflict then even the subjective aodel san airror political theories, but conflict is not a nora. In these models STRUCTURE is a product of HUMAN INTERACTION and organisation models are seen as fictions. There is wuch truth in this, that designing a chart of positions is no guarantee that the organisation vill in fact keep to the proposed nodel. Behaviour, process and individual purposes are considered rather than institutional goals. The only study of a school based on this

1. Tony Bush, Theories of Educational Management, Harper and Row, London, 1986, p. 89. 
subjective or PHENOMENOLOGICAL approach which Bush knows is that done on Rivendell school by Best et al. In such oodels the school is not a monolithic organisation but each teacher has an interpretation of the school. Structure is not inposed but created by the inter action of the participants. Little attention is paid to the relations between the organisation and the environment. Subjective aodels are priarily prescriptive and do not he thinks present a clear framevork for analysis. It seess to that while an organisation could be exanined in terns of any of the other nodels this subjective nodel could also be applied because it vould focus on aspects aissed by the others.

Greenfield's theory has apparently been the subject of much criticisa. As Bush says "The focus on individual meanings offers an additional diaension in our atteapts to understand schools and colleges but, on its own, subjective theory fails to explain processes and behaviour in education." Hills has said that "when one examines organisations one noticeable feature 2

is their sinilarity and high degree of order" and Bush says that teachers "emanate from a comnon professional background which often results 3 in shared meanings and purposes." So even the subjective nodel vith its emphasis on individual differences does not change this, Subjective models counterbalance the emphasis on structure, routine and the depersonalising effects which sone models appear to have. Both types of models if used in conjunction give an overview of institutions and an understanding of the behaviour of individuals within them.

AMBIGUITY models derive fro the notion that abiguity is a major

1. Tony Bush, Theories of Educational Management, Harper and Row, London, 1986, p. 103.

2. and 3, Ibid, , p.104. 
feature of decision making in aost public and educational organisations. Goals are not alvays clear. There is also a degree of uncertainty as to the outcomes of processes, and effects on individuals. The aetaphor LOOSECOUPLING has been used in this model to describe the tenuous links between groups in such organisations, that is to say there is a degree of flexibility in the vorkings of each part of the organisation. Structures in large organisations are complex and often overlapping so "charts conceal wore than they reveal about the patterns of relationships in institutions." Aabiguity models fit vith professional autonony in such things as relationships vith clients and in what is called in this aodel FLUID PARTICIPATION in decision making. Schools are subject to many influences in their environments and Iong term planning and decision making are affected. Decisions are not alvays planned but wade on ad ad hoc basis to suit conditions and needs. Anbiguity oodels stress advantage in decentralisation. The loose coupling of units in such an organisation is seen as a positive aspect: "A loosely-coupled systen can isolate its trouble spots and prevent the trouble from spreading." ${ }^{2}$ Cohen and March in 1974 proposed a GARBAGE CAN wodel where they sau decision making in schools as fundamentally anbiguous, its technology unclear and participation fluid. They distinguished three choices in decision making, by OUERSIGHT, FLIGHT, or RESOLUTION. Bush says "The garbage can model has a clear application to educational institutions where there are wany participants yith ready- ade solutions to apply to different probleas." All other theories presune that goals

1. Tony Bush, Theories of Educational Managenent, Harper and Rov, London, 1986, p.111.

2. Ibid.,p.113.

3. Ibid.,p.116. 
are clear, whereas anbiguity nodels stress their problematic nature and it is believed that in the process of decision making goals are discovered. Anbiguity aodels exist in an abiguous vorld where events and circuastances are alvays changing, and ensure that management in education is a hazardous and changeable activity, influenced by ore than arket forces. There is anbiguity of purpose, power, experience and success. In these circumstances leadership can be participative or avoid direct involvenent in policy making and concentrate on structural and personal natters.

If heads choose like-aindad staff they avoid probleas in following their chosen model. In anbiguity nodels leaders are said to be primarily catalysts, negotiating rather than comanding. Bush agrees that most schools have anbiguous features. "So anbiguity perspectives can be regarded prinarily as analytical or descriptive approaches rather than normative theories. They clais to mirror reality rather than suggesting that organisations SHOULD operate as anarchies." The degree of unpredictability is exaggerated. Predictablity is dependent largely on stability--so during tiase of change the ambiguity nodel flourishes. Such models offer little guidance to leaders-- and proponents of such theories as the garbage can oodel admit this but their theory had not been fully explored at this point in time [Bush 1976] What this model, which Baldridge has called, "organised anarchy" does, is add another dimension to the other more usually favoured oodels

Bush calls his five aodels vindows or different ways of looking at educational institutions. Taken together they give a picture of

1. Tony Bush, Theories of Eductational Managenent, Harper and Rov, London, 1986, p. 122.

2. Ibid.,p.124. 
administration in UK schools at least. One sodel may predoninate in a particular school but any one of the others may also be reflected there. Influential factors Bush believes vill be; the size of the school, the organisational structure, the time devoted to manament and availability of resources. The rate and nature of change is al so a pover ful influence. Not one or all of these gives a complete picture of educational adainistration as Bush agrees. Some, such as Ellstroa, have clained that it is possible to use all of then to appraise organisations where "the models are vieved as coapatible, rather than as autually exclusive alternatives." This I believe is possible, for each model is not only a view of the school but a way of seeing on the part of the researcher 5. If you look at a school through only one vindow you vil only see part of it. A school evolves and may consciously or not adopt one or other of the sodels at different tiaes in its history. What Bush calls windows wight equally well be described as metaphors, words such as democracy, bureaucracy, political, garbage etc. None of these can be taken literally and in no two situations vill the terms have precisely the same meaning. They are called models which as Black has shoun are a type of metaphor, a vay of perceiving. They help to describe and structure how reality is perceived by using something vith which ve are already familiar to illuminate or help structure a neu perception. Fornal nodels for instance have any of the features associated with military organisations but this metaphor vould probably have little appeal in educational circles whereas models fron business manageaent may seen innocuous enough until their implications are fully explored.

1. Tony Bush, Iheories of Educational Managenent, Harper and Row, London, 1986, p. 133. 
Gareth Morgan is avare that aetaphors construct our vorld for us as he closely exanines the inages that pervade organizations. Effective managers he says are skilled in the art of "reading" sittuations, and it is metaphors that lead us to see and understand organizations in distinctive yet partial ways:

Metaphor is often just regarded as a device for embellishing discourse, but its significance is much greater than this. For the use of metaphor implies A WAY OF THINKING and A WAY OF SEEING that pervade how we understand our vorld generally. For example, research in a vide variety of fields has demonstrated that metaphor exerts a forative influence on science, on our language and on how ve think, as vell as on how ve express ourselves on a day-to-day basis.1

In 'reading' organizational life there is always, he says, some theory being applied. These theories are all based on metaphors "Many of our taken-for -granted ideas about organization are metaphorical, even though we nay not 2 recognize then as such."

The main aetaphors he examines include organisations as; mechanisas, organisos, cultures, brains, political structures, psychic 'prisons', states of flux and transformation, for:

By using different wetaphors to understand the coaplex and paradoxical character of organizational life, ve are able to manage and design organizations in vays that ve ady not have thought possible before. 3

It is not difficult to see the relationship between his metaphors of business organizations and those of education.

Organizations that are designed and run in a mechanistic fashion are usually bureaucracies says Morgan and nost are bureaucratized to some degree. The influences can be traced back to the military and he cites Frederick the Great of Prussia 1740-1786 who had a vision of a mechanized

1. Gareth Morgan, Inages of Organization, Sage publication5, California, 1986, p. 12

2. and 3. Ibid.,p.13. 
army which he shaped fron a mob, modelling it on Roman lines introducing ranks and uniforas, standardized regulations, increased specialization of tasks, the use of standardized equipment, the creation of a coemand language, and systematic training which involved aray drill. Men were taught to fear the officers wore than the eneay. He can see parallels here vith schools; uniforms, hierarchical levels of authority, school rules and discipline all being traditional facts of school life and as we have seen from the traditional inages of headmaster he vas usually a figure to be feared, Nevell has said that "School systems generally have adopted a line-andstaff type of organisation. This type of organization vas taken from the military service and business, and has served the needs of traditional organizations." The mechanistic model persisted for good reasons;

Mechanistic approaches to organization have proved incredibly popular, partly because of their efficiency in the performance of certain tasks, but also because of their ability to reinforce and sustain particular patterns of power and control. The wachine metaphor has particular appeal for individuals and groups who wish to exercise a close control over people and their activities... 2

Charles Babbage advocated a scientific approach to organisation and management eaphasizing the iaportance of planning and appropriate division of labour. Morgan lists the characteristics of the machine metaphor; goals and objectives are set and ained for, everything organized rationally and efficiently, every detail specified and every job detailed, It is largely a matter of planning and control.

Adan 5aith praised the division of labour in his Health of nations in 1776, and Max Meber vith his definition of bureaucracy noted that

1. Clarence A. Newell, Hunan Behavior in Educational Adninistration, Prentice-Hall, New Jer sey, 1978, p,119

2. Gareth Morgan, ICalifornia, 1986, p.38. 
bureaucratic form and ecchanisation of industry vere comparative and he vas interested in the social consequences of this. Managenent theorists and practitioners such as Frenchnan Henri Fayol, Aaerican F.H. Mooney and Col. Lyndall Urvick of Britain vere all interested in problems of management which vas seen as a process of planning, organization, comand, coordination and control, and their theories becane known by various acronyas such as $M B O$ and PPBS.

Frederick Taylor an American engineer pioneeered what is now known as scientific aanageaent which advocated time and sotion studies, detailed and winute observation and organisation. Both industrial production and of fice vork vere influenced by this, but these methods although a groving trend, produced huaan problems for humans are not robots. Others in this vein vere Frank and Lillian Gilbreth.

Willian Taylor quotes the first director of the London Institute of Education who said "Unless the machine can be stopped its use for the 1

educator is gone." And Taylor also says that to conceive of human behaviour in terms of mechanisas is "one of the oldest conceits of our language and 2 thought." However these ideas do not translate easily into the educational scene;

...an interpretation of quality control dravn from industrial practice (those techniques of inspection based on sanpliag methods) is of only very limited application to the determination of quality in non-marketed goods as 'education.' There are problems defining quality. The use of the vord 'control' iaplies a pattern of relationships that bears little relationship to the human reality of institutional and systeas management. The production metaphor suggests a degree of precision in the process of inspection that we know cannot be achieved in educational settings.... The inages invoked by quality control invite unhelpful conparisons vith processes that

1. Willian Tayl or, Metaghors of Education, Heinemann, London, 1984, p.9.

2. Ibid.,p.9. 
have little to do with education, and lend a superficial glanour to bureaucratic values. 1

One wight iagine that these iages vould by now be outdated but in fact they are still giving cause for concern to those interested in education in the fullest sense of the tern and not aerely as training. The current problem is that any people do see education as a marketable conmodity and seek to inpose the language of business onto education so that there is now a preoccupation vith accountability, quality control and perfornance indicators.

Henri fayol in France focussed on middle management and to him poor methods vere the result of a lack of theory. His principles of adainistration composed five eleaents plan, organize, coamand, coordinate, control, but he also emphasized flexibility and a sense of proportion. Fayol believed that training for administration could begin early. He said that "it can and should be acquired in the same vay as technical ability, first at school, later in the workshop."

Roberts Owens says that in 1887 "Hoodrow Wilson was the catalyst Who crystalized early thinking about the professionalization of 3

administration." He stressed the inportance of the search for principles and considered it a fit subject for university study. By the tine of Fayol and Taylor says Ovens the Western vorld vas beconing an "organizational society". Life vas becouing more complicated, there vas increasing conflict, labour unrest, revolution, and the rise of comaunisn. In the nev urban

1. William Taylor, Metaghors of Educatition, Heinemann, London, 1984, pp.14-15.

2. Robert 6. Ovens, Organizational Behayiour in Schools, PrenticeHall, New Jer sey, 1970, p.6.

3. Ibid.,p.4. 
industrial society Max Weber sav hope in bureaucracy as an ideal forn of organization in ideal circumstances. Dwens assigns Taylor, Fayol and Heber to the era of scientific aanagement between approxiately 1910-1935. Luther Gulick and Lyndall Urvick urote an influential book in 1937 which promoted the ideas of; line and staff, span of control, unity of coasand, and delegation of responsibility.

Ovens calls the next period the Huaan Relations sovenent from 19351950, which spavned the concepts of; aorale, group dynanics, democratic 1 supervision and personnel relations. By 1938 Chester Barnard had written his influential book on The Eunctions of the Exectutive. The newer style of administraton was based on scientific enquiry involving psychologists, sociologists and political scientists.

Another popular aetaphor of organisation says Morgan is that which considers it an organisa, and grev fron the frustrations and probleas associated with the aechanistic model. It focusses on 'needs' and environaental relations. We are encouraged to understand how organizations are born, grow, develop, decline and die, and how they are able to adapt to the changing environaents. We look also at relations between species, and the evolutionary patterns found in the interorganizational ecology. " Where organisation had previously been seen as a technical problem now it was concerned about social needs and how these affected vork perforeance. The recognition of needs such as those outlined by Abraham Maslow began to be taken into consideration. Beginning vith the nov vell known studies at the Western Electric Company in Chicago under Elton Mayo, work motivation was

1. Robert 6. Owens, Organizational Behayiour in Schools, PrenticeHa11, New Jersey, 1970, pp.6-7.

2. Gareth Morgan, Inages of Organnization, Sage Publications, Cali fornia, 1986, p.14. 
explored and psychologists became interested in how work could be structured to nodify systems in order to create motivation. Human and technical needs began to be seen as interdependent.

The organism metaphor has strengths and linitations says Morgan. There is an enphasis on understanding relations between organizations and their environaent and a perception that iaprovement can come through attention to 'needs.' It also realises that internal balance is necessary and that there exists a range of options. It allows for innovation and has contributed to the theory and practice of organizational development especially through the contingency approach, that is adaptgation to the environaent. It focusses on 'ecology' and interorganizational relations but as he reminds us "Sonetimes it is said that a vay of seeing is a way of 1 not seeing." One linitation is that we are led to see organisations in a way that is too concrate "Organizations are very much products of visions, ideas, norms, and beliefs, so that their shape and structure is much wore fragile and tentative than the material structure of an organism..... [and]... they depend upon the creative actions of human beings" ${ }^{2}$ Organizations, unlike organisas, also have a choice as to whether they wish to compete or to collaborate. They are not alvays unified and there nay be schisas and conflict, so the emphasis on unity aay be a veakness. There is also the danger says Morgan that the aetaphor may become an ideology, but one yould inagine that this could happen to any aetaphor.

The population-ecology view of organization in ef fect develops an equivalent ideology for modern times, holding up a nirror to the organizational vorld and suggesting that the viev ve see reflects a lav of nature. In effect, natural lav is invoked to legitimize

1. Gareth Morgan, Ingages of Organization, Sage Publications, Cali fornia, 1986, p. 73.

2. Ibid,, 0.74 , 
the organisation of society."

The danger in this is that ve fail to see that humans have pover to make choices and influence their vorld.

The organism metaphor recognizes relationship with the environment on which it is dependent. Systems theory took the living organism as a model of how organizations vork, as Morgan says "Early systems theory thus developed as a biological metaphor in disguise, ${ }^{2}$ Where the mechanical nodel sav an organisation or institution as self-contained just as a machine can be, the syteas approach conceives of open as vell as closed systens. We can see from earlier descriptions of schools that some appear closed of $f$ fros their environaents leading a singular life of their own, a ainiature world within the vorld, Some exclusive and very traditional educational institutions still cultivate such exclusivity and independence.

Taylor refers us to Davies and his criticisn of the systems approach:

It may be useful to conceptualise the vhole complex of educational institutions as comprising a 'systen', so long as ve do not allow the neatness and simplicity of the aodel to become reality. Perhaps all educational institutions display certain 'essential features'... The point is that this whole apparatus of terms used to display relationships, fit, and order obscures certain sorts of issues by sharpening our awareness of other 5.3

So he thinks ve should be fairly sceptical about systens theory. Bertalanffy himself said that the theory could end up in meaningless analogies, for instance if one considered the state an organisa then the individual could become subsumed within it like an unimportant worker in a

1. Gareth Morgan, Images of Organizzation, Sage Publications, California, 1986, p. 76 .

2. Ibid,po.45.

3. Willian Taylor, The head as manager: some criticisas, inThe Role of the Head, Routledge and Kegan Paul,London, 1976, p. 45. 
beehive.

Systeas theory "has pervaded all fields of science and penetrated 2

into popular thinking, jargon and sass aedia" said Bertalanffy, It has undoubtedly affected educational adeinistration. It created the tendency to viev the schools as oodels, be they forsal, hierarchical, bureaucratic or whatever and to assume that they go no further than that. In fact as Bertalanffy points out it is precisely those non-linear (i.e. non-eodellable) aspects of a systen, the interaction within the systen, that the theory attempts to deal with; going beyond structure to exanine the vorkings of the parts. It can therefore be exanined on many levels, the physical, the intellectual, the spiritual, the social, edical, philosophical, social, whatever.... It looks not only at organization, nasing of parts, assigning of rights and duties, but can also exanine the functioning day by day, hour by hour, ninute by ainute, as recent studies of schools (e.g. Michael Rutter's Eifteen Ihousand Hours) have done,

What can be aissing is a holistic overviev of all the el enents and hov they achieve or othervise the function society ascribes to the education 'systen'. Clearly these two do not alvays coincide, as the spate of current criticism proves. Not only are the day to day vorkings put under the microscope but ve see that social policy may influence the outcoses also i.e. the school itself no atter how well it is organized and controlled way not be able to produce the answers ve ask for--ye have to look at what is going into the systel and the likely future path of the 'material' coning out at the other end of the system for the life patterns available

1. Ludvig von Bertalanffy, General Systeess Theory, George Braziller, Nev York 1968, p.35.

2. Ibid.,p.3. 
e.g. jobs etc, vill affect the ongoing business of the school because of the attitudes, background and aspirations of its 'clients'. These aspects vould be considered in the culture viev of organization. The 'system' is therefore not the vhole of education or even the sun of its parts but part of a life-long process inheriting influences fron the past decades and with concerns and influenced by the long range future. In this sense it is partially like a 'living' entity or organisa vith a history, a life, a future. An education systen is not schools, a departaent of education or curriculua or aerely what individuals extract from it, it is one facet of a culture and an aspect of human Iife and history both of the individual and his/her society and tiue. As Bertalanffy says model-building has become 50 fashionable it is hard to imagine that his idea at first aet with so auch resistance. The grouth of cybernetics helped to develop the theory but that is only one part of a general theory of systems.

Kuhn describes scientific revolutions as paradigas vhere in traditional science the 'parts' are broken down and put together again in d linear fashion. Systeas theory deals with aore general, non-linear problems than the analytical -summative ones of classical science says Bertalanffy and GST as it has becone known is not a search for vague and superficial analogies but it vould seen that 'systen' as applied to education has in fact becose just that. In a sense education is not a systen but an impingeaent on huadn nature of other systems it is an effect or result not a systen in itself. For instance one could give different replies to the question "Are you educated?" and "What education have you had?" Corporate [body metaphor] identity in schools is deliberately conjured

1. Ludvig von Bertalanffy, General Sxstems Theory, George Braziller, Nev York 1968, p.19. 
as it is in corporations to instil loyalty, pride etc. In the one instance the end motive is profit in the other the aims are nore diffuse for one is prescribing ains for chidren usually and their future. Both physical and mental control are also involved.

The systens viev looks at the vorld in terns of relationship and integration says Capra and "although ve can discern individual parts in any system, the nature of the vhole is alvays different from the mere sua of its parts," Order, patterns, relationships are all integral to a systeas approach and systens are seens as either open or closed, wholes within wholes. In nature they already exist, in organizations ve try to find the or create the artificially. The open systeas are those which "have to maintain a continuous exchange of energy and matter with their 2

environment to stay alive." This is described usually vith the notion of 'feedback'. A living organisa unlike an artificial systen is self-regulating and has a self-adjusting capacity, known as 'homeostasis' and not to be confused vith equilibriua.

Whatever the limits of the systems approach it helped say Morgan to break out of the bureaucratic aodel and it establishes congruencies betven different systeas. Newer metaphors have emerged since but the old ones still persist as Hedley Beare says "School is too much an institution, too overly an organization which demands human conforaity. The school is one of the aost heavily bureaucratized institutions in the vorld." so this theory has helped to change some of the more restrictive attitudes to

1. Frit jof Capra, Ihe Iurnigig Point, Fontana, London, 1982, p. 287.

2. Ibid.,p.291.

3. Hedley Beare,School and Community as Educational Partners, in Policies for Participation, ed. John Watson, N.Z.C.E.R.1977, p. 175. 
educational administration, or at least given us another vay of looking at organizations even if sone of the like aany of the schools have not changed. It was two British researchers Tom Burns and G.M.Stalker, Morgan tells us, tho established in 1950 the distinction betveen mechanistic and organic approaches to organization and aanagenent. But as he reainds us "Theories, like readings are interpretations of reality."

The principles of classical management theory as they became known, were not alvays the right ones to follow for different businesses required different systeas. Some actually suited the bureaucratic style for some purposes especially for adss production but not in the saaller situations. To be successful the more mechanistic style requires a stable environant. The electronics industry developed in an organistic vay with everyone having input initially.

It is interesting that theories of evolution should also have influenced ideas about business. Change is a natter of evolution says Morgan and "evolution is alvays a pattern of relations enbracing organizations and 3

their environments." What we look for in organizations are collaborative relations and what ve have learned he says is that "organizations are open systeas and are best understood as ongoing PROCESSES rather than as collections of parts." Through this vieu ve become aore conscious of the need for flexibility, perceive needs, appreciate interaction, consider a range of options and are prepared for innovation.

1. Gareth Morgan, Inages of Organization, Sage Publications, California, 1986, p. 50.

2. Ibid.,p.12.

3. Ibid, , p,69.

4. Ibid.,p,72. 
It is obvious that the education systea or a school vithin it is not an organisa any more than a business is but it has parallels vith an organisa, so that it can be iagined as such and planned and controlled using this wetaphor. What is lacking is in fact corporate identity as a reality, and where this does appear to exist to sone degree, as in 'character', 'clinate', 'structure' etc. it is an artificial 'grid' overlaid as it vere on the group of people sharing a coason physical base usually and with comaon aspirations. The school is in existence for the sake of the individual and increasingly for the sake of society, especially now it seens for the econowy of that society. The most successful schools like the nost successful businesses aay have an organismic view of thenselves and deliberately vork in this vay or are administered on this model. What organisaic unity the school does share is created by the systems metaphor which it consciously or not employs and serves. Such a metaphor way be excellent for planning as it gives a sense of structure, it enables one to have a view, albeit a biased one, of the relationship between the parts but no theory can ever airror practice exactly.

A never metaphor is the organisation as a 'brain':

The metaphor draus attention to the iaportance of inforation processing, learning and intelligence, and provides a frame of raference for understanding and assessing modern organizations in these teras. And it points to a set of design principles for enhancing these qualities. 1

The brain itself has been described throughout history in many ways, with different metaphors, and Morgan examines two of these, the brain as an inforation processing computer and the brain as a holograph. He believes that by using the brain as a metaphor for organization ve aay improve our

1. Gareth Morgan, Inages of Organization, Sage Publications, Cali fornia, 1986,p.14. 
ability to organize in a sanner that promotes flexibility and creativity for "no aan-aade systen cooes close to atching the sophistication of even the siaple kinds of brains,"

The metaphors used so far of mechanisa, bureaucracy and organise have been useful for organizing people there planning relies on predictability but breaks down in situations where people are required to handle the unexpected and there is a need for sone degree of autononous rational behaviour and adjustment, not merely acting in a process and product fashion. He need organizations which in fact act like rational huaan beings. The brain is therefore an obvious metaphor for organization to enulate in the sphere of organizational intelligence. Sometines the brain metaphor is used says Morgan in relation to strategic manageant and control but less often is the organization itself vieved as a brain.

What is now known as the "decision-aaking approach" vas pioneered by Herbert Simon and his colleagues:

his theory of decision making leads us to understand organizations as kinds of institutionalized brains that fragaent, routinize, and bound the decision making process in order to make it manageable, 2

The use of conputers has contributed towards this task and the information 5ystem becomes an integral factor in any organization. The question now says Morgan is whether the organization itself is capable of learning. Cybernetics grew during the war he says from the desire to combine nathematics theory, engineering, social and medical science and comauncations theory "to create achines vith the adaptive capacity of organisas."

1. Gareth Morgan, Inages of Qrganizzation, Sage Publications, Cali fornia,1986, p.79.

2. Ibid.,p,81,

3. Ibid.,p. 85 . 
Current interest is also in how to use this in organizations.

The concept of negative feedback, a process which elininates error is an integral part of cybernetics. Where traditionally a aster plan vith clear objectives is usually broached, with a cybernetic approach one exanines all the possibilities both positive and negative. A sinilar style of planning known as the RINGI is practised in Japan says Morgan and can eliainate problematic factors before a plan goes into action. It is hovever a protracted process.

A wore exciting vay to viev the organization as a brain is to consider holographic principles. Holography invented in 1948 by Dennis Gabor:

uses a lenseless canera to record information in a vay that stores the whole in all the parts. Interacting beams of light create an "interference pattern" that scatters the information being recorded on a photographic plate, known as a hologran, which can then be illuninated to recreate the original inforaation. One of the interesting features of the hologran is that if it is broken, any single piece can be used to reconstruct the entire inage. Everything is enfolded in everything else, just as if ve vere able to throv a pebble into a pond and see the whole pond and all the waves, ripples, and drops of vater generated by the splash IN EACH AND EVERY ONE OF THE DROPS OF HATER THUS PRODUCED. "1

In such a view of organisations then every part has the potential capacity of the vhole or the vhole is airrored in the parts. It is now thought that the brain functions in such a wanner. This vould explain the nassive computations it is capable of handling, far in excess of any known computer ds yet.

Neuroscientist Karl Pribram of Stanford University has suggested that the brain functions in accordance with holographic principles: that memory is distributed throughout the brain and can thus be reconstituted from any of the parts. 2

1. Gareth Morgan, Images of Organizaticion, Sage Publications, Cali fornia, 1986, p. 80 .

2. Ibid.,p. 80 . 
The brain reseables a holograph in its patterns of connectivity. All parts of the brain are closely interdependent. We also knov that the right and left brains combine to produce patterns of thought. The secret of the brain's capacity seeas to rest on this connectivity. The principle of redundancy makes it extremely flexible and adaptive; that is, it allows for error and probability and allows new functions to develop. It is endlessly adaptive just as ve aight vish an organization to be. It has been suggested therefore that by:

building patterns of rich connectivity between sinilar parts ve can create systens that are both specialized and generalized, and that are capable of reorganizing internal structure and function as they learn to meet the challenges posed by nev denands. 1

For an organisation to function as a holographic brain would require

that the principles of REDUNDANT FUNCTIONS and REQUISITE VARIETY yere built in, that is siaultaneous specialization and generalization. In effect noone could turn around and say "That's your problea " for everyone vould be involved and there vould be no fixed roles.

The principle of ainiau critical specification says Morgan suggests that anagers and organizational designers should primarily adopt a facilitating or orchestrating role, creating "enabling conditions" that 2

allow a systen to find its oun form. Such a design allows waxinun flexibility and requires that one should specify only what is absolutely necessary for a desired activity to occur. In a real life situation, at a neeting for example the role positions can circulate and change. Much tine can be taken if organization is completely random but:

If, hovever, they use their autonomy to learn how to find

1. Gareth Morgan, Inages of Qrganization, Sage Publications, Cali fornia,1986, p. 97.

2. Ibid., p.101. 
appropriate patterns of connectivity, they can develop a remarkable ability to find novel and increasingly progressive solutions to coaplex probleas. Such systeas typically find and adopt a pattern graded in a hierarchical wanner, in that sets of subsystems link to higher-order systeas, but the pattern is emergent rather than imposed.1

As yet very fev organizations he says function in this aode.

Innovative organizations Morgan suggests need to be designed as learning systems. The Japanese style is cybernetic. In his view "nost organizations reflect a bounded rationality because they are populated by 2 people." But holographic styles can break beyond the bounds of single winds by combining the cognitive capacity of the group. And as he says nodern brain research has shown that there is a side of the brain underused so far, that is its holistic, analogical, intuitive and creative capacity.

If new organizational designs can tap these creative possibilities they vill provide further aeans of extending and transforaing organisational capacities for rational action.3

Organizations reflect their tine period. Bureaucracy for instance belonged to the age of the written word, whereas with modern communications technology we can look to different ideas and eethods and nev metaphors. The brain metaphor does hovever tend to over look the el enent of conflict that arises in human institutions and the role of power. The learning process he says requires a degree of openness and self-criticism that is alien to traditional modes of aanagement.

One sight expect that educational administration vould favour just such a aodel, involved as it is so closely vith the process of learning, however most of the evidence seems to point to firmly entrenched modes of

1. Gareth Morgan, Images of Organization, Sage Publications, Cali fornia, 1986, p. 103.

2. Ibid.,p.107.

3. Ibid.,p,108. 
adainistration. It is probably one of the slovest to change because it is rooted in a long tradition and because any experiments are difficult to justily. There is another reason for resistance to change which I suspect is nearer to the truth. Morgan says that the inclination of most sanagers is to cultivate secrecy, exclusion, and a perceived need to keep a tight rein on all operations. It is essentially the protection of personal pover. In the educational situation this pover is knovledge which has traditionally been acquired pieceneal through the long apprenticeship of schooling.

any oove towards self-organization must be accompanied by a major change in attitudes and values, the realities of pover aay be reinforced by an inertia steaning from existing assumptions and beliefs. Learning and self-organization generally call for a reframing of attitudes emphasizing the importance of activeness over passiveness, autonony over dependence, flexibility over rigidity, collaboration over competition, openness over closedness, and denocratic enquiry over authoritarian belief. For many organizatons this way call for a "personality change" that can only be achieved over a considerable peri od of tine.1

The reframing of attitudes could mean abandoning old metaphors and finding nev or more appropriate ones.

According to Morgan the rise of Japan as a successful industrial power has ade us increasingly aware of the relationship between culture and anagement. The metaphor itself is a vord originally applied to the tilling of land. We can in fact perceive of organizations as cultures for;

Organization is now seen to reside in the ideas, values, norms, rituals, and beliefs that sustain organizations as socially constructed realities. 2

Thesge constitute patterns of shared aeaning. Morgan proposes an interesting thesis that just as we once defined ourselves by nationality so

1. Gareth Morgan, Inages of Organization, Sage Publications, Cali fornia, 1986, p. 109.

2. Ibid, p.14. 
now there is a tendency to define oneself by work and position vithin an organization so that workers of a specific type throughout the vorld nay have aore in coman with each other than with some of their compatriots. If this noticeable wovement increases then it could be one aethod of bonding across nations for he thinks that : "Ways have to be found of binding the society together again...., and any of the sajor cultural siailarities and differences in the yorld today are occupational rather than national." One of the characteristics of culture is that it creates a for of enthrocentrise says Morgan and this happens in the vorkforce also. Hierarchical structures for instance separate people by their roles and tasks. Unions exist to protect this very phenomena and act in his words as a counterculture. If one relates this idea to the educational systen the sinilarities still exist for each 'level' of teaching is clearly narked by differential pay and social status. School is a very elaborately constructed culture with its rituals, traditions, and private language, One is initiated into it at an early age and although each has as we have been told its oun cliaate or character they all have a great deal in comen. It has affinities for instance with other public institutions notably the prison systen because most of its clientele does not attend there voluntarily.

Culture shapes the character of organization says Morgan and corporate culture develops an ethos. Positive reinforcement is used by many firms to develop this identity, for it does not develop merely from following rules. Organisational psychologist Karl Weick describes the process through which we shape and structure our realities as one of ENACTMENT, Culture- is "an active, living phenomenon through which people

1. Gareth Morgan, Inages of Organization, Sage Publications, California, 1986, p, 113 . 
create and recreate the vorlds in which they live... [and].... Organization becomes the enactaent of a shared reality."

In schools there is an avareness of the cultural nature of the curriculua "The curriculum is ... intervoven vith the social fabric that sustains it...Common education vill be based upon the universal eleaents of the culture and such aspects of the specialities as are of general concern." It is also said that when a society moves fron a class to a classless society reanants of the class culture persist in the schools.

The test of leadership is often how vell one can create this sense of shared reality for "cohesive groups arise around shared understandings." Modern organizations says Morgan are sustained by belief systems that eaphasise the importance of rationality; their faith in these processes is less than rational but: "The nyth of rationality helps us to see certain patterns of action as legitimate credible, and noral, and hence to avoid the vrangling and debate that would arise if ve vere to recognize the basic uncertainty and ambiguity underlying aany of our values and actions." The culture aetaphor provides the "glue" to weld the organisation together and " focuses attention on a husan side of the organization that other 5 metaphors ignore or gloss over." It gives people hovever a false sense of power for they are often under controls they are not fully aware of.

Political aetaphors focus on the sets of interests, conflicts and pover

1. Gareth Morgan, Images of Organization, Sage Publications, Cali fornia, 1986, pp.130-131.

2. B.O.Smith, W.O.Stanley and J.H.Shores, Cultural Roots of the Curriculun in The Curriculus:Contexts. Design and Developgent, Oliver and Boyd Edinburgh and Open University 1971,p.16.

3. Morgan, p,133.

4. and 5. Ibid,, p,135. 
plays that shape organisational activities. Organization says Morgan is intrinsically political even though the anabers nay avoid facing this fact. They usually, he found, prefer to think of thenselves as rational entities untouched by politics. This is seen particularly in education as John Davies explains when he describes the traditional approach of those in education and hov there is now "a rejection of that long-enduring fiction that the schools of America are apolitical, and repeated eaphasis on the closeness of the relationship betveen the polity on the one hand and the education systed on the other." Politics are an essential aspect of organizational life Morgan asserts. We vould do vell he thinks to consider its original neaning:

the idea of politics stens from the view that, where interests are divergent, society should provide a means of alloving individuals to reconcile their differences through consultation and negotiation.2

Politics to Aristotle for instance meant creating order out of diversity. By looking at organizations as systeas of governaent we can he thinks appreciate aspects which are often ignored, When ve use terss such as autocracy and democracy we are draving parallels he says with political systens. Studying organizations from a political stance generally entails examining INTERESTS, CONFLICT, and POWER, and pover influences tho gets what, when and hov. The prinary source comes from authority. He describes. two types, charismatic which comes from earned respect and traditional from position such as royalty, and bureaucratic or invested authority legitinated by procedural means or as a right because of ownership or on

1. John L.Davies, 'The Politics of Education' some theoretical and comparative considerations, in The Politics of Education in Nev Zegaland, ed. Margaret Clark, N.Z.C.E.R., Well ington, 1981, p.2.

2. Gareth Morgan, Ingaes of Organizatzion, Sage Publications, Cali fornia, 1986, pp.142. 
merit as in a meritocracy. All of these are found he says in sodern organizations. One can recognize their parallels in the education systen from the ailk monitor right through to a vice -chancellor or ninister for education.

Control of resources is one source of pover and something has already been said about the power a head is invested vith and hov competition for scarce reources creates conflict in schools. Rules and regulations can also be manipulated as a pover ploy, as in the example Morgan gives of "vorking to rule." Decision-making is another area where influence can be brought to bear and as he notes "One of the nost effective ways of getting a decision is to allow it to be ade by default." Much pover therefore lies in the business of organizing such things as agendas.

One area of control that probably applies particularly to the educational sphere is in the control of knowledge and information. Those who politically vithhold information are sometiaes called "gatekeepers" for they can successfully prevent people from obtaining knowledge. The examination systens of schools can be vieved in this light in the sense that control over curriculum, books and resources can be a liniting factor in the personal acquisition of knovledge.

New technology, as Morgan points out, is increasingly used not to diffuse infornation but to control access to it and to keep people under surveillance. There is also the vested interest in the power of being an expert to who other people turn for information. What Morgan calls boundary management occurs where access to people is prevented by protective associates

1. Gareth Morgan, Inages of Organizization, Sage Publications, Cali fornia, $1986, \mathrm{pp}, 166$.

2. Ibid.,p.167. 
and he cites the case of Nixon's aides, who vere said to have prevented hie getting infor aation on Watergate, as an example.

The ability to cope vith uncertainty and the control of technology are two other sources of pover that Morgan mentions. As vell as interpersonal alliances, netvorks and informal organizations vithin the sain organizaton, for "The skilled organizational politician systematically builds and cultivates such inforal alliances and netvorks. ".. which is a 1 vay of vinning friends and pacifying potential eneaies, One other major area of politicking is in what he calls counterorganizations such as unions. These groups act as pressure groups and cope vith the pover of the organization by mintaining counter-pover and this can be a career in itself.

If leadership involves an ability to persuade others then it is also defining reality for others. Morgan discusses three aspects of symbolic management, the use of inagery, the use of theatre and the use of ganesmanship. The first arises in the language deliberately used to conjure up, for exaple, inages of group solidarity. The theatrical devices are the performances enacted to convey power and may also be reflected in the arranged setting of e.g. the office furnishings. Tining and presentation are also used as pover ploys for dranatic effect. Some people treat the whole organization as a gale to be played, vith skill, and sometimes vith cunning.

Gender stereotypes also have their part in the power relations says Morgan and "Whether or not gender is perceived as a factor shaping pover relations, the choice or inclination toward one gender management strategy or another can have a major effect on one's success and general influence vithin an organization.

1. Gareth Morgan, Ingges of Organization, Sage Publications, Cali fornia, 1986, pp. 173. 
A paradox which Morgan found in these studies of pover was that most people when intervieved expressed a feeling of powerlessness even though they appeared to have in some cases considerable pover. There vere in fact structural factors defining their stage of action.

This deep structure of pover leads us to recognize the importance of factors such as class relations in deteraining the role ve occupy vithin organizations and hence the kind of opportunity structure and povef to which ve have access. It dravs attention to the vay educational systems and other processes of socialization shape basic elements of culture.1

Pover both attracts pover and is a route to aore pover and yet Morgan finds it difficult to define. It is definitely connected, he thinks, to patterns of dependence "However it is far from clear whether pover should be understood as an interpersonal behaviour phenomenon or as the anifestation of deep-seated structural factors"--this is a question for the sociology 2 of organization But fron the illustrations he has given it is possible to analyze some of the pover ploys in operation in any organization. Political science, says Morgan, speaks of pluralist and unitary societies. The forner is one where groups compete but where unity cones Iron diversity, or where they are antagonistic and radical change is needed to restructure sociaty. The latter, an older viev, is where there is a vision of a unitary whole, such as when the sovereignty of a state is upheld. Organizations, are like nicrocosms of these larger societies and each frame of reference [or aetaphorI leads to a different style of 3 management.

Morgan found that people avoid admitting that they are involved in

1. Gareth Morgan, Images of Qrganization, Sage Publications, California, 1986, pp.183.

2. Ibid.,p.185.

3. Ibid.,p.187. 
politics in the vorkplace even though they observe and coment on its raaifications all around them. We should, he thinks, accept the reality and use it for fruitful analysis and discussion.

The political metaphor encourages us to see how ALL organizational activity is interest-based and to evaluate all aspects of organizational functioning vith this in aind... The setaphor also helps to explode the ayth of organizational rationality.l

This oyth helps to overcone the contradictory nature of organizations which in effect are competitive and cooperative at one and the same time.

The eaphasis on rationality atteapts to bind together a political systen which, because of the diversity of interests on which it builds, always has a latent tendency to sove in diverse directions, and sometines to fall apart.2

The political metaphor helps us to accept the lack of harnony and unity as a necessary feature. We then have a better understanding through it of human behaviour in organizations and ve recognize the sociopolitical implications of different types of organization and the roles they play in society. The danger says Morgan is that once ve are alerted to the political nature of an organization it can raise our oyn poltical avareness and behaviour, and "its use may generate cynicism and aistrust in situations were there was 3 none before." This he 5ays is a very real danger and the wetaphor can become a tool in our own personal political noves. Many current uritings on manageaent use this as a ploy and breed a negative view of organizations as traps set aerely to exploit people.

This kind of thinking loses sight of the nore general iaplications of the political eataphor, such as the Aristotelian vision of politics as a constructive force in the creation of social order, and the possibility of using political principles to exanine and restructure

1. Gareth Morgan, Inages of Organization, Sage Publications, Cali fornia, 1986, pp.195.

2. Ibid.,p.195.

3. Ibid.,p.197. 
the relationship betveen organization and society.

As vith the nature of metaphor itself ve return once nore to Aristotle and it seeas that ve also have problems deciding vhether one should align on the side of the individual or the group. This seens to me to lead to the tricky question of elites and whether ve can ever escape the apparent necessity for some people to take leadership roles which inevitably suggests that they also have aore pover. The political metaphor, thinks Morgan, asy err on the side of overstating the case for the individual.

The allegory of Plato's cave explores the nature of reality and how we perceive it. Much of that we consider real is really illusion and some of our creations, says Morgan, become traps for us, and he describes such as "psychic prisons," a metaphor for the way we construct an illusion of reality and become trapped by our ovn thoughts, ideas, baliefs or preoccupations originating in the unconscious mind. This "oetaphor offers any important insights about the psychodynamic and ideological aspects of organization." Where Plato thought one should seek enlightenment through the pursuit of objective knovledge the modern psychoanalyist believes that we should seek to understand ourselves because ve create or own vorld. This metaphor of the psychic prison is really asking us to what extent our organizational behaviour is shaped by our personalities and our repressions. Interestingly many of the rules in early churches vere concerned he says with controlling sexual behaviour and Michael Foucalt considers that mastery and control of the body is fundanental for control over political and social life.

1. Gareth Morgan, Inages of Organization, Sage Publications, California,1986, pp.198.

2. Ibid., p.15.

3, Ibid.,p.208. 
"Historically a strong case can be made for the idea that anality has been the ajor for of repressed sexuality shaping the nature of organizations." This goes beyond individual personalities even though we may see ample evidence of it in individual behaviour. So the unconscious concerns of individuals are reflected in the organization. Women are inclined says Morgan to see Freudian interpretations as unbalanced and analyse organizations in a different vay. They are particularly aware of male dominance and patriarchal structures and perceive a basic need to change fundanental organizational values.

Becker's viev of the vay we behave relates to the fact that ve try to create an illusion of inmortality in order to cope vith our inevitable deaise. Thus organizational behaviour is seen as part of a quest for 2

imortality. Klein believes we build defences against anxisty. On this hypothesis 8ion has described three typical behaviours called DEPENDENCY in search for a leader, PAIRING where a messiah is avaited, and FIGHT-FLIGHT in which group fears are projected onto an eneny of some 3 kind. Drganizational behaviour is sometions a defence against anxiety says Morgan. Blaning 'scapegoats' is a syabol of this type of behaviour. Sometimes aspects of culture in an organization may be clung to even in the face of pressure to change what Morgan calls a kind of 'teddy-bear' syndrome. Fear of loss is significant and has been labelled the theory of transitional phenomena, What ay be needed in fact is a substitute phenomend during the period of change. Jungean archetypes are also considered for

1. Gareth Morgan, Inages of Qrganization, Sage Publications, Cali fornia, 1986, p. 209.

2. Ibid.,p.213.

3. Ibid.,p.217. 
they are found indreans, ayths, and ideas of priaitive, ancient and nodern man "structures of thought and experience, perhaps embodied in the structure of the psyche or inherited experience, which lead us to mould 1 our understanding of our world in a patterned way. Thus they influence how we cope with the vorld. This idea is more full explored he says in the work of Robert Denhardt in In the Shadov of Organization.

Where bureaucracy is designed to ninimise the hunan factor Jung's thinking would lead us to accept the fact that this can never be removed. "The pathologies and alienations ve find in organizational contexts can, from a Jungian standpoint, be interpreted as a manifestaton of this essential 2

wholeness of the psyche. Morgan refers to Frye's work on mythology and literature, which has been explored aore fully in a previous chapter here, and which shows the preponderance of certain themes for "archetypal structures give people a sense of place in their oun lives and in history and thus help then to make sense of who and where they are in the grand order of things. Whether organizational life reflects these basic patterns has yet to be explored. What has been done so far suggests that ve may all be prinitives at heart, "reproducing archetypal relations to aake sense of the basic dilemas of life,"

These psychic metaphors have been labelled "black hole" by some, but, says Morgan, visions of confinement are usually accompanied by visions of freedon so perhaps ve have a source of creative energy still to be tapped. Much of human behaviour is still aysterious to us but through

1. Gareth Morgan, Images of Organization, Sage Publications, California, 1986, p. 224.

2. Ibid, $p, 225$,

3. Ibid.,p.227. 
exanining concepts such as those described as psychic prisons ve at least explore the aspects which ve all share and which must influence and affect our relationships with each other especially in the groups and organizations in which ve are involved. David Bohm has said that if ve try to study the vorld in causal teras:

we vill not discover the all-iaportant "lavs of the whole" eabedded in the iaplicate order. To discover these ve have to understand the movement, FLUX, and change that PRODUCE the vorld ve experience and study. "I

For our vorld is itself in a constant state of flux and change. Morgan explores this notion by considering three different inages of change. The first is called Autopoiesis; the logic of self-producing systems. He usually suppose he says that change comes from the environment. But to Humberto Maturana and Francisco Varela, two Chilean scientists, all living systeas are closed. They self-create and they self-renew which is where the ter autopoiesis comes in. Any patterns of interaction in which they aight engage are alvays self-referential, "Thus a systen's interaction with its "environment" is really a reflection and part of its ovn 2 organization." The inlications of this for people in relation to organizations is fairly clear. The person is alvays a separate entity to the organization. I think of the analogy of a swimmer who enters a pool which is teaporarily disturbed but not changed by hia/her, and tho is hi a/herself affected in some ways whilst in the vater and even later but emerges the same in essence as before going in. In their viev "There is no beginning and no end to the system because it is a closed loop of interaction." This

1. Gareth Morgan, Inages of Organizzation, Sage Publications, Cali fornia, 1986, p. 234 .

2. Ibid.,p.236.

3. Ibid.,p.237. 
conjures up a vision of endless sets vithin sets vithin sets like looking endlessly into a nirror which is not unlike the holographic effects Morgan previously described, Their version of how the brain works is that "it establishes and assigns patterns of variation and points of reference as expressions of its ovn mode of organization. The systen thus organizes its environment as part of itself." We have become trapped in our thinking as observers they would say. Change has to come from "randon variations WITHIN the total systen. These aay sten from randon modifications introduced through processes of reproduction, or through the combination of chance interactions and connections that give rise to the development of nev 2

systea relations,"

Other research described by Morgan shows that systeas can be transformed by randomess, fluctuations instabilities and quantum jumps. What is necessary is a critical level of support. This theory is in opposition to Darwinian theory says Morgan. Systems do not adapt to the environaent nor does the environaent select the systen configuration that survives but "It is the PATTERN [my emphasis], or whole, that evolves. "

Organizations which see themselves as discrete entities are disadvantaged says Morgan, their egocentrisn linits then. Just as a face in a nirror is dependent on a host of conditions for its existence such as the biological processes that create and sustain the face and the physical and cultural conditions required for the existence of the airror, the defining features of organizations are dependent on a host of less obvious contextual relations that

1. Gareth Morgan, Ioages of Organization, Sage Publications, Cali fornia, 1986, p.238.

2. Ibid.,p.239.

3. Ibid.,p.240. 
must be maintainad if the organization is to continue to exist. To pursue an unrealistic identity is therefore futile. An avareness of the theory of autopoiesis enables organizations to face change and allows then to evolve in an open-ended fashion. Successful strategic development can never be unilateral "the process is alvays dependent on complex patterns of reciprocal connectivity that can never be predicted or controlled."

These patterns of interaction and mutual causality are circular says Morgan so we require a nev vay of thinking. Notions of positive and negative feedback go some way to explaining then. Linear thinking says Magorah Maruyana leads to linear solutions whereas "When ve analyse systeas as loops rather than lines ve invariably arrive at a auch richer 3

picture of the syste under consideration." Once again patterns are at the base of physical and cognitive activity.

Another facet of organization derives fron traditional thinking such as Tao which identifies the oppositions vithin nature for "the vay of nature is characterized by a continuous flux and vholeness shaped by the dynamic interplay of yin and yang." Essentially such thinking leads to a notion of a search for balance and developed what is called the dialectical method. Marx used this aethod to search for the "primary tensions or contradictions shaping a given society, and to trace their repercussions on 5 the detailed pattern of social life." Contradictions and conflict are

1. Gareth Morgan, Inages of Qrganization, Sage Publications, Cali fornia, 1986, p. 246 .

2. Ibid., p.249.

3. Ibid.,p.252.

4. Ibid., p. 255

5. Ibid, p. 257 . 
as part of the nature of social life. Our society continues to evolve says Morgan through dialectical process even if some of his predictions have not eventuated and we see change as coning probably through "irreversible pollution of the planet, from pressures in the Third World, or fron nuclear holocaust, rather than fron a revolution initiated by the vorking class." One vay of understanding change therefore is to examine it as Marx did as the product of the tension betveen opposites and analyse these but our linear habits of thinking often prevent us doing this. "A dialectical inagination invites us to enbrace contradiction and flux as defining features of reality... [and]... The choice that individuals and 5ocieties ultimately have before them is thus really a choice about the kind of contradiction that is to shape the pattern of daily life."

Organizational problems cannot therefore be solved in a piecemeal fashion. Problems aay be, says Morgan, the natural consequence of the logic of the system which is one of the three described by him, either selfproducing systems that create thenselves in their ovn inage, or the result of circular flows of positive and negative feedback, or alternatively as a product of a dialectical logic. Linitations he finds in this aetaphor are that it can be too idealistic and can meet resistance. Also we see the logic of a situation more often in hindsight than before. In trying to predict the future ve are alvays still embedded in the present and the past.

Morgan's final metaphor for organization is that of Instruaents of domination. Here the focus is on the potentially exploitative aspects of

1. Gareth Morgan, Inages of Qrganization, Sage Publications, California, 1986, p.264.

2. Ibid,,pp.265-267. 
organization that is how ue use then for our oun ends. This really examines the negative aspects of organizational life such as occupational health hazards and the effects on people of organizations concerned mainly with profit. Weber, says Morgan, analysed three types of domination as legitiwate foras of authority or power; the charisnatic, the traditional and the rational-Iegal. Like others he sav bureaucracy as a poverful dominating force. Morgan says that "The real value of these perspectives is that they show hov even the most rational and democratic forms of organization can result in aodes of doaination, there certain people acquire and sustain a comanding influence over others, often through subtle processes of 1 socialization and belief."

This is easily seen in school administration structures which use several types of pover control, particularly usurping the parental or natural [traditional?] authority over children by rationalizing that it is their future vell-being which is their priae concern, and coercive legal pover because schooling is mandatory as vell as the bureaucratic hierarchies vithin the adainistration at school level and vithin state departments of education. There are also charismatic leaders who have influenced the philosophy of schooling, figures such as those considered in the previous chapter.

Morgan quotes Arthur Miller's play Death of a Salessman as a metaphor

for "the vay organizations often consune and exploit their employees." Nowadays many of us are familiar with the redundancy syndrome and increasingly in education and in the labour arket youngsters are led to expectations

1. Gareth Morgan, Inages of Organizization, Sage Publications, California, 1986, p. 278.

2. Ibid.,p.279. 
that are never fulfilled because of econoaic considerations.

There is a strong case says Morgan for asserting that organization has alvays been class-based. And even though donination and exploitation eay be not be the intended or stated ains they are often the effects of organization that is isplicit rather than explicit. Bowles and Gintis illustrate hou with their reproduction theory of education the systen is 1 utilized to protect and reproduce a doninant power group. In education it is the control of knowledge and resources which is the dominant area of control the 'gatekeeping' function that has already been referred to. It is possible to see the modern state and multinational corporations as 2 partners in systematic domination says Morgan.

The usefulness of the donination metaphor as Morgan sees it is that so-called rational action can be dysfunctional or have unintended consequences and the ataphor dravs our attention to this factor, whereas traditional theory often ignores values and ideology in a vain atteapt to appear neutral. It enables us to examine the negative aspects of organization and to enable us to understand such things as the 'then and us' attitudes. "The strengths of the domination metaphor thus provide the basis for a truly radical critique of organization and organization theory" even though its critics vould 5ay that it it can lead to "a crude conspiracy theory of 3 organization and society." But as Morgan has shown donination may occur because of the internal logic of an organization and the aetaphor can transcend the conspiracy theory, Besides if one believes Marilyn Ferguson

1. 5. Bowles and H.Gintis, Schooling in Cagitalist Anerica, Routledge and Kegan Paul, London, 1976.

2. Gareth Morgan, Inages of Organization, Sage Publications, Cali fornia, 1986, p.313.

3. Ibid, p.317. 
there is also a new vave of thinking which she calls the Aquarian conspiracy

Which is vorking positively tovards a non-exploitative and aore sharing 1

5ocial systen. The factor ve have to face up to perhaps is that dominance

is not avoidable and ve need to consider the nature of leadership, authority,

responsibility and accountability, the very notions which educationists are

also concerned about. As Morgan says:

We live in a vorld that is becoming increasingly complex. Unfortunately our styles of thinking rarely atch this coaplexity. We often end up persuading ourselves that everything is more simple than it actually is, dealing vith conplexity by presuinng that it does not really exist. This is very evident in the way fad and fashion dowinate approaches to organizational analysis and problew-solving, an interest in one type of solution or set of techniques quickly giving vay to another. 2

The challenge he believes is to deal with complexity:

by building on the use of metaphor--uhich is basic to our vay of thinking generally--ve have a means of enhancing our capacity for creative yet disciplined thought, in a way that allows us to grasp and deal vith the many-sided character of organizational life. And in doing so, I believe that ve can find nev yays of organizing and new ways of approaching and solving organizational problems.2

Nevell when describing concepts of organization in education says also that prescribed rules for action have sainly been recognized as less useful than the capacity to analyse the condition of an organization and adapt and plan with consideration for the future and the present situation. He says:

Although the traditional concepts are still useful in certain respects, modern organizational theory when utilized vith administrative insight allovs more flexibility and requires less reliance upon fixed and rigid patterns. 4

1. Marilyn Ferguson, The Aguarian Conseiracy, Granada, Great Britain, 1982.

2. Gareth Morgan, Inages of Organization, Sage Publications, Cali forni a, 1986, p.16.

3. Ibid.,p.17

4. Clarence A. Nevell, Human Behaviour in Educational Adninistration, Prentice-Hall, New Jersey, 1978, p.120. 
Nothrop Frye speaking of educational inagination said that anyone entering a profession had to at least aake a gesture to recognize the ideal existence of a world beyond his oun interests. Peter Ramsay says that there are difficulties vith the tern professionalisn because as Millerson says there is adherence to a static model rather than an avareness of a process of developent. Sone models are already proving thenselves out noded. Merdydd G. Hughes for example believed that the oedical nodel vas an apt one for schools aanagenent where analysts and clinicians compleaent each other's work. In view of the current 5 tate of medical organization it is doubtful whether such a nodel is nov seen as an ideal one.

Authority, responsibility, accountability and democracy seen to be the enduring terms in all of the literature yet none of the codels adequately takes care of then. Accountability is a chimera says Taylor. Beeby says that ferms such as hierarchical or denocratic never tell the whole story. Policy does not simply 'filter' down, and Parsons said the same thing, that "people 'lower down' typically must exercise types of conpetence and shoulder responsibilities which cannot be regarded as simply 'delegated' by their 'superiors'." A 'systes' simply does not vork like this as Beeby says:

An education system can remain living and responsive to the needs of the children in its care only if, at every level in the hierarchy there is roon for the individual to exercise inagination and initiative...3

1. Meredydd 6. Hughes, Educational Administration Pure or Applied, in nevsletter of the Cononveal th Council for Educational Adainistration No. 35 , October 1984.

2. T. Parsons, in Adginistrative Thenory in Educatilion,ed. Andrev W. Halpin, Macaillan, London, 1958, $p, 46$.

3. C. E. Beeby, Moving Targets, N.Z.C.E.R., Wellington, 1986, p.xlii. 
Donald A. Schon sees nost of the difficulties in managent occuring in problem-solving, and as he says problems are not given they are constructed by us. "Each story constructs its ovn vigy of reality through the complementary process of NAMING and FRAMING" or what Devey called the 1

"problematic situation." Draving on his social policy experience Schon says once ve see a slum for exanple as a blighted area ve are convinced that the 'blight' must be removed as it is seen in teras of a medical metaphor. And in this situation something is removed that aight destroy netvork and community support systens. The aetaphors ve use consciously or unconsciously therefore seriously affect our vays of seeing and solving problems. We discover truth through what he calls story telling and need to search beyond the 'surface' to the 'deep' eetaphors that they reveal, He can become nore aware of what he calls frame conflicts by looking at 'facts' in different franes. We all use this aethod intuitively says schon but no technical term has been given to it. What happens is that:

In each case the cognitive work involves participants in attending to new features and relations of the phenomena, and in renaming, regrouping and reordering those features and relations, 2

Works such as that cited by Gareth Morgan can go a long vay to making people avare of the aetaphors doninating their institutions. Some people recognize them. Sylvia Ashton-Warner described vorking in Aaerica as like exploring a nev culture vith no compass for she found 'authority' to be resisted, yet she believes in the need for leadership. In her approach at school it seems that each day is:

A shape contoured by benign routine which helps to stabilize, which

1. Donald A. Schon, Generative Metaphor: A Perspective on ProbleaSetting in Social Policy, in Ketaghor and Thought, ed.David Ortony, Caabridge University Press, New York, 1979, p. 264.

2. Ibid, , p.276, 
in turn engenders responsibility. for in aking a ney kind of school, stability and responsibility are najor requirements for freedon of the wind.1

She believes that ve should try to replace obsolete terainology with a new vocabulary of the future, for how can ve talk of 'equality' when ve have terms like 'head of department'. Much tine and energy she says is spent discussing deaccracy but where she asks is the original vision:

Vision does not cone in any attractive packages but explodes in one aind alone, and it is fragaented and diffused when all are equal, which in practice turns out to be "All are authorities." 2

The metaphor she chooses for leader ship is a very apt one:

...1 use the word "conductor" in the text of an infant roos, as of an orchestra uhere any playing together interpret one vork, led by the vision of one composer. I do not recall seeing orchestras in rehearsal stopping for pleasant conferences to change a passage in the music since all are equal and have EVERY RIGHT. Besides, "conductor" concerns itself with something living, with unity, shape and rhythm; with a common intention and, above all, wholeness... none of which you are likely to see in "Head of Department." 3

She may be talking of an infant classroom but this is a reflection or microcosm perhaps of any educational institution or the vhole systen.

Macpherson exasines the vay educational administration is a reflection of our culture and conceptions and how various people have. explored this. There is auch Iiterature influenced by Mead for example which looks at the syabolism of roles and patterns of interaction referred to metaphorically as 'structures' and the symbolis varies with each culture. One study by Silverman and Jones found that administrators were driven by the dominant metaphors of their organisations. Seven meanings of structure for instance vere apparent in a study by Macpherson.

1. Sylvia Ashton-Warner, "Iegacher." in Ameriça, Cassell, London, 1972, p.172.

2. Ibid.,p.165.

3. Ibid., p.188. 
Although structure is from a Latin vord 'to build', and refers to the construction, the composition or the inherent patterns in concrete, observable, aechanical or organic systens, all meanings used by the R.D.E's [ Regional Directors of Education] vere figurative. They vere social constructs inferred from events over time. Converting the abstract to concrete, reification vas videly evident, despite the metaphorical nature of the tera. In some settings reification vent even further, into deification. 1

Metaphors vere being used he says to sustain a natural systems viev of reality, to perpetuate a bureaucratic rationality and to legitimate a structural-functional way of valuing practices. Which leads Macpher son to stress that "all adeinistrators should develop a socially critical avareness of their practices, especially vith respect to the adainistration 2

of cultural capital..."

In sumation he says that "order is constructed in schools and systens through the dynamics of culture (nyths, aetaphors, rituals, Ianguage, ceremony) and through the systematic structuring of knowledge (selection, organisation, transaission, distribution, control and justification)." 'Development' and 'reform' are therefore metaphors for a dialectical process which he sees eabedded in social contexts whereby in his vords a facet of social reality is being constructed. In view of my own reading in this area this appears to be true, there is no escape from metaphor even in educational administration.

1. R.J.S. Macpherson, Taking up and Justifying Organisation: The Creation and Control of Knovledge about being organised, in newsletter of the Commonwealth Council for Educational Adainistration. No.41, 1986, 0.8.

2. Ibid.,p.10.

3. Ibid.,p.12. His use of 'myth' appears to be not the artistic or literary sense but in the oore usual one in ordinary language of falsity of conception. 
CHAPTER VII

METAPHOR IN SCIENCE

"Metaphor was the beginning of visdom, the earliest scientific aethod,"

The history of science is also a history of scientists trying to cope vith language. As Andrev Ortony says "One of the doainant presuppositions of our culture is that the description and explanation of physical reality is a respectable and vorthuhile enterprise--an enterprise that we call "science". Science is supposed to be characterized by precision and the absence of anbiguity, and the language of science is often thought to be correspondingly precise and unabiguous--in short literal." To positivists this is so but the relativist view is that "the objective vorld is not directly accessible, but is constructed on the basis of the constraining influences of hunan knouledge and language."

The nature of the language problen for scientists is multifaceted. First there is the need for nasing of natural phenonena i.e. for labelling and classification. Then there is the need to describe scientific

1. C. Day Levis, The Pogtic Inage, Jonathan Cape, London 1947, p. 25.

2. Andrew Ortony ed. Metaphor: A Multidinensional Problem Metaphor and Thought, Cambridge University Press, New York,1971.p.1.

3. Ibid. 
theories, discoveries and lavs. Both of these areas influence how ve speak and urite about science and also how it is taught and learned. Nowadays ve are also interested in how the scientific aind yorks i,e. hov new ideas come about and because of an increasing study of language and of the nature of knouledge ve have a vhole range of 'languages' which impinge on science itself e.g. semiotics, semantics, syabolic logic. The rapid grouth of science has nade scientific language a problea, as Sir Arthur Quiller -Couch has declared disapprovingly :
When it became an accepted custom for each nation to use its own language in scientific treatises, it certainly was not foreseen that sen of science would soon be aking discoveries at a rate which left their skill in words outstripped; that having to invent their terms as they went along, yet being careless and contenptuous of a science in which they have no training, they vould bombast out our dictionaries with monstrously invented words that not only would have made Quintilian 5tare and gasp, but vould affront the decently literate of any age, 1

Then he goes on to describe his horror at, the to us, innocuous vord 'antibody'. Fairly harsh criticism of aen of science whose difficult work is compounded by having al so to construct a language to describe it. Richards was also aware of such criticisas. "These complaints are, comonly, that they are avkuard or difficult to pronounce or too long, and that they are not labels but compacted descriptions or explanations. The prejudice is 50 strong that even the lexicographers succuab to it."

Lancelot Hogben's The Vocabulary of Science is a useful overview of general linguistic probleas in science, particularly concerning the first problem for scientific language, that is naning. For this purpose his definition of science is "the written record of man's understanding of

1. Sir Arthur Quiller-Couch, On The Art of Uriting from lectures given at Cambridge 1913-14, Canbridge University Press, 1938.p.29

2. I. A. Richards, Philosoghy of Rhetoric ${ }_{2}$ Oxford University Press, New York, 1936.p.76. 
nature" , a history of wore than five thousand years of influence from

Egypt, Mesopotania, the Phoenician colonies, the Greek vorld, China, India and the Moslee vorld. He clains that we have little appreciation of the iapact on our own world of the influence of Western Christendon in the formation of an international CONSTRUCTED vocabulary: "This vorld-vide vocabulary of Western science is the nearest thing to the lexicon of a truly global auxiliary that ankind has yet achieved. It derives its stock-in -trade alnost exclusively from two dead languages." These are of course Latin and Greek, and if Shakespeare said he had little Latin and less Greek then apparently according to Hogben oodern students have even less, since it became unfashionable in the school curriculun. However this is not seen as a handicap if students come to Hogben's vork ready "to make lively associations with already familiar terms" ${ }^{3}$ this sounds remarkably like another description of aetaphor ].

The vocabulary of science enters ordinary language and becones international at an extraordinarily fast rate: "What vas yesterday the jargon of the expert becones an ingredient of the vernacular." This vordbuilding Hogben approves of but does not favour the modern habit of for ming acronyms such as used by military and sales people, because they are known only to the initiated and are meaningless in any other language, whereas using 'traditional' methods as vith his example TELEPHOTOGRAPHY, ve can recognize the roots of this word and, as he points out, with a basic

1. Lancelot Hogben FRS, The Vocabulary of Science, Heinemann, London, 1969.p.3.

2. Ibid.p.3.

3. Ibid,p.4.

4. Ibid.p.4. 
vocabulary of a thousand roots ve can have perautations of millions of

vords. It is by this means that ve have coped with the accelerated grouth of scientific discovery and the need for nev names. Nor is there any need to study classical authors as formerly, for a basic vocabulary can be ade available and easily memorised as his book demonstrates.

Hogben sees Christendon as having stopped the development of pagan science--the murder of Hypatia a syabol of this in A.D.415,--and the work of Augustine a part of this sovement. Within four centuries Latin had been imposed as the Lingua franca of the monasteries of Western Christendom. It was only through necessary work on the calendar and on herbal medicine that this stranglehold vas released:

Such vas the situation in the century A.D.1150-1250 when monks such as Adelard [ Abelard? ] of Bath and Jevish scholars vho had studied in the Moorish seats of higher learning in Spain, circulated Latin translations of the Arabic texts through which Mestern Christendom, like the Moslen vorld at an earlier date, had access to the teaching of Euclid, Ptolemy, Galen and Aristotle. These translations, especially (alas) of Aristotle, noulded the teaching curriculun of the European universities which took shape in the sane period. 1

He traces Western development in science from this period. In Mediaeval Europe "Latin was everywhere the medium of instruction, and 2

knovledge of Latin was the gateway to study."

By the aid-seventeenth century so many nore people vere involved in 'scientific' work and study and not all had been trained in Latin so it diainished as the Lingua franca of science e.g. "In 1687, Newton had published his Principia in Latin. Seventeen years later his Optics appeared 3 in English,"

1. Lancelot Hogben FRS, The Vocabulary of Science, Heinemann, London, $1969,0.7$.

2. Ibid.,p.9.

3. Tbid.,p.9, 
The need for a universal language of science prompted several people to try to develop a special language for this purpose e.g. Wilkins and Leibniz; and Descartes had apparently also suggested such a need. None of these atteapts became generally adopted and it vas the vork of Linnaeus and Lavoisier which established a precedent yith their systems of classification.

Greek words had been used by the Romans for the Greek science they had inherited but adapted to their ovn spelling:..." a Greek component of the vorld-vide vocabulary of Western Europe vas already latent in the Latin used by aen of science in Mediaeval Christendom.

This is one reason why Western science turned to Greek when it ran short of vernacular vocabulary resources in the eighteenth century of our era."

Latin persisted longest in Teutonic countries one reason being says Hogben that they were less able to adopt foreign influences into their language unlike English which had already absorbed much French influence. As he says there vas "A vell-established PATTERN for adapting any newcomer 2

from the same source." German language had absorbed few foreign influences and Hogben considers this one reason why people such as Faraday could communicate more easily and ore videly than his German counterparts and Britain developed a tradition of popularising scientific vork. Tovards the later part of the century French chemists such as Lavoisier vere involved in language reform which was easily assimilated by the British because they used a "comaon stock of terminals,"

1. Lancelot Hogben FRS, The Vocabulary of Science, Heineann, London, $1969, p, 12$.

2. Ibid.p.13.

3. Ibid.p.14. 
Hogben acknouledges our debt, particularly for language, to the Greeks, though he is critical of the, to him, overrated influence of Plato and Aristotle, of whon he says :

...the impact of his [Aristotle's] teaching on that of the Mediaeval universities of Western Christendon vas largely retrograde. He dis - wissed valid and incontrovertible evidence which led Eapedocles (circa 465 B.C.) to conclude that air has veight. Therevith he rejected the cogent case advanced by Democritus (circa 430 B.C.) in support of a particulate theory embracing air and vapours as a third--what ve now call gaseous-state of atter. He also bequeathed to posterity a MYSTIQUE which discouraged a rational approach to both the study of terrestrial gravitation and an understanding of combustion. 1

Catholic Europe vas studying Greek science through Latin texts based on Arabic translations, for the study of Greak was not encouraged by the papacy and Mediaeval universities did not offer Greek. By the fifteenth century Byzantine refugees had brought Greek manuscripts to Italy and once printing from movable type began, Greek texts became videly available. The imaediate effect says. Hogben was not to influence scientific nomenclature but to cause religious controversy. He found evidence of fev Greek teras before 1750 (i.e. in the Shorter Dxford Dictionary), By 1800 these had aultiplied enoraously, because of nev discoveries, including 'living creatures and their parts, synthetic substances, units of measurement, 2 instruments and other inventions." Biological classification vas foremost anong these in its influence and "any advance of biological knovledge between 300 B.C. and A.D.1600 was trivial compared with progress between A.D. 1600 3 and 1750." This had three main causes; comercial horticulture, colonization of the Nev World, and the invention of the aicroscope which despatched such

1. Lancel ot Hogben FRS, The Vocabulary of Sccience, Heinemann, London, 1969, p. 17.

2. Ibid, $, p, 18$.

3. Ibid., p.19 
beliefs as that of spontaneous production, from Aristotle's time and teaching. Previously most categorising had been of herbal medicinal plants. To cope vith the huge influx of nev findings vas a problea.

Linnaeus published his Systenatas Naturae (1735) and firaly established a tradition of giving every organisa two nanes, generic lof genus) and specific (of species). Later John Ray published his Methodus Plantaruff. The second volume of the Systemata had, Hogben says, the nost impact on science. Jung was also interested in the uriting of a standard -ized plant taxonomy. Hogben says the beauty of Linnaeus' systen is his " meticulous classification of descriptive terms to clarify his classificatory 1 system for plants." At the beginning of the second volume is a coaplete glossary of all adjectives used "(a) to label characteristics of different parts of a plant (b) to describe its habit, site and uses, if any." Another unique feature of the second volume reinforced the trend in scientific nomenclature, that of turning directly to Greek for vordbuilding, Linnaeus vrote in Latin, all the descriptive vocabulary is exclusively Latin but the names of all the major divisions of the classification systee have Greek roots "thus starting a nev fashion." He Was the first therefore to establish a specialized vocabulary and a PATTERN for using it.

If science consisted merely of naning then this grouth of scientific vocabulary would have sufficed but Lavoisier akes it clear why this vas not 50 . French academicians in 1787 published the Methode de Nonenclatures Chemigue

1.Lancel ot Hogben FRS, The Vocabulary of Science, Heinemann, London, $1969,0.24$.

2.Ibid. p.24.

3.1bid. p,24 
by Guyton de Morveau, Lavoisier, Berthollet and Fourcroy. What Lavoisier says on language is quoted by Hogben: Languages "are are not merely passive signs to express thought, they are also analytical systems by means of which ve advance from the known to the unknown and to a certain extent in the anner of athenatics... an analytical method is a language and a language is an analytical eethod..." He quotes from hila at some length and what he 5ays is very relevant to this thesis:

If languages are really instruments fashioned by wen to aake thinking easier, they should be of the best kind; and to strive to perfect them is indeed to work for the advancenent of science...this method which must be introduced into the teaching of chemistry is closely connected with the refor of its nomenclature. A vell-composed language adapted to the natural and successive order of ideas vill bring in its train a necessary and imediate revolution in the method of teaching, ve shall have three things to distinguish in every physical science: the series of facts that constitute the science, the ideas that call the facts to aind and the vords that express then. The vord should give birth to the idea; the idea should depict the fact.2

One could go into endless debate on these stateants in the light of present day thinking e.g. which cones first the word or the idea, what is a fact, what do we wean by 'mind' or 'idea', hovever Hogben believes that Lavoisier nay have been inspired by Linnaeus. This correlates vith Holton's viev which I shall refer to later, that metaphors can help to pass on ideas or germinate ideas in 3

later science, what Bergland calls the passing on of 'memes' or what 4

Korzybski calls our 'tiae-binding capacity'. An excellent exaaple of

1. Lancelot Hogben FRS, The Vocabulary of Science, Heinemann, London, 1969, p. 28.

2. Ibid.p.28.

3. Ibid.p.28,

3. Richard Bergland, The Fabric of Mind, Penguin Books, Australia, $1985, p .7$. The word comes originally from Richard Dawkins The Selfish Gene, Oxford University Press, Oxford 1976.

4. Alfred Korzybski, Sccience and Sanity, The International NonAristotlean Library Publishing Co., Pennsylvania, 1941, 2nd ed., p.39. 
which is given by Mary Hesse :

Galileo's success vas not due entirely to the inspiration of a solitary genius, for it is possible to trace his method of coabining experiment and theory back into the schools of the later Middle Ages in Oxford and Italy, and to trace his nev conceptions regarding motion back to the logical schools of Paris in the fourteenth century...., these early gropings tovards a nore adequate scientific method...... It took centuries to find the right principles and aethods of procedure...1

Hogben suspects that one reason for the grouth of a chenical industry in Britain, France and Sveden vas the diminishing of vood as a natural fuel source and the subsequent search for alternatives. Whatever the original reasons chemistry grev apace and with it the need for a revision of its language which Guy de Morveau did in 1781-2 vith specific instructions:

1.Every substance should have a name in contradistinction to a phrase.

2. Names should be given 'according to the nature of the things intended to be signified by then.'

3. 'When the character of the substance is not sufficiently known to deteraine the denomination, a name which has no meaning' is better than one which conveys 'an erroneous idea.'

4.For 'new denominations, those which have their roots in the most generally known dead languages' are preferable, so that 'the vord may be suggested by the sense and the sense by the vord.'

5. The denominations should be consonant with the structure of the natural language which accomodates thea. 2

Hogben believes that it vas the compatibility of the French and English language which created rapport between their scientists. The french went on, to define units of temperature, calories, litres etc, Lavoisier did not survive the Revolution but his ideas did.

Another form of labelling, known as eponywous, had sometimes been adopted by horticulturalists and also physicists. It vas the fashion of naning after people or what Hogben disapprovingly calls

1. Mary B. Hesse, Sccience and The Human Inagination, SCM Press Ltd.,London, 1954.p.32.

2. Lancelot Hogben FRS, The Vocabulary of Sçience, Heinemann, London, 1969, p. 32 . 
'ancestor-vorship'; forgiveable he says only where there is no known antecedent in classical language. Hogben never aentions aetaphors, only scientific vocabulary, as his ain is mainly to provide an easy key for nonclassical science students to understand scientific terms and their origins. His outline of the history of scientific terminology makes us ayare of the difficulties faced by scientists in having to baptise as it vere their foundlings, and the need for an internationally understood language to do this.

Theodore Savory has presented a siailar study of scientific 1 1 anguage and asserts that ve should be grateful to those who supply or suggest nev names for scientific phenomena, and agrees with Hogben that most scientific vords derive from Greece or Rome. Faraday appealed to Whevell for suitable vords to describe his results, and thus we got the terws 'anode' and 'cathode'. The scientist, Savory believes, has an advantage over the literary person because no emotion needs to be conveyed by his words, his words come from a necessity rather than choice. His terns and definitions must be clear because the dissemination of scientific knouledge is by the printed rather than the spoken vord whereas sost other areas of knovledge trace their origins back to the spoken vord. Pronunciation of scientific teras is consequently not unifora. Scientific vords also do not change their meanings [unless they are supplanted] as other vords change their associations in philological terms. In this respect he feels they come closer to the 'closed' symbolisa of mathematics. Some have described science as an eneny of language because of this static nature. Yet he agrees that vords such as 'utility' in wartime and 'atonic' more recently, have becone emotively charged in previously unforeseen vays.

1. Theodore Savory, The Language of Science, Andre Deutsch,1953. 


\section{English scientific vocabulary began says Savory with Geoffrey}

Chaucer and he lists references from his vork to illustrate this. Shakespeare by comparison has fev scientific references. The vords Chaucer used, such a5 salt peter, vitriole and agnesia vere taken from Latin and Greek. Bacon was the first to use the vords 'acid' and 'dissection' in their aodern 5ense. In his time the human body vas a focus of interest. The vord skeleton does not aean bones says Savory but comes from skelete literally 'dried up'. As science grew so did the study of senantics. Nenton's theory of gravity changed the aeaning of the word and later as the nature of light was explored the vord ether lost its old sense of the mythical atmosphere breathed by the gods.

One might ask where aptaphor fits into this scientific scene which seens so far to be concerned only with naning or catachresis, defined by Max Black as "the use of a vord in a nev sense to remedy a gap in the vocabulary," ${ }^{1}$ There is a sense in which every scientific vord is a aetaphor because it has been transposed from its original use to atch the scientific fact or object, that is, the vord is a bridge between the knoun or already naned and the 'new' that which already existed but is only nevly known or discovered. In this sense language is all aetaphoric as Nietzsche believed, for a vord as so sany have pointed out is only "the sign for the thing signified." Another name for Nev Zealand for example is Aoteorod aeaning land of the long white cloud, Both names refer to the same country but have different origins and referents. What the teras actually mean to individuals depends on innumerable factors including race, age, political

1. Max Black, Models and Metaghors, Cornell University Pres5, New York, 1952, p.32.

2. R.I.Aaron, The Theory of Universals, Clarendon Press, Oxford, 1952, p.16, 
and religious beliefs. The name is not the place and the place is not the name. Metaphor is really an abstract tern as one cannot adequately define aetaphor, only the aetaphoric, for each nev metaphor is unique. As for the single vord

.... a vord is a conventional sign and a conventional sign is only significant to an intelligence possessing a concept by which the significance of the word is established. In other vords as vell as a conventional sign there is also a natural sign or the concept. 1

Willian of Ockhan vho said this vas discussing universals but I believe what he says applies to metaphor also. He says a distinction has to be made between two kinds of terms 'terms of first intention' and terms signifying terms themselves and those are 'terns of second intention.' He says "the terms of natural sciences, for instance, are terms of first intention, those of logic are terms of second intention." He tend he thinks to confuse the sign and the thing signified. A metaphor is in this sense an intellectual abstraction.

Like Hogben Savory is concerned mainly with the lexis of science and does not explore hov scientific theories arise or hov they becone transaitted to other people. The scientist avoids figures of speech in his prose says Savory and attempts to use enotionally neutral vords. For this reason he resorts to the closed symbolism of mathematics vhenever possible as in the forsulae of chemistry. Yet an example of how a scientific term can be metaphorical is given by Savory when he says that the word 'automatic' derived from autos, self, became applied to any kind of movement which came from a cause within the noving object:

Thus the beating of the heart and the peristalsis of the intestine

1. R.I.Aaron, The Theory of Universals, Clarendon Press, Oxford, 1952, p.16.

2. Ibid.,p,16. 
vere autonatic. Fron this the phrase autonatic machines vas meant to iaply that the internal nature of the sachine enabled it to perfor its functions as if autonatically, that is to say it vas a comparative, almost a metaphorical description; and since a aachine reacts unconsciously and alvays in the sane vay to the stinulus which sets it going, the adjective acquired its present aeaning of unthinking--invariable. 2

Other writers do recognise metaphor in science. Burke for instance :

Indeed as the documents of science pile up, are ve not coning to see that whole vorks of scientific research, even entire schools, are hardly more than the patient repetition, in all its ramifications, of a fertile metaphor? Thus ve have at different eras in history, considered an as the son of God, as an aninal, as a political and economic brick, as a machine, each such metaphor, and a hundred others, serving for an unending line of data and generalizations. 2

An avareness of metaphor is important because of its presence as an 3

organizing element in enquiry says fernandez.

Some scientists not only acknowledge the usefulness of metaphors to their work but clain also to use a special type of netaphor. Exegetical or pedagogical metaphors help to explain theories such as 'electron cloud'. Such metaphors are an aid to visualisation but are not alvays particularly insightful. What Boyd calls 'theory-constitutive' metaphors do more than this, they act, as Kuhn has described, to establish fundamentally nev theoretical perspectives.

...metaphor serves as a non-definitional aode of reference fixing which is especially well suited to the introduction of teras referring to kinds whose real essences consist of coaplex relational properties, rather than features of internal constitution. 4

1. Theodore Savory, The Language of Science, Andre Deutsch, 1953, p. 69.

2. James W. Fernandez, 'The Perfornance of Ritual Metaphors', in The Social Use of Metaghor, ed J. D. Sapir \&J.C.Crocker, University of Pennsylvania Press, 1977, p. 100.

3. Ibid, p.101.

4. Richard Boyd, "Metaphor and Theory Change; What is "Metaphor" a Metaphor for?', ed.A.Ortony Metaghorer and Thought, Cambridge Univer si ty Press, 1979, p. 358. 
The wore interesting aetaphors Boyd believes are those for which there is no adequate paraphrase. There are exanples in cognitive psychology of references to coaputer-like husan attributes lin a previous age the aachine was a conmon analogys. Psychologists use vords such as 'progranaing' and 'feedback' because 'psychologists do not generally speaking, nou know how to offer literal parahrases which express the same theoretical ideas." This is illustrated by current debate over the tern "functionalism". The cognitive content of theory-constitutive aetaphors cannot be ade explicit. It is a perennial problem of course to describe nature in anything but human terns because of our oun nature. Even robots, computers and other man-made objects tend to be based either on an hinself or his mode of thinking. He are reminded once wore of our legs on tables and hands on clocks. Even computers have to sisulate the linear fashion in which man speaks and thinks.

These theory-constitutive metaphors become shared property among scientists whereas literary metaphors belong to their author's vork, even though the reader has his personal share in them that is generally a private concern, moreover the literary aetaphor once public rapidly becomes outdated or cliche or part of ordinary language. The scientific metaphors which Boyd speaks of are as he says more like conceits which other scientists explore rather as the literary critic treats those of the uriter.

The sciences in general, and psychology in particular, are selfreflective disciplines, and the explication of theoretical concepts-netaphorical or not--is an essential part of the task of scientific enquiry. 2

1. Richard Boyd, Metaphor and Theory Change: What is "Metaphor" a Metaphor for?',ed.A.Ortony Metaphor and Thought, Canbridge University Press, 1979, p.361.

2. Ibid., p. 362 . 
Boyd describes literary interaction metaphors as having CONCEPTUAL OPEN-ENDENDNESS "The function of a literary metaphor is not typically to send the informed reader out on a research project." Whereas theoryconstitutive metaphors display INDUCTIVE DPEN-ENDEDNESS. They are an invitation as it vere to "explore the similarities and analogies betveen features of the prisary and secondary subjects, including features not yet 2

discovered, or not yet fully understood." I think Boyd underestinates the pover of literary aetaphors for sparking inaginative thinking and further metaphor-making, but it is true that these sental processes go on wostly in private whereas scientists tend to work together in teans and in Iaboratories and in that sense their metaphors are common 'tools' to work with. Metaphors then can be invitations to research and "Theoryconstitutive metaphors...represent one strategy for the accommodation of language to as yet undiscovered causal features of the vorld" ${ }^{3}$ or in seventeenth century teros 'cut the vorld at its joints'. He wight equally have said that they are often initially 'guesses' which have still to be proved. Garrett has uritten of the process by which new ideas are born in sciance, He analyses it as having five stages: The problean, Frustration, Incubation, Illuaination (the flash of genius) and Verification. It is obviously at the fourth stage that metaphor plays its part.

It is in the nature of metaphorical language to be imprecise, non-

1. Richard Boyd, "Metaphor and Theory Change: What is "Metaphor" a Metaphor for?', ed. A. Ortony Metaghor and Thought, Canbridge University Press, 1979, p. 363.

2. Ibid., p. 363 .

3. Ibid., p. 364 .

4. Alfred B. Garrett, The Flagh of Genius, D.Van Nostrand Co. Ohio, 1962, p, 4 . 
referential and essentially heuristic as an eapiricist theory of language vould suggest says Boyd. His contention is that the teras of theoryconstitutive metaphors may refer even though they lack explicit definition, but this is not inperative. A general theory of non-definitional reference is therefore required for:

Scientific aetaphors raise truly fundamental issues about language and linguistic conpetence, and the theory of reference required to understand thee has several quite startling consequences, which are important both to an understanding of aetaphorical language, and to an understanding of language in general. We shall discover, for example, that there is, in an iaportant sense, no such thing as LINGUISTIC precision; there are rational strategies for avoiding referential anbiguity, but they are not a reflection of rules of linguistic usage, 1

Putnan and Kripke say that ve can refer to things by using "terminology which bears the right sort of historical relation to antecedent introduction ceremonies, or by employing stereotypical descriptions which look like 2 definite descriptions but are not." Field also suggests that there is a relation of PARTIAL DENOTATION between certain words and features of the world which is importantly like reference. In a sense languages have a history or genealogy. Putnan believes that a PRINCIPLE OF BENEFIT OF DOUBT is appropriate when assessing the reference of terms in the work of previous scientists, and A DIVISION OF LINGUISTIC LABOUR involving deference to scientists and other experts is essential to reference, So scientists are avare of the lack of precision and definition in the nature of their vork which is usually a collaborative effort. According to Putnam paradigns becone essentially true when accepted over tiae.

To Kuhn a paradign is not a theory but a disciplinary aatrix because

1. Richard Boyd, Metaphor and Theory Change: What is "Metaphor" a Metaphor for?', ed.A.Ortony Metaghor and Thought, Canbridge University Press, 1979, p.377.

2. 1bid.,p.377. 
it is composed of ordered elements. It is in a sense a metaphoric view of the vorld, it can never be 'true' or 'literal', Scientific education has alvays placed a heavy eaphasis on aodelling, acquiring of traditional modes of thinking and perceiving and requiring aininal personal interpretation.

All nodels have similar functions. Among other things they supply a group with preferred or permissible analogies and aetaphors. By doing so they help to deteraine vhat vill be accepted as an explanation and as a puzzle solution; conversely they assist in the determination of the roster of unsolved puzzles and in the evaluation of the importance of each,1

Each initiate learns the paradigas within which he or she will work. But even when learning these paradigms the student does in fact create his oun knouledge "Having seen the resenblance, grasped the analogy [uhich he has created for himself] betveen two or more distinct problems, he can interrelate symbols and attach them to nature in the vays that have proved effective 2

before." With practice he/she acquires the gestalt of the group or gains what Michael Polanyi calls 'tacit knovledge' learned by doing science rather than by acquiring rules for doing it. Kuhn believes that "our seeing a situation as like ones ve have encountered before aust be the result of neural processing, fully governed by physical and chemical lavs... recognition of sinilarity [which is the basis of metaphor] nust be as fully systeatic as the beating of our hearts." It might even be genetically laid down. Changeux is interested in what it means to have mental isages and in his studies of neural activity in the brain it seens to be that "We become conscious of the vorld by burning out the synapses that lead to

1. Thomas S. Kuhn, The Structurere of Scigntific Revolutions, University of Chicago Press.1962, p.184.

2. Ibid., p. 183.

3. 1bid.,p.194. 
mental inages inconsistent vith the vorld outside." He believes a kind of Darvinism operates in which only certain neuronal activities are stored and viable connestions are burned in by experience and learning, which vould account says Atkins for an individual'5 deep linguistic structure. We talk of knoving as seeing says Kuhn but ve cannot see electrons and have to be satisfied with a metaphor, He suggests hovever that eventually this will not suffice and in the long run it vill have to be eliainated in favour of a more literal node of discourse. This raises the question of how ve can do vithout aetaphor. He considers decisions about theory to be "ultimately personal and subjective, some sort of nystical apperception is responsible for the decision actually reached" for the human element cannot be eradicated; scientists he says aake choices based on a mutiplicity of human reasons and feelings. Translating a theory or vorld viev into one's ovn language is not to aake it one's own for it may be used vithout being internalized. The paradign passes on through the process of education. This conversion he likens to a gestalt suitch. The puzzle solvers play the game to new rules, they vork vithin a new paradign, their vision of the vorld is influenced by new aetaphors which vill also eventually be replaced. Kuhn largely agrees vith Boyd and says "Metaphor plays an essential role in establishing links betveen scientific language and the vorld." Metaphors change as the theories change. Science is a process of continual communication and dialogue breaking down old paradigas and creating new or partially new ones.

1. P.W.Atkins, 'No 5oul, and not Special', a review of Neuronal Man: The Biology of Mind by Jean-Pierre Changeux, Dxford, in London Review of Books 21 May 1987,p.18.

2. Thomas S.Kuhn, The Structure of Scientific Revolutions, University of Chicago Press, 1962,p.199.

3. Thomas S.Kuhn, 'Metaphor in Science', in Metaghor and Thought, ed.A.Ortony, Cambridge University Press, New York 1979, p. 415. 
Boyd overvieus all the theories in this field so far and proposes to analyse the notion of reference in terms of EPISTEMIC ACCESS, that is, the use of a tern vill have to answer the question "To which kind (or kinds), or property (or properties) or magnitude etc. does our use of this term afford us epistenic access?" As an example the tern DNA peraits scientists to report to each other to publish articles, promote criticisn and debate, and akes possible verbal reasoning. "The use of language nakes possible not merely the formulation of theories and publicity and cooperation in their assesssment; it adkes possible for reasoning (Whether individual or public) to be VERBAL reasoning: to take place in vords."

Boyd covers much of the same ground as Hesse in her work al though he has no reference to her. Epistemic access then is a feature of language use and synthesises most of the current thinking about the nature of scientific language. It gives the non-scientist also a route to understanding terms such as 'black hole' by giving accesss to the expert's knouledge of such a concept. Boyd argues that this is contrary to empirical vievs of concept acquisition in that the lay person does not have to acquire the concept 'black hole' for himself, he gains it vicariously as it were from those in the knov--it is available to him if he chooses to use it at vhatever level--and to learn more about it if he so vishes--it can become part of his language repertoire this stock of vebs and inages ] even though he aight use it with linited knowledge of its fullest meaning. So acquiring this concept 'second-hand' as it were shows that wuch of linguistic conpetence is not distinctly linguistic--but a general social and intellectual skill. Much of what is called learning in science is

1. Richard Boyd, Metaphor and Theory Change: What is "Metaphor" a Metaphor for?', ed.A.Ortony Metaghor and Thought, Canbridge University Press, 1979, p.383. 
just such acquisition, learning the jargon, the patterns, and never really getting to grips vith acquiring personal aeaning for oneself.

Once scientific discoveries have been ade it is not linguistic or scientific rationality which dictates the unique new referent for the tera in question says Boyd, but our need to accomnodate it to our causal structure of the vorld, it is a routine feature of the process of reference, and a routine response to the acquisition of new knouledge. New knouledge therefore is acceptance of new meanings at different levels of accommodation depending on whether one is a scientist or a lay person. Boyd concludes that:

If the articulation and refinement of a body of wetaphors all involving the same aetaphorical theme proves to be genuinely fruitful in scientific theory-construction, then the only epistemologically plausible explanation is that most of the relevant metaphorical expressions refer, and that the metaphorical statements in question -vhen interpreted in the light of the non-standard referents of their metaphorical terms--express important truths.1

And furthermore:

Reference is continuous if the ters in question continues to provide epistenic access to the same kind. Similarly, several roughly sinultaneous uses of some terms are coreferential if they are embedded in patterns of usage which afford epistemic access to the sane kind(s)?

The empiricist viev, since Locke has been that scientific terms and method are precise and this precision comes fron terms which are "associated with fixed, conventional, and explicit definitions of their extensions or referents"... and methods which involves "Precision in reasoning, careful experimental design, diligent reporting of data, proper control of

1. Richard Boyd, Metaphor and Theory Change: that is "Metaphor" a Metaphor for?', ed.A.Ortony Metaphor and Thought, Canbridge Univer sity Press, 1979, p.401.

2. Ibid., p.402.

3. Ibid, p. 403. 
experinental variables, precision in measurement." The first sort of precision in teras is a matter of following linguistic rules. When Black says that metaphors lack scientific precision, Boyd believes it must be because they fail to aeet the first of these empirical tests of precision. To Boyd there is no linguistic precision, there are no rules to follow.

Boyd's explanation makes one think of another metaphor, that this complex relationship is like the network of a large fanily tree where relationship is oeasured in blood ties, marriage etc. and what he does is show hov aetaphors bond ideas and link them sometiaes tenuously, as in fanily relationships, to others. If a metaphor becomes redundant or replaced by a never nodel then this analogy still fits as in disease, death etc. or in more extended family relationships. If 'no man is an island' certainly it begins to appear that no vord or metaphor is either, once in circulation it becomes public property and becomes, destroyed, popularised or refined according to human inclination and needs. If referents or ostension of general terms vere precisely fixed says Boyd they could not 'cut nature at its joints' as Hune and Locke realised -and in the epistemic access viev reference is a social rather than a private phenomenon. To cope with difficulties arising froe this Boyd says ve have to apply methodological principles of rational enquiry--not linguistic principles:

Assess evidence in the light of the best available GENERALLY accepted theory unless compelling evidence dictates its rejection. Rely on the advice of recognised experts. When your standards of evidence contrast sharply with those of others, seek to identify the source of conflict and so on.1

Boyd's approach is essentially a dialectical one.

1. Richard Boyd, "Metaphor and Theory Change: What is "Metaphor" a Metaphor for?', ed.A. Ortony Metaghor and Thought, Canbridge University Press, 1979, p, 405. 
Pylyshyn is not satisfied with Boyd's approach. He sees the functionalanalysis and systematic-reduction such as used in artificial intelligence and computing fields, which he calls a top-doun approach, as more useful and precise. He says "any setaphor which leaves one feeling that a phenomenon has been 'explained' even though only a superficial level of functional reduction of process explanation has been offered, is to my aind (presuabably also by Boyd's criteria) unproductive." This vould be true he clains of Boyd's example of 'demon' and Freud's metaphor of energy and flov--also of a large number of metaphors in cognitive psychology. Metaphors can be too comfortable he thinks--when accounts come to REST on then. He does appreciate that metaphor is "not unproductive of research.,. on the contrary the very intuitiveness of the aetaphor inspires a buaper srop of experimental research. What it does tend to inhibit, however, is the process of functional reduction." For him metaphors aake too many assumptions and what sight be a metaphor to Boyd could be literal to him. This same problem occurs of course in philosophy and literature,

Another problen with metaphor is that at first it vas considered to have no part in science--now it is recognized, there are adherents who see it as a pivotal part of science--others vho see it as only part of the process of discovey, of explanation and teaching--and some tho vould prefer to eliainate it al together because of its nebulous nature. There is nov enough evidence to prove that metaphor is intrinsic to science. It is as well to be avare of the dangers of aetaphor which Pylyshyn reminds us of and it wust be true as he says that there are metaphors which do more harm than good.

1. Zenon W.Pylyshyn, Metaphorical Imprecision and the "Top-Doun Research Strategy", in Metagher and Thought, ed. A. Ortony, Canbridge Univer sity Press, 1979, p.431. 
Boyd concludes finally that "there are no distinct principles of Iinguistic precision in science, but rather that linguistic precision is one of the consequences of aethodological precision of a quite general 1 5ort. A aetaphor should be used in science he thinks when an important siailarity or analogy exists between its priadry and secondary subjects. "The imprecision of metaphors does not preclude their employaent as constituents of scientific theories...they refer by virtue of SOCIAL and intersubjective (as opposed to personal) mechanisms, which connect scientific research vith independently existing (objective) features of the vorld,"

Dedre Gentner comes to similar conclusions about metaphors in science and says that "overlap in relations is necessary for the perception 3

of similarity between two domains." In complex analogies it ady be are difficult to identify the relations that are to be preserved and there may be several relevant relationships as in Ruther ford's solar systen nodel of the hydrogen atom. "A science analogy must be seen as a systen of sappings, not an undifferentiated set of predicates to be judged simply by their 4 correctness in isolation." Gentner uses the term 'analogy' to cover metaphor, siaile and model. The structural quality of a good scientific analogy requires bare specificity, usually this is something faniliar, and the internal structural characteristics require priarally clarity and richness. In expressive analogy such as we have in literature a rich collection of

1. Richard Boyd, "Metaphor and Theory Change: What is "Metaphor" a Metaphor for?", ed.A.Ortony Metaghor and Thought, Canbridge University Press, 1979, p.406.

2. Ibid, , p.406,

3. Dedre Gentner, 'Are Scientific Analogies Metaphors?', in METAPHOR Problens and Perspectiveges, ed.D.S.Miall, Harvester Press, Great Britain, 1982,p.111.

4. Ibid.,p.114. 
associations is valued whereas in explanatory analogy an abstract, vell clarified, coherent system of relations is valued. Gentner raises sone interesting questions as to whether the naive models of novices develop into those of the experts in stages parallel to those of the development of the topic and whether analogies start off rich and unclarified and become pared down. She believes that it is here that the creative process in science may be involved.

Martin and Harre think that "we need aetaphor because in sone cases it is the only vay to say what ve mean since the existing semantic fields of the current terainology referentially related to the subject in question are inadequate to our oun thought." They ake a clear distinction betveen a metaphor and a nodel or non-linguistic analogue:

\begin{abstract}
An object or state of afairs is said to be a model when it is vieved in terns of its relationship to some other object or state of affairs... if we use the inage of a fluid to explicate the supposed action of the electrical energy, we say that the fluid is functioning as a sodel for one conception of the nature of electricity. If, however, we then go on to speak of the 'rate of flow' of an 'electrical current', ve are using metaphorical language based on the fluid nodel. 2
\end{abstract}

This suggests that the model precedes the wetaphor, a debatable point as one 'thinks' the metaphor and then explains vith the nodel. Clive Sutton believes that "The model, just like the metaphor from vhich it is derived exerts a persuasive pover upon those who take it seriously. "It is true as Martin and Harre say that further metaphors 'spin off' the original one, and:

Speaking metaphorically on the basis of a nodel, a scientist is enabled not only to posit but to refer to theoretical entities by the use of teras which transcend experience in that their semantic content is not fully determined A PRIORI by the empirical conditions for their application. Meaning is not exhausted by the conditions

1. J.Martin and R. Harre, 'Metaphor in Science', METAPHOR Problegs and Persegctives, ed.D.S. Miall, Harvester Press, Great Britain, 1982, p.89.

2. Ibid, $p, 100$. 
of assertability.

Metaphor is necessary to science as they see it for:

The metaphoric employment of a term brings about a reordering of its senantic field, as vell as those of the tern with which it is used, so generating nev intensional contents, est of which are yet to be explorad.... realist construal of science requires predicates, of which those created by metaphorical usage of existing eapirical predicates are the very exenplar. 2

Lavoisier sould speak of 'facts' as if they vere divinely inatable but modern scholars doubt factual statements. Nietzsche said that physics was only an interpretation and arrangement of the vorld not an explanation of it and that all truth is a huan creation historically conditioned. Science constantly looks for order and patterns and tries to ake language fit this task but Ianguage has a personality of its own and does not always oblige. Words bring vith them their own life history, colour and associations. These san confuse the science expert as much as the initiate. They are inadequate tools for the complete understanding of science even metaphor which is a complex and sophisticated use of language cannot adequately express the nature of the universe. As van fraasen says "Acceptance of a 4

theory is not belief." We are linited by our own humanity:

Since Einstein we have to live with the truth that we vill never be able to understand coopletely the universe because the innate structure of our brain is inadequate to do so. Even Einstein, although he calculated vith the fourth diaension, was incapable of experiencing its reality. 5

1. J.Martin and R. Harre, 'Metaphor in Science', MEIAPHOR Problems and Persegctives, ed.D.S.Miall, Harvester Press, Great Britain, 1982, p.101.

2. Ibid., D.104.

3. Ibid, introduction p,xvi.

4. Bas C.van Fraasen, Inages of Science, University of Chicago Press, 1985, p. 281 .

5. Holmar von Ditfurth, 'Science Popularisation:Getting to the Heart of the Matter', UNESCO Eeatures No.754. 
This is seen as a positive factor by some people for it akes us more tolerant, less dogmatic and von Ditfurth believes it brings us to where a religious sense begins, a conclusion Mary Hesse vould concur with. She tells us that scientists should no longer hold a positivist view, even though wany still do, because "in the light of aodern physics it is no longer possible to regard science as a literal description of what exists in 1

nature." She believes that linguistic analysis gives us insight into the

nature of scientific neaning:

...scientific theories describe nature in teras of ANALOGIES drawn from familiar types of experience. The analogies nay be drawn from classical mechanics (as in billiard-ball theories of the aton), from pure athematics (as in much of adern physics), or even from voluntary human behaviour (as in aninistic and theological types of 'science'). Analogical description is not literal description as previous generations of scientists inagined, but neither is it entirely unrelated to the reality of nature. It oves its successs both to the fidelity to nature as revealed in experiments, and to the fertile inagination which selects appropriate analogies fron familiar experience and familiar types of language, and thus exhibits relations between one aspect of experience and another. 2

There is a groving avareness of the importance of metaphor in science, I.A.Richards said "even in the rigid language of the settled sciences we do not eliainate or prevent it vithout great difficulty."

Shibles found that "Whole philosophies and theories are seen to be expanded 4

metaphors." And David Miall came to the conclusion that "Philosophy, psychology, literary theory and science--all find theaselves challenged to define their scope and aims by this presence at the heart of their

1. Mary B.Hesse, Science and the Human Imagination, SCM Press Ltd, London, 1954, p.12.

2. Ibid., p.12.

3. I. A.Richard5, Phi10sophy of Rhetoric, Oxford University Press, New York, 1936, p. 92.

4. Warren Shibles in preface to Analysis of Metaghor in the Light of W. M_Urban's theories, Mouton, The Hague, 1971, p.10. 
activities this one phenomenon, metaphor.'

Shibles saintains that each philosophy, school of science etc. is based upon a nuaber of basic metaphors (he includes analogies) which are then expanded into various 'universes of discourse', Gerald Holton says one aight question this because in the face of reason and positivisa, "metaphors by definition are flexible, subject to a variety of personal interpretations, and often the results of an overburdened inagery."

Therefore they may be natural to the artist but not to the scientist, and he quotes Jurbayne as being critical of some of the aetaphors used by some scientists in particular Descartes and Newton, on Mechanism. But Holton is avare that linguists and historians have proved to us that metaphor is linked to our thinking ability. Holton speaks of our 'store' of metaphors which is inclined to make one inagine a mental thesaurus of metaphors such 3

as those described by Carol Clark in Web of Metaghor --but this is a misnower if we believe that the best aetaphors are products of 'nev' thinking.

Holton believes that "oodern science began with a quarrel over 4

aetaphor". In Book I of De Revolutionibus, Nicolaus Copernicus, speaking of his vision of the universe criticised those vhose theories portrayed lack of balance or aesthetic harmony which he sav as integral in such a Divine creation: "Yet the metaphor of uniform circular notion as the divine key for solving the problems posed by the phenomena--even in antiquity--had

1. David Miall, ed.METAPHOR Problems and Perspectives, Hunanities Press Inc., N. Jersey, 1982, p. xviii.

2. Gerald Holton, Metaphors in Science and Education, Chapter VII of Metaphors of Education ed.W.Taylor, Heinemann, London, 1984.p.92.

3. Carol Clark, The Web of Metaghor, Studies in the Imagery of Montaigne's Essai 5, French Forum Publishers, 1978.

3. Holton, p. 92 . 
infected the thinking from which the scientific revolution of the 1

seventeenth century cane." Such a metaphor as Holton points out is not merely one of Aristotelian transfer of neaning but what Sir Ernst Gombrich 2

calls "a restructuring of the vorld". Metaphors then can have profound and long-lived influence.

For a more recent example of the pervasive power of metaphor Holton cites the case of Thomas Young in 1804 and his ideas about the nature of light as a vave phenomenon--which is based on an analogy comparing light inpulse to sound vaves from organ pipes. This 'intuitive' leap, although it later proved urong, was remarkable in that he linked two areas of study formerly unconnected, but his study of sound and his observation of Neuton's rings had led hi to this remarkable conclusion. As Holton says one looks in one's students for evidence of such imaginative thinking--and he also describes this as "an examplar of the creative function of metaphor 3

in the nascent phase of the scientific inagination."

Other remarkable examples Holton cites are from Faraday's notebooks as vell as Fern and Maxuell. His favourite is one by Einstein described in his own handuriting as "the happiest thought of ay life" -that is pertaining to his theory of relativity in 1907. As Holton says "The urges to find analogies, and thereby to simplify and unify the various branches of a science, are actively at work in the background of the research of these

1. Gerald Holton, Metaphors in Science and Education, Chapter VII of Metaghors of Educationed. W. Tayl or, Heinemann, London,1984.0.94

2. Ibid.,p.94.

3. Ibid.,p.96.

4. Ibid.,p,96, citing an unpublished manuscript from about 1919 entitled in translation 'Fundamental Ideas and Methods of Relativity Theory, Presented in their Development' at the Einstein Archives in Princeton. 
1

explorers." It is particularly interesting that these are from personal notebooks and give us an insight into how that mind vas vorking at the tiue and how aetaphor becomes a vay of explaining sometimes to oneself--this is inportant. There is no sense here of ornament or substitution --the vords used mirror the aind at that moment in time. This is what wakes such notebooks so fascinating to read, one al wost enters into that person's thought PATTERNS. Teachers could perhaps share more in the thoughts of their pupils in science just as the journal writing in English has proved a fruitful area for teacher -pupil dialogue.

Lian Hudson finds sinilar evidence in his references to Hatson's account of the discovery of the structure of DNA ..." unless sone very special trick existed, randoaly twisting two polynucleotide chains around one 2

another should result in a mess." An interesting mixture here of aetaphor and idiomatic 5peech. And Garrett speaks of Thomson's 'raisin pudding' model to describe the aton as a atrix of positive and negative charges of electricity, which was prevalent until his pupil Rutherford came along.

Metaphor then in science as Holton discovers is sometines an expression of deep insight, of bridge-building--not all of which prove correct or productive but often part of a aovenent touards a solution. He finds another scientist with a similar vieu and quotes hio "Wherever one looks in the history of particle physics, one sees this maical transmutation, producing new theories fron old through a process of analogical

1. Gerald Holton, Metaphors in Science and Education, Chapter VII of Metagehors of Educationed.W. Taylor, Heineaann, London,1984.p.97.

2. Lian Hudson, Erames of Mind, Penguin Books,U.K., 1968. Hudson is discussing the differences in perception of convergers and divergers and is here illustrating with excerpts fron Watson's account of the discovery of the structure of DNA, in Hatson, J.D. The Double Helix, Weidenfeld and Nicolson, London, 1968. 


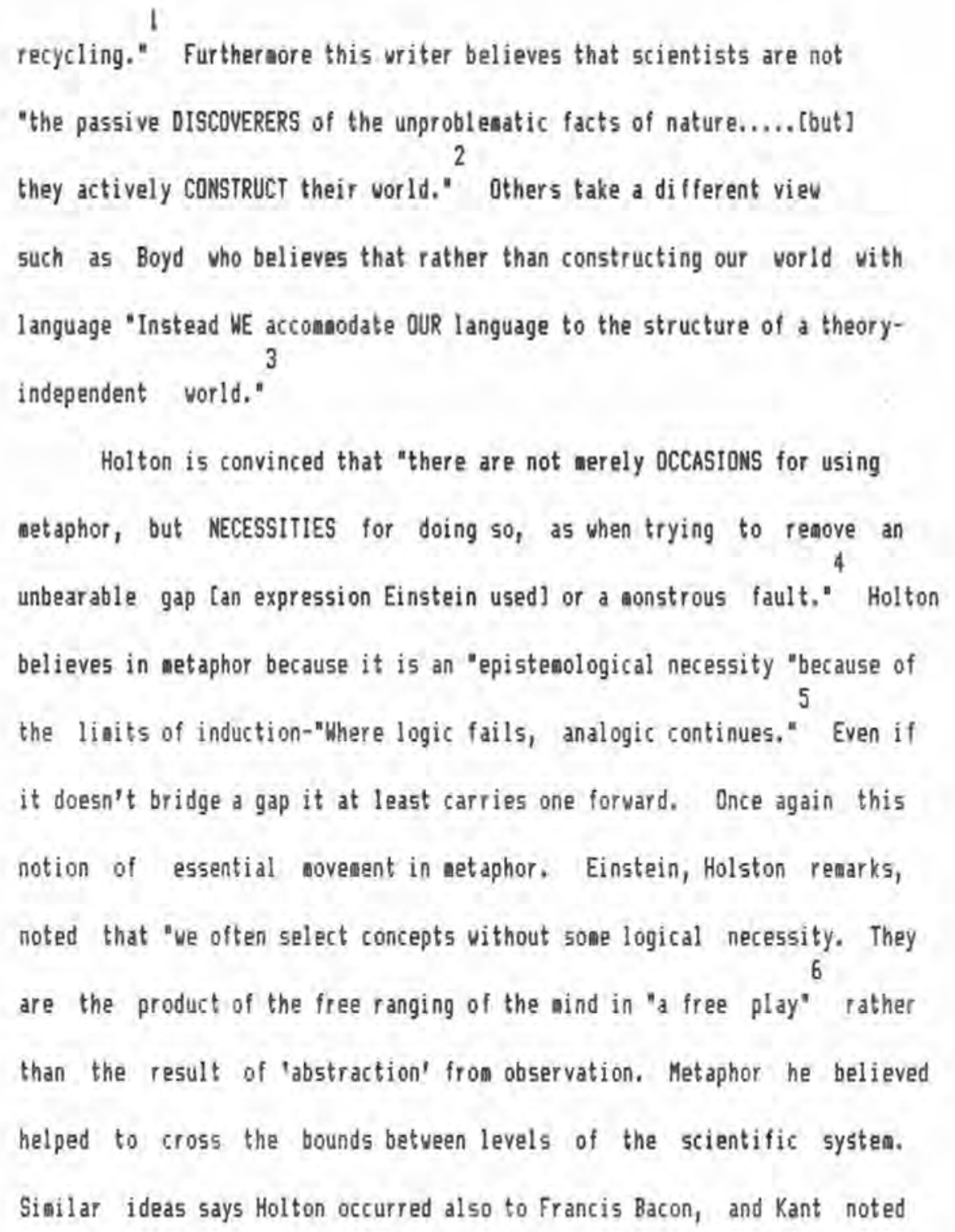

1. Gerald Holton, Metaphors in Science and Education, Chapter VII of Metaghors in Education ed. W. Taylor, Heinenann, London, 1984.p. 98. citing Pickering, A. (1980) 'Exemplars and Analogies' Social Studides of Science, 10, pp.497-508.

2. Ibid.,p.98.

3. Ibid, p.98.Citing David Boyd in Metaghor and Thought ed. Andrew Ortony, University of Cambridge Press, New York, 1979.p.408.

4. Ibid.,p, 98 .

5. Ibid., p. 98.

6. Ibid.,p.98. Quoting Holton,6. 'Einstein's Search for the Weltbild', Proceedings of the American Philosophical Society, 125(1), February 1984. 
that "the inagination does not distinguish between life-world experience and scientific experience, " Such experiences have even led scientists to describe ions for example as if they could be seen.

One very interesting observation Holton makes is a reference to Gombrich who said that "the linear character of language nakes it hard to hold in aind some concepts that become quite evident when put in diagramatic 2 form." This ade me think of the times vhen one resorts to diagrams to explain for example a coaplicated Shakespeare plot to a class or the vay ve portray ausic as notes on lines separate for each voice or hand yet ousic is not truly linear. It is perhaps the linear style of our language uhich holds us back...as it aust also be our vay of thinking. Marilyn Ferguson believes this is so:

We construct all our explanations on a linear model that exists only as an ideal... Seanticists like Alfred Korzybski and Benjanin Whorf warned that Indo-European languages trap us in a fragmented model of life. They disregard relationship. By their subject-predicate structure, they nould our thought, forcing us to think of everything in terms of siaple cause and effect. For this reason it is hard for us to talk about--or even THINK about--quantun physics, a fourth diaension, or any other notion vithout clearcut beginnings and endings, up and down, then and now. 3

Goabrich said "This aay be one of the psychological reasons for our instinctive equation betveen seeing and understanding." (We say "I see what you mean.") As Holton says "The constraints of the two dimensional surface on which to drav or print aust after all, affect our thinking

1. Gerald Holton, Metaphors in Science and Education, Chapter VII of Metaphors in Education ed. W.Taylor, Heinemann,London, 1984.p. 99.

2. Ibid, ,p.100

3. Marilyn Ferguson, The Aguariann Conspiraçy, Granada, Great Britain, 1982, p.160.

4. Holton,p.100.citing Gombrich,E.H.1972 Symbolic Inages: Studies in the Art of the Renaissance, London: Phaidon. 
constantly." Cicero too is quoted: "The metaphors dravn fron the sense of

sight are much more vivid, alaost placing before the mind's eye vhat ve 2

cannot discern." Holton says that a catalogue of scientific metaphors vould include many "visualizable metaphors and ...anthropomorphic and folkloric metaphors. Human life, the life cycle, and human relationships pervade, in sometimes only slightly disguised form, the most sophisticated scientific papers, and aore so, our textbooks." Which immediately aakes one think that hunting for these and discussing then could be an interesting exercise for students.

Never sciences Holton says borrow their metaphors fron the established sciences yet they have draun then fron basic human experiences. 'Body' metaphors he says are common [Carol Clark found these were often 4

applied in politics] and he 5ays as Macrae points out "our experience of 5

our bodies is prescientific." [This can only mean that the label science

did not exist]. Because science is constantly changing so it constantly needs new language and new metaphors to describe new things or events or to replace old ideas and as Holton says the search for the nev often borders on the tasteless. He senses a aove from metaphors of order and haraony to more destructive levil?] connotations. As he says "It is indeed the terninology of a restless, even violent, world, " On the contrary I keep

1. 1.Gerald Holton, Metaphors in Science and Education, Chapter VII of Metaghhors in Education ed. W.Taylor, Heinemann, London, 1984. p. 105.

2. and3.tbid., p.100.

4. Carol Clark, The Web of Metaphor, Studies in the Imagery of Montaigne's Es5ais, French Forum Publishers, 1978.

5. Holton, p. 101.McRae, D. G. (1975) 'The Body and Social Metaphor'in Benthall, J, and Polhemus, T, The Body as a Medium of Expression, London, Allen Lane.p. 67.

6. Holton, p.102. 
finding evidence of recurring isages of light and patterns which is why 1 have stressed or emphasised these throughout this vork vherever they occur in my findings. Perhaps even with metaphors one only sees what one is looking for.

Holton is avare also of the 'metaphoric' state of the student in the science classroom, head full of preconceived notions and metaphors, of which he/she is largely unavare--some peculiarly his/her oun, sone of them part of the folklore of the tiee and place one lives in. The richness of metaphor in science (some examples he gives are; big bang, inertia, negative feedback..) may be effective tools for the scientists, but "pathetic 1 fallacies for students." This is a neglected area in metaphor study, the tvo-way process involved between the metaphor-aaker and the aetaphorunraveller, there has to be an area of shared understanding, of common knovledge and assunptions before a metaphor is meaningful. This is the area where knowledge can be transaitted, where learning and teaching can take place. There seems to be insufficient evidence as to the effects of aetaphor on the listener-receiver. For example when Berggren refers to Marvel's "green thought in a green shade" as an example of an effective poetic schema, we can take it that he and presumably other literary critics or philosophers vould accept this as a metaphor. What is unknoun to us is exactly what Berggren visualizes or [wary of Richard's admonition about Literally 'seeing'] what Berggren thinks about vhen he contemplates or reads this metaphor. Just as interesting would be to know what Marvel's thought processes vere as he constructed this attractive line... and what

1. Gerald Holton, Metaphors in Science and Education, Chapter VII of Metaghhors in Education ed, W.Taylor, Heinemann, London, 1984.p. 102.

2. Douglas Berggren, The Use and Abuse of Metaphor, 1 , The Reviene of Metaghysics, Volume XVI, No, 2 Issue No.62,p.248. 
every reader since has thought. This ve nay never know, but ve need aore research into the effects of sose such lines. So often in literature the 'right' interpretation is 'fixed' by the literary critics who are revered and respected in natters of standards and taste. Too much 50 perhaps. Some readers and teachers are so iabued vith the standards and beliefs of their oun teachers that they are fearful to state their oun opinions. There are some tho vill go so far as not to teach e.g. a Shakespeare play they have not 'done' before, because they have not been taught what to think and say about it. One vonders if sinilar things happen in science, whether certain ideas or theories get misrepresented or onitted froa school curricula. Contentious issues such as theories of evolution vould obviously reflect different vieupoints and no science teacher could possibly keep abreast of everything new in science.

If one reflects on what Turbayne says about metaphors and myths--if ye recognize that myths are untruths about truth which are difficult to explain of understand in ordinary language then several possibilities eaerge... they cater for 'siaple' intellects for whon the truth vould be too difficult to understand; there is no truth therefore ve lie (or mythmakers or those in pover do) about phenomena we cannot understand; or people are deliberately aisled because those who know the truth (have seen the light?) do not really want others to do the sane. Syabolisa of ayths and metaphor then becomes a way of preserving elites. Such is the effect of the metaphors in some aystical poetry such as described by Lutfi Abas.

Margaret Mead believes that the public is scientifically illiterate because 'key' metaphors are not shared. She also noticed that

1. Lutfi Abas, Symbols in Kemala's Poems:A Study of Signs in Mystical Poems insemiotics Unfolding ed. Tasso Borbe, Mouton, Ansterdam, 1979 pp.681-688. (Described in more detail p. 142 of this study.) 
scientists ainly talk to other scientists, and it may be true to say that one's language reflects and reveals one's vorld viev. Searle also has much to say on this, This area of difficulty is highlighted Holton believes by the vork of such people as R. Horton on African Thought. Holton examines soae of the conaon metaphors of science including a particularly interesting one relating to the TASK of the sciences i.e. their function, and here he finds the most dynamic one to be that of "the nountaineer gradually ascending, and thereby gaining not merely the conquest of the peak, but the aesthetic, largely visual thrill of an OVERVIEW, encompassing the vhole circular arga below, from horizon to horizon, and, in the unearthly stillness at that high altitude, seeing at a glance the vay the details of the landscape below fit together in one meaningful picture." This is the sane metaphor I used ayself in introducing this vork but one which occurs in other vorks 2 such as The Conscious Use of Metaghor in Qutward Bound by Stephen Bacon in which he considers the philosophy of that type of instruction a paradign which is "truly holistic" and in which he sees the individual's struggle with the vilderness as a parallel to the human search for the subline. Also in Richard Bergland's The Fabric of Mind he sees the intellectual pursuit of knowledge as metaphoric expedition or exploration as T.H. Huxley who said in 1887 "The known is finite, the unknown infinite; intellectually ve stand on an island in the middle of an illimitable ocean of inexplicability. Our business in every generation is to reclain a little more land."

1. Gerald Holton, Metaphors in Science and Education, Chapter VII of Metaphors in Education ed. W. Taylor, Heinemann,London, 1984.p.106.

2. Stephen Bacon, The Conscious Use of Metaghor in Outuard Bound Colorado Outuard Bound School, Denver, Colorado, 1983.

3. Richard Bergland, The Fabric of Mind, Penguin, Australia, 1985, p.6 citing Huxley, T.H., Collected Essays, Macaillan,London, 1906. 
Bergland speaks of pitons of progress as vhen mountaineers wark their routes, and of standing on the shoreline of vonder. He is aware that "A special kind of tension at once links us to and separates us from our intellectual institutions." It say grou from this: "you and I are meant to find new 'truths' at the shoreline; the institutions are supposed to keep 1

the truths at the centre." His new paradiga is that the brain is a gland not a repository of electrical impulses but a horsone secreting gland working in cohorts with the other glands of the body; I vas going to use the vord harmony, in a state of health this vould probably be aore correct. He is avare that his view vill be resisted by the scientific establishment as nost 'new' ideas are resisted until in Kuhn's terns a paradign shift occurs. In his book he stated:

Without comaitment to a paradign there can be no science... the study of paradigas is that prepares a student for neabership in a particular scientific conaunity. Men whose research is based on shared paradigms are conatted to the saee rules and standards for scientific practice. ..scientific revolutions are inaugurated by a growing sense that an existing paradigm has ceased to function adequately in the exploration of an aspect of nature." 2

This human desire and need for the vision, the holistic sense is what draus people to meditation to the search for a sense of unity with nature for the aeaning of life. For a time people believed science aight offer answers to questions which religions never seemed to satify. Now more and more there seeas to be a sovenent tovards a combination of all three. Literature vicariously explains or mirrors life but there is a sense in which literature is all lies, art also goes some vay to appeasing this internal desire for aesthetic or spiritual harmony. There are some who find the most satisfaction

1. Richard Bergland, The Fabric of Mind, Penguin, Australia, 1985, p.6.

2. Ibid., quoting Kuhn,T.S., The Structure of Scientific Revolutions, University of Chicago Press, 1962. 
in mathematics or in music. Whatever the pursuit there is a common thread, that is the search for pattern, for order or at least a recognition of this where it seems to exist and a drive to establish it artificially as in taxonomies etc. Language gives order to thought or is it the other vay about, which does come first the vord or the idea? There is a spate of literature now trying to give us this holistic viev e.g. The Aguarian 12

Conspiracy, Ihe Iurning Point. The difficulty in teaching is to bring young people as rapidly and painlessly as possible to this point universally and yet give then tiae and space to learn by and for theaselves and to arrive at this level naturally; also for them to question our paradigas and to reflect on possible new ones. The amount of scientific knouledge nov must be vast compared with that of a century or even a decade ago. He surely do not vant to force or pressure-feed youngsters so we need expert methods which do not waste their tine and yet develop skills sequentially or in tempo vith their aaturation. This is not an easy task-it surely means also that we have to look at learning as a vhole not merely within subject boundaries. More and aore ve need to read, urite and think across subject areas, not simply vithin them. There is no reason why poems cannot be uritten about gases and atons and why art cannot study scientific model5. Each individual needs to develop his or her ovn view of the vorld. The physicist says he is searching for the harmony which links all the phenomena he observes. Holton calls this the metaphor of the Weltbild-which can be traced from Goethe, Schleiernacher and Alexander von Humboldt.

1. Marilyn Ferguson, The Aguarrian Conspiraç, Granada,U.K.,1982.

2. Fri jof Capra, Ihe Iurning Point, Fontana, London, 1983.

3. Gerald Holton, Metaphors in Science and Education, Chapter VII of Metagehors in Eduçatzion ed. H.Taylor, Heinemann,London, 1984.p.107. 
What all seem to be striving for is a 'Grand Unification Theory' John Ziman revieving Holton says "Unification is the Supreae Project of Science, metaphysical and religious in inspiration." ${ }^{1}$ Holton says tvith slightly ironic tonel that scientists have even been known to lapse into poetry on this matter. He sees the recurring wetaphors of science as circles ever increasing, joining, rising, as linked to the dominant 'mountain-climbing' metaphor. The latest advances on this unification theory vere reported after a recent 300th Anniversary to celebrate Newton's work. It is now thought that the elementary constituents of the universe are nothing but different aodes of vibration of tiny string-like 100p5, called "super-strings"--a new aetaphor.

Perhaps the nost surprising finding in studies of scientific vork is the close resenblance to things norally described in the real of religion. Holton quotes Einstein uho said: "The state of feeling which makes one capable of such achievements is akin to that of the religious vorshipper or of one who is in love; his daily strivings arise from no deliberate decision or programae, but one of iamediate necessity," An exalted aspiring state--is this what drives scientists--if 50 how are we to develop this joy, this excitenent, this love, this sense of vonder and thirst for knouledge [visdom?] in our students? I an reminded also of the vords of Dr Paul Brunton: "Scientists aay lead the way from sheer materialis into the discovery of the Spiritual Self. If they continue to investigate they vill ultiately find the Truth, for there is nothing else

1. John Ziman, 'What shall we look into now?', London Reviegy of Bogks, 21 May $1987, p .16$.

2. Gerald Holton, Metaphors in Science and Education, Chapter VII of Metaghors in Education ed. W. Taylor, Heinemann, London, 1984.p. 109.

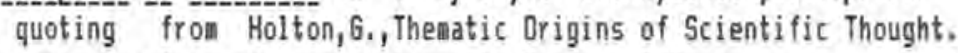
Cambridge, Mass.; Harvard University Press.p.378. 
they can find. Their path is getting narrover and narrover that aetaphor again! I. It is leading then inescapably tovards the Spirit."

Holton sees metaphors such as he has described as serving four functions :

1. To serve the individual privately.

2. To serve the circle of the indoctrinated.

3. To serve both of these and the wore ignorant public

4. Chiefly to serve the nore ignorant public.

Writers I have aentioned such as ferguson and Capra are doing wuch vork in this fourth area. To share what Holton calls 'key metaphors' of science is a difficult task. This perhaps leads into a rather sensitive educational sphere. From Plato's tiae on the problea has been how aany elite can fit on this metaphoric mountain top--can ve all make our way there? If this is desirable how do ve achieve this equality of outcoae? The scientist clearly has a duty Holton believes, to be avare of the "metaphoric distance" betveen himself and his colleagues and students. Metaphors need to be used with care for they can be as aisleading as they can be meaningful. A clear example of mis-learning can come unintentionally from practical demonstrations also, says Holton, reducing information to media style presentation in order to teach and communicate, can seriously adulterate the original concept. Any examiner is faniliar vith learned but misunderstood concepts. For this reason Holton prefers the lively personal presentation. An interesting anachronism in these days when other people are urging more use of e.g. computer and programed instruction. He sees a clear importance

1. Dr Paul Brunton, The Inner Realitity, Rider \& Co, London, 1970, p.113.

2. Gerald Holton, Metaphors in Science and Education, Chapter VII of Metaghors in Education ed. W. Taylor, Heinewann,London, 1984.p.110. 
in the personal dimension and the place of discussion. From his ovn observations he has seen that "the sore successful denonstrations are actual happenings .... a personal comitment..., is the [necessary I element," What he does not oention which is probably just as important is the discourse which is usually available in live perforances--and, as he says:

The scientist-educator of course negotiates easily the jump betveen the ground metaphor and its debased forms that actually come to the eye in the classroon. [via films, charts, diagrams etc.] But the nev student may not be able to follow hin in aking this leap, the more 50 as usually nothing is said about any necessity to make one, 2

This is a tinely warning for all teachers. There is still a need for 'bridge-building'--the person who helps us, who truly teaches, oves between the 'tenor' and the 'vehicle' the 'focus' and the 'frane' of the metaphor; sonetimes to help us construct our oun personal metaphors of underst anding.

This is where metaphors are useful to science particularly in the need for explanation. Berggren agrees for he says that an intelligible explanation must be vitally metaphorical and here no less than in poetry stereoscopic vision is essential and "the better or aore generally explanatory a theory is, the more extensively metaphorical it has becone." What is perhaps rarely explained to children is the fact that metaphor 5 are part of science as they are of literature.

Holton says that Gombrich has pointed out the difficulty which the priaitive mentality has in distinguishing betveen representation and symbol

1. Gerald Holton, Metaphors in Science and Education, Chapter VII of Metaphors in Educationg ed. H. Taylor, Heinemann, London, 1984.p, 111.

2. Ibid.,p.111.

3. Douglas Berggren, The Use and Abuse of Metaphor,11, in The Reviege of Metaphysics, Vol.16, pt.3, 1962,p.460 
1

Sperber explores this. Holton's vien of netaphor is :

In what I have said, I have associated nyself with BOTH of two competing vievs of metaphor: I see metaphor acting sonetines as a aeans for the transfer of meaning across discontinuity, as a bridge or boat is a means for transferring a person across a river; lthis in itself is a dominant literary aetaphor ] or, in other cases, as a more active tool of aetamorphosis, of a restructuring of a portion of the vorld vieu.ln either case, the wetaphor has explicit or implicit boundaries. Since the metaphor is alvays contingent on the context, its boundary vill also change as the context shifts... But while the detailed shape and pover of a metaphor changes, I see a constancy that endures, and that I regard as the thematic centre of the setaphor.2

So myth and metaphor are a necessary part of the mystique of science, what Holton calls the aythopoeic function and he calls on Turbayne to support his view: "[Be] avare there are no proper sorts into which the facts aust be 3 allocated, but only better pictures or better metaphors."

Sorting things out, aaking patterns, finding links, making sense out of nonsense, this is vhat aetaphor and science is about. Making aistakes, getting things wrong, unlearning and relearning is part of an individual's groving and learning experience just as it is a part of science. Most of us have grown up believing that to be 'scientific' is to be clear, precise, logical, unemotional, objective and zealous in the perpetual pursuit of truth. Scientists are often portrayed in literature and filas for example, as coldly clinical, living in a vorld of esoteric beings who speak a language barely understood by ordinary mortals. In recent years science has come to be identified also vith the creation of a frightening environment in which not only deadly organisms are stored and classified

1. Dan Sperber, Rethinking Syabolism, Cambridge University Pres5,1975.

2. Gerald HoIton, Metaphors in Science and Education, Chapter VII of Metaghors in Education ed. W. Taylor, Heinemann, London, 1984.p.112.

3. Ibid, p.113 citing Turbayne, C.M. (1962), The Myth of Metaghor, Conn.: Yale University Press.P.217. 
but in which an's ability to travel in space, to manufacture ultinate veapons of destruction and even to play God with husan genetics has further removed and elevated scientists as something akin to superhuman or inhuman, good or evil, depending on one's point of view. Dur increasingly 'scientific' vorld especially the technology of human comunication systems has further heightened this sense of the pover of science. Brock Utne has uritten on this in particular:

Nature is regarded as feninine, and the scientific quest as an essentially virile, asculine adventure vith penetration as the key to anly success... in Bacon's vords "conquer and subdue her and (even) shake her to her foundations." 1

Scientists she says speak of 'mastering' nature and science has become a dogaa just like Christianity. She considers that they thrive on competition as auch as any soldier and the reason why they are insensitive to social responsibility is because as John linan says they acquire a set of ideas that aakes them part of a cult. They can become so obsessed with enquiry they lose sight of ethical considerations. Like Virginia Woolf she thinks that our compartmentalisation of knowledge is partly to blame. We know that our language structures our viev of the vorld and our concepts therefore betray our attitudes and beliefs and nould our behaviour. For instance as Brock-Utne says the concept of vork in Marxist teras ignores the vork of vonen. Likevise vomen are beginning to question male concepts of 'security' and 'defence' as vell as 'science'.

Yet'science'is also about searching and about learning. It is in every childhood question "Why ?", in every thoughtful gaze in wonder at new Iife, at beauty in nature, and in the struggles to solve problems in ordinary everyday situations. The science already known to us has helped us

1. Brigid Brock-Utne, Chapter 4'science, Higher Education and Peace Research', Educating For Peace, Perganon Press, 1985, pp111-142. 
understand our environment and ourselves, we use it al 50 to understand the past and to try to predict the future. Defining science is not easy now but in 1858 William Wheuell could say with authority:

The sciences to which the name is most comonly and unhesitatingly given, are those which are concerned about the material world; whether they deal with the celestial bodies, as the sun and stars, or the earth and its products, or the elements; whether they consider the differences which prevail anong such objects, or theif origin, or their mutual operation. And in all these Sciences it is faniliarly understood and assuned, that their doctrines are obtained by a comson process of collecting general truths from particular observed facts, which process is terned INDUCTION. It is further assuaed that both in these and in other provinces of knowledge, 50 long as this process is duly and legitioately perforaed, the results will be real substantial truth. 1

\section{2}

He even spoke of "doctrines of solid acknowledged certainty" yet when ve look to a more modern philosopher of science there is a much less certain tone. Mary Hesse vith a more holistic viev than Hogben shows hov an alternative view has been established with the aid of philosophy, of social science, herneneutics and the sociology of knovledge. In her early vork Science and 3

the Hunan Imagination she traces the development of scientific thinking particularly the theories of planetary wotion and how they developed and how new knowledge vas treated by science. According to Hesse our thinking has been strongly influenced by the Greek philosophers to whon a life of conteaplation was the ideal as an's most noble faculty was his reason. The aaterial vorld vas regarded as in sone vay a linitation or corruption of the perfect world of for and spirit so their aim vas to cultivate the soul to dwell on Perfection--which vas to be found in the static and unchangeable features of the vorld. Contemplation therefore favoured

1. William Whewell,D.D.,History of Scientific Ideas Vol,1,J.W.Parker and Son, London, 1858.p.4.

2. Ibid.,p,3.

3. Mary Hesse, 5ciencce and The Hunan Imagination, London, 1954. 
athematics and astronony and cultiyated the belief that the heavenly bodies vere "divine, eternal, uncorruptible and unchanging." Practical work and experiments vere not favoured. When this era went into decline because not everyone aspired to the ideal life of philosophy people turned, says Hesse, to religious aystery cults from the East. History like the planets vas assuned to go in endless cycles. Christianity brought new hope and purpose, she believes, either denying the main assumptions of Greek thought or re-interpreting thea.

According to Hesse the new religion was the Hebrew religion of the old testamant--the nev church was to early christians the New Israel--and we have still not worked out, she thinks, the adjustment of these two vieus of 1 ife--the Hebrew faith and Greak philosophy which still held sway up to the seventeenth century in watters of science.

Augustine is acknowledged as the aain influence in assimilating Greek learning to Christian theology--but for hin the earth was to be studied not merely as contemplation and knouledge for its ovn sake but to assist in the vorship of God. This was a period coping also with wagic and astrology, In her vords natural science became the 'handmaid of theology', and it becane usual to "look in nature for allegories and synbols 2 of the divine activity." She quotes Michael Roberts on this type of analogy:

The four-element theory for example, was of very little value for the purposes of cheaistry or engineering, but it possessed one great merit which our ninety-odd element theory does not: it gave an account of the facts of cheaistry which was at the same time an allegorical picture of the realities of the spirit. The relations of earth, dir, fire and water, it seemed, corresponded in some vay

1. Mary B. Hesse, Science And Ihe Human Imagination, SCM Press Ltd., London, 1954.p.16.

2. Ibid,pp.19. 
to the relations of body, spirit, intellect and love. The facts of cheaistry, expressed in such terms, were subjects for the poet, and science, philosophy and poetry vere often one.... it is difficult to say whether the vorks are to be taken as narratives of chemical experinents, as allegorical norality, or as sybolic poetry, or as a combination of all three ....Even today, ve find ourselves talking of the vorld of religion and art in netaphors and analogies related to a chemistry or physics which ve know is obsolete. 1

As Hesse says, mediaeval scientists seened to trust Greek and Latin vriters and did not try to verify their stories of birds and beasts with direct observations of nature at first but she sees evidence of sculpture dravings and illuminated manuscripts beconing increasingly naturalistic as time vent on. Like Hogben she traces an iapetus and stimulus given to knowledge from the Arabic versions of Greek texts once they became available. Now Arisotle's vork becane aore widely known and something of a threat to the church which Aquinas nanaged to avert by velding the two systeas of thought together, to the detriment of science Hesse believes and which confirmed "Aristotelian cosaology as the world view of the educated man... whilst for ordinary people the Christian drama of redemption vas the unquestioned framework of their lives, and they represented it in terms of an astronony which vas more Greek than Christian." Consequently their 'vorld' vas shattered by the rejection of this in the sixteenth and seventeenth century. Hesse explains the influence of this cosmology--for the Greeks:

The only motion worthy of divine beings was conceived to be circular motion and the ast perfect body.... is spherical, therefore the heavenly bodies and the earth must be perfect spheres... In the heavens motion vas naturally circular... on earth and in the regions below the moon motion vas naturally up and down in straight

1. Mary B. Hesse, Science And The Human Imagination, SCM Press Ltd., London,1954.p.20, citing Roberts, M., The Modern Mind, London, 1937. Hesse also adds a footnote to the effect that an example of Robert's last point can be seen in Little Gidding by T.S.Eliot.

2. Ibid, ,p.22. 
lines...the earth being at rest at the centre of the vhole system.

In the heavens atter vas called 'aether' which was considered eternal, unchanging and incorruptible. On earth vere the four eleaents earth, vater, air and fire--all in ceaseless flux and instability. Anyone who questioned this belief vas in fact a heretic--and for such yas Anaxagoras exiled from Athens in the time of Pericles. The difficulty of accepting such divinities uas nitigated for the Christians by acknouledging that God had created these heavenly 'divine' bodies..

The source of a force to create novenent vas never adequately explained except in teras of 'spirits' and 'invisible angels'--and heaven was considered to be out in space and hell in the bovels of the earth. Dante's Divine Comedy portrays just this belief systen (1314). It yas also believed that the aovement of the planets created ausic. Hesse is not averse to this 'mediaeval' notion that nature is synbolic of religious truths and vonders why we do not believe that "science is given to men that they may glorify God through His work and that they may use it for wan's good."

The alternative theory to that of Aristotle was Ptolemy's theory of epicycles (A.D.150) which originated in the work of Hipparchus of Rhodes in the second century B.C., but because this included the earth as one of the planets it yas considered impious, so Aristotle's theory was almost universally accepted throughout the Middle Ages as providing the 'true' description of the mechanics of the universe. Some "reconciled the two systems by thinking of Ptolemy's epicycles not as descriptions of real

1. Mary B. Hesse, Science And The Human Imagination, SCM Press Ltd., London, 1954.p.23.

2. Ibid.,p.27. 
motions, but as atheaatical fictions, only useful for purposes of 1

calculation." This vas the status quo until Copernicus vhen "as one suddenly sees the solution of an anagran, or the rearrangenent of the kaleidoscope, he sav the tremendous sioplification which vould result from giving the earth rotation on its ovn axis, and revolutions about the sun. ${ }^{2}$ The novelty of this idea vas difficult to accept and little advance vas ade until Galileo (1564-1642) who has been described as the first scientist of the modern age, by combining mathematics and the use of a telescope. I have referred previously to Hesse saying that such methods conbining experisent and theory can be traced back to the later Middle Ages, her point being I believe that ideas such as this do not come from a vacuun. She speaks of "these early gropings touards a more adequate scientific method... it took 3 centuries to find the right principles and aethods of procedure." Galileo did however supersede the Aristotelian system. Galileo's uethod was to "idealize the real vorld, and then a first approxiation had been ade with ideal conditions it is then possible to come back to reality and correct some of the errors due to factors which have been left out." This method says Hesse became the dominant one in science and the pursuit of knowledge generally,

Following Galileo, Descartes foraulated a law of dynanics that "a body under no forces describas a straight line with uniform velocity" --which still left the ootion of the heavenly bodies unexplained--until the

1. Mary B. Hesse, Science And The Human Imagination, SCM Press Ltd,, London, 1954. p. 30.

2. Ibid.,p.31.

3. Ibid.,p.32.

4. Ibid.,p.36.

5.Ibid.,p.36. 
postulation of elliptic orbits by Kepler. How he reached his theory is "a curious illustration of hov things happen in the early stages of science" Because he believed the sun to be the most agnificent body in the universe he proposed, on false preaises, that the sun forces the planets around rather as the spokes of a wheel push round its rian, thus creating the first step towards Neuton's theory of gravitation that the curves described by the planets are ellipses.

Seventeenth century scientists of the nev Royal Society in London were still puzzling over this problen of the heavenly notions when Neuton told the he had already solved it, which when published gave us his Principia Mathematica in 1687:

For the first time a single simple hypothesis--that of gravitational attraction--yas capable of explaining both notion of inaninate bodies on the earth and the eotion of the solar system. This vas conclusive proof that Aristotelian physics and Aristotelian cosnology were inadequate, together with the whole theory of the heavenly and sublunar regions, the ausic of the spheres, the pictorial representation of heaven and hell and the rest of the imaginative vorld picture of the Middle Ages. In its place a nev cosmology based on Neutonian mechanics began to eamerge, a cosmology which has been called the 'billiard-ball universe', in which reality was conceived solely in terns of particles of matter moving under their mutual gravitational attraction and colliding with one another in an infinite threedimensional space. 2

It becomes evident that science is closely linked to man's view of himself and his universe, his place in it, and his beliefs and it becomes clear that each 'advance' in knowledge is built on the thinking of previous people and their theories and also how crucial it is that these are accepted by one's contemporaries. Also apparent is the way man has learned gradually to combine observation, language, historical knouledge, iagination, use of

1. Mary B. Hesse, Science And The Human Imagination, SCM Press Ltd., London, 1954.p. 37.

2. Ibid.,p.37 
tools and general knovledge. A nain idea nay cone fron one person but that person's thoughts are cast into a common pool and sonetiaes create ripples for a long tine aftervards.

Hesse suns up this development as largely attributable to Christian influence; groving freedon from fear of denonic powers in nature; the grovth of practical arts and techniques (practical vork not despised by Christians) and a rejection of the Greek analysis of matter and fora as the basis of science. In her view it is Christianity which removes the taint of evil fros all things in nature ean included, for to her thinking, "in Hebrew and Christian thought evil in the world is not 1 inherent but is the result of an's disobedience," She cites Sir Thonas More and Sir Thomas Browne in support of this argument and Bacon who considered man's fault to be arrogant rationalism instead of "recognizing in thea [yorks of nature] the stamp of the creator hiaself." Aristotle, she says, had also recognized the design aspect in nature, but freek thought looked to a study of nature as subject for philosophy rather than control of the environant which Bacon extolled in his works and which was stated in the aims of the Royal Society,

Descartes had also stated that scientists should not concern themselves with ultinate ansvers because these can never be known. So to Hesse modern natural science only began when Christian presuppositions about nature had displaced those of the Greeks.

According to Hesse it was the seventeenth century which sav "a subtle

1. Mary B. Hesse, Science And The Human Inagination, SCM Press Ltd., London, 1954.p. 40.

2. Ibid.,p.41,citing Taylor,H.D. Thought and Exeression in the Sixteenth Century, Nev York 1920, p.370. 
change in the use of language and in the meanings of iaportant words" subsequently leading to the division between the language of science and the language of poetry and religion. Michael Roberts whon she cites has studied this and shoun how scientific ways of speaking about 'fact' and 'truth' and the mechanistic outlook influenced and confused people. Hobbes had noted hou vords vere abused by being used metaphorically "that is, in other senses than they are ordained for." Scientists at this point vere trying to make their use of language more exact and logical and such was Royal Society policy.

Thus the ultimate reality of matter and the limitations of knouledge to the five senses becane the habit of thought of ordinary aen, not because they read the work of Hobbes or of Hume, but because the very language they spoke vas better adapted for dealing vith these aspects of experience than with the aesthetic and the emotional.3

Thus plain speech became the primary for of expression and this according to Hesse even influenced the Church and led to literal transliterations of the gible and a aove to rigid fundaentalisa. The effect on poetry she believes was to sake poets lose confidence in metaphor and create eighteenth century poetry dull to our ears. 'Words like 'truth', 'reason' and 'knouledge' had narrowed in scope...they were interpreted with reference to the methods and results of science." 'Reason' becane not an all-eabracing idea of noral, aesthetic and intellectual powers but purely logic, 'Inagination' covered anything not included in reason. Coleridge was to criticise this idea of logic and wrote on the importance of this new concept of iamaginaton. Truth was considered not to be found in poetry but

1. Mary B. Hesse, Sccience And The Human Inagination, SCM Press Ltd, London, 1954. p. 55.

2. Ibid.,p.55.

3. Ibid.,p.56. 
only in that which could be tested by scientific nethod and described in plain unambiguous language. Science in effect becaee a ney kind of 'religion' to dominate the Western vorld and which she says reaains unshaken even by new findings.

Biological evolution theories vere the first to dispel sone of the mechanistic view, but in physics it persisted to the nineteenth century. A nev study of man vas also developing as Conte established sociology and his theory of three stages of human development, the theological, the wetaphysical and the positive:

In the theological stage explanations of natural phenomena is in terms of the actions of the gods, in the metaphysical stage it is in terms of abstract principles and forces, fod being replaced by Nature, and in the positivist stage there is no attempt at explanation in teras of ultiaate courses at all, but all facts are siaply described in relation to one another. 1

He introduced the idea of a new religion of Humanity or Positivist religion.

Ideas about evolution had filtered through the decades says Hesse long before Darvin articulated then --another example of how scientific ideas are themselves evolutionary--although as she says not every one sav developent in teras of progress. Rousseau looked back to a primitive Golden Age which he considered ve had lost. Darvin's Origin of Species in 1859 seened proof of historical progress. Herbert Spencer and Thonas Huxley were among those who considered it a cause celebre. Lay interest in science increased at this point and prople began to see the story of the development of science as the story of theaselves and became consequently more sceptical of religion, a problen which liberal minds of the nineteenth century tried to address.

1. Mary B. Hesse, Sccience And The Human Inagination, SCM Press Ltd., London, 1954. p.61. 
Hesse describes how the aechanistic viev of the universe and especially the popular 'billiard-ball theory of atoas' as described by Newton and his contemporaries was replaced eventually by three developments in physics; the electronagnetic theory of radiation, the theory of relativity, and the quantum theory. Clerk Maxvell was responsible for the first theory, about the propagation of light and electrosagnetic vaves such as radio vaves. No vay could be found to describe the aotion of such waves because "A wave is not a physical thing but a PATTERN in some aaterial." No mechanical nodel could approxinate to the 'aether' or substance in which these vaves were thought to nove, so they [that is he and his successors] offered a mathematical explanation "for a scientific explanation does not necessarily require a model which can be pictured in terms of the notions 2 of particles of atter." This vas the first theory to depend chiefly on mathematical symbolism and hardly at all on representational models. It has since become typical of the theories of athematical physics. Hesse says that the significance of this did not register for some time. This reminds ae of soaething Whevell said in his earlier philosophy of science, that "Our fundamental ideas are not acquired from the external vorld by our senses, 3

but have some separate and independent origin." for instance ve have no faculty for foraing an idea of space. It is not obtained by experience "vhether ve call the conception of space a condition of perception, of an idea, or by any other term, it is something originally inherent in the mind

1. Mary B. Hesse, Science And The Human Inagination, scM Press Ltd., London, 1954.p.70.

2. Ibid., p. 70 ,

3. Willian Whevell,D.D. History of Scientific IdeasVol.1, John W. Parker and Son, London, 1858.p.77. 
perceiving, and not in the objects perceived." Our senses are not necessary then in order to sake sense, which means ve are not constrained in our inagination and not sense-dependent. Richards ade a siailar point that descriptive language does not need to create 'pictures'. Hesse says it vas relativity theory which finally displaced the 'billiard-ball' idea of the universe. Michelson and Morley found that the speed of light vas constant whatever the speed of the body against which it was measured. Einstein's conclusion from this gave us his theory of relativity "The essential point is that the further we go in examining the ultinate particles of nature the less like particles do they become, and the less does their behaviour conform to the laws of Nevtonian aechanics " The consequences of this are:

First the absolute space-time system of Newton is denied. The universe ceases to be a collection of bits of matter noving about in a boxlike space with absolute velocity, and becomes a more ismediate description of our experience. Velocity and time and the other qualities of bodies become notions [netaphor 5?] which are relative to soneone measuring them--ve begin to have as it vere a relative human vieupoint upon nature instead of the absolute god-like viev point inagined by classical physics. 3

Thus our notions of reality become less static, more inaginative, nearer perhaps to poetry and religion. One is reainded also of Piaget and his belief that children have to invent knowledge as it vere through their oun experiences. As Hesse says knowledge becomes our knovledge linited by our capacities.

Laplace's theory of determinism became outdated says Hesse because

1. Willian Whewell, D.D. History of Scientific Ideas Vol.1, John W. Parker and Son, London, 1858.p. 94.

2. Mary B. Hesse, Scignce And The Hugan Inagination, SCM Press Ltd., London, 1954.p.74.

3. Ibid.,p.76 
particles "do not have any sivultaneous position and velocity." So we can no longer believe that human actions are aechanically deternined. She explains hov athenatics has become increasingly iaportant to science which no longer needs visible aodels for proofs and traces the development of Euclidean geometry which after tventy-tvo centuries vas outdated by Reisann about 1859 with new ideas about the geonetry of space. She demonstrates how mathematics has become increasingly pure, abstract and difficult for lay people to appreciate. The advent of symbolic logic replaced Aristotelian syllogisas. People like Leibniz also considered that a logical objective language could be practically applied in diplonatic work there confusion over accepted aeanings sometiaes causes discord. Midnineteenth century George Boole used calculus or algebra to construct a logic whereby Aritotelian logic vas represented symbolically. It had been assumed previously that "all propositions vere reducible to the subjectpredicate fora"--but it becane evident that "in mathematics itself the notions of inequality, the convergence of an infinite sequence, and many other types of argument cannot be put in the subject-predicate form" Some hoped that all philosophy might be reduced to just such a logical form--but as Hesse states:

Such a formal symbolic language can never be a substitute for thought, because the application of a symbolic method to any empirical subject atter presupposes very careful analysis of the subjectaatter, and a reasonable certainty that its essentials have been grasped and properly expressed in language. In other words it presupposes that the york of clarification has already been done, and it is precisely here that difficulties arise which are not only confusions about the use of language, but are fundamental disagreements about the nature of the vorld. Again, there are some

1. Mary B. Hesse, Sciience And The Human Imagination, SCM Press Ltd., London, 1954.p.78.

2. Ibid,, 0.86 . 
aspects of experience which are best expressed in language which is full of metaphor, and some necessary overtones of meaning are lost when a vord is precisely and uniquely syobolized. The vagueness of living languages as compared vith mathematics is the price they pay for their full applicability to the vorld and their capacity for growth. 1

Nineteenth century developments tended to a type of relativism and a rejection of absolutes. If this akes us distrust logic when applied to the real world Hesse sees this as an advantage. Experimental knowledge is seen to have huaan and aterial liaitation. It became accepted that our understanding wight be finite and that the existence of a superior being who did understand vas indeterninable. Hesse sees this as a nev hunility in man Which in itself has religious overtones: "The nev attitude is nore consistent with the Christian viev of an as a dependent creature vhose 2 existence is essentially bound up vith that of the universe." So to her rationalism is not the threat for the twentieth century but relativisa--the belief that everything "is relative to historical circunstances or to the 3 psychological needs of the individual."

Humans tend says Hes5e to explain things in terms of what is known to them even though these things thenselves aay not be understood. Thus myth explains nature and in science explanations are often based on analogies as in vave theories likened to those of the sea. But she vonders if it is still true to say that "science attempts explanations in terms of pictures and analogies drawn fron the faniliar vorld." Scientists have usually adopted a positivistic approach with an eaphasis on data of sense

1. Mary B. Hesse, Science And The Human Imagination, SCM Press Ltd., London, 1954.p. 88.

2. Ibid., p.90.

3. Ibid, p. 90 .

4. Ibid.,p.92. 
experience as described by philosophers such as Hume. They all prefer experiaental results to theories. A nev for of positivisa hovever tends to avoid general statenents about the nature of the universe. Toulnin she says is certain that ve should avoid general explanations fron scientific research. Too wch of this he thinks tends to false notions of science anong lay people and distorts technical terms used in science. Hesse quotes J.D.Bernal as also believing that the function of a theory is to organize existing knowledge and can only be appreciated by the initiated involved with it. To his the scientist does not seek doguatism and is quite satisfied with the uncertainties which are the nature of scientific work.

Hesse herself can see no reason why 'scientific myths' cannot be used in a vider field if they have relevance, nor does she think that common teras used in science should not still be part of comon speech, for the influence flows both ways, and "it is clear that categories of interpretation vithin science have been influenced by prevailing religions and 2

philosophical ideas ." Which, incidentally, makes one wonder how in our ovn times vhen so much science is devoted to veaponry hou much those involved become inbued with the rationale for their manufacture. Hesse and like-ainded philosophers feel some justification in aingling philosophy and 3

science. She quotes Maisman who has said that scientific concepts have an 'open texture' or are not complete within themselves. Kant set a tradition for philosophers to consider other knouledge as "greatly

1. Mary B. Hesse, Science And The Human Inagination, SCM Press Ltd., London,1954.p. 94.

2. Ibid., p.,97.

3. Ibid.,p.97. 
1

outveighing scientific knowledge in importance" and considered religious and noral knouledge to be possible but distinguished from scientific knouledge because of the dual nature of reason--pure scientific reason which sees the phenomena of nature, and practical reason which can penetrate the essence of things, Opinion is divided as to how to interpret these two. Science seems to have distanced aen and their knowledge of themselves from the knouledge of things--a dichotony which Hesse sees in Buber's I and Thou. One knouledge is subjective, the other objective: "The iapersonal attitude of observation, experiment, measurement, is replaced in personal relationships by something more dynaic, in which deaands are aade and responses given and in which the vhole personality is judged by the quality 2

of its response." A relation of encounter can be achieved between people and their vorld Hesse believes and here she states what seens to be the basis of her own philosophical viewpoint: "The deepest levels of our experience are not comprehended by our relations vith other persons, but in the relations of all of us to the God who is the ground of all existence." This may be true for her and for many others but not necessarily for all of her readers, though it is true as she says that poets have expressed their knouledge of God through encounters with people or with the reality of nature itself. Enmet, in her interpretation of Buber calls this power of creative avareness "spirit...it seems to come of grace, it creates the moment of relationship, of comanication of whole-ness; it is thus the bond of unity; and it coaes with the pronise that it vill lead us into truth."

1. Mary B. Hesse, Scigence And The Human Imaginatition, SCM Press Ltd., London, 1954.p. 98.

2. and 3. Ibid.,p, 100 .

4. Ibid.,p.101. Citing Emat, O.M., The Natture of Metaghysictal Thinking, London, 1945, p.212 
One reads siailar thoughts by those who describe transcendental meditation. Hesse believes such experiences can be part of science as other scientists have vitnessed in their perusal of other scientists' journals and notes (see Holton on Einstein earlier in this chapter 1 As this apea is not her main theae she does not pursue it but I vill refer later to Green and his Shabby Curate of Poetry vho has wore to say on this. The question Hesse is left vith is whether scientific theories actually bring us nearer to the reality of things and whether knouledge has to be divided up into scientific and non-scientific contexts and attitudes. Whitehead has a holistic viev and Hesse herself has demonstrated in her survey of scientific developents and particularly theories about the naturg of the universe, the interdependence of science and culture. It is in the present century that she sees division between science, history, poetry and theology: " in practice the business of science is carried out aore and aore in aathematical teras which the layean cannot follow, and the resulting situation is rationalized by a theory which declares the languages of science and the humanities to be mutually untranslatable."

A problem which all philosophers of science have tried to address Hesse says is how to distinguish betveen the various classes of description science uses for example to describe 'real' objects, sense experiences, rationalisation and experiences which are not available to sense experience but do exist. She describes the attempts of people such as Hume, Pearson; Russell and Whitehead whose vork she seeas to favour. Purely logical constructs do not easily apply to all categories of experience and controversy erupts over the responsibility for decisions. Descriptions of

1. Mary B. Hesse, Science And The Hunan Inagination, 5CM Press Ltd., London, 1954.p. 105. 
scientific perceptions of sense data alone are not considered acceptable. Inevitably she says we have to accept the explanations that scientists themselves use when describing their experiments--but linguists can exanine this language used in scientific concepts.

The operational theory of concepts tried to define science in terns of operations only, but even this vas not always possible because in soae cases the actual physical operations are impossible; measuring space, for example. She quotes Dingle explaining how science has changed. The theory of relativity has changed the conception of the nature of physical science: "Formerly science vas regarded as the study of an external vorld, independent of the observer whose experiments and observations vere siaply neans of finding out how the world vas constructed and by what lavs its behaviour vas governed. The eaphasis has now shifted from the nature of the vorld to the operations of experiment and observation." As Hesse expresses it nore simply ve cannot regard measuring the diameter of an electron in the sane vay that ve might have measured a half-crovn. On the other hand she thinks there is no need "to rush to the other extreme and deny the validity of any analogy which has no inmediate justification."

The most difficult problens about the status of concepts arise apparently in the oodern quantum theory of atoms for an observer in a laboratory researching this would 'see' nothing resembling an electron only photographs and instrument readings. Even where measurements cannot physically be ade they are still deemed possible. It seens says Hesse that "we cannot escape the conclusion that scientific theories involve two sorts of

1. Mary B. Hesse, Science And The Hugan Inagination, 5CM Press Ltd., London, 1954.p.127.

2. Ibid., p.129. 
concepts--those which can be measured and therefore operationally defined, and those which enter into theories as part of the apparatus for correlating observations." More complex scientific concepts cannot be operationally defined. We have to consider therefore two kinds of scientific concepts the theoretical and the experimental. To illustrate hov language describes such a theoretical concept Hesse describes the dynanical theory of gases developed during the nineteenth century. There is a relation betveen the volume in which a gas is contained, its teaperature, and the pressure exerted upon it. Boyle's Law says the volume varies inversely as the pressure. GayLussac's Lav says hov the absolute temperature varies directly as the pressure. This can be written as $P=$. These lavs can be regarded says Hesse $\checkmark$ as first-order generalisations of the experinental results--sunarising them in a convenient form. But, she says, a scientific theory has to do nore than this--and link this relation vith other aspects of the behaviour of gases, their chemical composition, behaviour near the point of liquifaction etc. "This is vhere second-order generalisations, or hypotheses are required, and where concepts usually enter which are not operationally definable." In this situation it is postulated that gases consist of a large number of similar particles (aolecules) in randon aotion. Subsequently the dynaics of a systen of such particles is worked out to see whether any of the relations arrived at can be identified with the lavs of Boyle and Lussac-"Such a set of identifications, which will be mathematical equations, constitute the DICTIONARY which translates the theoretical language of the 3 hypothesis into the experinental language of the laws." The system of

1. Mary B. Hesse, Science And The Human Imagination, SCM Press Ltd., London, 1954.p.132.

2. and 3, Ibid.,P.135. 
particles can be regarded says Hesse as a dynanical MODEL, or ANALOGUE of

the ga5:

If a aodel is to be scientifically useful, it must be familiar to U5, with its laus vell vorked out, and it aust be easy to extend and generalize it 50 that its other properties, which we have not 50 far used, may be related if possible, with the other properties of gases. The oodel aust have as it vere, a life of its own, which is independent of these properties of gases which ve are using it to explain. 1

Analysis of models can be carried out with nost of the theories of nodern physics--as examples she says "the theory of heat conduction depends on the model of fluid flow; all wave theories and field theories depend ultinately on aodels taken from hydrodynanics... and even quantun theory...c an be shown to depend essentially on the simple dynamics of particles--it akes use of 2 analogies taken from this theory, but vith restrictions of meaning." This is I suppose sinilar to literary critics using teras such as tone, texture etc. to describe objects which in reality do not have these qualities.

Hesse says sometimes "the nodels used in physics are purely aathematical in character, and this is why the vord analogue is generally

1. Mary B. Hesse, Science And The Hunan Inagination, SCM Press Ltd., London, 1954.p.136.

She has an interesting and very relevant footnote here quoting fron Locke's Essay Concerning the Hunan Understanding, IV, xvi, 12.:

"We see anisals are generated, nourished, and nove; the loadstone dravs iron; and the parts of a candle; successively aelting, turn into flame, and give us both light and heat. These and like effects ve see and know: but the causes that operate, and the manner they are produced in, we can only guess and probably conjecture. ANALOGY in these matters is the only help ve have, and it is from that alone ve draw all our grounds of probability. Thus observing that the bare rubbing of two bodias violently one upon another produces heat, and very often fire itself, ve have reason to think, that what we call HEAT and FIRE consists in a violent agitation of the iaperceptible minute parts of the burning atter...A vary reasoning from analogy leads us often into the discovery of truths and useful productions, which vould othervise lie concealed."

2. Ibid, , p.137. 
1

preferable to model" as the latter may suggest something mechanical or picture -like. Satisfactory analogies ady not ony explain a theory but "give grounds for predictions and extensions of the theory." She describes two extrene types of analogy as used in science... ainor ones used merely as heuristic devices and later discarded, not appearing in a finished work. A historical example she cites is a 'mistake' such as that of Kepler's nodel of the sun and planets as a wheel hub vith spoke and ria. Major ones are particle theory or an analogy which becomes generalised into a view of the universe and which may become as it vere a public property. Weiner has suggested that human beings have been described similarly,... as machines of their tine, for example seventeenth and eighteenth century clockwork mechanisms described by analogies from dynamics, nineteenth century heat engine analogies based on thermodynanics, and currently communication devices from electronics: "Analogies like these deternine the phenomena to be taken into account, and therefore the direction of research, and the whole framevork of a theory."

Hesse maintains that some scientists see all analogies simply at the level of aids to discovery. Hutten thinks that "this usage of nodels never gives a reliable interpretation because they carry surplus meaning from crude atteapts to understand the vorld and may therefore seriously iapede 4 the iaprovenent of knovledge." [This sounds faniliarly like the criticisms of metaphor in other areas of knowledge $]$ But as Hesse

1. Mary B. Hesse, Science And The Human Inagination, ScM Press Ltd., London, 1954,p.138.

2. Ibid.,p.139.

3. Ibid.,p.140,

4. Ibid.,p.14t, 
says all the implications of an analogy as for exanple in aodels are not alvays fully appreciated when they are first used. To her aind "the heuristic function of analogies must be regarded an essential part of scientific 1

theories." She examines the meaning of the vord analogy and says that in logic since the seventeenth century it has meant identity of some of the characters of the things related by the analogy or observed characters stored in common. "Thus if analogues have properties $\mathrm{Pl}, \mathrm{P2}, \ldots \mathrm{Pn}$, in comon, and some other properties different, we can argue to possession of another comon property $P_{n+1}$ with some degree of probability if the possession of $\mathrm{P}_{1}, \ldots \mathrm{Pn}_{\mathrm{n}}$ is relevant to the possession of $\mathrm{Pn}_{n+1}$ but not 2

othervise." But it is difficult sometines to say how one property is relevant to another--when the properties of things aay be so similar in some respects and not others, for example things may share common properties of size, colour and veight but only one way be edible-- "so an analogy is not reducible to a list of resenblances and differences, but involves an element of direct recognition of association of properties, and a valid argument froe analogy aust ultimately rest upon this recognition." Therefore induction from past experience to future experience, of from particular observation to general laus is rather problematic in modern logic. "In modern logic then it would generally be agreed that an analogy in science seans simply an identity of logical or mathenatical structure betveen certain parts of a theory and the experimental results." Hesse says that we cannot simply get rid of analogies by use of abstract

1. Mary B. Hesse, Sccience And The Hugan Imagination, SCM Press Ltd., London, 1954.p.141.

2. and 3. Ibid.,p.142.

4. Ibid., p.143. 
mathenatics "mere identity of some aspects of structure does not indicate why an analogy is useful in predicting future experience." This study should make it clear that the use of analogy and metaphor is a a timehonoured vay of building up human experience.

Hesse finds that Mediaeval scholars had greater insight into use of analogical use of language than those of the seventeenth century. Modern logic only recognizes two types of relation, identity and difference, they recognized three, one of these being analogy. "Put in teras of their subject-attribute logic, this meant that qualities could be predicated of a subject in three vayss univocally, analogically and equivocally," ${ }^{2}$ Her example is 'tabbit' as a name of species of animal i.e. predicated univocally of all instances of this anial. If ve use this word to describe a person this is analogical. If we use it as in "Welsh rabbit" it is to equivocate. Because the person described as rabbit could be described in other vays than as 'rabbit' this is not a good analogy she reflects and has 'degenerated' [strange choice of vord] into metaphor. She distinguishes between metaphor and analogy by the use of the vord 'anger' which can be univocally predicated of human beings, but can also be used to describe 'an angry sky' i.e, a metaphor which need not be used if we describe e.g. the weather conditions indicating a storm; but to describe a dog as angry she believes we are using something more than analogy Ithis is in fact anthroponorphisn of which more later l in giving the dog a human attribute. God is also sometimes spoken of as 'angry' in the same sense that people are angry. But as she says Mediaeval philosophers did not have to cope with our problen of using analogical language to describe unfamiliar

1. and 2. Mary B. Hesse, Science And The Hunan Inagination, SCM Press Ltd., London, 1954.p.144. 
structures in nature as produced by scientific experisents. To use mathenatics in describing nature is alvays analogical

What Hesse observes is a swing in philosophy from viewing theories as univocal descriptions e,g. 'billiard-ball atous' to now regarding then as pure equivocation and this leads to more enquiry as to how ve use language. To her, "scientific theories vhen verified ARE regular PATTERNS [ay emphasis] of natural phenomena, which may of course include the aind and body of the observer hinself.' This is an important comment, the acknowledgement that the person involved is as it were part of the process and has enormous iaplications for science and for language study. What phil 05ophers seek to discover 5ays Hesse is whether these patterns are part of the objective structure of the vorld which ve discover--or are they something we impose on what say in fact be chaos. In sumary these are the realist standpoint and the positivist. Both imply different assuaptions and Hesse sees both as correct. What created difficulties in earlier times vith the naive realist or the eechanistic view vas the fact that the vay the world was explained was seen as the only way-until physics refused to confors.

But if ve abandon such a restricted conception of existence ... we leave the yay open for an interpretation of experience which asserts the real existence of all patterns in nature which are expressed by scientific concepts correctly used. We do actually recognize patterns in observable nature which are as much 'there' as the nore easily distinguished physical objects which are components of the patterns. Not only that but there seems also to be a kind of continuity betveen our perception of ordinary objects and our inference to such scientific concepts as the fundamental particles.2

As Hesse concludes ve way doubt our own faith in scientific lavs yet ve

1. Mary B. Hesse, Science And The Hugan Imagination, ScM Press Ltd., London, 1954.p.146.

2. Ibid, ,p.15t. 
have faith that every day vill be to a degree predictable and that our oun aicrocosaic vorld will not disintegrate before our eyes. These are inductive conclusions about the future:

And such descriptions of experience is all that metaphysics can hope to achieve. Exactly the same considerations apply to scientific lavs and theories. They are regular PATTERNS [my emphasis] having continuous existence, which dre discerned in present avareness. When they are discerned clearly and expressed precisely [perhaps here she aight have added..given the constraints of human language, logic and linear thinkingl we have exactly the same faith in their continued functioning that ve have in the continuity of physical objects, and for the same reasons. 1

Analogies in science, whether sechanical, athenatical or historical can be considered says Hesse more or less adequate--as long as ve realise they are descriptions-there vill alvays be roon to criticise the not only scientifically but also concerning the religious and metaphysical nature of the universe. To try to divide scientific and religious descriptions of experience is to Hesse iapossible. They aay both deal with different vays of looking at the sane experience but they inevitably overlap, "Problens about 'reality' or 'existence' vould not vorry us if we had not for so long been used to thinking of reality and existence in terms of hard aterial particles--the sort of existence a stone has, or one of Galileo's smooth balls 2

rolling down an inclined plane." Whitehead has told us that "our difficulty in understanding the PATTERNS of activity disclosed in modern science is due to our preoccupation with sense perception to the exclusion of other aspects of experience--those of emotions, purpose and so on." Others also think that analogies of machines have dominated science

1. Mary B. Hesse, Science And The Hunan Inagination, SCM Press Ltd., London, 1954. p. 152.

2. Ibid., p. 156 .

3. Ibid.,p.157. 
for too long and that cooparing the vorkings of the brain to particles in motion or even to electronic computing aachines aay be misleading. There is a tendency to believe that ye should look for analogies in human society itself and there is says Hesse "a recognition that science itself needs some of the resources of poetry in order to express its insights into human nature, and that poetry and imagination are vays of attaining to the truth as vell as logic and atheaatics."

Hesse has sought to prove that science is inextricably linked vith culture and religion. In the light of her obvious Christian faith she see a fusion betveen science and religion rather than a division. She sees analogies as essential to scientific descriptions and so the vork of science is to her a aeld of rigorous analytical research iabued with faith and inagination. Former times when there vas less division between art and science seen to her to have been more humane.

It is interesting to see that twenty years later in another work Hesse gives an interesting definition of science saying "it is essentially a learning device, and all the aodels of the structure of science describe What are essentially mechanisos of learning. " She also gives aore specific consideration to the role of metaphor and its explanatory function 3 in science, adopting Black's interaction theory of wetaphor which she believes gives a satisfactory conception of scientific theories as metaphors. The folloving diagran vill perhaps illustrate hov she appears to ane to relate

1. Mary B. Hesse, Sccience And The Human Imagination, 5CM Press Ltd., London, 1954.p.162.

2. Mary Hesse, Revolutions and Reconstructions in the Philosoghy of Science, The Harvester Press, Britain, 1980,p.125.

3. Max Black, Models and Metaghors, Cornell University Press, New York 1962. 
this to science:

Black FOCUS FRAME

Hesse SITUATIONS or REFERENTS

Hesse PRIMARY SYSTEM SECONDARY SYSTEM

e.g. Black wan is dolf

Hell is a lake of ice

In Science The Dowain of the the ExpLANANS (explanation)

Hesse EPLANANDUM(to be explained)

described in observation describable in language or the language observation language of a familiar theory from which the oodel is taken

e.g. Hesse sound is propagated by wave notion

gases are collections of randomly

aoving aass particles

Metaphors according to Hesse usually depend on a shared or conmon language with shared assumptions or beliefs termed 'meaning' which are not fixed, and in scientific contexts the prisary and secondary systems may both be highly organised by netvorks of natural laws. What connects the two systeas way be what other people have described as 'analogy', 'intiaations of sinilarity', 'a programme for explanation', 'a framework through which the primary is seen'. As Hesse says this does not wean that ANY secondary can be a source of aodels for any priaary. Randon or unusual connections can be ade in art or poetry. Hesse agrees vith Black that metaphors are not siaply comparisons. She interprets metaphors as working by "transferring the associated ideas and implications of the secondary to the priary systens. These select, emphasise, or suppress features of the priaary; nev slants on the prinary are illuninated; the priaary is 'seen through' the frane of the 1 secondary." In the fusion of the two, original meanings sometians shift and

2. Mary Hesse, Revolutions and Reconstructions in the Philosoghy of Science, The Harvester Press, Britain, 1980.p.114. 
nerge. As she accepts the consequences of this interaction viev for theoratical nodels she see "sone incompatibility with assumptions generally made in the deductive account of explanation (something she delves into in detail in her book] namely that descriptions and descriptive laus in the domain of the explanandum remain empirically acceptable and invariant in meaning to all changes of explanatory theory."

A aetaphor used for the first tiae is intended to be understood, othervise it is nonsense and does not conanicate. Accepting this is a rejection therefore of "all vieus which make metaphor a wholly non2 cognitive, subjective, enotive or stylistic use of language," Both literal uses of language and metaphoric she says follow linguistic rules. Rather than draving a line between the two Hesse sees a need to trace out the various mechanisms of meaning-shift and their interactions. She asks what is the REFERENT of a nodel or metaphor and finds that it seems to be the primary system.

Critics have said that if ve take aetaphor literally it becomes myth. Hesse concludes that metaphoric use is not replaceable by any literal expression. A theoretical concept may fail because it is meaningless or false; she gives as an example theat is a fluid'. A feature of poetic metaphor is its initial iapact and novelty. Scientific metaphors differ in that thay may be unexpected but they are

... meant to be exploited energetically and often in extreme quantitative detail in quite novel observational doaains; and if two models of the same primary system are found to be mutually inconsistent, this is not taken (PACE the complementarity interpratation of quantun physics) to enhance their effectiveness, but rather as a

1. Mary Hesse, Revolutions and Reconstructions in the Philosophy of Science, The Harvester Pres5, Britain, 1980.p.115.

2. Ibid.,p.116. 
challenge to reconcile then by autual eodification or to refute one of thea. Thus their truth criteria, al though not rigorously formalizable, are at least auch clearer than in the case of poetic metaphor. 1

Scientists in her viev may be looking for perfect metaphors vhose referent is the donain of the explanandum whereas literary metaphors can be acceptably iaperfect. It has occurred to me that in literature far from the sane metaphor having shared or sinilar meanings to all readers even though the focus aay have a generally shared understanding the final interpretation is often not public but personal and depending on ones experiences.e.g. metaphors in English poetry particularly older poens set in English countryside with associations peculiar to that country are not recognised innediately by all English speaking people, but they can be learned. This is seen when Ney lealand children read such poetry e.g. Keats' "black purgatorial rails" in The Eve of Saint Agnes are strange to then, partly because the mediaeval style of toabs is not known to nost of then nor the religious allusion to purgatory; another example wight be the seasonal differences and references assumed to be known.

Hesse believes that "the deductive nodel of explanation should be MODIFIED and SUPPLEMENTED by a view of theoretical explanation as metaphoric redescription of the domain of the explanandua." Not all explanations are aetaphoric, nor is metaphoric terainology in itself explanatory but the essence of a theoretical explanation is that it introduces into the explanans new vocabulary or even new language. Having argued that the aetaphoric viey can satisfy the orthodox criteria for a scientific explanation she concludes that:

1. Mary Hes5e, Revolutions and Reconstructions in the Philosoghy of Science, The Harvester Press, Britain, 1980.p.119.

2. Ibid., p.120. 
There is ONE language, the observation language, which like all natural languages is continually being extended by aetaphoric uses, and hence yields the terminology of the explanans. There is no problem about connecting explanans and explanandum other than the general problem of understanding how metaphors are introduced and applied and exploited in their prisary systeas.1

This is a process that ve as yet do not understand but to exanine the problem of the 'meaning of theoretical concepts' is a move tovards solving this. Finally she says ' In the netaphoric viev...since the 'domain of the explanandum' is described in terninology transferred from the secondary 2

systen" the original language of observation must shift in meaning and extend vocabulary and there vill be more likelihood of prediction even if not true but it vill be rational because "rationality consists just in the continuous adaptation of our language to our continually expanding world, and aetaphor is one of the chief means by which this is accoaplished," The essential element that links art and science is I believe metaphor. The area where, as I said in ay introduction huaans are at their most creative. If we look at hov primitive people and children observe and understand the vorld or hov ve often interpret it for thea ve vill see that it is deeply metaphoric--though it may appear in the guise of aninism (possibly totemisa) and anthroponorphisa.

Anthropomorphisa figures quite videly in children's literature. Janke and Norton say "There is no consensus that all anthropomorphisa should be avoided in children's literature, but science educator 5 generally agree that non-fiction science books should not attribute human thoughts,

1. Mary Hesse, Reyolutions and Reconstructions in the Philosoghy of Sccience, The Harvester Press, Britain, 1980, p.122.

2. Ibid., p,123.

3. Ibid.,p.123. 
1

motives, of emotions to animals or plants." Yet these sane authors

in a recommended book Ihe Amazing Dandelion suggest a list of activities and one of these is Pretend you are an ant and describe a dandelion plant fros that perspective. How might the plant be useful to you? So the reverse process is obviously approved of!

Our attitude to aninals is confusing and it is considered by Austin Hughes that "overeaphasising the appealing or unappealing aspects of aninals may detract from our appreciating serious study and description." Furthermore "The question of uhether or not ve are justified in attributing a purpose to an animal's actions is one that is still being debated by biologists, psychologists and philosophers of science. The consensus seeas to be that it is better to speak of the function of a bit of anial bahaviour 3

rather than its purpose." We have always had apparently a tendency to personify nature or natural forces but this can cause real problems in teaching science. For instance problematic statements involving the attribution of purpose go beyond anthropomorphosizing other animals to in effect anthropomorphosizing all of nature. Along these lines teachers can sometimes make careless statements such as 'A humingbird has a long bill 50 that it can reach into flowers and suck out nectar." "What is wrong is the iaplication that the humingbird has a long bill for a purpose. Essentially such a statement enbodies an incorrect interpretation of the nature of 4 adaptation."

Hughes is criticised in a later article by Sharefkin and Ruchlis who

1. Dalnar Janke and Donna Norton, 'Good Tales For Teachers', Science and Children, Vol.20 No.6 March 1983.

2. Austin Hughes, Sccience and Childgren, Apri1 1973, pp10-11.

3, and 4, Ibid. 
believe that "there is a conceptual level for young children below which 1

it is irrelevant." Nor do they believe that teachers of young children should have to avoid "any hint of anthroponorphisa and personification in their attempts to comanicate ideas... [because] children in the lower prinary grades are generally at the pre-operational or concrete operational stage of thinking" and anthropouorphism can help them to learn about their observed vorld. Which supports ay earlier contention that much learning for children involves unlearning what they already knov. They say that new ideas have to be linked to concepts a child already has and in their viev these are often related to anthroponorphism and personification e.g. children relate easily to real or imagined feelings of animals such as 'the dog is happy to see you,' What they do stress is that it is probably more useful for the teacher to be attungd to the child's individual cognitive level as manifested by his comments and responses than to be overly concerned vith the precise scientific formulation. With good teaching that is sensitive as well ds sound, no dichotony needs to exist. As they say ve can be scientifically precise and turn people off science. Where I agree particularly with these writers is in theit final comment "We need wore discussion of formulation of concepts so that teachers way become expert in reconciling the needs of subject natter in the light of what ve knov about child development and the usage of words."

In a study reported by Jay Blanchard and George McNinch kindergarten children vere aore successful learning dissiailar groups of words from cue cards with anthropomorphic cues than fron picture cards or plain word cards. Their conclusion was "Perhaps anthropomorphisn cues are superior to

1. 2. and 3. Belle D. Sharefkin and Hy Ruchlis, Anthropomorphism in the Lover Grades, Sciences and Childrenn, March 1974. 
explicative-illustrated and no-picture cue conditions because as attentional cues, they do just that: focus attention... [because of the]....nisdirected tendency in young learners to ascribe humanness to non hunans. This process focuses consciousness and attention vhile probably engaging inagery or organization processes that can contribute to the active elaboration of words in memory. The elaboration affects depth of processing as vell as 1

storage and recall." They believe it is a transient phenomenon and vould be abandoned in most children as anthropomorphisn gives yay to a more naturalistic viev of life. Thus it is the type and content of the picture that controls the effects which suggests that it does not harm vord-learning in young learner 5. Perhaps what ve are seeing here is also the beginnings of the later capacity to construct netaphor 5.

Podendorf says to be vary of oversiaplifying science for children and avoid using the vords 'all', 'always' and 'never'--because 'Children need to become faniliar with the idea that the natural environment is an orderly one and that there are definite PATTERNS, [ ay eaphasis] but that there are also constant and nevly found exceptions to almost all of the rules and/or laws which make up the patterns." She also criticises anthropomorphism and teleology in children's science books, because they lead to urong ideas and oversiaplified vays of thinking e.g. 'squirrels bury acorns in the ground so they vill have food in winter.'

Osborne and Gilbert discussing students' conceptions which they bring to science also mention the anthropocentric and egocentric views of children for example their use of the word 'force' and the prevalence of

1. Jay Blanchard and George Mc Ninch, The Effects of Anthropomorphism On Mord Learning, JNLCF Educ Research, Vol.78, No.2.

2. Illa Podendorf, Characteristics of Good Science Materials for Young Readers, Library Irends, April 1974 pp.425-431. 
animisn i.e. a tendency to endow objects with feeling and will or a 1

purpose. This is an area which needs nuch nore research. Whilst we are developing and encouraging inaginative and creative ways of thinking, seeing and speaking particularly through reading ve are laying down patterns of thinking which have to be broken up or reformulated in the child's aind in order to accomodate mathenatical and scientific thinking. Could this in fact be one reason why some people becose literate but not numerate and vice versa.

Piaget was one of the first to study animise systematically. He referred to it as "the tendency anong children to consider things as living and conscious" and to be part of the development of the concept and of life. Huang questioned the prevalence of anioism and considered that it vas an illusion and Safier suggested that ideas of animisin had been fed to children. Klinberg likevise thought it difficult to prove in young children. Studies seem inconclusive except for Piaget's original work which suggests that children do not differentiate at first between living and inert bodies as they do not have the criteria to sake such distinctions. Boud says that Susan Isaacs was one of the first to coment on the "extraordinarily confusing and conflicting information" which ve give children about animals and "There is probably no moral field in which the child sees 50 many puzzling inconsistencies" in our attitudes to animals as pets and 2

a5 a food source. It yould appear that this entire area may need careful consideration and we need to critically exanine what wessages ve are conveying to children right from their earliest days.

1. Roger J.05borne and John K. Gilbert, A Technique For Exploring Students' Vievs of the World,Phys.EduEs, Vol.15 1980 U.K.

2. Alan D.Boud. The Development of Beliefs about Animals, Educational Research in the 1980'5, Vol.2, Collected Papers AARE. 
Metaphor is a vay of thinking, a way of looking, a vay of learning and a vay of teaching. For this reason it has to be iaportant in any huaan activity but perhaps especially to science. For the child coming to formal science lessons there is a body of knouledge already discovered and wany laws to be learned. From infancy hovever this child has been scientifically exploring the world data around hil or her, probing, touching and tasting initially. Later there are the endless questions which perceptive (or perhaps trained ) parents patiently try to answer. There is also the 'scientific' play with water, sand, building blocks, trucks and trains etc. Learning has been mainly experimental experience, Good teachers try to continue this process, adding more and wore experience to extend concepts. For the science teacher hovever this creates a mixed blessing for his/her students come with ainds full of ideas and beliefs which are firmly eabedded and which do not always accept or fit into the body of scientific knouledge which the teacher believes he/she is there to share with then and pass on. Roger Osborne and Peter Frayberg discovered in their study that even several years of teaching would often fail to change students' beliefs and attitudes e.g. that human aniaals ARE aniaals in biological terms. Many pupils cannot accept such a term because socially and aesthetically it goes against their beliefs about people even though as ve know very young children identify people and animals in the same category.

"Little eapirical work has been done on the role of explanation in 1 the teaching and learning of science" according to Pope and Gilbert.

1. Roger Osborne and Peter Freyberg, Learning in Science, Heinemann, New Zeal and, 1985 ,

1. Maureen L. Pope and John K. Gilbert, Explanation and Metaphor: Some empirical questions in science education. Eurrogean Journalal of Science Education, 1983, Vol,5. No.3. 
They believe that if the function of metaphor is as described by Petrie to "provide a rational bridge from the known to the radically unknoun" then it aust be ioportant to explanation in science. They find little evidence of empirical research in this area, apart from that done by Hesse. Such studies they feel must consider theories of knouledge, processes of teaching and learning, and the role of metaphor. Theories of knovledge adopt tvo polar positions, the realist and the constructivist. To the first reality is a stable arrangenent of subdivisions of objective facts whereas to the second reality is personally negotiated and each enquirer perceives a different world, factual knowledge is therefore negotiable.

The teaching of science they say, is also affected by one's viey of the nature of man and associated epistemology. Here they refer to the findings of Pope and Keen, the first model is the 'cultural transmission' view where the teacher is the 'engineer' and the student the 'machine'. The romanticist view as they call it stresses personal development, intrinsic goodness with emphasis on health, growth and emotional development. The 'progressivist' view they perceive as one in which the student's environment encourages active thinking and:

The acquisition of knovledge is seen as an act of change in patterns of thinking brought about by experiential problem-5olving situations. Reality is the interaction of human beings vith their environmentthe emphasis is on an active person reaching out to ake sense of a universe by engaging in the reconstruction and interpretation of experiences. The dialectical nature of 'conversation' could be taken as an appropriate metaphor here. 2

Finally there is the 'deschooling' view that knowledge should not be seen as

1. Petrie,H.G., Metaphor and Learning. In Metaphor and Thought, edited by A.Ortony, Canbridge University Press, 1979, pp,438-61.

2. Maureen L. Pope and John K. Gilbert, Explanation and Metaphor: Some empirical questions in science education. Europeann Journal of Science Education, 1983, Vol .5. No.3.p. 250. 
purely an intellectual concern. Relevance and the enotional as vell as intellectual life of the student are the key theaes here.

Black said that every metaphor is the tip of a submerged model and this Pope and Gilbert agree with. Furtherwore teaching styles vill reflect the dominant aodel of that person's view of his/her role. This vill be indicated by the style of questioning and of explanations. All of the models can be discerned in analyses of teachers at vork but aore evidence is required. The teacher will have a perspective or frame on the nature of knowledge and its development,i.e., they will have a personal episteaology." Those with a realist view will put the eaphasis on facts and aay vieu pupils as tabulae rasae. The realist vill also concentrate on literal Janguage forms, the 'constructivist' on 'the language of the possible'. 2 "Of the latter, the metaphor is the aost highly developed form." Here also the use of metaphor vill be influenced by the teachers' perceptions of their uses and as Pope and Gilbert declare:

We have no information on WHAT metaphors are included in science teachers' explanations, HOW OFTEN they are used, and WHY they are included. We should know sore, and be able to relate the inforation to the theory of knovledge held by an individual teacher. 3

We need to know where teachers stand on the realist/constructivist dimension. Edge has said that aetaphors from scientific or technological achievements can result in dehumanisation. I have referred elsewhere to the current objectionable phrase 'huanan resources'. We need to know, say Pope and Gilbert, what view or model is being projected towards students for their

1. Maureen L. Pope and John K. Gilbert, Explanation and Metaphor:Some eapirical questions in science education. Eurogean Journal of Science Education, 1983, Vol.5. No.3. p.251.

2. Ibid., $p, 253$.

3. Ibid.,p.254. 
oun thinking vill undoubtedly be influenced by the language used in teaching. Petrie's point that students vill interpret metaphor according to their own existing structure of conceptions has alrady been referred to. They vould like to see more research into the use of metaphor in science teaching and obviously favour the constructivist approach and consider Kell's metaphor of 'man-as-scientist' a good starting place to break down the supposed division betveen the 'experimenter and subject' in research. My oun view would be that each nodel they have described has its uses at sose point in the school curriculun and that by developing only one viev even in a single subject area we once again constrict learning styles. What is more iaportant is that teachers especially trainees should understand just how they are using language, what effects it has in the classroom on their students, themselves and the subject under consideration.

Osborne and Freyberg found in their study that the word 'living' caused auch confusion for science students. Many thought that fire, clouds and sun were 'living' because e.g. fire 'consumes' vood--the sun 'dies':

We say the fire is living because it behaves AS If it vere living. We talk of a 'live' vire and the 'living' bible. Like the word ANIMAL, the word LIVING has two comon meanings--d scientific one and one used in everyday language. The problea for pupils in science classroons is to learn to tell which of these meanings is intended on a particular occasion.1

Problems arise in classrooe situations al so where teachers and students do not share the same neanings and where "Pupils siaply fail to construct 23 meanings from the teacher's flow of words." As Barnes has shown children often learn to play the teacher's game and give an air of knoving

1. Roger Osborne and Peter Freyberg, Legarning in Sçience, Heinemann, Nev Zeal and, 1985. p. 32.

2. Ibid, p, 33 .

3. Barnes, D.,Langugage Ihe Learnger and The School, Penguin,U,K.1969. 
by using familiar but improperly understood teras. Bernstein's learning 1

'codes' and Corson's 'lexical bar' also operate in this situation.

Dsborne and Freyberg say:

Children exposed to scientific explanations can only generate aeanings fron their oun viev of the vorld and their oun aeanings for the words used in explanations. Appreciation of vieupoints based on our scientific history and technological culture can only develop slowly. As Gibran 50 eloquently expressed it no man can reveal to you ought but that which lies half asleep in the davning of your knowledge', 3

Adults they say have learned to cope vith aultiple meanings "often by utilising linguistic or other contextual clues. Pre-adolescent children, hovever, usually have difficulty in recognising when a metaphorical rather than a literal meaning is intended. Analogies, too, can lead to unanticipated 'meanings' being acquired--not only verbal analogies but 4

those iaplied in diagramatic representations." Their answer is to

suggest that teachers confront the realities of classroom learning; appreciate the importance of children's existing ideds; try to understand these ideas and to realise how children's ideas compare with the view of scientists. It is obvious that an important factor in this approach would be to raise teacher's avareness of the complexities of language including an appreciation of the nature and functions of metaphor.

Beverley Bell says that learning in science is conceptual change from the non--scientific ideas of the vorld which the child brings to the classroom, it is about constructing nev ideas by generating the links

1. Basil Bernstein, 'Dn the Classification and Framing of Educational Knowledge', in Knowledge and Control, ed.M.F. D. Young, Collier Maciillian,London, 1971.

2. David Corson, The Lexxical Bar, Pergamon Press,1985.

3. Roger Osborne and Peter Freyberg,Learning in Sciience, Heinemann, New Zealand, 1985, p.56, citing Gibran, K. The Prophet, Heinemann, London, 1926 . 
betveen existing knovledge and incoaing stimuli and accepting nev ideas as part of one's belief system. She thinks we have probably neglected the role of feelings in this area and not only are the questions teachers ask important but how they ask then. Also how often she wonders do ve include the special interests and experiences of girls who often enter science because of social issues and concerns. Sinilar concerns are voiced by Janet Burns who sees science teaching as:

.... a type of teaching that is based on a science governed by facts and rules, steming froe the science of Nevton and Galileo. It's an objective, value-neutral, detached, dispassionate pursuit... 2

And which she believes most women are not interested in. Its nature is such that it dravs predoninantly convergent thinkers in her view, and this results in a dogmatic, fact-oriented discipline, a science based on the idea of one absolute answer and from which divergent thinking is excluded. Divergence hovever is rewarded at the highest levels "because ultinately it is divergence that is essential for breaking new ground and saking new 3 discoveries." An acknovledgment of the value of metaphor and an appreciation of the uses of language in science teaching particularly could help to break down rigid attitudes that have made science a male-dominated area for so long. An acknowledgement that science teaching needs revision vas highlighted by a report in Britain which recognized that "the factual and theoretical content of sany existing courses vill need to be sharply

1. Beverley Bell, Curriculum Officer Dept. Education N.Z., speaking at a W.I.E.R. meeting Wellington on Science Education: Current Issues and Concerns June 251987.

2. Janet Burns, Science Research Officer, Victoria University Wellington, quoted by Marita Vandenberg in Science with SexAppeal, N.Z. Listeneng January 30,1388, p. 23.

3. Ibid. 
1

pruned" vithout losing any of the discipline's rigour. The document

also testifies to the perceived need for science to bear relation to

practical, social, economic and political issues of our times. This is

ratified by Ferguson who says that "an educational systen that pushes 'right answers' is scientifically and psychologically unsound." She sees an increasing need for divergence, creativity and holistic attitudes.

Clive Sutton says that in our attitude to science teaching ve could learn from earlier scientists for apparently Thomas Huxley in his public lectures discussed the origins of vords such as yeast, leaven, spirit and alcohol, and "In 50 doing he shoved science as a human endeavour, a struggle to wake sense of and describe aspects of the world and he avoided isolating it from other areas of knouledge," Sutton is convinced that actaphor is important to science for "it is indeed through figures of speech that those Who generate nev ideas are able to bring order to their perceptions, the phenomenon of how they are used deserves the close attention of anyone who is interested in the developaent of thought." Teachers help learners to 'see' by using siniles and analogies..." they are acts of persuasion....[for.] wetaphorical language, and the imagery behind it, is a major cognitive aid, 5

a means by which new thoughts are begun." He says that the partial

1. Marcus Chown, School science for all--but who pays?,New Scientist March 1985, p.8

2. Marilyn Ferguson, The Aguarian Conspiraçy, Granada, Great Britain, $1982, p .331$.

3. Clive Sutton, Metaphorical Imagery: A Means of Coping With Complex And Unfaniliar Information in Science', Durhas and Nexcastle Researcch Reviegy, Vol, IX,No.467, Spring 1981,p.218.

4. Ibid.,p.216.

5. Ibid.,p.219. 
recognition of the importance of this is a part of the constructivist approach and the implications for teaching are not yet worked out. We are now concerned with "knowledge re-creation by individual learners...each 1 learner has to rebuild it for hioself", as the Bullock report reninded us. One could wake a conparison between religion and faith as an analogy for old science teaching and the new. The former tries to indoctrinate by precept, training and what soae would call indoctrination, the latter by trying to convert by models, personal searching and practice. Sutton believes as I do that rhetoric and teaching are not far apart "at least part of the teacher's job seens to be to persuade the learner into certain ways of seeing 2

things.' others viev it more as induction into established concepts. One problen nov as he sees it is to balance both vieus. Pursuing both at once he thinks could lead to over-guided discovery and pseudo-open questions. To ay mind one has to be eclectic, using an amalgan of the best of old methods and the new.

How children see things says Sutton can be the grouth points for learning even if they have to be changed or abandoned later. Figurative language as he says, teases the aind into action and rather than being wary of analogies ve should push then to their linits

Petrie argues that metaphors are heuristic necessities in teaching science especially when students are faced vith the difficulty of understanding complex problems and metaphor vould be used to bring about conceptual change--by creating anomalies for the student. By working out such anomalies students vould find their own way to the truth, that is

1. Clive Sutton, Metaphorical Imagery: A Means of Coping With Complex And Unfamiliar Information in Science', Durhan and Neycastle Resegarch Revieg, Vol. IX, No.467, Spring 1981, p.219.

2. Ibid., p.220. 
construct their ovn experience in order to create a nev paradigm. Green on the other hand believes that aetaphor is not a vital part of the pedagogic process although it could be used as a teaching device. He sees learning sonething as akin to finding the oissing premiss in a joke and where learners cone to a problen difficult to solve they are sinilar to those tho do not see a joke. In this case it is not just metaphors which they need, what they are really faced with is not an anowaly but a paradox or apparent contradiction. "What ve vant is to lead students to see a way of holding to the truth of both propositions...vithout thinking they are in opposition." The tension experienced by the student is not created by a metaphor as Petrie believes but what Green calls 'a paradox in the wind of the student on the basis of preaisses he already accepts" and which require use of his inagination. The point both Green and Petrie make is that the student is vorking out his ovn explanation and saking aetaphors in his own nind, and both are avare of the need for inagination. The metaphor, or exemplar as Petrie calls it, does not have to be offered by the teacher; the netaphoric process can be going on in the student's oun head until he finds sonething to link with the new inforation.

As Green says, what ve have going on [unfortunately] in many classrooms is not a true learning situation but one where "Truth passes from the professor's notes to the students vihout going through the head of either." The teacher or textbook might use metaphor, model or analogy to give clues, to demonstrate a theory or lav, but the student must bring his or her

1. Thomas F.Green, 'Learning vithout Metaphor', Metaghor and Thought, ed, A.Ortony, Cambridge University Press, New York, 1979, p. 468.

2. Ibid.

3. Ibid, ,p, 472, 
oun mind to bear on the issue and sort out the nev inforation, possibly

constructing personal aetaphors to do so. If there is no 'dialogue' in his/her head or no discussion or active participation in the classroom then the ney knouledge nay not be assinilated or acconmodated adequately but be merely another item of stored information which is held or borroved but not personally ouned or in Green's view it is like a joke which is neither understood nor appreciated.

So scientists observe the vorld, they formulate theories, they examine phenomena and describe and classify vithin the constraints of language conventions. Where a word does not exist they invent one generally falling back on the ancient languages of Greece and Rone or they put an old word to new use, catachresis. In formulating theories they often have recourse to metaphor, in fact there is some basis for saying they think in metaphor. They certainly use it to describe and explain and also use closely related nodels and analogies. Children and priaitives tend to interpret nature anthropomorphically. Laymen and students learn their science partly through the process of metaphor which helps to bridge and fuse old and new knowledge. Where scientific knouledge was once considered a fixed body of data, of facts and truths it is now nore generally perceived as an evolving 'vieu' rather than sioply a groving 'body'. It has in some respects becoae simplified even though fragmented and specialised, As one science writer said we no longer have to record and notice every falling apple, but it is also acknouledged that some 'truths' are almost unavailable, incomprehensible or at least beyond our linear thinking to fully comprehend, Truly pure thinking which is not dependent on sense data is probably only possible in the area of mathenatics.

For children we create an unbelievably complex scenario for then to 
operate in. Consider for instance the stories of Father Christmas, the tooth fairy and bogeymen of Victorian times who still exist for many children. Then the ayths, legends and fairy stories and fables and stories of aniaals who speak and have teaparties. This is vithout the religious myths which Geering clains ve all believe in. Moreover the modern child is assaulted every day vith a barrage of aetaphors and syabols from television filas and advertising. It vould be interesting to know how much confusion is created in a child's aind and how auch or if any of this is helping to establish and nurture his or her oun creativity and imagination.

One interesting area of potential research vould be finding out hov children develop a scientific or mathenatical bent as opposed to a literary one. He need to know whether this is something to do vith brain function and development of patterns of thinking (left-brain right-brain differences perhaps) or is it as I suspect a fault in our ways of teaching and learning, that is, in our education system. There is a scarcity of inforation in this area. Prople are often channelled into arts or science at the later stages of schooling but any bias to one or the other is probably developed much earlier. Hudson studied the stereotyping of artists and scientists and came to the conclusion that:

...ve are bound to envisage the intellectual grouth of the individual, the evolution of his characteristic frame of aind as the product not only of his genetic endowaent and hormonal secretions, but of a continual traffic with his context-with parents and teachers, examinations and curricula, prejudices and ayths. 1

The aetaphors ve live by as Lakoff and Johnson called then vould no doubt be an iaportant part of this background,

Before beginning this study I believed that metaphor was important to science adinly for teaching purposes that is as a hauristic device for

1. Liam Hudson, Erames of Mind, Penguin, 1968, p.103. 
transmitting knowledge particularly for 'bridging' fron the known to the unknown. I had little appreciation of how wuch it is involved in the making of science i.e, in theory formulation--nor did I realise that the area vas such a contentious one. Scientists appear to be divided in their oun opinion as to how to describe science and uhat constitutes aeaning and truth. To set the context for ay research I found Hogben and Hesse useful as they gave me an overvieu of science which as a non-scientist I needed. Hesse found that our struggle to articulate science is part of our nature and closely linked to our avareness of our spiritual relationship with the earth and our tine on it. Hogben deals mainly with terminology but this helps one to appreciate that science has to $d r$ av on the comaon language stock or semantic field to which we all have a claim. In doing 50 it gives old vords nev meanings and creates new words from old. Because language can never be precise enough, these 'labels' have an in-built capacity for nisinterpration and aisuse. They are also subject to change (e.g. spelling, pronunciation, use and interpretation) and to redundancy as they are replaced or rejected in the light of nev theories. The language of science therefore is not fixed but in constant flux. Hesse gave ne a sense of historical perspective also, though she manipulates her ideas on science to nake a statement about Christianity rather than leaving us to our own conclusions. There is no doubt even froa ay brief glimpse into the vorld of science that many scientists speak of 'religious' experiences. Also as Hesse points out, our thinking, which influences our language and vice versa is also influenced in turn by the social, political and religious cliate in which ve live. Changes of attitude and belief can be detected in the metaphors of science just as in art or literature.

The tools that have been used in science have increasingly developed sophisticated techniques and extended thereby the parameters of scientific 
investigations thus creating oore problems in description and analysis. Logic, maths and artificial languages have all been used to sumarise such findings but even these have to be 'translated' eventually into conventional predicate structures and percolate down to the lay level and the public view of science to give us a general understanding of the universe and our position in it even if as Green said the scientists thenselves are alvays a step or leap ahead of us. Ortony sakes a comment on metaphor in science education which puts the vhole issue into perspective:

I have suggested that the transmission of new scientific ideas and theories is but a special case of purveying ideas that are new (for the intended audience). We have a vord for this general activity "teaching", 1

There is no doubt that the practitioners of science and of art must inevitably, eventually, cose closer together. For this we need a fuller understanding of the huwan aind and an increased awareness and appreciation of the finer nuances of language and I believe that Korzybski makes the clearest statement about this:

The main difficulties ahead are neuro-semantic and neuro-linguistic because for more than 2,000 years our nervous systems have been canalized in the inadequate, intensional, often delusional, aristotelian orientations, which are reflected even in the STRUCTURE OF THE LANGUAGE ve habitually use, 2

Everything created in nature is a vork of art fashioned by some superhuman force to a design or pattern which scientists attempt to understand. This is difficult because the scope is 50 vast and never static and even apparently inanimate objects are active in an atonic sense. To comprehend the grand design the scientist can only examine those parts of it available

1. A. Ortony, ed. Metaghor and Thought, Cambridge University Press, $1979, p, 15$.

2. Alfred Korzybski, Science and Sanity, The International NonAristotelian Library Publishing Co., Pennsylvania, 1933, p.xviii. 
to his senses and theorize imaginatively about the rest. The work is like that of one doing a giant jigsa vhere the pieces have no clearcut edges or colours. Artists on the other hand appear to fashion pieces of their own and thereby capture something of the essence of cration itself in their own creative acts. They initate as it vere the patterns of the patternmaker. Like scientists they conbine the use of all their husan faculties both physical and spiritual.

The link between art and science appears to be wade by metaphor and pattern, Scientists cannot escape metaphor any sore than artists can. Metaphoric expression seems to be an inherent part of our complex make-up, far from being superfluous or aerely stylistic as once thought, it has proved to be both rational and necessary even in science.

Benjamin Lee Whorf has said that scientific words are often conveniently vague, markedly under the sway of patterns in which they occur. That in fact science and poetry are alike, for they rise above literal reference and mundane details "lifting towards Arupa (the pattern world par excellence), towards the world of infinite harmony, sympathy and order, of unchanging truths and eternal things." A tern like stardust, he says, has no reference of its own but "reference is the lesser part of meaning, patternment the greater. Science, the quest for truth, is a sort of divine madness like love."

1. Benjanin Lee Whorf, quoted in Semantic5, ed.K. Thurman, Houghton Mifflin Co., Boston, $p, 12$.

2. Ibid. 
CHAPTER VIII

METAPHOR IN PSYCHOLOGY

And how could a psychoanalyst of today not realize that his real of truth is in fact the vord....1

If ve vonder at all how and why language studies relate to psychology ve have only to exanine the vork of Jacques Lacan. Jan Miel writing of hin says that the object of psychoanalysis is as Freud discovered -the unconscious, and this is observed and studied in dreass and free association. Lacan reminds 45,5 ays Miel "that all the material available to the analyst is verbal: what is analyzed in the psychoanalytic interview is not the patient's dreans but the patient's report of his dreans." Which is the reason why Freud spent so much time analyzing patients' Ianguage. As Miel says "linguistic analysis is in fact the method appropriate to the 3

study of the unconscious." Freud had to invent his oun terms, says Miel, because Linguistics vas not established as a discipline but Lacan has shown that they are virtually interchangeable vith those of structural

1. Jacques Lacan 'The insistence of the letter in the unconscious' in Strructuralised ed. Jacques Ehrmann, Anchor Books U.S.A., $1970, p .103$.

2. Jan Miel 'Jacques Lacan and the structure of the unconscious', in Structuralisem ad. Jacques Ehrmann, Anchor Books U.S.A., 1970,p.98.

3. Ibid., p. 98 
linguistics, which has led hin to the conclusion that "The structure of the unconscious is the structure of language." Moreover, "our theory of the personality aust be revised to account for the peculiar 2 dominance of language and Iinguistic structures in it.' In Freud's theories of the ego the child is noted in early development as being fascinated by his oun inage--"This represents for the child, usually for the first time, the inage of itself as a unified controllable body." This leads presuably to the ability to imagine oneself as another. IChildren and adults are also getting feedback from others as to what their 'ioage' is] Language develops likevise: "The abstractive nature of language, which in fact aakes human knouledge possible, amounts to a siailar denial of reality." We understand our environment by naming and describing it but even vhen not engaged in dialogue we still enjoy denying reality. I take this to mean that we 'play' vith ideas and vords even when not engaged in using them for comunication and these uses are in a sense artificial because vords are artificial they have no reality in the vorld ve observe--any functions they have are that we ascribe to them or are in the very nature of language, which ve do not fully understand. In discourse vith others ve have to observe conventions such as granatical correctness, courtesies, rituals etc. but in our ovn ninds language has free rein.

This Ianguage vithin us is vhat Miel describes as the "forgotten language" of the unconscious "an archaic language lurking beneath our

1. Jan Miel 'Jacques Lacan and the structure of the unconscious', in Structuralism ed. Jacques Ehrmann, Anchor Books U.S.A., 1970, p.98.

2. Ibid.,p.99.

3. Ibid.,p.99.

4. Ibid.,p.99, 
supposedly objective discourse, just as our prial narcissisa lurks beneath all our relations to others." Miel says that ve have an illusion of autonomy, objectivity and stability where we should recognize intersub jectivity and becoming.

In psychoanalysis normal dialogue is suppressed and the language of 2 the patient "recovers the archaic language." Lacan says "that what the psychoanalytic experience discovers is the unconscious in the whole 3

structure of language." I Which makes me vonder what relevance this must have to Literature where presusably vriters indulge in just such language i.e. it has no practical purposeful function except usually for pleasure.]

Language and its structure exist before any individual aakes his entry into it. Sufferers from aphasia have language difficulties "which divide naturally between the two poles of the signifying effect of what we call here 'the letter' in the creation of meaning." ${ }^{4}$ A speaker is therefore "a slave of language" whose being is in nature, society and culture which latter Lacan says could vell be equated vith language. Lacan therefore sees linguistics as being at the centre of all scientific studies and as having created a revolution in knovledge. The essence

1. Jan Miel, Jacques Lacan and the structure of the unconscious', in Structuralism ed. Jacques Ehrmann, Anchor Books U.S.A., $1970,0.99$.

2. Jacques Lacan, 'The insistence of the letter in the unconscious', in Structuralism ed. Jacques Ehrmann, Anchor Books U.S.A., 1970 , p. 103.

3. Ibid, ,p.103.

4. Ibid.,p.103.

5. In a footnote he gives his definition of "linguistics" as the study of existing languages in their structure and in the lavs related therein excluding commication and information theories. 
of this is described in the formula he gives us:

i,e, the signifier over the signified, Which idea he attributes to Saussure.

The signifier and signified are seen as "distinct orders separated 1 initially by a barrier resisting signification." The mystery of language lies in the vay ve can use a word "in order to say something quite other than what it says." That is to say that the signifier does not ansver to the function of representing the signified. One amusing example he uses to illustrate his point is the use of the vords 'Ladies' and 'Gentlemen' as used to designate public toilets. Even in sentences, correct grammar and linear structure are not in themselves sufficient to alke sense. The clue he says to this aystery lies in Metonym. "We shall designate as metonyay then, the one slope of the effective field of the signifier in the constitution of aeaning...the other, it is metaphor."

Modern poetry, he 5ay5, has "taken us quite far in this domain by shoving that any conjunction of two signifiers vould be equally sufficient 3

to constitute a metaphor." In his aocking tone he adds that these two have of course to be as disparate as possible to constitute 'poetic spark' or 'metaphoric creation'. But, says Lacan:

The creative spark of the metaphor does not spring from the conjunction of two inages, that is of two signifiers equally actualized. It springs from two signifiers one of which has taken

1. Jacques Lacan 'The insistence of the letter in the unconscious' in Structuralism ed. Jacques Ehrmann, Anchor Books U.S.A., $1970, p .105$.

2. Ibid.,p.114.

3. Ibid.,p.115. 
the place of the other in the signifying chain, the hidden signifier then remaining present through its (metonymic) relation to the rest of the chain.... One vord for another: that is the formula for the metaphor.. 1

\section{Furthernore:}

We see, then, that metaphor occurs at the precise point at which sense comes out of non-sense, that is, at that frontier which freud discovered, when crossed the other way produces what ve generally call "vit'(Witz).. 2

So, as Lacan expressses it, we follow the letter in search of the truth ve call Freudian. Freud's vork is replete with philological references and "everywhere the apprehension of experience is dialectical, with the proportion of Iinguistic analysis increasing just insofar as the unconscious is directly 3

concerned." This is why Lacan believes that the "letter of the discourse" is vhere ve need to look for an understanding of the unconscious.

Freud affirns this, says Lacan, when he insists that the dream is a rebus and must be understood literally. Drean images are signifiers--"they allow us to spell out the 'proverb' presented by the rebus of the drean.' Hovever "the image's value as signifier has nothing whatever to do with what it signifies..." which is presunably the same as saying that a name is not a person or a vord is not the thing that it signifies. Lacan says that the reality of this has confused psychoanalyts who lack linguistic training.

Enstellung, translated as distortion, is what Freud shows to be the

1. Jacques Lacan, 'The insistence of the letter in the unconscious', in Structuralism, ed. Jacques Ehrmann, Anchor Books U.S.A.,1970, p.115.

2. Ibid.,p.116.

3. Ibid.,p.116.

4. Ibid, p.118. 
general precondition for the functioning of dreans... described, following Saussure, as the sliding of the signified under the signifier which is alvays active in speech (its action... is unconscious).1

What connection does metaphor have with this?

The Verdichtung, or condensation, is the structure of the superimposition of signifiers which is the field of aetaphor, and its very name, condensing in itself the vord Dichtung, shows how the process is connatural with the aechanism of poetry to the point that it actually envelops its properly traditional function.2

Metonymy, according to freud is the aain aethod by which the unconscious gets around censorship. Lacan likens the drean to the party game of mining charades where the onlookers have to guess the neaning from the aime. Hords in a drean are only one element of the perforance,

There is auch ignorance, says Lacan, regarding this conception of the unconscious and he believes that we need to define the locus of the unconscious. He reduces this to a formula:

$$
f(S) \underline{1}
$$

This shows the effects "not only of the elesents of the horizontal signifying chain, but also of its vertical dependencies, divided into two 3 fundaaental structures called metonymy and metaphor." This is further syabolized by:

$$
f\left(S, \ldots S^{\prime}\right) S^{2} S(-) 5
$$

Which I can only explain by quoting exactly shat Lacan gives as explanation:

that is, the metonymic structure, indicating that it is the connection between signifier and signifier which alone permits the elision in which the signifier inserts the lack of being into

1. Jacques Lacan, 'The insistence of the letter in the unconscious', in Structuralism, ed. Jacques Ehrmann, Anchor Books U.S.A., 1970, p.11\%.

2. Ibid, p.119.

3. Ibid.,p.123. 
the object relation, using the reverbrating character of aeaning to invest it with the desire aimed at the very lack it supports. The sign - placed betveen () represents here the retention of the line - which in the original formula marked the irreducibility in which, in the relations between the signifier and signified, the resistance of meaning is constituted.

(In a footnote he adds that the sign "represents congruence) 1

Presumably the 'resistance he speaks of here is what other uriters have described as 'tension'. Then secondly:

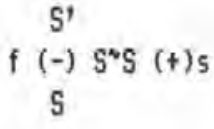

the metaphoric structure, indicates that it is in the substitution of signifier for signifier that an effect of signification is produced which is creative or poetic, in other words which is the advent of the signification in question. The sign + betveen () represents here the leap over the line- and the constitutive value of the leap for the emergence of meaning. 2

(footnote s' i,e. prime)

Lacan speaks of the Freudian universe, as people have spoken of the

Copernican universe, for his discovery also helps, to assign man to his place at the centre of the universe. The question for each of us is whether 'I an' the same that I speak of or is ay thought separate from myself: ...it is no less true if I take myself to the other, metaphorical pole in my quest for meaning, and if I dedicate ayself to becoming what I an, to coming into being, I cannot doubt that even if I lose ayself in the process, in that process, I am. 3

Lacan seens to be asking whether ve can discover ourselves, our being, through words. What we ought to say, he 5ays, is "I an not, wherever I an the plaything of ay thought; I think of what I an wherever I don't think I

1. Jacques Lacan, 'The insistence of the letter in the unconscious', instructuralise, ed. Jacques Ehrmann, Anchor Books U.S.A., 1970, p. 123 .

2. Ibid,,p.124,

3. Ibid., p.125. 
an thinking." This seems to be an essential mystery for:

This two-faced aystery is linked to the fact that the truth can be evoked only in that dimension of alibi in which all "realism" in creative vorks takes its virtue from metonyny; it is likevise linked to this other facet that we accede to meaning only through the double tvist of metaphor when ve have the unique key: the $S$ and the 5. of the Saussurian formula are not on the same level, and man only deludes hisself when he believes his true place is at their axis, which is nouhere, 2

At least, says Lacan, until Freud discovered it; the unconscious, whose realiby is inaediate and whose force comes from the truth and in the dimension of being. "The double-triggered mechanism of metaphor is in fact the very mechanisn by which the syaptom, in the analytic sense, is 3

deternined." Metaphor is in fact the bridge, the connection or 'spark' as Lacan calls it linking the trauma and its signifier. We hold a nenory, says Lacan, in which is found "that chain which insists on reproducing itself lbody netaphors for metaphor again] in the process of transference, 4 and which is the chain of dead desire." For the true nature of neurosis is a question which being poses for the subject " from the place where it 5 was before the subject came into the vorld, "(Freud's words)

This 'being' is "that which appears in a lightning moment in the void of the verb 'to be'." Freud's doctrine of the ego is reduced to a narcissistic relation--"And he grouped within it the synthesis of the perceptive functions in which the sensori-notor selections are integrated

1. Jacques Lacan, 'The insistence of the letter in the unconscious', in Structuralism, ed. Jacques Ehrmann, Anchor Books U.S.A.,1970, p.126.

2. Ibid.,p.126.

3. Ibid.,p.126.

4. Ibid, p.127,

5, Ibid, $, p, 128$. 
which deternine for wan what he calls reality."

The resistances which obstruct the message of the unconscious are mechanisms of defence. Among then are:

Periphrasis, hyperbaton, ellipsis, suspension, anticipation, retraction, denial,digression, ir ony, these are the figures of style (Quintilian's figurae sententiarum); as catachresis, litotes, antonosasia, hypotyposis are the tropes, whose terns impose thenselves as the nost proper labelling of these aechanisms. 2

Lacan asks whether we can really see these as aere figures of speech

"when it is the figures themselves which are the active principle of the rhetoric of the discourse which the patient in fact utters." ${ }^{3}$ He believes that we have resisted Freud's discovery because ve get used to reality and repress truth to avoid bestirring ourselves. We wust face the fact, he 5ay5, that "The unconscious is neither primordial nor instinctual; what it knovs about the elementary is no more than the elements of the signifier."

The end for man--to Freud--was "Wo es war, soll Ich verden. I must come to the place where that (id) was." A goal of reintegration, harmony 5 and reconciliation. His discovery, says Lacan, shows a radical heteronony in san. Others have said 'Know thyself' but what Freud says ye can attain is not the object of knowledge but "that which creates our being" which can be seen in our whims, aberrations, phobias and fetishes as vell as in our ordinary behaviour.

1. Jacques Lacan, 'The insistence of the letter in the unconscious', in Structururaliș ed. Jacques Ehrmann, Anchor Books U.S.A.,1970, p. 129 .

2. Ibid., p.129.

3. Ibid, , p,129.

4. Ibid., p. 130

5. Ibid,, 0.132 . 
To Lacan freud has aade tremendous inpact on our times and he accounts for such by saying that: "the slightest alteration to the relation between and the signifier...changes the whole course of history by nodifying the lines which anchor his being. " Which is why, in his estimation, Freud "founded an intangible but radical revolution." Unfortunately, says Lacan, aere psychological categorizers, such as many practitioners have become are not following the path he cleared, for "Freud by his discovery, brought vithin the circle of science the boundary between being and the object which seened before to sark its outer linit."

Lacan wishes us to understand that:

If the sympton is a metaphor, it is not a metaphor to say 50, no aore than than to say that ean's desire is a metonymy. For the symptom IS a metaphor whether one likes it or not, as desire IS a metonymy for all that men mock the idea.3

We have yet to discover, says Lacan, what links metaphor to the question of being and metonymy to its lack.

Lacan's interpretation of Freud puts metaphor at the very centre of our being. Whatever Aristotle told us about metaphor came eventually to be related to artificial uses of language for thetoric, inflated, persuasive speech, as though figures of speech vere something added to natural native language. Lacan's arguments, based on Freud's findings, presuppose a facility for such language vithin us all. It has been said that the eyes wirror the soul but from what Lacan has said it is language which gives the clue to our nature. We are what we say and think, and dream, and ve say

1. Jacques Lacan, 'The insistence of the letter in the unconscious', Structuralisse, ed. Jacques Ehrmann, Anchor Boooks U.S.A.,1970, p. 135 .

2. Ibid., p.136.

3. Ibid., p.137. 
and think aore than we know or understand.

What Lacan urote in 1957 is interesting because he foresees the iaportance of the close study of language in areas vhere forwerly it aight never have been considered important. It is true, as he says, that it is not the vorld which changes but our vision and understanding of it and people like Freud have enlarged this. Lacan's own work drew such criticism in France froe sone of his scientific colleagues. Freud's advice to ankind is not unlike some of the ore nystical maxims given to us by religious leaders, one is reminded also once again of those mysterious words "In the beginning was the Word." The search for truth embraces all disciplinesespecially Linguistics--Laçan vould no doubt say.

Liam Hudson says that when he first studied psychology ordinary language was ignored. His only avareness of metaphors vas of those which vere dominant at that time, such as the brain as a telephone exchange, aan studied as though he vere a rat and one's career path perceived as a series of hurdles or progress up ladders. He becane gradually aware that the wind might in fact be organised not like a mechanism but like a culture, and that the metaphors one lives by are not always appropriate. He also found hiaself trapped into a mental set which assumed people vere stereotypes. Research methods were also set into established patterns of action. It gradually became the task of psychologists to 'illuminate' or explain the workings of institutions, but metaphor was still an awkward topic even among linguists:

Although we vere shaking ourselves free fron certain patently aaladaptive metaphors, arbitrary or even positively obstructive in their effects, we were still not free to tell ourselves what we vere doing. Oddly, metaphor remained a taboo topic.1

1. Liam Hudson 'The Role of Metaphor in Psychological Research', in Metaghors of Education ed. H.Taylor, Heinemann,London 1984, pp.68-78. 
A heightened awareness of metaphor came to Hudson after reading On Being Blue by Willian Glass (1976) vhich describes hov an author urites sexual or erotic saterial. Metaphor is the key to this "the secret lies in seeing sentences as containers of consciousness, as constructions those purpose is to create conceptual perceptions." (Glass p.86) He writes of vriting as though one gave birth to a vork. Once again ve see that vords take on humanlike connotations.

Hudson vas al 50 impressed by Lakoff and Johnson's Metaphors He Live By (1980) for they too clain that our ideas are grounded in terms of our ideas about the physical and that ve can discuss meanings just as we can discuss gramar. As a consequence Hudson felt free to discuss and exanine metaphors in Psychology. To do this, he found one often has to ignore traditional boundaries betveen subjects.

In his work of fiction The Nympholets (1978) he was not totally satisfied with it as a novel but experienced the strange feelings one has as an author, a 'creator' of fictional people who do in fact seen to him very real, yet the narrator seews;

An uncomitted, slightly unpleasant figure, he seems to stand for the voyeurism of psychology; our tendency to pry into the lives of others, rather than living wholeheartedly for ourselves. He is an EMPTY an; the embodiaent, perhaps, of the emptiness that lies at the heart of empiricisa itself.1

In his book on images in works of art Bodies of Knouledge(1982) he has explored, as a psychologist, the "curious network of relationships between artist, model, inage and spectator " that arise when we choose to make a picture as an artist or photographer. It is in photography that he finds more perception of the nature of metaphor for " certain psychologically 
significant metaphors recur: fields, paths, thresholds, defensive barriers abound.' We assune, says Hudson, that metaphors are VAGUE but in photography this is not true. A 'field' is a specific field with identifiable formal properties. Psychologists, he believes, have neglected such detail;

We can easily be are precise, photography suggest5; and it is iaportant that ve should be so, because it is in detail and nuance that the dialectical dance betveen theory and evidence acquires vhatever value it possesses. 1

There is a danger in psychology, says Hudson that we treat people too simplistically. There are subtle complexities to be considered which transgress the boundaries of individual subject areas. We tend to focus he thinks on the siaple and "An excessively tidy or reductive psychology could distort those events it is supposed to explain." It is as we reflect on the subject itself that he thinks ve becone enthralled by netaphor. A rigid adherence to a particular metaphor in research perhaps can be successful but gisleading. On the contrary says Hudson

By analogy, I see no reason why psychology and the social sciences should not serve as a 'laboratory of aetapher'; one in which ve test and taxonomize, beconing knouledgeable about the points where metaphors and model5, theories and heuristic devices, fuse. Rather than living unvittingly, unreflectively, in the grip of certain aetaphors, ve could learn to pick and choose.2

One pervasive metaphor or ayth which concerns hin is the polarity seen between for instance heraeneutics, study of 'texts', and science. One is seen as 'soft' the other 'hard', one seeking 'illumination' the other 'control'. They create a tension and anbivalence which he perceives as desirable rather than unhealthy for people are inconsistent or bifurcated in nature, he sees this in hirself, and believes that it is exactly this kind of puzzle that psychology should seek to understand.

1. Lian Hudson 'The Role of Metaphor in Psychological Research' in Metaghor in Education, Heinemann, London, 1984, p.75.

2. Ibid.,p.76. 
The business vorld also exploits the psychological insights afforded by an understanding of aetaphor, and training manuals for business managers give wany instances of this. Julius Eitington's vork is typical. In this he describes the heuristic uses of analogy and aetaphor. He cites industrial psychologist Harry Levinson using a spider-veb metaphor to explain man's necessity for conmunication with other people: "In sun, the isages, thoughts, fantasies that ve constantly create in our heads can only be understood and thus anaged by interaction vith others."

A metaphor indicating resistance to change is known as the "Wallenda Complex" after a high-vire artist tho probably could have prevented a fatal fall if he had not been so conditioned to relying on his ablity to keep his balance vith a pole only. According to Eitington this same aetaphor has been used by an international peace advocate.

In the training situation personnel vork out metaphors to simulate their situations or problem e.g, to describe a style of managenent. Metaphors are considered more potent than analogies "because they encourage 2

(deaand) a greater change of perspective". Success has even been found in problem-50lving when groups assume the problen is solved and work backuards from the solution: "The inaging process lets us create our oun panoramic viev of the situation, with the helpful option of tracing causes/events backward and thus understanding wore objectively the forces 3 and factors at vork."

Another related problem-generating and solving approach is

1. Julius E. Eitington, Ihe Vinning Irainer, Gulf Publishing Co., Texas 1986,p, 136 ,

2. Ibid, p.138.

3. Ibid.,p.138. This idea is attributed to Dr Warren H.Schnidt of U.C.L.A. 
morphological analysis there attributes and elements are conbined in a natrix to break the fixed views and ideas ve generally have. The purpose of most of these techniques is to force creative and lateral thinking, to use both sides of the brain rather than relying on traditional sodes of operation. William Gordon of Synectics, Inc., Cambridge, Massachusetts is quoted as saying that one has to aake the strange familiar and this is where analogies are useful to build nev ideas onto old and break down natural conservatism. In such situations sometimes people are even asked to inagine themselves as inanioate object5. It is said that creating symbolic analogies can aid materially in creative problem solving, just as the phrase "protoplasnic kiss" is said to have inspired the neurologist Raaon Y Cajal.

Psychologist5, says Roger Tourangeau have concentrated aainly on two problems; how metaphors are recognized and hov they are interpreted. He sees metaphors as asking us to project one systen onto another. Presuably rather like putting a grid over a or one O.H.P. on top of another. The notion of things falling into 'natural categories' or domains is, he says, a popular one in psychology, and metaphors 'involve two systems, often Jravn from different dowains of experience. Despite their fundamental incompatibility, the two systens can stay adried because the one serves ds the nodel for the other.'

Metaphors do not alvays create semantic dnomaly says Turangeau and literal interpretaton of metaphor does not alvays violate the pules for

1. Julius E.Eitington, The Winning Irainer, Gulf Publishing Co., Texas 1986,p.151.

2. Roger Tourangeau 'Metaphor and Cognitive Structure', in Metaghor: Problems and Persgectives ed. David S.Miall, Harvester Press, Great Britain 1982, p.18. 
sentences to be 'sincere and relevant in context', Suggested tests for netaphor therefore often fail because a metaphor often deals with two apparent incompatibles. Yet "not just any two subjects can join to ake a metaphor." Iperhaps he should have said 'meaningful' metaphor for the juxtaposition alone surely creates technically a wetaphor ]

We project our oun systen of beliefs on to our interpretation of metaphor, says Turangeau "Conparison is...the last and least iaportant step in interpreting a metaphor." 2

In his own research Tourangeau found that readers infer some larger context for a metaphor. In one test, subjects were given sixty-four wetaphors that exhibited different combinations of congruence and agreenent. Another group rated them for preference. Ratings indicated a negative relationship between congruence and liking and a positive one betveen agreement and liking. On the whole they preferred aetaphors whose two subjects vere drawn from distant domains and those which confirmed their picture of the principal subject. This seems to indicate that we like ideas which ratify what ve already know and believe and yet we also appreciate novelty. Says Tourangeau "Novelty is one of the iaportant determinants of our response to a metaphor." ${ }^{3}$ A finding which would not have surprised Aristotle. Understanding a metaphor takes several stages :"During the main one ve recognize the metaphor, infer its subjects, create parallel beliefs about the principal subject and conpare these beliefs to our old beliefs."

1. Roger Tourangeau 'Metaphor and Cognitive Structure', in Mețaghor: Problens and Perspectives ed. David S.Miall, Harvester Press, Great Britain 1982, p.22.

2. Ibid.,p.27.

3. Ibid, p.32.

4. Ibid., p.33, 
Like other uriters Tourangeau is forced to use metaphor to describe metaphor, he calls it a system of belief which "gets nev life in a foreign land and takes root among the alien corn." To Tourangeau metaphor 'tests' what ve already believe or think we 'know'. As he says nore research needs to be done on the use of metaphor. It vould be interesting to know just how and why a aind takes flight into metaphor, why some do this constantly or frequently and soee rarely or never, and at what age one first recognizes metaphors of consciously uses then in speech and in vriting. We could probably also profit fron knowing nore about hou a translator's mind works when translating idion from one language into another which aust be a similarly complicated task of atching ideas, descriptions and concepts. Translators such as those of Lacan whon I mentioned earlier and of Derrida bemoan in their introductions the difficulties of translating such expressions as e.g. French word 'propre' with a suitable English synonym. With Lacan the translator even advises readers that they really ought to see the original to get the triue sense of the vork.

Furthermore, metaphor is so bound up vith our selves, our yays of thinking and expression that it takes on al nost human characteristics-something fontanier recognized in his treatise on metaphor (Les Figures du Discourse 1830) He said "Even though it is not a body but an act of mind, discourse... has nevertheless, in its different vays of signifying and expressing, something analogous to the differences of form and characteristics that are found in real bodies."

1. Roger Tourangeau, 'Metaphor and Cognitive Structure', in Metagahor Probleas and Perspectivese ed. David S.Miall, Harvester Press, Great Britain, 1982, p. 34

2. Pierre Fontanier, quoted in The Rule of Metaghor, Paul Ricoeur, University of Toronto Press, 1977, p.52. 
In his studies of aind control Jose Silva found that the brain is more energetic vhen it is less active. At lover 'Alpha vave' frequencies, similar to our half-avake state before sleep, the brain receives and stores aore inforation but it is hard to keep alert at these frequencies. The exercises he has developed call for relaxed concentration and vivid mental visualization.

Training in meditation techniques allows a person to tap in to this source of creative thinking. Silva claims that anything 'forgotten' is associated with experience that is never truly forgotten. For this reason tag associations are memory aids deliberately created to help remember information. He says " all experiences leave uenories firmly imprinted in

the brain." He also believes that dreass can be deliberately "programed' to help solve probleas. These dreans he speaks of are not the sane as those subjected to Freudian interpretation. His idea tends to fit in vith oun belief, unproven, that dreams, rather than coaing fron the unconscious begin in the conscious state and then become embedded in the unconscious from which sleep arouses the in higgledy-piggledy fashion. Silva believes that we underestimate the pover of words and often dull our appetite for life vith negative words.

There are two basic principles to his theory of mind control. The fact that we can only think one thought at a time and our concentration transforas it into action. This has led him to believe in the pover of self-healing, of aind over matter by the projection of positive inages. He describes mind control as the state such as Brahms allegedly went into when creating compositions, and described by Signund freud, in a paper on

1. Jose Silva and Philip Miele, The Silva Mind Control Method, Pocket Books, Simon and Schuster, Nev York, 1977, p.43. 
Listening. Other artists and scientists have described the sane. I believe Keats called it a state of 'yeastiness'. What I begin to vonder is whether the pover to produce aetaphors is symptomatic of a sinilar 'instant' state of creativity.

At normal working levels, says silva, the mind is bombarded with various stimuli. At the relaxed level more concentration and focus is possible. It is a type of self-hypnosis which we may often experience without fully realising what it is or how useful or iaportant it can be.

Silva's findings evolved from his knowledge of electricity and a perception that the human brain aight vork in a sisilar fashion. In studies of his techniques vith mentally disturbed patients they seemed to show that relaxation dininishes their anxieties siaply because in a relaxed state they are not possible. Greater feelings of warath and love seemed to be aroused which led hin to vonder if the state ve call 'love' or its energy is a factor to be considered, as "Perception is improved at the relaxed level of aind and body, and clear thought and judgment are 1

enhanced." It may therefore be true, as freud has suggested, says Silva, that a therapy of the future might depend priaarily on the nobilization of energy.

Perhaps we have not taken enough account of this need for relaxation in learning situations, and one vonders if school environments and some teaching methods are in fact not fully conducive to learning and wind enhanceaent. As Silva says:

The left heaisphere consciousness dominates most of our everyday living and is favoured by the educational system as vell as by the 5ocietal attitudes of the Hestern Horld. It is objectively

1. Jose Silva and Philip Miele, The Silva Mind Control Method, Pocket Books Simon and Schuster, New York,1977, p.194. 
oriented, and usually associated with the generation of much Beta brain wave activity. Right hemisphere consciousness seems to be prinarily subjective, receives secondary consideration in our education, and finds its greatest expression in the arts. It is generally accompanied by Alpha or Theta brain-wave emanations. 1

Methods such as those advocated by Silva effectively encour age nore use of the brain's potential and encourage right-brain function.

Betty Edvards confirms this neglect of right-brain potential in her work on developing innate artistic ability which she claims ve all have:

The object of draving is not only to show what you are trying to portray, but also to show You. Paradoxically, the aore clearly you can perceive and dray what you see in the external world, the more clearly the viewer can see You, and the nore you can know about yourself. Thus ...draving becomes a netaphor for the artist. 2

She summarises the characteristic functions of both sides of the brain and in the right mode she places 'Analogic', that is, seeing likenesses between things; understanding metaphoric relationship5. Drawing she describes as a way to quiaten the ceaseless huo of activity around us. It is sinilar in effect to what Silva spoke of. She also says that the "5chool world is mainly a verbal, symbolic vorld" where some learning styles e,g. the visual 3

are not catered for. Nev knowledge about the brain will she believes help us to develop teaching and learning styles which

...will enhance children's intuitive and creative pover5, thus preparing students to meet new challenges vith flexibility, inventiveness and imagination and with the ability to grasp complex arrays of interconnected ideas and facts, to perceive underlying patterns of events, and to see old problems in new vays.4

Metaphor-naking nust surely be one of these creative forms of thinking

1. Jose Silva and Philip Miele, Sillva Mind Control Method, Pocket Books, Simon and Schuster, New York,1977, p.214.

2. Betty Edwards, Draving on the Right Side of the Brain, Fontana/ Collins,U.S.A., 1979, p.23.

3, Ibid, p.195.

4. Ibid.,p.196. 
which ve need to develop and encourage, Which is all the nore reason why ve need to understand how and why they work. Edvards has another idea which seeas excellent. She says that when we teach young children ney vords, rather than siaply giving then names or 'labels' to learn we should explore the concepts. For instance in nasing a tree one could encourage inaginative ideas about the nature of the tree, its structure and function in the environment. In this way we teach them that a name is only a part of the object and ve hopefully keep alive a sense of vonder. As in draving practice the desire should be to see ever nore deeply.

Allan Paivio is avare of the complexity of this phenonenon of linguistic creativity particularly. As he says

...semantic productivity must be regarded as a salient design of netaphorical language, just as syntactic productivity is of language in general, despite the repititiousness of specific grammatical constructions in everyday speech. Hovever ve know even less about the psychology of semantic creativity than ve do about syntactic creativity, and the former must be counted anong the nost challenging theoretical problems that confront those who are interested in a scientific understanding of language behaviour.1

He quotes research on proverbs which failed to provide any adequate theory to describe the semantic relationship between a proverb and its interpretations. He believes that recent studies of memory and cognition do throw some light in this area. The perceptual basis of metaphor has been explored, he says, by such people as Susanne Langer (1948) and Arnheis (1969), also by Roger W. Brown (1958), Asch (1958), Dsgood (1953) and Werner and Kaplan (1963). None hovever "explain how perceptual processes and images achieve their abstract functions, nor hov they becone linked to language, but they do eaphasise the prinacy of such processes in the origins of

1. Allan Paivio, 'Psychological Processes in the Comprehension of Metaphor', Metaghor and Ihought,ed. Andrev Ortony, Caabridge University Press, New York, 1979, p.150. 
metaphor."

Other research shows that inagery is sonehow involved in the comprehension and recall of some netaphors but it is not clear why this is 50. As Paivio says metaphorical imagery may be quite different from literal inagery, It appears, says Paivio, to be of a symbolic or abstract nature. Malgady and Johnson came to the conclusion in their studies that When ve interpret a metaphor the constituents are encoded into a single feature representation. Verbrugge and McCarrell(1977) "concluded that metaphor processing involves the recognition of an abstract resenblance, or abstract relationship, between the vehicle and the topic domains, which is 2 more than the sun of the attributes of each constituent.' They could not however, say what was the precise nature of this abstract perceptual relation nor how it arises fron the separate parts.

Paivio discovered that there is no comprehensive theory to explain the workings of aetaphor based on studies of inagery. He believes research into memory be more fruitful for it has been found that "pictures are recalled better than vords, and concrete vords that readily evoke inages 3 are recalled better than abstract, low-inagery vords." When subjects vere required to learn pairs of abstract nouns sometines they blended the two into one inage e.g. 'boy scout' represented 'chance' and 'deed'. This is significant says Paivio because "the metaphorical connectionn was constructed by the subject hinself, in a manner analogous to the discovery of the

1. Allan Paivio,'Psychological processes in the Comprehension of Metaphor', Metaghor and Thought, ed.Andres Ortony, Cambridge Univer sity Press, Nev Yor k, 1979, p.157.

2. Ibid.,p.162.

3. Ibid.,p. 164 . 
comaon ground between the vehicle and topic of a novel aetaphor," Sinilar findings case from Paivio's own reseach with Katz(1975) where subjects had to learn pairs including soae nonsense vords associated with instances of several concepts, some low and some high in inagery value. The subjects had to learn the concepts and the results shoved that the iagery value of the conceptual categories, as well as imagery instfuctions, facilitated concept acquisition. As Paivio says "The study is relevant to metaphor interpretation because such interpretation is analogous to concept discovery. The subject must discover what the vehicle and topic have in common in a semantic, 2

conceptual sense,"

There is also considerable evidence according to Paivio that inagery contributes to the comprehensibility of sentences because it provides an additional (subjective) referential context for the interpretation of a sentence; 50 it seems reasonable to assune that it also contributes to the comprehension of metaphorical expressions. However the the context could be inappropriate if it draws attention to literal aspects says Paivio. He nakes no mention of the age of the subjects, presurably adults, because children often have difficulties with metaphor and there is also evidence such as that referred to by Colin Rose that there are people who have poor powers of iagery, depending on whather their neurolinguistic learning style is predoninantly visual, aural or kinesthetic.

Paivio asked some of his students to comment on his own statement that metaphor is a solar eclipse in that it both obscures and enlightens.

1. Allan Paivio, Psychological Processes in the Comprehension of Metaphor', Metaghor and Thought, ad. Andrev Ortony, Cambridge University Press, New York, 1979, p. 164

2. Ibid., p, 165 .

3. Colin Rose, Accelergated Learning, Topaz, England, 1986, 
He found that wost focussed on the vehicle and only one on the topic, suggesting that both strategies are possible but one way be preferred.

The aost relevant of his findings are that dual coding enhances the possibility of finding a ground in long-term aeaory; that integrated inages make for efficient information storage; inagery ensures processing flexibility; and topic and vehicle can both be retrieval cues for relevant inforeation; also that verbal processes keep search and retrieval on track by suggesting inages which may help to select 'appropriate' data from our memory banks.

Relevant research findings are $5 c$ arce says Paivio, mainly because comprahension itself is not fully understood. Further study of metaphor can add to this because both " 'ordinary language' and metaphor are continuous phenomena, involving coman cognitive and linguistic processes," It seems ve cannot understand how and why people use language in the ways that they do, if ve do not understand how they think, how they acquire language, and hov the two are connected. When we examine metaphor, its creation, use and interpretation ve are looking at only one coaplicated part of an obviously complex field.

Some of the more recent findings on learning are described by Colin Rose, previously referred to. His interest is in memory, particularly how it relates to language acquisition and as it is exemplified in the vork especially of Georgi Lazanov and his Accelerated Learning Progranmes. What Rose has to say is relevant because he stresses the importance of visulization and association as memory aids. There are fundamental techniques the brain uses, recognizing patterns and connections, sorting

1. Allan Paivio, 'Psychological processes in the Comprehension of Metaphor', Metaghor and Thought, ed.Andrev Ortony, Caabridge University Press, Ney York, 1979, p.171. 
and linking, which is of course what metaphor does. My ovn conclusion is that how metaphor works is probably illustrative of one way the brain vorks. A metaphor encapsulates thought in a condensed forn in a aenorable 'chunk'. We ady have been deceived by our pleasure in metaphor into not taking it seriously until quite recently and there is obviously a long vay to go. "Play is central to learning " says Rose. Playing vith words is something we all enjoy. It is a step further in this 'gaae' to link vords and ideas and to create associations--the basis of aetaphor. Such childlike play can be stifled he believes by schooling.

It must be obvious to teachers that a rich fund of ideas, inages and words has therefore to be made available to young learners. The fascination children naturally have for vords and ideas is corroborated by Joy Couley, celebrated New Zealand author, in a talk she gave world-vide in 1987. She said a child brings to a book three gifts which fey adults have, a sense of wonder, a readiness to accept nev experiences and "Then there is the feeling for the quirkiness of words: rhyme, rhytha, alliteration, nonsense language, doggerel, aniaal sounds--they are all appetising to the early reader. She is keen to explore all the fun that 2

language has to offer." Metaphor-making is an extension of this aptitude, interest and facility. 3

Rose says "We remenber things that have poverful associations for us." It is considered likely that we use only about ten per cent of our brain, maybe less and the measure of its potential is the number of

1. Colin Rose, Accelergated Learning, Topaz, England, 1986, p.92.

2. Joy Cowley, 'The Healing Power Of Language', New Zeal and Listenener, January $16-22,1988, p .35$.

3. Colin Rose,p.1. 
connections it can nake:

The brain is the only organ that expands through use. The more it is used either to acquire facts or in the process of creativity, the nore memory associations are formed. The more associations are for aed, the easier it is to renenber previously acquired inforation, and also to form new associations,i.e. create new ideas and concepts. This is a vitally iaportant 'virtuous circle', and reading is the key to forming it, 1

Man has so far in his history concentrated on atterial problens says Rose, and has achieved much in this area but philosophical problems have still to be resolved. To do this requires that ve develop both sides of our brains for:

We are trained to think in a pattern ve call logical... and this seens to involve one side of the brain--the left side. Learning aethods are generally not designed to stimulate the development of the side of the brain that processes concepts--the right side.2

The left deals mainly with language and wathematical processes, logical thought, sequences, analysis--'acadenic pursuits', whereas the right deals in music and visual impressions, pictures, spatial patterns, and colour recognition, also conceptual thought and abstract concepts. He dispels many of the 'myths' about the brain, such as that those who are artistic sust be poor at waths and that the brain can becone overloaded or deteriorates with age. Novelty aids memory says Rose and ast novel experiences are encountered in one's youth. Other aspects such as relaxation, exercise and nourishment are also important to its functioning. An interesting conclusion with which Katherine Mansfield vould have concurred is that every normal child is born a potential genius but needs a tich environaent and plenty of learning opportunities.

There is no learning without memory says Rose, and no agreement on

1. Colin Rose, Accelelerated Learning, Topaz, England,1986, p.10.

2. Ibid.,p.11 
how it vorks. We have short and long-term memory which may be likened to the random access memory of computers and storage or read-only menory. It is known that reading aloud helps to register (encode) saterial also that short term aemory has a fifteen second span which has been proved by observation of translators and court reporters. The time taken to learn something is also shortened if it is spaced out and active involvement enhances aemory rather than passive learning. Interference or distraction affects our memory and causes us to forget. People think of memory as if it vere a jug of linited capacity, says Rose, in fact it is illinitable and nore like a branching tree with potential for adding branches.

Stories are good menory aids says Rose and the more elaborate the story the better because a story links words to be remeabered and causes us to build up visualisations and "the plot provides an associative thread" 50 that one has only to recall a theme to trigger recall of the material. Rose says "If you create a poverful visual inage between two vords [ this is what a metaphor can dol remembering one vill trigger recall for the 2

ather." Also a list of iteas learned in picture form is wore easily learned than an equivalent printed list. This requires dual encoding, which is what Paivio referred to also. The ideal says Rose is not just dual but nultiple encoding. He refers to Reber (1967) ${ }^{3}$ as saying that shared relationships between words are often subconsciously recognized and when some grand chess masters play blindfold it is not each piece they recall but the overall patterns involved. Emotive, abstract words are the hardest to remenber because one cannot 'see' them so easily. One secret of

1. Colin Ro5e, Accelerateded Learning, Topaz, England,1985, p. 45.

2. Ibid.,p. 45 .

3. Ibid, ,p.46, 
memorising is to absorb the principles involved and get an overall

viev just as in a new place you would look at landarks first "This is a spontaneous and natural mapping principle." Which is similar to how ve cope vith a jigsav when ve have no picture guide and apparentiy this mapping instinct vas vital to primitive wan and even today some African tribes evidence a higher degree of visual or eidectic nemory than most Westerners. It is a fact says Rose that the single nost important factor in menory is visual menory. [ Which leads ae to vonder if cartoonists have this visual capacity highly developed. Are cartoons a kind of metaphor?] The experiences of the day, says Rose, are revieved during sleep and assimilated into new patterns of thought, belief, and future behaviour during dreans. It has been said by Chris Evans that "we sleep in order to dreas" and by Patricia Garfield "Dreams continue work begun during 2

consciousness."

Another memory aid is 'chunking' or breaking new material into assimilable parts just as ve remember the alphabet or phone numbers deliberately linited to a particular length. Sentences are norally of a length for us to cope vith, as are phrases in ausic, and rhythm also assists menorising, as praying monks discovered. In fact when one considers many of the aspects of church rituals they seen to have exploited much of the psychology ve are now learning to use for teaching. One thinks of candles and vindous and nusic and rosary beads, all aids to concentratrion on the topic in hand, and in Mediaeval times it was in churches that drama had its beginnings. Motivation, repetition, mnemonics all help also but highly visual association between vords or objects is the strongest memory factor

1. Col in Rose, Acceleratege Learning, Topaz, England, 1986, p. 48.

2. ibid.,pp. 50-51. 
and it is believed that we are capable of perfect visual memory for as

Rose says the brain is not a sponge but a vast netvorking system.

Every new fact or concept you learn adds to and links up with the existing netvork. So when you encode something new; it not only forms a link to the existing network, it also provides yet another hook onto which still aore associations can be hung or connected. So the nore you remenber the greater is your capacity for future learning and remenbering. 1

Association therefore is a vital factor in human meary. It is not surprising

then that humans express thenselves in metaphors which alake use of this

Vast network of stored as50ciations to create new and unique expressions.

Furthermore says Rose the brain does not process thought in a straight line logical sequence (the left brain might but the right brain does not) but connections are sparked and associations triggered. One vord sets off others in response and this can be shown in picture form. Thus if inforation is presented in this for a it accurately reflects how the brain vorks with its memory aaps. It is interesting when one reflects how children are captivated by picture books and comics even when their vord knowledge is linited and these often lead into reading. Dur eidectic menory is called hyperanesia or super menory and appears to be a right brain capability which is more obvious in children up to age ten.

There is evidence that our educational attitude, vith its eaphasis on logic and 'hard' facts, rather than frivolous images, may have educated eidectic memory out of us.2

E.R. Jaensch found more evidence of it in schools where sensory activities were encouraged and Professor Key said that anyone who wanted to make greater use of his brain-stored information "must learn how to move

1. Colin Rose, Accelergated Legarning, Topaz, England, 1986, p,63.

2. Ibid.,p.67. 
information from the unconscious into the conscious level of cognition."

The Ancients apparently understood the inportance of rhythm and memory and could chant entire stories such as the Iliad "to the heart-beat rhythm of a softly-playing lyre" wany parts of which vere reaenbered by the listeners. Confucius also deemed music necessary to the superior wan. It is believed that rhythm is at the heart of the Universe and the Natural World. Even plants have proved susceptible to music. All of which says Rose fits in vith the ideas of those Baroque composers vho alvays believed that there vas a sacred geometry to the Universe, and artists who discovered the Golden Mean.

Many of these ideas have been implemented in the language classses of Georgi Lozanov whose vork Rose describes. Essentially he creates a learning environaent designed to encourage are balanced left and right brain activity. Consequently the atmosphere is relaxed, students are encouraged to be confident of their learning ability, a holistic view of the naterial to be learned is presented rather than going fron easy steps to harder. The sost unusual aspect is that music is used to implement learning so that not only is language heard and seen and spoken, sonetines in unison, but music plays in the background so that all senses are involved and a rhythaic pattern matched to the learning process. Dr Budzynski has uritten:

Apparently the right hemisphere processes verbal material better if it is coded in rhythe or enotion. When someone speaks in a monotone, only the verbal, dominant hemisphere is activated. If the speaker adds intonation, the non-verbal side starts to pay attention. 3

1. Colin Rose, Accelerated Legrning, Topaz, England, 1986, p.69.

2. Ibid.,p.97,

3. Ibid., 0.89 . 
All that Rose says supports a new approach particularly eflective for teachers of language where memory plays such a large part. It is not concerned with setaphor as such but nevertheless there are attributes of metaphor such as the linking and association of ideas that fit in to these same ideas about the importance of association and how our minds are now thought to work, something nore than an electrical circuit or a cosputer. Music, says Peter Kline, makes you faniliar with the language you are studying --its patterns and rhythms. The other aspect that the accelerated learning progranos eaphasise is 'play', that is the fun aspect of learning which most of us lose after going to school. It might even be, says Rose the daytine equivalent of dreaning. Enotional involvenent or a high state of arousal encourages learning. Many writers on metaphor have pointed to the pleasure we take in metaphor because of its novelty, Hords can excite us because of their associative povers,

Patterning is central to our human nature. Rose says that as Science delves into the nature of atter ve are finding that all satter is in a state of vibration. He quotes Dr Donald Hatch who says "le are finding that the universe is composed not of matter, but of music." Different notes in music create patterns. Stephen Halpern has written "the forms of snow crystals, the andala faces of the flowers, actually resonate to the haraony of nature. Crystals, plants and human beings can be seen as ausic which has taken on fori.t?

1. Colin Rose,Accelerated Learning, Topaz, England, 1986,p.100.

2. 1bid.,p.101.

3. All of the above suggestions for ease of learning, music, rhytha, drana etc, are combined in musical drama such as opera. 
When we create inages in words, in poetry ve are likevise creating patterns or looking for thew. Metaphors balance two ideas creating harnony Where it did not appear to previously exist, because there are connections throughout nature that we have yet to discover. A physicist Robert Beck has said "The earth itself has a brain vave. There is no longer any question that man is a bio-cosmic resonator." We receive and send forth the energy patterns of our environment. As Rose says ve nead to tune in.

Even one's individual personality can be seen as a pattern according to Rose because the body virtually recreates every seven years therefore What you are is what you have created irrespective of the body you once had. He says that Socrates knew 50 long ago that the essence of teaching is to help people to articulate. Once you articulate, menory is captured. As auch as eighty per cent of the brain's function is visual thinks Win 2 Wenger. Articulation is important because it involves vhole brain activity. The conclusion of all of these findings is that children vill learn best if all the learning modes are involved, auditory, visual and kinesthetic. What we seen to have lost sight of in schools is the fact that the brain can cope vith a vast amount of information. We atteapt to help children by braaking knovledge up into that ve consider assinilable parts and in so doing ve destroy the necessary global or holistic viev that humans need to make sense of inconing information: 'Being exposed to a lot of material, but picking out parts in a planned sequence and seeing hov those parts fit into 3 the whole." The last part of this statement is the most important.

1. Colin Rose, Acceler atated Legarning, Topaz, England,p.104.

2. Ibid.,p.151.

3. Ibid, $, 0,220$. 
As teachers ve think ve have learning vell under control when ve are vell organised, knowledgeable and enthusiastic, but as teachers ve tend to forget to see things fros the students viev and in his or her life context. The whole process is wirrored I believe in the phenonena of metaphor which is a process of association, visualisation, transfer of ideas and craative thinking. To encourage creative, imaginative and independent thinking is one of out sain goals.

Lacan dravs our attention to the fact that language, both conscious and subconscious, is at the heart of the psychoanalyst's vork and that language gives an only a metaphorical sense of meaning and of his oun baing. Hudson likevise draws attention to our need to exanine language and particularly metaphors because they are more complex and more poverful than we have previously assuned, often controlling us and leading for example into rigid thinking such as produced the traditional dichotomy between arts and science.

Those tho have most to gain from such understanding have been quick to latch on to uses of the new information. Thus industrial psychology explores new ways of changing behaviour and imoproving performance in the workplace. Tourangeau adds little that is new but is avare that metaphor is linked to our ability to enlarge and add to our personal mental field. Jose Silva alnost stuabled on his inforation in his study of the aind as if it were an electrical circuit. His beliefs tie in also with traditional techniques for aind control as employed in yoga.

The importance of meditation, concentration, visualisation, relaxation, and activity are emphasised by Silva, Eduards and Rose. Paivio supports the iaportance of visualisation in perception, understanding and foration of concepts. Rose finds that research on accelerated learning shovs memory to be at the centre of learning. It is difficult to believe his statement 
that we are capable of remembering everything we learn, if we wish. So far it vould seen that we have underestiated our ovn capacity for learning and for creative thinking. Geniuses of the past appear to have coordinated both right and left brain activity and if we attempt to do this in schools we may revolutionize education. It seens to me that religious leaders have used and understood many of these techniques vithout our perceiving them as such. Celebrated yogis, such as Paramahansa Yogananda have demonstrated the almost superhuman powers ve are capable of if ve learn to concentrate and tune in to our subconscious which ay be in fact our greatest source of knowledge.

Howard Gardner and Ellen Winner summarised at a Chicago conference 2

some of the research on metaphor. Children vere tested on their competence in selecting paraphrases of metaphors and it yas found that until middle childhood children tend to interpret metaphors literally. They were decoded nore successfully if encountered in a situational context. In another sinile-production test where children had to add an appropriate ending to a short story there was a paucity of appropriate metaphoric productions at every age but the highest number of appropriate netaphors came from the youngest children which supports those tho believe in the natural creativity of childhood. Hovever this same group produced a large nuaber of inappropriate metaphors, It is difficult from their findings to decide whether the younger children have a special capacity or whether it is a symptom of the way their thinking is organized.

The researchers were also puzzled by the literalness of middle

1. Paramahansa Yogananda, Autobiography of a Yogi, Cali fornia, 1979.

2. Howard Gardner and Ellen Winner, 'The Development of Metaphoric Competenca:Implications for Humanistic Disciplines,' in Qn Metaghor, Sheldon Sacks, University of Chicago Press, 1978, pp.121-139 
childhood respondents and vondered vhether this vas a cultural influence or

a developmental 'stage'. They vere also intrigued by the right-brain

left-brain controversies and subjected brain-injured patients to tests. The

left-henisphere patients vith language difficulties all had trouble paraphrasing the metaphors and the right-brain patients vere reluctant but usually offered an appropriate response. With response to pictures depicting the metaphors the results were surprising. The aphasics made the right selection and the right-brain group in contrast to aphasics and noral control group chose the literal depictions. Which led the researchers to conclude that "metaphoric competence is not of a single 1

piece." What the aphasics seened to be able to do was to 'map' a

particular figure of speech onto a situation where it was likely to be uttered, even though they could not put into words the precise lexical meaning of that utterance.

More recently Jerre Levy has reminded us that ve should not think in terus of the brain working as two separate halves for their activities are integrated:

When a person reads a story, the right hemisphere may play a special role in decoding visual information, maintaining an integrated story structure, appreciating humour and emotional content, deriving aeanings from past associations and understanding aetaphor. At the same time, the left hemisphere plays a special role in understanding syntax, translating written words into their phonetic representations and deriving meaning from complex relationships among word concepts and syntax. But there is no activity in which only one heaisphere akes a contribution..., real creativity and intuition, whatever they may entail, almost certainly depend on an intimate collaboration between hemispheres $\ldots$ and it is quite inpossible to educate one henisphere at a time in a normal brain. 3

1. Howard Gardner and Ellen Winner, 'The Development of Metaphoric Competence:laplications for Humanistic Disciplines.' in On Metagher, Sheldon Sacks,University of Chicago Press, 1978, p.136.

2. Jerre Levy, 'Right Brain,Left Brain:Fact and Fiction', Psychology Ioday, May 1985, p. 44. 
Buky has noted that in a psychotic state a high number of metaphors way be used and can be sysptomatic of anxiety. They are either used with too great a connotation gap or more often are considered a reality as in paranoid.

Metaphor is a problem area for psychology as it is for other disciplines not only because the phenomenon itself is not fully understood and has special relevance to psychology, but because it is endenic in the language here as everyuhere else. "Metaphorical language has crept into scientific discourse "varned Hartaann, $K r$ is and Loewenstein. A problem Freud was avare of when he said that "the perception of our thought processes occurs only vith the help of vords" and it is common knouledge that "the language of inner experience is first and foremost 3

metaphorical." His own models were aetaphoric. He had what is clained to be an anthropomorphic model of the aind and states that "it is the task of scientific psychology to translate back into intrapsychic teras the language of events found in ayths, delusions, and religions, and to 'transfora metaphysics into metapsychology, :"

Whether anthroponorphisa can or should be removed fros psychology is debatable say Grossan and Sison, for "The physical metaphor iaplies a 5 physical oodel." However they find that it is not necessary to 'purge'

1. Bela Buky, 'The Systen of Metaphors Semiotically Considered', in Seniotics Unfolding, Tasso Borbe, Mouton, 1983,p.789.

2. William I.Grossman and Bennett Sinon M.D. (New York), 'ANTHROPQMORPHISM, Motive Meaning and Causality in Psychoanalytic Theory, published by The Division of Psychiatry, Montefiore Hospital, Albert Einstein College of Medicine, in Psychoanalytic Study of the Child, Vol.24,1989, p.81.

3. Ibid.,p. 84 .

4. Ibid.,p.94.

5. Ibid., p.100, 
the clinical theory of anthroponorphic language, for, "Anthroponorphic language is in no way incompatible vith systematic study of individual cases...[it] is not unscientific. It serves a nunber of useful purposes... there is no other language available,"

One could criticise research such as that described by Gardner and Winner as telling us aore perhaps about strategies used to cope with metaphor than about metaphor itself or about how people create then and Why. As Paivio has said there needs to be more reseach in this area which would not only lead to an understanding of imagery and verbal processes but vould shed light on "the processes underlying the discovery of nev metaphors" and also of the creative processes involved in art and science.

Vygotsky for whon "A vord is a nicrocosm of human consciousness" and his studies of children's formation of concepts and the nature of language and thought are exactly the type of research that vill assist teachers in understanding how children learn and thus enable them to be aore skilled in teaching.

At present we are not auch further on than when Shakespeare asked "0 tell ae where is fancy bred or in the heart or in the head?"

1. Willian I,Grossman and Bennett Simon M.D, (New York), 'ANTHROPOMORPHISM Motive, Meaning and Causality in Psychoanalytic Theory, published by The Division of Psychiatry, Montefiore Hospital, Albert Einstein College of Medicine, in Psychoanalytic Study of the Child, Vol,24, $1969,0.108$.

2. Allan Paivio, Imagery and Verbal Proceseses, Holt, Rinehart and Winston, U.S.A.,p.531.

3. Lev Vygotsky, Thought and Language, MIT Press Cambridge, Massachusetts, 1987, p.256. 
CONCLUSION

A vord is dead unless it's in your head.

A consideration of the nature of aetaphor reveals a vide range of beliefs and attitudes tovards this aspect of language, ranging froe Aristotle's assertion that it is a sign of genius through those who disapprove of it as a distortion of language and truth to more recent claims that it cultivates intinacy and is not only unavoidable but necessary to human thought and worthy of acadenic study. It appears to have evolved from recognition as a clever rhetorical device used to entertain and persuade, to a realisation that our perception of the vorld and ourselves is closely related to our use of language and aetaphor in particular so that one sees a preoccupation in earlier times vith classification and more recently an interest in theories of language. No ultinate definition of aetaphor eaerges but dominant or root aetaphors are recognized as playing a powerful role in the structuring of social identity. There appear to be no rules for metaphor but patterns emerge which are quite distinctive such as those evident in politics of literature or education. The nost extreae view is taken by Nietzsche who sees language as completely aetaphoric and imposing aeaning on the world but not truth.

From a literary point of view metaphor is seen as a vital life force and a power found particularly in myths and poetry, songs, folktales and 
fairy tales. Many metaphors, especially religious ones, have been taken very seriously as in the Christian view dominant in the Middle Ages where the vorld vas vieved as a book of God's metaphors. The aetaphors in literature reflect the preoccupations of each age as ve see in the discernible shifts from Classical tises to the influence of Christianity on the Middle Ages particularly, through to the Ronantic viev and the pervasive effects of a rising industrialisa and scientific viewpoint. The earlier the language that is examined the more evidence there is that there is a strong link betveen language and religious avareness. Many uriters testify to the essential mystery of poetic power which appears to be both visionary and priaitive, When ordinary language fails to express the deepest human feelings it is metaphor which enables us to express ourselves at least partially. Religious writings such as the Bible display the complex process of human endeavour to express the conviction that life has a purpose and that one needs to becone attuned to those revelations claimed by prophets and leaders of the past. Truth is variously described as unveiling or enlightenaent, a metaphor which pervades our language and is the most puzzling and mysterious of all of those encountered in this study. It is this sometimes aetaphysical aspect of metaphor rather than its structure which akes it difficult to describe and define.

The metaphors describing children reveal a human dilemea, which is, how to prepare young people for adulthood when adults are often childish and ignorant thenselves or overridden by concerns such as those of econowics and uncertain of the nature or purpose of their own lives tramalled as ve are vith legacies of our forbears. Our attitudes have varied therefore fron considering children as animals and receptacles of $\sin$ to tender plants or precious possessions, and in the process often denying them the autonony or authenticity which some have claimed is their right. The 
metaphors of childhood are inextricably linked with those of education, and history shows us that the vielding of power over children has often been a dominant concern of parents and society. The institutions of education reflect both the power structures of national politics and the more recent dominance of industrial organizations and bureaucratic management styles. All of these are further coaplicated by the insights and influences of the wodern social sciences 50 that an examination of the aetaphors in any area such as education or educational administration reflects the diversity of opinion in society and the dominant influences of certain leaders or groups tho are able to impose their metaphors on others.

What emerges is the idea that the vorld is constructed through the meanings which ve impose. These meanings are individually realised but wany of the are shared, so that in human groups there are common metaphors for which we have a general agreement as to meaning. Nevertheless meaning is alvays individual and it is the devel opment of this faculty of creating this meaning or personal understanding which is the main concern of teacher5. This is where metaphor has a particular value for it has been demonstrated that it can fore the vital link in helping to transform what one might call public seaning into personal knowledge. Teachers play a crucial role in establishing an appreciation of those meanings, evidenced in language and thought, both those which their pupils bring with them into the school situation, and introducing the to more particularized meanings and metaphors of for example the various subject disciplines. For this reason teacher 5 need an appreciation of the complexity of language and its psychological nature as vell as its use as a comanication tool. A study of metaphor could help the to develop this necessary insight and enable then to be more critically avare of the nature of language, its importance in the 
developaent of children, and to realise the rich diversity of metaphors in all areas of knovledge and aspects of huan $1 \mathrm{ife}$, not just in literature Where it has traditionally been thought to belong fairly exclusively.

From the for egoing chapters it is evident that there is a sense in which all language is metaphor as Nietzsche said and that the Bible is one large and rather glorious oetaphor. Dead metaphors ve give scant attention to they are the everyday tools of comanication their original references almost forgotten, their more subtle inferences lost unless they become entangled in a nev metaphor. For wit, charm, and insight ve look particularly to the poets whose facility vith metaphor is al oost unquestioned. We realize that there are others vho manipulate vords and metaphors for less worthy dis, the clever use of the poet's art in advertising is prominent. Just one recent example vill illustrate this, the advertisement in question shovs a secretary, woman naturally, attending to a photocopying machine with the caption My Hero'. This is a complex distortion of facts not only by suggesting that the machine is a person but also of the traditional notion of hero, for the heroes alluded to here are those of eminence in sport, rugby in particular which has been described by a New lealand headmaster as the dominant metaphor in Nev Zealand. The idea of the wachine as something to be venerated and the notion that sporting prowess and health and fitnes of the ale particularly is sonething to be vorshipped are also incorporated. So the advertisement cleverly encapsulates a vhole range of aodern thought including sexist attitudes to vomen in the vork force yet at the same time suggesting that technology is supportive by making routine vork easier.

1. Peter Quin, The National Metaphor, Ie Aya Ití, New Zeal and, 8th July 1989. 
We also see that metaphor 5 of a distinctive type often occur in patterns. Politics for instance has traditionally been described vith body aetaphors for we have alvays spoken of the 'body' politic and diseases affecting it. There has been a tendency to think of aetaphor as a Jiterary art or skill Which uriters particularly exercised but that the ordinary persons rarely practised. The reification of literature has had this effect. Psychoanalysis has done auch to encourage self expression and introspection and as has already been noted autobiography is a modern genre.

The school curriculum has more than a share of the blane for the attitude toyards metaphor treating it mainly as a literary technique unavare that it is a basic oode of human thinking but general information on how the aind varks is a fairly recent phenomenon encouraged greatly by the modern interest in the computer as a brain and vice versa, also enriched by modern medical knouledge of the brain's structure and chemistry. The emphasis traditionally has also been on what to teach and sometimes hov to teach rather than on how people learn. Undue emphasis has been given to memory and not enough to the process of thinking.

There is general agreement especially anong futurists that ve are living vith outmoded aetaphors inherited from previous gener ations. These have led to the exploitation of the earth's riches and a concept of man himself as a kind of machine or an extension of one. The metaphors of pover and politics in organization reflect this quite clearly. The schools also reflect the society in which they exist so they too have treated what seemed the more important or useful skills as priorities thus neglecting those areas which actually enhance our natural advantage over animals, mainly our artistic capacities in language and in art and a knouledge of our story, particularly those ayths and metaphors through which our ancestors made sense of prinal concerns which we still work to understand. 
If the Tower of Babel divided us originally, wars have also done wuch to fragment the people of the earth. Even religion designed like the myths to help us live in the world have often merely served to fossilize ideas which divide us further. Perhaps a realisation that language is at the very centre of our being and that metaphors particularly have great power over us even though they are self-constructed or inflicted aay go sone vay to d realization that any of our perceived differences are semantic only.

The metaphors of today reveal our collective psyche or unconscious. Some of the nore interesting ones and very easy to discern are in the language of sports. Armed varfare has its oun distinctive language and metaphors. Many of these have nou transferred to the sporting scene. The notion of sport as a competition or contest encourages the use of teras normally associated with baftle. One only has to look quickly over the sports section of a daily nevspaper to prove this. In one day for instance the folloving words and phrases surfaced from a New Zeal and Sunday paper:

Barry blitzeses experienced opposition McKenzie blitizes rival

Belliss pledges loyalty to home

Champion New Zealand bouler Peter Belliss last night knocked suggestions that he vould be deserting Nev lealand... (Ian Gault) Edgar's reign sagged... Rod Latham...the most gallant contributor Wood vins nailbiter shootout to qualify (Tennis)

...six victins caught... (Cricket)

Graeme Allen von't defend his No 1 plate this year

The match was beconing a virtual benefit for vetergans (Cricket)

Harvey is renouned for his victory over Norman....Norman narrowly escaped defeat.... swept his ogponent aside... mercilessly trounced his best friend and third-seeded compatriot... (Squash) 1

These few samples indicate the tone of nuch sports reporting, for international sport particularly seems to represent a kind of war and players fight their way through competitions at many levels to represent

1. Dominion Sunday Times, Nev Zealand, Ist February 1988. 
their countries. I have underlined 'reign,', 'gallant' and 'veterans' because the first two suggest overtones of royal or knightly behaviour such as the crusaders displayed and for which they von favours and honours. Likevise sports representatives vin aedals and cups $\mathrm{Y}$ ather like the spoils of var. We speak of old soldiers as veterans and now aged sportspersons are 50 labelled. Strange as it aay seen on reflection sportspeople are also often knighted for their services to sport but in reality this is for the glory they have brought to their country in the eyes of other countries. The fever with which ve greet the Olympics is syaptomatic of our attitude. Patriotic fervour rises in a spirit akin to that experienced under the siege of international war. It is not only in male sports that this aggressive competitive language predoainates. It is just as endenic in reports on women's sports also.

The epitone of this martial aspect of sports is portrayed in an article fron the sane paper in which Simon Barnes describes the intense aggression which seens like pure hatred as displayed by boxing champion Mike Tyson tovards his opponents in the ring. "With such men as Tyson violence is sanctified." Barnes 5ays boxing creates its own legends, building people up as idols and heroes especially vith a person like Tyson Who seems to represent escape from poverty and a racial ghetto. But more pertinent perhaps is what he says about the sport itself in comparison to others:

Most man-to-man sports are a form of stylized duelling--with a racket and a ball, or whatever. The eneity, the attacking, the defending are all metaphorical.

There is no metaphor in boxing; it is the real thing. Boxing is real fighting, perfectly genuine violence, a pastian whose perfectly genuine aim is to cause brain damage in the opponent... no vonder the contestants are avesone aythic men.

1. Simon Barnes, Dominion Sunday Iines, New Zealand,1st February 1988. 
To Barnes, and aany would agree with him, boxing is therefore not a sport. It is in fact open var, one wan against another. As he says the other sports make a pretence of battle. I an not so sure that boxing is the only one worth reflecting on, sone of the behaviour of players and spectators seems renarkably savage at times in other sports also, soccer hooliganisn in Europe is a particular example, and concerned like some warriors with gratuitous glory, which has even been labelled as patriotisa by the participants.

It is hard to imagine such fervour being applied to medical or educational issues although with the present Aids crisis the vorld ay unite in a 'war' on this as it has managed to do on diseases Ike smallpox. Some other areas also reflect this strong competitive element in their nature, the business vorld is particularly prone to using a similar kind of language. It vill be interesting to see if medical language takes on nore belligerent tones.

Cartoons are really metaphors because they seem to have wany of the features of metaphor in their distortion of reality, the tension they create and the 'truths' they atteapt to portray. Most writers on metaphor assume it is a verbal event but Sol Worth finds that caricatures do display a metaphoric mode and the same is true of filas also. 1 alvays think of Vincent Ward's film Yigi l as a metaphor of New lealand vith its sense of primal desolation and I at sure everyone has their own particular one which Captures many of the elements of a place.

Worth thinks of metaphor as a structure rather than an artifact or chunk of speech or uriting. "Metaphor is a comanicational code depending upon the recognition of structure and the assumption of intention on the part of the 'articulator', 'artist', 'producer', or 'creator' of the fore 
We are to treat as metaphor." What Gombrich has spoken of relating to

visual metaphors are the same "aspects of metaphor that are richly anipulated 2

by filamakers and painters." All are concerned vith interpretation

and comunication and within bounds of social knovledge and personal

beliefs.

A caricature, like a picture, is neither true nor false but, like a aetaphor, is a structure that reveals a set of meanings intended to comnunicate a certain set of relationships vithin some understood or understandable context or bounds. 3

If ve consider a political cartoon for instance, it has little effect if ve are unaware of the political sphere vithin which those caricatures operate or cannot recognize the exaggerated features of those prominent politicians there exposed. When Ricoeur speaks of opposition, clash, and shift of context in regard to metaphor Worth can recognize these as features of cartoon art. The shots of a fill [or the frames of a cartoon] create a similar effect "From this collision of ideas comes a synthesis--a new ided, depending on the previous shots but not being merely additive."

The nature of metaphor, setonyay, cliche and symbolism in fila is very vell explained and illustrated in a work by Barrie McMahon and Robyn Quin. They point out that television conmercials conmunicate the unknown in terms of the known. Sometimes a displacement occurs as when a food or drink is represented by analogy with a healthy or recreational aspect of life. We know that the two things are a mismatch but the displacement gives d different emphasis to the values by stressing the healthy or happy

1. Sol Worth, Seeing Metaphor as Caricature, Ney Litergary History, Vol. VI, No.1, Autumn 1974, p. 200.

2. Ibid, ,p.197.

3. Ibid, , p.204.

4. Ibid, , p.200, 
elements. As Wayne C. Booth has expressed it advertisers sell us 1

happiness. McCahon and Quin liken this to a conjuror's trick, for it is in this way that ve are unable to accuse them of false advertising. News items are metonymic because they take snippets of news and present thea as 2

if that vere tha vhole event.

What Worth says about netaphor in general is something schools need to be aware of: "Knoving about metaphor aeans knoving hov to organize the universe vithin our ninds, knoving systens of nyth, of gramar, of behaviour, value and art as they are defined by our group now, and have been in the 3

past. Cultural knowledge says Worth helps us to use this arvellous structure of human thought. It is my contention that if we do not bring this awareness to our pupils ve are depriving then of a full understanding of theoselves and the world in which they find theoselves. Marilyn Ferguson believes that formal education has shattered our ability to ponder and think and make creative connections "good art and good science." She also thinks that we are all born with creative capacities, they are not the 5

"franchise of a favoured minority." For her, meanings emerge from context and connectedness so we need people to help synthesize and pull things together. 'Context' in her view is "that which is braided together" and "Content is relatively easy to grasp once it has been given a

1. Wayne C. Booth, On Metagheror, ed. Sheldon Sacks, University of Chicago Press, Chicago, 1979, p. 66.

2. Barrie McMahon and Robyn Quin, Real Images, Macaillan, Australia, $1986, p, 195$.

3. Sol Worth, Seeing Metaphor as Caricature, Ney Literary History, Vol. VI, No,1, Autuan 1974, p.208.

4. and 5. Marilyn Ferguson, The Aguarizan Conspiraç, Granada, London, 1982 , p. 332 ,

6. Ibid., , p.333. 
framevork." 1 She cites a programe designed to help culturally deprived children which taught them to sake connections "in effect how to think 2

metaphorically." Impressive improvements occured and vere sustained. The originator of this approach J.J. Gordon "believes that learning is based on waking connections that relate the new to the familiar, an ability that has 3

been discouraged in any people," Ferguson has decided that "Denystification, decentralization, and despecialisation are the order of the day."

Patrick Creber speaks of this need to encourage children to appreciate figurative language, not just in traditional exercises of recognition of types of tropes and translation of what he terms 0ssified language but to see "the distincton between figurative language that is nov purely literal (the face of the clock or the legs of a chair) ... and figurative language which is merely stale and outworn..." They should be led he thinks to "compare the relative inadequacy of literal language vith what Ted Hughes has called the 'explosive conpression' of poetry or poetic prose." Not to admire it but to appreciate it and they should be encouraged to search for figurative language in their oun uriting "They must think, not adoire; they must see why such language is used and in what vay it is interesting to the 7 reader." What Creber says about poetry is true about all art, for as Picasso has told us "Art is a lie which alakes us realize the truth."

1. Marilyn Ferguson, The Aguarian Conspiraçy, Granada, London, p.333.

2. Ibid, p.2. and 3.p. 334

4. Ibid, p.350,

5. and 6.J.W.Patrick Creber, Sense and Sensitivity, University of London Press Ltd.,1967, p.125,

7. Ibid.,p.127.

B. quoted in Chai Potok, My Name is Asher Lev, Penguin, England,1972. 
The Opies have pointed out to us says Creber that much of children's oral tradition is "part of an essentially prinitive private world--and we 1

need to respect this." What ve need he says is to create opportunities for enjoyable, vide, vigorous experinent. He even speaks of letting them 'vallow' in metaphor.

The Logans have also said that ve should dispel the idea that the creative person is odd or eccentric and recognize that creativity "is a characteristic not alone of the aftist but al so of the scientist."

They found that there IS a high level of correlation between I.Q. and creativity just as Getzels and Jackson found, but creativity is not assured by this alone. What are more important are such factors as relative absence of repression, lack of self-defensiveness, and avareness of people and phenomena in the environment. They tend to define creativity in terms of originality as opposed to conformity. A nev definition I vould propose relates to the ability to make links between experiences and inforsation, to recognize patterns, to create patterns, to see unity in disunity and harmony where none existed before. Novelty or neuness is still a criteria. It is a process and product of recognition. Nearer to ay definition vould be Spearman who defines creative thinking as a process of seeing or creating relationships with both conscious and subconscious processes operating.

He believes that when two or nore ideas are presented, a person aay perceive then to be in various ways related (near, after, the cause of, the result of, a part of, etc.) He also holds that when any item and a relation to it are cognized, then the mind can generate in itself another item so related.3

1. J.W.Patrick Creber, Sense and Sencitivity, University of London Press Ltd., 1967, p.133.

2. Lillian M.Logan and Virgil 6. Logan Design for Creative Igaching MeGraw-Hill Conpany of Canada, Toronto, 1971, p.2.

3. Ibid., p.5. 
He oight have been describing exactly how a metaphor is constructed and why and how it vorks which is essentially the crux of ny thesis that an ability not only to recognize setaphor but to develop a facility in saking then is a desirable ain of education and part of that has loosely been termed the encouragement of creativity, which has often become aerely selfexpression-- when sometimes by a process more like serendipity real art or real new knowledge is created.

Barchillon say the Logans sav the thinking process as involved in creation into two kinds: COGIT, to shake and throw things together and INTELLI60, to choose and discriminate from many alternatives and then synthesize and bind together elements in new and original vays. I have stated previously that most human 'creations' dre a synthesis of already existing elements. I agree with the authors statement that adults have to realize that "creative perfornance is the prerogative of every child." nevertheless when I observe as I have done recently the style in which state nurseries entertain rather than teach youngstars makes me vonder at what points ve leave children to be creative and whether ve don't sometiaes need to be aore involved with them, perhaps they need to see nore artists and craftstmen actually at work. There are few children now who are able to actually observe their parents vorking as vas possible when artisans worked from their oun homes. Work rather than being an integral part of life is a separate activity, perhaps ve need nev metaphors for work al 50. Each time I see the children producing 'vorks of art' by pasting onto paper various detritus fron suburban hones I vonder if this is truly creative play. The need to create has to come from within so that only the

2. Lillian M.Logan and Virgil 6. Logan Design for Creative Ieaching MeGraw-Hill Company of Canada, Toronto, 1971, p.8. 
right circuastances need to be provided and sometimes the right stiaulus as from music or a story.

Children need to learn to recognize and appreciate patterns. The creative act says Koestler "does not create out of nothing, like the God of the 01d Testament; it combines, reshuffles and relates already existing but hither to separate ideas, facts, frames of perception, associative contexts." This activity is at the basis of learning and at the crucible stage of science. And culture is pattern also:

Culture is not merely a common code or even a common catalogue of answers to recurring problems; it is a coamon set of previously assimilated naster patterns from which, by an 'art of invention' sinilar to that involved in the uriting of ausic, an infinite nuaber of individual patterns directly applicable to specific situations are generated.2

Margaret Mead speaks of the importance of pattern in her studies of universal cultural patterns and complains that there are few people who are able to vork in this mode of pattern recognition, for "the separation of the arts and sciences has been accentuated, and fever students of semiotics 3 are aspirant poets or painters or ausicians, playurights or dancers." For which she blames the changes in education where:

no pattern has been crystalllised by literary and artistic selectivity, and ideological interpretations of history, and where there are no adult guides through the confusing waze, vith rare exceptions, the young anthropologist, linguist, semioticist, today does not yet have in his or her oun person the kind of sense of pattern which the previous pattern-seeking generation had.4

1. Arthur Koestler, The Ghost in the Machine, Picador, London, $1967, p .184$,

2. Pierre Bourdieu, Systems of Education and Systems of Thought, in Knovledge and Control, ed. Michael F.D.Young, Collier Macoillan, London, 1971, p.192.

3. Margaret Mead, From Intuition to Analysis in Communication Research, Seniotica, Journal of the International Association for Seniotic Studies, Voll, 1969, Mouton, The Hague, $p .19$.

4. Ibid.,p.19. 
Ironically one aid they now have is the technology to record and analyse and synthesize patterns that can be clearly documented, Rather than seeing larger patterns they are vorking from the aicrososm as it were to the macrocosm or struggling as she says "to find new personal integration 1 vithin this kaleidoscopic and fragnented vorld." It is only when ve recognize structures that ve can challenge the says Colin Evans. And Terence Havkes is convinced that it is aetaphor which binds the culture together, in a rough unity of experience, and "in the long run the 'truth' does not matter because the only access to it is by means of metaphor. The 3

metaphors matter: they are the truth," Metaphor said Patricja Parker is 4 a structuring principle. Fundamental intellectual patterns ve acquire says Bourdieu, have auch of their basis in schooling, which interiorizes master-patterns, and :

the Sapir-Whorf hypothesis is perhaps never so satisfactorily applicable as to intellectual life; vords, and especially the figures of speech and figures of thought that are characteristic of a school of thought, would thought as much as they express it.5

One of our basic problems is that the various schools of thought are not alvays in agreement, science versus arts being symptomatic of such divergence.

Martin Green writing from a humanist standpoint examines the prevalent

1. Margaret Mead, From Intuition to Analysis in Comaunication Research, Seniotica, Journal of the International Association for Seaiotic Studies, Vol I, 1969, Mouton, The Hague, p. 20.

2. Colin Evans, Authority, Knowladge, and The Acadenic Conference, Quinguerenes, Vol.8, No.1,1985, p. 80.

3. Terence Hawkes, Metaphor, Methuen and Co,Ltd, 1972, p. 91.

4. Patricia Parker, The Metaphorical Plot, in Metaphor: Problems and Persegectives, ed. David Miall, Huanities Press, New Jersey, $1982, p .155$.

5. Pierre Bourdieu, Systems of Education and Systews of Thought, in Knouledge and Control, ed, Michael F. D.Young, Collier Macaillan, London, 1971, p. 195. 
traditional and insidious dichotomy betveen the Sciences and the Arts. Auden said of scientists "Unfortunately, poetry cannot celebrate them, because their deeds are concerned with things, not persons and are, therefore 1 speechless." It is in fact language which they both share. Every scientific theory and action begins vith thought which develops into an articulated spoken or written form, is developed further by linguistic acts shared vith others, passed on (Bergland's 'aeas') to future generations--eabodied sometimes in scientific 'things' e.g. drugs etc. for human use. This supposed division like the left/brain right/brain paradign is blinding us to fundamental truths about human nature and potential. Schools are often the worst perpetrators of this schiso, splitting the arts and sciences quite rigidly. Green writes in defence of C.P.Snou's Rede lecture on 'The Tyo Cultures' a reply to Leavis who accused Snov of being ignorant of culture and of literature. Green sees this 'battle' between the two men as symbolic of hov far apart the tro cultures believe themselves to be, and says only a few writers try to bridge this gap including Stephen Toulmin and Jane Goodfield. We need he thinks someone who can do this for literature. As Green says the saddest aspect of this debate is the absence of appreciation on each side for theif respective intellectual abilities. He believes that training in science needs to be made broader and literature narrover:

There is auch oore hunility and realisa about their educational problems among scientists than among humanists. Literary students must be ade to see that they are not merely acquiring taste, but reasoning..... It is too easy to get through literature examinations by mere sensitiveness, just as it is by aere mechanicalness in science exaninations...both sides need to nove tovards a middle ade, a more generally intellectual oode. 1

1. Martin Green, Science and the Shabby Curate of Pogtry, Greenvood Press, Connecticut, 1964. Citing H. H. Auden, The Dyer'sHand, 1963.

2. Ibid.,p.28. 
It vould not take long he thinks to make science a nore humane discipline

if teachers were 50 trained and syllabuses changed. Exactly just such changes are apparent in the current revision of the form $1-5$ science syllabus in Nev Zealand. Research (e.g. Learning in Science Project) shoved that "nany students including the most able and senior students may not have learnt the scientific ideas as intended; that much of the Iearning has been rote and not aeaningful learning...it is not just a matter of revieving UHAT is 1 taught but HOW it is taught." What vas being taught also often seemed divorced from students' oun interests concerns and experiences. It is also now realised that a knovledge of the kinds of ideas students have is important to the teaching process for:

Before they begin formal science education, students have constructed for theeselves understanding of phenomena in their biological, physical and technological vorlds. These tend not to be the currently accepted scientific ideas and explanations. For example, many secondary students think of atter as continuous and nonparticulate; that light does not travel far from its source; or that plants obtain ready-made food from the soil... Students are active in making sense of their vorld. They are active in aking links betveen new inforaation and what they already know, in order to construct an understanding for themselves. These understandings may not be the ones anticipated by the teacher. 2

Snow believes the PATTERN of British education must be broken because the Western vorld is still managed by a literary culture. Green believes that it is prejudice which hinders progres5, but that "humanely taught, science trains the mind, 'prepares one for life', as fully as literature,...not that it can...serve the instinct for conduct as fully as literature...but...the instinct for truth is probably bettter served (better satisfied, disciplined, toughened) by science."

1. and 2. Report of the Second Meeting of the For 1-5 science Revision Comaittee, Auckl and July 1986.p.1.

3. Martin Green, Science and the Shabby Curate of Pogtry, Greenwood Press, Connecticut, 1964.p.28. 
Another tendency Green notes is for people to define their culture in teras of their country and that perhaps ve need a core universal meaning. He says that some people despise popularisation of science because they believe truth can only be conveyed in esoteric language which needs to be specially learned for each subject. [ This might be called an exclusive or elitist aodel of education] But in Green's viev the vorld ve nou live in, threatened by disaster, is one where ve have a responsiblity to inform and be inforaed for "ve hardly know what it is we stand for, fight for, or 1

are threatened for." He believes that thinking people need to believe in something, moreover "It is only when they [people] travel from one area of thought to another and participate inaginatively, that they get a feeling of exhilaration and comunity,"

William Stanley affirms this, saying that "science has failed to fill the gap left by the decline of aetaphysical and theological traditions." He believes that the pursuit of excellence has become a mere catchphrase--a slogan based on a technocratic conception of society, and would like to see a return to the Classical concept of character formation and civil involvenent, for ve seen to have lost the original purpose of education and he speaks of a metaphor of cultural crisis. We need wore than physical travel perhaps to broaden our minds.

Green says that fontanelle managed to make science amusing and fashionable and cites Fred Hoyle's book on the stars as a good example of what we need. Green is concerned that "The imagination of the modern

1. Martin Green, Science and the Shabby Curatate of Poetrry, Greenvood Press, Connecticut, 1964. p. 36.

2. Ibid, p.37.

3. William Stanley, Christopher Lasch as Social Educator, Educational Theory, Vol. 37, No.3, p.235. 
intelligentsia, in its most highly developed for as, is unbal anced, wisshapen; 1

it is over-literary..." Science for the layman has to remedy this deficiency.

He describes Polanyi's Personal Knouledge and his philosophy of science to

support his arguaent:

Empirical evidence alone [says Polanyi] has never constituted scientific proof; the beliefs in astrology or vitcheraft had a great deal of evidence to support them... The Copernican revolution satified people's reason, not their senses; indeed it went against their senses. Einstein, too, had no new facts, no observations to offer, but a nev rational scheme... Evidence alone, outside a structure of belief is of small value scientifically.....even science has its ovn passions; lives by them. Both the heuristic and the controversial passions are essential conponents of science, and researchers do not vork sinply by doubting their oun or other people's propositions. Doubt can, of course be a heuristic principle, but so can faith. Max von Laue discovered the diffraction of $x$-ray crystals because he believed more completely, more concretely, than other people in the theoretical picture of crystals and rays they all shared... He aust accept a different and nore metaphysical idea of truth. He can only explain the validity of even scientific theories by adaitting the idea that they ake contact with a hidden reality...Simplicity, SYMMETRY [ay emphasis] econony, are the arks of rationality, not the marks of truth as a whole, even scientific truth. We cannot account for our acceptance of scientific theories vithout acknouledging our response also to their beauty and theif profundity, two other categories of reality, and not ob jectively knovable. 2

Polanyi believes that acts of comprehension cannot be aeasured by purely objective standards "that skilful knoving is like skilful doing; both are performed by subordinating a set of particulars, either as clues or tools, to the shaping of a skilful achievement, whether theoretical or practical.

Green elaborates on this:

What mifests itself within the work of art [speaking of literary uritings in skills of imitation, invention, formal patterning, etc, manifests itself in the other books in other skills--of definition, of generalization, of argument.... It is all one mode of intalligence, theoretically unsystematized, but organically very unified, " 3

1. Martin Green, Sccience and the Shabby Curate of Poetry, Greenvood Press, Connecticut, 1964,p.40,

2. Ibid, ,p. 43 .

3. Ibid., pp.44-45. 
Green sees the newer literature as saying wore about what constitutes the happiness and holiness of persons, yet at the same time beconing aore inaccessible to scientists and vice versa. He slains that Voltaire created the broadly intelligent layaan of the eighteenth century and that George Eliot spoke for the educated mind of her day and that the wain scientific ideas of today are no more difficult for us to grasp than Nevton's vere in his time. He believes there is a groving belief that art yields more truth than any other intellectual activity and that the literary eind has unique pover to influence people. Generally, literary ainds, he thinks, tend to get hysterical in tone, which he sees even in hisself, but he believes that "the really intense and pure imagination ...has a vay of transcending its own limitations." Science he thinks can aoderate the literary eind and arrest its impulsiveness for "Science is the pover and magic of today; literature is the sense of inspiration and prophecy. " The best uriters he believes, employ sone scientific precision and "If our inaginations are to work on the stars, the sea, the flowers, in any vigorous way, we nust know things about them. He is convinced that the literay mind "sannot grasp the idea of ten thousand people. It can hardly count above two or three." I an sure many vould not agfee with his. There are writers e.g. Tolstoy whose canvas can take in a vhole country, a var or a revolution, and paintings such as Picasso's Guernica which can embody the horror and pathos of a large scale human drama. Solzhenitsyn's Nobel speech in defence of literature immediately comes to aind where he speaks of the great and blessed property of Art:

1. Martin Green, Science and the Shabby Curate of Pogtry, Greenwood Press, Connecticut, 1964.p. 50.

2. and 3. Ibid.,p.51. 
Art and literature can perfor the airacle of overconing man's characteristic veakness of learning only by his own experience... Art re-creates in the flesh all experience lived by other men, so that each van can ake this his own. 1

Speaking of National culture: "Nations are the vealth of sankind, they are its generalised personalities: the saallest of the has its oun particular colours, and enbodies a particular facet of God's design." He also defends the artist's right as apparently Camus did, to express nothing but his personal experience and his introspective reflections, because his gift is inborn. So the artist is seemingly driven by forces he cannot ultimately fully understand or control but uses merely to serve.

Far from seeing scientists as potential saviours for mankind Sozhenitsyn says "the scientists have nade no positive attempt to becone an important, independently notivated force among mankind. They shy away in Whole congress-loads froe the suffering of others: it is nore confortable to rearin vithin the frontiers of science." Hovever he believes ve each share in the responsibility for evil in the vorld--even the uriters-- but he sees literature as a unifying force "d single great heart beating in 4 response to the cares and sorrows of the vorld." And finally what is true for science and art "Mankind can only be saved if all men are concerned about everything" then ve will be able to see more clearly and fight 6

against lies for " One word of truth outweighs the whole world."

1. Alexander Solzhenitsyn, 'One Word of Truth', The Bodley Head, London 1972.p.14.

2. Ibid., p.16.

3. Ibid, p. 21 .

4. Ibid, p. 23 .

5. Ibid, p. 25 .

6. Ibid.,p.27. 
So Green sees a need for science and art to vork together as does Hesse and Solzhenitsyn. How this is to be achieved they do not say. Sone unifying force has to be generated. Traditionally the study of philosophy has attempted to be this synthesiser. We seen to need something at school level and at early adult level. The study of education and sociology attempts to be overseers in this sense but for children ve need to think of something nev, and I an inclined to think it will be in the area of language that we will need to re-consider how it is learned and applied. An early understanding of metaphor in all subject areas could possibly be the catalyst that helps us to wake sense of what is often disparate knowledge. If ve use words autoatically vithout seriously considering their multiple levels of meaning then we are merely mechanical.

Green's criticism of the literary aind has some truth, for all art is circuascribed by fraees and perhaps "our culture now lacks any integrated body of intellectual experience that includes both the really powerful categories-the scientific and the literary." Mcculloch is avare of this too, the piecemeal nature of research in education for instance and the lack of an overview which he believes history of education can help to furnish, and which must be aware of, and critical of change, especially of control of knouledge: "Education is concerned only partly with the dissenination of knowledge. It is al 50 about transmitting values, to the young and throughout life. So in our historical study ve vill be involved in distinguishing the knowledge and values of societies, and how they account for continuity and change in pover, authority and social organisation."

1. Martin Green, Sccience and the Shabby Curate of Poetry, Greenvood Pres5, Connecticut, 1964.p.53.

2. Gary McCulloch, Education in the Forning of Nev Zeal and Sociaty: Needs and Opportunities for Study, NZARE, Monograph No1, June1986, p. 27 
Green also sees the unfortunate sexual polarity ascribed to science and art and which Hudson described in Eranes of Mind. This is exacerbated by the predominant ailitary bias in wuch science. He quotes physics texts for example as being full of references to explosives, bridge-building etc. Hovever one of the effects Green sees is that scientists assuae an air of personal aridity and the literary persons suffer a sense of iapotence and consequently hysteria. Perhaps as Capra says we need to think nore androgynously because our perceptions of reality are inadequate for the times ve live in doninated as they have been by outmoded and patriarchal styles of thinking 1 and a mechanistic Cartesian vorld-viev.

Green says that science does contain the kind of truth most nonscientists are unavare of. As an illustration he describes what happens when mathematical and physical or chemical facts come together with simplicity 2 of style fusing with "the beauty of the largest kind of pattern." We each need he says to work out our oun relationship to science and decide what culture is. Ferguson afffiras this same idea;

We are duty-bound to search, question, open our ninds... [for] the nost poverful transformative ideas from modern science connect like parts of a puzzle. They support each other; together they for in the scaffolding for a wider world viev.

Each of these major ideas is a whole in itseli, a system for understanding a spectrum of phenomena in our lives and in society. Each also has uncanny parallels to ancient poetic and mystical descriptions of nature. Science is only now verifying what humankind has known intuitively since the davn of history. 3

She is avare of the overlap of poetry and science. Green speaks of Professor Oppenhei iner and his book Sciences and the Compon Understanding as

1. Frit jof Capra, The Iurning Point, Fontana, Great Britain, 1982.

2. Martin Green, Science and the Shabby Curate of Poetry, Greenwood Press, Connecticut, 1964.p. 55.

3. Marilyn Ferguson, The Aguariann Conseiraç $y$, Granada, Great Britain, $1982,0.163$ 
being effective in a sinilar way. Green says the responsibility for healing the two cultures lies vith the literary person because theirs is the Ianguage of aore general discourse. To him physics appears to bave a similar role in science to the oodern novel in literature "it has presented itself as the ultivate achievement of the iapersonal mode of 1 knowledge" and is just as 'pure' as oodern literature and although its consequences are social its purposes are not. He also believes that scientists tend to be insulated from others by their roles, and the nature of the institutions in which they vork, and this is further coapounded by their language and methods and isolation in their vork. He believes university teachers should be huanist but he does not define the term, except to say that they must be comitted to the whole scope of modern knouledge, and feel responsible for teaching others, not believing for instance that it has to be obscure like Eliot's description of poetry. Science fiction he says was excoriated by Scrutiny which is symptomatic of current patronising attitudes to things scientific. Polanyi he says has described Marxise as believing that all knovledge nust try to be purely scientific and objective but he (Polanyi) believes that " Only a society which shares 2

a faith can make individual faith possible." Therefore literature worldwide aust be free. The sane thought as Solzhenitsyn to whon I referred earlier.

To be socially responsible says Green one has to be sensitive to language and literature and therefore a literary training is a vital part of one's education, not necessarily to be an artist but simply a craftsman is sufficient. Modern style he says is not 'literary' in the traditional

1. Martin Green, Science and the Shabby Curate of Poetry, Greenvood Press, Connecticut, 1964.p.69.

2.Ibid., p.76. 
sense as it can be passionate, angry, critical, distrustful of huad nature, rebellious against traditional standards. For every citizen literary sensibility he believes could assist then to see through propaganda, to judge logic. It can also foster a concern for culture as a whole and a concern for education which leads one to a concern for the vhole life of an individual in society. Thus ve value uniqueness and people do not becone statistics even if that is hov they are represented and one develops scepticisa about political and econonic remedies. This development of sensitivity to people then is special to literature and creates in sone uriters theaselves too wuch sensitivity to cope as we have witnessed and in others it produces eccentricity or violent extremisa. Qthers have "a deep intuition of the sources of evil in the individual and of disorder in society." Some give us allegories of personal experience. Green questions why it is that we look to such people for social visdon when they cannot really deal with wore than one or a fer people in their view. Scientists he believes also contribute to our understanding of what it is to be huan and shov evidence of insight, humour, idealism and sensitivity of the same order.

One factor which keeps the two cultures apart says freen is that the context in which the scientist works is one where wuch government money is spent. "The research scientist finds himself in contexts of pover, and sonetines in positions of pover, utterly alien to the research scholar in literature." "On the other hand the literary person has little appreciation of the hunour, idealism and common sense which Green says forms the nucleus of sensibility in science: "Hostility to science... is a form of stupidity, which teachers of literature everywhere should be actively

1. Martin Gireen, Science and the Shabby Curate of Poetryy, Greenwood Press, Connecticut, 1964, p. 99. 
stanping out." ${ }^{1}$ Green hinself whilst teaching liberal studies at a

College of Advanced Technology 1962-3 tried to put his ideas into practice.

He found that generally speaking, in such institutions, literature and language studies are divorced from each other. Language is reduced to exercises in mechanical application of rules and practice in these. Ideas are not involved yet it is literature that needs to be taught so that the students realise that it is "a mode of knowledge, a truth discipline, just 2

as much as theit oun." Green reflects that few of us learn new attitudes except as a result of acquiring nev information. What he considered these students needed was in fact the last thing they or their tutors considered necessary, for they could only perceive of English as a technical subject. One might inagine that perhaps Science Fiction could prove to be the magic link between science and language arts but not according to freen. He has already said that "The scientific sensibility is oriented towards the 3

species, the literary tovards the individual." The scientific aind is not interested either, he says, in the ways in which individuals differ but in the large features of whole societies and although the best of these novels might excite the inagination he says they are rarely satisfying. He claims that it is not a genre but a sub-genre and is anti-literary. Religious sensibility can also be fostered by science, says Green. Much scientific work leads the nind up and out to those enormous distances of size before which reason quail $5 ;$ or to those recurient glimpses of being itself; to half the sources of all religious feeling. Moreover, it leads one out of those complexities of self -interrogation, those orgies of metaphor-making, in which 50 much

1. Martin Green, Science and the Shabby Curate of Pogtry, Greenwood Press, Connecticut, 1964.p. 101.

2. Ibid.,p.113.

3. Ibid.,p.126. 
potential religious feeling gets dissipated aoongst literary people. According to Green the average cultured nind finds the idea of progress crude and tends to a cyclic viev of history. The literary person for example has people like Honer and Shakespeare as measures of vorth, not expecting anyone to transcend thea. Yet in science and aaths for example we are all nore knowledgeable than people of the past. More inportantly "Teachers of science don't aake a point of demonstrating their subject's interactions with other modes of intelligence, as teachers of literature 2 do." He reminds us that "science is an exercise for the whole mind, including the imagination, just as history and literature are--in fact it 3

is one of the humanities." Even textbooks can be liberally conceived and he cites Gerald Holton's introductory physics course as an example. He discusses other sinilarly laudable vorks and says that they explain science as the expression of human personality in the same sense as art, politics, history and philosophy do. Koestler's biography of Kepler for instance illustrates that it is only the whole man's successful self-discipline that can be called the scientific method. He believes also that it is not in pointing out irrationalities that we prove the fact that science is one of the humanities for "The real romance of science is its rationalizing pover." Colin Evans also believes that we aust become nore skilful at comunicating across boundaries with people who do not share our preconceptions: "We aust find better ways of talking, better ways of

1. Martin Green, Sccience and the Shabby Curater of Pogtry, Greenwood Press, Connecticut, 1964.p.137.

2. Ibid, , p.138.

3. Ibid,,p.142.

4. Ibid, , p.153. 
writing, better ways of integrating our talking with our writing."

The age of nihilisi said Nietzsche would give vay eventually to "an age which vill carry heroism into the field of knouledge and vage vars for the 2 sake of principles." Truth as Raymond Wilson says "is located in the psychology of those tho subscribe to it and has no independent existence of 3 its oun."

David Pratt tells us that in opinion polls in the U.S. the art5 are always accorded the lowest status. Yet as he says there is basic human need to express oneself in this medium, and "these artistic impulses atrophy in most children after they start school." One reason he thinks is that artistic creativity is still seen as "a 'gift' received by an elite"

The prevailing ethos of the school is above all one of "left brain reductionism," where only rational, numerical, propositional, and verbal activities are valued. The intuitive, creative, spatial, appositional, and artistic qualities (right brain) are regarded as frills, peripheral to the serious business of school.6

The evidence here has suggested that both science and the arts can profitably use both sides of the brain. The scientist uses intuition and the artist needs discipline. Hov can we hope for unity in a vorld where ve ourselves are lopsided in our thinking, literally. for too long we have failed to integrate the dual activities of the brain and the consequent multiple aspects of learning. How auch human misery and confusion we may

1. Colin Evans, Authority, Knowledge, and the Acadeaic Conference, Quinguigremen, Vol.8, No.1, Jan. 1985, p.85.

2. David E.Cooper, Authenticity and Learnning, R.K.Paul, London 1983, p.1.

3. Raymond Milson, Metaphors in some Nineteenth and Twentieth century Fiction, Metaghors of Education, ed.H.Taylor et al., Heineaann, Univer sity of London, 1984, p.117.

4. 5. and 6. David Pratt, Curriculum for the 21st Century, Education Canada, Winter, 1983, 0.43. 
have caused by failing to develop whole people is incalculable. This is probably what Katherine Mansfield felt intuitively when she said;

It seens to ae that what one aims at is to vork vith one's mind and one's soul TOGETHER. By soul I mean the 'thing' that makes the aind really inportant. I alvays picture it like this. My aind is a very complicated, capable instrument. But the interior is dark. It CAN vork in the dark and throv off all kinds of things. But behind that instrument like a very steady gentle light is the soul. And it's only when the soul IRRADIATES the mind that what one does atters.1

The question for teachers is how ve are to enable students to achieve this integration in their own personalities. As Katherine said at the end of this letter "It's avfully, terribly difficult to get at." Perhaps if ve make sure that people understand the part that eetaphor plays in their own makeup and how the vorld about them is organized then we may move some way in the right direction. The essential element that links art and science is I believe metaphor. The area vhere, as I said in oy introduction, hunans are at their oost creative. If ve look at how prioitive people and children observe and understand the vorld or how ve often interpret it for them we will see that it is deeply metaphoric--though it ay appear in the guise of animism (possibly totemisa) and anthropomorphism.

Kathleen Raine goes so far as to say that in our materialist secular society "We are simply not educated in these things which above all make us human......To recreate a conmon language for the comounication of knovledge of spiritual realities, and of the invisible order of the psyche, is the problem now for any serious artist or poet, as it should be for 2 educator5." She makes the point that the goldsaiths, painters and sculptors

1. Katherine Mansfield, The Letters and Journals of Katherine Manstield, ed. John Middlet on Murry, Hutchinson, New Zeal and, 1984,p.261.

2. Kathleen Raine, The Inner Journey of a Poet, George Braziller, New York, 1982, p.13. 
of the past whose work we adnire vere not simply indulging in 'creativity' or 'self-expression' nor were they breaking with the past or going against tradition but were in fact fad by it. "They vere naking use of the shared knowledge of a spiritual tradition that illueinates their work, as it illuninated the iner lives of those vho participated in its unity of 1 culture." Once again the notion that ve need that link with the past. The poet aay vrite fron inspiration or intuition but his inagination is fed, as that of Yeats, by forays into other cultures and vide experience. This kind of knovledge is, she believes, "no less essential to the production of works of inagination than is the knowledge of, and respect for, the 'lavs of nature' essential to those who launch space aissiles." Such knowledge she realizes cannot be quantified. Such knouledge of course has little appeal to those who want everything to be accountable or subject to rigorous testing. Pratt says that we need teachers who above all else have the personal attributes of "Warnth, openness, concern, comaitment, and 3 responsiveness" for they will cultivate the personal and social qualities of their students, But there is aore needed than this. Even the wareest, most open, comitted, and responsive person can be misguided. Each of us carries in our heads a metaphor of what it is to be, and to be a teacher, and to teach. If we never examine these sodels then ve fail not oerely to be current but also to be dynamic self-reneving open systeas. As Bertalanffy says we need to seek not equilibriun but homeostasis, self-reneval, teenergizing. We need to be avare of the outmoded cliches in education and

1. Kathleen Raine, The Inner Sourney of a Poet, George Braziller, New York, 1982, p.13.

2. Ibid.,p.23.

3. David Pratt, Curriculum for the 21st Century, Education Canada, Winter, 1983, p.46. 
in society for as Kenneth Burke said "men's modes of symbolic action are 1 siaultaneously entanglings and entanglements." We need to knoy how to help our students to untangle thenf. We also need to know more about how the mind works and current studies of the brain are enabling us to do just that. Those who organize the schools for us, likewise need to be avare of the metaphors they rule with, and are ruled by. They nead to explore the larger concepts such as denocracy and equity, etc. 5o that each of us knows Whether ve are being aided or exploited. Paulo freire sav the need for literacy as a path to true democracy but perhaps ve have not sufficiently considered just what it is to be literate. The vord is in fact ironic because perhaps ve have been too literate and need to be, not illiterate, but to coin a vord metaliterate, that is being able to appreciate the intricate nature of the language ve use and developing consumate skill in using it. Before we reach this utopia it night be necessary as Marshall Gregory thinks to fight for the liberal arts, for "Those of ws who fight for the liberal arts are fighting for the life of the mind in society, for the freedom of our students' intellects, and for the vision of a better vorld 2

they wight want to create." Trends are going against us he thinks.

We have seen how scientific or rational thought cane to be the domitrant mode of thinking, epitomized 1 believe by people such as Robert Thouless vho believed that analogies have been useful in science only up to the point where theories could be expressed as mathematical equations. To his only the scientific sethod has value because it is based on facts, but

1. Kenneth Burke, Language as Syabolic Actínon, University of California Press, 1966, p.viii.

2. Marshall Gregory, If Education is a Feast, Why Do We Restrict the Menu? A critique of pedagogical Metaphors., College Ieaching, Vol.35, part 3, 1987. 
as we have seen even science changes its course as the paradigms and metaphors shift. Thouless saw our only hope for universal understanding to come from a aore rational approach to problems. An efficient deacracy, to hia, vould be one based on dispassionate reason "Its aembers vould be educated to distrust enotional language and the rest of the stock in trade of the exploiters of crooked thinking." But nou there are voices in this rational desert which science has led us into. Geraldine McDonald for instance is aware of how resources have been deployed in the areas of science and technology to the detrinent of aesthetics and the humities. We need a more balanced viev she thinks or, in her vords, "a description of successful constellations of procedures, places and people." "She hopes that "By the end of the century it vill be the turn of aesthetics and the humanities, "

Jerone Bruner also thinks that ve need to help aake the schools "d suitable metaphor for 1 ife," for he finds that they now reflect the dominant greed of society. He wants to design school environments that make people clever, and he speaks of networks that allow people to help thenselves, and uses a scaffold metaphor to illustrate the development of learning. He says that giving children oaterial is not enough, they need toys that challenge them, structured aaterials. He is adaant that "language is our best model of tutoring... Human knowledge and its acquisition are

1. Robert H. Thouless, Straight and Crooked Ihinking, Hodder and Stoughton, London, 1974, p.191.

2. and 3. Geraldine McDonald, Educational Research in a Science and Technology Future, Ney Zealand Journal of Educational Studies, Vol 20, No.2, November 1985,pp, 138-9.

4. Jerome Bruner, Schooling Children in a Nasty Climate, Psychology Ioday, January 1982, p. 58. 
social, dependent on language, on stored culture, on social modes 1

of transmission." But we have not examined these closely enough he thinks for ve have been too busily occupied vith individual achievenent.

I an not trying to argue for a curriculus that vould be only arts based, on the contrary what we seem to need is an integrated arts science nodel to combat the doainance of science and technology as at present and and to conbat an apparent decline in appreciation of the humanities. In a more recent article Pratt speaks convincingly of the need for ney curriculum. The Greek story-tellers he said understood the power of syabols. They recognized that living requires two complementary kinds of resource: "technical veapons for aggressive resolution of iamediate obstacles, as vell as the gentle aeans of guidance to ultieate goals." Nov we have vhat he calls "the technologists with their systematic procedures, ailitary metaphors, and their behavioural and positivistic language. On the other hand, there are the humanists, with their intuitive thinking, poetic language, and their subjective and interpersonal priorities." They both as he says speak different languages. "Conventional curriculun technology can deal with knowledge and skills, but it cannot provide useful guidance to teachers seeking to develop in their pupils attitudes, values, intuition or intrinsically valuable experiences." Their instrumentalise vhich pays attention to means and ignores ultimate ends also leads to a tendency to treat everything including people as a comoodity. Their writing purveys a

1. Jerome Bruner, Schooling Children in a Nasty Climate, Psychology Ioday, January 1982, p.63.

2. David Pratt, Curriculum Design as Humanistic Technology, Journal of Curriculun Studies, 1987, Vol.19, No,2,p.149.

3. Ibidr,p.150.

4. Ibid.,p.153. 
sense of aral vacuity even if this is not a personal attribute. The humanist view is not vithout its critics also and he details some of these but the question is how to profit from the best of both. His suggestion is to return to Maslow's hierarchy of needs which focusses on the client.

Peter Abbs reminds us that an aesthetic and creative education has not generally been understood but is often seen as a mode of therapy and free self-expression when in fact it it is a training in various forms of discipline for "all education whether it be in the natural sciences or the humanities should be aesthetically conceived." He stresses the importance of pattern, of harmony, of rhythm in all of one's activities. To achieve teaching which enbraces these ideas is he says absorbing, deanding, severe and relentless.

Robert Dearden in speaking of curriculum planning shows at the same time hov deceptive metaphors can be. He cites the instance of the 'National need' as a clain to justify the intervention of the Secretary of State in defining the schools curricului in the U.K.. Also in various surveys released at the time of his writing he searched for fundamental curricular principles in these documents and found instead, that teras such as'balance' and 'coherence', were frequently used. He questions their usefulness, for one can speak of balance with regard to alnost anything. When speaking of food values for example it does not necessarily mean equal weights of food as he points out. An inspectors' report on the B.Ed. is one he gives as an instance vhere it vas said that "education studies should be aore coherently built round a unifying thread of vocational relevance." "The same word

1. Peter Abbs, Proposal for a Ney College, Heinemann, London,1977, p.56.

2. Robert Dearden,Balance and Coherence: Some curricular principles in recent reports. Cangbridge Journal of Education Vol.11 Pt.2, 1981, p.112. 
'coherence' is also used of the school curriculua. The setaphors assume that we know what 'balance' and 'coherence' really mean in this sphere but they are as Dearden says 'vapid'. And the notion of 'national need' is he think merely a euphenisu to disguise the facts of economic life:

Thus The School Curriculue affiras in its second paragraph the apparently child-centred principle of developing individual potential to the full. In the following paragraph it defines that potential with references to the realities of adult life and, in the paragraph next after that, adult life is defined in terms of a technology-based econoay. 1

What Dearden illustrates here is the complexity of metaphors with which ve can become bamboozled particularly by policy documents and not only in education. Each person reading such a document brings to the reading his or her own concepts of such things as 'balance' and 'coherence', and cleverly written stateaents can deceive us by appealing to all parties concerned, unless thay are arare of the Ianguage traps vithin then, Dearden's concern in this instance is not to discuss the metaphors particularly but to point out the pragatic current approach to curriculua planning from a mainly economic point of view, but his comments speak also in my view of the dangers of inappropriate or inadequate metaphors, something ve need to be ever dlert to.

The richest repository of aetapher is our heritage of folk tales fairy tales, myths, legends and Biblical stories, and in our cultural store of prose, poetry and drama. Young Toki in Potiki by Patricia Grace had his own stories to explain his being and Grace says that our stories are given to us but any people never receive this gift. Although they have never

1. Robert Dearden,Balance and Coherence: Sone curricular principles in recent reports. Cambridge Journal of Education Vol.11 Pt.2, 1981 , p.116. 
been totally neglected they have suffered from the taint of doubt cast over them since classical times when metaphor gradually began to be vieved as ornamental rather than elemental. This led to a treataent of literary language as something esoteric, highly refined, 'precious' and above ordinary mortals. Nov that ve are nore avare of the true nature of aetapher ve can apreciate the fact that it is a normal aspect of language and indeed of thinking. It is not only a literary skill to create a metaphor it is part of the creative process through which ideas are expressed to convey nev ideas as in science and to enliven ordinary language for ve all appreciate vit, novelty and humour. In our own times particularly we have become nore conscious also that it can be put to less desirable purposes such as lies, propaganda and deceitful advertising but the realisation of the pover of language can transform one's thinking and one's outlook as in Portnoy's Complaint when he suddenly realised that vords are nore than 'bullets' of communcation fired at people, they are "little gifts, containing meanings," The difference between old and new metaphors is like the difference betveen fresh and preserved food, both sustain life but ve knov which ve prefer when it is available.

Language is also like music. There are infinite patterns of music yet to be discovered just as there aust be of language. We are patternmakers recognizing even in our linited linear fashion associations, structures, opposites, links, sinilarities and with the ability to create aeaning for ourselves. It has been said that metaphor is "an instrument for the act of creation which God forgetfully left.... in the inside of one of his creatures, as an absentainded surgeon sevs up one of his instruaents in the belly of

1. Philip Roth, Portnoy's Conglaint, Guild Publishing, London, 1982, p.221. 


\section{1}

his patient." It is just as vell he did for imagine how dull the world would be vithout it. We would have to cope vith a restricted vocabulary of dead metaphors and there would be no incentive to be creative or imaginative.

In recent years the English syllabus in New Lealand has attempted to raise consciousness about language vith the study of various registers as a part of its vork. However there is still a legacy of reverential attitudes to literature and a treatment of metaphor aerely as a literary technique to be anderstood in terms of other people's vriting. In a recent survey of children's writing metaphor was scarcely aentioned. The new enphasis on journal or process uriting encouraged particularly by Donald Graves has gone some vay to encouraging creative self-expression in children which goes further than the free and easy inaginative or creative writing that was once part of the veek's roster of English vork, for now proof reading and editing techniques are also explored. The ideal is for everyone to be a confident critic of both his or her own work and that of others. We also need to be convinced that every person is a vriter as much as they are a speaker, just as Betty Edvards tries to convince us that we are all natural artist5, if ve vould only use both sides of our brain.

One task for teachers and administrators nust be to create the necessary integration of science and art across the curriculum so that new metaphors of meaning arise and make learning the pleasure that it can and should be. There is also need for more reflective exanination of the power of figurative language in educational discourse. Metaphors are bridges and teachers especially are bridge-builders.

1. J.David Sapir, The Anatomy of Metaphor, in The Social Use of Metaghor, eds. J.D.Sapir, and J.C. Crocker, University of

Pensylvannia Pres5, 1977. Attributed to Ortega Gasset. p.32.

2. IEA Study of Written Composition, Dept. of Educ, Wellington, 1987. 
Eisner is convinced of the iaportance of aetaphor:

Metaphor breaks the bonds of conventional usage to exploit the power of connotation and analogy. It capitalises on surprise by putting meanings into nev combinations and through such combinations avakens our senses. Metaphor is the arch enemy of the stock response... What is ironic is that in the professional socalization of educational researchers, the use of metaphor is regarded as a sign of inprecision; yet nothing is ore precise than the artistic use of language. netaphoric precision is the central vehicle for revealing the qualitative aspects of life.1

Ernesto Grassi describes Rhetorical language as preeainent for it deals vith our most urgent problems concerning the nature of man. Insight into relations is basically not possible through a process of inference he 5ays, but through IN-SIGHT as invention. Vico continually emphasises this as primary over that which he calls "critical" i.e. purely rational thought.

The netaphor is, therefore, the original for of the interpretative act itself, which raises itself fron the particular to the general through representation in an image, but, of course, always with regard to its importance for human beings. The Herculean act is alvays a metaphorical one and every genuine metaphor is in this sense Herculean vork.2

And Cicero thought we surpassed ourselves he says in this ingenious activity.

The universal question ve all ponder is the reaning of life and ve have looked in the past to enlightenment from spiritual advisers, guides and prophets who have often spoken in mysterious metaphors. He still look to these but consciousness of life as a pattern helps us to understand that ve are perhaps only a thread in an intricate life tapestry, only one nover in the dance, one voice in the song. As Raymond Wilson says there is sisply no way of distinguishing the dancer from the dance and if we assume that there is, this nay simply be a reflection of the vay our language, as opposed

1. Elliot W. Eisner, The Educated Inagination, 5tanford University, 1979, p. 200.

2. Ernesto Grassi, Rhetoric às Philosophy, The Pennsylvania State University Press, 1980, p.7. 
to others, organizes our thinking.

The more universal the individual consciousness becomes the oore ve are one vith other people and our past, then ve can feel at one vith nature also, but unless ve can see and understand such a metaphor ve are constantly misled and confused. And if the sceptic or aore 'scientific' reader doubts the relevance of this metaphor for understanding the world ve live in and the way we live in it then I draw his or her attention to what Frit jof Capra has found:

The PATTERNS scientists observe IN NATURE ARE INTIMATELY CONNECTED WITH THE PATTERNS OF THEIR MINDS; vith their concepts, thoughts and values. Thus the scientific results they obtain and the technological applications they investigate vill be conditioned by their frame of aind. Although auch of their detailed research will not depend explicitly on their value system, the larger paradign within which this research is pursued will never be value-free. 2

It is iapossible for a human being to be completely objective even about the material world about him/her. I have stressed the vord pattern here as I have done throughout this work because every area of research has thrown up the same idea that we organise our conception of the vorld in terms of patterns, that ve recognize patterns, seek then out and create thea, because they are so ouch a part of nature and are even reflected in the vay ve appear to think. Bergland sagys "It is no accident that sankind's first paradigas involved patterns; it is difficult to conceive of models for 2 thought that do not involve patterns in one vay or another." And further on when discussing the brain as a gland he says "The mechanisms that drive thought are found all over the body and, wherever they live, they

1. Raymond Milson, Metaphors in some Nineteenth and Twentieth Century Fiction, Metaghors of Education, eds.W.Tayl or et al, Heineanan, London, 1984, p. 117.

2. Fritjof Capra, The Iurning Point, Fontana, London, 1982, p.77.

3. Richard Bergland, The Fabric of Mind, Penguin, Australia,1985, p.15. 
function at their highest level by recognizing the nolecular patterns of the conbination of hormenes that nodulate thought.... The mind is ade pattern dependent and cones to share in the ubiquitous secret of evolutionary survival: pattern recognition." Capra asserts that:

The conception of THE UNIVERSE AS AN INTERCONNECTED NEB OF RELATIDNS is one of two najor themes that recur throughout nodern physics. $77 \ldots$ Modern physics thus pictures matter not at all as passive and inert but as being in a continuous DANCING and vibrating notion whose RHYTHMIC PATTERNS are determined by the molecular, atomic and nuclear configurations.2

This same veblike structure is also seen in language where time and again reference is made to almost human aspects of speech. Words are born, die, have families are related to other vords, are constructed as 'figures' of speech. He spend a great deal of our thinking time making connections or relations between them, making associations as Jung recognized is one of our ain tasks and he used vord associations as a vay into the human aind. We perhaps need to remember what Richards said that "vords are not a mediun in which to copy life. Their true vork is to restore life itself to 3 order."

What we can see in the history of education and in writings on education are recurring metaphors which give us an insight into the main tenets on which the theory, philosophy and practice of education have becone based. Two of the recurring key metaphors are 'grouth' and light. The 'grouth' metaphor has been vell analysed and explored but I have found very little on the 'light' aetaphor which is even more prevalent and not only in uritings on education but other spheres al so, particularly religious.

1. Richard Bergland, Ihe Fabric of Kind, Penguin, Australia, 1985, p. 109.

2. Fritjof Capra, The Iurning Point, Fontana, London, 1982,p.79.

3. I.A. Richards, The Philosophy of Rhetoric, Oxford University Press, New York, 1936, p.125. 
Light as Fritjof Capra points out is a difficult concept for it is both a particle and a vave, or at least these vere the concepts originally used, until it vas realized that these properties depended on the experimental situation it vas in or on the interaction it vas forced to make with apparatus. This is a peculiarity says Capra which is oet continually, that tyo terms vhich seen opposite are used of one phenonena. He calls this notion one of coaplementarity which Bohr has suggested sight equally vell serve other areas than science. The classical notion of solid objects has been demolished 'Subatomic particles, then, are not 'things', in turn, are interconnections between other 'things' and so on." This is hov nodern physics represents the unity of the universe. Heisenberg is quoted as expressing it thus: "The vorld thus appears as a complicated tissue of events, in which connections of different kinds alternate or overlap or combine and thereby deteraine the texture of the whole."

If this has far-reaching implications for science then it wust also apply to teaching. Gregory Bateson, says Capra, has argued that it should be used as a basis for ALL definitions, and that this should be taught to our children in elementary school. Anything, he believed, should be defined not by what it is in itself, but by its relations to other things. He might vell have been talking about aetaphor for this is exactly what this consummately skilful verbal 'creature' does, enables us to aake abstract connections which help us to recognize wholes where before ve perhaps only dimly saw parts. Maybe we need to know more about the nature of light itself to understand the many references to illumination as a source of or route to wisdom. In Colin McCahon's painting Gate ItI 1970 there is what

1. Frit jof Capra, Ihe Iurning Point, Fontana, London, 1982, p.69.

2. Ibid.,p.70. 
might be a prophetic aessage "As there is a constant flow of light ve are born into a pure land."

It is the artist of course vho recognizes truths before the rest of us. Keri Hulne for instance says that she has been uriting about herself in the hope of "making a pattern" but what she has created 1 instead, to her aind, is "an old spiderweb." So to make sense of it all ye need the spider. She ends a collection of stories vith the folloving observation on the tern Windeater:

There isn't such a vord, eh. There's a lot of us around though. I came across the tern as a gift, if you like, a sort of found gift. For instance, you break up a perfectly respectable word, happily arried in all its component parts; you know it means several things, like a loafer or a braggart. Or a voman who takes part in certain rites. Or it can mean the acquisition of property without any return being aade, ds vell as a spell that is cast to punish somebody behaving in such an unmannerly fashion. That's when its a vhole unbroken word, but if you split it, a pover leaks out and becomes a woman trying to make sense of herself and her living and her vorld.

Which all goes to show the charaing naivety of us humans. Sense of a world indeed.

Any attempt to define the vorld or a word is pretentious indeed. But if all we have is language then ve need as teachers to share the pover over it.

1. Keri Hul me, Ie Kaihan The Windeater, Victoria University Press, New Ieal and, 1986, p.237, p.235. 
AARON, R.I., The Theory of Universsalss, Clarendon Press, Oxford, 1952.

A8AS, Lufti, Symbols in Kenala's Poems: A Study of Signs in Mystical Poems, in Segiotics Unfolding Vol.1I, Mouton, 1979.

ABBS, P., Proposal For a Ney College, Heineaann, London, 1977.

ADMINISIERING for EXCELLENCE, Report of the Task Force to review educational administration, New leal and, 1988 ,

ADRIAN, Arthur A., Dickens and the Parent Child Relationship, Ohio University Pres5, 1984.

ALCORN, Noeline, 'Learning to Manage Educational Institutions: Some Theoretical Considerations', Deltta 35, New Zealand, May 1985.

ARIES, Philippe, Centuries of Childhood, Penguin Education, 1973.

ARISTOTLE, 'On Poetics'-, The Works of Aristotle Vol.II, Encyclopaedia Brittanica publisher William Benton U.S.A. 1952.

-Rhatoric Bk.1.2. Encyclopaedia Brittanica, University of Chicago Press, 1952, Trans. by W. Rhys Roberts.

-No-Nonachean Ethics Book 31110 trans. by W. D. Ross. Great Books of the Western Nor1d, Chicago: Nilliam Benton, 1952.

ASHTON-WARNER, Sylvia, "Ieacher." in Ameriça, Cassell, London, 1972.

ASPIN, David, 'Metaphor and meaning in Educational Discourse' in Metaghors of Education ed. W. Taylor, Heinemann, London, 1984.

ATKINS, P.W., 'No Soul, and not Special', a reviev of Neuronal Mans The Biology of Mind by Jean-Pierre Changeux, Oxford, in London Revieg of Books, 21 May 1987.

BACON, Stephen, Ihe Conscious Use of Metaghor in Qutuared Bound, Colorado Outvard Bound School, Denver, Colorado, 1983. 
BARNES, D., Language The Learnerer and The School, Penguin,U.K., 1969.

BARNES, S., Dominion Sunday Iines, Nev leal and, February 1, 1988.

BARRINGTON, J.M., BEAGLEHOLE, T.H., Maori Schools in a Changing Society, N. Z,C.E.R.,1974.

BARROW, Robin,Plate and Eductation, Routledge and Kegan Paul, 1976.

------, Competence and the Head, in The Role of the Head, ed. R.S. Peter5, Routledge and Kegan Paul, London, 1976.

BARTHES, Roland, The Rustle of Language trans. by Richard Hovard, Hill and Wang, New York, 1986.

BEARE, Hedley, School and Conmunity as Educational Partners, in Policices for Particicigation, ed. John Watson, N.Z.C.E.R., 1977.

BEEBY, C. E., Moving Targets, N.Z.C.E.R., Wellington, 1986.

BEESING, Maria, O.P., Robert Noyosck, C.S.C., Patrick H.O.Leary, S.S., The Enneagran, Dimension Books, Nev Jersey, 1984.

BER6LAND, Richard, The Eabric of Mind, Penguin Book5, Australia, 1985.

BergrenN, Douglas, The Use and Abuse of Metaphor, in The Reviey of Metąghysicss, Vol.XVI, No.2, Issue No,62.

BERNBAUM, 6., The Role of the Head, ed. R.S. Peters, Routledge and Kegan Paul, London 1976.

BERNSTEIN, B., On the Classification and Framing of Educational Knowledge, Knoulgdge and Control, ed. F.M.D.Young, Collier Macaillan, London, 1971.

BERTALANFFY, Ludvig von, General Systens Theory, George Braziller, New York, 1968.

BLACK, Max., Models and Metaghors, Cornell University Press, New York 1962.

BLANCHARD, Jay, and McNINCH, George, The Effects of Anthropomorphism on Word Learning, JNLCF EduC. Research, Vol, 78, No. 2.

BOAS, George, The Cult of Childhood, The Narburg Institute, University of London, 1976.

BODKIN, Maud, Archetypal Patterns in Poetry, Oxford University Pres5, 1963.

BOOTH, Wayne C., 'Metaphor as Rhetoric: The Problem of Evaluation', in On Metaphor, ed. Sheldon Sacks, University of Chicago Press 1978. 
BORBE, Tasso,Seniotics Unfolding. Mouton Publishar 5, Berlin, 1983.

BOURDIEU, P., Systens of Education and Systems of Thought, in Knouledge and Control, ed. Michael F. D.Young, Collier Macaillan, London, 1971.

BowD, Alan D., The Developaent of Beliefs about Aninals, Educational Research in the 1980's, Vol. 2, Collected Paper 5 AARE.

BOWLES, 5. and GINTIS, H., Schooling in Capitalist America, Routledge and Kegan Paul, London, 1975.

BOWRA, C.K., Prigitive Song, Weidenfield and Nicholson, London, 1962.

BOYD, Richard, Metaphor and Theory Change: What is "Metaphor" a Metaphor for ?, ed. A.Ortony Metaghor and Thought, Cambridge University Press, 1979.

BRAMELD, Theodore, Patterns of Educational Philosoghy, Holt, Rinehart and Winston, 1971.

BREAL, Quoted in Metaghor an Annotated Bibliograghy and History, Whi tewater, Wisconsin, 1971 .

BREDESEN, Paul V., An Analysis of the Metaphorical Perspectives of School Principals, Educational Adninistration QuarterIy, Vol. 21, No. 1, Winter 1985.

BROCK-UTNE, Brigid, Chapter 4 'Science, Higher Education and Peace Research', Educating for Peace, Perganon Press, 1985.

BROOKE-ROSE, Christine. A Gragnar of Metaghor. Secker and Warburg, 1958 ,

BRUNER, J., Schooling Children in a Nasty Climate, Psychology Iodalay, January, 1982.

BRUNTON, Paul, The Inner Reality, Rider and Co., London, 1970.

BUKY, Bela 'The system of Metaphors semiotically considered' in Seniotics Unfolding ed. Tasso Borbe Mouton 1983.

BUEKE, K., Language as Symbolic Action, University of California Press, 1966

BURNS, J., Science With Sex Appeal,Listener, Neu Zealand January 30, 1988.

BUSH, Tony, Theories of Educationa! Management, Harper and Row, London, 1986.

CANTOR, Paul, Friedrich Nietzsche: The Use and Abuse of Metaphor, in Metaghor: Problens and Persegctives, ed. David Miall, Harvester Press, Sussex, 1982.

CAPRA, Fritjof, The Iurning Point, Fontana, London, 1982. 
CASTLE, E.8., Ancient Education Ioday, Penguin, London, 1961.

CHOWN, M., School Science for All--but Who Pays?, Ney Scientist, March, 1958.

CLARK, Carol, The ㅌep of Neteaphor, French For um, Kentucky, 1978.

CLARK, Megan, senior lecturer, Victoria Univer sity of Wellington, speaking to the Institute of Policy Studies Seninar on 'Science and Technology: Attacking the Tventyfirst Century'. Reported in the Evening Post Wellington, Nev Zealand Septeaber the fifth 1987.

CLEVERLEY, J. The Schooling of China, George Allen and Unvin, Sydney, 1985.

COHEN, Ted, 'Metaphor and the Cultivation of Intimacy', in DN Metaghor, ed. Sheldon Sacks, University of Chicago Press 1978.

COLADARDCI, Arthur P., and GETZELS, Jacob W., The use of Theory in Educational Adginistrattion, School of Education Stanford University 1955

COLGATE, H.A., The Role of the Secondary School Head, in Ihe Role of the Head, ed. R.S. Peters, Routledge and Kegan Paul, London, 1976.

CONEY, Sandra, The Unfortunatee Experienent, Penguin, New Zealand, 1988.

COOK, Elizabath, The Ordinary and the Edbulouss, Cambridge University Press, 1969.

COOPER, David,E, Mettaghor, Blackvell, Oxford,1986.

Authenticity and Learning, Routledge, Kegan and Paul, London 1983.

CORSON, D., The Lexiçal Bar, Perganon Press, 1985.

COULSON, A. A., The Role of the Primary Head, in The Role of the Head, ed. R.S. Peters, Routledge and Kegan Paul, London, 1976.

CQVeNEY, Peter, Ihe Inage of Childhood, Penguin Books, England 1967.

CONLEY, J., The Healing Pover of language, Listenene, Nev Zealand, January 16,1988 .

CRANE, R.S., Languages of Criticism and the Structure of Poetry, University of Toronto Press, 1953.

CREBER, Patrick, Sense and Sensitivity, University of London Press Ltd., 1967.

CROSBIE, Sharon, The Drinking Games People Play, Doninion Sunday Iines, New lealand, 13th March 1988. 
CROSS, Ian, The God Boy, Whitcombe \& Tonbs, New Zaaland, 1974.

CROUCH, Colin, Education and Culture: Grounds for Cheerfulness, Cultture. Education and Society, Vol 40, No.4, Autuan 1986.

CULLER, Jonathan, Comentary, Ney Literary History, Vol. VI, No.t, Autuan, 1974.

DARLING, John, Education as Horticulture: Some Grouth Theorists and their Critics, Journal of Philosoghy of Education, Vol, 16 No $2,1982$.

DAVID, Jane L., Aid or Threat to Inprovement, Phi Delta Cagea, March 1988.

DAVIES. John L., 'The Politics of Education', some theoretical and comparitive considerations, in The Politics of Education in Nev lealand, ed. Margaret Clark, N.Z.C.E.R., Wellington, 1981.

DEARDEN, R.F., The Philosophy of Prinary Education, Routledge \& Kegan Paul, London, 1968.

Balance and Coherence : Sose curricular principles in recent reports. Cambridge Jornal of Eductation, Vol. 11, Pt.2, 1981.

DEESE, James, Mind and Metaphor: A Commentary, The Ney Literary History, Vol.VI, Autuan 1974.

De MAUSE, Lloyd, The Evolution of Childhood, in The Histogry of Childhood Souvenir Press, London, 1976.

DERRIDA, Jacques, White Mythology: Metaphor in the text of Philosophy, Ney Litergrary History, Vol.V1, Autuan 1974, No.1.

DEWEY, John, Experience and Education, in S.M. Cahn Philosoghical

Foundations of Education, Harper \& Rov, Nev York, 1970.

DITFURTH, Holear von, 'Science Popularisation: Getting to the Heart of the Matter', UNESCD Features no. 754

DOMINION SUNDAY TIMES, Nev lealand, 1st February 1978.

DUNN, Patrick, P., That Eneny is the Baby: Childhood in Imperial Russia, in The History of Childhood, ed. de Mause, Souvenir Press, London, 1976.

DURKHEIM, Emile, Elementary For 05 of Religious Life, in School \& Societty, Routledge and Kegan Paul in association vith Open University, 1971.

EDWARDS, Betty, Draying on the Right Side of the Brain, Fontana/Collins, U.S.A.,1979. 
EISNER, E.h., The Educational Inagination, Macnillan, New York, 1979.

EITINGTON, J.E, The Winning Irainer, Gulf Publishing Company, Texas, 1986.

ELLIOT, R.K., Metaphor, Imagination and Conceptions of Education, Metaphors of Education, ed. W. Taylor, Heinenann, London, 1984.

ERICKSON, Eric H., Childhood and Society, Penguin Books, London, 1950.

EVANS, C., Authority, Knouledge, and the Acadenic Conference, Quinguereme, Vol. 8, No, 1, 1985.

FERGUSON, Marilyn, The Aguarian Conspiraçy, Granada, Great Britain, 1982.

FERNANDEZ, James W., The Perforsance of Ritual Metaphors from The Social Use of Metaghor ed. J.D. Sapir \& J.C. Crocker. University of Pennsylvania Press. 1977.

FINLAYSON, D. F., School Climate: an Outmoded Metaphor?, Journal of Curriculun Studies

FONTANIER, $P_{2}$, quoted in The Rule of Metaghor, Paul Ricoeur, University of Toronto Press, 1977.

FRASSEN, Bas C. van., Images of Scíence, University of Chicago Press, 1985.

FRYE, Northrop, The Great Code The Bible and Literature, Harcourt Brace Jovanovich, Nev York, 1982.

, The Educateded Imanination, Indiana University Press, 1964.

GARDNER, H. and WINNER, L., The Development of Metaphoric Competence:

Inplications for Hunanistic Disciplines, in

On Metaphor, ed Sheldon Sacks, University of Chicago Pres5, 1978.

GARRETT, Alfred, B., The Flash of Genius, D. Van Nor strand Co., Ohio 1962.

GEERING, Lloyd, Lecture at Douse Art Gallery, New lealand, on Myth the Ultimate Truth, 23rd April 1986.

Acts of Norship, NI Listener, April 2, 1988.

GENTNER, Dedre, 'Are Scientific Analogies Metaphors?', in MEIAPHOR Problemes and Persegctives, ed, D.S. Miall, Harvester Press, Great Britain, 1982.

GoodMAN, Nelson, 'Metaphor as Moonlighting', in On Metaphor, ed. Sheldon Sacks, University of Chicago Press, 1978.

GOVERNMENT MANAGEMENT, Brief to the Incoming Government, Vol. 11, Education Issues, Published by the Treasury, Mellington, Nev leal and, 1987. 
GRASSI, E., Rhetoric as Philosophy, The Pennsylvania State University, 1979.

GRAY, Kin, 'Edgecunbe teenagers look back on quake', EYening Post, Wellington, New Lealand, May 4, 1987.

GRAVES, Robert, The White Goddess, Faber and Faber Ltd., London, 1961.

GREEN, M., Science and the Shabby Curate of Poetryy, Greenvood Press, Connecticut, 1964.

GREEN, T.F., Learning Without Metaphor, in Metaghor and Thought, ed. D. Ortony, Cambridge University Press, Nev York, 1979.

GREENE, Maxine, Philosophy and Teaching, Handbogk of Research on Ieaching, ed. M.C. Wittrock, Macnillan, New York, 1986.

GREER, Germaine, quoted in the editorial, The Evening Post, Wellington, New Lealand, March 161988.

6REGORY, Marshall, If Education is a Feast Why do ve restrict the Menu? A Critique of Pedagogical Metaphors, College Ieaching, Vol. 35, Part 3, 1987.

GROSSKAN W.I., and BENNETT, S., Anthropomorphism Motive Meaning and Causality in Psychoanalytic Theory, published by the Division of Psychiatry, Montefiore Hospital, Albert Einstein College of Medicine. Psychoanalytic study of The Child 1969, Vol.24.

HARRIES, Karsten, Metaphor and Transcendence, in Qn Metaghor, ed. Sheldon Sacks, University of Chicago Pres5, 1978.

HARHAN, Willis, The Coming Transforation, The Futurtist, 1977

HAWKES, Terence, Metaghor, Methuen, London,1972.

HAYAWAKA,S.I., Language in Thought and Action, George Allen and Unvin, London, 1966.

HEL.MS, Donald B, and Turner, Jeffrey, Exploring Child Behayiout, H.B. Saunders, Philadel phia, 1976.

HESSE, Hermann, A Guest at The Spa, in Autobiographical Writings, Jonathan Cape, London,

HESSE, Mary 8., Science and the Hunan Imagination, SCM Press Ltd., London, 1954.

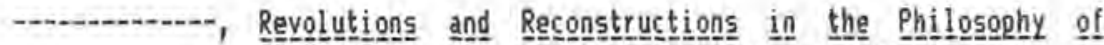
Science, The Harvester Press, Britain, 1980.

HOBBES, Thomas, Leviathan, Encyclopaedia Brittanica, Willian Benyon U.S, A. 1952, Ch. 4. 
HOGBEN, Lancel ot, FRS, The Vocabulary of Science, Heineaann, London 1969.

HOGgART, Richard, An English Iemper, Chatto and Windus, London, 1982.

HOLTON, Gerald, Metaphors in Science and Education, Chapter v11 of Metaghors of Education, ed. W. Taylor, Heinemann, London, 1984.

HUDSON, Liam, Efanes of Mind, Penguin Books, U.K., 1968

The Role of Metaphor in Psychological Research, in Metaphors

of Edycation, ed. W. Taylor, Heinewann, London, 1984.

HUGHES, Austin, Science and Children, April 1973.

HUGHES, Meredydd 6., The Professional Administrator: the case of the secondary school head, in The Role of the Head ed. R.S. Peters, Routledge and Kegan Paul, London 1976 .

HULME, Keri, Ie Kaihau The Windeater, Victoria University Press, New Zealand, 1986.

The Bone Peogle, Spiral, New lealand, 1983.

ILLICK, Joseph E., Child rearing in Seventeenth Century England and America, in The History of Childhood, ed de Mause, Souvenir Press, London, 1976.

JANKE, Dalnar, and NORTON, Donna, 'Good Tales for Teachers', Science and Children, Vol. 20, №. 6, March 1983.

JARDINE, David W. and MORGAN G.A.V., Morgan, Analogy as a model for the Development of Representational Abilities in Children, Educcational Theory, Sumer 1987.

JEFFreYS, M.V.C., The Aigs of Education, Pitman Publishing, London, 1972.

JOHNSON, Mark, Philosoghical Perspectives on Metaghor, University of Minnesota Pres5, Hinneapolis, 1981.

JoNES, Richard H., Eantasy and Eeeling in Education, Penguin, London, 1972.

JUNG, Carl, Man and His Syabols, Picador, London, 1964.

KEY, Ellen, The Century of the Child, G.P. Putman \& Sons, Nev York \& London, 1909.

KOESTLER, A., The Ghost in the Machine, Picador, London, 1967.

KORZYBSKI, Alfred, Science and Sanity, The International Non-Aristolean Library, Lancaster, Pennsylvania, 1941. 
KUHN, Thonas S., The Structeture of Scientific Revolutions, University of Chicago Press, 1962.

'Metaphor in Science', in Metaghor and Thought, ed. A. Ortony, Canbridge University Press, New York, 1979.

LACAN, J., The insistence of the letter in the unconscious, in Structuralise, ed.Jacques Ehrmann, Anchor Books, U.S.A.

LAKOFF, George, and Mark Johnson Metaghors Me Live By University of Chicago Pres5, 1980.

LAMQ, Hilary, Hriting Perfornance in Ney Zealand Schools an I.E.A. Study, Department of Education, Wellington, 1987.

LANGer, Susanne K.,Philosoghy in a Ney Key, Harvard University Press, Canbridge, Massachusetts, U.5.A., 1942.

LAWRENCE, Elizabeth, The Origins And Grouth Of Modern Education, Penguin Books, England, 1970.

LAWTON, Denis, Metaphor and the Curriculum, Metaghors of Education, Heinenann, London 1984.

LEAVIS, F.R., 'Half a century of arousing academic enmity' a Times profile by Victoria Brittain, Iines, London, February 17,1975.

LEE, Harper, Io Kill a Mocking Bird, Penguin England, 1967.

LEONARD, George D., Eductation and Ecstasy, John Murray, Great Britain, 1970.

LEVY, J., Right Brain, Left Brain: Fact and Fiction, Psychology Ioday, May 1985.

LEWIS, C. Day, The Pogtic Image, Jonathan Cape, London, 1947.

LINZEY, T.J., University of Otago, How to kill a Metaphor, a paper presented to the P.E.S.A. Conference, Melbourne, August, 1987.

Self Esteea, Self Concept and Self Realization, Paper given at N.Z.A.R,E, Conference, Hellington.

LOGAN, L.M. and Logan V.G., Design for Creative Ieaching, McGraw-Hill Company of Canada, Toronto, 1971.

LYMAN, Richard B, Jnt., Barbarisa and Religion: Late Roman and Early Medieval Childhood, in The History of Childhood ed. de Mause, Souvenir Press, London. 1976.

MACPHERSON, R.J.S., Taking up and Justifying Organisation: The Creation and Control of Knowledge about being Organised, in nevsletter of the Congueal th Council for Educational Adginistration, No. 41, 1986. 
MALCOLM, Margaret S., The Almost Invisible Woman, Set 7B, No. 2, iten 12 N.Z,C.E.R., Wellington.

MANSFIELD, Katherine, Journal of Katherine Mansfield 1904-1922, ed. John Middleton Murry, Mutchinson, Nev Zealand, 1984.

The Letteres and Journals of Katherine Mansfigld, ed. C. K. Stead, Penguin, England, 1978.

MARTIN, J. and HARRE, R., 'Metaphor in Science', MEIAPHOR ProbIeas and Perspectives, ed. D.S. Miall, Harvester Press, Great Britain, 1982.

MARVICK, Elizabeth Wirth, Nature versus Nurture: Patterns and Trends in Seventeenth Century French Child-Rearing, in History of Chilohood, ed de Mause, Souvenir Press, London, 1976.

MeCULLOCH, 6., Education in the Forming of Nev Zealand Society: Needs and Opportunities for Study, NZARE Monograph, No.1, June, 1986.

MCDONALD, G., Educational Research in a Science and Technology future, New lealand Journal of Educational Studies, Vol. 20, No, 2, November, 1985.

Mclaughlin, Mary Martin, Survivors and Surrogates: Children and Parents from the Ninth to the Thirteenth Centuries, in Ihe History of Childhood, ed de Mause, Souvenir Press London, 1976.

McMAHON, Barrie and QUIN, Robyn, Real Igages, Macnillan, Australia, 1986.

McNAUGhTON, Iona, Life at the Sharp End of an Energency, Dominion Sunday Iines, New Laal and, October 23rd 1988.

MEAD, M., From Intuition to Analysis in Communication Research, Semiotica, Journal of the International Asoociation for Semiotic Studies, VoI.1, 1969, Mouton, The Hague.

MIALL, David, ed. METAPHOR Problems and Persegectivess, Hunanities Press Inc., Nev Jersey, 1982.

MIEL, J., Jacques Lacan and the structure of the unconscious, in Structuralisg, ed. Jacques Ehrmann, Anchor Books,U.S.A.

MILler, Steven, Some Coment on the Utility of Metaphors for Educational Theory and Practice, Educational Iheory University of Illinois, Summer 1987.

MINTZBERG, Henry, The Manager's Job: FolkIore and Fact, Set No. 1 1985, N.Z.C.E.R., reprint from Harvard Business Reviev.

MOFFET, Janes, Actirge Voice, Boynton/Cook, U.S.A., 1981. 
MooIJ, J.J.A., A Study of Metaghor, North Holl and Publishing Co., 1976.

MOORE, F.C.T., On Taking Metaphors Literally, in Metaphor: Problems and Perseectives, ed, David Miall, Harvester Press, 1982.

MORGAN, Gareth, Lnages of Organizatkion, Sage Publications, Cali fornia, 1986.

NATTINGER, Jane5, R., Connunicative Language Teaching: A New Ketaphor, IESQL Quarterly, Vol. 18, No. 3, Septeaber 1984.

NEWELL, Clarence A., Hugan Behaviour in Educational Adøinistration, Prentice-Hall, Nev Jersey, 1978.

NYBERG, David, Pruning the Grouth Metaphor, The Educational Eorut Novenber 1975.

ORTONY, Andrew, ed. Metaphor: A Multidimensional Problen Metagehor and Thought, Cambridge University Press, Nev York, 1971.

OSBDRNE, Roger J., and GILBERT, John K., A Technique for Exploring Students Views of the World, Phys. Educs, Vol, 15, 1980.

OSBORNE, R. and Freyberg, P.,Learning in Sccience, Heinemann, Nev lealand, 1985.

OWENS, Robert 6., Organizational Behaviour in Schools, Prentice-Hall, New Jersey, 1970.

PaIVIO Allan, Psychological Processes in the Comprehension of Metaphor, in Metaghore and Thought, ed. Andrew Ortony, Cabbridge University Press, New York, 1980.

Imagery and Verbal Processes, Holt, Reinhart and Minston, U.S.A., 1971.

PARKER, P., The Metaphorical Plot, in Metaphor: Problems and Perspectiyes ed. David Miall, Humanities Press, New Jer5ey, 1982.

PARSONS, T., in Adginistrative Thgory in Education, ed. Andrew W. Alpin, Macaillan, London, 1958.

PATTISON, Robert, The Child Figure in English Literature, University of Georgia Press, Athens, 1978

PETERS, R.S., Authority Reseonsibility and Education George Allan \& Unvin, London. 1973.

PETERS, Tom and AUSTIN, Nancy, A Passion for Excellience, Collins, London 1985.

PETRIE, Hugh G., Metaphor and Learning, in Metaghor and Thought, ed.

D. Ortony, Canbridge University Pres5, New York, 1979.

PODENDORF, Illa, Characteristics of Good Science Materials for Young Readers, Library Irends, April 1974. 
POOLE, Roger, The end of a Humanist Enterprise, Culture, Education and Education and Societsy, Vol 40, No 4, Autuan 1986

Nue Culture Education and Society, Vol. 40, No 4, Autumn 1986.

PQPE, M.L. and GILBERT, J.K., Explanation and Metaphor: Some empirical questions in science education, European Journal of Sccience Eductation, Vol.5, No.3, 1983.

POTOK, C., MY NAgen is Asher Ley, Penguin, England,1972.

PROTHEROUGH, Robert, Shaping the Inage of the Great Headnaster, British Journal of Educational Studies, Vol. $x \times \times 11$, No. 3 October 1984.

PRATT, David, Curriculum Design as Humanistic Technology, Journal of Curriculug Studies, 1987.

Curriculum for the 21 st Century, Education Canada, Vinter, 1983.

PYLYSHYN, Zenon, W., 'Metaphorical Imprecision and the "Top-Down Research Strategy", in Metaphor and Thought, ed. A. Ortony, Cambridge University Press, 1979.

QUILLER-COUCH, Sir Arthur, On the Art of Uriting, from lectures given at Cambridge 1913-14, Cambridge University Press, 1938.

QUIN, Peter, Authority Figures, Ie Aya Itti, Porirua, New Zealand, June $10,1988$.

1988 .

RAINE, K., The Inner Journey of a Poet, George Braziller, New York, 1982.

REYNoLDS, David, The Delinquent School, in The Process of Schooling, eds. M. Hammersley and P. Woods, Routledge and Kegan Paul and Open University, 1976.

RICHARDS, I.A. Intergretation in Ieaching, Routledge and Kegan Paul, London 1949

-Philosoghy of Rhatoric, Oxford University Press, New York, 1936,

RICHARDSON, Eluyn S., In the Early World, N.L.C.E.R., Wellington, 1972.

RICOEUR, Paul, The Rule of Metaghor, trans. by Robert Czerny, University of Toronto Press, 1975. 
The Metaphorical Process as Cognition, Imagination, and Feeling, in On Metaghor, Sheldon Sacks, University of Chicago Press, 1978.

ROBERTSON, Priscilla, Hone as a Nest: Middle Class Childhood in Nineteenth Century Europe, in The History of Childhood, ed. de Mause, Souvenir Press, London, 1976.

ROBINS, R.H, 'The Structure of Language,' 'Language in Education, Routledge and Kegan Paul in Association vith Open University, London, 1972.

ROGERS, Robert, Metaphor a Psychoanalytic Viegy, University of California Press, 1978.

ROSE, C., Accelerateded Learning, Topaz, England, 1986.

Ross, Janes Bruce, The Middle Class Child in Urban Italy, Fourteenth to Early Sixteenth Century, in The History of Childhood, ed. de Mause, Souvenir Press London, 1976.

ROTh, P., Portnoy's Cogelaint, Guild Publishing Company, London, 1982.

RUDKAN, Brian, 'The Day Our Buildings Cane to Li fe', Listenner, Nev Zaaland, April 11, 1987.

RVDER, Father Tom, quoted in the Auckland Hergld, 29th June 1987.

SAPIR, J.D., The Anatony of Metaphor, in The Social Use of Metaghor, eds. J.D.Sapir and J.C.Crocker, Univer sity of Pennsylvania Pres5, 1977.

SAVER, Jeffrey, review of The Dreaging Brain by Allan Hobson, in London Reviey of Books, August 4, 1988.

SAVORY, Theodore. The Language of Science, Andre Deutch, 1953.

SCHEFfLER, Israel, Philosophical Models of Teaching, Philosophical Foundations of Education, ed. S.M. Cahn, 1970. Fron Haryard Educational Revieu, Vol 35, Spring 1965.

SCHLECHTY, Phillip C. and JOSLIN, Anne Walker, Images of Schools, Ieachers College Record, Vol. 86, No, 1, Fall 1984.

SCHON, Donald $A_{2}$, Generative Metaphor: A Perspective on Problea Setting in Social Policy, in Metagehor and Thought, ed. David Drtony, Cambridge University Press, Nev York, 1979.

SCIENCE REVISION COMMLTTEE, Report on For 1-5 Science, Auckland, July, 1986.

SHAKESPEARE Hillian, Haglelet, Oxford Edition. Romeo and Iuliet. 
SHAREFKIN, Belle d, and RUCHLIS, Hy, Anthroponorphisa in the Lower Grades, Science and ChiIdren, March 1974.

SHIBLES, Warren A., Metaphor an annotated Bibliography and History, The Language Press, Wisconsin, 1971.

Analysis of Metaghor in the Light of W.M.Urban's Thagries, Mouton, The Netherlands, 1971.

SILVA, J. and MIELE P., The Silvad Mind Control Method, Pocket Books, Sinon and Schuster, Nev York, 1977.

SMITH, Anne B., Children's Ideas About Teachers and Principals, SEI No. 2, 1985, N.Z.C.E.R., Nev Zealand.

SMITH, B.O., STANLEY, W.O., and SHORES, J.H., Cultural Roots of the Curriculue in The Curriçilum: Contexts Oliver and Boyd, Edinburgh and Open University 1971.

SMITH, Marshall S., Educational Indicators, Phí Deltta Capged, March 1988.

SOLZHENITSYN, A. One Word of Iruth, The Bodlay Head, London, 1972.

SPERBER, Dan, Rethinking Syabolism, Cambridge University Press, 1975.

STANLEY, H., Christopher Lasch as Social Educator, Educatilional Ihegery, Vol.37, No.3.

STERN, J.P., 'Nietzsche and the Idea of Metaphor', in Nietzsche: Inagery and Thought, ed. Malcol Pasley, Methuen, London, 1978.

STICHT, Thomas G., Educational Uses of Metaphor, in Metaphor and Thought, ed. D. Drtony., Cambridge University Press, New York, 1979.

SutToN, C., Metaphorical Inagery: A Means of Coping with Coaplex and Unfasiliar Information in Science, Durhan and Newcastlle Research Reyien, Vol. IX, No. 467, Spring, 1981.

TAYLOR, Willian, Metaphors of Educational Discourse, in Metaphors of Education, ed. W. Taylor, Heinemann, London 1984.

-...-...-.-.-The Head as Manager, in The Role of the Head, ed R.S. Peters, Routledge and Kegan Paul, London, 1976.

THOULESS, R.H., Strraight and Crooked Ihinking, Hodder and Stoughton, London, 1974.

TOMPKINS, P. K., The functions of human comaunication in organization in Handbook of Rhetorical and Compunication Theory eds. C. A. Arnold and J. W. Bover 5, Allyn and Bacon, Neuton, MA, 1984.

tourangeau, R., Metaphor and Cognitive Structure, in Metaphor: Problems and Perspectiveses, ed. David S. Miall, Harvester Press, Great Britain, 1982 . 
TRACY, David, Metaphor and Religion: The Test Case of Christian Texts, in On Metaghor, ed. Sheldon Sacks, University of Chicago Pres5, 1978.

TRIBLE, Phyllis, Feminisa and Scripture, reported by Yvonne Van Dongen, Auckland Star Nev lealand, 27th July 1986.

TRILLING, Lionel, The Liberal Imagination, Mercury Books, London, 1950.

URBAN, Wilbur Marshall, Humanity and Deity, George Allan and Unvin, London, 1951.

UYGOTSKY, L., Thought and Language, MIT Press Cambridge, Massachusetts, 1987.

WALKERDINE, Valerie, From Context to Text: a psychoseniotic approach to abstract thought, fron Children Ihinking Ihrough

Languageg, ed. M. Beveridge, Edvard Arnold, London, 1982.

WALIER, John F., A Period of Ambivalence: 18th Century Aaerican Childhood, in The History of Childhood ed. de Mause, Souvenir Press, London, 1976.

WARNOCK, Mary, Schools of Thought, Faber, 1977.

WARREN, A. Shibles, Analysis of Metaghor In The Light of W.M. Urban's Theories, Mouton, The Netherlands, 1971.

WATTS, John, Sharing it Out: The role of the head in participatory Government, in The Role of the Head, ed, R.S. Peters, Routledge and Kegan Paul, London 1976.

WAYNE, C.Booth, 'Metaphor as Rhetoric: The problen of Evaluation,' in Sheldon Sacks, On Metaghor, University of Chicago Pres5, 1978.

WEIMANN, Robert, Shakespeare and the Study of Metaphor, Nev Literarary History, Vol.6., No.1, Autuan 1974.

HHEWELL, Willian, D.D., History of Scientific Ideas, Vol. 1, J.W. Parker and Son, London, 1958.

WHORF, B.L., quoted in Semantics, ed. K.Thurman, Houghton Mifflin Co., Boston.

HILSON, R., Metaphors in Some Nineteenth and Twentieth Century Fiction, Metaghers of Education, eds. W. Taylor et al., Heinemann, University of London, 1984.

WORTh, Sol, Seeing Metaphor as Caricature, Ney Litergafy History, Vol V1, No. 1, Autuan 1974.

YOGANADA, Paranahansa, Autoghiograghy of a Yogi, Self-realisation Fellowship, California, 1979. 
ZACHARIAH, Matthew, Lumps of Clay and Groving Plants: Doninant Metaphors of Education in the Third World, 1950-1980,

Comparativige Education Revieg, Vol. 29, no. 1, 1985.

ZIMAN, John, What Shall We Look Into Now?, London Reviege of Books, 21 May, 1987. 